\title{
A DOCUMENTAÇÃO PEDAGÓGICA COMO ESTRATÉGIA PARA A CONSTRUÇÃO DO CONHECIMENTO PRAXIOLÓGICO: O CASO DO OBSERVATÓRIO DA CULTURA INFANTIL - OBECI
}

Tese apresentada ao Programa de Pós-Graduação em Educação da Faculdade de Educação da Universidade de São Paulo para obtenção do título de Doutor em Educação.

Área de concentração: Didática, Teorias de Ensino e Práticas Escolares

Orientadora: Dra. Mônica Appezzato Pinazza

São Paulo

2019 
Autorizo a reprodução e divulgação total ou parcial deste trabalho, por qualquer meio convencional ou eletrônico, para fins de estudo e pesquisa, desde que citada a fonte. 
FOCHI, Paulo Sergio. A Documentação Pedagógica como estratégia para a construção do conhecimento praxiológico: o caso do Observatório da Cultura Infantil - OBECI. Tese apresentada à Faculdade de Educação da Universidade de São Paulo para obtenção do título de Doutor em Educação.

Aprovado em: 12 de abril de 2019

Banca Examinadora

Prof. Dra. Mônica Appezzato Pinazza

Instituição: Universidade de São Paulo - USP

Julgamento:

Prof. Dra. Tizuko Morchida Kishimoto

Instituição: Universidade de São Paulo - USP

Julgamento:

Prof. Dra. Júlia Oliveira-Formosinho

Instituição: Universidade Católica Portuguesa - UCP / Porto/ Portugal

Julgamento:

Prof. Dra. Maria Carmen Silveira Barbosa

Instituição: Universidade Federal do Rio Grande do Sul - UFRGS

Julgamento:

Prof. Dra. Maria da Graça Souza Horn

Instituição: Universidade Federal do Rio Grande do Sul - UFRGS

Julgamento: 

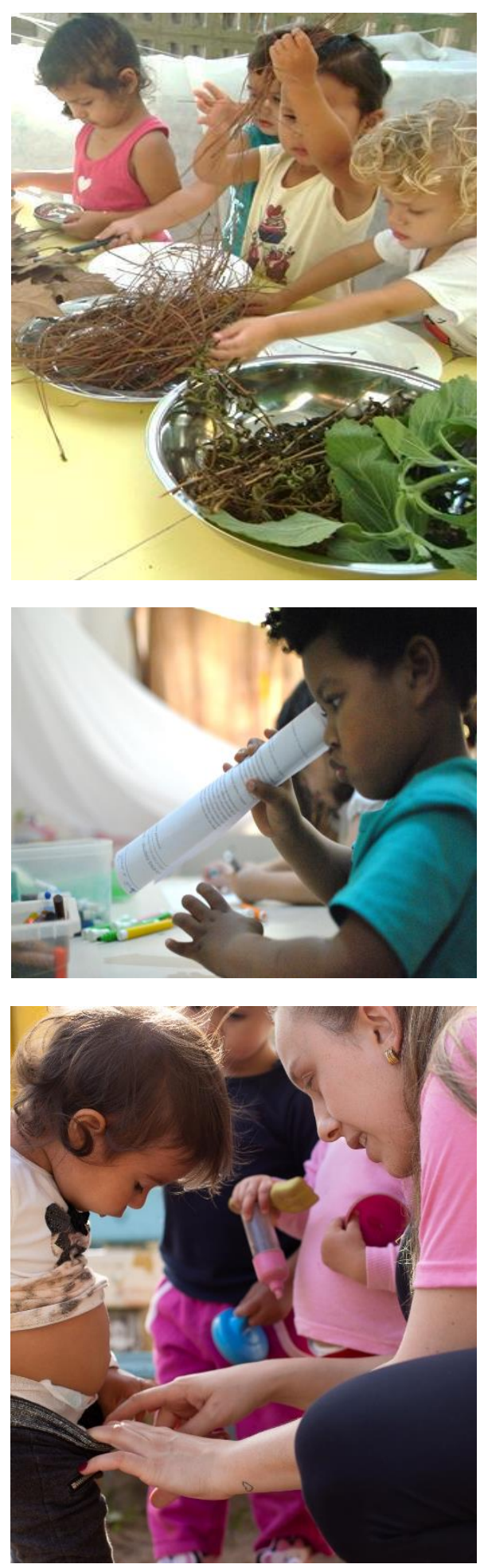

Dedico esta tese a todas as crianças, professoras, coordenadoras pedagógicas e diretoras das escolas participantes do OBECI, pela curiosidade, pelo assombro, pela coragem e pelo compartilhamento do desejo em fazer uma escola amável e honesta para os meninos e as meninas.

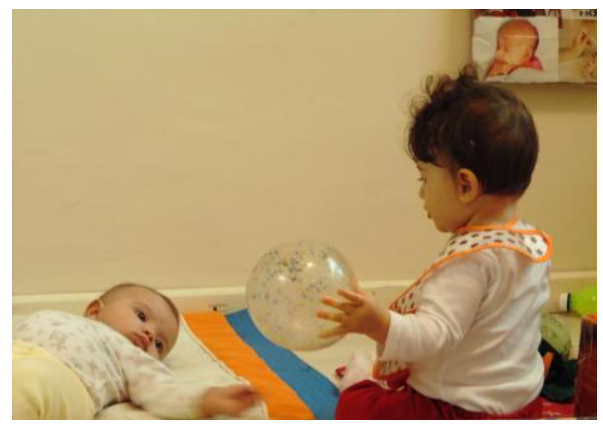


Esta tese contou com o auxílio da Coordenação de Aperfeiçoamento de Pessoal de Nível Superior - Capes por meio de concessão de bolsa sanduíche no exterior. 


\section{Agradecimentos}

Costumo dizer que os agradecimentos das teses e dissertações costumam ser uma parte recheada de humanidade nos trabalhos. De alguma forma, é onde se fala dos encontros, das vulnerabilidades, da finitude, do acolhimento e dos afetos. Por isso, quando me coloquei a escrever os meus agradecimentos, me recordei de uma das crônicas do livro Não existe mais dia seguinte, do querido amigo Vitor Necchi. A primeira crônica, Provas que vivi, narra cenas que gostaria de ver em fotos que não existem, e, por isso, precisa se dedicar a recordar esses instantes que permanecem sem registros.

Conforme fui listando os nomes daqueles que quero agradecer, assim como o autor, desejei imensamente ter as "provas" de seus gestos, supondo que, em fotografias, eu pudesse expressar melhor a emoção e meu sentimento de agradecimento a todas as palavras, abraços, conversas e disponibilidade de cada um e cada uma que foi companheiro/a dessa longa e intensa jornada que é doutorar-se. Como não as tenho, tentei escrever algumas palavras. Assim, com um grande carinho, agradeço:

à Liliane, Juliana e toda equipe da EMEI Joaninha; à Silvana, Carolina, Gilnéia e toda equipe da Espaço Girassol; à Ivana, Vanessa e toda equipe da Escola Mimo de Gente; à Alexandra, Luciane L. e toda equipe da EMEI João de Barro; à Cristiane e Danielle e toda equipe da EMEI Aldo Pohlmann; à Luciane V., Luciane P. e Letícia, por aceitarem ser mais que companheiras na pesquisa no OBECI, serem cúmplices e entusiastas em partilhar sonhos e esperanças. Por estarem ao lado das crianças e por manterem acesa a curiosidade e o desejo por saber mais;

à Mônica Appezzato Pinazza, minha orientadora, pela acolhida na USP, por ter compreendido o meu tempo para fazer as coisas acontecerem, pelo entusiasmo com a tese e por ter se colocado de forma tão disponível e aberta ao longo desses quatro anos;

à Teresa Godall, pela acolhida em Barcelona, pela sua escuta e abertura em dialogar, pelas provocações e pela disponibilidade em me receber na Universidad de Barcelona;

à professora Tizuko Kishimoto, pelo seu olhar atento na banca de qualificação e pelo aceite em fazer parte dessa etapa final;

à professora Maria Carmen, a Lica, professora e amiga que tive o privilégio de construir ao longo desses últimos anos, pelo aceite em estar ao meu lado em mais uma etapa da minha vida; 
à professora Maria da Graça, que me estendeu os dois braços em todos os momentos que precisei, desde o começo do doutorado até o final. Teu carinho, cuidado, escuta e entusiasmo são a razão de eu ter conseguido chegar ao fim. Não há palavras que poderão expressar todo o meu agradecimento a ti;

à Julia Oliveira-Formosinho, que me acolheu em Portugal com olhos entusiasmados e generosos, pelos diálogos tão produtivos, pelo constante incentivo para fazer esta tese e continuar nos caminhos da Pedagogia, por me ensinar tanto e me inspirar a transformar a realidade;

às professoras que compõem a banca de avaliadores suplentes, professoras Marcia Gobbi, Silvia Cruz, Monica Baptista, Susana Fernandes e Tacyana Ramos, por aceitarem estar de alguma forma ao meu lado neste momento tão importante;

ao professor João Formosinho, que, com toda a generosidade, me provocou a pensar tanto sobre metodologia e, especialmente, pelo carinho e diálogos compartilhados;

à Josiane Pareja, minha grande amiga e parceira de tantos sonhos, que me acolheu em São Paulo, que me incentivou, me escutou e foi parceira de tantas risadas e conversas longas, que foi presença e apoio incondicional em todos os momentos;

ao Carlos, que chegou no meio do caminho, me oferecendo carinho e disponibilidade, que pegou em minha mão para atravessarmos essa caminhada juntos, que foi presença na solidão do doutorado sanduíche, que me encorajou e me escutou de forma tão amorosa nos momentos em que precisei;

às minhas grandes amigas Ana Luiza, que me ofereceu o pôr-do-sol, conversa fiada $\mathrm{e}$ disponibilidade, Queila, que vibrou a entrada no doutorado e que foi companhia constante, e Sariane, pelas trocas, encontros e gestos sinceros;

aos meus colegas e amigos da Unisinos, Maurício, Marita e Isabel, que me apoiaram durante esse período e, especialmente, à Sabrina, pela revisão atenta e cuidadosa da tese;

ao grupo do Contextos Integrados de Educação Infantil, especialmente à Meire, que me acolheram e partilharam esse percurso;

à Carol, minha terapeuta, que me ajudou tanto para que o Paulo homem (re)encontrasse o Paulo menino nesse momento do doutorado. Talvez foi por esse encontro que a tese chegou ao fim;

à minha família, meu pai Sergio, minha mãe Jurema (in memorian), minhas irmãs Daniela e Fernanda, minha madrinha Olga e minha vó Maria (in memorian), que me viram crescer e me ofereceram o que tinham para me ajudar a chegar aqui. 
FOCHI, Paulo Sergio. A Documentação Pedagógica como estratégia para a construção do conhecimento praxiológico: o caso do Observatório da Cultura Infantil - OBECI. Tese (Doutorado em Educação). Faculdade de Educação, Universidade de São Paulo, São Paulo, 2019.

\section{RESUMO}

Esta tese tem sua problemática de pesquisa centrada na constituição de uma comunidade de apoio ao desenvolvimento profissional, o Observatório da Cultura Infantil - OBECI, e na Documentação Pedagógica como estratégia para a construção do conhecimento praxiológico. O OBECI, criado em 2013, é composto por quatro escolas de Educação Infantil (duas públicas e duas privadas) da região metropolitana de Porto Alegre, RS, e tem como questão central a organização da vida cotidiana das instituições de Educação Infantil de modo que evidencie o papel da criança no processo educativo, convidando a reposicionar o papel do professor. A estratégia que este observatório tem utilizado para investigar e formar é a Documentação Pedagógica fundada por Loris Malaguzzi. Por isso, parte desta tese dedica-se a reconstituir o pensamento de Malaguzzi a respeito da Documentação Pedagógica a partir dos projetos supervisionados pelo pedagogo ao longo de 30 anos (1963 - 1993). Além disso, buscando evidenciar o conhecimento praxiológico sustentado pela Documentação Pedagógica e construído pelo OBECI, é narrado o processo de criação desse Observatório, suas ideias centrais, seus processos formativos e o modo como tem desenvolvido o tema da Documentação Pedagógica a partir de Malaguzzi. A partir disso, apresenta-se o conhecimento praxiológico emergente do OBECI a respeito do espaço educativo, dos materiais, da gestão do tempo, da organização do grupo e da relação entre adulto e criança. Tal conhecimento, derivado do trabalho de formação desenvolvido, é restituído desde o ponto de vista dos próprios profissionais das escolas, assim como, do investigador, a fim de explicitar a Pedagogia desenvolvida nesses contextos. Destaca-se que esta tese afirma a Pedagogia como campo de conhecimento, logo, para responder as exigências deste campo, optou-se por um estudo de caso pelos processos de uma investigação praxiológica (FORMOSINHO, 2016; OLIVEIRAFORMOSINHO, FORMOSINHO, 2012). Por fim, conclui-se que uma tese desenvolvida nos domínios da Pedagogia, ou seja, interessada nos processos de transformação do cotidiano praxiológico situado e contextualizado, encontra no modelo narrativo sua melhor forma de expressão enquanto uma tese pedagógica.

Palavras-chave: Pedagogia. Educação Infantil. Desenvolvimento Profissional. Investigação Praxiológica. Documentação Pedagógica. 
FOCHI, Paulo Sergio. Pedagogical Documentation as a strategy for the construction as praxiological knowledge: the case of Observatory of Childhood Culture - OBECI. Tese (Doutorado em Educação). Faculdade de Educação, Universidade de São Paulo, São Paulo, 2019.

\begin{abstract}
This study has the research problem centered on the constitution of a community to support professional development named Observatory of Childhood Culture - OBECI, and in the Pedagogical Documentation as a strategy for the praxiological knowledge construction. The OBECI, created in 2013, is composed by four Early Childhood Education (two public and two private) in the metropolitan region of Porto Alegre - RS and has as central question the organization of day to day life in these institutions evidencing the role of the child in the educational process, inviting to reposition the teacher's role. The strategy that this observatory has used to investigate and form is the Pedagogical Documentation founded by Loris Malaguzzi. Therefore, part of this dissertation is devoted to reconstituting the Malaguzzi's thoughts regarding Pedagogical Documentation from the projects supervised by the pedagogue over 30 years (1963 - 1993). In addition, in order to demonstrate the praxiological knowledge supported by the Pedagogical Documentation and built by the OBECI, the text narrates the creation process of this Observatory, his central ideas, his training processes and the way in which the subject of Pedagogical Documentation has been developed from Malaguzzi. From this, we present the emergent praxiological knowledge of OBECI for the educational space, materials, time management, group organization and the relationship between adult and child. Such knowledge, due to the work training developed, is shared from the point of view of the school's professionals, as well as the researcher, in order to explicit the pedagogy developed in these contexts. Highlighting that this dissertation affirms the Pedagogy as a field of knowledge and to respond all requirements of this field, we chose a case study through the praxiological research process (FORMOSINHO, 2016; OLIVEIRA-FORMOSINHO, FORMOSINHO, 2012). Finally, I concluded that a dissertation developed in the field of Pedagogy, in other words, interested in transformation process of praxiological day to day situated and contextualized, find in the narrative model a better expressive way while a pedagogical dissertation.
\end{abstract}

Keywords: Pedagogy: Childhood Education. Professional Development. Praxiological Research. Pedagogical Documentation. 


\section{SUMÁRIO}

INTRODUÇÃ

Um mesmo caminho para os métodos e para as aspirações ................................. 16

A história que carrego em meus ossos ............................................................ 17

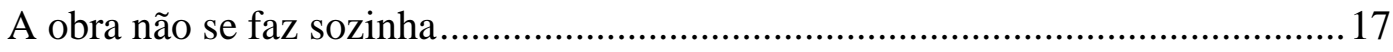

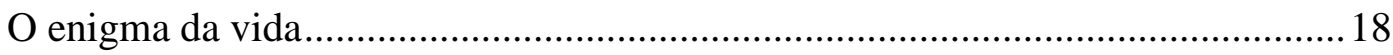

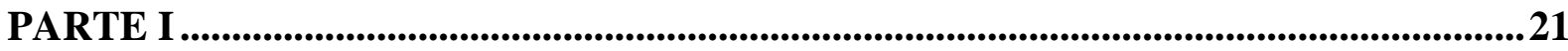

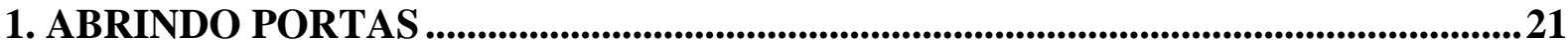

1.1 As perguntas, hipóteses e objetivos da tese ....................................................26

2. TEXTUALIDADE E ABORDAGEM METODOLÓGICA DA TESE ...........................33

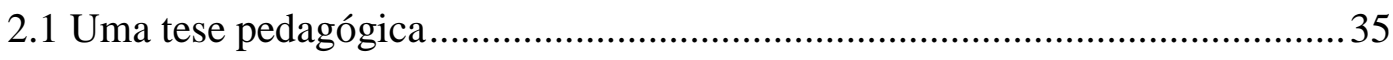

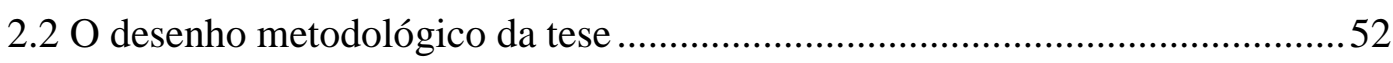

2.2.1 Estudo de caso pelos processos de uma investigação praxiológica ..........53

2.2.2 Análise de conteúdo e triangulação dos dados .......................................55

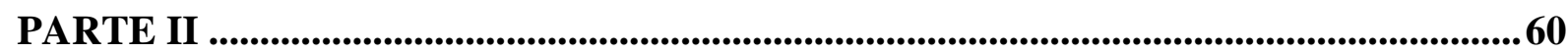

1. A DOCUMENTAÇÃO PEDAGÓGICA EM LORIS MALAGUZZI ...........................60

1.1 Preparar o terreno para construir uma revolução pedagógica: o período entre 1945 e 1963 68

2. A DOCUMENTAÇÃo PEDAGógicA COMO ESTRATÉgia PARA A RENOVAÇÃO DO PENSAMENTO PEDAGÓGICO ........................................................72

3. A DOCUMENTAÇÃO PEDAGÓGICA COMO ESTRATÉGIA PARA ESCUTAR AS CRIANÇAS E CONSTRUIR DIÁLOGOS .........................................................................87

4. A DOCUMENTAÇÃO PEDAGÓGICA COMO ESTRATÉGIA CRIAR PERTENCIMENTO E TRANSFORMAR OS CONTEXTOS.......................................97

5. A DOCUMEnTAÇÃo PEdAgógiCA COMO ESTRATÉgia PARA CRIAR SITUAÇÕES DE APRENDIZAGEM SIGNIFICATIVAS .............................................108 


\section{A DOCUMENTAÇÃO PEDAGÓGICA COMO ESTRATÉGIA PARA COMUNICAR}

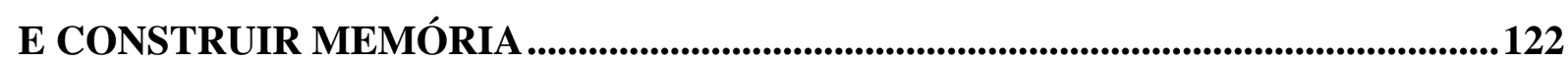

7. A DOCUMENTAÇÃO PEDAGÓGICA COMO ESTRATÉGIA PARA FORTALECER A IDENTIDADE .......................................................................................134

PARTE III

1. O OBSERVATÓRIO DA CULTURA INFANTIL - OBECI: A DOCUMENTAÇÃO PEDAGÓGICA COMO ESTRATÉGIA PARA CONSTRUÇÃO E SUSTENTAÇÃO DO CONHECIMENTO PRAXIOLÓGICO...............................................................................138

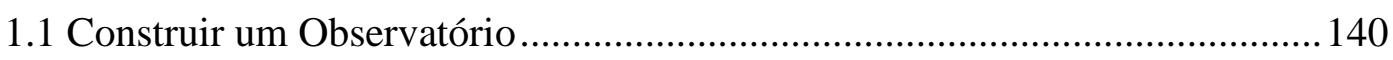

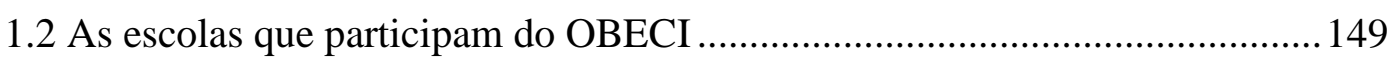

1.2.1 EMEI João de Barro ..................................................................... 153

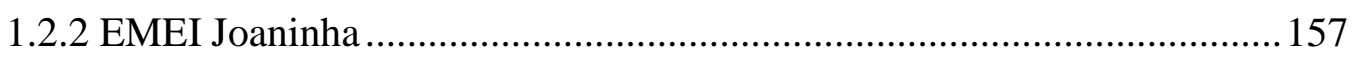

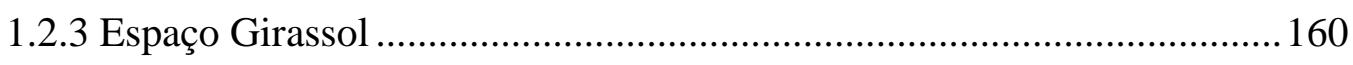

1.2.4 Escola de Educação Infantil Mimo de Gente ........................................ 164

1.3 As ideias assumidas como guias do trabalho ............................................ 167

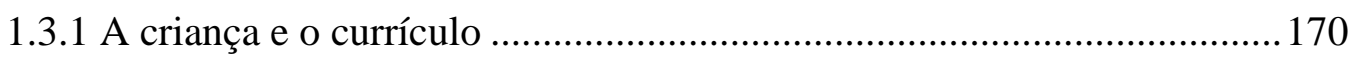

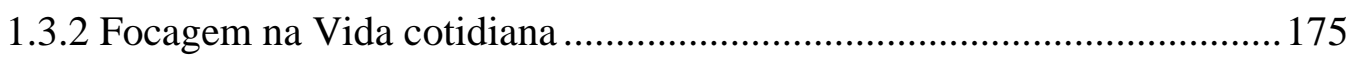

1.4 Os processos de formação no OBECI …..................................................... 180

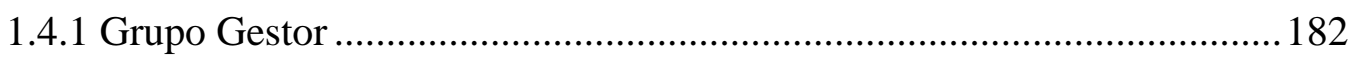

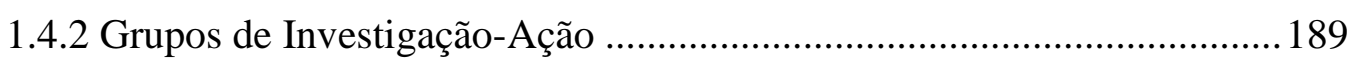

1.4.3 Encontro das Escolas Observadoras ...................................................205

1.4.4 Jornada de Educação Infantil ..........................................................206

1.5 A Documentação Pedagógica no Observatório da Cultura Infantil ................207

1.5.1 A construção dos processos documentais no interior da instituição de

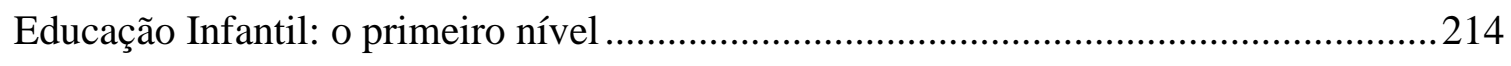

1.5.2 Comunicar os percursos de aprendizagem: o segundo nível..................224

2. ORGANIZADORES DA AÇÃO PEDAGÓGICA .............................................................239 
2.1 O processo de análise e de formação para chegar aos Organizadores da Ação

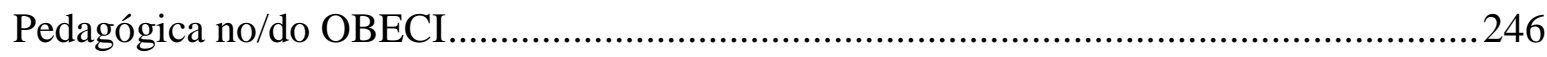

2.2 A organização do Espaço Educativo ..............................................................2. 263

2.2.1 A descentralização do adulto..............................................................265

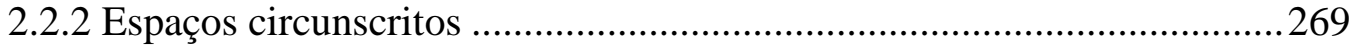

2.2.3 A identidade do espaço comunicada .................................................2273

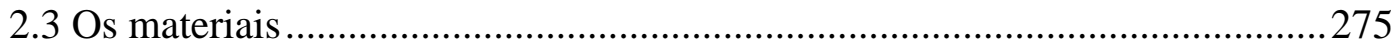

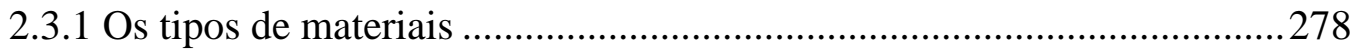

2.3.2 Alguns critérios para escolher os materiais .......................................282

2.4 A organização do tempo......................................................................286

2.4.1 Possibilidades para organizar a jornada .............................................28

$2.5 \mathrm{O}$ trabalho nos pequenos e no grande grupo ..............................................293

2.5.1 Diversos arranjos para os diversos momentos da jornada educativa ......296

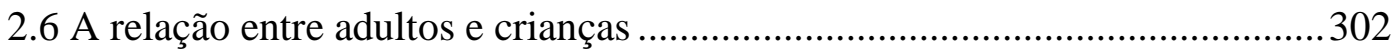

2.6.1 Acolher o universo das crianças ......................................................... 305

2.6.2 Não criar dependência e não criar o abandono........................................307

2.6.3 As interações são o coração da Pedagogia ..............................................308

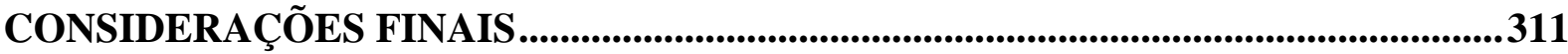

REFERÊNCIAS BIBLIOGRÁFICAS ..........................................................................316

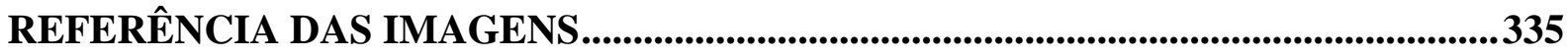

APENDICE A - MODELOS DE TERMOS DE CONSENTIMENTO E AUTORIZAÇÃO

APENDICE B - SISTEMATIZAÇÃO DE CARGA HORÁRIA E ATIVIDADE DOS PROCESSOS FORMATIVOS DO OBECI ................................................................346

APENDICE C - SISTEMATIZAÇÃO DOS CONTEÚdOS DOS PROCESSOS

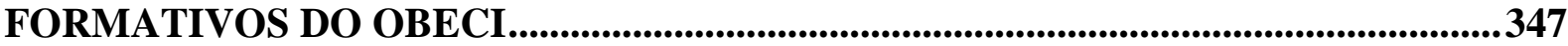




\section{MÃOS PARA SENTIR O TEMPO}
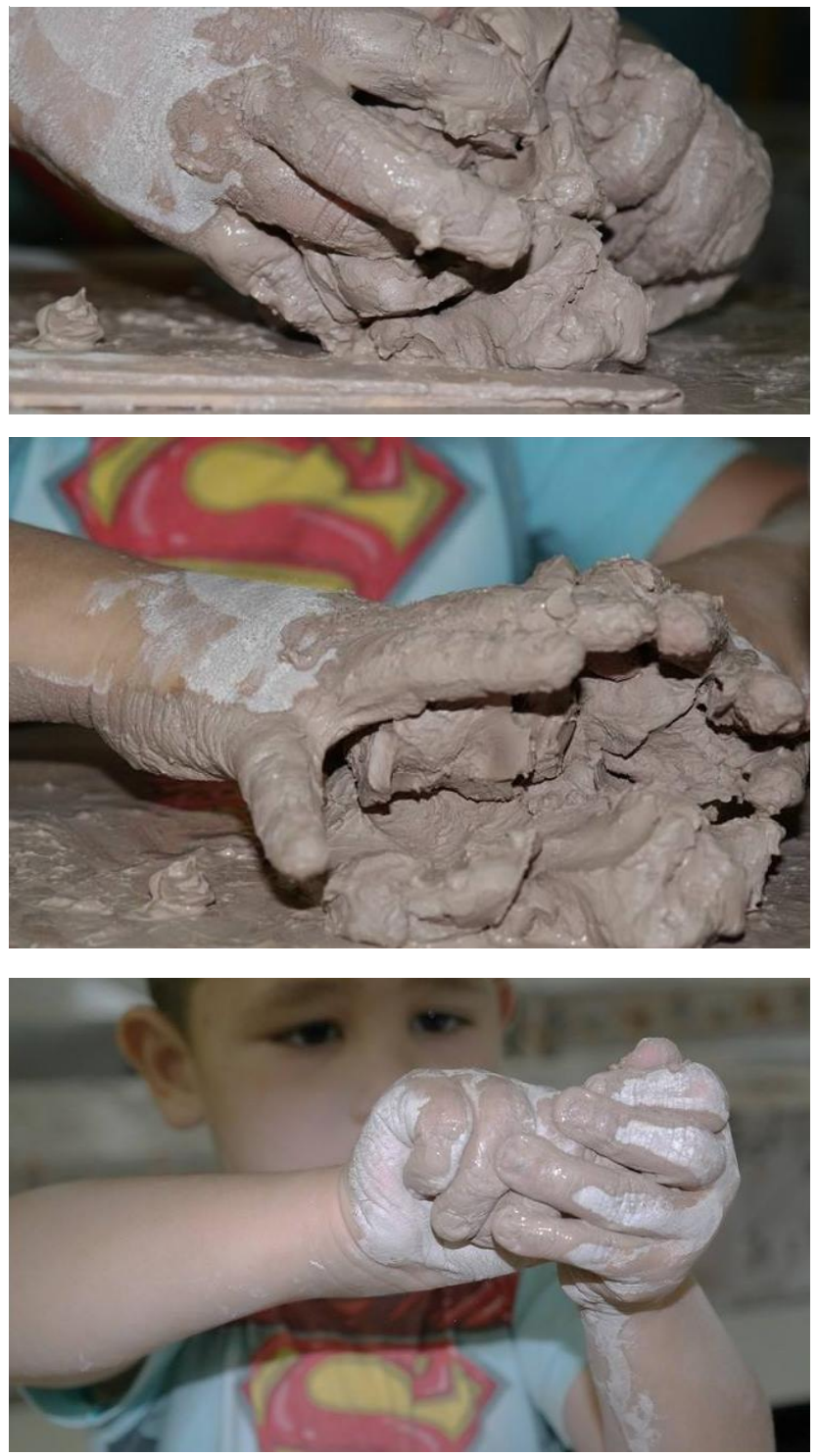

Criança | Pedro, 3 anos Professoras | Viviane, Julia Texto | Viviane Imagens | Viviane EMEI João de Barro
O barro e as mãos de Pedro conversam com intimidade ancestral.

O barro é matéria-prima para

conhecermos a história da civilização e as mãos são a gênese lúdica da história da criança.

Mãos e barro são um binômio fantástico, daqueles que Rodari gosta. Que se fundem criando metáforas visuais esculpidas em um jogo de descobrir ao amassar, apertar, enrolar, construir, desconstruir...

Um binômio que suspende o tempo e envolve Pedro em uma longa jornada de compreender o mundo e a si mesmo através das mãos.

O tempo das mãos do Pedro com o barro também faz com que ele perceba transformações.

'Minha mão tá branca!'

Exclama o menino compreendendo que o tempo do seu gesto muda o estado das coisas. 


\section{INTRODUÇÃO}

Mobilizado pela mini-história que dá abertura a esta tese, retomo um dos ensaios mais brilhantes que li sobre teoria e prática fora dos domínios da Educação. O arquiteto finlandês Juhani Pallasmaa, no seu livro La mano que piensa, relaciona diretamente as mãos com a nossa capacidade de pensar e expõe de que forma na história da nossa civilização as mãos ocupam um papel crucial na transformação da destreza, da inteligência e das capacidades conceituais do homem. Nos oito ensaios que compõem o livro, o arquiteto problematiza o predomínio da palavra em nossa civilização e mostra o quanto a corporeificação dos conceitos ainda é silenciada mesmo que ocupe um papel fundamental na elaboração do conhecimento tácito da vida cotidiana. Também a professora Viviane, por meio de três imagens, narra a aventura de Pedro em compreender que o tempo do seu gesto com o barro transforma o estado das coisas. O tempo, o gesto, as transformações e o conhecimento em processo poderiam compor o campo semântico da trajetória que deu origem a esta tese. Mais além, na metáfora de Palasmaa e de Pedro, reconheço-me e encontro a síntese da compreensão do que é conhecimento nesta investigação.

O conhecimento, em seu escopo cognitivo, emocional e social, forma um todo complexo que não separa a mente do corpo, a razão da emoção. Nesse sentido, é muito difícil apartar a compreensão que construímos a respeito de algo da sua vivência. Não se sabe ao certo os limites do que molda e o que é moldado nessa relação dialógica entre a cultura e o biológico, ou, dizendo de outra forma, dos limites da linguagem que temos para conceituar e a nossa experiência existencial no mundo. Pallasmaa (2012, p. 14) afirma "nem é a cabeça o único lugar do pensamento cognitivo, uma vez que nossos sentidos e toda nossa existência corpórea estruturam, produzem e armazenam diretamente conhecimentos existenciais silenciosos. $\mathrm{O}$ corpo humano é uma entidade sábia”. Nesse sentido, conforme o autor constrói seu argumento sobre a inteireza do conhecimento, também mostra que os limites que estabelecemos entre a racionalização de um conhecimento e a experiência que o gera é, senão, um modo artificial que dispomos para inventar uma dada realidade.

A obra desse arquiteto é, para mim, uma metáfora da tese que apresento. As mãos misteriosas, que trabalham, que se fundem com os olhos e mente, como fala Pallasmaa (2012), é a representação das instituições que, juntas, constituem o contexto de minha pesquisa: o Observatório da Cultura Infantil - $\mathrm{OBECI}^{1}$. Assim como as mãos se desenvolveram ao longo

\footnotetext{
${ }^{1}$ Nesta tese, sempre que me refiro ao Observatório da Cultura Infantil, utilizarei OBECI, Observatório ou a essa comunidade de apoio ao desenvolvimento profissional.
} 
da história da civilização, refinando seu gesto, esse contexto tem se transformado e tem sido transformador em cada uma das instituições que o compõem. E é justamente sobre os processos de transformação que esta tese se interessa e está comprometida.

Por isso, o que compartilho nas próximas páginas é uma jornada de aprendizagem intensa que perseguiu a recursividade entre uma dada circunscrição teórica (as pedagogias participativas), que cria uma dada lente de leitura para essa realidade, e um contexto específico de pesquisa (o OBECI), que se constituiu e se transformou para criar novas realidades. Logo, a tese, enquanto conhecimento que produz, está fertilizada por um encontro pessoal com a complexidade do objeto estudado. Essa é também a síntese do campo em que esta tese se inscreve, o da Pedagogia, que é uma ciência que se constitui entre a teoria, a prática, as crenças e os valores (OLIVEIRA-FORMOSINHO, 2007). Daí de sua exigência em ser tramada na complexidade e na sutileza da experiência, ou, então, "[...] estará fadada a permanecer alienada e especulativa - e pode, na melhor das hipóteses, apenas elaborar relações racionais entre os elementos aparentes" (PALLASMAA, 2012, p. 151).

Além desta Introdução, cujo título é Mãos para sentir o tempo, organizei outras três partes centrais e algumas Considerações Finais, em forma de conclusão desta tese. Cada parte da tese pode ser lida individualmente, considerando que há o desenvolvimento de um argumento central e estruturante para as partes e para a tese como um todo. O texto também pode ser lido em seu conjunto, já que as partes estão entrelaçadas em suas complexidades e recursividades que uma tese situada no campo da Pedagogia exige. A centralidade da tese está na parte III, quando desenvolvo sobre o OBECI e a escrevo no paradigma da narratividade respondendo a exigência de uma peça metodológica nos domínos da praxiologia. Ao mesmo tempo, tanto a parte I, em que apresento os pressupostos que orientaram a pesquisa, como a parte II, em que desenvolvo sobre a construção de um conceito central para a tese que é o da Documentação Pedagógica em Loris Malaguzzi, auxiliam a dar os devidos contornos à discussão central, por isso, é que optei por tal organização.

As mini-histórias que dão título a cada parte da tese são metáforas do cotidiano das escolas $^{2}$ que compõem o OBECI e que, além de simbolizar uma chave de leitura para o texto, são também a voz das crianças e dos professores que se entrelaçam ao longo da tese. Assim, tomando emprestado algumas metáforas que Pallasmaa (2012) constrói em sua obra para tornar

\footnotetext{
2 Embora no Brasil não haja um consenso sobre a terminologia utilizada para nomear a instituição que acolhe as crianças da Educação Infantil (centro, unidade, escola), na tese irei adotar o termo escola, pois, no contexto do Rio Grande do Sul, região em que se realiza a pesquisa, é dessa forma que se nomeia. Reforço que com isso não estou enfatizando a escolarização da Educação Infantil, muito pelo contrário, a defesa da tese é que se reconheça a especificidade desta etapa da Educação Básica.
} 
visível a interação entre as emoções, a imaginação, a inteligência, a produção (a obra, a prática), a teoria e a vida, apresento o modo como estruturei esta tese.

\section{Um mesmo caminho para os métodos e para as aspirações}

Estabelecendo uma grande crítica à arquitetura demasiadamente conceitual, Pallasmaa (2012) convida o leitor a recuperar uma verdadeira e genuína conexão com o que nos propomos fazer para descobrirmos como engendrar os saberes, os conhecimentos, as intuições e os fazeres necessários. O mais importante, segundo Pallasmaa (2012, p. 147), é “[...] estar suficientemente conscientes de suas aspirações e de seus métodos [...]" para não querer caminhar em duas direções opostas ao mesmo tempo.

Nesse sentido, na Parte I da tese, construo a narrativa metodológica ao passo que explicito também meus anseios e aspirações com o texto que aqui se apresenta. Unir as aspirações e os métodos foi mais do que uma estratégia de escrita: antes, foi uma necessidade de traduzir o caminho percorrido para dar a devida coerência que significa escrever uma tese nos domínios que a Pedagogia exige.

Meu compromisso com as crianças e com os professores de crianças tem sido o motor propulsor no meu investimento profissional. É isso que me conecta efetivamente com o objeto estudado nesta tese. Por isso, vou mostrando as razões que me levaram a criar o OBECI ao mesmo tempo que vou dando alguns indícios do que desenvolverei nas partes seguintes em termos da herança teórica e do campo em si.

Do ponto de vista metodológico, explicito as hipóteses, os objetivos, as perguntas que guiam a tese, os instrumentos para a produção dos dados e as abordagens utilizadas para ler e analisá-los. Também invisto em uma discussão sobre o que é escrever uma tese pedagógica e a exigência que esse tipo de tese nos faz na escolha metodológica, por isso da investigação praxiológica.

Assim, nesta primeira parte, ao mostrar os cortes epistemológicos que fiz, explicito as escolhas que tive de tomar para construir uma certa coerência entre os métodos e as aspirações, dizendo de outra forma, entre as escolhas teóricas e o campo de pesquisa em si. 


\section{A história que carrego em meus ossos}

Pallasmaa (2012, p. 150) afirma que não há como fazer algo em um determinado campo sem ter a consciência da tradição em "[...] em seus ossos. [...] A grande dádiva da tradição é que podemos escolher nossos colaboradores”. Daí que, na Parte II, reconstruo o pensamento pedagógico de Loris Malaguzzi sobre o tema da documentação pedagógica.

Malaguzzi é quem funda o conceito de Documentação Pedagógica de que nos valemos no interior do OBECI, estratégia fundamental para o desenvolvimento do processo formativo para essa comunidade. No entanto, na medida em que avanço no desenvolvimento da escrita da tese, senti uma forte necessidade de sistematizar a reflexão sobre o tema da Documentação Pedagógica em Loris Malaguzzi, uma vez que o que temos à disposição na língua portuguesa, italiana, espanhol, catalã e inglesa, não mostra o percurso desenvolvido pelo pedagogo a esse respeito.

Por isso, cartografo um conjunto expressivo de materiais (textos, capítulos de livros, vídeos, entrevistas, revistas, projetos publicados, catálogo das mostras) que tratam do conjunto de trabalhos supervisionados por Malaguzzi ao longo de 30 anos e remonto o modo como o pedagogo foi construindo o conceito de Documentação Pedagógica ao passo que foi também construindo o conhecimento praxiológico junto às escolas de Reggio Emilia.

Anteriormente a essa sistematização, eu já tinha me debruçado sobre esse referencial por muitos anos e esboçado algumas categorias que sintetizavam as ideias centrais sobre o tema da Documentação Pedagógica em Loris Malaguzzi. Assim, na medida em que fui trabalhando com os materiais que utilizei para o desenvolvimento do tema, reiterei algumas ideias iniciais e reconfigurei outras para estruturar o pensamento do pedagogo sobre a estratégia da Documentação Pedagógica. O argumento, por fim, é de que o conceito da Documentação Pedagógica emerge contemporaneamente ao momento em que se constrói o conhecimento praxiológico nas escolas de Reggio Emilia e, por sua vez, é a estratégia para sustentá-lo.

\section{A obra não se faz sozinha}

Sem dúvida, uma das companhias de uma tese é a herança teórica: a tradição, como fala Pallasmaa (2012), que em si constrói a sua própria sabedoria. Mas também há outras companhias, que são aquelas que compõem a própria pesquisa. Não há obra que se faça sozinha. 
O trabalho que constitui a tese propriamente dita é o esforço de colaboração e vontade de muitas pessoas. Esses sujeitos são os que compõem as instituições participantes do OBECI e que estiveram ao longo dos seis anos da pesquisa comprometidos em olhar para os seus cotidianos pedagógicos com vista a transformá-los.

Assim, na Parte III, mostro a constituição do OBECI e o modo como essa comunidade de apoio ao desenvolvimento profissional tem sustentado um dado processo formativo. A construção deste Observatório surge com a finalidade de constituir uma comunidade com profissionais da educação infantil que estivessem interessados em refletir sobre o cotidiano pedagógico e problematizá-lo para transformar.

Nessa parte, trato sobre a constituição e sustentação dessa comunidade de apoio ao desenvolvimento profissional bem como as crenças formativas em que fomos nos inscrevendo. Indico as instituições que compõem o OBECI por meio de cartas de identidade e explicito os diferentes processos formativos que fomos construindo ao longo dos seis anos. Também discuto as ideias centrais que partilhamos, tais como a focagem no cotidiano, a perspectiva de criança e currículo, com isso, mostro a herança teórica que partilhamos. Além disso, como uma das ideias centrais no OBECI é a Documentação Pedagógica, apresento o modo como temos compreendido essa estratégia na tentativa de traduzir como investigamos dentro do Observatório.

Graças ao trabalho densamente documentado ao longo destes seis anos, alguns conteúdos e processos formativos foram emergentes e mostraram a necessidade de refletir e constituir algumas linhas orientadoras para o trabalho pedagógico. A isso chamamos de Organizadores da Ação Pedagógica e, com esses organizadores, restituo o conhecimento praxiológico produzido no interior do OBECI a partir do quadro teórico que temos nos situado e que foi sustentado a partir da Documentação Pedagógica.

\section{O enigma da vida}

Por fim, seguindo as pistas de Pallasmaa (2012, p. 152-153), termino a tese com o propósito de “[...] entrelaçar os vários códigos em uma visão de mundo múltiplo [...]”. O arquiteto recupera a função primeira da arquitetura, dizendo que a ela cabe a função de dar os significados existenciais de como ocupar o mundo (PALLASMAA, 2012).

Encerrar a tese com as aprendizagens que fiz ao longo desse percurso foi o modo que encontrei para compartilhar com os leitores a complexa trama que é investigar, formar e situar- 
se na Pedagogia, pois isso significa estar implicado com a vida em processo de professores, coordenadores pedagógicos, diretores, crianças, e a minha mesmo, como pesquisador. Ao longo da tese, tomando emprestado o conceito de Oliveira-Formosinho (2002a), fui construindo uma arquitetura de diálogos para dar a concretude de como acredito que Pedagogia que comungo pode dar novos significados à formação dos professores e às jornadas de aprendizagem das crianças. Esse é meu enigma de vida, como diz Pallasmaa (2012). E tem encontrado sua forma de resistir a todas as injustiças sociais por meio de uma Pedagogia que verdadeiramente acolha os direitos das crianças e dos adultos que trabalham com elas.

Pallasmaa (2012, p. 153) advoga que “[...] a arte não deveria aumentar ou reforçar a miséria humana, e sim aliviá-la". Acredito, por fim, que a aspiração de uma tese pedagógica não pode ser a de sublinhar a miséria educacional, justificando-se pelo intento de representação da realidade. Ao contrário, o propósito deve ser o de alargar as possibilidades, criar novos horizontes possíveis e investigar ideias e novos modos de nos colocar como investigadores. Além disso, colocar os professores e crianças em uma relação educativa, oferecendo a eles e, sobretudo, comprometido com eles, a construção de possibilidades de uma nova utopia cotidiana. 


\section{UM MESMO CAMINHO PARA OS MÉTODOS E PARA AS ASPIRAÇÕES}

Em uma sessão com material não estruturado, dois grandes amigos partilham da alegria de descobrir como construir com peças de madeira.

Mas a construção que se estabelece não é apenas com os materiais, é com a difícil tarefa de tornar-se grupo, de acolher o outro em suas jornadas de aprendizagem.

Assim que chega, Pedro rapidamente seleciona uma grande quantidade de materiais. Inicialmente, começa a construção sozinho.

Aos poucos, Pyetro se aproxima e manifesta seu interesse em brincar com o amigo por meio de olhares e sorrisos. O pedido é aceito e os dois decidem partilhar a aventura de arquitetar em companhia. Uma ponte ou um caminho... uma travessia para aprender a brincar com o outro.

O caminho construído por Pedro e Pyetro conecta tanto suas aspirações em descobrir o mundo quanto o prazer de partilhá-las entre amigos.

Crianças | Pedro, 2 anos; Pyetro, 2 anos Professoras | Viviane, Julia Texto | Viviane Imagens | Viviane EMEI João de Barro
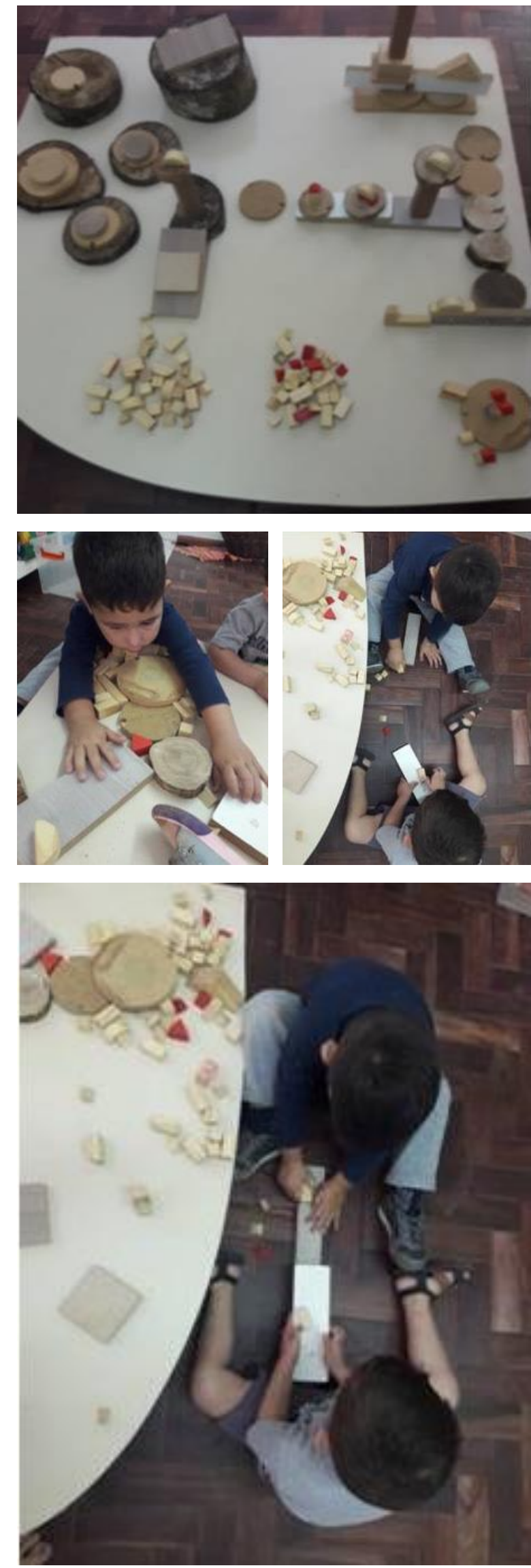


\section{PARTE I}

\section{ABRINDO PORTAS}

Chiara Zamboni (2002, p. 22) inicia o primeiro capítulo da obra El perfume de la maestra: en los laboratórios de la vida cotidiana lembrando que "Hannah Arendt, em uma apresentação radiofônica de 1964, dizia: 'não acredito que possa existir nenhuma experiência de pensamento sem experiências pessoais. Todo o pensamento é meditação, é pensar como consequência de algo"”. A proposição de Arendt me provoca a garimpar as experiências pessoais que foram dando corpo em direção a esta tese. Para além de disciplinas cursadas e textos publicados ao longo dos quatro anos do doutoramento, as experiências vividas no âmbito do trabalho, do meu envolvimento com o campo da Educação Infantil e, também, aquelas que na vida particular foram se atravessando, são parte importante do que veio a se constituir como a sistematização de algo que já vem sendo gestado antes mesmo do meu ingresso no doutorado em 2015.

Inevitavelmente, a circunscrição do tema da tese centrado na constituição de uma comunidade de apoio ao desenvolvimento profissional que se ocupa da documentação pedagógica como estratégia para a construção do conhecimento praxiológico foi interpelada pela minha experiência docente no curso de Pedagogia que se depara com os dilemas e fragilidades da formação inicial de professores que atuarão ou já estão atuando na Educação Infantil. Além disso, foi atravessada pelo contexto social e político que avista retrocessos assustadores que refletem na ideia de sociedade que vínhamos construindo nos últimos anos e, de forma imediata, nos investimentos e garantia da Educação Infantil como direito de todos os meninos e todas as meninas. Logo, isolar a pesquisa desse entorno que afeta a mim, como pesquisador, e aos demais sujeitos envolvidos é uma tarefa praticamente impossível, uma vez que, como já observado por Zamboni (2002, p. 22), “[...] pensamos como consequência de alguma pressão da nossa existência histórica, pelo compromisso próprio e singular com a contemporaneidade". Assim, o que se constitui nesta tese é consequência do meu compromisso com as crianças e com a formação de professores da Educação Infantil e responde às inquietações e perguntas que nos últimos anos venho me fazendo sobre os processos de formação de professores. 
Esse compromisso me leva ao encontro de um campo teórico que ajuda a responder sobre como construir uma escola mais honesta, como nos fala Bruner $^{3}$ (1999 apud STROZZI, 2016, p. 62), e mais amável, como advoga Malaguzzi (apud Hoyuelos, 2006), uma vez que, ao pensar no cotidiano das instituições da Educação Infantil, reconheço a oportunidade de responder à exigência ética para com os direitos das crianças e dos adultos que ali estão (SOUSA; FOCHI, 2017). Daí que, desde meu percurso no mestrado, assumo a Pedagogia como campo de conhecimento, pois percebo que é na relação pensante do acontecer das coisas que conseguimos renunciar aos discursos dominantes. Estou entendendo por "discursos dominantes" aquilo que Dahlberg, Moss e Pence (2003, p. 190) chamam de nexus saber-poder: “[...] aqueles regimes de verdade que tentam determinar para nós o que é verdadeiro ou falso, certo ou errado, o que podemos ou não podemos pensar e fazer".

De fato, a Pedagogia acolhe a natureza do conhecimento em movimento, e, por isso, refletir sobre aquilo que se faz é crucial para responder aos pedidos sociais. Isso porque a escola situa-se em uma lógica de mudança, uma vez que representa uma instituição que, necessariamente, encontra-se situada em uma sociedade que se transforma cada vez mais rapidamente.

Não apenas o interesse pelo campo da Pedagogia se originou em meu mestrado ${ }^{4}$. Naquela ocasião, eu estava interessado em saber sobre as ações dos bebês em contextos de vida coletiva e, por isso, acompanhei, durante pouco mais de três meses, a vida de oito bebês e dois adultos estáveis no cotidiano de um berçário, buscando capturar os “[...] espaços vazios, momentos em que, aparentemente, nada acontece, mas que possuem a síntese e a beleza da vida" (FOCHI, 2013, p. 46).

Embora meu interesse estivesse centrado nos bebês, considerei fundamental a troca ativa com os adultos responsáveis, em especial, com a professora daquele grupo. Por essa razão, após as tardes em que acompanhava o cotidiano dos bebês, ocorreram encontros junto à professora para contrastar reflexões a partir dos registros gerados tanto por mim, quanto por ela. Essa experiência demonstrou-se muito produtiva para o processo formativo daquela

\footnotetext{
${ }^{3}$ Fala realizada por Jerome Bruner nas escolas de Reggio Emilia, citada por Paola Strozzi no texto Um dia na escola, um cotidiano extraordinário In: ZERO, Project. Tornando visível a aprendizagem: crianças que aprendem individual e em grupo. São Paulo: Phorte, 2014. p. 60-79.

${ }^{4}$ FOCHI, Paulo Sergio. “Mas os bebês fazem o quê no berçário, heim?”: documentando ações de comunicação, autonomia e saber-fazer de crianças de 6 a 14 meses em um contexto de vida coletiva. Dissertação (Mestrado em Educação), Programa de Pós-Graduação em Educação, Universidade Federal do Rio Grande do Sul, Porto Alegre, 2013.
} 
professora, de tal modo que, notavelmente suas intervenções em relação às crianças foram se transformando ao longo da pesquisa.

Ao refletir sobre o percurso metodológico vivenciado no decorrer da pesquisa do mestrado, que se estruturou a partir dos princípios da documentação pedagógica, percebi o impacto que gerou para a formação daquela professora e também para mim, como pesquisador. A reflexão, a partir de dados da vida cotidiana, é um mecanismo inerente da Documentação Pedagógica (MALAGUZZI, 1988), tendo em vista que a possibilidade de se colocar diante de observáveis, ou seja, de indícios das práticas realizadas para e com as crianças, permite ao adulto confrontar suas escolhas e problematizá-las para as desnaturalizar. Com isso, cria-se a oportunidade de tomada de consciência ${ }^{5}$ sobre a ação docente a partir da reflexão testemunhal da vida cotidiana.

As relações pedagógicas travadas no interior das escolas de Educação Infantil estão longe de ocupar um plano de consciência, tanto em um nível pessoal (do professor), como em um nível coletivo (do conhecimento pedagógico partilhado). Possivelmente, isso se dê pela novidade que a pedagogia da Educação Infantil representa em termos da invenção da docência e da compreensão em nível da ação e da reflexão sobre a especificidade dos saberes e conhecimentos da área (BARBOSA, 2016). Ainda estão em construção os saberes necessários para atender às demandas dos bebês, das crianças bem pequenas e das crianças pequenas ${ }^{6} \mathrm{em}$ instituições coletivas. Ademais, há de se considerar o distanciamento que a academia - os cursos de Pedagogia e os Programas de Pós-graduação em Educação - tem feito, seja em termos da formação inicial, seja no que se refere à pesquisa sobre o cotidiano da escola e, em especial, dos saberes pedagógicos necessários para levar a ação pedagógica a cabo.

Intrigado com a experiência vivida no mestrado, sobretudo no que diz respeito ao processo formativo vivido pela professora, iniciei, em 2013, um projeto experiencial com outras instituições de Educação Infantil para refletir a possibilidade de levar a cabo os modos de reposicionar os adultos e organizar a vida cotidiana dentro das instituições. Um projeto experiencial, tal como afirma Dewey (2010), dá-se nos modos de interação entre um passado (o que vivi junto à professora na investigação do mestrado), o presente (constituir o OBECI) e o projeto de um futuro (a recursividade do conhecimento que emerge dessa comunidade). É

\footnotetext{
${ }^{5}$ John Dewey, Michael Fullan, Andy Hargreaves, Lawrence Stenhouse, Loris Malaguzzi, José Contreras, Julia Oliveira-Formosinho, João Formosinho e Mônica Appezzato Pinazza também abordam sobre a consciência da prática educativa. Aqui, no entanto, apenas estou indicando sumariamente o percurso do OBECI e, posteriormente, na parte 3 , desenvolverei com profundidade o tema.

6 Conforme terminologias utilizadas em alguns documentos que temos disponível no cenário nacional, a organização etária para a Educação Infantil se divide em bebês, crianças bem pequenas e crianças pequenas.
} 
nesse cenário que nasce o lócus de pesquisa desta tese, o OBECI, um pequeno grupo de escolas com o interesse particular na reflexão e transformação de seus contextos. Uma comunidade que, inicialmente, formou-se pelas equipes gestoras (diretora e coordenadora pedagógica) de três escolas que aceitaram meu convite para reunirem-se sistematicamente e problematizar suas instituições pensando a respeito das dinâmicas da vida cotidiana, da ação pedagógica, do lugar das crianças e do papel do professor, da gestão pedagógica e da formação dos professores. Essa comunidade foi se ampliando e, hoje, envolve cinco instituições, além do trabalho formativo que logo se alargou, abarcando seus professores ${ }^{7}$.

Importante destacar que, ao tempo do início do OBECI, não havia ingressado no doutorado, e isso não foi por acaso. Entendo que uma pesquisa situada na formação de professores envolve uma temporalidade alargada para acolher a amplitude de aspectos que precisam ser considerados para não cair apenas em fabulações de mudanças, ou seja, "[...] slogan inoperante, como a retórica profissional e política vem fazendo" (ROLDÃO, 2001, p. 116). Assim, em 2015, é que ingressei formalmente no doutorado, garantindo um largo tempo para o desenvolvimento da pesquisa, seis anos ao todo.

Há um dilema fundamental e transversal que atravessa esta pesquisa: querer constituirse uma tese que responda à Pedagogia enquanto um campo de conhecimento em si mesmo, que conhece as suas fronteiras, mas não as delimita, porque a sua essência está no diálogo e na integração (OLIVEIRA-FORMOSINHO, 2007; SOUSA, FOCHI, 2017). Portanto, em se tratando da relação pedagógica na Educação Infantil, que busca o nexo "[...] entre o saber o que fazer e aceitar o desconhecido" (CONTRERAS, 2010, p. 247), o desafio é como desenvolver um texto que possa contribuir com a construção do estatuto da Pedagogia, mas que não se transforme em um receituário, reduzindo e simplificando a complexidade do ato pedagógico, e tampouco caia em abstracionismos e jogos discursivos que não apontam horizontes ou pistas a serem pensadas por quem faz Pedagogia.

Oliveira-Formosinho (2007) identifica dois modos de se fazer pedagogia: o modo transmissivo e o modo participativo e, a cada um desses, também identifica características distintas em relação à concepção de criança e de adulto, da visão de mundo e de escola, de compreensão sobre a aprendizagem e a relação educativa. Tais visões não se distinguem apenas por questões epistemológicas, mas especialmente pelo modo que cada uma compreende o

\footnotetext{
${ }^{7}$ Embora cinco escolas participem do OBECI, para fins de pesquisa, são quatro instituições que compõem a investigação: duas públicas e duas privadas. Na Parte III desta tese, explicito com mais detalhes essa questão e a constituição do OBECI.
} 
acesso e a mediação aos processos sócio-histórico-cultural pelos quais crianças e adultos participam (SOUSA, FOCHI, 2017).

De fato, a Pedagogia que busco é aquela situada na família das Pedagogias Participativas, que em sua pluralidade reconhece a criança e o adulto como partícipes da construção das suas jornadas de aprendizagem (OLIVEIRA-FORMOSINHO, 2007). Uma Pedagogia que se desenvolve em companhia sincrônica (com as famílias, com as crianças, com os pares formadores e investigadores) e diacrônica (reconhecendo a herança teórica que nos sustenta) (OLIVEIRA-FORMOSINHO, 2017). Busco um tipo de Pedagogia “[...] que me oriente, que me ajude a construir um sentido do que fazer, que não se apresente como uma resposta metodológica, como um plano de ação" (CONTRERAS, 2010, p. 248). Por isso, uma Pedagogia que não se afasta do saber que nasce da experiência e não se reduza a modelos assépticos e silenciadores. Pelo contrário, “[...] uma pedagogia que não nos roube a pergunta pessoal pelo sentido do que fazemos [...]. Uma pedagogia que, enquanto nos mostra um caminho, não nos tire nenhuma das perguntas que esse próprio caminho vai nos mostrando como respondê-las" (CONTRERAS, 2010, p. 248).

Sendo professor da área da Educação Infantil e formador de professores para essa etapa ${ }^{8}$, meu interesse ao ter realizado esta pesquisa foi o de conhecer os contextos que fazem parte da pesquisa e intervir no cotidiano pedagógico desses contextos, de modo colaborativo e com vistas à transformação, qualificando-os baseado em uma ética que respeita as crianças e os adultos em sua condição aprendente, criadora, pensante e atuante no e com o mundo. Parto do pressuposto de que é preciso evidenciar o papel da criança no processo educativo, convidando a reposicionar o papel do professor nesse processo, a fim de construir um conhecimento praxiológico que responda à complexidade das instituições de Educação Infantil sem que se perca a criança e o adulto na relação educativa.

Assim como a busca pela relação pensante com o acontecer das coisas e dos saberes provenientes da experiência para construir o conhecimento praxiológico, o trabalho que está em curso no OBECI diz muito do que pretendo que esta tese evoque. Ou seja, a crença que tenho de que quando fazemos algo com um determinado grau de consciência, criamos uma atmosfera possível para renunciar aos discursos dominantes e transformar os contextos em que estamos inseridos. Nesse sentido, na sequência, serão apresentadas as perguntas que norteiam este estudo, bem como as hipóteses e objetivos da tese.

${ }^{8}$ Desde 2013, atuo como coordenador e professor da Especialização em Educação Infantil na Universidade do Vale do Rio dos Sinos - Unisinos e, desde 2014, como professor de graduação em Pedagogia na mesma universidade. 


\subsection{As perguntas, hipóteses e objetivos da tese}

Esta tese tem como hipótese que uma comunidade de apoio ao desenvolvimento profissional pode dar suporte ao desenvolvimento profissional e organizacional, ocupando-se da Documentação Pedagógica como estratégia para a construção do conhecimento praxiológico. Nesse viés, entendo por conhecimento praxiológico o conhecimento situado, que articula dialogicamente o sujeito ao seu contexto para responder à complexidade do cotidiano pedagógico. É um esboço da epistemologia da prática construída na dialogia entre o interior e o exterior, ou seja, entre a práxis ${ }^{9}$ (ação situada) e a interatividade com uma dada herança teórica (modelos pedagógicos e pedagogos) e atravessada por uma ética (crenças e valores) (OLIVEIRA-FORMOSINHO, 2007). Por isso, o conhecimento praxiológico não se trata de uma descrição da prática nem da aplicação de uma teoria, mas da elaboração de um conhecimento pedagógico que emerge junto aos práticos e que se sustenta em um quadro teórico para responder à complexidade da transformação da prática educativa cotidiana.

Formosinho e Oliveira-Formosinho (2012, p. 601) advogam que "[...] se nós queremos desenvolver conhecimento sobre a transformação, nós precisamos praticar a transformação [...]"; portanto, trata-se de "[...] agir e investigar a ação para a transformação; formar na ação transformando-a; investigar a transformação para construir o conhecimento praxiológico" (OLIVEIRA-FORMOSINHO, 2016a, p. 18).

Assim, o fenômeno estudado nesta tese é complexo, situado e multidimensional. Isto é, aceita a incerteza e o inacabamento próprio do conhecimento humano e, por isso, não acredita que este seja "[...] um processo linear, acumulativo, que avança iluminando onde estava escuro, ignorando que toda luz também produz, como efeito, sombra" (MORIN, ROGER, DOMINGO, 2002, p. 49-50). Dado seu contextualismo, o caminho desta tese foi se construindo conforme seu próprio caminhar para responder a sua autoprodução e auto-organização sistêmica (MORIN, 2017). Logo, não tem a pretensão de ser um pensamento completo (MORIN, ROGER, DOMINGO, 2002), mas um pensamento que busca construir uma explicação aceitável dos fenômenos que se estuda sem dogmatizar ou compreendê-los como verdades. Contudo, para dar visibilidade aos acontecimentos, interações e conhecimentos produzidos, os processos de transformação investigados são densamente documentados e suficientemente aproximados dos contextos pesquisados (OLIVEIRA-FORMOSINHO, 2016a).

\footnotetext{
${ }^{9} \mathrm{Na}$ sequência eu apresento o entendimento a respeito do conceito de práxis.
} 
Ao tratar da complexidade do fenômeno educativo, "[...] falamos de processos e de práticas de caráter objetivo e subjetivo; depois falamos de transformação e desenvolvimento de sujeitos humanos (crianças e adultos), da sociedade e da cultura, apontando para uma caminhada de aperfeiçoamento cujas ideias são metas, quiçá utópicas” (AMADO, 2013, p. 28). Então, como uma investigação em educação, “[...] o paradigma da investigação em educação não é senão o paradigma emergente... o paradigma da complexidade" (AMADO, 2013, p. 70).

Stenhouse (1998, p. 42) estabelece uma diferença entre investigação em educação, aquela "[...] realizada dentro do projeto educativo e enriquecedora da instituição educativa", e investigação sobre a educação, o modo que "[...] a história, a filosofia, a psicologia e a sociologia [realizam] uma investigação sobre a educação desde o ponto de vista disciplinar que, as vezes acidentalmente, realizam uma contribuição à instituição educativa". Nesse sentido, a presente tese é uma investigação em educação porque, além do que já foi mencionado anteriormente, relaciona-se com a prática da educação e "se estabelece mediante uma teoria da pedagogia em algum nível de generalização ou por uma ampliação da experiência que informa a prática, ou, proporcionando o marco para a investigação na ação como um instrumento para explorar as características de determinadas situações" (STENHOUSE, 1998, p.42). Além disso, em se tratando da relação entre os sujeitos participantes da pesquisa e o investigador, “[...] os professores devem sentir-se intimamente implicados no processo investigado e os investigadores devem justificar-se frente aos docentes, não os docentes frente os investigadores" (STENHOUSE, 1998, p. 42).

Nesse seguimento, é preciso ter cuidado para não usar uma "saia de anzóis", prendendo-se no caminho e arrastando consigo tudo o que há por perto, de tal modo que já não se consiga mais se movimentar. O campo educacional é dinâmico, complexo e, muitas vezes, torna-se difícil conseguir isolar uma temática. Na circunscrição de um problema em uma investigação em educação, é necessário encontrar o justo equilíbrio entre um limite possível de ser analisado e executado em termos de uma pesquisa e de um texto de tese, e, por um outro lado, não perder de vista as relações interdependentes que são próprias desse campo (por exemplo, adulto e criança, desenvolvimento profissional e desenvolvimento da organização, escola e comunidade em que está situada). Por isso, pode-se dizer que, pela sua confluência social, o campo educacional não é um mar de certezas, estático, previsível e totalmente delineável. Pelo contrário, uma investigação em educação é, utilizando uma expressão de Hoyuelos (2006), como lançar-se em um mar de incertezas com pequenos arquipélagos de certeza. 
Desde minha experiência de pesquisa no mestrado, tenho assumido a posição de que o papel da investigação em educação e do investigador, tal qual destaca Alarcão (2001, p. 136), pode ser definido pelo "[...] desejo de conhecer e, se possível, intervir [...]" em uma realidade situada $^{10}$. Comungo, tal como Lewin advoga (1988, p. 41 apud ARAÚJO, 2011, p. 102), da ideia de que "[...] investigação que apenas produza livros não será suficiente". No atual cenário brasileiro, poderíamos dizer que as investigações que apenas servem para alimentar o currículo lattes e que não se comprometem com a transformação dos contextos de pesquisa permanecendo ancoradas em teorias interpretativas que por vezes aniquilam e desempoderam ainda mais a escola e os profissionais - não podem ser suficientes para uma investigação em educação.

Recentemente, compreendi que essa natureza de investigação se situa nos domínios da investigação praxiológica (FORMOSINHO; OLIVEIRA-FORMOSINHO, 2012; OLIVEIRAFORMOSINHO, 2016a; FORMOSINHO, 2016). Essa perspectiva de investigação compreende que, para o cumprimento efetivo dos direitos das crianças e dos profissionais das escolas infantis, é preciso avançar o plano discursivo, ou a retórica nominalista, ou seja, "[...]a manipulação nominal de conceitos sem qualquer influência no quotidiano praxiológico, a adoção do nome sem o respectivo conteúdo praxiológico" (OLIVEIRA-FORMOSINHO, 2016a, p. 19). A definição de praxiologia, como teoria e estudo da práxis, circunscreve essa possibilidade de, simultaneamente, investigarmos o campo, refletirmos e nos engajarmos ética e moralmente com ele (OLIVEIRA-FORMOSINHO, FORMOSINHO, 2012; PINAZZA, 2014; FORMOSINHO, 2016).

Oliveira-Formosinho (2016a, p. 19), ao referir-se à investigação praxiológica, desvela a relação emergente deste domínio investigativo no que tange à formação, à transformação e à informação:

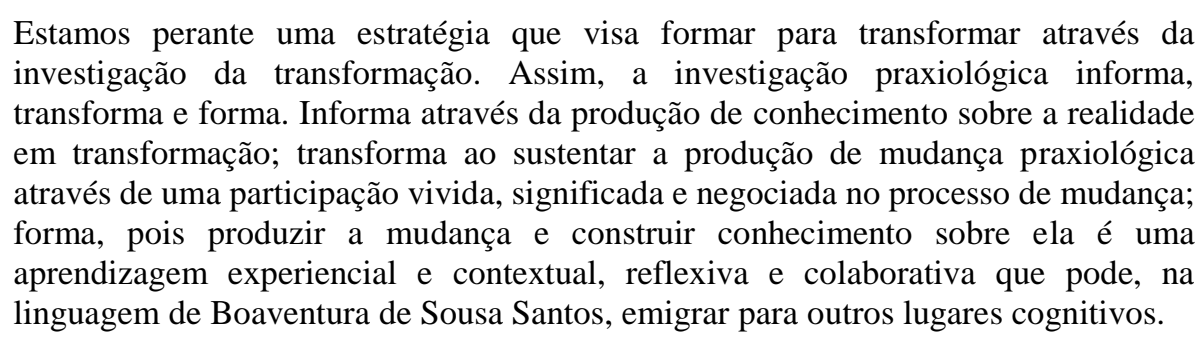

Assim, é no comprometimento com o cotidiano praxiológico das escolas, convidando os profissionais a refletir e transformar os contextos de modo colaborativo, que advogo a

10 Talvez esse seja um pequeno arquipélago de certeza. 
possibilidade de configurar a escola como um lugar privilegiado para a efetivação dos direitos das crianças e dos profissionais. Por isso, para atender a essa complexa tarefa, o modo escolhido para pesquisar em educação foi a investigação praxiológica, uma vez que, assentada em um determinado plano teórico, é possível reconstruir a prática em uma natureza participativa ${ }^{11}$.

Ademais, compreendendo a Pedagogia como campo teórico, no qual situo esta tese, e como uma ciência de natureza praxiológica, esta forma de investigação responde aos objetivos de pesquisa do campo pedagógico. Neste caso, o de compreender a construção do conhecimento praxiológico a partir da estratégia da Documentação Pedagógica no interior de uma comunidade de apoio ao desenvolvimento profissional. Dessa forma, delimitei a problemática de pesquisa centrada (i) na constituição de uma comunidade de apoio ao desenvolvimento profissional, o OBECI, e (ii) na Documentação Pedagógica como estratégia para a construção do conhecimento praxiológico. Para tal, organizaram-se duas grandes questões e outras específicas. A primeira delas questiona:

1. Como constituir e sustentar uma comunidade de apoio ao desenvolvimento profissional como o OBECI?

Essa questão se desdobra em três:

a. Que compreensão construímos de uma comunidade de apoio ao desenvolvimento profissional e como a construímos?

b. De que modo a formação em contexto, em uma comunidade de apoio ao desenvolvimento profissional, comprometida com a reflexão e transformação do cotidiano das escolas de Educação Infantil, contribui para a afirmação das pedagogias participativas?

c. Quais processos e conteúdos formativos emergem em uma formação situada em uma comunidade de apoio ao desenvolvimento profissional como essa?

Vale dizer que não é comum nos contextos brasileiros a constituição de comunidades de apoio ao desenvolvimento profissional. Os espaços de formação que conhecemos em nosso país são os acadêmicos (universidades, faculdades, institutos de educação superior), as empresas privadas que vendem cursos e palestras temáticas, ou organizações não governamentais que criam alguns produtos ou metodologias para implementar ou assessorar redes municipais, estaduais ou privadas de ensino ${ }^{12}$. Por isso, entender a constituição dessa

\footnotetext{
${ }^{11} \mathrm{Na}$ sequência, irei tratar com maior aprofundamento sobre a investigação praxiológica.

${ }^{12}$ Nos últimos anos, diferentes fundações e organizações da sociedade civil sem fins lucrativos têm ocupado um importante nicho na formação de professores. Mônica Knöpker (2018), em sua tese "Fazendo o neoliberalismo
} 
natureza de organização formada por um pequeno grupo de escolas e refletir sobre os desdobramentos é parte estruturante desta pesquisa para posterior análise dos processos formativos nela constituídos e o conhecimento praxiológico emergente dessa comunidade.

Também o modo como a formação foi acontecendo dentro dessa comunidade pode revelar uma possibilidade formativa a outros contextos. Por isso, a descrição densa desse processo objetiva, ao mesmo tempo, (i) partilhar o modo que a pesquisa ocorreu em nível metodológico; (ii) evidenciar os processos formativos vivenciados dentro do OBECI; e (iii) localizar os conteúdos emergentes a partir desta comunidade de apoio. Pressuponho que a cartografia dos conteúdos emergentes dessa comunidade de apoio ao desenvolvimento profissional pode conter indícios importantes para a formação de professores e para a construção do conhecimento praxiológico da Educação Infantil.

A segunda questão propõe:

2. De que modo a Documentação Pedagógica pode ser utilizada como uma estratégia para a construção e explicitação do conhecimento praxiológico?

Essa pergunta se desdobra em duas:

a. Em que medida a Documentação Pedagógica cria, sustenta e explicita o conhecimento praxiológico?

b. Como as comunicações a respeito da vida cotidiana das escolas, decorrentes do processo formativo do OBECI, evidenciam suas concepções de criança, de docência e da Pedagogia?

No Observatório, percebemos a Documentação Pedagógica como uma forma de produzir conhecimento praxiológico sobre a Educação Infantil a partir da oportunidade de aprender a olhar as experiências das crianças na escola e evidenciar o seu papel no processo educativo, convidando a reposicionar o papel do professor e a construir um contexto educativo de qualidade. Nessa estratégia, a comunicação $0^{13}$ das experiências dos meninos e meninas revela a concepção que o adulto tem a respeito das crianças, da docência e da Pedagogia. Assim, tem-

funcionar 'dentro de nós': um estudo sobre a atuação de organizações da sociedade civil sem fins lucrativos na forma(ta)ção docente", analisa os efeitos de verdade que tais grupos pretendem disseminar. Um recente exemplo é a elaboração da Base Nacional Comum Curricular que foi iniciada por um conjunto de professores e pesquisadores universitários e representantes das secretarias estaduais de educação e foi finalizada por um grupo de organizações da sociedade civil lideradas por outra grande corporação "sem fins lucrativos".

13 Estou chamando comunicação todo o material físico que a escola ou o professor constroem a partir de um processo investigativo com as crianças. Essas comunicações, geralmente, são vídeos, painéis, exposições, livros, livretos e apresentações em Power Point. A comunicação é parte da estratégia da documentação pedagógica, mas não é em si a estratégia da documentação pedagógica. Ao longo da tese, isso será amplamente discutido. 
se nessas comunicações a possibilidade de interpretar e reprojetar o trabalho educativo além de explicitar as crenças pedagógicas partilhadas pela instituição.

Uma vez entendido isso, optou-se por reconstruir os conceitos da Documentação Pedagógica em Loris Malaguzzi a partir dos projetos documentados e publicados ao longo de 30 anos de sua trajetória junto às escolas municipais de Reggio Emilia ${ }^{14}$. Assim, ao mesmo tempo que se restitui a constituição do conceito da Documentação Pedagógica, também se restitui o conhecimento praxiológico construído no interior daquelas instituições.

Do mesmo modo, buscou-se nesta tese compreender e restituir o conhecimento praxiológico que no interior do OBECI tem se desenvolvido ancorado pela estratégia da Documentação Pedagógica. Além de revelar nossas concepções de criança, professor e escola, entendo que o conhecimento pedagógico situado pode oferecer elementos estratégicos para a compreensão de uma dada perspectiva de Pedagogia Participativa na Educação Infantil no cenário brasileiro, e torná-la partilhável pode servir como fonte de inspiração a outros contextos.

A Documentação Pedagógica é para o OBECI aquilo que conecta e sustenta os diálogos entre as instituições participantes. Também é o modo pelo qual constituímos a triangulação entre investigação, formação e Pedagogia. Logo, institui-nos como uma comunidade de apoio ao desenvolvimento profissional que constrói e explicita o seu conhecimento praxiológico emergente.

Desse modo, esta tese tem como objetivo geral compreender de que maneira a construção de uma comunidade de apoio ao desenvolvimento profissional que se vale da estratégia da Documentação Pedagógica contribui para a transformação da vida cotidiana das instituições participantes ao mesmo tempo que constrói e explicita um dado conhecimento praxiológico.

Desse objetivo, decorrem os seguintes objetivos específicos:

a) Aprofundar o conhecimento a respeito da constituição de comunidades de apoio ao desenvolvimento profissional;

b) Explicitar os processos formativos vividos no contexto do OBECI;

c) Compreender os processos e os conteúdos emergentes do processo de formação em contexto em uma comunidade de apoio do desenvolvimento profissional;

\footnotetext{
14 As razões da delimitação dos 30 anos serão explicitadas na Parte II desta tese, uma vez que o trabalho de Malaguzzi com as escolas públicas de Reggio Emilia completou quase meio século.
} 
d) Compreender e refletir acerca da Documentação Pedagógica como estratégia de formação, transformação e explicitação do conhecimento praxiológico;

e) Refletir e explicitar o conhecimento praxiológico emergente dos contextos que compõem o OBECI.

Na sequência, seguindo a discussão sobre os aspectos que estruturam o desenho desta investigação, discuto a textualidade da tese, enfatizando o entendimento que construo a respeito de uma tese pedagógica e também a abordagem metodológica, apresentando os dados utilizados bem como os instrumentos e técnicas para a interpretação. 


\section{TEXTUALIDADE E ABORDAGEM METODOLÓGICA DA TESE}

A clássica obra de Umberto Eco, Como se faz uma tese, sustenta que a tese “[...] constitui um trabalho original de pesquisa, com o qual o candidato deve demonstrar ser um estudioso capaz de fazer avançar a disciplina a que se dedica" (ECO, 2008, p. 2). Destaca, ainda, que envolve um esforço em se "descobrir" algo, considerando que, em se tratando de uma tese no campo humanista, obviamente não se faça referência a uma descoberta revolucionária (o autor exemplifica com a teoria da relatividade), mas a "descobertas mais modestas" (ECO, 2008 , p. 2). De qualquer modo, revolucionária ou modesta, é fato que a descoberta, ou a tese, "deve produzir um trabalho que, teoricamente, os outros estudiosos do ramo não deveriam ignorar, porquanto diz algo de novo sobre o assunto" (ECO, 2008, p. 2).

O autor ainda elenca dois aspectos importantes para uma tese "servir" após seu término. O primeiro consiste em pensar a tese como o mote para algo maior, para alguma coisa que possa ser desenvolvida posteriormente (ECO, 2008). O segundo, algo que contribua com o campo, lugar em que os profissionais possam encontrar horizontes, como o autor exemplifica: "que ajude o diretor de um organismo [...] em sua profissão" (ECO, 2008, p. 5).

Ademais, fazer a tese significa ter competência de projetar um percurso, quer seja pela capacidade de recolher, relacionar e reexaminar dados, quer seja pelo modo com o qual compartilha o percurso de pesquisa. Isso significa dizer que "[...] não importa tanto o tema da tese quanto a experiência de trabalho que ela comporta" (ECO, 2008, p. 5). O autor italiano observa, que ao contrário do que se possa imaginar, “[...] não foi sobre economia política, mas sobre dois filósofos gregos, Epicuro e Demócrito" (ECO, 2008, p. 5) a tese desenvolvida por Marx. Ou seja, não sendo um acidente de percurso da pesquisa, ocorre que "Marx foi talvez capaz de analisar os problemas da história e da economia com a energia teórica que conhecemos exatamente porque aprendeu a pensar sobre os seus filósofos gregos” (ECO, 2008, p. 5).

Seguindo as pistas de Eco (2008), parece-me que esta tese atende à exigência de avançar no campo do qual me dedico; convoca os demais pesquisadores da área para pensar a partir do que aqui está sendo discutido; situa-se em um plano maior, ou seja, a pesquisa não foi criada para a tese e nem se pretende que ela esgote por aqui; e, por fim, dá horizontes aos profissionais do campo.

Eco (2008) identifica alguns tipos de tese: a preterida Tese Panorâmica, enfadonha e perigosa, segundo o autor; a Tese Monográfica, preferível pelo seu caráter ensaístico; a Tese Histórica, que situa um conceito neste ou naquele autor, neste ou naquele período de tempo; a 
tese Teórica, "que se propõe atacar um problema abstrato" (ECO, 2008, p. 11) e, quase como uma variação desta; a Tese Experimental, como uma alternativa para as disciplinas aplicadas, “[...] pois há o direito de enfrentar experimentalmente uma questão a fim de obter um método de pesquisa e trabalhar em condições razoáveis de laboratório, com a devida assistência" (ECO, 2008, p. 12). Dentre estas, refere-se à Tese Histórica e à Teórica como possíveis de serem elaboradas na Pedagogia.

Nas descrições dos diferentes tipos de tese tratadas por Eco (2008), confesso ter dificuldade para situar, tanto do ponto de vista teórico quanto metodológico, a tese que aqui apresento. Na perspectiva de Pedagogia que comungo, não se trata de escrever um trabalho que aproxime uma teoria já consagrada a um contexto ou tipo de práticas que dele emergem. Também não considero produtivo o simples apanhado de perspectivas em um dado período histórico ou "igreja teórica", com a finalidade de enunciar conceitos. Tenho a impressão de que, na maioria desses casos, o campo empírico - geralmente apartado do restante da tese - serve apenas para justificar os conceitos, as hipóteses e as teorias já previstas de antemão. Mesmo em perspectivas mais próximas do paradigma pós-estruturalista, a minha suspeita é que a empiria serve somente como disparador para discursos elitistas, para não dizer egoístas, que, no fim, servem apenas ao próprio pesquisador ou a pequenos e seletos grupos distantes da escola ${ }^{15}$.

No percurso de elaboração desta tese, refletindo sobre as provocações de Eco (2008), fui remontando alguns argumentos que não apenas podem me ajudar a defender esta pesquisa como uma tese, mas de tipificá-la como uma tese pedagógica ${ }^{16}$. Por isso, mobilizado em (i) contribuir com o campo da Pedagogia, em especial, a Pedagogia da Infância; (ii) evidenciar aspectos que considero fundamentais para aqueles que, assim como eu, estão interessados em compreender e transformar os contextos de Educação Infantil e acreditam na formação de professores contextualizada à possibilidade desta transformação; (iii) construir a tese a partir de contextos reais, do envolvimento com o campo e de um trabalho prolongado, que, ao mesmo tempo que delimita um recorte de análise para a tese, não impede a continuidade do trabalho que está envolvido; (iv) fazer visível o percurso da tese tanto no nível investigativo quanto no nível formativo; e (v) pensar o quadro teórico que já temos constituído no campo da(s) Pedagogia(s) da Infância como orientação do trabalho investigativo, formativo e da ação

\footnotetext{
${ }^{15}$ Não é objetivo aqui fazer um apanhado dos tipos de pesquisa em educação que temos produzido no Brasil nos últimos tempos. A crítica que faço é a partir do campo teórico em que me situo e, ao longo da tese, o explicito.

${ }^{16} \mathrm{E}$ talvez, com isso, abrandar meu problema em não me contentar apenas em produzir a tese, mas de contribuir efetivamente com o estatuto da Pedagogia.
} 
pedagógica em instituições de Educação Infantil, respondo à questão “qual é minha tese”, antes afirmando que esta é uma tese pedagógica.

Assim, na seção seguinte, assinalo alguns argumentos que me mobilizam a pensar este trabalho como uma tese pedagógica. Ao mesmo tempo, situo em termos de paradigma investigativo em que assento o ideário metodológico e epistemológica desta pesquisa.

\subsection{Uma tese pedagógica}

Uma tese pedagógica se assenta no âmbito das investigações praxiológicas ${ }^{17}$ (FORMOSINHO, OLIVEIRA-FORMOSINHO, 2012; OLIVEIRA-FORMOSINHO, 2016a; FORMOSINHO, 2016), ou seja, em "um modo de fazer investigação que responde simultaneamente à necessidade social da transformação que beneficia as pessoas e os contextos e encontra modos de investigar essa transformação e produzir conhecimento" (FORMOSINHO, OLIVEIRA-FORMOSINHO, MONGE, 2016, p. 9). Fazer uma tese pedagógica requer comprometimento com a transformação dos contextos, pois se entende que é na investigação das transformações que é produzido o conhecimento que interessa à Pedagogia, o conhecimento praxiológico.

Oliveira-Formosinho (2016a), ao situar a investigação praxiológica como uma possibilidade de pesquisa e promoção de processos transformativos, sinaliza que essa modalidade investigativa se aproxima do arcabouço teórico da investigação-ação. Alerta, no entanto, que a crítica que tem sido feita a essa última metodologia é “[...] a de que é mais ação do que investigação, [...] de que a natureza participativa dos processos é, muitas vezes, mitigada" (OLIVEIRA-FORMOSINHO, 2016a, p. 18). Por isso, para evitar essas armadilhas de perder-se na ação esquecendo os processos elaborados para ou com a ação, a autora chama atenção para a ideia de que “[...] é a documentação densa dos processos transformativos que providencia a informação necessária para que possam ser estudados" (OLIVEIRAFORMOSINHO, 2016a, p. 18) em uma investigação praxiológica. Também, é uma abordagem

\footnotetext{
17 Ao escolher a Pedagogia como campo de conhecimento a ser desenvolvido o estudo, desde o mestrado, deparome com as questões metodológicas. Nos trabalhos de tese e dissertação acessados, observo que há uma forte tendência na utilização de metodologias oriundas de outros campos (Sociologia, Antropologia, Filosofia, Psicologia, Artes). Logo, os textos produzidos estruturam-se de acordo com essas áreas. Em minha dissertação, escolhi uma estratégia pedagógica (Documentação Pedagógica) para utilizá-la como metodologia de pesquisa e escrevi um texto com algumas características que considero pedagógicas. $\mathrm{Na}$ tese, busco a investigação praxiológica como alternativa para tratar dos processos de transformação, que, do meu ponto de vista, são o tipo de metodologia que mais se enquadra no campo da Pedagogia, pois há um exercício em qualificar as ideias sobre um texto pedagógico e de exercitá-lo na própria escrita da tese.
} 
metodológica que contribui " [...] no sentido de melhor cumprir o desiderato de fundir a ação e a investigação, incluindo as vozes dos participantes" (OLIVEIRA-FORMOSINHO, 2016a, p. $18)$.

Em uma revisão realizada sobre os paradigmas do conhecimento nas investigações da práxis educativa, João Formosinho (2016) chama atenção para os limites da perspectiva aplicacionista e positivista nas pesquisas em educação. $\mathrm{O}$ principal é que tal modo de compreender a realidade, além de simplificá-la, não se centra nos contextos e nem nos processos, mas em generalizações insuficientes que são apresentadas como verdades.

A resposta para a complexidade da investigação em educação para esse autor está na investigação praxiológica, e, assim, destaca oito ideias centrais sobre esse domínio investigativo $^{18}$, a saber (FORMOSINHO, 2016):

a) Assumir a complexidade da experiência das crianças e do ato educativo;

b) Reconhecer o holismo do ser humano;

c) Reconhecer que a ação humana é contextual e situada culturalmente;

d) Reconhecer que a ação humana não é completamente previsível;

e) Reconhecer a conectividade no desenvolvimento humano;

f) Reconhecer que o rigor está na proximidade e não na distância;

g) Assumir a intersubjetividade da educação;

h) Assumir como variável central a perspectiva pedagógica desenvolvida nos contextos pesquisados.

A respeito dessas ideias, sumariamente, pode-se dizer que o holismo a que Formosinho (2016) se refere, acolhe a complexidade e renuncia as simplificações ou divisões tanto em relação à noção das crianças e adultos como à noção da ação educativa. Segundo o próprio autor, "uma visão holística da educação é o respeito pela complexidade das identidades da pessoa humana [...], pela sua experiência de aprendizagem do mundo e de si próprias, e pela complexidade do ato de educar" (FORMOSINHO, 2016, p. 21).

Nesse sentido, para investigar em educação é preciso conjugar esforços para construir uma compreensão das dinâmicas “[...] recursivas entre as partes [...]” (FORMOSINHO, 2016, p. 23), não reduzindo assim a um processo somatório, pois “[...] o todo não assimila as partes, e a soma das partes não substitui o todo" (FORMOSINHO, 2016, p. 22). Logo, o autor destaca que a construção social dos contextos os localiza em um dado recorte espaço-temporal e uma

${ }^{18}$ Essas ideias foram extraídas e sintetizadas a partir de um montante de cinco páginas em que Formosinho (2016, p. 21-26) explicita de forma ampliada cada uma delas. 
dada cultura. Por isso, para atender a essa dimensão situada, é necessário compreender ecologicamente a aprendizagem, uma vez que "a aprendizagem de cada criança, e do grupo, a aprendizagem dos profissionais, desenvolve-se nos seus contextos plurais e sociais e nas suas interações" (FORMOSINHO, 2016, p. 23).

Da mesma forma, considerar a construção social da realidade e agência dos sujeitos implica reconhecer sua imprevisibilidade, mesmo que parcial. É próprio da linguagem não conseguir explicar a ação humana, tampouco temos como categorizar e antecipar suas ações. Assim, do mesmo modo que as ações humanas não são totalmente previsíveis, “[...] a aprendizagem e o progresso das crianças e dos profissionais também não o são" (FORMOSINHO, 2016, p. 23).

Por certo, diferentemente do paradigma positivista que confere rigor no distanciamento, aqui, a proximidade é um sine qua non para o investigador (FORMOSINHO, 2016). Quanto maior for a proximidade do investigador com o contexto investigado, melhor poderá compreender as dinâmicas das situações educativas. Bogdan e Biklen (1994, p. 48) também chamam atenção para o fato de que "os investigadores qualitativos assumem que o comportamento humano é significativamente influenciado pelo contexto em que ocorre"; assim, é somente na proximidade que o investigador pode compreender o modo pelo qual, mutuamente, contexto e sujeitos se influenciam.

Dessa maneira, "o conceito de rigor na investigação praxiológica é o oposto [do paradigma positivista] - baseia-se na proximidade, na interação intensa com os atores, na colaboração com eles e na longa imersão do investigador/formador no contexto" (FORMOSINHO, 2016, p. 24). Somente assim é possível documentar densamente as diferentes vozes para poder narrar a complexidade do fazer educativo. Como o próprio Formosinho (2016, p. 22) destaca, "esquecemo-nos de que a maneira como vemos o mundo é aprendida": é na proximidade que também se assume o valor subjetivo das lentes do investigador. $\mathrm{O}$ conhecimento que se produz, portanto, é também subjetivo, mas,

\footnotetext{
na triangulação das vozes dos atores [...], ao longo dos tempos do cotidiano de aprendizagem, e a triangulação de instrumentos pedagógicos de observação que interrogam a documentação pedagógica e a fazem falar sobre a aprendizagem experiencial, situada, contextual, cultural, são de importância primordial para conseguir uma apreciação mais autêntica das aprendizagens transformativas, dos seus processos e realizações (FORMOSINHO, 2016, p. 25).
}

Por fim, um aspecto fundamental nesta abordagem metodológica é considerar em qual modo de fazer pedagogia se estabelece o contexto, uma vez que as Pedagogias Transmissivas 
e as Pedagogias Participativas têm visões de mundo, de ser humano e de conhecimento drasticamente diferentes (OLIVEIRA-FORMOSINHO, 2007).

Não considerar esse aspecto é não entender a estreita relação entre uma dada escolha pedagógica e o que ela provoca como processo educacional. É considerar que a Pedagogia é neutra. Portanto, "a situacionalidade da ação educativa que convoca o contexto e a cultura pedagógica para a sua coerência e compreensão requer que a intencionalidade educativa analise, compreenda e interprete a variável contextual central - a pedagogia desenvolvida" (FORMOSINHO, 2016, p. 26). Quando se explicita a Pedagogia, é lhe dado um nome, afastando-se dos riscos e perigos que há nas pedagogias anônimas (FORMOSINHO, 2007), nas pedagogias oficiosas do sistema (FORMOSINHO; MACHADO, 2005), nas pedagogias sem nome (FORMOSINHO, 2018), que se centram na "racionalização burocrática da vida social, construindo progressivamente a pedagogia burocrática como pedagogia ótima" (FORMOSINHO, 2018, p. 20).

Um outro aspecto que me faz creditar maior importância para as investigações praxiológicas é o alerta que Cochran-Smith e Lytle (2002, p. 138) fazem para o fato de que "a maior parte da investigação educativa é percebida pelos docentes como algo irrelevante para o trabalho de cada dia, logo suas crenças na investigação são contaminadas e, assim, não aceitam que a investigação possa ser relevante e nem que eles mesmos possam ser investigadores”. Sacristán (2012), ao analisar o campo das tendências investigativas na formação de professores no ideário pós-positivista, compreende a Pedagogia como uma ciência que não se reduz à técnica pedagógica: “a prática pedagógica é uma práxis, não uma técnica. E investigar sobre a prática não é o mesmo que ensinar técnicas pedagógicas” (SACRISTÁN, 2012, p. 95). É, então, a partir dessa afirmação que se funda a metáfora do professor reflexivo (Dewey e posteriormente Schön), ou do professor investigador (Stenhouse), superando uma visão receptiva e aplicacionista.

Sacristán (2012) também tenciona a relação teoria e prática que, a meu ver, fornece advertências pertinentes a serem problematizadas quando se reflete a respeito da formulação de uma tese pedagógica. A primeira dessas advertências é "se com a reflexão busco a prática, é porque a ciência não pode me dar. Esta afirmação deveria levar-nos a pensar, a nós que acreditamos estar fazendo ciência" (SACRISTÁN, 2012, p. 96). Nesse sentido, questiono-me: se produzir uma tese é contribuir com o estatuto de um campo, o que é produzir ciência no campo pedagógico? 
A respeito disso, Sacristán (2012) diferencia ciência de pensamento e aponta que todos nós, em um primeiro nível, atuamos de acordo com o que pensamos. No caso específico que o autor está discutindo, sobre o que e como estamos produzindo ciência na formação de professores e qual seu valor para os próprios professores, comenta: “[...] o grande fracasso da formação de professores está em que a ciência que lhes damos não lhes serve para pensar" (SACRISTÁN, 2012, p. 99).

Formosinho (2001) e Oliveira-Formosinho (2005) afirmam que na formação dos professores estão envolvidas a experiência como alunos, a formação profissional e, dentro dela, a prática pedagógica (estágio). Logo, na experiência de ser aluno por tantos anos, aprende-se, mesmo que de maneira implícita, sobre ser professor. Como destaca Oliveira-Formosinho (2005, p. 4), “o posterior processo de formação profissional poderá desconstruir e reconstruir essas aprendizagens ou simplesmente estabilizá-las". No entanto, para desconstruir e reconstruir as aprendizagens que sustentam a docência, é preciso superar os abstracionismos e generalismos da formação profissional.

Agimos pelo que pensamos, não pela ciência que nos deram, e isso significa que estamos agindo de acordo com as nossas crenças e valores; agir pela ciência - e a ciência pode nos fazer pensar - significa mobilizar o pensamento para modificar o nosso modo de agir (SACRISTÁN, 2012). Porém, o próprio Sacristán (2012, p. 100) observa que "o pensamento não explica a ação, o pensamento é parte da ação, mas não é toda a ação. [...] Os professores, por mais que pareça estranho, são pessoas que sentem e querem... não só pensam". Assim, significa que existe outra parte da ação, que não é o pensamento, mas sim a "vontade" que o outro tem.

Um processo investigativo que visa à construção do conhecimento praxiológico não pode perder de vista as vontades que motivam os professores a agir do modo que agem, para então, convidá-los a transformar seu cotidiano pedagógico, uma vez que “[...] para educar é preciso que se tenha um motivo, um projeto, uma ideologia. Isso não é ciência, isso é vontade, é querer fazer, querer transformar. E querer transformar implica ser modelado por um projeto ideológico, por um projeto de emancipação social, pessoal, etc" (SACRISTÁN, 2012, p. 100).

Aliás, Bruner (2001) já abordou isso ao discutir sobre a relação entre agência e colaboração como os "inimigos da hegemonia", e afirma que "o objetivo da agência e da colaboração competentes no estudo da condição humana é atingir não a humanidade, mas mais a consciência. E mais consciência sempre implica mais diversidade" (BRUNER, 2001, p. 97). A emancipação social profissional desejada no interior de uma instituição se dá, assim, na 
intersecção do acolhimento das diferenças e do reconhecimento da capacidade de agir de cada professor.

A partir dos argumentos que vêm sendo apontados, pode-se afirmar que o campo pedagógico é complexo por isso torna-se difícil de estabilizar princípios ou verdades homogêneas e, dada a sua dinamicidade, árduo de ser traduzido. Mas, ao mesmo tempo, requer uma explicitação pedagógica para emancipar e melhor compreender o conhecimento profissional prático.

Ao que tudo indica, a tendência para responder a essa complexidade implica a superação de uma visão de homem reativo, passando ao reconhecimento da agência do homem como criador. Além do mais, estabelece um diálogo respeitoso entre o conhecimento já sistematizado com o produzido pelos práticos, visto que "a formação de profissionais tem um referencial central na epistemologia da prática" (OLIVEIRA-FORMOSINHO, 2016a, p. 20), e isso indica uma modalidade específica de produção de conhecimento. Ademais, o conhecimento é entendido em sua provisoriedade, ou seja, é preciso a aceitação dos limites na representação cognitiva da realidade.

Essa relação entre homem e conhecimento, ao mesmo tempo em que manifesta a efemeridade sobre os processos cognoscentes, também põe valor ao conhecimento tácito. Nesse sentido, as reflexões de Sacristán $(2012$, p. 96) apontam para outra particularidade de se fazer uma tese pedagógica: "não há conhecimento firme, seguro, que possibilite uma prática correta, porque a prática deve ser inventada pelos práticos. Quer dizer, a prática não pode ser inventada pela teoria [...]. O problema é saber o papel que cumpre a teoria na invenção da prática".

Se, por teoria, entendermos a definição apontada por Rinaldi (2012, p. 113-114), talvez seja possível encontrar o lugar de um determinado tipo de teoria na invenção da prática:

[...] compreender significa elaborar uma interpretação, o que chamamos de "teoria interpretativa", que é uma teoria que atribui significado às coisas e eventos do mundo, uma teoria no sentido de uma explicação satisfatória... apesar de também ser provisória. É algo mais do que uma simples ideia ou grupo de ideias; deve ser agradável e convincente, útil e capaz de satisfazer às nossas necessidades intelectuais, afetivas e estéticas. Ou seja, deve nos dar uma sensação de concretude que gera uma sensação de beleza e satisfação. De certa maneira, uma teoria, se possível, deve ser agradável para os outros também e precisa ser ouvida pelos outros. Isso tona possível transformar um mundo que é intrinsecamente pessoal em algo compartilhado: o meu conhecimento e a minha identidade também são construídos pelo outro. Compartilhar teorias é uma reposta à incerteza e à solidão.

Assim, teoria é aquilo que nos dá um lugar para as coisas do mundo que estavam aí, ocupando espaços anônimos ou invisíveis. Ao passar para o campo da possibilidade de ser explicada, compreendida, nomeada, mesmo que provisoriamente, abre janelas para outros 
mundos possíveis (BRUNER, 1997a). Nesse sentido, a teoria é, inevitavelmente, a prova de que não estamos sozinhos. Somos interpelados pelas pessoas, pelas coisas - são nossos intercessores, segundo Deleuze (1992) - para podermos criar um conceito, uma explicação. Mesmo que não percebamos, existe algo que emerge da nossa experiência no e com o mundo, que nos mobiliza a atribuir significados. Por isso, o papel da teoria na construção da prática, tendo a herança pedagógica do século XX como fonte (OLIVEIRA-FORMOSINHO, KISHIMOTO, PINAZZA, 2007), é o de restituir e sustentar a visão de mundo, de homem (especialmente a de criança) e de conhecimento.

Ainda, no âmbito da relação entre o investigador e os contextos, nos domínios da práxis, faz-se necessário o alargamento da concepção de investigador. Como afirma Formosinho (2016, p. 29), "na investigação praxiológica, o investigador é o principal instrumento da pesquisa e um ator essencial para a transformação", pois, ao mesmo tempo, desempenha o papel de investigador e de formador. Por sua vez, como um princípio ético, é de fundamental importância que este declare suas intenções (FORMOSINHO, 2016) ${ }^{19}$.

Isso coaduna com o que Bogdan e Biklen (1994, p. 47) afirmam sobre o papel do investigador: "na investigação qualitativa, a fonte direta de dados é o ambiente natural, construindo o investigador o instrumento principal”. Também Bogdan e Biklen (1994, p. 48) alertam que "para o investigador qualitativo divorciar o ato, a palavra ou o gesto do seu contexto é perder de vista o significado" e recorrem a Clifford Geertz para ampliar suas ideias, reiterando que "uma boa interpretação do que quer que seja - um poema, uma história, um ritual, uma instituição, uma sociedade - conduz-nos ao coração daquilo que pretende interpretar" (GEERTZ, 1973 apud BOGDAN; BIKLEN, 1994, p. 48).

No caso específico desta tese, o investigador assume esse papel de importância como um dos instrumentos da pesquisa, tanto do ponto de vista do papel de formador, que promove e sustenta os processos de transformação, como no papel de investigador, para poder analisar, compreender e restituir o conhecimento praxiológico produzido. A proximidade do investigador, como já afirmado, é ponto fulcral na investigação praxiológica.

Como já discutido, a investigação educacional praxiológica estuda os processos da transformação educativa; logo, a práxis é o lócus da investigação (OLIVEIRAFORMOSINHO, 2016a; FORMOSINHO, 2016). Práxis é “a ação educativa situada [...], fecundada em saberes teóricos e investigativos, assumindo um sistema de crenças, valor e ética.

\footnotetext{
${ }^{19}$ No Apêndice A, constam os modelos de Termos de Consentimentos livres e Esclarecidos, além do Termos de Acordo feito com as escolas participantes deste estudo. Estes foram alguns dos cuidados éticos desta pesquisa.
} 
A práxis é uma ação complexa que procura no cotidiano a ética das relações e das realizações, da participação de todos os atores envolvidos" (FORMOSINHO, 2016, p. 27).

Assim, o conhecimento praxiológico é o que se busca com esse tipo de investigação. Isso significa a explicitação das teorias, a contextualização da prática e a sustentação nas crenças e valores. Segundo Formosinho (2016, p. 28), "é uma práxis que resulta da integração de saberes, técnicas, e rotinas, com as emoções, sentimentos e afetos que envolvem toda a ação humana". Essa categoria de conhecimento, o praxiológico, é o que sustenta a práxis e, ao mesmo tempo, que emerge dela. É o que orienta e ajuda a explicitar as crenças pedagógicas, as concepções teóricas e a reforçar a visão democrática da construção do conhecimento.

Ainda sobre o que tange ao papel do investigador e do investigado, compartilho o que Sacristán (2012, p. 94) adverte: “os professores trabalham, enquanto nós fazemos discursos sobre eles. [...] Esta situação sociológica, política e epistemológica pode ser uma explicação do que tem sido a investigação sobre professores". Acredito que, em se tratando de um trabalho como este, há de se superar o discurso sobre os professores e passar a produzir com eles. Aliás, Stenhouse (1998) já advertia a respeito dessa questão ao diferenciar uma investigação em educação de uma investigação sobre educação. Além disso, o investigador deve assumir uma posição implicada, dialogada e cooperativa com os professores, acolhendo e criando um espaço legítimo em que ele possa revistar sua própria experiência. Por isso que Goodson (2007a; 2007b), ao tratar do capital narrativo, advoga sobre a promoção da voz do professor e não apenas de escutá-la:

[...] em outras palavras, o modo como as pessoas teorizam, projetam, historiam sua vida e suas orientações, será uma nova forma de capital cultural que inaugurará um novo modo de reprodução social. É isto que procuro e que penso ser uma linha de pesquisa animadora e instigante, de estímulo e curiosidade, não apenas porque é de interesse acadêmico para mim, mas porque tem um potencial significativo para alterar as modalidades sociais de mudança (GOODSON, 2007a, p.80).

Assim, narrar também pode ser uma forma de negociar significados para nossas vidas e de produzir teorias, projetando futuros. E produzir esse capital narrativo, em termos pedagógicos, poderá ser uma alternativa de mudança na medida em que os professores e as crianças, na escola, se sentirão engajados ética e moralmente aos seus discursos, sentimentos e ações.

Em nosso percurso no interior do OBECI, o capital narrativo está diretamente ligado à estratégia da Documentação Pedagógica. Para os professores, coordenadores e gestores, comunicar as jornadas de aprendizagem dos adultos e das crianças representa a construção de 
uma trama de sentidos que nos ajuda a compreender a cultura da infância e a cultura pedagógica, mais do que explicar.

Morin (2017, p. 51) alerta que "explicar não basta para compreender. Explicar é utilizar todos os meios objetivos de conhecimento, que são, porém, insuficientes para compreender o ser subjetivo". Por assim entender, não documentamos para construir um acúmulo de materiais textuais e imagéticos sobre as crianças, mas documentamos para construir um capital narrativo que nos ajude a compreender a aventura do conhecer que os meninos e meninas fazem desde sua chegada ao mundo, que professores instituem na sua prática pedagógica e que se transforma em um testemunho ético, cultural e pedagógico. Nesse sentido, "a compreensão humana nos chega quando sentimos e concebemos os humanos como sujeitos; ela nos torna abertos a seus sofrimentos e suas alegrias. [...] É a partir da compreensão que se pode lutar contra o ódio e a exclusão" (MORIN, 2017, p. 51).

Morin (2017) defende ainda que tentar compreender a humanidade envolve superar as separações e distanciamentos para, então, conjugar uma pedagogia conjunta. Segundo o filósofo, fazer isso é a "iniciação à lucidez", ou seja, sujeitarmos um mesmo acontecimento a diferentes pontos de vista para adentrarmos nas diferentes camadas e possibilidades que há em um mesmo acontecimento cria um contínuo recomeço, é regenerativo.

O distanciamento que, com frequência, percebe-se nas investigações entre quem faz a pesquisa e quem é pesquisado mantém instalada uma correspondência que se reproduz na relação pedagógica (quer na relação professor - criança, quer no formador - professor): um sabe e diz como deve ser feito, enquanto o outro não sabe e depende das regras estabelecidas pelo outro para conduzir o seu caminho. É importante refletir a respeito da conexão entre o saber do professor e o saber externo, ou entre o saber produzido no espaço da escola pelos práticos e o saber que poderá ser produzido fruto da investigação sobre a prática em um diálogo entre o interno e o externo, ou, entre uma experiência local e a construção de sentidos que se pode fazer em nível global.

$\mathrm{Na}$ verdade, isso se assemelha ao que Moss (2016) comenta na relação entre o conhecimento produzido em um âmbito micro e a forma pela qual pode ter representatividade e significado em um plano macro ${ }^{20}$ sem que se perca a construção de significado situada. Para tal ideia, o autor estabelece algumas características que, hoje, uma pesquisa deve adotar:

\footnotetext{
${ }^{20}$ Assim como os demais autores a que recorri para elaborar as reflexões acerca de uma tese pedagógica, Peter Moss não discute a respeito disso. O autor está tratando sobre como o conhecimento que foi produzido em Reggio Emilia pode ser inspiração e exemplo para outros contextos mais amplos. No entanto, o que o autor destaca como característica de pesquisa e da produção do conhecimento na contemporaneidade me ajudam a pensar a elaboração de uma tese pedagógica.
} 
[...] uma visão que respeite uma ampla gama de pesquisas e trate os achados como conhecimento local, sempre produzidos em um contexto particular, sempre parcial, provisório e sempre sujeito à deliberação, ao diálogo e à interpretação; em outras palavras, nenhuma pesquisa pode ou deve absolver cidadãos da responsabilidade de pensar e atribuir significados (MOSS, 2016, p. 120).

$\mathrm{Na}$ investigação praxiológica, Formosinho (2016, p. 34) chama isso de “[...] importação dos saberes produzidos por outros lugares sociocognitivos [...]", enfatizando que "a identificação de saliências partilhadas é então aberta ao debate sobre o seu significado e permite diálogos com outros contextos". Não se trata de generalização, mas da possibilidade de uma experiência local dialogar com a experiência global e inspirar a reconstrução de novas experiências locais.

Aproveito para localizar as questões ontológicas, epistemológicas e metodológicas para a construção de uma tese pedagógica. No que diz respeito à questão ontológica, ou seja, àquilo que significa a ideia de realidade, é preciso reconhecer a parcialidade e provisoriedade do campo, além de que não está completamente dado, mas é produzido pelos modos como o investigador interage, pela forma que olhamos para os dados, pelas perguntas que estabelecemos e pela nossa capacidade de ver, analisar e compreender os fenômenos.

Oliveira-Formosinho (2002, p. 100), abordando as questões ontológicas, reforça que, na visão de uma investigação construtivista, "não existe um mundo objetivo - independente da atividade mental humana e da linguagem humana simbólica (BRUNER, 1990) ${ }^{21}$. A realidade existe então enquanto construção mental, dependendo a sua forma e conteúdo das vivências sociais, num tempo e num espaço”.

Nessa perspectiva, as questões epistemológicas de uma tese pedagógica envolvem uma abertura ao diálogo e uma diversidade de interpretações e a tentativa de superar, em alguma medida, a forte tendência de ter no conhecimento a resposta única, a verdade. Por sua vez, pelo caráter dialógico e relativo, compreende-se que o conhecimento é construído na interação entre o homem e o mundo; e, portanto, não o abstém da produção de significados. Recorrendo outra vez a Formosinho (2016, p. 35), “a pesquisa em ciências sociais é sempre uma ciência de interpretação das interpretações dos atores, um duplo processo hermenêutico, isto é, uma ciência social do social". A respeito disso, Formosinho (2016, p. 34-35) reforça:

Pois parte de uma visão democrática do mundo que assenta nos valores da liberdade, colaboração, solidariedade e participação, numa epistemologia da contextualização que valoriza a ação situada, contextual, comunitária e cultural, numa epistemologia da participação que vive a distribuição do poder e a ética da participação, numa 
epistemologia do rigor que documenta os processos do cotidiano educativo com sistematicidade e densidade, rigor e ética, proximidade e autenticidade.

Assim, respondendo às questões metodológicas, entende-se que os dados são gerados a partir da capacidade que o investigador tem de documentar densamente as transformações dos contextos. Do mesmo modo, os resultados são sempre representações cognitivas parciais e estão fortemente atrelados ao papel do investigador e do processo de investigação.

Oliveira-Formosinho (2002b, p. 100-101) observa que a construção do conhecimento se define por uma posição hermenêutica e dialética. Para a autora, em se tratando da questão metodológica,

A natureza das realidades como construções mentais intangíveis, fundadas na experiência social, com uma natureza local sugere que as construções individuais só podem ser explicitadas através da interação que acede às construções por um processo hermenêutico de descrição e interpretação e um processo dialético de comparação e contraste das construções dos respondentes com as do investigador e com outras construções disponíveis (o patrimônio teórico disponível).

Portanto, ao afirmar que o conhecimento é produzido contextualmente, não significa dizer que não se apoie na herança pedagógica já construída, muito pelo contrário, é a partir dela que conseguimos produzir uma noção de realidade - não vista como processo de aproximação ou adaptação conceitual, mas uma lente que nos ajuda a olhar e compreender os fenômenos educativos.

Por esse motivo, do ponto de vista metodológico, os processos inerentes da Documentação Pedagógica - observar, registrar, interpretar para projetar e comunicar - me parecem atender à especificidade da construção de uma tese pedagógica. A respeito da Documentação Pedagógica, "para Malaguzzi, significa a possibilidade de discutir e dialogar "tudo com todos"” (HOYUELOS, 2004b, p. 7). Na Documentação Pedagógica, ao mesmo tempo que se produz memória acerca das crianças, da Pedagogia e da ação docente, também se converte em uma plataforma democrática, aberta ao diálogo, à troca e ao compartilhamento (HOYUELOS, 2004b, 2006; RINALDI, 2012; FOCHI, 2013, 2016b; MOSS, 2016; OLIVEIRA-FORMOSINHO, 2016c; PINAZZA, FOCHI, 2018). É um fórum em que as múltiplas vozes são incluídas, escutadas e visibilizadas.

Formosinho (2016, p. 31) destaca que a Documentação Pedagógica, por poder tornar visíveis os processos de transformação, permite "integrar o cotidiano vivencial que nos aproxima da realidade vivida (crianças e equipe educativa em ação) com a informação produzida por outros meios sobre o processo de recriar essa realidade, no contexto de uma ética da convivialidade e colaboração entre os atores centrais envolvidos". Isso reforça porque a 
Documentação Pedagógica tem se revelado uma importante estratégia para sustentar e compreender o conhecimento praxiológico construído na interatividade entre crianças e adultos nas instituições de Educação Infantil (FOCHI, 2013, 2016b; OLIVEIRA-FORMOSINHO, 2016c; SOUSA, FOCHI, 2017).

Referente ao aspecto metodológico para a construção de uma tese pedagógica, recupero algo que chamei de "três movimentos coincidentes" em meu estudo de mestrado quando utilizei da estratégia da Documentação Pedagógica para o desenvolvimento da pesquisa (FOCHI, 2013, p. 54-55):

O primeiro é pelo fato da Documentação Pedagógica se preocupar, como postura política, em tornar visível a imagem da criança, não simplesmente para mudar a retórica, mas para criar uma espécie de outra cultura sobre o que a humanidade fala a respeito das crianças e, com isso, abrir possibilidades de reelaborar as questões científicas a respeito. O segundo movimento é por reconhecer a criança não somente como capaz, mas também o adulto. [...] Por isso contemplo, na organização da metodologia, um momento que chamei de "contrastes", para trazer o professor para um espaço-tempo reflexivo. Além disso, esse momento tinha o objetivo de compartilhar aspectos e pontos de vista, como também, gerar ações-reflexõestransformações no seu fazer, por meio de perguntas que o próprio professor, em diálogo com o pesquisador, pudesse identificar. O propósito era gerar um modo de investigação com a qual, em cada encontro, as perguntas que nascessem seriam guias para orientar a pesquisa, bem como a prática da professora, e não formas de verificação de resultados. O último movimento é o da especificidade de interesse, em outras palavras, as perguntas feitas para conduzir um processo documental são sempre em relação às crianças, ao professor e à pedagogia [...].

Ao revistar esses argumentos, reafirmo minha crença a respeito dessa estreita relação entre o campo teórico escolhido (a Pedagogia), a abordagem metodológica utilizada para levar a cabo a pesquisa (nos domínios da investigação praxiológica), a força que há na Documentação Pedagógica como estratégia para a construção do conhecimento praxiológico, o endereçamento do estudo (os professores e as escolas) e algo que se pretende desenvolver nesta tese, a estrutura da escrita pela qual é comunicado o estudo em questão (o texto pedagógico).

Alarcão (2001) observa que as questões ontológicas, epistemológicas e metodológicas não são suficientes para pensarmos um paradigma de investigação, e acrescenta outras duas questões: teleológica, "[...] ou seja, a relação do investigador com o destino a dar ao conhecimento gerado ou as repostas às perguntas 'a quê e a quem se destina?"” (ALARCÃO, 2001, p. 137), e dialógica, que se refere “[...] às formas de comunicação do conhecimento na relação do investigador com os outros (indivíduo e sociedade), que implica a resposta à pergunta 'como divulgar e difundir?"” (ALARCÃO, 2001, p. 137). 
Esses dois aspectos levantados por Alarcão (2001) me remetem a um texto de Contreras (2010), que discute "a busca por texto pedagógico", destacando o quão raro é encontrar, na atualidade, um texto do gênero:

Contreras (2010), ao referir-se aos diversos educadores que no passado produziram textos que nos ajudam a entender a educação, as relações travadas entre as crianças e os adultos, os modos como se concebia o conhecimento, observa que hoje temos pouca literatura a respeito. E, dentre as perguntas e hipóteses que autor lança sobre esse fenômeno, questiona se antes havia experiências mais abertas à escuta e não tanto a uma relação predeterminada e gerencialista, assim como temos hoje. Ou, se antes os professores se perguntavam a respeito do seu fazer e do seu papel, enquanto hoje temos esse papel pré-fixado. Ou, ainda, se hoje perdemos a atenção em relação às crianças e à juventude, deixando de ter interesse por escutar o que eles têm a nos dizer, mantendo-nos mais preocupados com o que extrair deles. Nesse viés, pontua:

\begin{abstract}
Ou não será, talvez, que o que temos perdido seja a potência da literatura em educação, isto é, os modos de escrever que estão atentos às palavras e a sua força exploratória e expressiva, aquela escritura como modo de indagação das vidas que vivemos e na linguagem que nos ajuda a perceber, a pensar e a criar? Será que a própria linguagem da pedagogia e, portanto, a possibilidade de pensar e fazer educação, tem se identificado cada vez mais com os modos de administrar sistemas do que com as formas de atender e entender a infância e a juventude e a nossa relação com elas? (CONTRERAS, 2010, p. 253).
\end{abstract}

A busca por textos pedagógicos, pelo autor, é também um anseio frente à formação de professores que, segundo o estudioso, carece de textos que tenham algo a dizer para aqueles que se encontram em seus processos iniciais de formação. A ausência desse tipo de texto, ao meu ver, representa a ausência daquilo que é "pedagógico" nos cursos de Pedagogia, além disso, reforça a dificuldade de circunscrever e firmar essa área em seu estatuto científico. Todavia, de um modo especial, atribuo a ausência dos textos pedagógicos à falta de autores, dentro e fora da escola, que possam ter o que dizer, que se sintam encorajados e identificados com a ação pedagógica, com aquilo que emerge das relações travadas com as crianças, com outros adultos e com o próprio conhecimento que está sempre em construção. Contreras (2010, p. 249, grifo do autor) argumenta que:

Não busco teorias, e sim textos. Não busco uma escrita que se apresenta como um compendio de saber, mas sim aquela que se situa simplesmente como um texto, com o desejo de contar, que não classifica aquilo que se escreve como teoria ou como prática. E sobretudo, busco textos com um autor ou autora que tem algo a dizer a respeito do que se passa com sua experiência de educador ou educadora; me interessa essa visão de quem faz, cria, escuta, pensa e vai fazendo emergir algo que nasce desse escutar, pensar, olhar o que faz. Precisamente porque estou buscando aquele saber que não se coloca por cima do que se vive, e que não se desconecta de quem o vive, me interessam os textos de quem conta desde sua experiência docente. 
Essa ideia de texto pedagógico responde, ao meu ver, às questões teleológicas e dialógicas apontadas por Alarcão (2001), pois remetem tanto a um nível da forma de texto a ser difundido, como ao tipo de conteúdo que interessa em um plano pedagógico. Nesse viés, acredito que uma tese pedagógica é aquela que consegue dar conta de exaltar a potência de uma literatura pedagógica.

Listo alguns pedagogos que, no curso da história, produziram textos pedagógicos: Célestin Freinet, Loris Malaguzzi, Bruno Ciari, Mario Lodi, Madalena Freire. E, ainda, a sugestão de Contreras (2010), Vivian Gussin Paley, que, segundo o autor, é a expressão máxima de uma potência literária pedagógica:

Quando digo potência literária não estou pensando tanto em suas qualidades como literatura, mas sim em sua forma de escrever como um modo de pensar o que vive, o que faz, o que chega dos meninos e meninas com quem compartilha seu fazer cotidiano e na forma que sua escritura alcança aquele nível de reflexão viva que te coloca como leitor nesse pensar sobre aquilo que ela está perguntando-se (CONTRERÁS, 2010, p. 253).

Um texto pedagógico é sempre uma tentativa de compartilhar o valor educativo que se pode atribuir a uma experiência docente, à experiência das crianças na escola e ao desejo de escrever para melhor compreender e, dessa forma, argumentar e dialogar com outros desejavelmente com outros professores. É uma alternativa de traduzir contextualmente a complexidade da educação e de alguma forma intenciona iluminar e dar valor educativo a algo ou a alguém.

Contreras (2010) toma, como exemplo de textos pedagógicos, as produções de Vivian G. Paley e destaca que a potência literária pedagógica de sua obra não está na descrição de suas atividades com as crianças ou com os educadores com os quais a autora trabalha, mas pela capacidade de compartilhamento, à luz de alguma pergunta guia, "algo que dê o que pensar na relação que vive com as crianças" (CONTRERAS, 2010, p. 254). Em seus textos, existe uma polifonia de vozes que entrelaçam suas indagações, o que as crianças dizem, o que os professores comentam e o que ela própria pensa a respeito. Em um texto pedagógico, portanto, tem o adulto, tem a criança e tem uma herança pedagógica.

No tocante a isso, gostaria de comentar que, na produção da dissertação, vivenciei a tensão em fazer uma pesquisa focada nas ações das crianças sem deixar de considerar o adulto. $\mathrm{Na}$ tese, a tensão continua, porém focada na formação de professores de Educação Infantil enquanto me pergunto sobre como não perder as crianças.

A reflexão sobre essa tensão e esse dilema que me acompanham parece ser respondida parcialmente na tentativa de pensar um texto pedagógico. Ora, se esse texto é a busca por uma 
vontade de querer saber sobre as crianças, sobre a docência, ou ainda, sobre como, na fronteira entre a docência e as crianças, construímos o conhecimento a respeito da própria infância e da docência, é inevitável que crianças e adultos andem juntos também no texto.

No trabalho do OBECI, temos optado por investir na escrita de mini-histórias e processos documentais como forma de exercitar a escrita de textos pedagógicos pelos professores, colocando-os a pensar sobre o que as crianças fazem e também sobre seu papel na relação educativa com as crianças. Os gestores e coordenadores pedagógicos têm feito esse mesmo exercício abordando o processo de gestão organizacional e as diferentes vozes das crianças e dos adultos que constituem o cotidiano praxiológico ${ }^{22}$.

O uso das "mini-histórias" serviu como categorias de análise em meu estudo de mestrado (FOCHI, 2013). Inspirado pelo livro Como eschucar la infância, de David Altimir, entendi que a escrita das mini-histórias sobre o cotidiano nos ajuda a tornar fatos episódicos visíveis e que, se mantidos na sombra, podem deixar muitos aspectos a respeito do valor educativo da Educação Infantil esquecidos ou perdidos, assim como as formas que as crianças usam para conhecer e se relacionar com o mundo.

A definição que Altimir (2010, p. 84) dá para a ideia de mini-histórias é “[...] de pequenos relatos, alguns com um denso passado, outros com muito futuro e, alguns, simples instantes". No OBECI, temos tratado as mini-histórias como as rapsódias da vida cotidiana que, ao serem narradas textual e imageticamente, tornam-se especiais pelo olhar do adulto que as acolhe, interpreta-as, e dá valor para a construção da memória pedagógica.

Já os processos documentais estão ligados diretamente a uma estrutura narrativa de planejamento e metainterpretação do cotidiano praxiológico que temos criado e utilizado dentro do Observatório e serve, ao mesmo tempo, para ir construindo uma memória pedagógica e cultural do trabalho e um convite ao professor compreender o percurso das crianças para retroalimentar a própria prática durante o desenvolvimento do trabalho.

Acredito que as mini-histórias e os processos documentais podem ser formas de evidenciar as crianças em suas zonas de conhecimento e, contemporaneamente, mostrar como os professores que estão nas escolas do OBECI narram as crianças e encaminham sua prática pedagógica, ou seja, são evidências do processo formativo decorrente do próprio OBECI. Também são um modo de trazer as diferentes vozes para o texto da tese, pois, como já foi dito anteriormente, em uma tese pedagógica, pressupõe-se a polifonia de vozes.

${ }^{22} \mathrm{Na}$ Parte III desta tese, desenvolvo a respeito das mini-histórias e dos processos documentais, demonstrando como as escolas que participam do OBECI têm produzido essas modalidades de textos pedagógicos. 
A respeito das mini-histórias, tenho experimentado, junto das minhas orientadas de graduação no curso de Pedagogia, a escrita de categorias de análise dos seus trabalhos de conclusão de curso utilizando as mini-histórias ${ }^{23}$. Outra modalidade de texto pedagógico que tenho utilizado são os diários. Com algumas orientandas, experimentamos a construção de diários a respeito de algumas crianças, focalizando um tópico em questão, narrando, em um período de tempo mais prolongado, o percurso dessas crianças, a relação dos adultos, e as questões que se podem pensar a partir desses escritos ${ }^{24}$. Outro ponto que quero destacar é o uso das mini-histórias nos Estágios Supervisionados em Educação Infantil, também no curso de Pedagogia. Inspirado pelo que estamos desenvolvendo no OBECI, tenho proposto às alunas a escrita de uma mini-história semanal como mote para indicar os rumos do planejamento da semana seguinte e comunicar para as famílias a vida cotidiana. Ao final, as alunas elegem algumas das mini-histórias escritas ao longo do estágio demonstrando o "fragmento da vida cotidiana" que marcou o período da intervenção e elaboram uma reflexão a partir desta. É interessante observar o modo pelo qual as alunas têm operacionalizado a escrita das minihistórias e dos diários, e, mais interessante ainda, os desdobramentos e efeitos formativos que eles provocam nas alunas. Esses exercícios têm sido interessantes na elaboração de textos pedagógicos dentro do curso de Pedagogia.

Voltando às questões teleológicas e dialógicas, segundo Alarcão (2001), ao anunciar as tendências evolutivas nos paradigmas de investigação, uma das características dos textos comunicados é serem "mais humanistas, com a interpenetração de estilos de gêneros e recursos a imagens, metáforas explicativas e exploração de modalidades multimídias" (ALARCÃO, 2001, 140). Essa é uma boa pista e, ao mesmo tempo, um bom exemplo do que considero na produção de uma tese pedagógica. As imagens, os textos, as metáforas e outros recursos de linguagem auxiliam na construção de textos plurais, pois a imagem não precisa ser utilizada como recurso ilustrativo à palavra escrita, mas, contemporaneamente, ser uma metalinguagem. Nesse caso, cria-se uma abertura para o interlocutor produzir novas interpretações, respeitando

23 Um dos trabalhos aborda a transformação dos espaços internos e dos materiais ao longo do estágio supervisionado com crianças de 2 e 3 anos. As mini-histórias produzidas pela aluna servem como estrutura para articular as análises a respeito do quadro teórico sobre os espaços e as brincadeiras das crianças no contexto organizado por ela (DAL-RI, 2016). Em outro trabalho de conclusão de curso, a aluna discute sobre os segredos do pátio de crianças de 4 e 5 anos. Ao construir mini-histórias sobre as brincadeiras das crianças no pátio e compartilhar com elas, Oliveira (2016) descobre novas narrativas e pistas para a construção de algumas categorias para pensar a organização do espaço externo.

${ }^{24}$ Com uma orientanda, por exemplo, produzimos o diário de duas crianças de 11 meses ao longo de três meses, compartilhando as suas experiências cotidianas como modo de pensar um currículo narrativo (MARQUES, 2016). Com outra orientanda, produzimos o diário de duas crianças, focalizando sua interação com a literatura infantil, destacando em dois diários narrativos os modos pelos quais duas crianças contam histórias a partir do uso de livros literários (MORSCHEL, 2016). 
os diferentes interlocutores e construindo "escritos de divulgação com vários níveis de profundidade, com vistas a uma maior acessibilidade por públicos diversos; [...] a divulgação de estudos em aberto, sem apresentação de conclusões" (ALARCÃO, 2001, p. 140).

Vale lembrar que Hoyuelos (2006) advoga sobre o quão importante as metáforas são para aproximarmo-nos da infância. Segundo ele, Malaguzzi utilizava-se das metáforas como "uma conquista criativa capaz de reinterpretar o mundo para vê-lo com outras lentes" (HOYUELOS, 2006, p. 176). As metáforas servem para nos ajudar a dar nomes ou criar explicações para fenômenos e coisas que resultam difícil porque é próprio da linguagem de que dispomos. Logo, Hoyuelos (2006, p. 176) observará que, na obra pedagógica de Malaguzzi, a metáfora "abre o mundo do possível, do indeterminado, da transgressão imprescindível para abordar a realidade de maneira inesperada. Desta maneira, a metáfora para Loris é uma força transformadora do real, uma rede de novos valores criativos distantes das garras do já sabido".

Escrever uma tese pedagógica é, assim, uma conquista criativa para refletir textualmente como estruturar um texto que não aparte a teoria da empiria, sem fazer aproximações simplistas entre um campo teórico consolidado e os dados empíricos gerados. Pelo contrário, uma tese pedagógica precisa ser concebida como a produção do conhecimento praxiológico que se traduz na escrita de um texto pedagógico e, portanto, se estabelece na relação dialógica entre prática, teoria e um sujeito portador de crenças e valores.

Arrisco afirmar que uma tese pedagógica não serve para explicar fenômenos abstratos a partir da aproximação de teorias estabelecidas, tampouco para paralisar-se em críticas retóricas ou em discursos nominalistas isentos de comprometimento com o contexto de pesquisa. Também não é utilitarista, em um senso prescritivo, ou, ainda, verificável de hipóteses a priori estabelecidas. Suponho, longe disso, que uma tese pedagógica é aquela que enfrenta efetivamente o nexus saber-poder travado no âmbito da relação pedagógica (centrado no adulto e na transmissão do conhecimento), no âmbito da formação (na hierarquia entre o saber especializado e o saber do prático), assim como, no âmbito da investigação (em que a escola, o professor e as crianças são apenas motes de discursos no saber do especialista que vai até a escola dizer como fazer). Enfrenta tais nexus de saber-poder, posto que uma tese só é pedagógica porque sua centralidade está na transformação dos contextos educativos.

Buscando responder a essa perspectiva de tese pedagógica, na seção seguinte, discuto o desenho metodológico explicitando, portanto, os instrumentos e técnicas para a interpretação dos dados. 


\subsection{O desenho metodológico da tese}

Antes de me debruçar sobre os últimos aspectos da metodologia, é importante salientar que, como afirmam Bogdan e Biklen (1994, p. 85), “em um estudo analítico, as decisões são tomadas à medida que este avança". Logo, as escolhas que explicito no desenho metodológico não foram tomadas a priori e, em muitos casos, aconteceram intuitivamente até que se definiram efetivamente as técnicas e métodos que seriam utilizados para circunscrever os dados de pesquisa e analisá-los. É certo, no entanto, que o fôlego para desenvolver a pesquisa e conseguir conduzi-la por seis anos é um somatório de autodisciplina e paixão, "em investigação, a autodisciplina só pode levar até um certo ponto. Sem um toque de paixão pode não ter fôlego suficiente para manter o esforço necessário à conclusão do trabalho ou limitar-se a realizar um trabalho banal" (BOGDAN; BIKLEN, 1994, p. 86).

Como foi apresentado neste capítulo, algumas definições estavam tomadas desde o princípio da pesquisa: a necessidade de um tempo maior que o período do doutoramento, já que se tratam de processos de transformação; o campo em que a tese se situa, a Pedagogia; a utilização da Documentação Pedagógica como estratégia central para o desenvolvimento do trabalho; a transformação dos contextos como mote para o desenvolvimento da investigação; o quadro teórico em que este estudo se insere.

Por isso, muitos elementos metodológicos serão apresentados detalhadamente no próprio capítulo (Parte III) em que me dedico à análise do percurso desenvolvido pelo OBECI, como é o caso da caracterização dos contextos investigados e da explicitação do percurso desenvolvido. Também a Documentação Pedagógica, principal processo de recolha de dados, será amplamente desenvolvida tanto na Parte II, em que remonto o tema na obra de Loris Malaguzzi, como na Parte III, em que discuto o modo como temos desenvolvido essa estratégia dentro do Observatório. Na verdade, a Parte III deste trabalho é que se pode considerar efetivamente a peça metodológica da tese, já que se busca responder a exigência de escrever sobre os processos de transformação dos contextos investigados.

Aqui, no entanto, explicito quais fontes de dados foram utilizados para a elaboração desta tese e a técnica e instrumento utilizados para a sua interpretação. 


\subsubsection{Estudo de caso pelos processos de uma investigação praxiológica}

Esta tese caracteriza-se como um estudo de caso pelos processos de uma investigação praxiológica $^{25}$. Como afirmam Amado e Freire (2013, p. 125), os estudos de caso, "pela sua natureza holística, tendem a refletir a complexidade dos fenômenos que estudam". Também Stake (2007, p. 11) reforça “[...] que um estudo de caso consegue captar a complexidade de um caso único", por isso, justifica-se como o melhor a ser estudado. Para esses autores, a perspectiva holística do estudo de caso oferece ao investigador a mútua compreensão da particularidade e da complexidade de um caso singular.

Um primeiro aspecto a ser compreendido é a própria definição de qual é o caso (STAKE, 2007; AMADO, FREIRE, 2013). O caso “caracteriza-se pela sua delimitação natural ou integridade fenomenológica [...] e deve ser reconhecido como tal pelos membros que a constituem" (AMADO, FREIRE, 2013, p. 126-127). O caso é "algo específico, algo complexo, em funcionamento. [...] O caso é um sistema integrado" (STAKE, 2007, p. 16). O caso desta tese é o OBECI: é um contexto de desenvolvimento profissional específico pois envolve um grupo de pessoas específicas que se encontram para um determinado tipo de atividade com um determinado fim: a transformação dos seus contextos de origem.

Também os contextos de origem (escolas) compõem a complexidade deste caso específico. Os gestores, coordenadores pedagógicos e professores, assim como as transformações que estes vêm realizando nas escolas, são as próprias variáveis que, em um estudo de caso, são impossíveis de serem separadas do contexto. Se o OBECI se constitui por essas pessoas que se encontram para debater, compartilhar, refletir e retroalimentar os processos de transformações das suas escolas, o caso em questão a ser analisado e interpretado é o fenômeno caracterizado no interior do OBECI, que é gerado pelo próprio OBECI nas escolas e que constitui o OBECI por aquilo que as escolas produzem no seu interior.

Portanto, o segundo aspecto a ser compreendido é ter a clareza de qual fenômeno se pretende entender no caso específico. Stake (2007, p. 238) destaca que o critério primordial para definir o fenômeno a ser estudado em um caso é a oportunidade de aprender, já que "[...] nem tudo sobre o caso deve ser estudado". Já para Amado e Freire (2013, p. 127), "qualquer fenômeno apresenta múltiplos aspectos e o investigador precisa selecionar aquele ou aqueles

\footnotetext{
${ }^{25}$ Em busca realizada sobre outras pesquisas que se situam em um estudo de caso com processos da investigação praxiológica, apenas foi encontrado o trabalho de Joana Catarina Mendes da Silva de Sousa, cujo título é Formação em Contexto: um estudo de caso praxiológico, do ano de 2016, defendida na Universidade Católica Portuguesa, com orientação da professora Júlia Oliveira-Formosinho (SOUSA, 2016).
} 
sobre os quais se concentrará na recolha e análise de dados, de modo a compreender as interações entre o fenômeno em estudo com seus contextos".

No caso do OBECI, o fenômeno que se busca compreender é a construção do conhecimento praxiológico sustentada por meio da estratégia da Documentação Pedagógica no interior de uma comunidade de apoio ao desenvolvimento profissional. Para tal, não se pretende fazer comparações entre as quatro escolas participantes, mas, a partir das experiências que estas escolas vivenciaram nos seis anos da pesquisa, interpretar para construir compreensão aprofundada dos sentidos produzidos no interior do Observatório sobre o fenômeno em questão.

Oliveira-Formosinho (2002b, p. 91, grifo meu), em um texto que aborda especificamente sobre o uso dos estudos de caso em Educação, afirma que "conduzir um estudo de caso para construir compreensão aprofundada é hoje corrente, no âmbito das ciências humanas e sociais, e é compatível com diferentes correntes teóricas, com diferentes técnicas de investigação e com diferentes paradigmas epistemológicos”. Também Kishimoto (2002, p. 153) afirma que o estudo de caso "[...] é uma metodologia de pesquisa adequada à investigação de questões atuais da prática pedagógica, ao possibilitar o mergulho no seu contexto". A natureza dinâmica do conhecimento pedagógico e a emergência de reflexões que respondam à complexidade do ato educativo nos convocam a buscar um quadro metodológico que também responda a essa dinamicidade e complexidade.

A respeito da generalização, Stake (2007) salienta que o objetivo de um estudo de caso é a particularização, já que a preocupação primeira é o caso em si, em sua unidade e complexidade: "o propósito do estudo de caso não é representar o mundo, mas representar o caso" (STAKE, 2007, p. 245). Nesse sentido, esta investigação se caracteriza como um estudo de caso intrínseco (STAKE, 2007), pois busca criar compreensão dos fenômenos que caracterizam o caso em si. Logo, o que posso inferir é que os dados de um estudo podem ser generalizáveis com a finalidade de compreender outras realidades ao mesmo tempo que nos fornecem indícios para avançar epistemologicamente em relação ao fenômeno estudado.

Por fim, Amado e Freire (2013, p. 136) afirmam que "o estudo de caso implica que o investigador se situe no quadro do paradigma da complexidade, o único que nos permite reconhecer que tudo é solidário com tudo”. Essa afirmação corrobora o que anteriormente já foi tratado a respeito da complexidade do fenômeno educativo e da necessidade em buscar um quadro teórico e metodológico que acolha tal complexidade. 
Uma vez discutidos os argumentos orientadores para um estudo de caso, passo agora ao modo pelos quais os dados foram tratados nesta tese, valendo-me da análise de conteúdo e da triangulação dos dados.

\subsubsection{Análise de conteúdo e triangulação dos dados}

Uma investigação centrada nos processos de transformação da práxis “[...] apresenta fortes exigências ao nível metodológico, pois dirige-se à práxis e à sua transformação" (OLIVEIRA-FORMOSINHO, 2016a, p. 22). Responder às demandas do cotidiano pedagógico tanto em nível de investigação como de conhecimento profissional, requer a construção de um quadro interpretativo que acolha a complexidade da escola e a complexidade das situações que lá acontecem.

Para empreender tamanho desafio, como se sugere na investigação praxiológica (OLIVEIRA-FORMOSINHO, 2016a; FORMOSINHO, 2016), é necessário ter declarada a intenção da transformação e documentá-la densamente. Como adverte Oliveira-Formosinho (2016a, p. 22), “a documentação informa sobre os processos transformativos, quando analisada e interpretada permite construir conhecimento sobre eles e disponibilizá-lo", o que confere rigor e atende ao seu intento democrático. Do mesmo modo, a documentação densa dos processos de transformação também inclui as diferentes vozes que a compõem, engajando as diferentes vozes subjetivamente e responsabilizando-as de forma cooperativa e participada.

Isso requer, no entanto, um modo de conceber os processos investigativos e formativos que efetivamente envolva a todos e os comprometa com os processos. Não será naturalmente que os profissionais e o investigador se sentirão corresponsáveis pelos processos transformativos. É necessário estar comprometido ética e moralmente com os contextos, aberto ao emergente para criar outras formas de fazer e pensar o cotidiano pedagógico.

No OBECI, nossa escolha desde o princípio tem sido o uso da Documentação Pedagógica como estratégia para ver e transformar o cotidiano, reposicionando as crianças e os adultos na relação educativa (FOCHI, 2016b). Tanto os gestores e coordenadores pedagógicos como os professores observam, registram e interpretam para projetar a transformação em suas instituições. Compartilham para contrastar internamente no OBECI e com seus pares em suas escolas. Comunicam os processos e os resultados das transformações por meio dos processos documentais e das mini-histórias. 
Nesta investigação, esses dois recursos de textos pedagógicos (processos documentais e mini-histórias) serviram para construir a triangulação dos dados e a análise do conteúdo. Além desses recursos, sistematicamente foi realizada a escrita de alguns documentos reflexivos, convidando os profissionais envolvidos com o OBECI a pensar sobre os processos formativos e transformativos vividos tanto em um nível pessoal como institucional. Também, em todos os encontros do grupo gestor, foi escrita uma memória que reúne o que é discutido dentro do grupo. A cada encontro, um participante escreve a memória e disponibiliza a todos antes do encontro seguinte. Além disso, foi utilizado o caderno de notas do pesquisador como uma espécie de diário de campo, que apoia na compreensão dos processos analisados. Todos esses dados foram fundamentais para a elaboração do texto da tese, uma vez que é a partir da imersão e dos movimentos de ida e retorno aos dados que foi possível ir construindo a narrativa da construção do OBECI e das transformações nas escolas participantes. No quadro abaixo, sintetizo os documentos utilizados para compor os dados de análise para a tese.

Quadro 1 - Dados de pesquisa

\begin{tabular}{|c|c|}
\hline $\begin{array}{l}\text { Tipo do documento } \\
\text { / quem produziu o } \\
\text { documento }\end{array}$ & Formato / ano / assunto \\
\hline \multirow{3}{*}{$\begin{array}{l}\text { Textos Pedagógicos } \\
\text { Produzido pelos } \\
\text { coordenadores } \\
\text { pedagógicos, diretores } \\
\text { e professores }\end{array}$} & $\begin{array}{l}\text { Mini-histórias } \\
\text { Rapsódia da vida cotidiana das escolas com caráter episódico. Material com um pequeno } \\
\text { conjunto de fotos e um breve texto. } \\
\text { (2016) MH. Ativ. Jardim, MH. Atividade Comum; MH. Postura adulto; MH. Ir ao banheiro; } \\
\text { (2017) Escolas participantes experimentam a escrita semanalmente. Realização da I Mostra de } \\
\text { Mini-histórias; (2018) GIA Acompanhamento Projetual - Escrita de mini-histórias semanais } \\
\text { Escolas continuam escrevendo mini-histórias semanalmente. Realização da II Mostra de Mini- } \\
\text { Histórias }\end{array}$ \\
\hline & $\begin{array}{l}\text { Processo documental macro com observáveis sistematizados em PowerPoint } \\
\text { Material organizado pelas escolas para compartilhamento no grupo gestor do OBECI com a } \\
\text { finalidade de reflexão a respeito de uma temática elencada (às vezes, por cada escola, às vezes } \\
\text { partilhada pelo grupo). Geralmente, nesse material, reúnem-se fotos, breves anotações e, em } \\
\text { alguns casos, pequenos vídeos. O formato utilizado foi Power Point. } \\
\text { (2013) Biblioteca, Soninho; (2014) Alimentação; (2015) Uma tarde na turma x. (2017) } \\
\text { Transições; (2018) Microtransições }\end{array}$ \\
\hline & $\begin{array}{l}\text { Processo Documental dos Grupos de Investigação-ação } \\
\text { Material construído ao longo da investigação-ação (Ciclos de Simbolização, Brincar Heurístico } \\
\text { e Acompanhamento projetual) com a finalidade de comunicar os percursos de aprendizagem } \\
\text { das crianças e as ações educativas do professor. Material em PowerPoint, reunindo exemplares } \\
\text { das produções das crianças, fotos, falas das crianças, textos reflexivos do professor e, em } \\
\text { alguns casos, pequenos vídeos. } \\
\text { (2015) Dente de leão; (2016) Com olhos de criança; Brincar Heurístico. (2017) Ciclos de } \\
\text { Simbolização e Brincar Heurístico; (2018) Brincar Heurístico e Acompanhamento Projetual }\end{array}$ \\
\hline $\begin{array}{l}\text { Memórias dos } \\
\text { encontros do grupo } \\
\text { Gestor } \\
\text { Produzido pelos } \\
\text { coordenadores } \\
\text { pedagógicos e diretores }\end{array}$ & $\begin{array}{l}\text { Textos em tom narrativo, redigido pelos diferentes membros do Grupo Gestor, com o objetivo } \\
\text { de criar memórias dos encontros do grupo. A escrita dos textos inicia no final de } 2013 \text { e são, } \\
\text { efetivamente, incorporados pelo grupo a partir de } 2014 \text {. } \\
\text { Textos e algumas imagens dos encontros ou imagens de referência. } \\
\text { (2013) } 31 \text { páginas referentes aos } 12 \text { encontros; (2014) } 47 \text { páginas referentes aos } 8 \text { encontros; } \\
\text { (2015) } 70 \text { páginas referentes aos } 11 \text { encontros; (2016) } 64 \text { páginas referentes aos } 15\end{array}$ \\
\hline
\end{tabular}




\begin{tabular}{|c|c|}
\hline & $\begin{array}{l}\text { encontros; (2017) } 70 \text { páginas referente aos } 14 \text { encontros; (2018) } 85 \text { páginas referente aos } 14 \\
\text { encontros }\end{array}$ \\
\hline $\begin{array}{l}\text { Reflexões sobre a } \\
\text { participação das } \\
\text { escolas no OBECI } \\
\text { Produzido pelos } \\
\text { professores com apoio } \\
\text { dos coordenadores } \\
\text { pedagógicos e diretores }\end{array}$ & $\begin{array}{l}\text { Documento elaborado pelas escolas, no final de 2016, para reflexão sobre os impactos nas } \\
\text { instituições a partir da participação no OBECI. Documento organizado em quatro partes. Na } \\
\text { primeira, uma reflexão sobre a escola; na segunda, reflexão do diretor; na terceira, reflexão do } \\
\text { coordenador pedagógico, e, na quarta parte, a reflexão dos professores que participaram dos } \\
\text { Grupos de Investigação-Ação (GIAs). } \\
\text { (2016) documento, com total de } 77 \text { páginas, referente às cinco escolas; (2017) documento, } \\
\text { com total de } 70 \text { páginas, referente às cinco escolas; (2018) documento com total de } 60 \\
\text { páginas }\end{array}$ \\
\hline $\begin{array}{l}\text { Notas do pesquisador } \\
\text { Produzido pelo } \\
\text { pesquisador }\end{array}$ & $\begin{array}{l}\text { Cadernos com anotações do pesquisador a respeito dos encontros com o Grupo Gestor, } \\
\text { encontros com os professores nos GIAs, encontros das Escolas Observadoras, Jornadas e } \\
\text { demais atividades ligadas ao OBECI. } \\
5 \text { cadernos de anotações. }\end{array}$ \\
\hline
\end{tabular}

Fonte: elaborado pelo autor.

Esses dados foram submetidos a um longo processo de desconstrução e reconstrução, quer seja para responder à complexidade do estudo em questão, quer seja para poder aprofundar e compreender os fenômenos em uma visão múltipla. Segundo Formosinho (2016, p. 32), "transformar dados brutos em dados de investigação é essencial para credibilizar qualquer investigação. [...] A triangulação de dados densos provenientes de várias fontes permite chegar a uma saturação da informação recolhida”. Também Stake (2007) observa que a triangulação é uma forma de credibilizar e dar rigor às investigações qualitativas. Na investigação praxiológica, Formosinho (2016) sugere a triangulação dos tempos para reconhecer e compreender os processos transformativos e a triangulação das vozes, como uma visão participativa e democrática deste modo de fazer pesquisa. Stake (2007) também se refere à triangulação das fontes, ou seja, aos instrumentos e técnicas de recolha dos dados.

Com os dados gerados no OBECI, é possível triangular os tempos, as vozes e as fontes, uma vez que a pesquisa envolve seis anos, em quatro contextos distintos, com diferentes documentos gerados (processos documentais, mini-histórias, reflexões, memórias e cadernos de notas do pesquisador), e estes são elaborados pelos diferentes participantes. Assim, foi possível uma ampla triangulação dos dados para se chegar ao resultado interpretativo partilhado nesta tese.

No entanto, para conseguir trabalhar com o conteúdo dos dados, é preciso buscar alguma técnica que auxilie na interpretação. Formosinho (2016) destaca que a análise de conteúdo é um instrumento valioso à investigação praxiológica, tal como na investigação qualitativa. Também Amado (2013) comenta que a análise de conteúdo, pelo seu caráter flexível, é facilmente adaptável a diferentes técnicas de recolhas de dados e aberta a interferências interpretativas. 
Após quatro anos da pesquisa, a proximidade com o campo e uma análise flutuante (AMADO, 2013) das memórias fizeram com que se chegasse a algumas categorias emergentes (FORMOSINHO, 2016). Na condução do trabalho, que seguiu nos dois anos seguintes, essas categorias foram sendo dialogadas e explicitadas para o grupo, resultando no que nomeamos como Organizadores da Ação Pedagógica (ver Parte III desta tese).

Com o uso do software MaxQDA ${ }^{26}$, foram analisadas criteriosamente as memórias escritas pelos participantes do OBECI, estruturando o seu conteúdo a partir das categorias que a priori se havia levantado na análise flutuante, atentando-se também para as possíveis categorias emergentes. A leitura exaustiva desse material possibilitou a estruturação das categorias e subcategorias considerando o quadro teórico, objetivos e hipóteses da pesquisa.

O manejo desses dados foi fundamental para os últimos dois anos de pesquisa, explicitando nos documentos que foram elaborados nesse período a compreensão que o grupo construiu ao longo dos quatro anos iniciais do OBECI. Assim, especialmente na Parte III desta tese, em que se discute o percurso do Observatório, construo tal reflexão a partir dessa ampla e adensada análise dos dados, que não apenas constroem a dialogia do tex to em termos das vozes, dos feitos e das identidades presentes, como também respondem à exigência do que é uma investigação nos domínios da praxiologia. De fato, esta terceira parte é tipicamente um texto vivo e legítimo de uma investigação praxiológica porque atende a essa triangulação que Oliveira-Formosinho (2016a) e Formosinho (2016) destacam: da formação, da investigação e da intervenção.

Também vale destacar que a análise de conteúdo foi utilizada para a leitura dos materiais que estruturam a Parte II desta tese, em que se analisa o conteúdo de diversos projetos supervisionados por Malaguzzi, buscando compreender a construção do conceito da Documentação Pedagógica.

${ }^{26}$ Segundo Nodari, Soares, Wiedenhoft e Oliveira (2014, p. 4), “os Softwares de Análise de Dados Qualitativos (SADQ) são programas que utilizam bancos de dados que possibilitam uma extensão na forma com que textos podem ser trabalhados, proporcionando maneiras de administrar e estruturar os aspectos da análise qualitativa". Para esses mesmos autores, em relação especificamente ao software do MaxQDA, "O Maxqda, pacote lançado em 1989, permite organizar, avaliar e interpretar os dados coletados, facilitando a criação de relatórios que podem ser compartilhados com outros pesquisadores" (NODARI; SOARES; WIEDENHOFT; OLIVEIRA, 2014, p. 5). 


\section{A HISTÓRIA QUE CARREGO EM MEUS OSSOS}
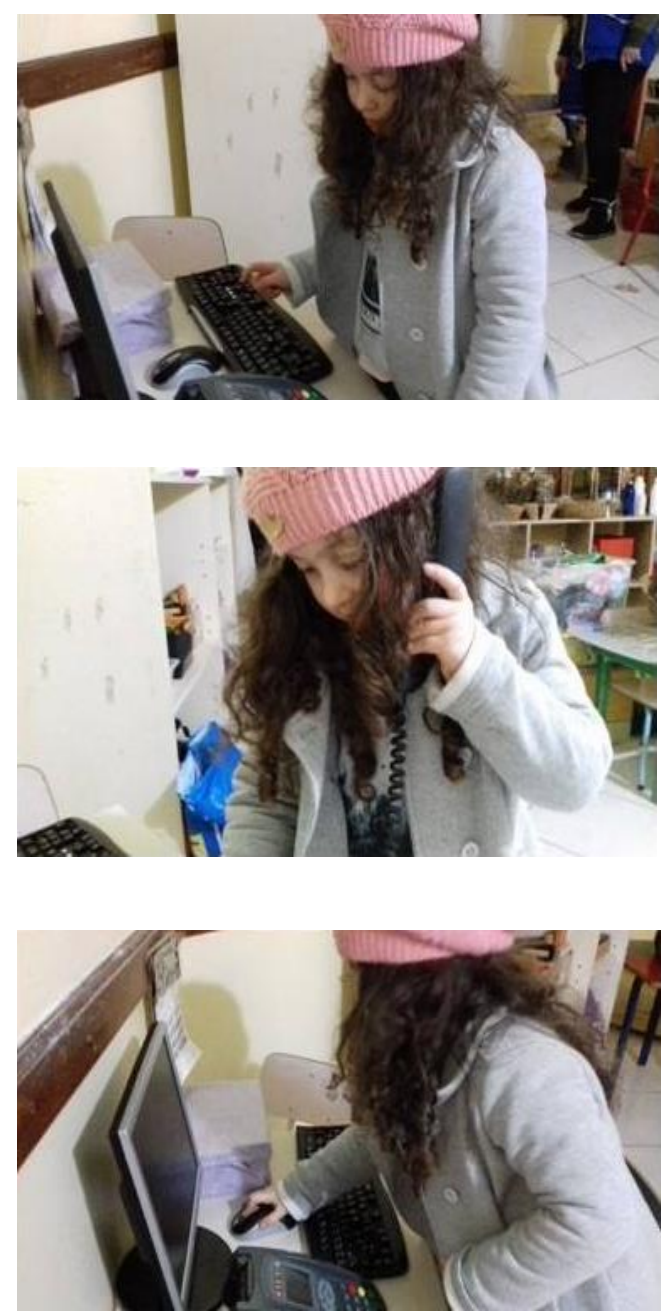

Criança|Sophia, 5 anos Professoras | Raquel, Dinara Texto | Raquel Imagens | Raquel Espaço Girassol
Em nossa sala de referência, temos um dos espaços organizado que é nomeado pelas crianças de escritório. Sophia descobre muitas possibilidades de compartilhar suas vivências cotidianas de fora da escola enquanto brinca nesse espaço.

Concentrada, Sophia digita no teclado e em seguida atende o telefone:

- Pizzaria Jardim do Lago, boa noite!

- Sim, pizza de quê? Tem de camarão e calabresa.

- Qual o endereço? Número 50? Tá bom, vai demorar trinta e sete minutos.

Encerra a ligação e volta a digitar para anotar o pedido.

Sua narrativa, rica em detalhes, mostra a atenção de Sophia para o seu entorno familiar, já que sua mãe gerencia uma pizzaria na cidade.

Mas também evidencia como o espaço e os materiais servem para as crianças criarem enredos lúdicos. 


\section{PARTE II}

\section{A DOCUMENTAÇÃO PEDAGÓGICA EM LORIS MALAGUZZI}

Desde meu primeiro contato com a Documentação Pedagógica, o grande propósito que identifico nessa estratégia é o de recuperar o sujeito epistêmico, de problematizar o nosso "estar no mundo" ou estar em uma instituição educativa, provocando-nos a assumir a autoria dos percursos que ali são trilhados. Isso significa responsabilizar-se subjetivamente com o cenário educativo que temos, ou seja, assumir que a realidade não está dada e distanciada da nossa relação com ela.

Não delegar a ação pedagógica ao senso comum, tampouco a teorias abstratas, mas conseguir construir uma prática em que a reflexão do próprio estar com as crianças permeie um universo mais profundo de interpretação tem coincidido com aquilo que alguns autores estão procurando compreender na constituição do estatuto da Pedagogia enquanto uma ciência praxiológica (MALAGUZZI, 1968; FREIRE, 1979; ROCHA, 2001; HOUSSAYE et al., 2004; BARBOSA, 2006; OLIVEIRA-FORMOSINHO, 2007; PINAZZA, 2014; MEIRIEU, 2016).

Dessa forma, a escolha da Pedagogia como campo de conhecimento e da Documentação Pedagógica como estratégia educativa são coincidentes no seu fim, ou seja, na transformação da realidade e na construção do conhecimento praxiológico. Do mesmo modo, a constituição de uma comunidade de apoio ao desenvolvimento profissional como o $\mathrm{OBECI}^{27}$ transforma-se em lócus privilegiado para acolher e desenvolver este campo de conhecimento e esta estratégia, já que esta também se constitui a partir do conhecimento situado e do objetivo de transformar a realidade.

A Pedagogia é a ciência que traduz as teorias e os conceitos que atualmente estamos buscando no campo educativo para a primeira infância (conceitos como a perspectiva de criança e currículo das Diretrizes Curriculares Nacionais para a Educação Infantil - DCNEI, por exemplo). Mais ainda: dentro da Pedagogia é que podemos formular estratégias para concretizar tais ideias. Daí que a Documentação Pedagógica, sendo uma estratégia genuinamente do campo pedagógico, pode ser uma importante resposta contra a traição do potencial das crianças e dos adultos (MALAGUZZI, 2001). Nessa perspectiva,

Os profissionais da educação de infância sempre fizeram algum tipo de documentação - livros das crianças, livros da sala de atividades, livros da aprendizagem das crianças.

${ }^{27}$ O OBECI já foi tratado sumariamente na Parte I e será amplamente discutido na Parte III. 
No entanto, as teorias e os conceitos atuais sobre documentação pedagógica beneficiam dos diálogos em torno dos paradigmas da metodologia de investigação das últimas cinco décadas do século XX (Azevedo, 2009), bem como dos debates do final do século XIX e de todo o século XX em torno do ethos das pedagogias participativas (OLIVEIRA-FORMOSINHO, 2016c, p. 113, grifo do autor).

A Documentação Pedagógica não cabe em uma pedagogia qualquer, ao contrário, é uma estratégia que responde ao intento da família das pedagogias participativas, pois reivindica uma outra imagem de criança e adulto e situa-se em uma perspectiva de conhecimento aberto à construção de sentidos (PINAZZA; FOCHI, 2018). A razão que justifica o que se afirma é o fato de que a Pedagogia e a Documentação Pedagógica têm no cotidiano o lócus para a construção do conhecimento praxiológico. Nesse sentido, “o ethos central das pedagogias participativas é a práxis diária de observar, escutar, documentar e responder às crianças, apoiando-se nos processos críticos da documentação de situações de aprendizagem" (OLIVEIRA-FORMOSINHO, 2016c, p. 110, grifo do autor).

Nesse viés, a Documentação Pedagógica é uma estratégia potente para apoiar o professor na reflexão sobre as crianças e sobre sua própria identidade (MALAGUZZI, 1968; HOYUELOS, 2006; FOCHI, 2013; OLIVEIRA-FORMOSINHO, 2016c). Isso porque dá ao adulto a agência que lhe é necessária para efetivamente construir a educação como porta para a cultura (BRUNER, 1997a; OLIVEIRA-FORMOSINHO, 2016c). Além disso, oferece ao campo da Pedagogia os elementos fundantes - prática e teoria - para a atualização do próprio campo (VECCHI, 2013; FOCHI, 2013; OLIVEIRA-FORMOSINHO, 2016c) e transforma-se em importante instrumento para o fortalecimento de uma identidade para a Educação Infantil (MALAGUZZI, 1968).

Oliveira-Formosinho (2016c) refere-se à recriação do papel das crianças como um processo revolucionário. Para a autora, “o direito das crianças à aprendizagem, visto como uma experiência vivida, cultural e democrática, desafia os educadores a serem pensadores profundos a respeito das identidades das crianças, bem como a respeito das suas próprias identidades e papéis" (OLIVEIRA-FORMOSINHO, 2016c, p. 114). Na busca por essa reflexividade do professor que acolhe o universo das crianças e da escola como um espaço privilegiado para a construção de conhecimentos, deparamo-nos com a necessidade de uma outra Pedagogia. Fazse necessário, muitas vezes, traduzir em prática uma concepção que ainda está no plano discursivo.

É nesse cenário que a Documentação Pedagógica aparece, uma vez que, “pela especificidade dessa abordagem, perguntar-se sobre as demandas da prática pedagógica, da 
ação docente e sobre as crianças gera a produção de um conhecimento dinâmico e atualizado" (FOCHI, 2015a, p. 149).

Destaco que usualmente se reduz a Documentação Pedagógica apenas a um conjunto de registros com tema pedagógico, associando-a somente ao campo da visibilidade dos percursos das crianças, mais especificamente aos registros, ao documento em $\mathrm{si}^{28}$. Tenho entendido a Documentação Pedagógica enquanto um conceito do campo pedagógico e, por isso, tenho chamado de estratégia para diferenciar do verbo documentar (ato de produzir registros) e do substantivo documentação (o produto comunicado). Para Hoyuelos (2004) a ideia de estratégia é uma oposição a linearidade do pensamento positivista, logo, uma estratégia se constói no curso da ação, modificando-se conforme os eventos vão surgindo e demandando novas soluções para responder à complexidade inerente de toda a ação educativa (HOYUELOS, 2004). Hoyuelos (2004, p, 71), citando Capra (1996), dirá que a estratégia supõe: “a) a atitude para empreender ou buscar na incerteza tendo em conta a própria incerteza; b) a atitude para modificar o desenvolvimento da ação em dunção do aleatório e do novo”. Por isso, a Documentação Pedagógica enquanto uma estratégia, configura-se um conceito potente para o o campo pedagógico já que acolhe a dinamicidade e as incertezas do campo de modo a responde-lo frente a sua complexidade.

São dois os processos coexistentes que envolvem a estratégia da Documentação Pedagógica: um está relacionado ao modo como o professor planeja, organiza e cria estratégias de aprendizagem e o outro está relacionado à forma como torna visíveis as aprendizagens das crianças. Portanto, o processo de comunicar as experiências das crianças na escola é um dos pilares que estruturam a Documentação Pedagógica, mas não o único.

Na verdade, Malaguzzi (2001) diz que a comunicação é uma atitude ética para tornar visível a competência das crianças e, ao mesmo tempo, de tornar pública a importância da instituição e de seus profissionais para os meninos e as meninas. Assim, o momento da comunicação deve ser compreendido em uma perspectiva de processo, de provisoriedade e de resultado.

Processos, pois o que interessa comunicar não é o que as crianças fazem ou sabem, mas como as crianças operam para construir seus saberes, quais as estratégias utilizadas ou construídas por elas para alcançar seus desejos, uma vez que “documentar como aprendem as

\footnotetext{
${ }^{28}$ Recentemente conduzi, por encomenda do MEC, uma pesquisa que recolheu amostras, de todas as regiões do país, daquilo que as escolas estão nomeando como Documentação Pedagógica. É muito presente a ideia do registro apenas como entendimento de documentação pedagógica, ausente de reflexão e de articulação com a didática cotidiana.
} 
crianças é uma das questões fundamentais da escola ativa, da escola que valora, respeita e confia na criança, do qual desconhecemos os limites de seu potencial” (RTEIC, 2012, p. 14). Provisoriedade, visto que implica assumir que o conhecimento é provisório. Não estamos falando de verdades únicas e absolutas sobre as crianças, tampouco se deseja que o processo comunicado seja compreendido como um retrato da realidade, ao contrário, é sempre uma forma de interpretação que adultos estão construindo sobre os percursos dos meninos e das meninas na escola. Por fim, resultado, pois existe um compromisso de evidenciar os caminhos que resultaram da ação das crianças em seus projetos pessoais ou em grupos. Mesmo que parcial ou provisório, existe algo a ser compartilhado, se entendermos o percurso que as crianças vão traçando também como um produto de sua experiência educativa.

No entanto, é importante enfatizar que aquilo que é concretizado em uma comunicação para ser compartilhado tem sentido educativo quando nascido da reflexão e da ressignificação da prática educativa, pois seu valor está em articular o conteúdo ao processo (DAHLBERG, MOSS, PENCE, 2003). O conteúdo refere-se àquilo que as crianças dizem, fazem e o modo como os adultos se relacionam com isso, enquanto o processo refere-se à possibilidade de rever o conteúdo e o modo como se comunica a respeito (DAHLBERG; MOSS; PENCE, 2003).

Logo, entendo que a Documentação Pedagógica constrói um novo sentido ao termo didática, ressignificando-a com um especial sentido investigativo da vida cotidiana e com um valor testemunhal de uma imagem de criança, adulto e escola. Essa forte relação entre a Documentação Pedagógica e a didática que se constrói na vida cotidiana é uma espécie de didática gestáltica que Malaguzzi criou como alternativa a todo o aparato musculoso que a escola tem. Para o pedagogo, a gestalt "[...] é um caminho de saída decente e culta para abandonar o monopólio que, até então, mantém no campo educativo a palavra verbal como única forma de relação na ação didática" (HOYUELOS, 2004a, p. 111). Daí sua preocupação em comunicar sobre a pedagogia das escolas a partir de outras linguagens que não apenas a palavra, como podemos ver nos exemplares das comunicações provenientes dos projetos que serão analisadas e amplamente discutidas a seguir.

Isso posto, para desenvolver sobre o tema da documentação pedagógica, optei por reconstruir o conceito a partir dos projetos emblemáticos que deram origem às comunicações em forma de publicações (livros, vídeos, artigos) das experiências das escolas de Reggio Emilia, no centro - norte da Itália, na região de Emilia Romagna, no período em que Loris Malaguzzi esteve à frente deste modelo educativo. Decidi fazer um mergulho profundo nos projetos documentados e nos textos que Malaguzzi escreveu, sobretudo com a publicação recente 
sistematizada por Peter Moss e uma equipe de Reggio Emilia (Paola Cagliari, Marina Castagnetti, Claudia Giudici, Carla Rinaldi e Vea Vecchi ${ }^{29}$ ) em que compilam transcrições de palestras, cartas enviadas por Malaguzzi, textos escritos para revistas e jornais e outros documentos do pedagogo. É importante reforçar que o conhecimento produzido por Malaguzzi são as próprias escolas, vivas, em seus projetos educativos com o mais alto grau de consciência pedagógica, ética e política.

Também há inúmeros textos introdutórios que Malaguzzi escreveu para contextualizar ou explicitar alguns conceitos dos projetos que foram publicados das experiências das escolas de Reggio Emilia ${ }^{30}$. O pedagogo sempre teve uma grande preocupação em explicitar os conceitos que muitas vezes poderiam passar desapercebidos quando se lia uma comunicação de um projeto, já que, para o pedagogo, a comunicação dos projetos era uma importante concretização do conhecimento que estava desenvolvendo.

Além destes textos, a obra e pensamento de Malaguzzi foi sistematizada por Alfredo Hoyuelos em sua tese de doutorado e publicada em quatro livros ${ }^{31}$. Esses livros têm um valor muito grande para compreender o cenário ampliado e complexo em que podemos situar o pedagogo italiano. Hoyuelos nos ensina a ler Malaguzzi, que vale dizer, não é tarefa simples, já que o pedagogo italiano se ocupa de inúmeras metáforas e imagens para explicitar suas ideias.

O livro organizado por Susanna Mantovani, Nostalgia del futuro: liberare speranze per una nueva cultura dell'infanzia, para homenagear Malaguzzi após sua morte, também reúne textos importantes para a compreensão da sua longa trajetória, e o livro Loris Malaguzzi e la scuola a nuovo indirizzo, de Franco Frabboni e Battista Quinto Borghi, discute a construção da pedagogia social e popular do pedagogo italiano. Ambos os livros, dedicados a problematizar e ampliar a obra desenvolvida por Malaguzzi na cidade de Reggio Emilia, também foram importantes para o mapeamento que aqui se fez.

Para o OBECI, a Documentação Pedagógica é assumida como teoria e metodologia de investigação, formação e transformação, e nós temos nos debruçado sobre uma ideia de Documentação Pedagógica situada, ou seja, estamos falando das contribuições originárias de

${ }^{29} \mathrm{O}$ livro foi originalmente publicado em inglês com o título Loris Malaguzzi and the Schools of Reggio Emilia: a selection of his writings and speeches: 1945 - 1993 e posteriormente traduzido para o espanhol com o título Loris Malaguzzi y las escuelas de Reggio Emilia.

${ }^{30}$ Posteriormente indicarei quais são os projetos analisados.

${ }^{31}$ La complejidad en el pensamiento y obra pedagógica de Loris Malaguzzi, 2003; Loris Malaguzzi: biografia pedagogica, 2004a; La ética en el pensamiento y obra pedagógica de Loris Malaguzzi, 2004b; La estética en el pensamiento y obra pedagógica de Loris Malaguzzi, 2006. 
Loris Malaguzzi e de sua experiência com as escolas municipais de Educação Infantil de Reggio Emilia $^{32}$

Os projetos documentados em Reggio Emilia, supervisionados por Malaguzzi, oferecem uma multiplicidade de interpretações. Há neles o valor da pluralidade, pois estabelecem uma relação entre pensamento e significado, transformando-se em uma plataforma aberta que nos oferece a oportunidade de pensar mais e melhor sobre diferentes aspectos das crianças, dos adultos e da Pedagogia.

Embora estejamos falando de uma estratégia educativa que já completa mais de cinquenta anos, ainda não temos tão claramente circunscritos os conceitos que compõem a Documentação Pedagógica. Como muito do que Malaguzzi desenvolveu, existe o valor da intuição, a sua vasta e diversificada herança teórica e a atenção ao emergente da prática, o que jamais o obrigou a estagnar em ideias ou conceitos elaborados por ele próprio. Talvez por isso seja tão difícil estruturar sua obra e pensamento.

É importante destacar que "ler Malaguzzi" tem sido uma tarefa que envolve um amplo exercício de relações e articulações com outros textos, autores, imagens e pensamentos. Sobretudo no exercício de análise que me propus fazer, em que tive de buscar os materiais oriundos dos projetos para melhor compreender do que tratavam seus exemplos e apontamentos e, assim, ler as imagens elegidas, a forma das publicações, o fio narrativo, as vozes das crianças e dos professores. É um tipo de leitura que particularmente me agrada exatamente pela força que há em cada palavra, imagem e metáfora utilizada pelo pedagogo e que nos faz migrar para outros lugares cognitivos e interpretativos.

Realizei um levantamento dos projetos documentados e publicados no período de 1963, data de abertura da primeira escola municipal de Reggio Emilia, até 1993, período anterior à morte de Malaguzzi (30 de janeiro de 1994). Foi me valendo de três conceitos-chave da Documentação Pedagógica que me movimentei para compreender e cartografar as categorias de análise que apresento:

(i) Metainterpretação, que na literatura italiana encontramos como ricognizione, conceito-chave para a observação e análise daquilo que foi documentado. É um modo de re-conhecer e re-interpretar algo que já aconteceu;

(ii) Progetazzione, palavra emprestada do campo da arquitetura e sem tradução para o português, significa o modo como o conhecimento é colocado em

\footnotetext{
32 Durante os anos de 1968 e 1974, Malaguzzi foi assessor pedagógico no município de Modena. Algumas de suas elaborações iniciais a respeito da Documentação Pedagógica também se deram neste município. No entanto, foi em Reggio Emilia que desenvolveu principalmente seu trabalho (HOYUELOS, 2004a; 2006; BORGHI, 1998).
} 
relação para a construção de novos saberes. Denota que o conhecimento se constrói in itinere, e, portanto, não está dado. Daí que o tipo de pensamento que se reconhece nessa estratégia é o pensamento projetual e o porquê que a Documentação Pedagógica por vezes se confunde com a própria didática do trabalho desenvolvido;

(iii) Restituição, termo que significa devolver com significado algo. Restituir a experiência é construir o significado de um percurso, mesmo que de forma provisória e parcial, devolvendo e dando valor à aprendizagem e à subjetividade do outro.

Durante estes trinta anos analisados, compreendi o quanto o conhecimento sobre a Documentação Pedagógica é fruto do próprio desenvolvimento da imagem de criança, da docência e da própria identidade das escolas. Há, sem dúvida, um marco no desenvolvimento da experiência de Reggio Emilia que foi o próprio entendimento sobre a Documentação Pedagógicos nos anos 80, quando da realização da primeira grande mostra “ $L$ 'occhio se salta il muro".

Do mesmo modo, a estruturação das categorias foi um processo que se desenvolveu muito antes da tese. Nos últimos dez anos, tenho me ocupado em ler, estudar, fazer cursos e levar a cabo as ideias da Documentação Pedagógica. Na medida em que fui me apropriando dessa concepção, também fui estruturando um modo de explicar as ideias centrais da Documentação Pedagógica. Assim, as categorias que utilizei para contrastar com os projetos analisados foram sendo elaboradas ao longo de muitos anos, mas, no exercício de escrita que me propus fazer para esta tese, foi revisto e reestruturado na medida que a imersão no material utilizado indicava pistas importantes a serem consideradas ${ }^{33}$.

Assim, identifiquei os conceitos que compreendi construírem o pensamento relativo à Documentação Pedagógica em Loris Malaguzzi. Inicialmente, havia pensando em construir temporalmente estes argumentos, mas, ao analisar cada projeto, entendi que poderia facilitar a compreensão do leitor e ser mais fiel ao próprio pensamento complexo do Malaguzzi se realizasse uma apresentação menos linear possível, e, sim, estruturada pela força dos conceitos internos da Documentação Pedagógica. Assim, a apresentação do infográfico a seguir (Figura 1) é simplesmente para dar uma visão da linha do tempo dos projetos analisados para compreensão temporal.

\footnotetext{
${ }^{33}$ Para a elaboração das categorias, também me inspirei no que Tomaselli e Zocchi (2009) sugerem como resposta ao questionamento do porquê documentar: para construir memória, para dar identidade, para refletir, para projetar, para construir sistema, para comunicar, para construir qualidade e para inovar.
} 
Figura 1 - Linha do tempo dos projetos analisados

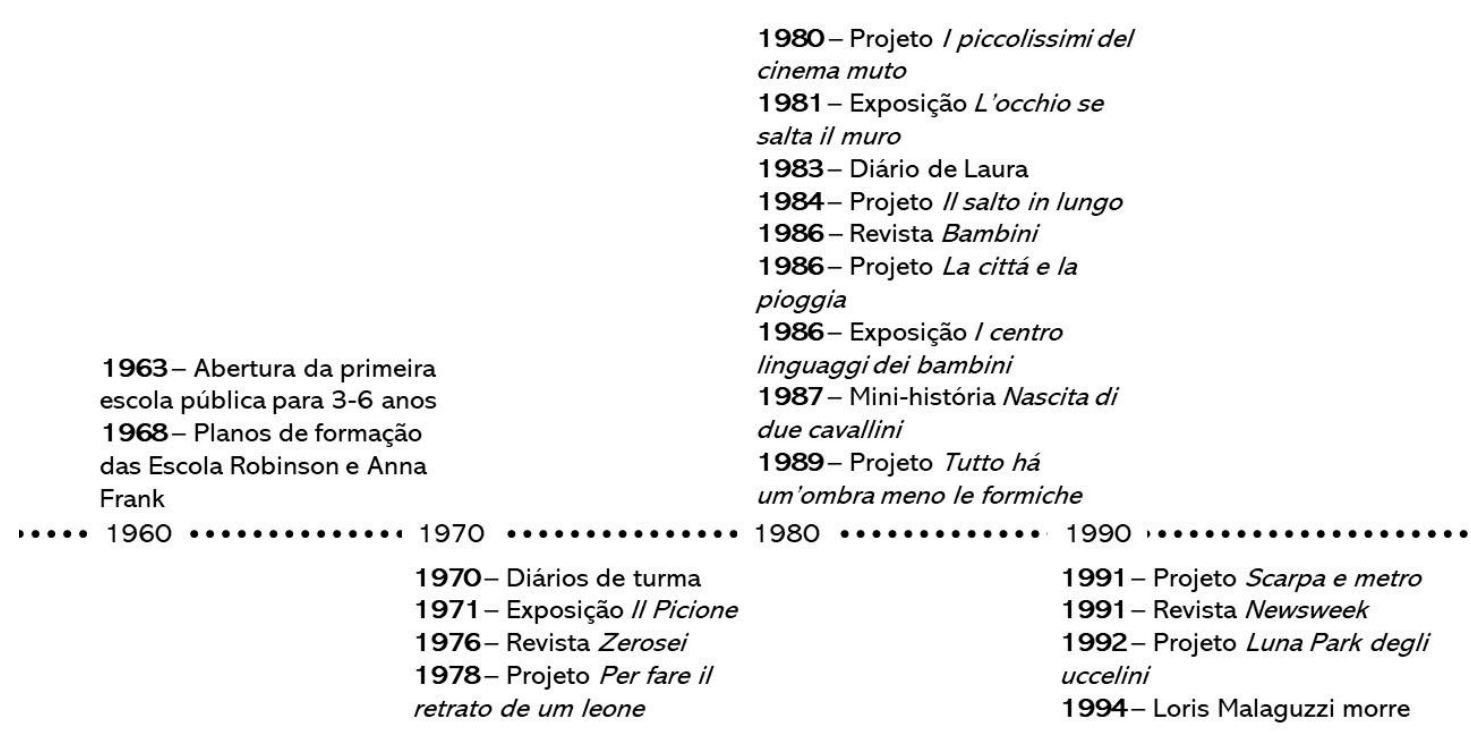

Fonte: elaborado pelo autor

Ao mesmo tempo, na medida em que cartografava os conceitos relativos à Documentação Pedagógica, fui compreendendo outros conceitos que estão diretamente ligados a essa estratégia, ou seja, aqueles relativos à construção do cotidiano praxiológico. Simultaneamente, o conhecimento praxiológico encontrado na obra de Malaguzzi é explicitado ao lado dos conceitos que se conectam aos da Documentação Pedagógica.

Sou consciente da complexidade que há nas obras e nos projetos documentados nas escolas de Reggio Emilia. Por isso, recupero o que Hoyuelos (2003, p. 67) descreveu ao tratar sobre a obra e pensamento de Loris Malaguzzi: “esta complexidade só a conseguiremos se

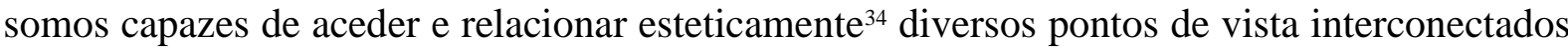
para chegar a essa montanha, que é o metaponto de vista ou o metaconhecimento".

Também destaco que compreender o modo como Malaguzzi desenvolveu seu trabalho no interior das escolas de Reggio Emilia tem o objetivo de explicitar um quadro teórico importante para minha trajetória profissional e para o OBECI. Não estou reconstituindo o pensamento de Malaguzzi a respeito da Documentação Pedagógica para aplicar nas escolas participantes do Observatório, ao contrário, enquanto uma importante referência, Malaguzzi ajuda-nos a pensar e construir um modo particular de refletir sobre a Documentação Pedagógica e sobre tantos outros temas que o pedagogo problematizou ao longo de sua trajetória. Aliás,

${ }^{34}$ Bateson foi genial ao propor uma ideia de estética como o ser sensível à estrutura que conecta as coisas aos acontecimentos. 
compreender o pensamento de Malaguzzi é também compreender que a Pedagogia se faz na proximidade das crianças e dos contextos, não por mera aplicação ou importação de modelos.

Antes, no entanto, irei situar brevemente algumas questões históricas e políticas que antecederam este período e que são basilares para o que veio a ser desenvolvido posteriormente como um modelo de trabalho, de formação, de investigação e de comunicação das experiências educativas ${ }^{35}$.

\subsection{Preparar o terreno para construir uma revolução pedagógica: o período entre 1945 e}

1963

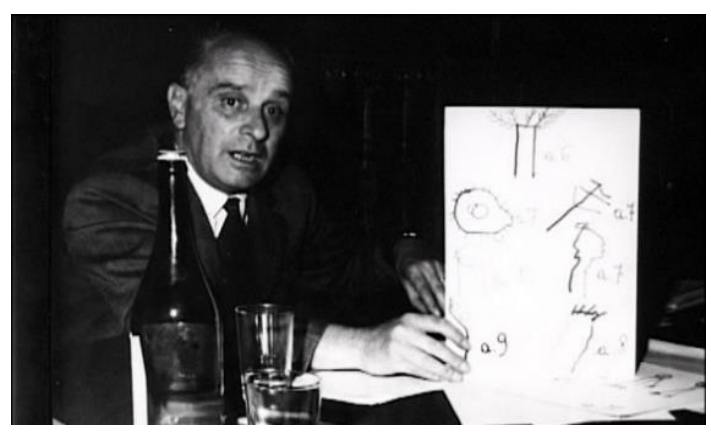

Pode-se afirmar que o fim dos anos quarenta, imediatamente após a segunda Guerra Mundial, até o fim dos anos sessenta foi uma etapa muito importante para a estruturação política da Educação Infantil em Reggio Emilia. Foram momentos de produção da cultura do debate, da participação social e de um verdadeiro laboratório

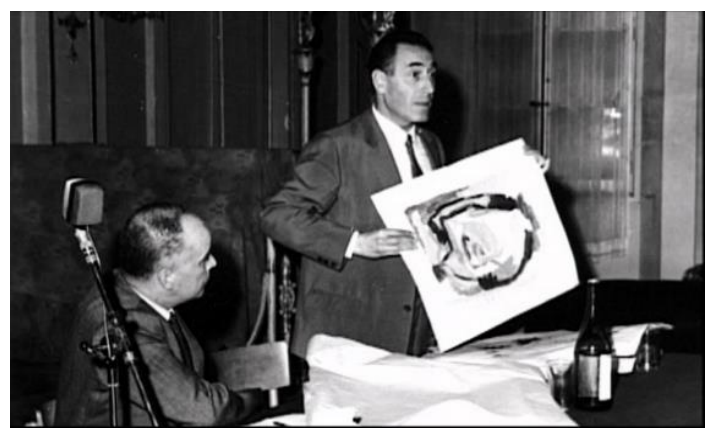
de cidadania. Um período denso de iniciativas em que Malaguzzi foi promotor e colaborador e que impactaram, não apenas Reggio Emilia, mas todo o seu entorno. Hoyuelos (2003, p. 41) comenta que:

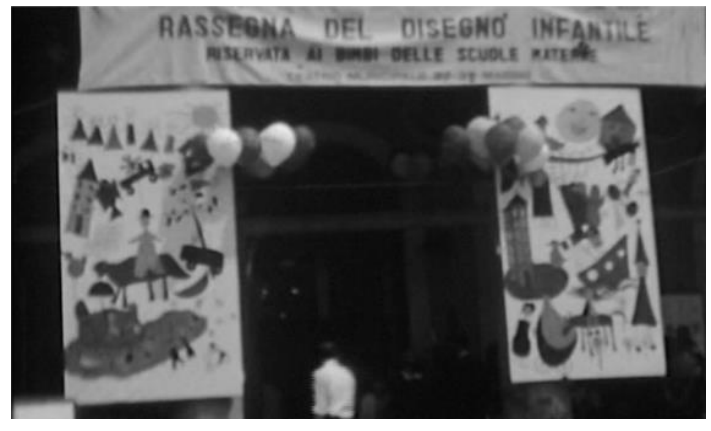

Malaguzzi teve a sorte de crescer ideologicamente com pessoas e com uma cidade que acreditava na educação como a melhor maneira de formar gerações mais livres, que odiassem a "obediência" que a tradição fascista italiana havia imposto, que aceitassem a transgressão apoiada em conceitos que a convertessem criativa. Este contexto foi e é propício para acolher suas ideias, e Malaguzzi soube adotar esse âmbito como um lugar habitável para construir seu pensamento e sua obra. Um pensamento e uma obra que estão dentro dos cidadãos (homens, mulheres, meninos e meninas), que sabem utilizar sua força social para reivindicar seus direitos políticos, todavia ainda por construir.

35 As imagens utilizadas ao longo da tese, serão referenciadas as fontes ao final da tese. Além disso, destaco que elas servem como uma linguagem a mais para compreensão do percurso pedagógico aqui apresentados, não como simples ilustração. 
Durante esse período, ocorreram importantes negociações entre os grupos civis, de representações feministas e de trabalhadores com o poder público para a municipalização das escolas. A mudança da gestão das instituições era uma condição fundamental para a transformação que se desejava, uma vez que, praticamente em sua totalidade, estavam sob o domínio da igreja católica. Este fato foi marcante para a concretização do ideal de escola pública e laica.

Do mesmo modo, com a municipalização das instituições, começou a ampliação da oferta, e foi aí que se abriu uma porta para as negociações das condições de trabalho dos profissionais que atuavam nas escolas infantis e, especialmente, para a compreensão e afirmação da noção de Gestão Social Participativa, momento em que as famílias e os profissionais das escolas formaram comissões para debater a gestão das instituições e discutir o seu financiamento (Comitati Scuola-Città) ${ }^{36}$.

Também foi nesse período que Malaguzzi realizou suas primeiras experimentações pedagógicas. É nessa época que organizou os primeiros seminários de estudos e as primeiras mostras de desenhos das crianças na cidade.

Nas colônias de férias que haviam em Reggio Emilia e que, por algum tempo, Malaguzzi foi responsável, propôs para os profissionais envolvidos construírem uma espécie de documento biográfico das crianças para poder utilizá-lo como instrumento para diálogo com as famílias. Esse é, sem dúvida, o primórdio do que mais tarde foi se sofisticando para se transformar na Documentação Pedagógica nas escolas de Educação Infantil.

Também era uma época intensa e fértil na transformação social e cultural na Itália. Já circulavam no campo da Educação Infantil as contribuições do pensamento de Maria Montessori (1870 - 1952), de Rosa Agazzi (1866 - 1951) e Carolina Agazzi (1870 - 1945), as quais Malaguzzi, embora já houvesse manifestado suas críticas, reconhecia a importância e o valor para a construção do campo. Nesta mesma altura, Malaguzzi aproximou-se de Bruno Ciari e de todo o pensamento do Movimento de Cooperação Educativa, cujo principal referente era o francês Celestin Freinet. Para Malaguzzi (1980 apud HOYUELOS, 2004a, p. 60), Bruno Ciari representava "[...] a inteligência mais apaixonante da pedagogia da infância".

\footnotetext{
${ }^{36}$ A respeito deste tópico, pode ser aprofundado nas obras Una storia presente: l'esperienza dele scuole comunali dell'infanzia a Reggio Emilia, de Ombretta Lorenzi, Ettore Borghi e Antonio Canovi (2001), na obra Loris Malaguzzi: biografia pedagógica, de, Alfredo Hoyuelos (2004a) e na obra Loris Malaguzzi y las escuelas de Reggio Emilia, de Paola Cagliari, Marina Castagnetti, Claudia Giudici, Carla Rinaldi, Vea Vecchi e Peter Moss (2017). Nesta última obra, há diversos textos, transcrições e conferências que Malaguzzi realizou ao longo do período que esteve à frente do trabalho desenvolvido em Reggio Emilia.
} 
Bruno Ciari já havia desenvolvido um trabalho de grande valor nas proximidades de Reggio Emilia, em Bolonha. Além disso, foi um forte defensor da municipalização das escolas infantis, segundo Hoyuelos (2004a, p. 60): “Ciari trabalhou para dar uma identidade pública à escola da infância e pensava que a formação da criança se realiza através de um projeto de educação integral, na qual a prática da liberdade estaria garantida somente se fosse retirada do monopólio e poder da educação católica".

Ciari é considerado um marco na educação democrática italiana, além de defender as ideias de uma escola não confessional e não autoritária. Sua formação é marcada pelo pensamento de John Dewey e Celestin Freinet. Era preocupado em fazer da escola um campo de promoção cultural e não um instrumento de privilégio de alguns, de conexão com a vida e da formação de "[...] um novo homem para uma nova sociedade" (CIARI, 1978, p. 18). Bruno Ciari faleceu em 27 de agosto de 1970 com apenas 47 anos.

As ideias de Malaguzzi coadunam com as de Ciari, quer seja pela retirada da educação da infância dos domínios religiosos, quer seja pela renovação pedagógica. Para ambos, "a escola devia trabalhar para construir uma didática credível, autêntica e capaz de promover a potencialidade da criança e uma renovada profissionalidade do professor" (HOYUELOS, 2004a, p. 60).

Também foi neste período, meados dos anos sessenta, que Malaguzzi se interessou pelos estudos de Jean Piaget e, com a atenção fortemente voltada para as crianças de 3 a 6 anos, propôs uma série de estudos e intervenções para compreender as estruturas lógicas do pensamento infantil. Para o pedagogo, "as

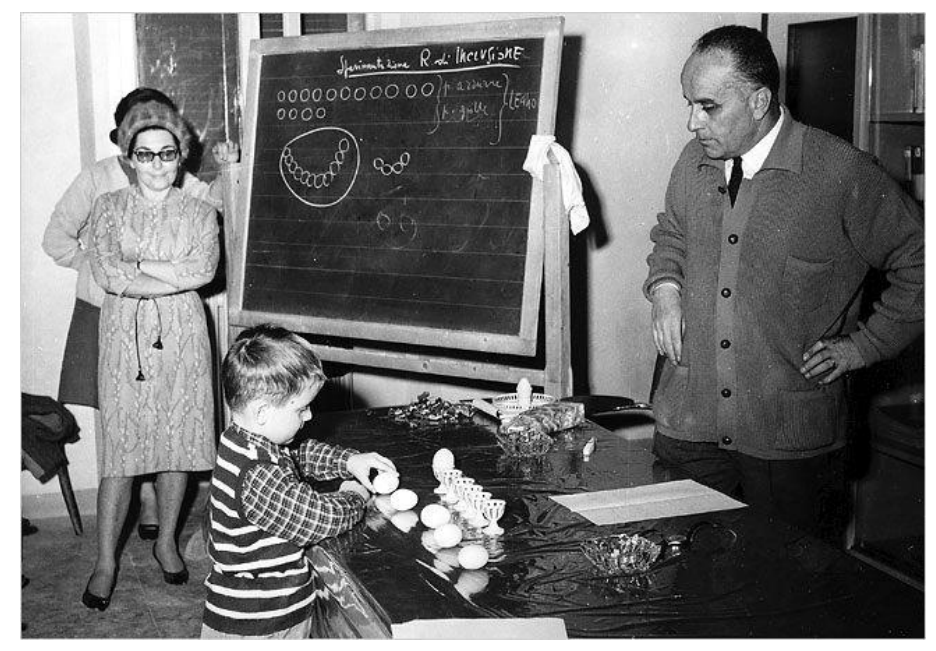
estruturas básicas dos conceitos matemáticos são idênticas a das estruturas básica do pensamento" (MALAGUZZI, 1967, p. 143). Porém, vale advertir que o pedagogo italiano não estava propondo uma educação setorizada, disciplinar para as crianças, ao contrário, para Malaguzzi (1967, p. 143-144), “o pensamento lógico se constrói e se aperfeiçoa tanto com o estudo da ciência, da linguagem falada e escrita, do desenho, da arte, da música, etc”.

Malaguzzi (1967) estava convencido que era na experiência pessoal da criança que ela nutriria seu pensamento. Na sua relação com o entorno - os adultos, as outras crianças, os 
materiais (preferencialmente não estruturados, adverte o pedagogo), a cultura como um todo -, a criança participa "[...] de uma tensão cultural que favorece sua perfeita integração com os outros elementos de vida e de educação" (MALAGUZZI, 1967, p. 142).

No ano de 1967, a Scuola di Cella, a primeira escola inaugurada depois da segunda guerra mundial que até então era administrada pela UDI (Unione Donne Italiane), é municipalizada e passa a ser chamada de Scuola XXV Aprile, em alusão à data em que terminou o período fascista na Itália. Em 1968, Malaguzzi assumiu como consultor das Escolas Municipais de Modena. Começou, nesse momento, um duplo desafio: continuar o trabalho que estava fazendo em Reggio Emilia e iniciar um novo trabalho em uma nova cidade.

Até aqui, já havia se avançado muito, especialmente no que diz respeito à estruturação política e legal que sustentaria o trabalho que posteriormente foi se desenvolvendo. Duas escolas já haviam sido abertas sob a responsabilidade do governo municipal. Muitas das escolas que eram gestadas por cooperativas estavam sendo municipalizadas.

Analisando o percurso de Malaguzzi até a data de seu falecimento, em 30 de janeiro de 1994, arrisco-me a dizer que foi a partir do início dos anos 1960 até o início dos anos 1990 que o pedagogo construiu e concretizou sua obra pedagógica. Obviamente, graças ao que já havia construído junto com seus inúmeros parceiros de trabalho e à mudança radical de quase 20 anos pós-guerra que tornaram possível aos anos precedentes ser o período de efervescência pedagógica de todo o trabalho.

Nesse período de 30 anos (1963 - 1993), mapiei os projetos, estratégias formativas, revistas e exposições que identifiquei como emblemáticos para o que veio a ser reconhecido como a Documentação Pedagógica, marca essencial das escolas infantis municipais de Reggio Emilia. É possível perceber que estes projetos são marcados por profunda transformações na medida em que se percebia a complexidade do trabalho pedagógico.

São seis as categorias que estruturei para pensar a Documentação Pedagógica como estratégia: i) renovar o pensamento pedagógico; ii) escutar as crianças e construir diálogos; iii) criar pertencimento e transformar os contextos; iv) criar situações de aprendizagem significativas; v) comunicar e construir memória; vi) fortalecer a identidade.

Na sequência desta parte da tese, apresentarei seis categorias que estruturei a partir da imersão na obra de Loris Malaguzzi e nos projetos supervisionados pelo pedagogo. Ao longo dessas categorias, ao mesmo tempo que dou visibilidade aos conceitos estruturantes da Documentação Pedagógica, mostrarei o conhecimento praxiológico produzido ao longo da experiência pedagógica das escolas de Reggio Emilia. 


\section{A DOCUMENTAÇÃo PEDAgógiCA COMO ESTRATÉgIA PARA A RENOVAÇÃO DO PENSAMENTO PEDAGÓGICO}

O fim dos anos 1960 e o início dos anos 1970 são um período em que Malaguzzi se interessou em defender a Pedagogia como a ciência que poderá transformar e renovar o pensamento pedagógico. Em uma conferência realizada em Modena, Malaguzzi (1968), ao apontar a necessidade de enfrentar diversos problemas na transformação política e pedagógica do que se desejava construir como modelo de escola da infância, lançou uma pergunta importante: "qual é a posição da pedagogia frente aos nossos problemas?" (MALAGUZZI, 1969c, p. 161).

Na sequência, o pedagogo convidou para que voltemos para nossas crenças e retomemos que ideia de Pedagogia temos. Consequentemente, para responder à pergunta anteriormente feita por Malaguzzi, só é possível "se tivermos uma concepção dinâmica e não mumificada da pedagogia” (MALAGUZZI, 1969c, p. 161). A reivindicação feita por Malaguzzi é muito importante para compreendermos o valor da Pedagogia e sua diferenciação em relação a outros campos do conhecimento. Sua crítica à imobilidade do conhecimento pedagógico da época não é privilégio daquele tempo. Muito pelo contrário, mais do que nunca é basilar a renovação e o reconhecimento da Pedagogia em sua dinamicidade, isso porque o locus da Pedagogia é a práxis educativa (OLIVEIRA-FORMOSINHO, 2007) e, por isso, é de sua essência, como campo de conhecimento, a atualização e a renovação:

\footnotetext{
Ou a pedagogia - como todas as ciências humanas - se renova, se reconstrói, se atualiza segundo as novas referências do tempo, ou perderá sua função, sua legítima capacidade não apenas de corresponder aos dias em que vive, mas sobretudo, de prever, antecipar e preparar para os dias de amanhã (e são esses, por certo, os dramas e as crises que nossas escolas estão vivendo) (MALAGUZZI, 1969c, p. 161).
}

Mais profundo ainda é o que Malaguzzi manifesta quando se trata de pensar uma pedagogia da infância. Para o pedagogo, "uma pedagogia viva, autêntica em suas funções e em seus valores, a pedagogia que nós desejamos, tende a separar o máximo possível a Escola da Infância do velho e do novo modelo assistencial, da velha e da nova forma de fingir educar" (MALAGUZZI, 1969c, p. 161).

Com efeito, o que Malaguzzi já havia compreendido era que a escola, a docência e a própria criança deveriam ser sempre um tema de interrogação, de contínua revisão e reformulação da compreensão, pois são temas que precisam estar de acordo com os contextos em que estão inseridos. Por esse ângulo, sempre que nos voltarmos aos temas da infância e da 
sociedade como um todo, é preciso reconhecê-los em sua dinamicidade. Logo, como afirma Vecchi (2013,p. 106), “o conhecimento pedagógico e psicológico, por consequência, deve estar aberto sempre para os canais de escuta e interpretação para evitar converter-se em filtros demasiado míopes ou opacos para a realidade que atravessa". Mais ainda, em se tratando da época e do contexto local que o pedagogo estava inserido, era urgente mudar as visões de criança que se tinha: uma criança passiva, vazia e que ainda não era.

Distanciar-se dessa visão significa mudar não apenas a prática educativa estabelecida nas escolas, mas “[...] colocar a primeira pedra para a reestruturação da escola básica que se deseja como um fato absolutamente improrrogável, que pode inovar na educação da criança, dos jovens e adolescentes" (MALAGUZZI, 1969c p. 162). Para Malaguzzi, era preciso assumir um campo de conhecimento que atendesse à dinamicidade com que se modificam as noções de criança e de conhecimento, e, por conseguinte, tal campo deveria responder à complexidade que emerge em cada tempo histórico e cultural.

Mas Malaguzzi tinha uma visão muito definida a respeito de que Pedagogia estava se referindo. Vecchi (2013) irá alertar a crítica que Malaguzzi já havia feito em relação à formação pedagógica. Segundo a autora, a formação pedagógica tende a separar a teoria da prática e transforma a "[...] prática na prima pobre" (VECCHI, 2013, p. 106). Por isso, Malaguzzi utilizava a imagem de uma bicicleta como metáfora de sua visão pedagógica: "para avançar, temos que pisar com força em ambos os pedais e manter um bom equilíbrio; um pedal representa a teoria; e o outro, a prática; pisando apenas em um pedal não chegaremos tão longe” (MALAGUZZI apud VECCHI, 2013, p. 106).

Sou partidário dessa visão a respeito da Pedagogia. Acredito que não podemos cair no risco de nos ocupar de teorias - por mais belas e sedutoras que possam ser - sem inseri-las em um contínuo confronto crítico com a realidade. Valendo-me

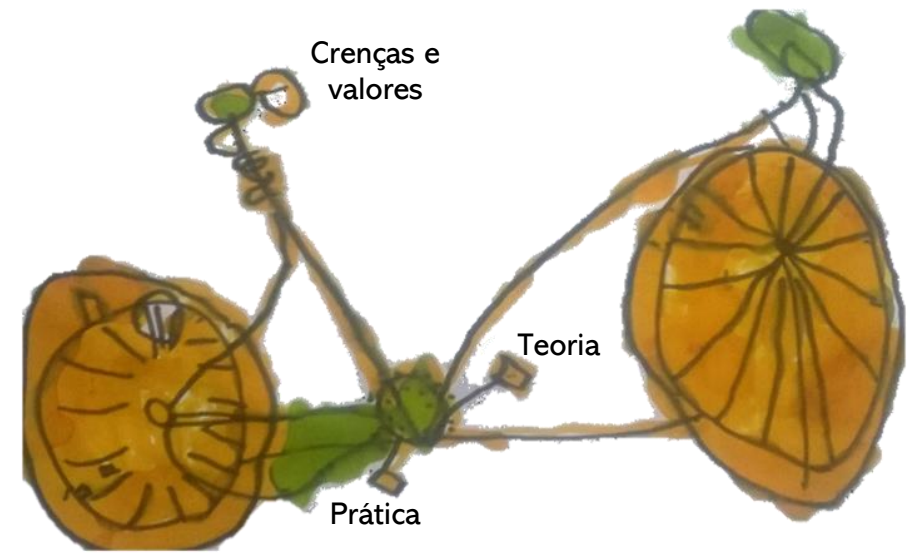
desta imagem da Pedagogia proposta por Malaguzzi, arrisco-me a propor uma releitura. $\mathrm{Na}$ verdade, suponho que a triangulação que Oliveira-Formosinho (2007) se refere à Pedagogia, como teoria, prática e crenças e valores, agrega um aspecto central para a imagem de Malaguzzi. Coloca um sujeito sobre a bicicleta imprimido ritmo a ela. Um sujeito que tem crenças e valores 
e que transforma e é transformado pelo movimento teoria-prática. Este alguém produz o equilíbrio e o desequilíbrio à Pedagogia, cria movimento, pausas, acelerações e esperas.

O que distingue a Pedagogia que emerge das escolas municipais de Reggio Emilia é que os professores “[...] dão forma, por meio dos projetos educativos e da prática cotidiana, às teorias expressas sem traí-las" (VECCHI, 2013, p.113) e sem apegar-se demasiadamente a elas, abrindo espaço para a dúvida e assumindo que "o ato de escutar a realidade cultural, social e as crianças modifica as teorias de referência" (VECCHI, 2013, p.113). Ou seja,

\begin{abstract}
Como qualquer atividade humana, a pedagogia nos exige ter os ouvidos atentos para as coisas que nos rodeiam, especialmente porque versa sobre a educação e essa preciosa parte da humanidade que são as crianças. Caso contrário, se arrisca a perder o contato com o centro de sua reflexão e prática - as crianças - e transforma-se em uma disciplina baseada simplesmente em série de regras que podem aplicar-se, a princípio, demasiadas seguras em si mesmas e "cristalizadas" com o tempo (VECCHI, 2013, p. 106).
\end{abstract}

Segundo Vecchi (2013, p. 105), a Pedagogia que Malaguzzi reivindicava era "uma pedagogia sensível às linguagens poéticas e não contida rigidamente em fórmulas préconcebidas". A abertura de Malaguzzi a outras disciplinas e campos de conhecimentos não o distanciava da Pedagogia, ao contrário, sua curiosidade e atenção para a vida contemporânea fazia com que Malaguzzi levasse para as discussões pedagógicas os diferentes aspectos que encontrava em suas tantas e variadas leituras. Na verdade, "estas leituras se reinterpretavam e se relacionavam com a pedagogia, algo que Malaguzzi fazia sem perder nunca de vista a parte vital da pedagogia: conectar-se com as crianças pequenas" (VECCHI, 2013, p. 105).

Como já foi mencionado anteriormente, a Pedagogia acolhe de modo especial a estratégia da Documentação Pedagógica exatamente por tratar da dinamicidade e da dialogicidade em relação ao contexto em que estão situadas.

A ideia de Malaguzzi a respeito da necessidade da observação também é fruto dessa época. O pedagogo estava convencido da necessidade do adulto aprender a ver a criança para poder construir a relação educativa. Para o pedagogo, isso significa "[...] tirar a criança do anonimato" (MALAGUZZI, 1967, p. 141). Nesse sentido, observar, na perspectiva malaguzziana, não é contrastar com padrões predefinidos (DAHLBERG, MOSS, PENSE, 2003; HOYUELOS, 2004a; FOCHI, 2013), mas assumir uma postura crítica e interessada frente à criança em sua relação com o contexto de que faz parte. É uma busca constante e inacabada por compreender e se assombrar com as belezas e descobertas sobre o que e como as crianças fazem e aprendem. Em suma, Malaguzzi (1967, p. 140) dirá que 
o que se necessita, citando Claparède, é de uma constante presença da postura científica, quer dizer, da nossa atitude de nos assombrarmos frente aos fatos cotidianos em nossa vida profissional, de ter o desejo de interrogar estes fatos e de tentar obter uma resposta, submetendo-os à observação metódica e ao experimento.

Desde aquele momento, o pedagogo já sabia da importância de conciliar a atuação do adulto com uma atitude curiosa e investigadora. De não dar a criança e o contexto como dados, mas de compreender que nos constituímos na relação com as coisas e com o mundo ${ }^{37}$.

Já no final da década de 1970, em uma publicação no ano de 1968, Malaguzzi anunciou uma série de itens conquistados nos anos anteriores na construção das escolas municipais de Reggio Emilia. Para o pedagogo, esses aspectos tinham sido elogiados pela imprensa especializada, sendo que são tais aspectos que indicam o que caracteriza uma boa escola:

encontros com as famílias, reuniões periódicas, jornadas de estudos para as professoras, formação da equipe, conferências pedagógicas para os pais, exposições didáticas, criação direta do material educativo, experimentações didáticas, congressos de estudo com os quais participam professores de outras cidades constituem os momentos produtivos de formação, de atualização, de investigação que caracterizam o trabalho das nossas Scuolas Materne Comunali (MALAGUZZI, 1968, p. 148).

Tudo isso foi redesenhando a cultura do interior das escolas. Malaguzzi parecia ter encontrado o ponto exato para fazer uma grande revolução. Seu diálogo com as diferentes áreas enriquecia os debates que o pedagogo travava. Com a arquitetura, Malaguzzi delineou os projetos arquitetônicos das escolas, do mobiliário e da atmosfera estética que a ele era tão cara, ${ }^{38}$ e dela, assim como do design, vai buscar sua compreensão de projeto e de pensamento projetual $^{39}$. Na sua relação com a arte, Malaguzzi incorporou dentro da escola a presença de outros profissionais, tais como a figura do atelierista ${ }^{40}$ e do diálogo com o teatro ${ }^{41}$, para fazer crescer o valor para as tantas linguagens da criança, as cem, como ele próprio mais tarde escreveu. Com a literatura, Malaguzzi aproximou as professoras do universo fantástico ${ }^{42}$. $\mathrm{O}$

\footnotetext{
${ }^{37}$ Embora o interesse de Malaguzzi no tema da observação tenha se dado cedo, o aprimoramento da compreensão por parte dos professores precisou de mais tempo. Em um tópico a seguir, irei tratar disso.

${ }^{38}$ Essa valoração podemos perceber em seus diálogos e aproximações com Tullio Zini.

${ }^{39} \mathrm{O}$ termo progetazzione, que mais tarde será discutido, é um empréstimo que Malaguzzi irá buscar na arquitetura e no design para mudar o paradigma do planejamento na Educação Infantil. Um dos seus interlocutores é Bruno Munari, referência no que diz respeito ao tema da projetualidade no design.

40 Profissional de formação artística que desenvolve um trabalho semelhante ao do coordenador pedagógico, mas que trabalha em parceria com os professores de referência das turmas nos projetos de aprendizagem das crianças, na elaboração das documentações pedagógicas e na formação.

41 Como exemplo, podemos falar da entrada de Mariano Dolci, que foi o primeiro marionetista a ser contratado pelo poder público na Itália.

42 Malaguzzi tinha um forte apreço pelo universo literário e uma grande aproximação com Gianni Rodari. O livro Gramática da fantasia, escrito por Rodari, é dedicado às escolas de Reggio Emilia, pois decorre de um trabalho de formação que realizou na cidade, em novembro de 1972, chamado de "Encontros com a fantasia".
} 
pedagogo sabia da importância dos múltiplos diálogos: esta era a demanda do pensamento moderno - "[...] a universalidade e ecumenicidade da cultura" (MALAGUZZI, 1967, p. 139).

E foi assim que se tornou visível e mais dialógico o trabalho desenvolvido dentro das escolas em Reggio Emilia. Foram anos determinantes para o que, mais tarde, veio a ser reconhecida como uma das experiências mais exitosas no campo da renovação pedagógica na educação da infância.

Malaguzzi também antecipou aquilo que se tornou o antídoto à escolarização e à ideia de improvisação do trabalho do professor, ou seja, a Documentação Pedagógica. Segundo o pedagogo, "a professora observa, encoraja, anota, volta a propor, comprova. As professoras têm cadernos de observação onde atualizam com fatos significativos do seu trabalho, de suas experiências, das diferentes atuações das crianças, com uma atitude de reflexão crítica e de maravilha" (MALAGUZZI, 1968, p. 149).

Aborrecia-o a falta de hábito do registro dentro do âmbito educativo. Também era do seu incômodo todo o aparato musculoso - divisão disciplinar, organização do tempo por períodos, centralidade nos conteúdos, a homogeneização da aprendizagem, a compartimentação da visão de criança, para citar alguns destes itens que compõem este aparato - que a escola de Ensino Fundamental já tinha e que a Educação Infantil havia incorporado de algum modo. Igualmente não suportava o espontaneísmo. O cotidiano educativo, como o próprio Malaguzzi definia, “[...] era uma verdadeira universidade, ou seja, um lugar de aprendizagem real e respeitável” (CAGLIARI et al. 2017, p. 119). Daí seu grande esforço em criar estratégias para que os professores fossem tomando consciência sobre o seu próprio fazer, sobre o conhecer as crianças e assumir o valor cultural e político que uma escola representa em uma dada sociedade.

Uma das estratégias que apareceu no final da década de 1970 são os planos de formação. Malaguzzi escreveu um plano de trabalho em parceria com as professoras da Scuola Anna Frank e Scuola Robinson, primeiras escolas municipais de Reggio Emilia. A ideia era investigar, junto das crianças, possibilidades expressivas a partir das histórias de Robson Crusoé e Pinóquio. Na verdade, esse plano de trabalho foi decorrente da prática que anteriormente já havia sido conduzida pelo pedagogo em ambas as escolas. A partir desse trabalho, "percebemos a oportunidade de oferecer a atenção e a reflexão dos colegas como um dos muitos pontos de referência para a temática educativa da infância e, com isso, estamos convencidos de que possa animar também em outras escolas discursos e confrontos concretos" (MALAGUZZI, 1969a, p. 151). 
A proposta de compartilhar um plano de trabalho com outras pessoas que não estiveram presentes ao longo da experiência é uma chave importante de compreensão a respeito da Documentação Pedagógica. Não se trata de um relato de experiência, que mostra pontos altos ou pontos baixos de um trabalho, mas se oferecem as reflexões e os pensamentos que um determinado grupo construiu no sentido de "animar" e gentilmente oferecer um, dentre tantos, itinerários de trabalho ${ }^{43}$. Sem sombra de dúvidas, esta é uma marca do trabalho de Malaguzzi. Até hoje, quando acessamos os projetos que foram desenvolvidos nas escolas de Reggio Emilia é, de alguma maneira, uma oportunidade de se ocupar da reflexão que um determinado grupo fez e que pode nos mostrar a interlocução entre uma dada herança teórica, uma práxis e a chave de leitura interpretativa desse grupo em um certo contexto. Obviamente, não se trata de tentar repetir como uma receita, mas de compreender os aspectos centrais que podem oferecer a outros grupos, outras escolas, possibilidades de construírem seus próprios trabalhos ${ }^{44}$.

Nesse plano de trabalho, Malaguzzi fez uma forte crítica às perspectivas metodológicas que "[...] tornam-se espaços metódicos demasiados amplos para a ocasionalidade, a dispersão e a espontaneidade" (MALAGUZZI, 1969a, p. 151). Considero esse aspecto muito importante de ser destacado, já que é comum ver associado ao trabalho de Reggio Emilia uma falsa e equívoca leitura de "livre expressão"45. Logo, chama atenção a necessidade de se criar um itinerário de trabalho a ser oferecido para as crianças e as professoras:

um dos múltiplos itinerários possíveis que compõem a obra educativa, capaz de orientar o caminhar juntos, o crescer juntos, que é o módulo essencial de uma educação igualmente tranquilizadora e libertadora que tento, nos níveis do possível e de maneira progressiva, as primeiras organizações e integrações do conhecimento. Organização que não quer dizer sistematicidade, e tampouco simples adição (MALAGUZZI, 1969a, p. 151).

No documento voltado à orientação de um plano de trabalho para as demais escolas, Malaguzzi manifesta a sua compreensão da qualidade de um método e de sua adaptação: “um método, se é bom, será sempre, e nós honramos com perfeita coerência ainda que o

43 Podemos citar como exemplo o projeto publicado no livro As cem linguagens da criança: a abordagem de Reggio Emilia na Educação da Primeira Infância - volume 1, organizado por Carolyn Edwards, Lella Gandini e George Forman (1999), com a narrativa do projeto "Múltipla simbolização no Projeto do Salto em Distância" (p. 177-194).

${ }^{44}$ Um exemplo de translado de planos de trabalho pode ser acessado no livro As cem linguagens da criança: a abordagem de Reggio Emilia na Educação da Primeira Infância - volume 1, organizado por Carolyn Edwards, Lella Gandini e George Forman (1999), com a narrativa do projeto "A cidade na neve - aplicação da abordagem multissimbólica em Massachusetts", que se inspira no projeto a Cidade na chuva, desenvolvido em Reggio Emilia (p. 235-252).

${ }^{45}$ A esse respeito, desenvolvo também na Parte III ao relacionar com os modelos de escola que Tonucci sugere. 
proporcionemos de acordo com as disponibilidades objetivas dos protagonistas" (MALAGUZZI, 1969a, p. 152).

Também o documento se refere à orientação de que seja feita uma "exposição permanente" e sugere que esta proposta esteja em relação com o processo de investigação das duas histórias:

[...] se trata de uma preciosa documentação que cresce com o conto e que exige um boa localização entre o interior e o exterior das salas: como satisfação para os autores e como estímulo continuamente disponíveis para a memória e para a reflexão das crianças; e, finalmente, como testemunho de um trabalho realizado por e com as crianças, que as famílias possam ler de forma clara e apreciar (MALAGUZZI, 1969a, p. 156).

A ideia de uma exposição permanente foi um modo que Malaguzzi encontrou para construir contínuas interações com as famílias e a cidade. Para o pedagogo, a educação de crianças precisa ser uma declaração pública. Nesta imagem emblemática da investigação que as crianças fizeram a partir da história de Robinson

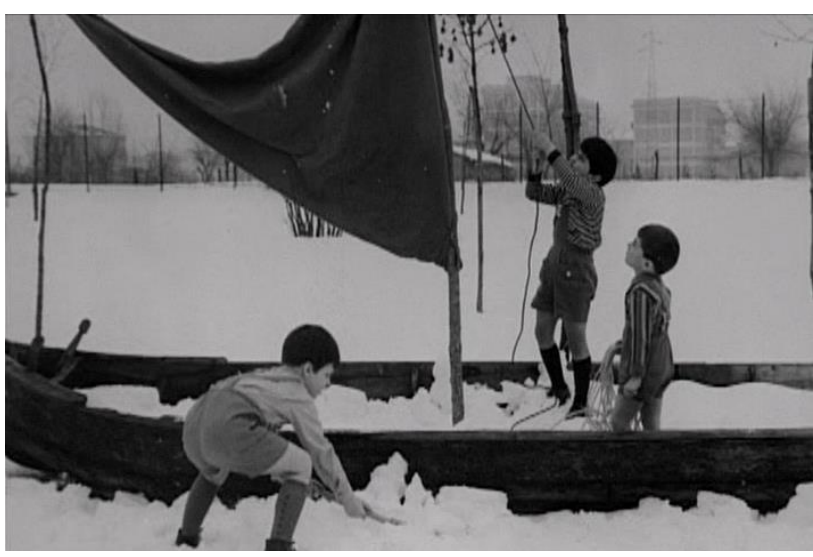
Crusoé, mostra um barco que os pais levaram para a escola e, com a ajuda das crianças, colocaram no pátio, para se transformar em espaço para as crianças viverem as aventuras que o personagem da história havia percorrido.

Até os anos de 1970, pode-se dizer que Malaguzzi se empenhou "na busca de uma definição e legitimação da identidade cultural para a scuola da infância comunal" (CAGLIARI et al., 2017, p. 117). Conforme o pedagogo,

\begin{abstract}
Nossas responsabilidades estavam claras. Muitos olhos, não todos benevolentes, nos seguiam. Tínhamos que nos equivocar menos possível, encontrar rapidamente nossa identidade cultural, tornar-se conhecidos, nos armar de confiança e respeito. [...] Era uma época de efervescência. De ajustes e adaptações contínuas das ideias, da seleção de projetos e intenções que tínhamos que produzir conciliando as expectativas das crianças, das famílias e refletir nossas competências ainda que estavam por amadurecer (MALAGUZZI, 2012, p. 31 apud CAGLIARI et.al, 2017, p. 115).
\end{abstract}

É inegável que, nesse período, germinou o que, na década seguinte, começou a ser concretizado. Na experiência pedagógica de Reggio Emilia, a virada para os anos de 1970 é um marco de ruptura com o passado. Foi entre o ano letivo de 1970 e 1971 que se deu a construção da emblemática Scuola Diana e, imediatamente, na sequência, a aprovação do novo 
regulamento para as escolas da infância e para as creches ${ }^{46}$. Foi a partir desse novo regulamento que se definiu a exigência de formação para os profissionais, a definição da carga horária de 36 horas semanais, o tempo dedicado para a formação e planejamento e a dupla pedagógica (docência compartilhada). Nesse mesmo período, foi aberta a primeira creche municipal (para crianças de 0-3 anos), o que significava uma mudança significativa para o modelo de educação que se tinha na Itália.

Tudo isso formou o contexto ideal para Malaguzzi empreender suas ideias e sua força pedagógica. Com a expansão do atendimento (na década de 1970, abriram-se mais de 15 escolas municipais e mais de 10 creches municipais) e com o cenário que haviam construído na década anterior, Malaguzzi se dedicou profundamente ao trabalho pedagógico.

Malaguzzi não suportava o anonimato das crianças. Também não lhe agradava a ideia do trabalho pedagógico permanecer escondido ou apenas confiado à memória. Ele acreditava que era necessário criar "um testemunho cultural e pedagógico da própria profissão" (HOYUELOS, 2006, p. 194).

Também sabia que os professores não gostavam muito de escrever sobre sua prática e sobre as crianças. Segundo o pedagogo, “é mais fácil que um caracol deixe rastros do seu próprio caminho, do seu trabalho, que uma escola ou uma professora deixar marcas escritas de seu caminho, do seu trabalho" (MALAGUZZI, 1989 apud HOYUELOS, 2006, p. 195).

A estratégia dos diários de turma, ou cadernos de trabalho, ou caderneta de fatos e reflexões ${ }^{47}$, são um marco importante para compreender os ideais pedagógicos de fundo de Malaguzzi no começo de sua jornada como pedagogista. Os diários foram a ferramenta para o pedagogo manter-se próximo ao trabalho dos professores e de convidá-los a dar testemunho sobre a própria experiência profissional:

Se tratava de grandes cadernos, com linhas ou quadriculados, escritos com uma certa elegância e uma ordem indiscutível. [...] Na primeira página, se indicava o nome da escola e grupo, os nomes das professoras que irão escrever e o ano escolar de referência; na segunda página, se anota o nome de todas as crianças, a data de nascimento e as respectivas datas de ingresso [...]. Poderia ocorrer de se colocar a fotografia das crianças. Não faltavam os desenhos das crianças, as cartas e convocatórias de reunião da direção (BORGHI, 1998, p. 189).

${ }^{46}$ Regolamento dele Scuole Comunali dell'Infanzia

${ }^{47}$ Foram encontradas diferentes denominações para este caderno que Malaguzzi exigia das professoras em Módena e Reggio Emilia no final dos anos sessenta e início dos anos setenta: Diario di sezione, Quaderno di lavoro, quadernone Fatti i riflessione. 
Borghi (1998) realizou a análise de quatro diários supervisionados por Malaguzzi entre os anos de 1969 e 1972 em Módena ${ }^{48}$. Segundo o autor, são inúmeras as formas como cada professora se utilizava destes diários no dia a dia educativo; porém, o propósito maior que se mantinha em todos eles era o fato dos diários serem utilizados para a recolha de informações da realidade educativa a fim de construir uma compreensão daquilo que se fazia e do que era possível fazer melhor.

A partir dessas análises, Borghi (1998, p. 190) elenca alguns "binômios-chave" que auxiliam a "ler" profundamente o que se esconde nos diários:

a) Documentação sistemática e ocasional - um dos aspectos de análise dos diários faz referência à intenção de quem os escrevia (BORGHI, 1998). Tanto para as professoras que tinham por hábito o uso mais sistemático deste instrumento quanto para aquelas que o faziam ocasionalmente, era possível perceber o valor reflexivo; além disso, segundo o autor, "não queremos dizer que uma escolha seja pior do que a outra, ao contrário, nos limitamos a sublinhar que se trata de fins diversos e que tem resultados diferentes" (BORGHI, 1998, p. 190). No caso de um registro mais sistemático do diário, percebe-se "a existência de um fio comum: o professor não diz tudo, mas há uma seleção de coisas a dizer com base em algumas escolhas que são definidas “"upstream 49"” (BORGHI, 1998, p. 190). No segundo caso, de um registro mais ocasional, percebe-se "[...] um professor mais explorador do seu terreno" (BORGHI, 1998, p. 190), ou seja, o professor costuma registrar “[...] um pouco de tudo sem parar em aspectos particulares" (BORGHI, 1998, p.190).

b) Perspectiva da grande angular e teleobjetiva $a^{50}$ - no conjunto de diários observados, Borghi (1998, p. 191) ainda percebe dois tipos dominantes de estrutura desses textos: um primeiro modelo que poderia ser chamado de uma "crônica diária dos eventos descritos como acontecem no dia a dia educativo" (BORGHI, 1998, p. 191). Nesse caso, o diário oferece uma visão geral, ou seja, o professor tem uma visão mais próxima e mais ampliada, como uma lente

$48 \mathrm{O}$ texto com a análise dos diários foi publicado por Battista Quinto Borghi no livro organizado por Susanna Mantovani em homenagem a Loris Malaguzzi: Nostalgia del futuro: liberare speranze per una nueva cultura dell'infanzia, publicado pela Edizioni Junior em1998.

49 "Upstream", em inglês, "a monte", em italiano: rio acima, literalmente, ou por cima. É uma expressão utilizada para referir-se a um fluxo ascendente.

50 Grande angular e teleobjetiva são dois tipos de lentes para câmeras fotográficas. A primeira é utilizada para pequena distância focal, mas com amplo campo visual, já a segunda é utilizada para fotografar a grandes distâncias com boa qualidade focal. 
grande angular. No segundo modelo, percebe que o professor encontra “[...] uma linha de discurso[...]" (BORGHI, 1998, p. 191), ou seja, um aspecto a ser aprofundado longitudinalmente através de "[...] microepisódios e experiências individuais" (BORGHI, 1998, p. 191), por exemplo, observar, registrar e refletir sobre o processo de adaptação de uma determinada criança.

c) Desordem e ordem - o autor explica que "existe uma modalidade de compilação dos diários que faz pensar que a professora não havia intenção de organizar segundo alguma ordem significativa de conteúdo, limitando-se à progressiva ordem dos dados dos acontecimentos" (BORGHI, 1998, p. 192). Neste caso, o autor vai dizer que este professor funciona por "imersão" e não por "abstração" (BORGHI, 1998, p. 192). De um modo, ganha-se no sentido de compreensão da natureza sistemática dos acontecimentos. Já do outro, valese da atenção ao contexto, "aos problemas que surgem no dia a dia" (BORGHI, 1998, p. 192). Em ambos, não se trata "de um sinal de desordem ou confusão, mas simplesmente um modo de entender a ação educativa" (BORGHI, 1998, p. 192).

d) Variáveis implícitas e variáveis explícitas - um dos fortes conteúdos dos diários são os “fragmentos da vida cotidiana” (BORGHI, 1998, p. 192). O autor observa que, mesmo diante de uma quantidade diversa de situações presentes nos diários, é possível observar alguns fios condutores, como variáveis, que explicitam um conteúdo que está implícito na própria situação cotidiana. O autor cita alguns exemplos:

- o número diário de crianças: a prática de contar com as crianças quantos estão presentes e quantos estão faltando se apresenta como um ritual significativo e forte: "contar todos os dias oferece um sentimento de pertencimento para cada um e fortalece a ideia de grupo" (BORGHI, 1998, p. 192).

- o menu diário: a prática de "relembrar que coisa se come diariamente contribui para descrever a história da comunidade de que se faz parte e que por um certo tempo se divide a mesma mesa" (BORGHI, 1998, p. 192) é um dos aspectos reconhecidos no contexto de análise dos diários. Há um valor cultural e simbólico na comida; assim, valorizava-se muito a 
oportunidade de compartilhar os horários de alimentação nas escolas, ${ }^{51}$ pois "há uma relação com a comida de que era muito personalizada e não anônima como nas atuais circunstâncias de cozinhas industrializadas" (BORGHI, 1998, p. 192).

- a pedagogia do cotidiano: os diários continham o verdadeiro valor da continuidade e descontinuidade que há na vida cotidiana, ou seja, "todos os diários evidenciavam aquilo que acontecia dia após dia" (BORGHI, 1998, p. 193). A partir dos relatos cotidianos, é possível ir compreendendo a atmosfera em que se situava aquele grupo de crianças e adultos, reconhecem-se as características de um dado tempo, de uma dada localidade e de um dado grupo de pessoas.

e) Trabalho educativo da professora: pensar e agir - a prática de registro no diário se dá ao término dos acontecimentos: "A professora, através da escrita, repercorria, a posteriori e em silêncio, àquilo que havia precedentemente realizado com as crianças" (BORGHI, 1998, p. 194). O autor afirma que esta modalidade é distinta das demais, pois não permite que o professor pare e reflita com calma sobre o que passou, sendo "[...] similar a um combatente que se coloca no fronte durante uma ação de defesa e que não lhe é consentido parar e continuar a fazer a sua batalha sem poder parar muito para olhar o entorno e compreender o que está acontecendo" (BORGHI, 1998, p. 194). E é desse posicionamento que vem o nome do caderno de "fato e reflexão", pois uma vez registrado o fato escolhido para constar no diário, oferecia, posteriormente, ao professor a possibilidade de refletir longitudinalmente aquilo que foi anotado. Também era uma característica importante dos diários a noção de que eles eram do grupo e não de cada professor, ou seja, o docente devia compilar "o pensamento e ação de todos os professores do grupo e não individualmente" (BORGHI, 1998, p. 194). Nesse sentido, o diário configurava-se como uma voz polifônica do grupo, sujeito a múltiplos olhares e percepções.

f) Sujeito e contexto - um dos aspectos muito importantes dos diários é a relação entre sujeito e contexto. "Raramente as crianças estavam presas em si mesmas [...], mas mais frequentemente em relação à dinâmica que incessante e

51 É importante destacar que Malaguzzi deixou seu trabalho em Modena exatamente porque não estava de acordo com a decisão da administração municipal em centralizar as refeições em uma cozinha central e com isso deixar de serem feitas em cada escola (BORGHI, 1998; HOYUELOS, 2004a). 
constantemente se envolvia" (BORGHI, 1998, p. 194). Graças ao forte interesse de Malaguzzi pela perspectiva de Vigotsky, sua orientação para as professoras era para que se centrassem no contexto que as atuações das crianças se desenvolviam. Nesse sentido, Malaguzzi orientava as professoras para "não prender a criança nela mesma e ter em conta também o contexto no qual está inserida, pois fazer isso não significa apenas prestar atenção na evolução de cada criança, mas acolher também aquilo que contribui para determinar tal evolução" (BORGHI, 1998, p. 194). Dessa forma, Malaguzzi defendia que a cultura se transformava na "caixa de ferramentas" das crianças, entendendo que seu pertencimento, em um sentido antropológico, dava-se pelo "direito da criança ao desenvolvimento da mente e da sua aproximação aos saberes" (BORGHI, 1998, p. 194). Acreditava-se, assim, que "a documentação, para ser válida, deve[ria] ser contextualizada" (BORGHI, 1998, p. 194).

g) Abordagem experimental e ecológica - em alguns casos, os diários perseguem uma determinada situação particular e, por isso, o professor acaba registrando e reunindo elementos por um certo período. No entanto, isso não significa que a narrativa ocorra linearmente. Graças à condição vivencial, in $l o c o$, em que os professores estão inseridos, vão percebendo que "um problema remete a outro problema até que a atenção originária parece não existir mais" (BORGHI, 1998, p. 195). Isso porque a professora parece ir criando uma lente de aumento graças à quantidade de registros que vai produzindo: “A professora tende a registrar tudo aquilo que vê quase com a convicção que a quantidade de informações recolhidas possa dar a ver qualquer coisa de nova e de diferente do que se havia visto inicialmente" (BORGHI, 1998, p. 195). Nesse sentido, as coisas não são vistas isoladamente, mas percebidas em suas relações de interdependência, ampliando os sentidos. $\mathrm{Na}$ verdade, “os diários se manifestam em um ponto de vista ecológico, aberto à incessante mudança de condições e cuidadoso em captar as situações em sua riqueza e complexidade" (BORGHI, 1998, p. 195).

h) Abordagem estática e dinâmica - muitos dos diários possuem uma espécie de descrição das próprias reações subjetivas dos professores diante de determinadas situações. Isto, no entanto, "oferece a possibilidade da reanálise sobre a própria atitude em cada situação educativa que se está envolvido" 
(BORGHI, 1998, p. 196). Este olhar distanciado oferece o tempo necessário para o reexame e a compreensão mais ampliada de uma dada situação. Assim, o autor também destaca que "o diário, neste caso, torna-se um instrumento de auto clarificação da própria ação educativa. Trata-se de uma visão retrospectiva para reler o trabalho à distância e com um olhar objetivo e imparcial" (BORGHI, 1998, p. 196).

É importante destacar que não se encontra o termo "documentação pedagógica" nos textos que datam até o final dos anos 80. É na virada dos anos 80 para os anos 90 que começam a ser nomeadas a união das diferentes estratégias de observação, registro, interpretação e comunicação como Documentação Pedagógica. No entanto, podemos perceber, a partir dos binômios apontados por Borghi (1998), que, desde as primeiras experiências com o que veio a ser posteriormente nomeado como Documentação Pedagógica, houve a compreensão de que esta seria uma estratégia oportuna para o professor conhecer e reconhecer a sua prática e de pensar sobre a ação pedagógica e retirá-la das sombras do automatismo. Neste caso, os registros feitos nos diários, aspecto central para a estratégia da Documentação Pedagógica, são fontes de reflexão, análise, memória e suspensão do fazer cotidiano. Acolhem a visão do professor sobre si mesmo e sobre a experiência educativa como um todo, incluindo as crianças em suas atuações plurais. Tornam especial o efêmero, que facilmente poderia passar despercebido, ou mesmo, mostram a grandeza de um projeto de aprendizagem. Na verdade, o que vemos é o nascimento de uma estratégia baseada na pesquisa do professor sobre a sua própria formação, sobre o respeito ao valor contextual das crianças e sobre o valor da narratividade como forma de produzir conhecimento e renovação do pensamento pedagógico.

Esses elementos conformam o reconhecimento do ato educativo na complexidade que há nele. Percebemos que nos diários existe uma amplitude de interesse, ou seja, os projetos e a vida cotidiana têm o mesmo valor educativo. $\mathrm{O}$ ato de comer e uma situação de um dado projeto não se opõem ou se distanciam frente ao valor subjetivo para a criança, pois ambos compõem a jornada de aprendizagem dos meninos e meninas.

Um outro tipo de diário também foi emblemático na história pedagógica de Reggio Emilia. Publicado pela primeira vez em 1983, Il

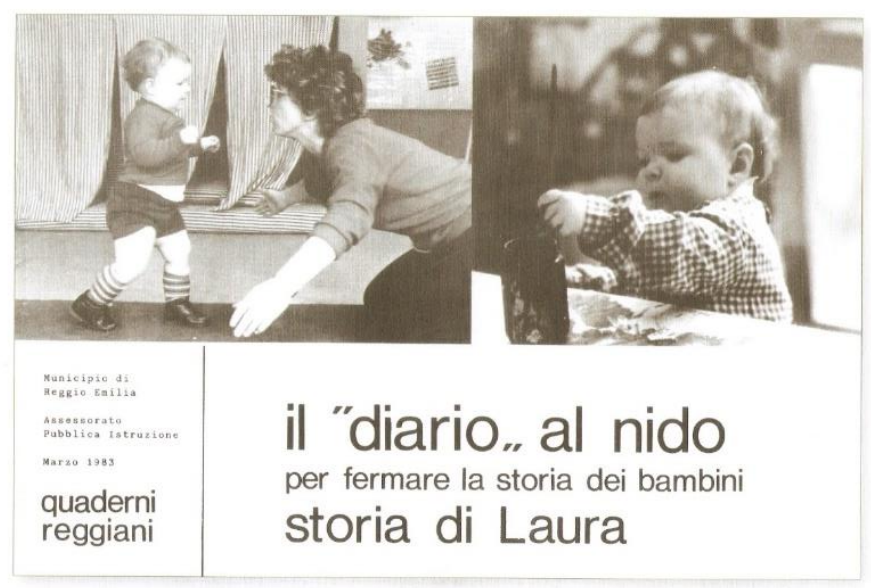


diário al nido per fermare la storia dei bambini: storia di Laura ( $O$ diário na creche para narrar a história das crianças: história da Laura), o documento narra o processo de chegada de uma criança de 10 meses à creche por meio de imagens e anotações das professoras. Em pouco mais de 15 páginas, Laura, a protagonista, tem suas aventuras e desventuras de chegada na creche Arcobaleno narrada pelos olhos das duas professoras, Eluccia e Ivetta, que a acompanham nesse momento.

No diário, há uma das imagens mais emblemáticas da história pedagógica das escolas infantis municipais de Reggio Emilia. A última história do diário, Il tic-tac dell'orologio, mostra um momento especial entre Laura e Eluccia olhando um catálogo repleto de imagens. A professora narra o profundo interesse de Laura com as imagens do catálogo. Destaca as palavras que a menina ensaia ao ver imagens de homens e mulheres, "mamãe" e "papai", e sublinha o cuidado e atenção de Laura ao virar cada página. Ao encontrar umas imagens de relógios no catálogo, a professora comenta à Laura que é igual ao que ela estava usando, e aproxima do ouvido de Laura para que a menina perceba o som dos ponteiros. Laura, atentamente, fixa-se ao som do relógio da professora e, após alguns instantes, coloca seu ouvido nas imagens de relógio do catálogo parecendo buscar o "tic-tac". Esta sequência de imagens se encontra ainda hoje na entrada da creche, em um grande painel, e representa uma grande metáfora do projeto educativo de Reggio Emilia.

Este diário foi reimpresso em inglês com o título The diary of Laura: perspectives on a Reggio Emilia Diary, editados por Carolyn Edwards e Carla Rinaldi no ano de 2009. Nessa versão além da cópia do diário original em italiano com tradução para o inglês, narra-se o reencontro de Laura e sua mãe, 20 anos após a experiência original do diário, com as professoras na creche Arcobaleno. Também, nessa versão, há textos reflexivos de diferentes especialistas que analisam a contribuição que o documento pode ter ao campo educativo.
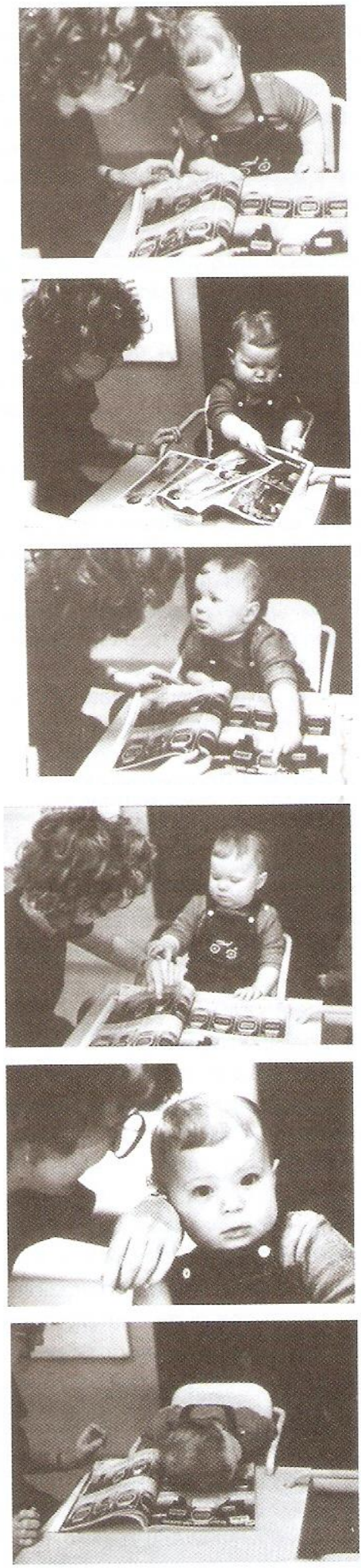
Carla Rinaldi, pedagogista da creche, escreve um texto introdutório do diário alertando para o valor que este tipo de documento pode ter para os educadores, "para autoanalisar-se, junto aos colegas, o como e o porquê dos acontecimentos e dos comportamentos de cada criança; para informar aos pais e juntos, ler e interpretar os 'sinais da criança no contexto da experiência"” (RINALDI, 2009, p. 25-26). Por sua vez, também há um valor do documento para os pais, "[...] como uma ocasião para se aproximar da criança e (re)indagar através dos olhos dos educadores [...] para conhecer como a criança é distante dos pais e imersas em uma área existencial diferente daquele familiar” (RINALDI, 2009, p. 26). Também há um valor para as crianças, como uma oportunidade de que esse documento, "quando a criança cresça, lhe conceda a possibilidade de ler alguns fragmentos da sua própria história" (RINALDI, 2009, p. 26).

É importante destacar que a escolha em construir um diário está relacionada à leitura de uma dada realidade. Naquele contexto, o serviço educativo para o 0-3 anos ainda era uma novidade e havia uma certa insegurança por parte dos pais. A construção do diário foi um meio de conexão e relação com as famílias para mostrar o valor da experiência educativa para as crianças menores de 3 anos. Mais ainda: foi uma oportunidade para a própria equipe educativa compreender seu papel nesse momento, pois se ocupava de refletir sobre o processo de acolhimento das crianças na sua chegada à creche.

Mais uma vez, o que se pode perceber é a compreensão que havia de que um projeto educativo se faz no engendramento de diferentes aspectos que marcam a vida cotidiana das crianças em suas jornadas de aprendizagem. Do mesmo modo, essa compreensão assinala um valor ecológico e contextualizado que é dado às diferentes experiências dos meninos e meninas nas creches e pré-escola. $\mathrm{O}$ valor narrativo das experiências já estava sendo germinado para o que posteriormente ganha força e vai caracterizando-se como uma marca da experiência reggiana. O professor compreende que narrar e compartilhar sobre sua prática transforma-se em uma oportunidade produtiva para reconhecer o seu próprio fazer, conhecer as crianças e de torná-la visível.

Há um último aspecto que gostaria de destacar a respeito dos diários. Não se trata de transformá-los em instrumento burocrático, mas de compreendê-los como "instrumento precioso que dá lugar à história, única e partilhada, de cada criança e seus educadores, marcando o começo de um trajeto em comum, que se construirá a partir de relações recíprocas" (ARCOBALENO, 1995, p. 25). 


\section{A DOCUMENTAÇÃO PEDAGÓGICA COMO ESTRATÉGIA PARA ESCUTAR AS CRIANÇAS E CONSTRUIR DIÁLOGOS}

Se os diários e os planos de formação podem ser considerados o prelúdio do que veio a ser concretizado como a estratégia da Documentação Pedagógica, os dois projetos que vou abordar neste tópico podem ser considerados o alfa e o ômega das reflexões sobre a documentação pedagógica em Loris Malaguzzi. Per fare il ritratto di un leone (1978/1979) e Il Luna Park degli Uccellini (1992) talvez sejam os projetos mais emblemáticos acompanhados por Malaguzzi e, não por acaso, os mais conhecidos em nível internacional.

Per fare il ritratto de un leone (Para fazer o retrato de um leão) foi um dos primeiros projetos de longa duração que Malaguzzi supervisionou em parceria com Carla Rinaldi, na Scuola La Villetta, em que foi utilizado o uso do vídeo como instrumento de comunicação do projeto $^{52}$. O projeto surgiu quando o então atelierista Giovanni Piazza e a professora Amelia Gambetti mostram a Malaguzzi os desenhos das crianças sobre os monumentos de leões de uma praça central da cidade de Reggio Emilia, Piazza San Prospero.

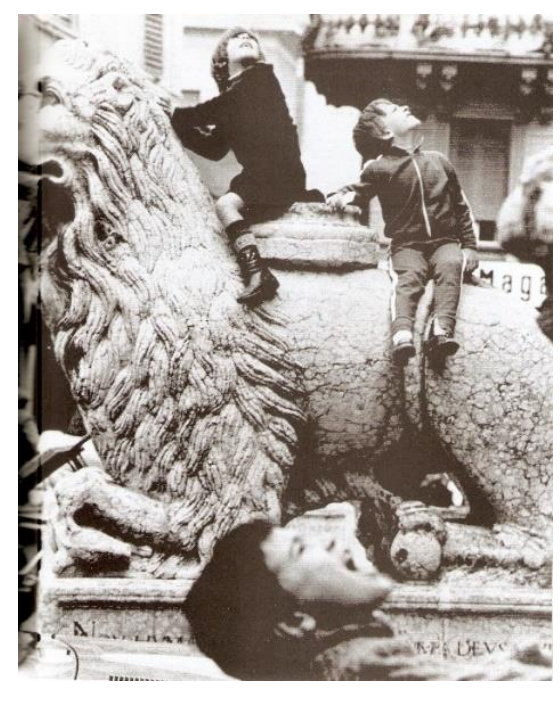

Esses desenhos são provenientes de um projeto amplo que se desenvolveu nas escolas infantis de Reggio por muitos anos com o intuito de estabelecer uma relação entre as escolas e a cidade $^{53}$. Nessa ocasião, Malaguzzi percebeu uma certa imaturidade por parte dos adultos na prática de observação das crianças durante os projetos (HOYUELOS, 2004a). Por essa razão, Malaguzzi propôs a Amélia e Giovanni que desenvolvessem a continuidade do projeto, aprofundando-se no tema da observação e focalizando-se em tornar visível o processo das crianças nas diferentes situações propostas, muito mais que o produto.

Amelia Gambetti, em entrevista dada a Lella Gandini (2016), comentou que aquele foi um momento importante para o aprofundamento a respeito do tema da observação, visto que por meio de diferentes estratégias, mas sobretudo, da utilização do vídeo, era possível compreender mais e melhor a respeito do papel do adulto e do modo como as crianças constroem seus conhecimentos.

52 Per fare il ritratto de um leone (vídeo). Comune di Reggio Emilia, junho, 1987, 30min.

53 Mais adiante, nesse mesmo capítulo, irei apresentar outros projetos que estavam localizados nessa mesma investigação da relação das escolas com a cidade e aprofundarei melhor o tema. 
Este primeiro vídeo didático dos projetos de Reggio Emilia nasceu da convicção de Malaguzzi em comunicar o projeto e os objetivos educativos e de utilizá-lo na formação de outros professores (HOYUELOS, 2004a). Essa estratégia se conecta com aquela utilizada pelo pedagogo com os planos de formação nos anos sessenta: um projeto vivido com as crianças, quando densamente documentado e refletido, pode ser de grande valor para outros profissionais aprenderem e compreenderem melhor as crianças e o papel do professor.

Ao longo dessa experiência, podemos encontrar elementos importantes na compreensão do pensamento pedagógico de Malaguzzi e, sobretudo, do que deve se ter em mente ao valer-se da estratégia da Documentação Pedagógica. Um desses aspectos é o “[...] de nunca esquecer que um projeto deve ser contextualizado o máximo possível" (HOYUELOS, 2004a, p. 107). Malaguzzi (2005d, p. 54) destaca a respeito disso quando narra sobre o projeto:

\begin{abstract}
Aproximar-se de um grande leão de pedra que está sobre uma escada de uma igreja, em uma praça da cidade, imóvel e inofensivo, ali há muitos séculos, entre bancas de verduras e tecidos, para as crianças se constitui um encontro cujos os contornos perceptivos, emocionais, lógicos e históricos estão todos por recompor-se. São esses problemas e essas interrogações, e as crianças advertem, que abrem os caminhos ao interesse e ao conhecimento.
\end{abstract}

Seu forte interesse em levar a cabo projetos que estabelecessem relações com a cidade também se justificava no sentido de mostrar para as crianças como as coisas estão sempre situadas em um dado contexto. O leão da praça, naquela cidade, ganha novas narrativas e novos significados quando as crianças conseguem percorrer uma jornada de aprendizagem rica que acolhe seu universo.

Do mesmo modo, ao comunicar a respeito, também não se pode perder de vista esse aspecto, especialmente no que diz respeito às crianças, "prestando muita atenção à imagem que não deve contar uma criança isolada, mas uma criança em um contexto" (HOYUELOS, 2004a, p. 107). Para o pedagogo italiano, o valor da narrativa sobre a aprendizagem da criança é aquele que consegue fazer ser vista a beleza e o prazer das

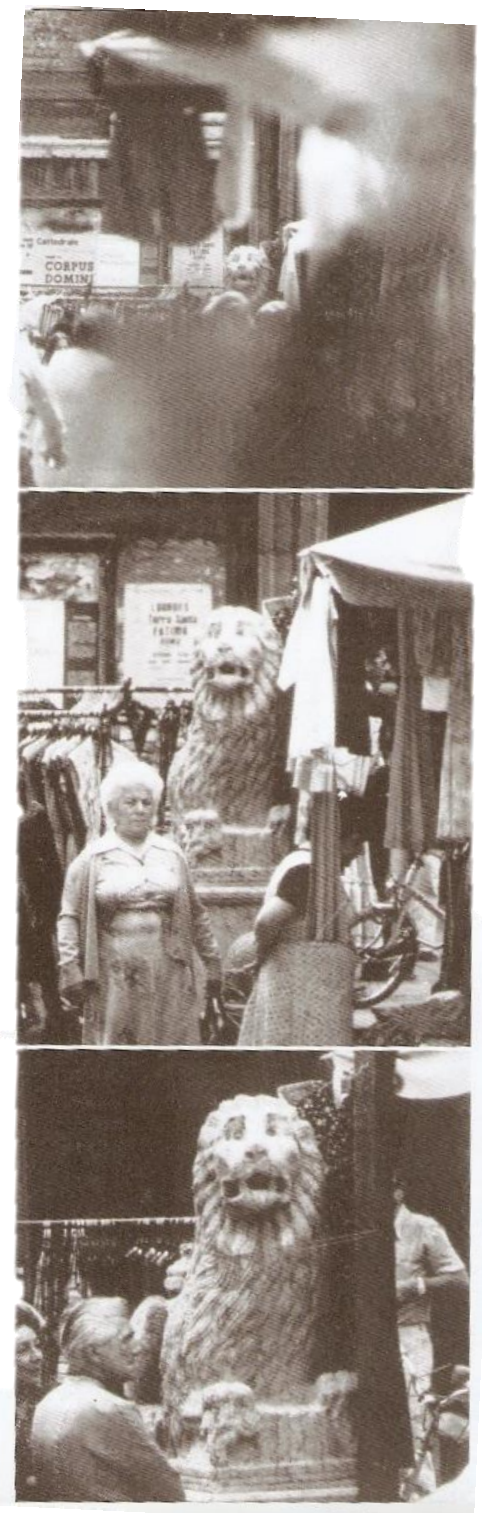


crianças, descobrindo e explorando o mundo. Hoyuelos (2004a, p. 107-108) pontua que

O aspecto do prazer é uma presença forte no pensamento e na obra de Malaguzzi. Uma estética - nunca um fim em si mesma - que valoriza a potencialidade da criança, que a respeita, que não a trai, evitando de oferecer aquela imagem usual da infância estereotipada ou engraçadinha que, por consequência, suscita no adulto uma postura muito banal.

É por isso que o projeto Per fare il ritratto de un leone é considerado um marco na construção da visão teleológica educativa de Malaguzzi a partir de uma outra visão de criança (HOYUELOS, 2004a). Uma imagem de criança que Malaguzzi reclama ser sempre declarada através do modo como propomos uma determinada situação de aprendizagem e do modo como narramos e argumentos a respeito.

A criança de Malaguzzi, feita de cem linguagens, foi um marco importante neste projeto. Gambetti (2016, p. 178) explica que a experiência deste projeto "[...] se conectava com a teoria das cem linguagens da criança - as muitas maneiras com que as crianças se expressam, contam histórias e experimentam". Isso porque Malaguzzi propunha que se experimentassem diversas linguagens com as crianças para investigar sobre o leão: sombra, argila, desenho, fotografia, medidas, fantasias, teatro de marionetes. Vale lembrar que o primeiro esboço do poema "as cem linguagens" data de fim dos anos setenta, contemporaneamente ao projeto. Este é uma versão mais curta e diferente da que mundialmente ficou conhecida, mas que mostra o intento de Malaguzzi em expressar por meio do texto a relação entre a imagem de criança e as propostas que estavam vivenciando nos diferentes projetos das escolas.

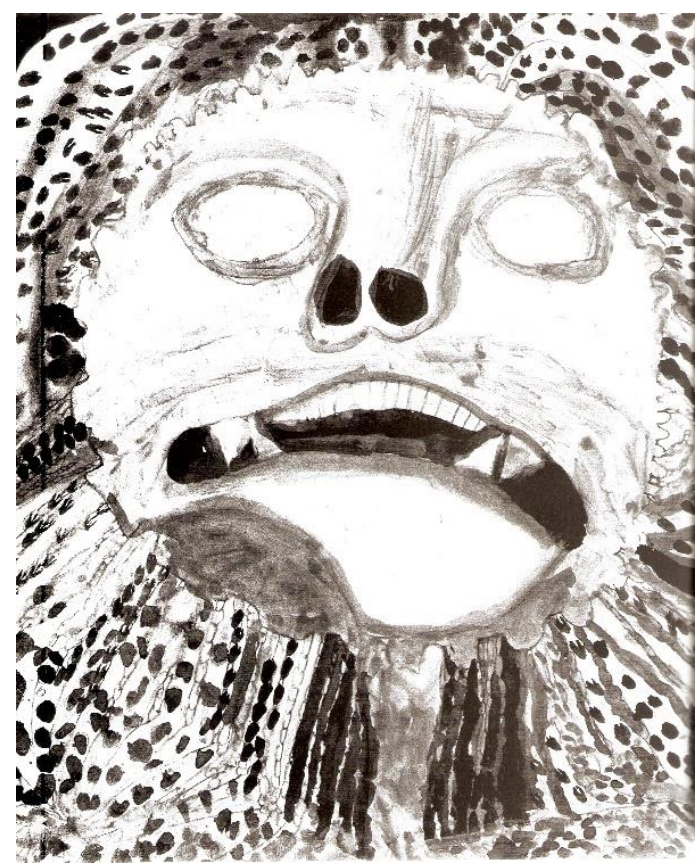

A criança tem cem linguagens e roubamos noventa e nove.

Escola e cultura

Trabalham para separar

Corpo-cabeça

Fazendo pensar sem corpo

Colocando em conflito

O brincar e o trabalho

A realidade e a fantasia

A ciência e a imaginação

$\mathrm{O}$ dentro e o fora

O brincar do autorretrato

Me busco para encontrar-me

E para tomar-me a mão

O brincar de carpintaria

A cabeça pensa

Depois

As mãos falam

Um pensamento criativo gera muitos outros 


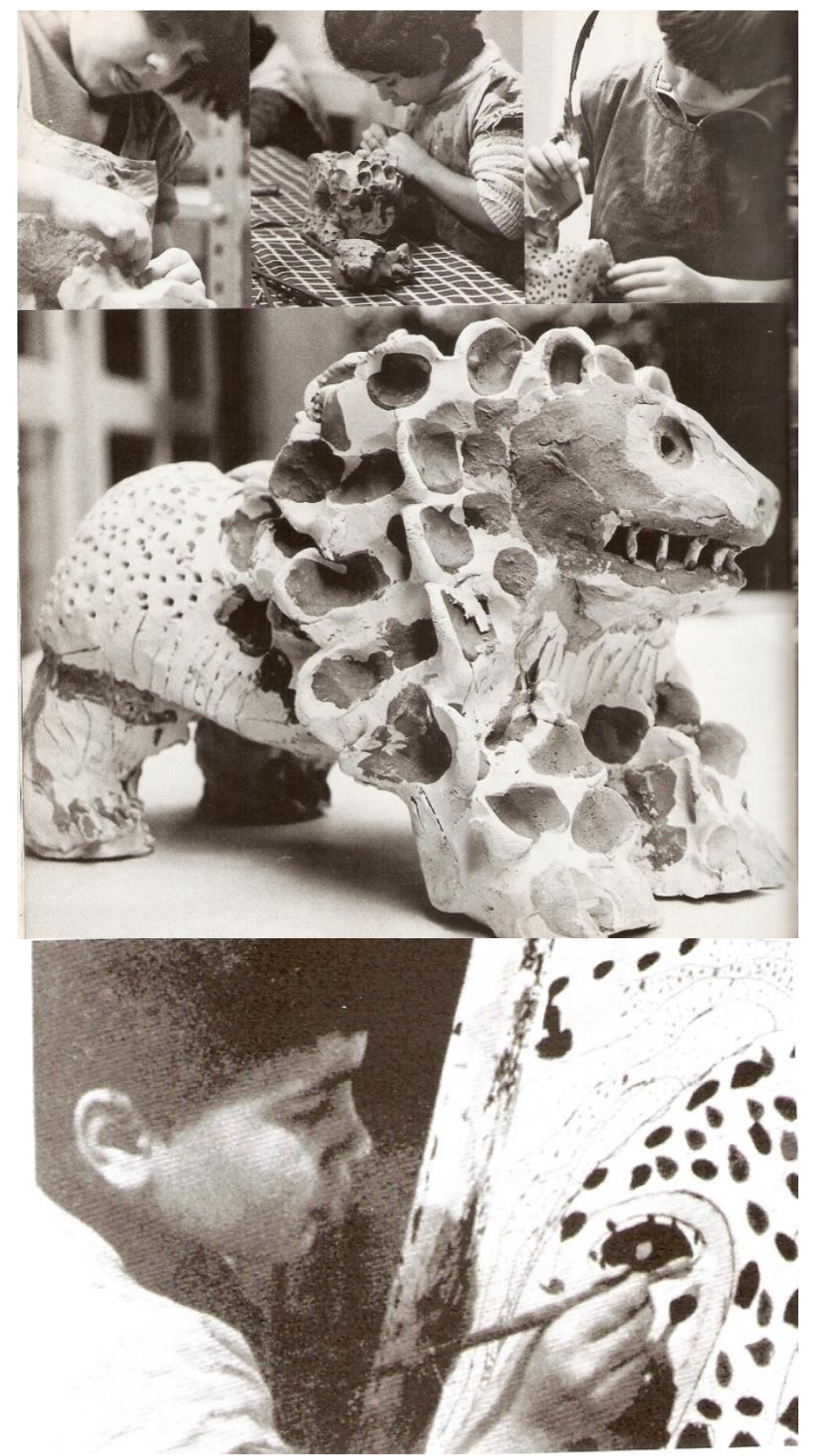

O brincar de música

Também os sons podem

ser gerados pelo uso

imaginativo da razão

O brincar de escultura

Reinventar as coisas

Para inventar outras coisas

O brincar de impressão

Para dizer

A quem quero bem

As coisas de que gosto

O brincar das fantasias

Sou

Era

Não sou mais

Não sou mais

Era

Sou

O brincar de marionetes

O marionete

Pelas coisas

Que dirá

Que não dirá

Que fará

Que não fará

Para fazer o possível

Aquilo

Que não é

É impossível

O que é (MALAGUZZI, s/d, p. 292)

A reciprocidade entre

OS

aspectos didáticos e os aspectos comunicativos são centrais na estratégia da Documentação

Pedagógica. Ou seja, não se separa a visão de conhecimento, criança e adulto que se declaram por meio das diferentes comunicações (vídeo, painéis, slides, livretos e etc) do modo como se faz acontecer o dia a dia da instituição.

Amelia e Giovanni relatam o quanto Malguzzi e Carla Rinaldi os provocavam a pensar e melhorar tanto o modo como conduziam o projeto, quanto o modo como documentavam. A professora e o atelierista falavam da "eterna insatisfação" de Malaguzzi, convidando sempre a explicitar as razões das escolhas feitas, "as capacidades das crianças tinham o poder de fascinálo e de conquistá-lo, e quando essa última não acontecia de modo apropriado, ou quando a proposta não era adequada em relação a tal capacidade, expressava críticas duríssimas" (HOYUELOS, 2004a, p. 108). 
Essa era a ética de Malaguzzi. Sua fidelidade para com as crianças o movimentava e fazia com que provocasse os professores e atelierista que trabalharam com ele de forma intensa.

Os desenhos do leão se transformaram em símbolo do projeto educativo de Reggio Emilia. Ele estampa livros e diversas publicações, além disso, desde 1995, também é um prêmio concedido a pessoas ou instituições que apoiam os projetos das escolas de Reggio Emilia, o prêmio "Leoni di Piazza San Prospero". A data de entrega do prêmio anualmente é a mesma data do falecimento de Malaguzzi, 30 de janeiro.
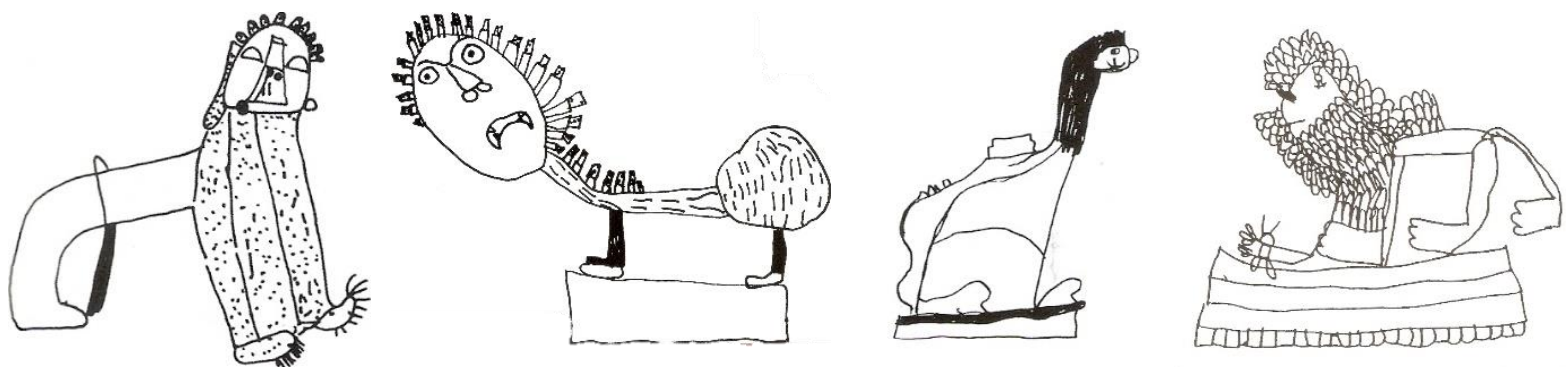

Outro projeto de longa duração, Luna Park degli uccelini (Um parque para os pássaros) (1992), foi o último projeto supervisionado por Malaguzzi. Assim como o anterior, este projeto teve como pedagogista Carla Rinaldi, o atelierista Giovanni Piazza e as professoras Amelia Gambetti e Teresa Casarini, na Scuola La Villeta.

O projeto foi acompanhado por George Forman e Lella Gandini, pesquisadores dos Estados Unidos que já conheciam alguns projetos desenvolvidos em Reggio Emilia. No entanto, os pesquisadores tinham o desejo de acompanhar todos os momentos do desenvolvimento de um projeto para poder apresentar aos educadores norte-americanos a respeito da anatomia dos projetos reggianos. Foi então que pediram autorização a Malaguzzi para documentar em vídeo o desenvolvimento de um projeto em todas as suas etapas. Malaguzzi, não por acaso, os conduz para a Scuola La Villeta, uma vez que estava seguro de que ser acompanhado por pessoas de fora, por um longo período, seria bem acolhido por parte daquela equipe (GANDINI, 2015).

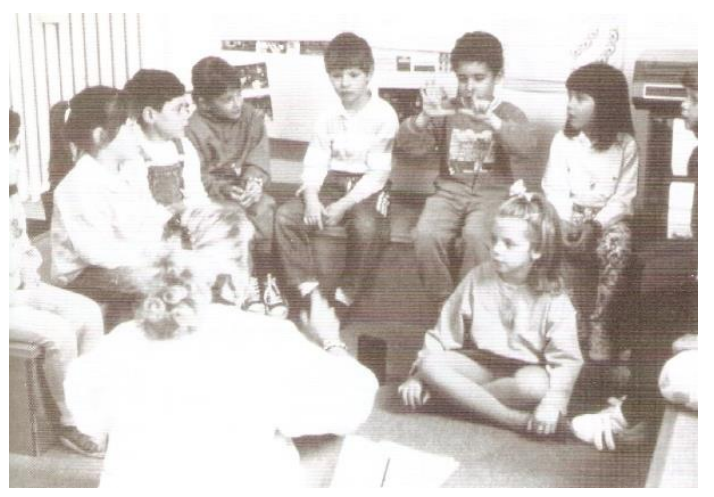


$\mathrm{Na}$ assembleia “o que podemos fazer”, um pequeno grupo de criança de 5 e 6 anos decidiu projetar um parque de diversão para os pássaros. Para Malaguzzi, as assembleias eram um dos momentos importantes da jornada diária das crianças, pois nesses momentos os meninos e meninas vivenciavam verdadeiros laboratórios de

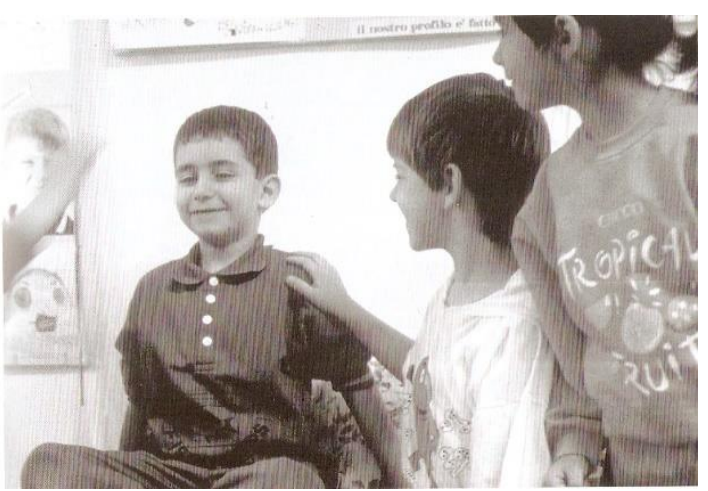
cidadania e democracia. Também para o pedagogo, especificamente nesse tipo de assembleia que se faz em diversas situações ao longo do ano, eram oportunidades para "[...] se discutir e formular novos projetos de trabalho" (MALAGUZZI, 2006b, p. 11).

Esse projeto foi levado a cabo por um pequeno grupo de crianças. A elas cabia ir informando ao grande grupo sobre o desenvolvimento do projeto e, em certos momentos, acolhendo as ideias e propostas.

O projeto Luna Park degli uccelini aconteceu no ano seguinte em que a escola já havia realizado uma investigação sobre o quintal, Il parco, "[...] no qual as crianças haviam registrado com um gravador o som do parque com os animais e com os elementos naturais" (HOYUELOS, 2004a, p. 180). Atentos ao fato que de que algumas crianças não haviam participado diretamente do projeto do ano anterior e que ainda poderiam ser aprofundados muitos aspectos sobre o tema do quintal, Malaguzzi propôs acolher os argumentos das crianças sobre um parque para os pássaros:

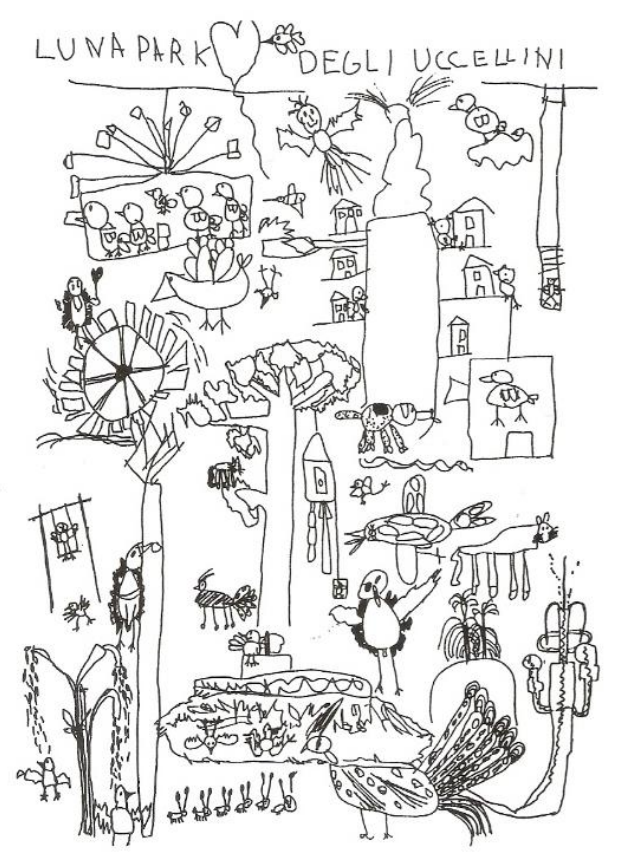

A ideia tomou forma em uma assembleia sobre "o que podemos fazer". [...] Todos os meninos e meninas podem dar suas contribuições. Depois, trata-se de comprovar como os companheiros recebem. Assim, as ideias voam, serpenteiam, se amontoam, reaparecem, se dissipam lentamente ou se diluem. Até que finalmente uma toma forma, voa mais alto e conquista vitoriosamente o interesse do grupo (MALAGUZZI, 2006a, p. 9).

Esse é um exemplo de projeto que dá muito valor às teorias das crianças, que se preocupa em acolher o universo dos meninos e meninas e colocá-los em relação ao longo do desenvolvimento do projeto, que não banaliza as hipóteses das crianças em detrimento a uma ideia de saber pronta a ser transmitida. A visão de conhecimento está diretamente articulada com a estratégia de organizar as crianças em 
pequenos grupos e de reconhecer que elas produzem suas teorias para construir sentidos particulares e coletivos. Nesse sentido, Hoyuelos (2004a, p. 179) destaca que

um aspecto importante é ver em que modo as crianças são capazes de construir teorias, como elas têm origem e como são expressas através da linguagem verbal, gráfica e relacional. A inovação está em analisar com proximidade o como nascem as teorias e em que modo essas teorias se originam na relação ou interação social quando se criam grupos de cooperação e grupos de discussão entre as crianças.

Hoyuelos (2004a, p. 180) irá destacar que, nesse projeto, podemos compreender “"[...] como também se pode perceber, em outras ocasiões, a confiança na possibilidade da infância. Uma confiança que a Malaguzzi parece ser sempre insuficiente".
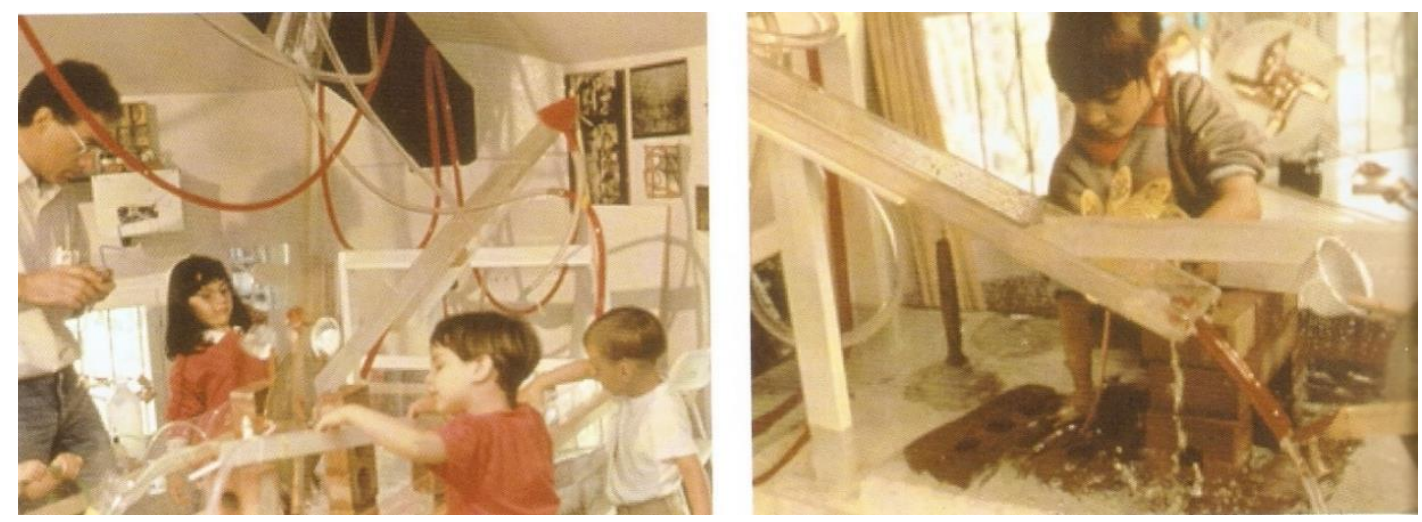

Uma das estratégias fundamentais para reconhecer e acompanhar o modo como as crianças se movimentam ao longo do projeto - e portanto, reconhecer as suas teorias - foi centrando-se, com muito empenho, em diferentes estratégias para documentar. Além do vídeo produzido $^{54}$, Amelia, Teresa e Giovanni, com apoio de Carla e Loris, foram sistematizando estes registros a partir de "[...] mapas conceituais para analisar como se movia e como se modificava o pensamento das crianças" (HOYUELOS, 2004a, p. 180), como esses que mostro a seguir:
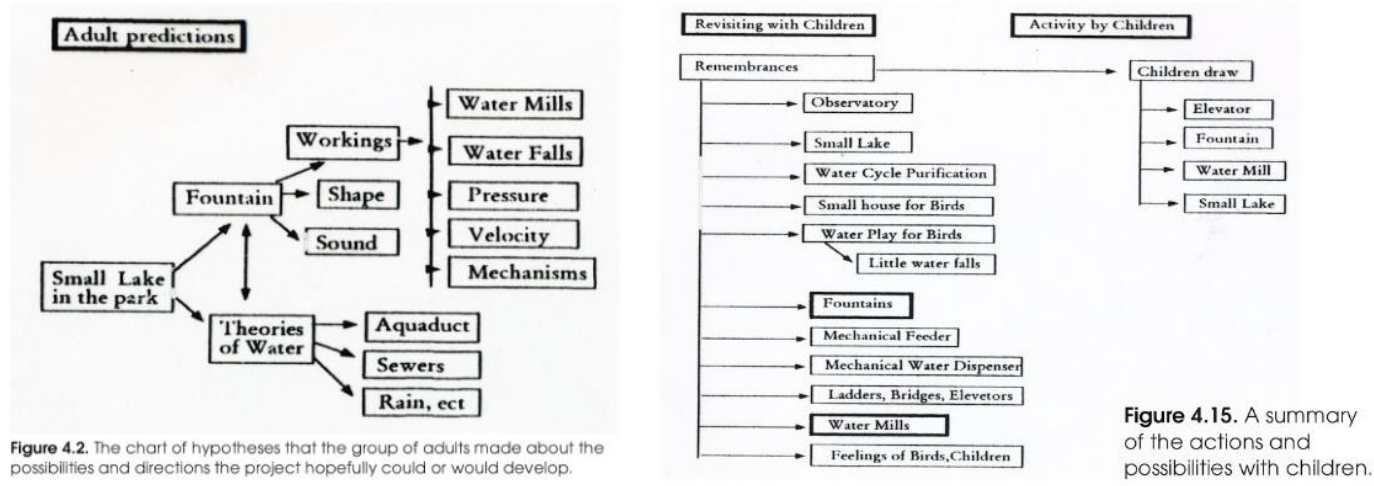

${ }^{54}$ An amusement Park for birds. George Forman; Lella Gandini; Loris Malaguzzi; Carla Rinaldi; Giovanni Piazza; Amelia Gambetti. (vídeo), Performanetics Press: 1993, 1h45min. 
Esses encontros foram cruciais para a perceber quais eram as perguntas e que caminhos poderiam seguir no projeto. A primeira pergunta que se fez às crianças foi "Vocês se lembram que coisa havia no quintal no último ano?" (HOYUELOS, 2004a; GANDINI, 2016). A partir dessa pergunta, lançada em uma assembleia, foi se estruturando o projeto na medida em que outras assembleias foram acontecendo e as crianças foram avançando em suas investigações e diferentes propostas organizadas por Amelia e Giovanni.

Poucas vezes se vê explicitado o papel do adulto nas comunicações dos projetos ao longo dos trinta anos analisados ${ }^{55}$. Ocorre que, nesse projeto, o papel do adulto foi motivo de muitas discussões e confrontos. O uso do vídeo como recurso para acompanhar o desenvolvimento do projeto também possibilitou às educadoras reconhecerem suas modulações nas intervenções com as crianças.
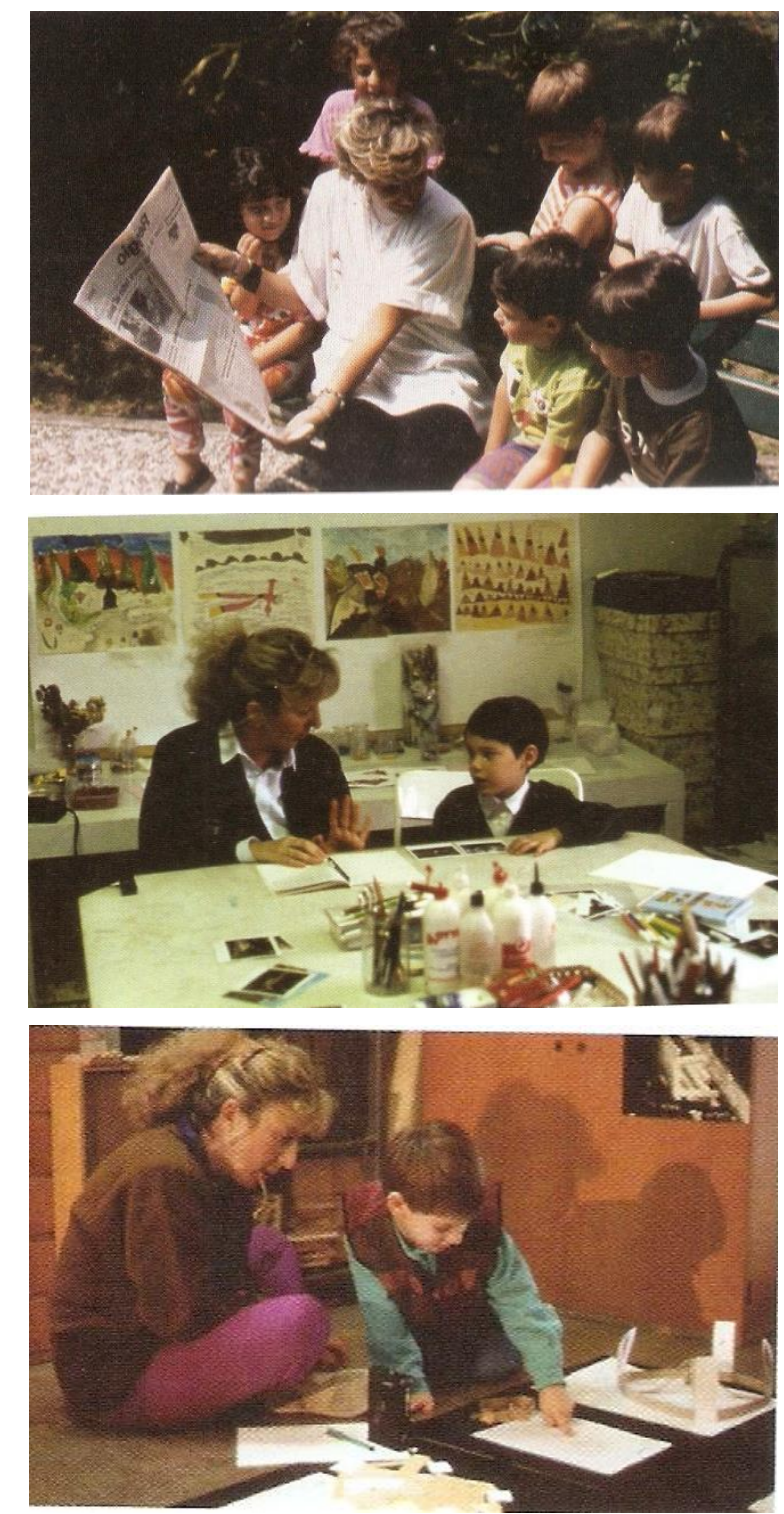

Gambetti (2016, p. 178) relata que esse foi sempre um exercício difícil, mas de muitas aprendizagens: "ser observado enquanto você está envolvido em um relacionamento com as crianças é uma situação que também o ajuda a aprender as estratégias de questionar e de como intervir interagindo com elas".

Aqui pode-se, também, destacar a forte relação entre o projeto desenvolvido e as escolhas em relação a sua comunicação. Essa é uma dimensão basilar para a Documentação Pedagógica, já que a relação entre a estratégia didática e o modo de construir a comunicação correspondem a uma escolha que coloca adultos e crianças a investigarem seu entorno. Logo, é importante ressaltar que aquilo que é compartilhado não é a Documentação Pedagógica em si, mas apenas a comunicação. A Documentação Pedagógica é a estratégia sustentada na

\footnotetext{
${ }^{55}$ Além desse, o outro projeto que aborda a respeito do papel do adulto é Scarpa e metro, que será abordado logo a seguir.
} 
observação, nos registros produzidos, na interpretação com a finalidade de projetar e na comunicação.

A comunicação desse projeto em formato de vídeo e de publicação também foi um esforço para comunicar sem fechar conclusões, deixando aberto, para que quem assistisse ou lesse, para criar suas próprias conclusões.

Nesse projeto, em especial, Malaguzzi escreveu um capítulo, que se pode ter acesso na publicação Le fontane, especificamente sobre o papel do adulto. Com muito cuidado para não se transformar em uma receita, o pedagogo italiano vai declarando pistas importantes na reconceitualização do papel do adulto na Educação Infantil.

Uma dessas pistas é referente à necessidade de aprender a observar, pois assim “[...] se consolida o valor da observação como procedimento de investigação das formas de aprendizagem e desenvolvimento" (MALAGUZZI, 2006c, p. 13). Isso é explicado pela visão de conhecimento declarada por Loris, que, além disso, é uma outra pista que é dada a respeito do papel do educador: "a forma de aprender e de conhecer é individual e o que interessa é descobrir e compreender que interações servem aos pequenos para construir seu conhecimento e sua capacidade, e a forma que estas podem ser aprofundadas ou modificadas" (MALAGUZZI, 2006c, p. 13).

Quando se parte de uma visão de conhecimento que não está dada, pronta, observála como estratégia para conhecer as crianças e conhecer os modos como aprendem se converte em longo e contínuo caminho para o adulto entrar em relação com cada menino e menina, compartilhando com isso as jornadas de aprendizagem. Aprende o adulto sobre a criança enquanto a criança aprende sobre o que deseja aprender.

Um outro aspecto apontado pelo pedagogo é saber apoiar as crianças em suas decisões, comunicações e atividades. Para isso, é preciso saber "respeitar os tempos de ação e de pensamento das crianças, assim como os tempos de
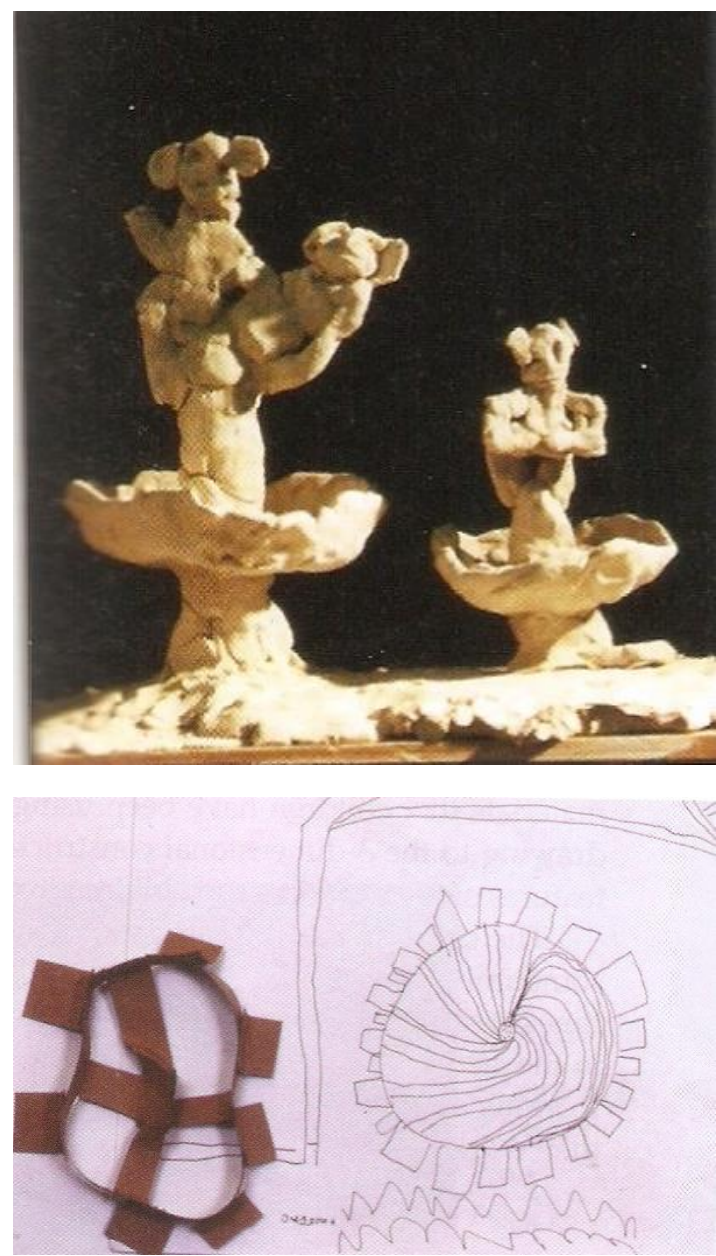
pausa e de indecisão. [...] Ajudar as crianças a expressar com clareza as suas reflexões, [...] a não ter medo de equivocar-se, a confiar na legitimidade de suas ideias" (MALAGUZZI, 2006c, p. 14).

Para conseguir atender a esse perfil de educador, a sugestão é sustentar por meio de pilares da Documentação Pedagógica, já que aqui reside uma constante investigação, suspensão, compreensão e ressignificação da identidade da escola, dos professores e das crianças na relação educativa.

Nesse projeto, especificamente, compreendemos que o papel dos professores envolve registrar, observar e interpretar o processo de construção do conhecimento para outorgar os conhecimentos construídos entre as crianças, das crianças com os adultos, delas em seus contextos relacionais.

Por fim, esse foi também um projeto com grande participação das famílias. Como as estratégias de comunicação eram ampliadas, em diversos momentos foi compartilhado, com as famílias, o desenvolvimento do projeto, convidando-os a participarem junto das crianças e dos professores. A concretização disso foi a construção do parque com as famílias: “em um

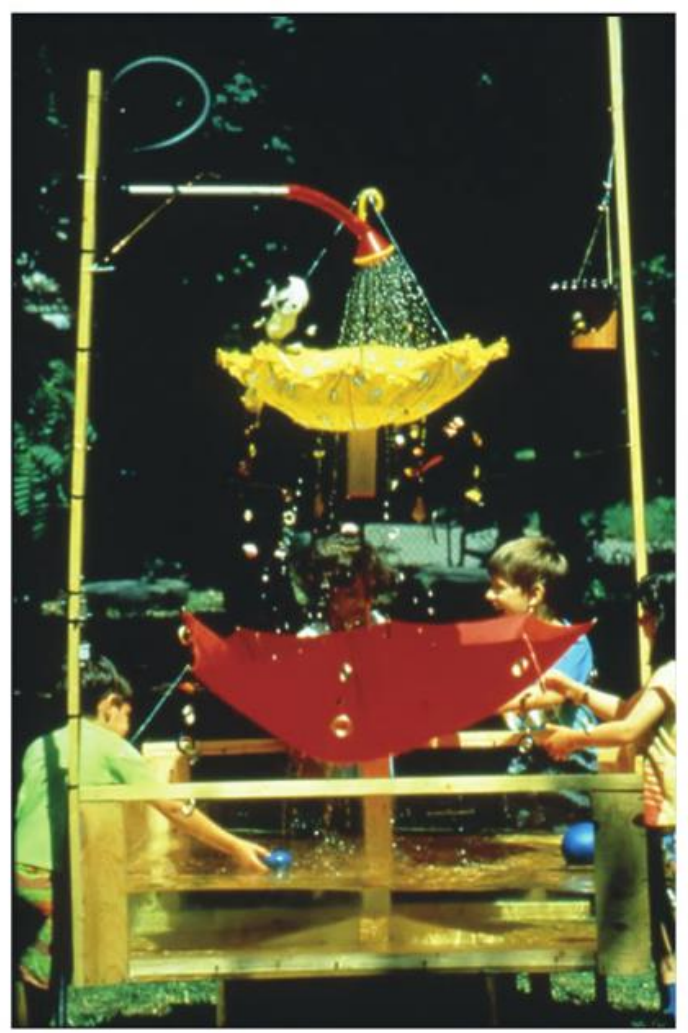
desses encontros, foram os próprios pais que tiveram a ideia e expressaram o desejo de construir eles mesmos uma fonte para os pássaros" (HOYUELOS, 2004a. p. 181).

Sem nenhuma dúvida, das imagens emblemáticas que se têm da experiência pedagógica de Reggio Emilia, uma delas é fruto desse projeto. Obviamente, pelo acompanhamento que George Forman e Lella Gandini deram e, com isso, pela divulgação internacional que foi feita, o Parque dos Pássaros assim como o Leão da Praça São Próspero são ícones da experiência pedagógica reggiana. 


\section{A DOCUMENTAÇÃo PEDAgógica COMO ESTRATÉgia CRIAR PERTENCIMENTO E TRANSFORMAR OS CONTEXTOS}

Baseado nos estudos da psicologia ambiental, que aborda a qualidade de reconhecer e identificar-se com o local que se está inserido para o bem-estar humano, Malaguzzi, durante alguns anos, propõe às escolas que investiguem com as crianças elementos facilmente percebidos na cidade ${ }^{56}$. O objetivo era compreender "[...] que imagem de cidade são capazes de criar as crianças de 5 e 6 anos, buscando compreender em que medida reconhecem seus distintos elementos e como os organizam em um sistema articulado e unitário" (BONILAURI; DESTEFANI, 1995, p. 69).

O projeto envolvia dezenove escolas municipais e era organizado em duas partes. A primeira parte tratava de um estudo inicial em forma de questionário enviado para as escolas participantes com algumas orientações e com a função de identificar alguns elementos que respondessem ao objetivo principal. No questionário havia oito grandes perguntas e algumas subperguntas, como apresento na sequência.

Quadro 02 - Questionário inicial

1) O que é uma cidade?

2) Você vive em uma cidade? Como se chama?
a. Sabe o nome da rua em que vive?
b. Sabe o número da sua casa?
c. Por quê tem um número a sua casa?

3) Você vive em uma cidade que se chama Reggio Emilia. Sabe o nome de outras cidades?

4) Como sabemos que começa uma cidade?

5) Tem pessoas que não vivem em uma cidade? Então, onde vivem?

6) Por que os homens constroem cidades?

7) De quem são os edifícios, as lojas, as fábricas, as oficinas?

a. De quem são os trens e transvias?

b. E as igrejas?

c. E os bancos?

d. De quem é esta escola?

8) A cidade é governada por uma autoridade. Como o nomeiam?

Fonte: BONILAURI; DESTEFANI, 1995, p. 71.

Bonilauri e Destefani (1995) comentam a respeito das intenções de cada pergunta presentes no Quadro 02. Segundo as autoras, a primeira pergunta tem a intenção de compreender, de forma mais genérica, o modo como as crianças se expressam verbalmente em relação à cidade, verificando que elementos são mencionados por elas. A segunda pergunta, já mais específica, busca saber se as crianças têm algum domínio dos códigos convencionados em

56 Projetos como La città e la pioggia, El león y su retrato e Luna park degli uccelini são alguns exemplos de projetos que estavam envolvidos nesta grande temática. 
relação à cidade e de que forma já manifestam sua relação de pertencimento a um dado lugar. A terceira, quarta e quinta perguntas exploram os limites entre o urbano e o rural e buscam saber se as crianças dão identidade ao ambiente e como estabelecem relação entre as pessoas e o seu entorno. A sexta pergunta se desenvolve buscando compreender como a criança identifica as funções e atividades que acontecem na cidade. Para as autoras, essa pergunta se relaciona com a primeira, pois "[...] ajuda a compreender as experiências que a criança vive diretamente na cidade e aquelas outras que vive indiretamente, através das figuras adultas que o rodeiam" (BONILAURI; DESTEFANI, 1995, p. 71). Por fim, a sétima e a oitava perguntas procuram revelar que experiências as crianças têm em relações a temas políticos da cidade.

A segunda parte estava voltada para o desenvolvimento específico de cada escola a partir da identificação de subtemas que representassem "diversos significados dos hábitos locais, bem como, do espaço urbano como espaços de signos e símbolos ou como espaço vital" (BONILAURI; DESTEFANI, 1995, p. 68-69).

Participaram cerca de 8 a 10 crianças em cada escola, da faixa etária de 5 e 6 anos, e, de acordo com o andamento de cada projeto em cada escola, poderia se optar em ampliar a experiência para o restante das crianças ou apenas em manter o pequeno grupo e ir criando situações de comunicação e compartilhamento para o grande grupo nas assembleias. Em relação ao adulto, os professores em parceria com os atelieristas deveriam se aprofundar no tema anteriormente, buscando compreender possíveis pontos de aprofundamento e de ampliação com as crianças e deveriam eleger quais instrumentos de recolha de dados, de observação e de registro utilizariam ao longo do desenvolvimento do projeto (BONILAURI; DESTEFANI, 1995).

Diante dessas consignas, os subtemas identificados por cada escola, a partir do grande tema, foram organizados conforme mostra o Quadro 03.

Quadro 03 - Subtemas das escolas para o projeto

\begin{tabular}{ll}
\hline \multicolumn{1}{c}{ Escola } & \multicolumn{1}{c}{ Subtema elegido } \\
\hline Diana & A cidade e a chuva \\
Michelangelo & O semáforo \\
Pablo Neruda & O hospital \\
Robinson Crusoé & O escritório de um edifício \\
8 de Março & O córrego Cróstolo \\
Anna Frank & Os arcos \\
Ada Gobetti & O supermercado \\
Belvedere & Os números da cidade \\
Salvador Allende & O jornal: A gazzetta di Reggio \\
San Maurizio & A via Emilia \\
La Villetta & A biblioteca \\
Girotondo & A rua que passa na frente da escola
\end{tabular}


E. Tondelli

R. Franchetti

Andersen

Martiri di Villa Sesso

Camilo Prampolini

Bruno Ciari

XXV de Abril
A casa do campo

A loja de móveis

$\mathrm{O}$ aeródromo

$\mathrm{O}$ quiosque

$\mathrm{O}$ mercado de fruta e verduras

A cidade e suas portas

O mapa da cidade

Fonte: BONILAURI; DESTEFANI, 1995, p. 70.

Esses temas foram selecionados a partir de orientações que Malaguzzi havia encaminhado para as escolas: “que o tema ofereça elementos didáticos 'fascinantes'; que faça parte da experiência e vivência cotidiana das crianças; que se possa enquadrar nos objetivos educativos; que se possa desenvolver em termos de disponibilidade e tempo" (BONILAURI; DESTEFANI, 1995, p. 70).

Dados esses elementos contextuais, aqui irei me debruçar sobre La città e la pioggia (A cidade e a chuva), projeto de longa duração na Scuola Diana e que teve grande repercussão em função da experimentação da abordagem multissimbólica e do modo como foi explorado o uso da fotografia pelos professores como elemento de prefiguração.

No final dos anos de 1970, o uso da máquina fotográfica como recurso pedagógico, sobretudo de observação, já era uma constante nas escolas municipais de Reggio Emilia. A diversidade de formas que os professores e atelierista foram

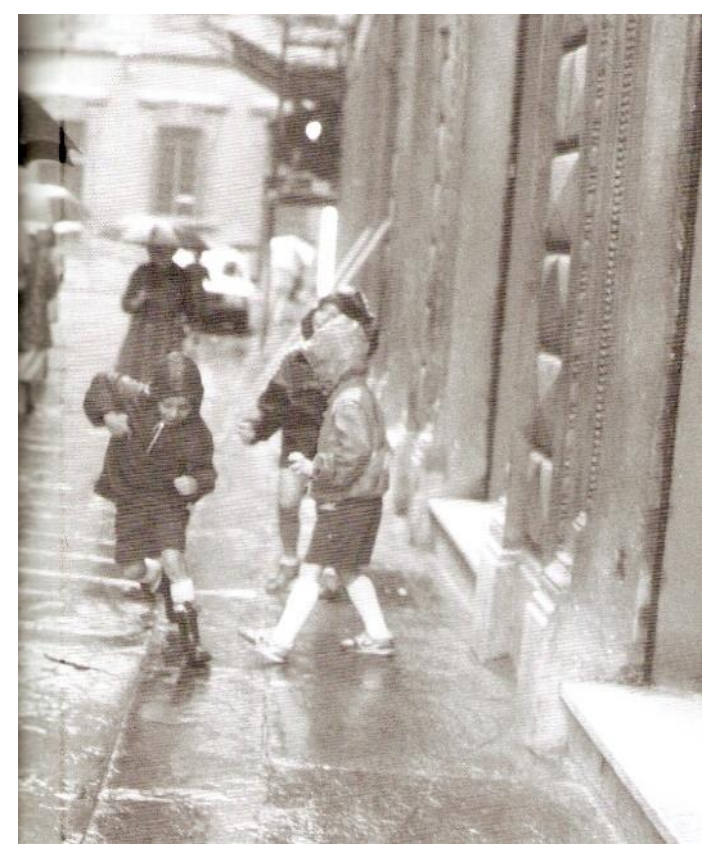
descobrindo para o uso desse recurso ultrapassava a perspectiva de observação e registro apenas das experiências das crianças, mas avançava no sentido de utilizá-los como recurso para compreender o contexto que se oferece à criança, algo que pode ser entendido como uma captura do verdadeiro projeto pedagógico.

Nesse projeto, os professores também empreenderam jornadas de aprendizagem com as crianças e se ocuparam de fotografar a cidade na chuva para poder antecipar desde o ponto de vista adulto sobre o que supunham que se transformava na cidade. A partir desse exercício prefigurativo, podia-se pensar em algumas estratégias que posteriormente poderiam ser levadas a cabo com as crianças. 
A prefiguração não se trata de uma antecipação de proposta que deverá ser repetida pela criança, mas uma experimentação pessoal do adulto para poder vislumbrar mundos possíveis, como diria Bruner (1997b), posteriormente construídos e significados pelas crianças.

Havia o desejo de saber como as crianças se movimentavam e construíam suas narrativas sobre a cidade com a chuva. Como observa Malaguzzi (2005a, p. 80 ), "A cidade e a chuva são uma das infinitas versões da cidade. Uma versão que conecta a acontecimentos particulares, que desloca as experiências, percepções e os pensamentos das crianças".

Para Hoyuelos (2004a, p. 146), neste projeto, há claramente um salto conceitual na experiência pedagógica reggiana, “[...] poder refletir sobre o modo pelo qual as crianças agem na cidade com chuva e em poder refletir sobre o modo pelo qual as crianças conceitualizam a relação entre elas e a cidade modificada pela chuva".

O projeto La città e la pioggia também foi um laboratório para as reflexões a respeito de uma transformação didática que Malaguzzi desejava. $\mathrm{Na}$ virada para os anos 80, "Malaguzzi havia lido a teoria da percepção e da Gestalt, provavelmente havia ficado fascinado, e sente a necessidade impulsora de verificar de
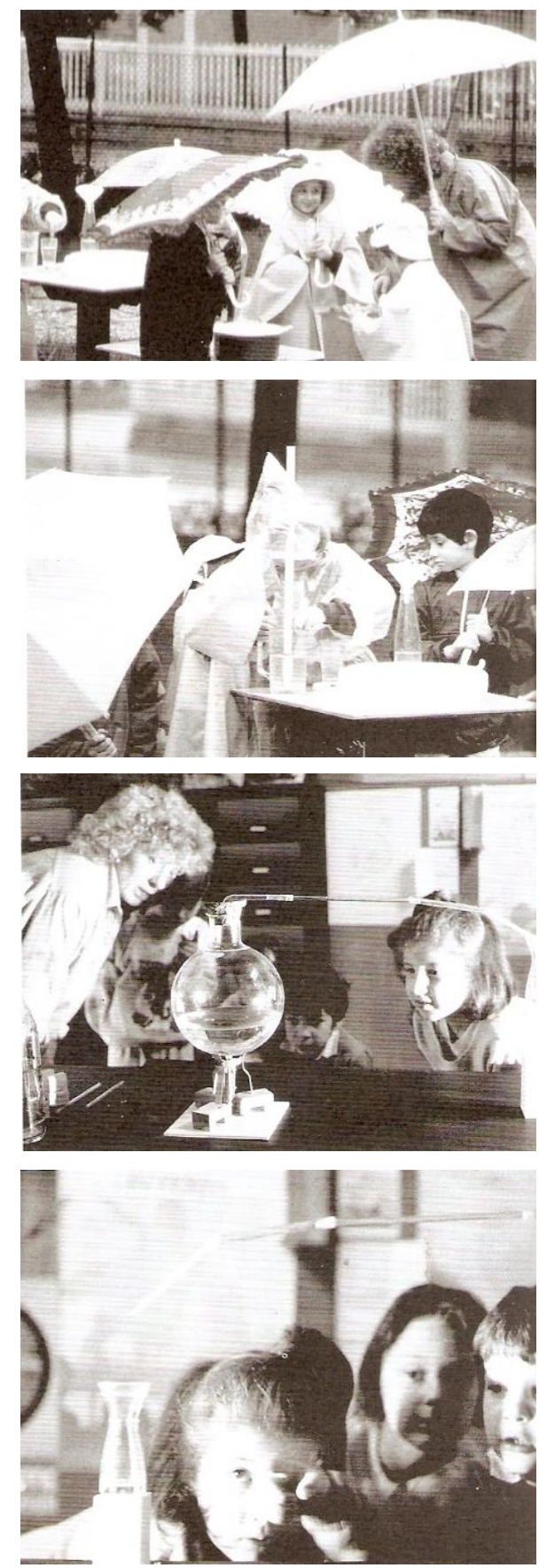
que modo tais ideias podem ser transformadas em uma didática” (HOYUELOS, 2004a, p. 111).

Essa foi uma alternativa que o pedagogo buscou por muito tempo, por meio de muitas estratégias, para romper com o aparato musculoso da escola da palavra. Assim, uma das estratégias marcantes neste projeto foi a criação, por assim dizer, da abordagem multissimbólica (FORMAN; LEE; WRISLEY; LANGLEY, 1999), que também pode ser identificada em tantos outros projetos e que, ainda hoje, poder ser vista como uma constante no trabalho desenvolvido em Reggio Emilia. 
Forman (1989) comenta a respeito dessa experiência com o projeto em destaque como uma oportunidade singular para aprendermos a fazer boas perguntas para as crianças. Perguntas, segundo ele, que ajudam a criança a pensar sobre o que estão pensando.

$\mathrm{Na}$ abordagem multissimbólica, as crianças começam com uma espécie de discussão verbal sobre ideias gerais a respeito da chuva (primeiro ciclo: discussão). Enquanto aguardavam a chuva, realizaram alguns desenhos iniciais sobre suas teorias a respeito da chuva (segundo ciclo: desenhos iniciais e discussão adicional). Esses desenhos servem como uma plataforma de teorias para orientar o professor em como ampliar as propostas que são oferecidas para as crianças. Veja-se o exemplo abaixo:

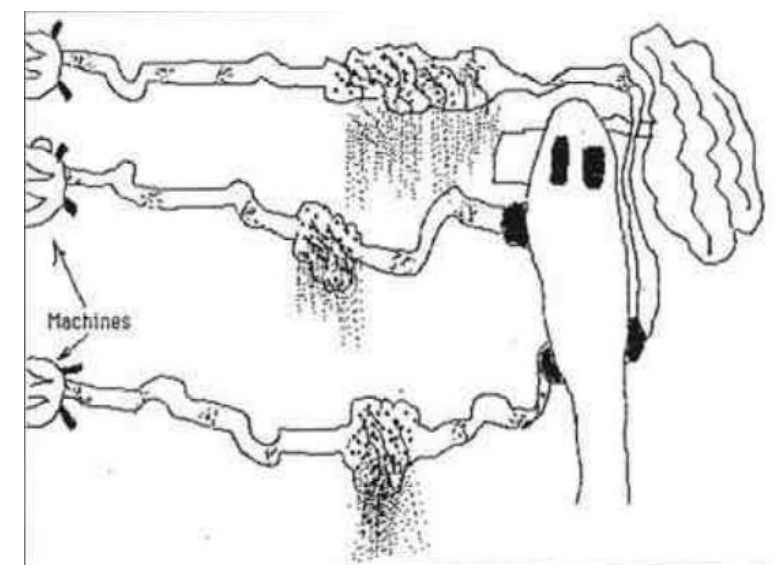

"No céu existem alguns tipos de máquinas que nunca acabam ... se uma fica esvaziada há outra pronta imediatamente. Elas têm uma espécie de canos, os canos vão para o meio das nuvens, tem água dentro das nuvens, a água dentro das nuvens nunca acaba, se acaba não é bom, porque então não choveria mais, então o cano cheio de água volta para dentro das máquinas, onde tem uma espécie de alavanca e quando a máquina está cheia de água que os canos trouxeram, ele liga e começa a chover. "Matano, 5 a (FORMAN, 1989, grifo do autor).

A abordagem multissimbólica tem por premissa a experimentação de diversas linguagens, procurando focalizar-se em como uma linguagem é generativa da outra e de que modo essas linguagens se complexificam e se modificam entre elas. Forman (1989) identifica nove ciclos na abordagem ${ }^{57}$, que não devem ser vistos como roteiros pré-definidos, mas que servem como um horizonte para o professor pensar em propostas em que as crianças possam transladar entre as diferentes linguagens ${ }^{58}$. Os ciclos mapeados por Forman (1989) não se tratam de uma receita, e, sim, de uma cartografia do que se percebe no desenvolvimento do projeto:

O projeto em Reggio Emilia continuou por muitas semanas, incluindo atividades como gravação em áudio dos sons da chuva em diferentes superfícies e uma representação gráfica posterior desses sons, um passeio à cidade, pleno de dúvidas que haviam sido levantadas nas discussões e desenhos em sala de aula, desenho de

57 Os ciclos que Forman, Lee, Wrisley e Langley (1999) identificam são Discussão; Desenhos iniciais e desenho adicional; Simulação; Uso do Desenho como referência; A experiência; Os desenhos após a experiência; Ampliação; Aprofundamento; Mais ampliação e aprofundamento.

58 A abordagem simbólica é um dos focos de investigação do OBECI. Na Parte III desta tese, poderá ser compreendido mais a respeito quando será tratado sobre os Processos Formativos, especificamente, no Grupo de Investigação-Ação Ciclos de Simbolização. 
água da chuva do céu para mãos no chão, levando até as casas, uso de uma sequência de fotografias que mostram um céu em transformação e desenho posterior dessas mudanças no papel, desenho de uma cidade antes e durante um temporal, e desenho de muitos exemplos mais de aprendizagem multissimbólica (FORMAN, LEE; WRISLEY; LANGLEY, 1999, p. 236).

Quando o projeto foi comunicado - vale lembrar que esse foi um projeto que fez parte da exposição I cento linguaggi dei bambini (As cem linguagens da criança) - , é possível perceber dois aspectos importantes: o primeiro, que podemos ver as teorias de cada criança em relação à cidade na chuva, como nos desenhos e narrativas a seguir. Isso se deve ao fato de que o registro e a observação das teorias das crianças vinham sendo uma tônica nos projetos reggianos. Além disso, a interpretação dessas teorias como catalizadora para a construção da continuidade do projeto também pode ser fortemente percebida.

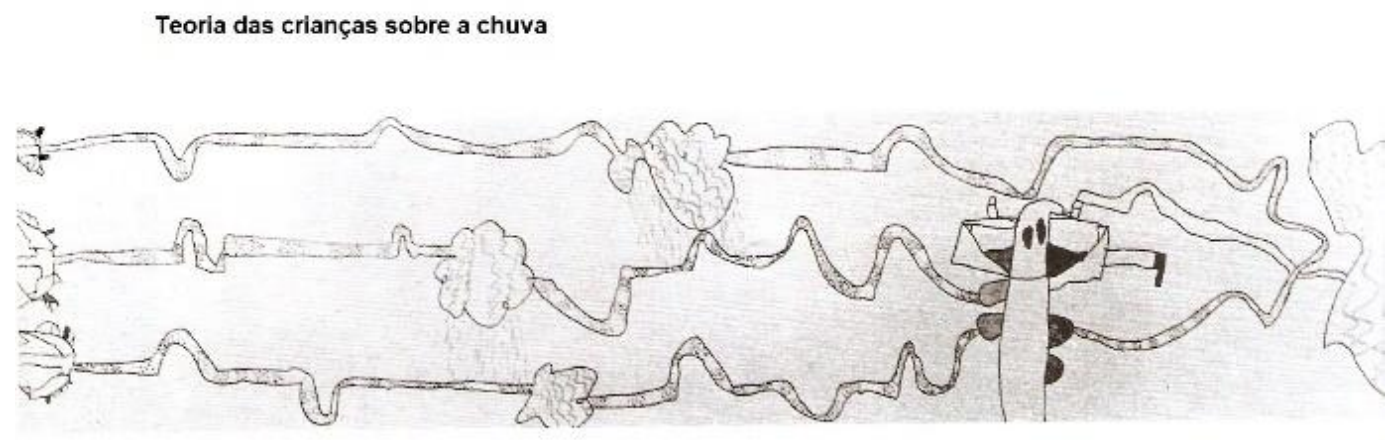

No céu há uma espécie de máquinas que são infinitas.... Se uma se esvazia, em seguida há outra preparada.

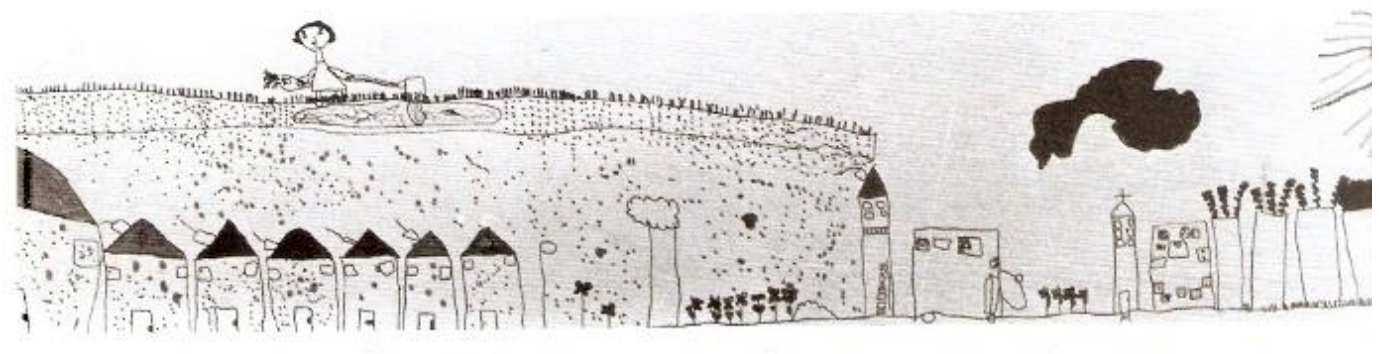

Eu acredito que è Deus que faz chover, quando está regando suas flores e ai caem algumas gotas.

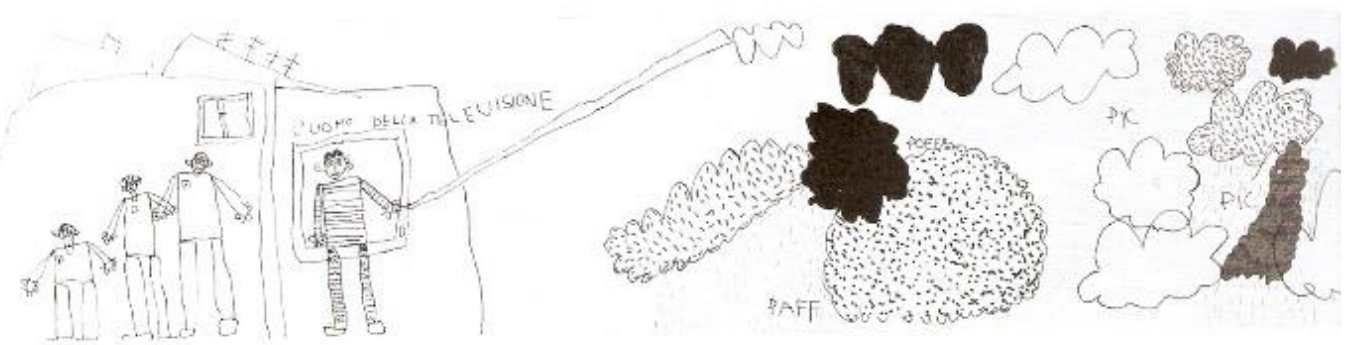

Meu pai sabe, e é ele que me diz de manhă se chove ou năo. Ele sabe porque vê na TV. 
O outro aspecto é que há uma clara relação entre a didática gestáltica experimentada por Malaguzzi nesse período e o modo como é comunicado a respeito. Ou seja, também são utilizados recursos evocativos para além da palavra, que mostram, por meio de sequências de imagens, narrativas visuais. Essa foi se transformando em uma marca para o trabalho comunicativo realizado nesta experiência educativa.
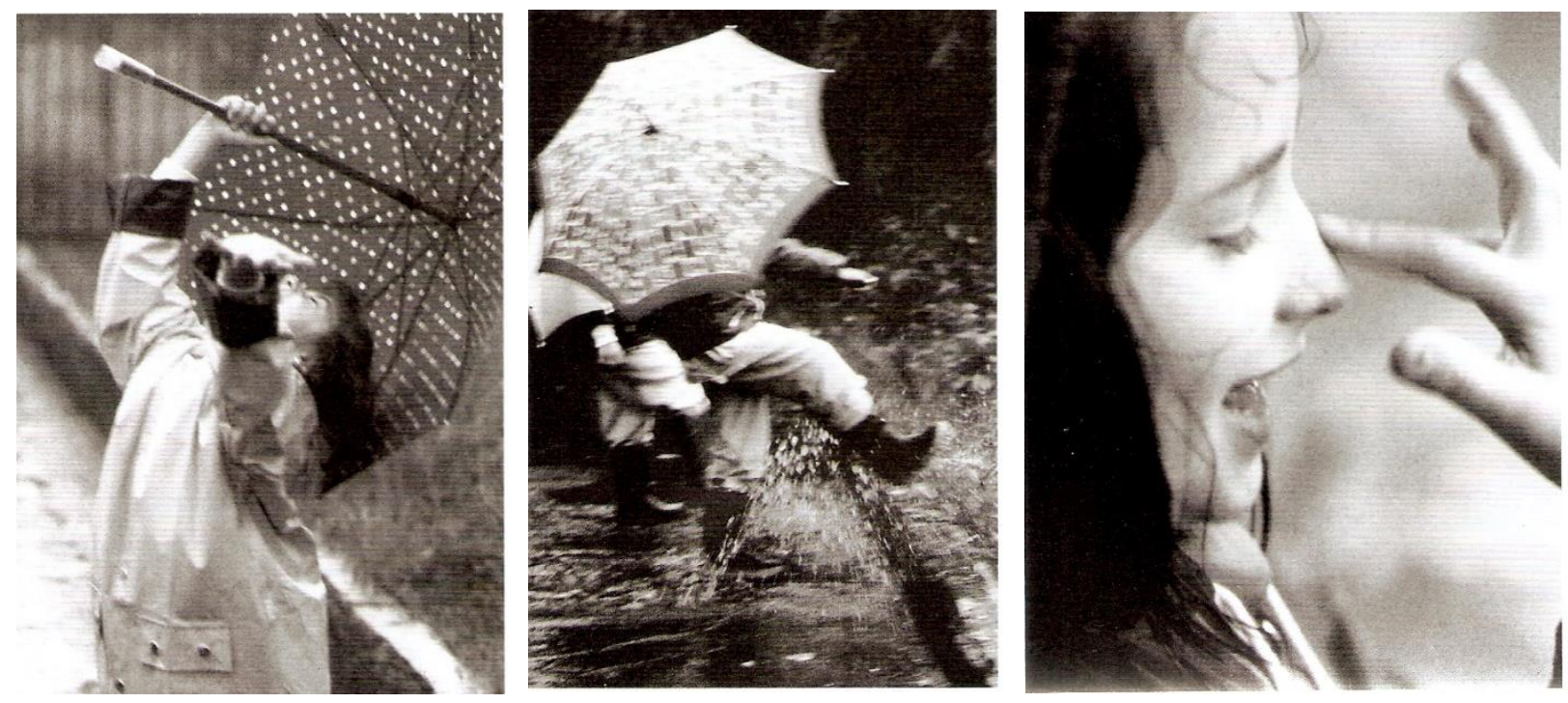

Em se tratando de imagens, vamos para o final dos anos de 1980, quando Malaguzzi supervisionou o primeiro projeto na creche, I piccolissimi del cinema muto (Os pequenos do cinema mudo). Nesse projeto, o que podemos perceber é a força que Malaguzzi dá para os gestos, olhares e expressões a partir de imagens no lugar das narrativas verbais das crianças, como se pode perceber muito nos outros projetos.

Esse foi um projeto muito debatido entre as professoras da creche Nido Gianni Rodari, Sonia Cipolla e Evelina Recerberi, a pedagogista Tiziana Filippini e Loris Malaguzzi. Ocorre que o pedagogo tinha muito interesse em construir a comunicação de um projeto na creche que tornasse visível uma outra imagem de criança e de serviço educativo para essa idade. Ele tinha a consciência de que até então haviam colocado mais atenção nas experiências da pré-escola e que, embora existissem algumas experiências pontuais de comunicações sobre pequenos projetos ou situações cotidianas da creche, havia uma lacuna nos projetos das escolas de Reggio Emilia com mais densidade e maior clareza em comunicar alguns conteúdos importantes sobre os bebês na creche.

A expertise de Malaguzzi sempre foram as crianças da pré-escola. Por isso, de um lado, havia um interesse por parte do pedagogo em se aproximar dos bebês e das crianças bem pequenas e, do outro, um desafio em conseguir cumprir com seu papel de provocador para a equipe da creche. Como conta Hoyuelos (2004a), por essa razão, não houve uma sintonia 
imediata entre Malaguzzi e a equipe. Precisou de um tempo e de uma grande disponibilidade de ambos os lados para que esse projeto também se tornasse uma oportunidade de aprendizagens mútuas entre Malaguzzi e a equipe da creche.

Estruturada como uma narrativa teatral em quatro atos, a comunicação conta a aventura de um pequeno grupo de crianças de 1 e 2 anos com um peixe, real e ficcional, na creche. A palavra é praticamente ausente nessa comunicação, e isso não é por acaso. Malaguzzi problematizava as questões ainda recorrentes naquela época que discutiam o que acontecia com as crianças e que era anterior à palavra:

\begin{abstract}
Nós mantemos a opinião de que as crianças nascem falando e falam com todo o mundo. Que a palavra, composta de sons que podemos identificar e interpretar, embora ainda demore para aparecer, não é um fato que impeça ou obstaculize a irreprimível, vital, ávida busca das crianças para construir amizades e pedir, enviar e reconhecer mensagens e discursos (MALAGUZZI, 2004a, p. 9).
\end{abstract}

O que chama atenção de Malaguzzi é a força de outras formas de comunicação, que não a palavra, utilizadas pelos bebês para construir e sustentar suas relações e vínculos. O desejo de comunicar, de evocar algo no outro, antecede o domínio da palavra como possibilidade de comunicação e, como observa Malaguzzi (2004a, p. 9), a palavra sairá “desse laboratório submergido e silencioso de tentativas, provas, experimentos para comunicar que as crianças têm construído para afinar seus instrumentos".

Malaguzzi soube sempre se valer dos projetos e das comunicações que decorriam deles para problematizar alguns temas caros à Educação Infantil, à Pedagogia, à infância. Não se tratava de apenas relatar uma experiência educativa, mas de mostrar como, a partir desta experiência, poderíamos pensar e conhecer a respeito de um universo ampliado de conteúdos e processos. Valer-se das imagens e de uma narrativa praticamente visual era a metáfora que o pedagogo precisava para discutir o valor das interações entre as crianças mesmo na ausência da palavra.

No primeiro ato da comunicação I picollissimi del cinema muto, narra-se desde o descobrimento pelas crianças do peixe em um livro de literatura infantil até a visita a uma pequena loja local que vendia pequenos animais e o retorno para a creche com dois peixes. $\mathrm{O}$ desafio de cuidá-los na creche e os diálogos silenciosos que surgiram entre as crianças e os peixes mostram o fascínio de descobrir e aprender. No primeiro ato, já se pode ver as brincadeiras dos bebês com sombras, projeções e com observações dos peixes no aquário. 


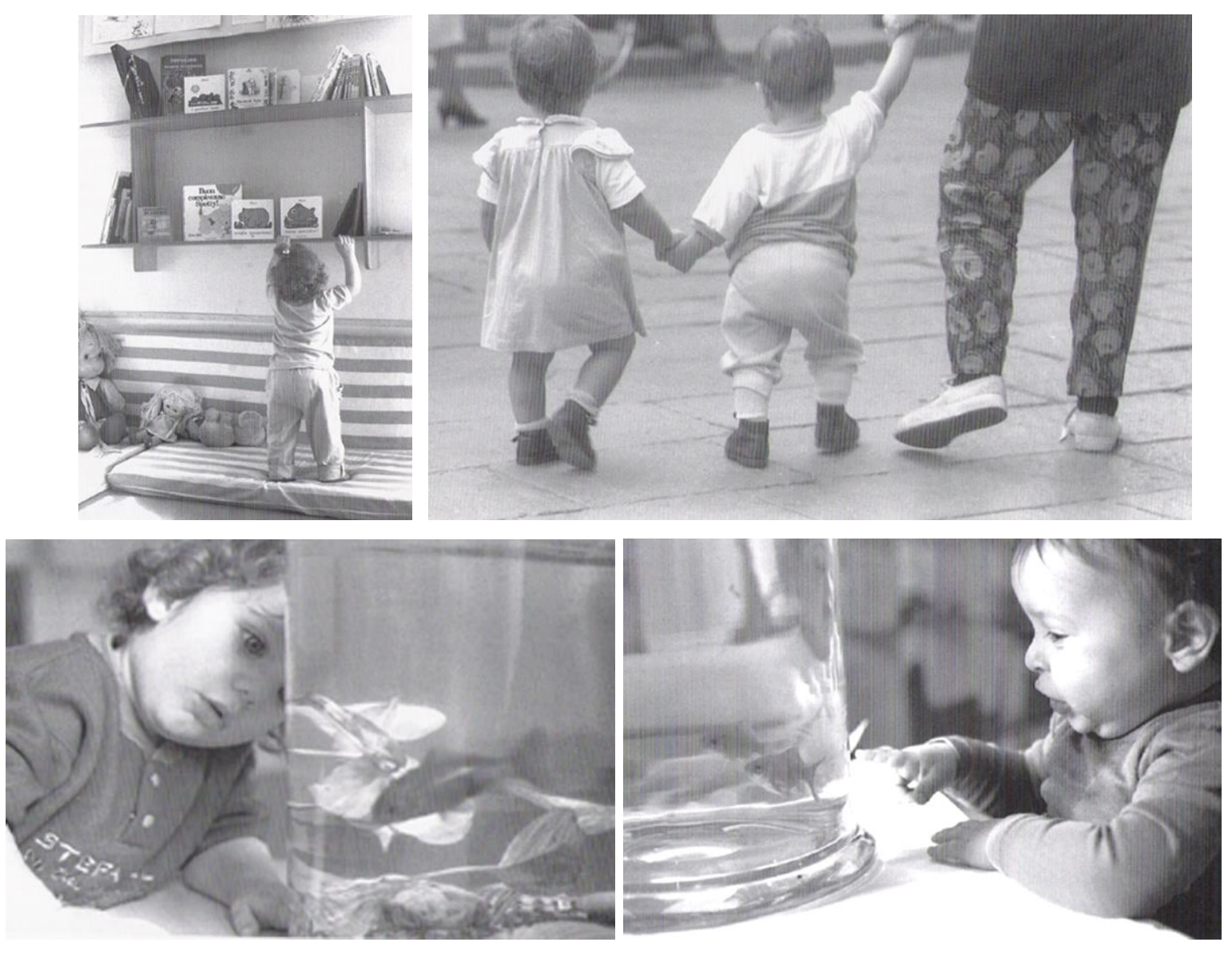

No segundo ato, momento do conflito da narrativa, é contado o momento quando um grande peixe de espuma aparece na sala dos bebês dentro de um caracol. Como narra Hoyuelos (2004b), o peixe de espuma surge quando Malaguzzi se interroga sobre as experiências gráficas das crianças e propõe para as educadoras utilizar um peixe que se pudesse manipular. Animado com essa possibilidade, Malaguzzi pede a Mariano Dolci que fizesse um outro peixe de espuma pequeno. Eis que as crianças criam um grande conflito: o peixe grande come o peixe pequeno.

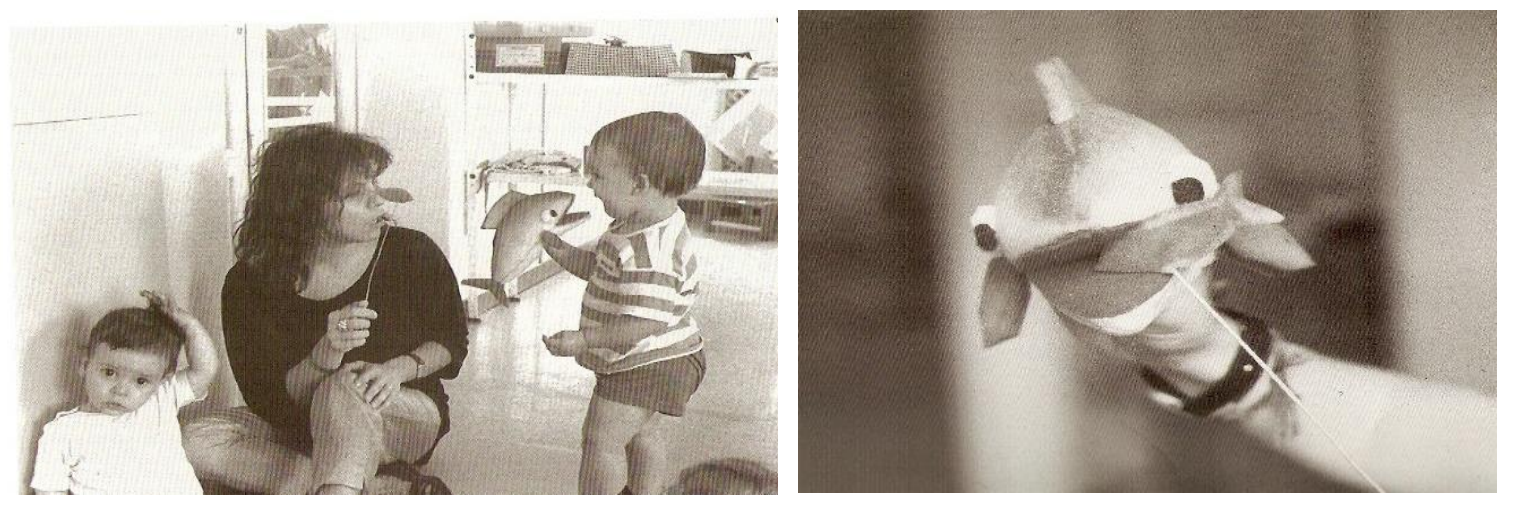

Havia em Malaguzzi um verdadeiro fascínio em observar como as crianças se movimentavam entre o real e o imaginário. Para o pedagogo, ali se escondiam verdadeiros tesouros para compreender o modo como as crianças iam criando suas teorias. Além disso, ele 
era apaixonado pela beleza e o prazer do conhecer e, por isso, "insistia sempre sobre o fato de que um projeto deveria fazer divertir as crianças e, então, fazer emergir a sua própria alegria" (HOYUELOS, 2004a, p. 156).

O temor de que o peixe de espuma pudesse comer também o peixe do aquário parece impulsionar nas crianças um espirito libertador, e, no terceiro ato, vemos uma criança salvando o peixe do aquário jogando pela janela o grande peixe de espuma. No último ato, uma criança salva o peixe que havia sido arremessado para fora. As demais vibram pelo ato de coragem e pela possibilidade do reencontro. $\mathrm{O}$ grande peixe retorna à sala e tudo volta a ser a alegria que deveria ser.

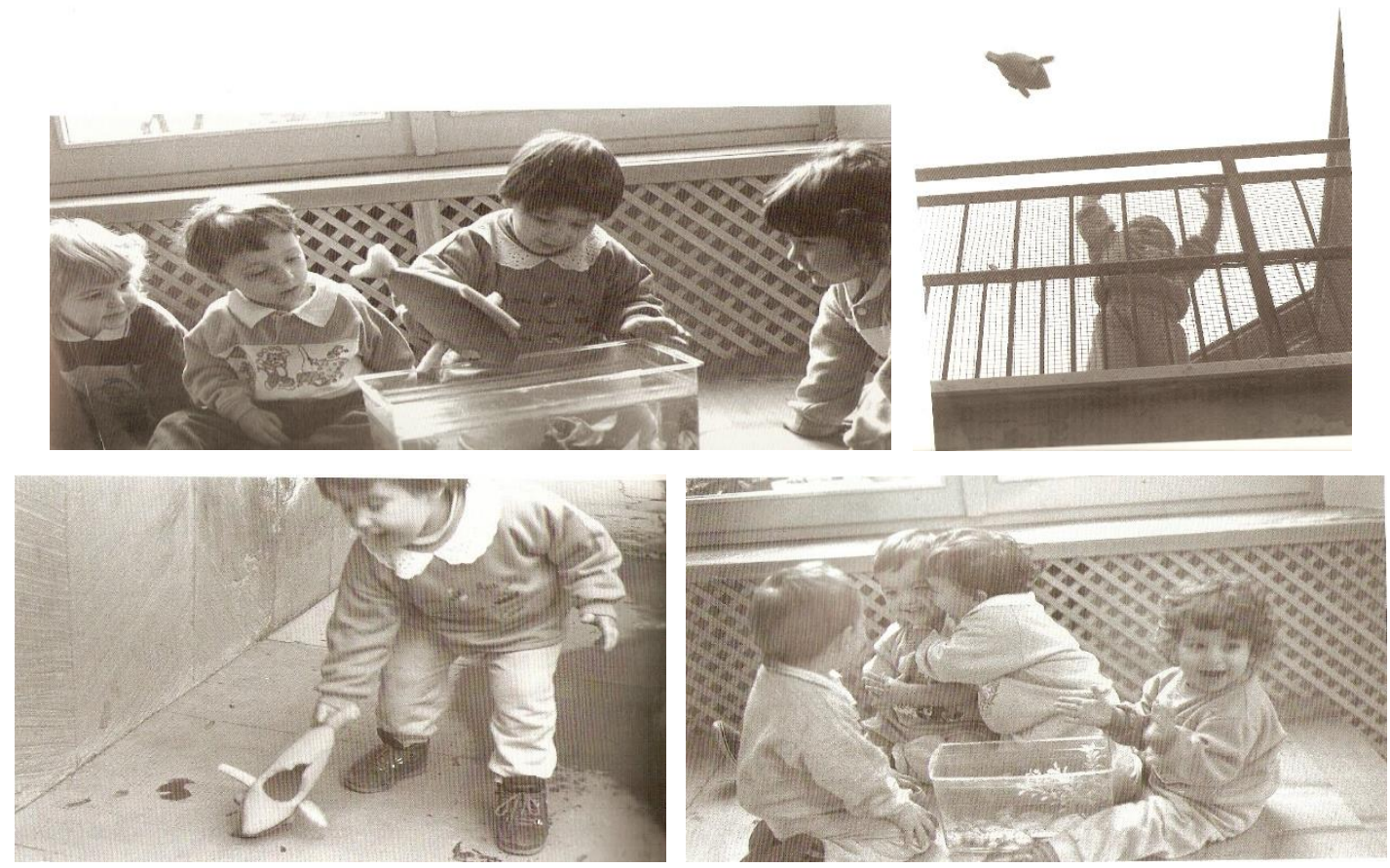

Malaguzzi (2004a), no capítulo introdutório da publicação I picolissimi del cinema muto, anuncia pistas interessantes para pensar uma didática da creche. $\mathrm{O}$ pedagogo fala do valor das interações entre as crianças e de como o adulto precisa se organizar e organizar o contexto de modo que privilegie isso. Chama atenção ainda a importância que há nas interações entre as crianças de idades semelhantes para construir sentidos coletivos para as relações que vão estabelecendo.

Para o pedagogo, é por meio das interações que as crianças migram para outros mundos, que geram conflitos cognitivos capazes de criar transformações emocionais, comportamentais, sociais. Nesse sentido, para Malaguzzi (2004b, p. 13), "se não existirem relações de autoridade ou de forte dependência, as crianças estão especialmente sensibilizadas 
para aproveitar o significado dos conflitos, experimentar a fascinação e apreciar as formas de aprendizagem reelaboradora e criativa, fundamentadas no descobrimento".

Por fim, uma outra advertência que Malaguzzi (2004b, p. 12) faz é a de que "as crianças nascem já preparadas e predispostas a atuar e pensar ativamente. Geneticamente abertas para socializar, comunicar, memorizar, retro atuar, transformar, aprender a pensar, as crianças se tonam competentes interatuando com as pessoas, as coisas, as ideias". Essa visão de criança, fortemente declarada em todos os projetos e comunicações, é, sem sombra de dúvidas, a revolução do pensamento de Malaguzzi. Não porque é discurso, mas porque é traduzida uma visão de criança no modo como os contextos são oferecidos a elas e como cotidianamente são travadas as relações dos adultos com os meninos e meninas.
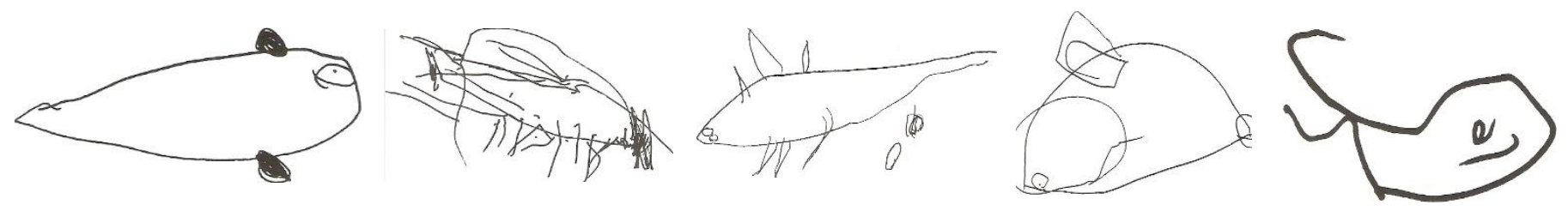


\section{A DOCUMENTAÇÃo PEDAgógiCa COMo ESTRATÉgia PARA CRIAR SITUAÇÕES DE APRENDIZAGEM SIGNIFICATIVAS}

Os três projetos que analiso nesta categoria são significativos na declaração da noção de conhecimento e aprendizagem no pensamento de Malaguzzi, pois mostram a proximidade e interesse do pedagogo pelo socioconstrutivismo (construtivismo social).

A vinculação de Malaguzzi com o socionstrutivismo não é naturalmente localizável em seus escritos. Pode-se dizer que foi um percurso longo, por diferentes campos e áreas de conhecimento pelos quais o pedagogo percorreu. No entanto, ocupando-se da reflexão desenvolvida pelos norte-americanos, George Forman e Carolyn Edwards, e de seu biógrafo, Alfredo Hoyuelos, pode-se afirmar a vinculação de Malaguzzi a essa abordagem.

Um dos indícios notáveis é o forte apelo de Malaguzzi para que as escolas não realizassem as investigações com as crianças no grande grupo. Para o pedagogo, o valor da aprendizagem das crianças é a compreensão de que o conhecimento é uma construção tanto subjetiva (e, portanto, individual), como de grupo.

Para Forman e Fyfe (2016), um sine qua non de uma prática educativa de qualidade é ter a clareza sobre a visão de conhecimento em que se está atuando. E, nesse caso, a crença em uma perspectiva socioconstrutitivsta (ou co-construtivista, como Forman e Fyfe (2016) se referem) implica fazer uma passagem da centralidade no conteúdo e nos fatos para voltar-se ao como se aprende e como se constrói sentido ao que se aprende. Nas palavras dos autores, "a educação das crianças se baseia em ajudá-las a criar sentido, a negociar com as outras em um contexto de simbolização (Gardner, 1983), comunicação (Tharp; Gallimore, 1988), narrativa (Engel, 1994; Taylor, 1993) e metáfora (Bruner, 1990) ${ }^{59 "}$ (FORMAN; FYFE, 2016, p. 249).

Então, os autores, ao analisarem o trabalho desenvolvido em Reggio Emilia, preferem nomear esse tipo de aprendizagem como "aprendizagem negociada" (FORMAN; FYFE, 2016):

\footnotetext{
$\mathrm{Na}$ aprendizagem negociada, os professores buscam descobrir as crenças, as suposições ou as teorias das crianças sobre a forma como o mundo físico ou social funciona. O seu estudo vai além da simples identificação do interesse das crianças. A sua análise revela os motivos por trás do interesse das crianças - não estritamente o que é familiar, mas que o paradoxo ou a curiosidade motivam seus assuntos de interesse. As crianças são encorajadas a falar sobre o que sabem antes de iniciar o seu projeto. De maneira semelhante, as crianças pré-verbais podem explorar novos
}

59 Os autores citam as seguintes obras no excerto: BRUNER, J. S. Acts of meaning. Cambridge: Harvard University, 1990; ENGEL, S. The Stories children tell: making sense of the narratives of childhood. New York: W. H. Freeman, 1994; GARDNER, H. Frames of mind: the theory of multiple intelligences; New York: Basic Books, 1983; TAYLOR, P. Narrative, pluralism, and decolonization: recent Carribean literature. College Literature, v. 20, n. 1, p. 78-89, 1993; THARP, R. G; GALLIMORE, R. Rousing minds to life: teaching, learning, and schooling in social context. Cambridge: Harvard University, 1988. 
objetos ou materiais de modo que o professor (observando suas estratégias) possa inferir quais são as suas teorias, dadas essas estratégias (FORMAN; FYFE, 2016, p. 249-250).

Desenvolver projetos em pequenos grupos significa transformar um grupo de crianças em um grupo de aprendizagem. Isso porque, quando um grupo de crianças é um grupo de aprendizagem, constrói-se em relação aos saberes e aos conhecimentos.

Essa visão de conhecimento e de como ela é traduzida no trabalho com pequenos grupos pode ser vista no projeto Il Salto in lungo (Salto em distância), no qual a equipe da Scuola Diana experimenta a proposta metafórica da sonda, sondas de investigação-ação (MALAGUZZI, 1988) ou experiências sondas (MALAGUZZI, 1995). Trata-se de uma ideia de Malaguzzi para entrar densamente na experiência da criança para uma metacompreensão dos recursos com as quais elas criam suas teorias (MALAGUZZI, 1988) e colocá-las em relação com o modo como os professores observam e interpretam tais teorias para elaborar as estratégias de aprendizagem. Por isso, em um esboço de um discurso de Malaguzzi, datado de 1988, sobre o tema da sonda de investigação-ação, o pedagogo inicia falando de concepções de criança, da construção do conhecimento pelas crianças, de qualidade de observação e do sentido das interpretações e registros (MALAGUZZI, 1988).

A ideia de chamar "sonda" vem do verbo em italiano sondare, que pode ser traduzido por tentar saber, investigar. A sonda "é uma investigação dirigida para a compilação de comportamentos, procedimentos, interpretações, atuações das crianças em torno de uma experiência delimitada e definida, que tende a reconhecer a qualidade, a variabilidade e a influência das crianças entre elas" (MALAGUZZI, 1988, p. 367). Na verdade, essa metáfora é uma proposta de Malaguzzi para mobilizar o professor para criar as condições adequadas para observar as investigações das crianças, o que significa entender que "se realiza com um número limitado de crianças, para garantir ao máximo o registro e a compreensão dos fatos e das hipóteses delas [...], em que a atitude do adulto é de apoio, não de interferência" (MALAGUZZI, 1988, p. 367).

Logo, pode-se dizer que a sonda, para Malaguzzi (1988), surge como alternativa para ensinar o adulto a observar. Observar não é sinônimo de simplesmente ver ou de comprovar ideias já previstas, mas querer saber e interpretar o modo como as crianças agem em seus processos de construção de conhecimento. Assim, Malaguzzi (1988), estabelecendo uma forte crítica aos modelos de observação que a comunidade científica oferecia (situações de observação laboratoriais, ou simplesmente descritivas), comenta quão privilegiada é a escola 
de Educação Infantil ao poder observar os procedimentos e processos das crianças na construção do conhecimento:

[...] é um terreno de experiências como nenhum outro, avidamente buscado pelas crianças e originariamente predisposto para as necessidades de socialização, de comunicação, de interação, de confronto, de interlocução e cooperação fecundadas para a formação da inteligência, do pensamento, da identidade do outro. E, por último, um terreno privilegiado para os adultos, para a observação, a reflexão, o conhecimento estratégico e avaliador das maneiras com as quais as crianças produzem e constroem condutas e formas evolutivas de conhecimento, dando a possibilidade, sempre para os adultos, de autoavaliação e autocorreção de suas expectativas, de suas hipóteses, de suas capacidades de previsão e de reflexão sobre os atos e as eleições que realizam com as crianças. Um terreno, então, que por meio de maturações recíprocas, reforça o conhecimento das crianças e dos adultos, produz formação e melhora a qualidade de suas relações e interações (MALAGUZZI, 1988, p. 367).

A sonda pode ser entendida como uma modalidade de investigação em que se organizam situações de aprendizagem para que se possa aprofundar algum conhecimento ou processo de aprendizagem das crianças e, por parte do professor, converter-se em uma privilegiada situação para adensar suas estratégias de observação, registro e interpretação. Nos termos do próprio Malaguzzi (1988, p. 368, grifos do autor), “a sonda é uma oportunidade, um instrumento predisposto para obter uma observação da observação e, sobretudo, um conhecimento do conhecimento, que segue sendo um dos feitos mais cobiçados e fecundos no âmbito dos processos individuais do conhecimento e da relação entre os indivíduos". O termo sonda foi utilizado até o ano de 2002, e não foi encontrado nenhum motivo particular para o desuso.

Voltando ao projeto Il salto in lungo, esse projeto "[...] identifica de forma literal o tema proposto ao grupo de crianças no qual lhes foi pedido que se convertessem em investigadores, criadores e organizadores de uma competição de salto em distância" (MALAGUZZI, 1995, p. 141). Foram 28 sessões com um grupo de quatro crianças de 5 e 6 anos, entre os períodos de março e abril de 1985, e uma professora de referência que tinha o papel de acompanhar e retroalimentar a investigação junto das crianças.

O projeto surgiu em um contexto em que Malaguzzi, após a exposição de 1981, L'occhio se salta il muro, estava preocupado de que a experiência das escolas municipais de Reggio Emilia fosse confundida com uma abordagem educativa de artes visuais. Por isso, propôs uma série de formações para as escolas, tematizando a respeito do conhecimento lógicomatemático (HOYUELOS, 2004a，2004b; CAGLIARI et al., 2017; FORMAN, 1999; FORMAN; EDWARDS; GANDINI; PUFALL, 1995).

Decorrente destas formações, as escolas e Malaguzzi foram determinando algumas focagens de investigação. É nesse período, por exemplo, que se realiza uma primeira pesquisa 
sobre o tema do computador como instrumento para comunicação (HOYUELOS, 2004b; REGGIO CHILDREN, 2005). Vale lembrar que, naquela altura, o computador era um grande desconhecido aos adultos e crianças, mas já se fazia presente de alguma forma no cotidiano. Malaguzzi acreditava que nenhum instrumento da cultura poderia permanecer fora da escola (HOYUELOS, 2004a).

Também o projeto Il salto in lungo foi um dos primeiros a ser documentado com um pequeno grupo de crianças. Os projetos anteriores que foram documentados eram mais extensos e, de uma forma ou de outra, envolviam mais crianças. Como observa Hoyuelos (2004b, p. 168), “[...] é o começo de um projeto que põe a atenção em como aprende o grupo e o indivíduo. O que chamamos de socioconstrutivismo, algo que despertou tantas reflexões nos professores norte-americanos Carolyn Edwards, George Forman e Peter Pufall".

No caso da Scuola Diana, o projeto surgiu em decorrência das observações das professoras do prazer e recorrência em que as crianças experimentavam situações de medições, ou, dos vocabulários que utilizam nessas situações ${ }^{60}$.

A partir desses indícios iniciais, Laura Rubizzi e Paola Cagliari estruturaram a sonda de investigaçãoação com o objetivo de compreender como as crianças de 5 e 6 anos afrontavam os problemas lógicomatemáticos relacionados com as medidas de distância.
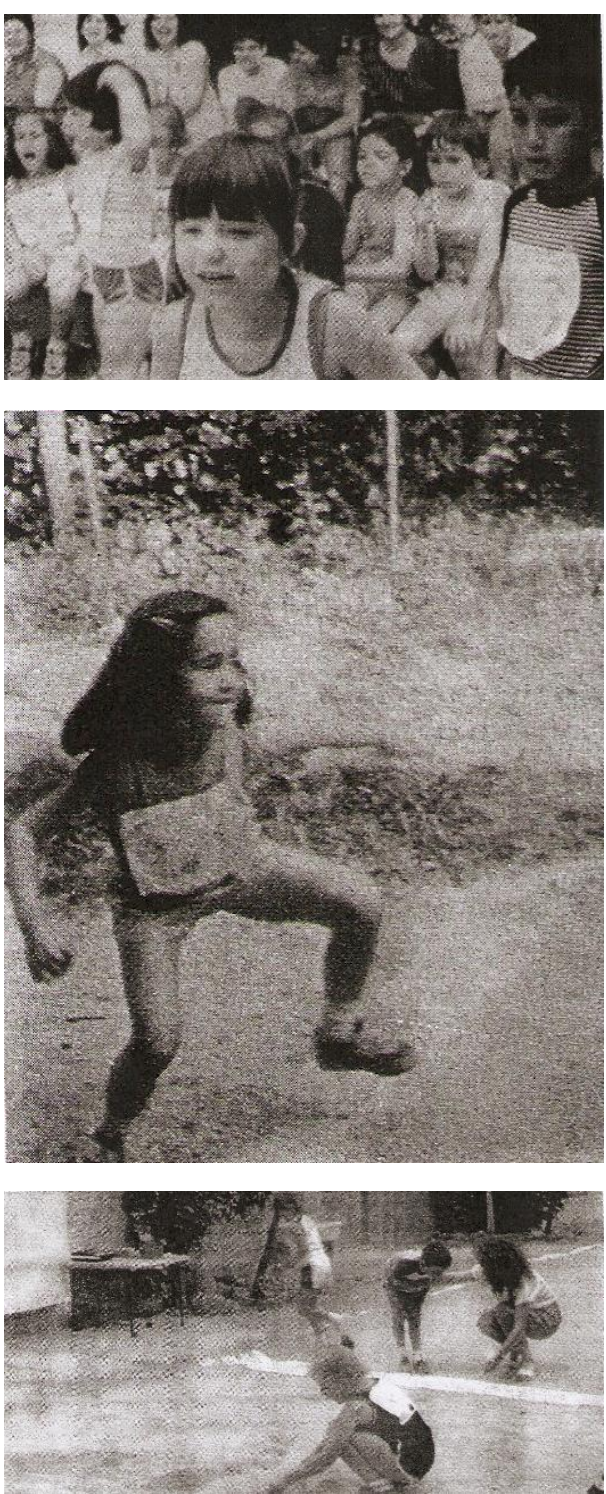
Na sequência, com Malaguzzi e Vea Vecchi, estruturaram algumas possibilidades de caminhos a serem percorridos e esquematizaram de que forma iriam documentar o projeto. Segundo Hoyuelos (2004b, p. 170), “essa era uma necessidade posta por Malaguzzi, que não fazia nenhuma diferenciação entre a realização do projeto e sua apresentação pública. Malaguzzi

60 Tive a oportunidade de escutar o relato da professora que conduziu esse projeto, Laura Rubizzi, em curso extensivo que participei sobre o Papel do Coordenador Pedagógica a partir dos pressupostos de Reggio Emilia (2014-2018) com módulos em Buenos Aires (Argentina) e Reggio Emilia (Itália). Na ocasião, foi que compreendi muitos dos caminhos que atravessam e levam a construção de um projeto desde a perspectiva desta abordagem educacional. 
exigia uma narração teatral do que acontecia com uma relação coerente entre imagem e texto que relatassem o que estava ocorrendo". A esse respeito, discutiram intensamente as diferentes modalidades de registro e observação do projeto e decidiram que fariam uma documentação direta, ou seja, que se estruturassem de antemão os procedimentos e a focagem de interesse e uma documentação sobre o que poderia emergir em cada situação (HOYUELOS, 2004a).

Além da estrutura da comunicação, os elementos que Laura, Paola, Vea e Malaguzzi discutiram ao longo do projeto, fez surgir uma modalidade específica de planejamento (o que mais tarde veio a ser chamado por eles de proggetazione). Hoyuelos (2004a, p. 133) comenta os detalhes desse processo de elaboração do planejamento:

Descreveram a estratégia utilizada para criar o grupo de criança que trabalharia no projeto, a metodologia de intervenção do adulto, os instrumentos que se deixaria à disposição das crianças; os materiais necessários para as construções e propostas, a pergunta inicial, o tipo de observação, a forma de seleção para a realização do campeonato do salto em distância, a previsão dos problemas que poderão aparecer referentes ao tema das medidas, a bibliografia necessária para estudar, os diversos encontros com especialistas, o desenvolvimento cultural do conceito de medida e dos instrumentos de medida.

Como narra Laura, o projeto foi um exemplar riquíssimo de como uma questão simples, como uma competição de salto em distância, poderia se converter em um desafio a crianças e adultos. Por isso, Malaguzzi promoveu alguns encontros com especialistas no tema da matemática para que as professoras e a atelierista pudessem aprofundar seus conhecimentos a respeito da linguagem matemática. Para Malaguzzi, essa poderia ser uma oportunidade para desconstruir a imagem que muitos - inclusive ele - tinham da matemática, como algo terrível e assustador (HOYUELOS, 2004a, 2004b). Hoyuelos (2004a, p. 132) alerta que Malaguzzi defendia uma perspectiva de matemática contextualizada, bem diferente da didática tradicional:

\begin{abstract}
A escola deve pesquisar a possibilidade da probabilidade e da combinação; é necessária uma aprendizagem para compreender e interpretar a realidade na qual vivemos: podemos analisar situações de incertezas com elementos de probabilidade, onde não existam o verdadeiro ou falso, mas gradações nas quais seja possível o menos ou mais certo, o pouco provável, o pouco certo etc. O sentido do número é presente na criança desde que nasce. A criança percebe e utiliza os códigos matemáticos muito antes de poder os compreender completamente.
\end{abstract}

Como o projeto estava sendo acompanhado pela equipe norte-americana, também foram muito proveitosas as discussões entre Malaguzzi e Forman a respeito do socioconstrutivismo (HOYUELOS, 2004b). Laura comenta das inúmeras situações em que confrontavam e discutiam com Malaguzzi e Vea e ressalta que Malaguzzi tinha uma forte competência em retirar da banalidade as ações das crianças (HOYUELOS, 2004a, 2004b). Também o pedagogo costumava ir acompanhando o esboço da comunicação que havia ficado 
a cargo de Vea Vecchi. Sua leitura era sempre um momento de muita preocupação, dado seu grau de exigência.

Durante as quase trinta sessões, as crianças observaram imagens de competidores olímpicos , discutiram em diversas situações de assembleia suas ideias e teorias, desenharam (como pode ser visto na sequência de desenhos a seguir), simularam saltos, fotografaram, gravaram em vídeo, voltaram a desenhar, criaram sistemas de medida e códigos comunicacionais e tantas outras situações que culminou em uma grande festa de competição de saltos em distância.

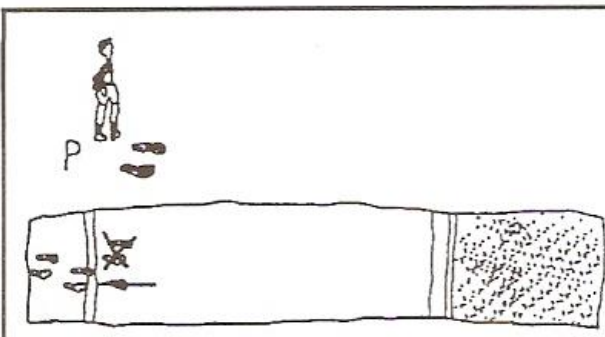

Figura 5a: Ponto de partida

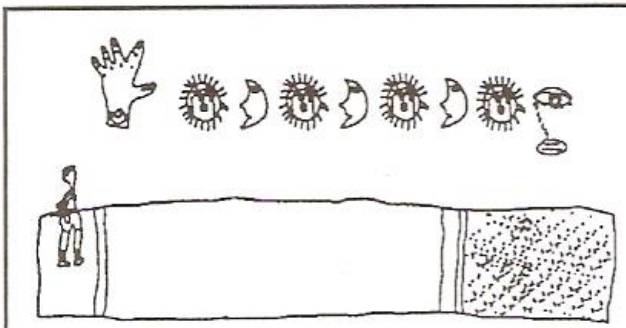

Figura 5c: Três dias de espera

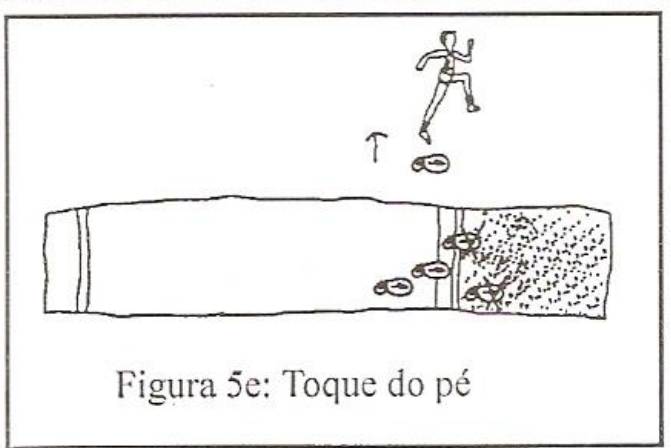

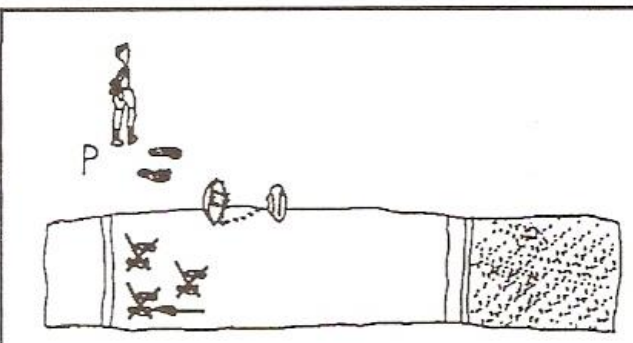

Figura 5b: Três falsas largadas

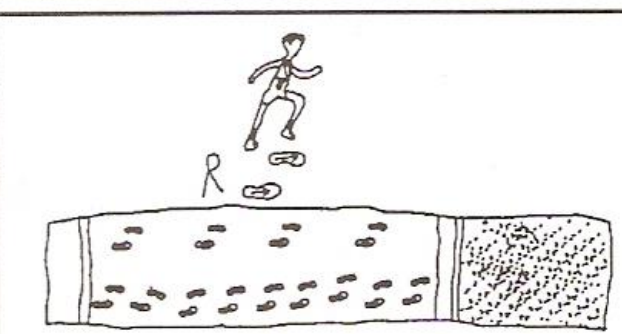

Figura 5d: A corrida

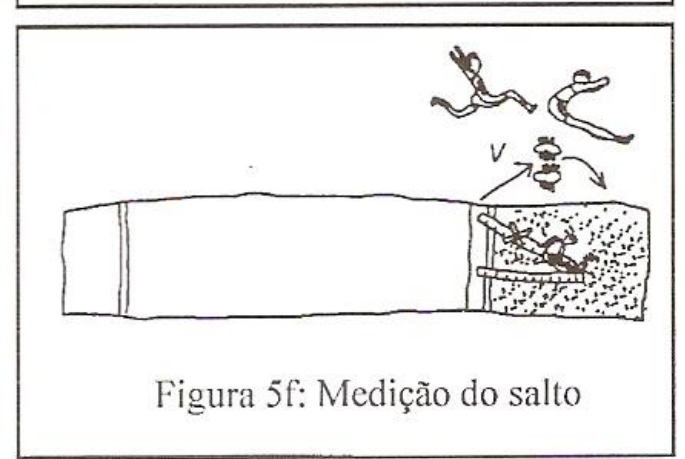

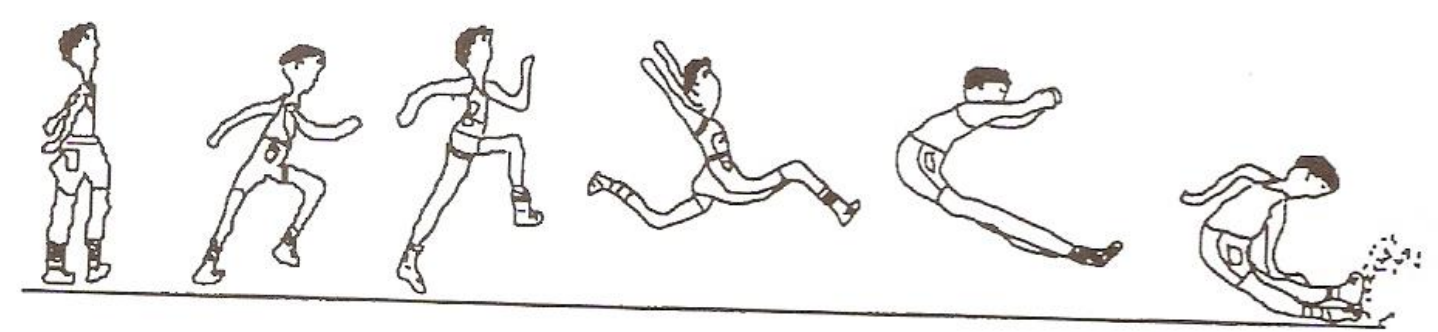


Situado em uma temática muito semelhante, Scarpa e metro (Sapato e metro) (1991), também é um exemplar de projeto que se movimenta dentro dessa zona de investigação: a sonda, o socioconstrutivismo e a maneira como as crianças afrontam os conhecimentos lógicomatemáticos. Esse projeto também ocorreu na Scuola Diana e se ocupou de compreender o modo como as crianças experimentavam os conceitos de medida. Foi realizado pela professora Marina Castagnetti, pela atelierista Vea Vecchi e por um grupo de 6 crianças (1 menina e 5 meninos) durante duas semanas (sessões de, aproximadamente, 40 ou 50 minutos diários).

$\mathrm{Na}$ introdução de uma das publicações a respeito do projeto, Malaguzzi (2005b, p. 10) reforça a noção do que entende por sonda: “[...] nossa investigação - ou sonda como nós a chamamos - não é nem uma simulação nem um experimento de laboratório, mas sim se inicia em um problema que as crianças tornam como um fato seu". Dito de outro modo,

\footnotetext{
A experiência se inicia em uma situação da vida real: o desejo das crianças em ter outra mesa para trabalhar no espaço da sala. Chamamos o carpinteiro e as crianças perguntaram:

- Poderia nos fazer uma mesa como esta?

- Necessito das medidas. Respondeu o carpinteiro. As crianças, temendo perder a oportunidade, disseram:

- Nós daremos as medidas. As crianças e o carpinteiro nos olharam, pedindo nossa aprovação.

- Claro, será um grande desafio! Imediatamente o carpinteiro advertiu as crianças:

- Sabem medir? A resposta das crianças foi rápida:

- E vocês? Sabem como fazer uma mesa exatamente igual a essa? E assim começa a aventura (CASTAGNETTI et al, 2005, p. 12).
}
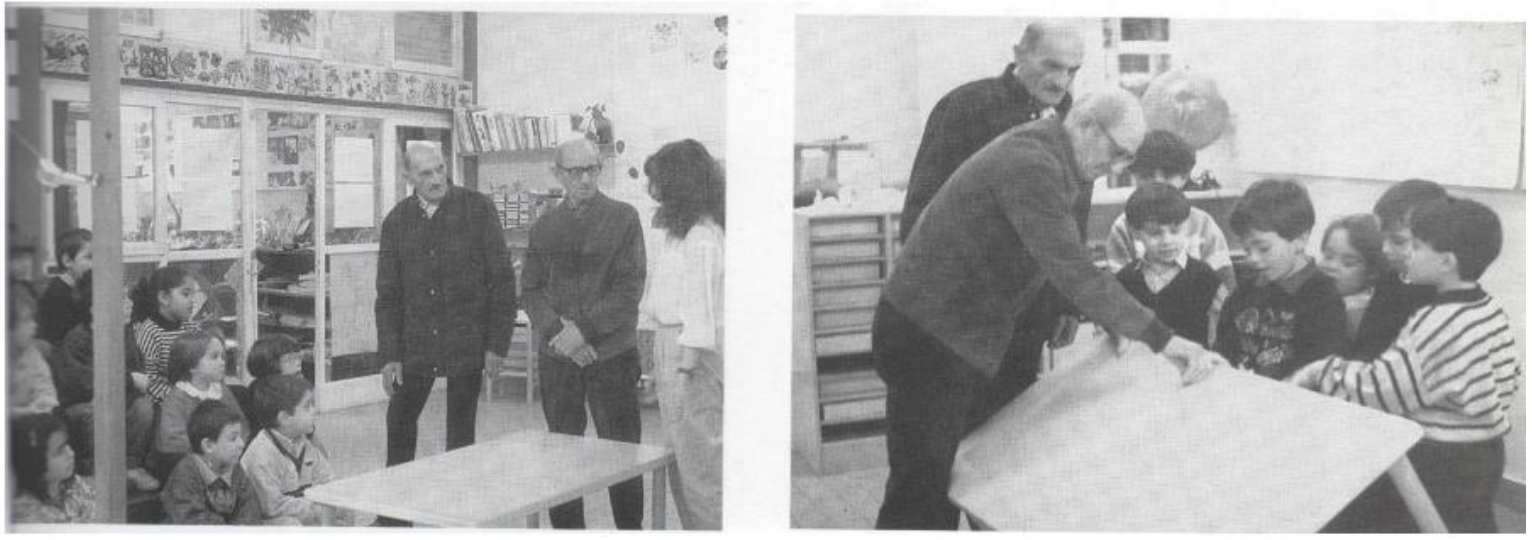

Esse era um projeto especial uma vez que mostrava o modo como um conhecimento lógico matemático é experimentado e significado pelas crianças a partir de um problema cotidiano, diferente de modo como se apresentava nos livros de didática: artificializado, com problemas fictícios, abstratos. Para o pedagogo, "se cremos que a educação deve partir de experiências reais, então a escola deve apropria-se dessas experiências e convertê-las em centros de estudo, investigação e aplicação prática" (MALAGUZZI, 2005b, p. 10). 
Malaguzzi (2005b) ainda informa os tipos de encaminhamentos que foram estabelecidos com as crianças: a decisão de trabalhar todas as manhãs no projeto, a possibilidade de que as seis crianças poderiam decidir se trabalhariam individualmente ou no pequeno grupo, a liberdade que teriam para tomar as decisões a respeito do andamento do projeto. Como o pedagogo ressalta, "é muito curioso ver até que ponto as crianças se comprometem com o projeto. As crianças tiveram todo o tempo de que necessitavam para pensar e fazer, criar e trocar ideias e resolver as aplicações práticas" (MALAGUZZI, 2005b, p. 11). Também foi acordado que, durante o projeto, o pequeno grupo de crianças que havia se voluntariado a participar informaria para as demais crianças o andamento.

Há um elemento diferenciado nesse projeto, pouco visto nos demais, que é a possibilidade de comunicar a respeito do papel do adulto. Nem sempre conseguimos localizar as ações dos adultos nas comunicações de Reggio Emilia daquela época. Via-se, sempre, a imagem da criança, as modalidades de construção do conhecimento por parte delas, os conteúdos envolvidos com os projetos, o que concretamente as crianças elaboraram, mas, excetuando um ou dois projetos, não havia muitas pistas sobre o papel do adulto.

No Scarpa e metro, graças à disponibilidade da professora de diariamente construir uma síntese a respeito do desenvolvimento do projeto e do contínuo intercâmbio com Malaguzzi a respeito, podemos compreender melhor a respeito do papel do adulto, assim como há a manutenção das reflexões a respeito do trabalho em pequenos grupos de crianças (HOYUELOS, 2004a). Malaguzzi (2005b, p. 11) irá destacar que

\footnotetext{
A função das professoras será basicamente a de ajudar as crianças nos momentos de revisão ou quando necessitam de alguma informação. Só intervirão quando as crianças se paralisarem, para ajudá-las a começar de novo e fazer as mudanças necessárias. Sua tarefa será também a de aumentar as situações que favoreçam o avanço, nos termos de Piaget, e identificar as zonas de desenvolvimento proximal, segundo Vygotsky.
}

O papel do adulto pode ser percebido tanto na narrativa que é feita sobre o percurso do projeto como no texto final que escrevem na publicação referente. No texto que se intitula A aventura de aprender, as professoras envolvidas, Maria Castagnetti, Laura Rubizzi e Paola Strozzi, que trabalharam em colaboração com a atelierista Vea Vecchi, contam sobre a aprendizagem como uma aventura das crianças e dos adultos a respeito da compreensão sobre a noção de medida construída pelas crianças e as diversas estratégias utilizadas por elas em informar suas teorias. Nesse sentido, a surpresa por descobrir algo não pode ser perdido de vista quando se propõe algo às crianças, inclusive a do adulto em relação a elas. Castagnetti et al. (2005, p. 67) alertam algo muito importante a esse respeito: 
[...] nossa consciência da importância que assume a documentação no projeto orienta a seleção dos instrumentos e o modo de observar. Finalmente, devemos abandonar a crença (encucada em nós pela nossa formação como professores) de que sempre sabemos o que é que as crianças devem aprender, que é democrático que todas as crianças aprendam tudo do mesmo modo, e que um professor é melhor quanto mais saiba por antecipação o que tem que fazer e como fazer.

Nesse momento, 1991, a ideia de Documentação Pedagógica já havia se consolidando como estratégia de trabalho e, mais do que nunca, reconhecia-se o valor que essa estratégia tinha para atender à complexidade do pensar e fazer pedagógico.
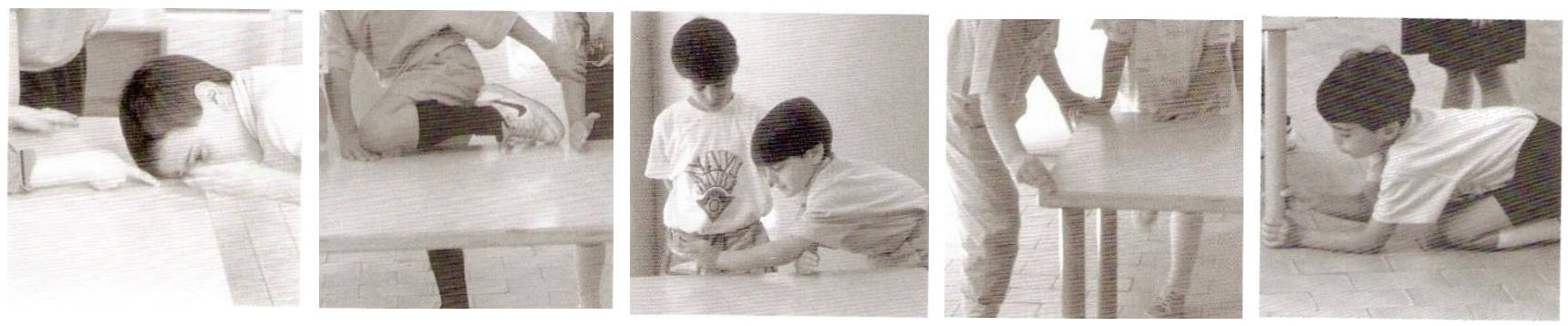

O processo de construção da comunicação do projeto foi muito negociado entre Malaguzzi e a professora, isso porque Malaguzzi percebia o valor que havia naquele projeto e sabia que era necessário saber comunica-lo muito bem. Malaguzzi foi apontando quais fotos eram necessárias colocar, que imagens poderiam ser emblemáticas para que o leitor pudesse entender o percurso que as crianças fizeram e, ainda, conseguia resgatar algumas situações que aos professores pareciam banais: Malaguzzi ajuda a perceber o valor e sentidos do pensamento das crianças (HOYUELOS, 2004a).

O projeto narra como as crianças foram se aventurando a descobrir possibilidades de criar sistemas de medida para informar aos carpinteiros através de um projeto para a nova mesa. O grupo descobriu como os egípcios se utilizavam do corpo e de partes do corpo para estabelecer medidas e se aventuraram a construir seu próprio sistema de medidas enquanto confrontam com os sistemas convencionais de que dispunham (CASTAGNETTI et al, 2005).

Esse projeto foi amplamente divulgado e apresentado em diversos fóruns em várias partes do mundo. Malaguzzi gostava de apresentar esse projeto, pois, para o pedagogo, entrava nos temas custosos e difíceis da Educação Infantil, além de mostrar a grande competência das crianças em construir teorias (HOYUELOS, 2004a). Em um desses eventos, em Paris, Malaguzzi fez uma solicitação diferente a Marina e à organização do evento. Solicitou que traduzissem para o francês a carta que as crianças escreveram e remeteram ao carpinteiro, "era como se sentisse o desejo que cada participante do congresso, tendo entre suas mãos qualquer coisa do projeto e qualquer coisa das crianças, pudessem compreender, sobretudo com emoção, a importância do que havia acontecido" (HOYUELOS, 2004a, p. 176). 


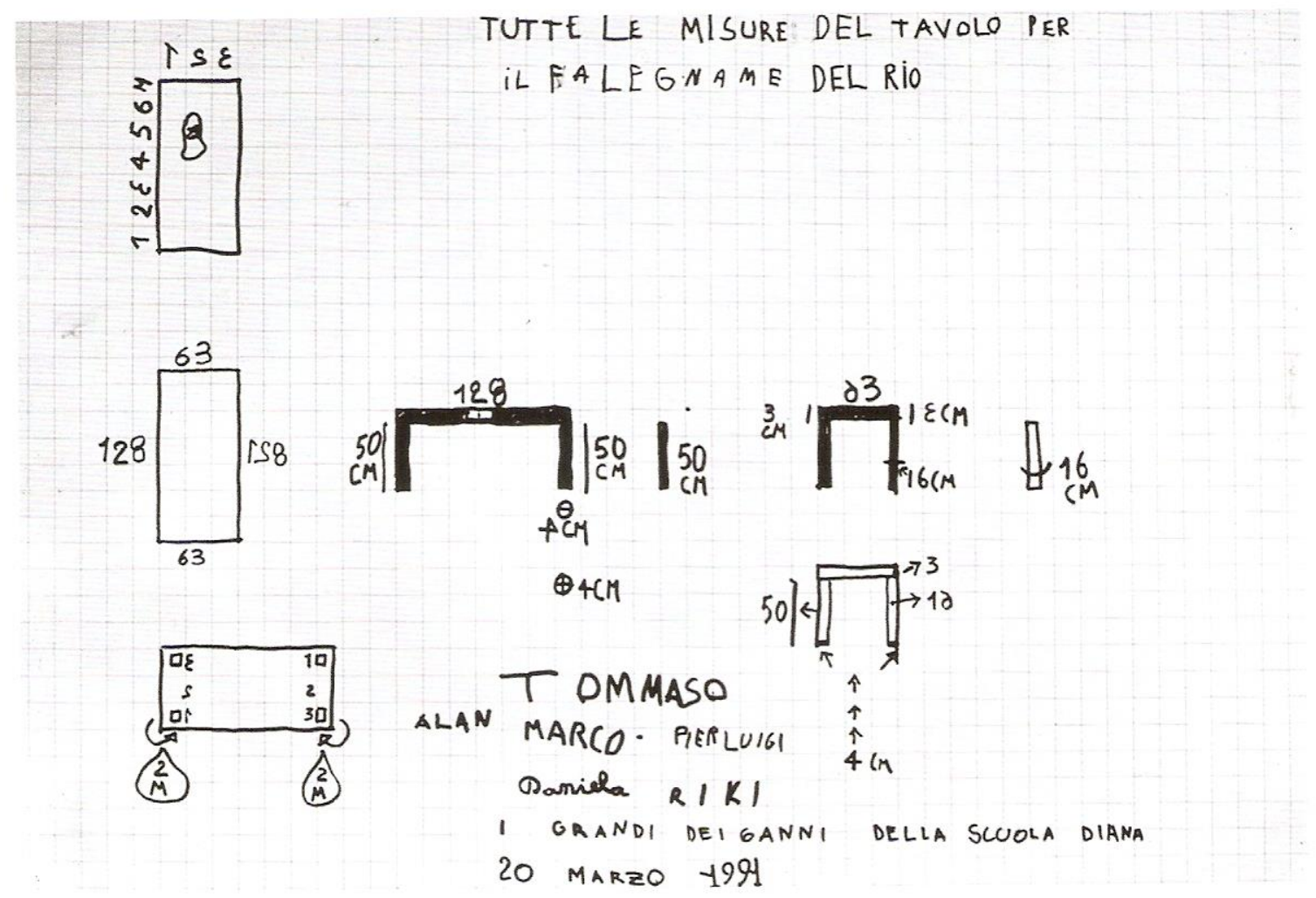

Na ocasião do evento, abriu-se um grande debate a respeito do modo como a equipe reggiana conduziu o projeto, sendo questionado se não deveria ter sido entregue para as crianças o metro desde o princípio. Carla Rinaldi (2005, p. 72-73) escreveu uma resposta a essa crítica:

Essa é a natureza do problema que se afrontou na discussão em Paris: como construir conhecimento significativo para aqueles que aprendem, como compartilhar com as crianças e os jovens a consciência do nosso conhecimento, de nossas construções mentais, das relações que existem entre as construções e os modos de observar e interpretar a realidade. A opinião do professor Malaguzzi, assim como a de muitos presentes, é a respeito de que os verdadeiros processos estruturadores são precisamente aqueles descritos na experiência do projeto Scarpa e metro. Processos que se estendem no tempo, que são compartilhados, que permitem pausas, silêncios, retrocessos, diferenças e divergências; processos que envolvem o indivíduo em sua totalidade cognitiva, afetiva e social. O verdadeiro problema, então, não é quando e como explicar ou apresentar os instrumentos canônicos de medida para as crianças (qual idade? de que forma?), mas sim, nos perguntarmos como podemos criar as condições que permitem o desenvolvimento de um pensamento divergente e criativo, como manter a capacidade e o prazer de confrontar nossas ideias com as dos demais no lugar de limitar-nos a reproduzir uma única ideia considerada verdadeira ou correta (o conhecimento legítimo, os códigos estabelecidos e as áreas disciplinares). Tudo isso é muito mais certo e mais importante quanto mais pequena é a criança. Não é somente uma questão pedagógica e didática, mas também de ética e valor.

As professoras envolvidas com o projeto escreveram que a experiência que se pode acompanhar na publicação Scarpa e metro é a amostra de "[...] parte de uma história na qual as estratégias didáticas vão se modificando através do tempo, graças à escuta atenta e ao desejo de 
dar respostas às crianças, famílias, professores e à cultura do entorno que investiga e controla novas paisagens de conhecimento" (CASTAGNETTI et al, 2005, p. 66).
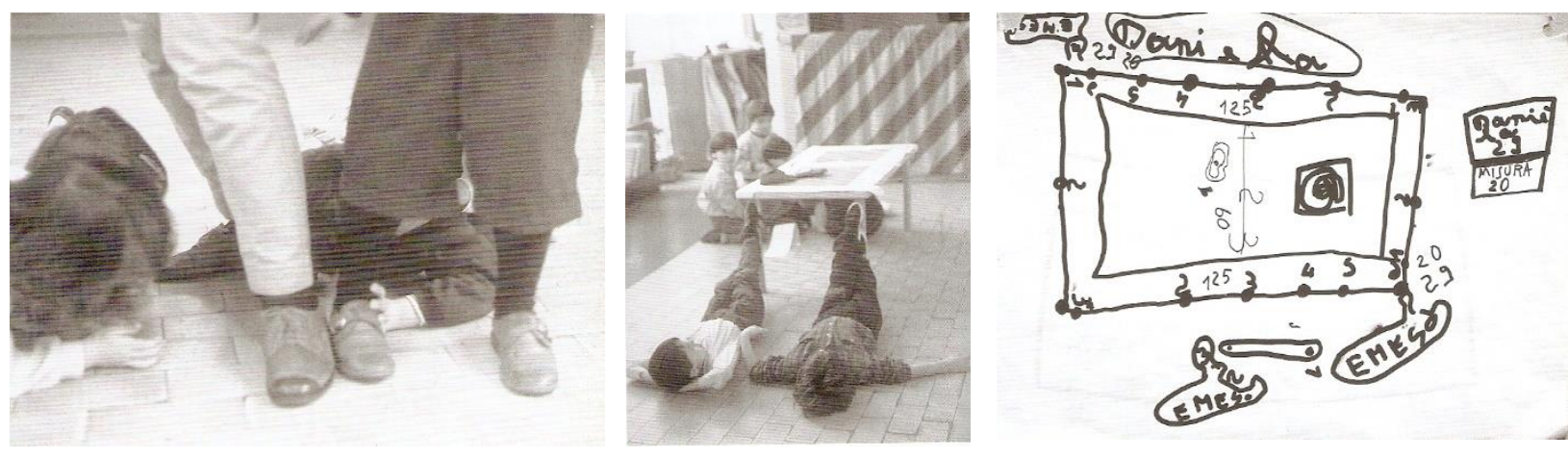

O terceiro projeto dessa categoria se refere a uma marca estética da experiência pedagógica das escolas de Reggio Emilia: l'ombra (a sombra) (1989). Essa investigação ocorreu em duas escolas, Scuola Diana e Scuola Gulliver, com crianças de 3 a 6 anos, durante três meses. A publicação resultante desse projeto, cujo título é Tutto ha un'ombra meno le formiche (Tudo tem uma sombra, menos a formiga), publicada pela primeira vez em 1990 pela própria Comuna de Reggio Emilia, foi reimpressa pela Reggio Children, em 1999. É a primeira publicação em formato de um livro dos projetos das escolas infantis de Reggio Emilia. Spaggiari (1999, p. 8) comenta que a intenção desse tipo de publicação é "iniciar a representar, em forma impressa, as ideias e a prática educativa que se realiza nas escolas infantis de Reggio Emilia [...] que, com o tempo, tem acumulado um patrimônio considerável de ideia e de recursos".

Narrativas visuais, falas das crianças, desenhos das crianças, narrativa do professor, diálogo com os mais variados campos do conhecimento são os elementos que compõem essa obra, assim como as que seguem na sequência dela. Trata-se de um texto com muitas vozes e que mantém sua centralidade em iluminar o modo como as crianças constroem o conhecimento.

Partes desse projeto também estiveram presentes na exposição L'occhio se salta il muro e se manteve também na exposição I cento linguaggi dei bambini, com o nome de Ombratilità s palavra inventada que propõe a ideia do estudo da sombra e poderia ser traduzida para o português como "sombralidade".

Há uma ambiguidade na investigação sobre a sombra que sempre fascinou Malaguzzi: a relação entre a ciência e a arte, entre o real e o fictício. Hoyuelos (2004a, p. 150) dirá que, para Malaguzzi, o encontro com a sombra é "um encontro poético, curioso, cheio de mistério. 
Uma mistura de analogia, fabulações, mistério e simbolismo. São ingredientes suficientes para fazer com que a criança manifeste o próprio desejo de interrogar o próprio assombro".

O espaço ficcional das investigações sobre a sombra são situações perfeitas para as crianças redescobrirem e inventarem enredos lúdicos ${ }^{61}$. Como destaca Spaggiari $(1999$, p. 8), "as palavras, as ações, as imagens e os pensamentos que são apresentadas na publicação Tutto ha un'ombra meno le formiche exaltam, como valor cardinal da educação, a 'liberdade criativa' tão cara à Rodari”.

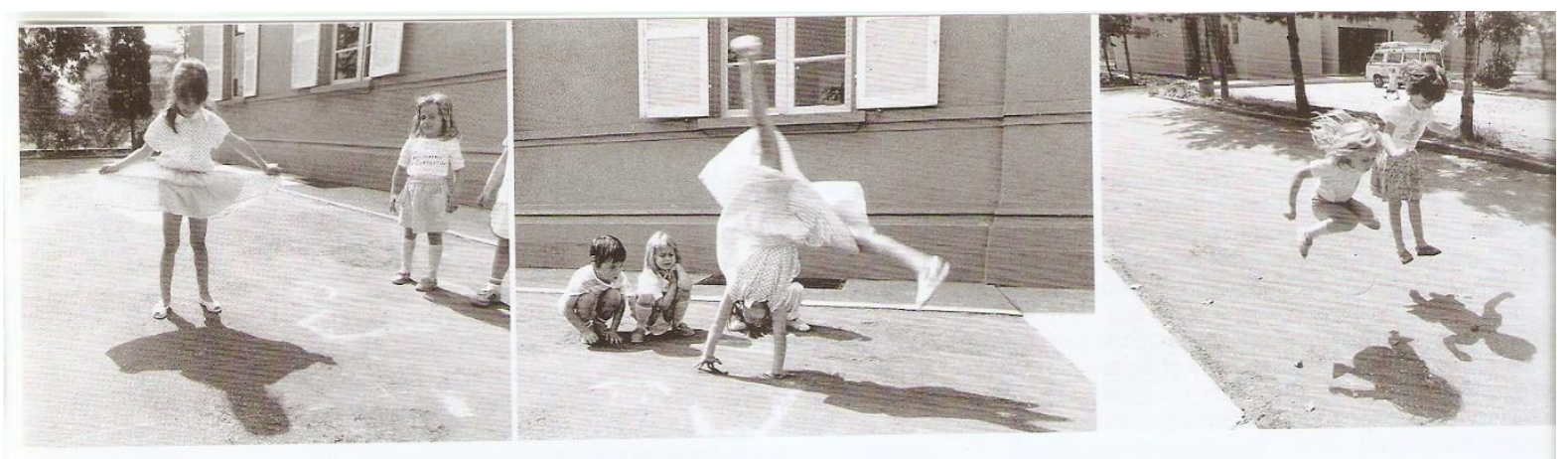

A liberdade criativa de que falava Gianni Rodari era de grande fascínio a Malaguzzi, isso justifica o convite feito no início dos anos setenta para uma formação com os professores das escolas infantis de Reggio Emilia que se chamaram "encontros com a fantasia" (dando origem ao célebre livro de Rodari "Gramática da Fantasia”, como já destacado anteriormente).

Um outro fator que, provavelmente, demarque a presença de uma investigação tão criativa e densa sobre a sombra é a presença de Mariano Dolci, marionetista que trabalhou por muitos anos junto a Malaguzzi e com as escolas municipais de Reggio Emilia. Como podemos ver em outros projetos, já havia experimentações com a linguagem da sombra embora ainda não fosse o conteúdo central do projeto. De toda forma, há o germe daquilo que culmina em uma investigação, como a deste projeto dedicado inteiramente à sombra.

Voltando à publicação decorrente do projeto, percebe-se que as crianças transladam e colocam em relação um sentido ficcional de imaginação e de brincadeira na relação com as sombras, com um sentido físico de exploração e de construção de teorias sobre como se faz uma sombra, quem faz a sombra, como controlar a sombra, o que é a sombra.

Por consequência, Malaguzzi se encanta com as teorias que as crianças criam sobre a sombra e sobre os usos que as crianças fazem de algumas palavras para dar sentido à experiência que estão vivendo, ou mesmo da liberdade que as crianças sentem para inventar palavras. No prólogo que escreve para a publicação, Malaguzzi (1999) vai retomando diversas frases das

${ }^{61} \mathrm{Na}$ Parte III, apresento como temos tratado o tema das sombras em um dos Grupos de Investigação-Ação (GIA) como mote para investigação das crianças. 
crianças que podem ser encontradas ao longo do livro e que, para o pedagogo, são verdadeiros exemplares do quanto as crianças são pesquisadoras o tempo todo.

Da mesma forma, o pedagogo continua, por meio dessas vinhetas do projeto, "a esclarecer que as crianças não vivem - como muitos ainda afirmam - dimensões e reflexões míticas e pré-intelectuais, ao contrário, são capazes de construir pensamentos e reflexões porque o conhecimento está com elas desde o nascimento, no próprio coração da vida" (MALAGUZZI, 1999, p. 28).

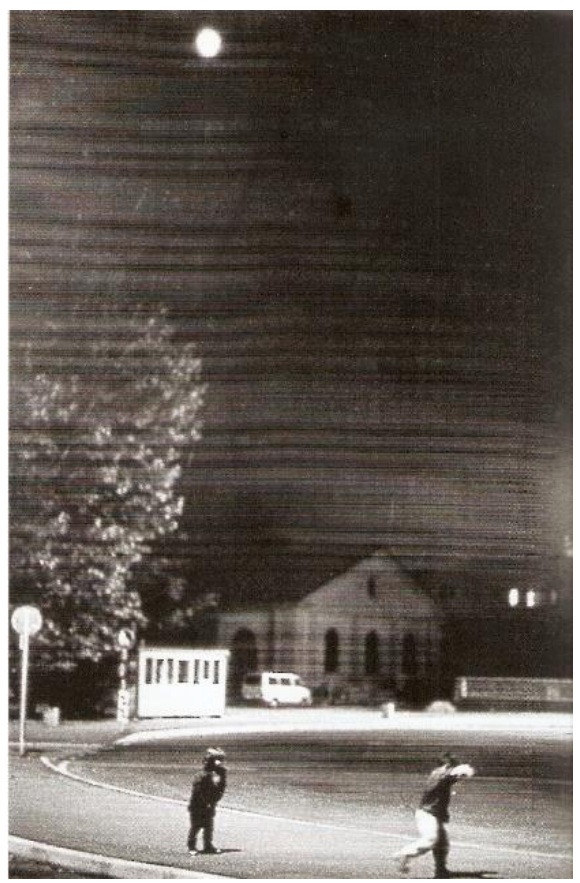

Há um outro ponto interessante que se encontra no projeto sobre a investigação da sombra noturna, o que significou para as escolas terem que repensar o modo como acompanhar as crianças nessas investigações. Passear pela cidade à noite pode ser algo da ordem do impensável. Não para educadoras que estão maravilhadas com as descobertas das crianças frente a um fenômeno tão familiar e ao mesmo tempo tão misterioso:

Quanto mais se está com as crianças, mais se aprende como se desperta sua curiosidade pelo mundo e como a sutileza de seu pensamento sabe contemplar as coisas sutis, que são as que escapam da materialidade, dos reconhecimentos fáceis, das formas definidas e das leis de invariabilidade. Aquelas que se tocam e não se tocam, que se esbarram entre o real e o irreal, que têm o sentido do mistério e concedem amplas margens interpretativas (MALAGUZZI, 2005c, p. 118).

Aventurar-se por terrenos tão desconhecidos, como os da sombra, transformavam-se em verdadeiras jornadas de aprendizagem para os adultos. Também eles se colocavam diante do desconhecido, daquilo que ainda precisava ser explorado e descoberto. Essa é uma experiência que recupera o sujeito cognoscente que muitas vezes se perde na visão mítica do adulto que já sabe, que já aprendeu. Mais ainda, faz com que o adulto se abra para acolher o ponto de vista das crianças, uma abertura ao desconhecido.

Um outro elemento importante do projeto diz respeito ao modo como os professores e atelierista foram tentando articular os processos individuais e os processos coletivos de aprendizagem das crianças. Vale dizer que esse era um período de aproximação ao pensamento socioconstrutivista e, por consequência, havia o interesse em compreender a relação entre a parte e o todo na construção do conhecimento. Segundo Hoyuelos (2004a, p. 149), "nesse projeto, são aprofundados de maneira exaustiva alguns processos individuais e, ao mesmo tempo, são mapeados os diversos percursos individuais que se entrelaçam com os de grupo". 
Especialmente na publicação, podemos perceber essa ambivalência, por assim dizer, do conhecimento subjetivo e do conhecimento partilhável. Em certos momentos, vamos acompanhando a elaboração da criança individualmente e,
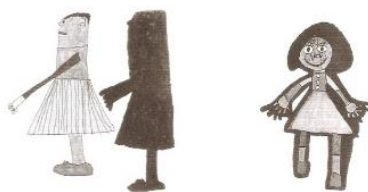
imediatamente em seguida, já estamos em meio a um colóquio de pensamentos e ideias de um pequeno grupo de crianças.

Por fim, há aqui uma questão importante, assim como nos projetos que temporalmente antecedem a esse: não percebemos com clareza o papel do adulto. E isso não é por acaso, "Malaguzzi era consciente de que havia deixado em segundo plano para dar mais evidência aos processos das crianças"
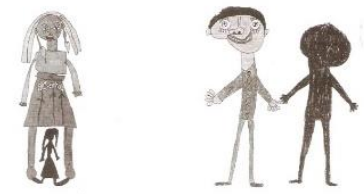
(HOYUELOS, 2004a, p. 151). Também, segundo Hoyuelos (2004a), ainda não eram tão bem documentados os projetos de tal sorte que pudéssemos compreender os processos das crianças desde um ponto de vista narrativo. Isso irá surgir com mais força nos projetos subsequentes a esse.
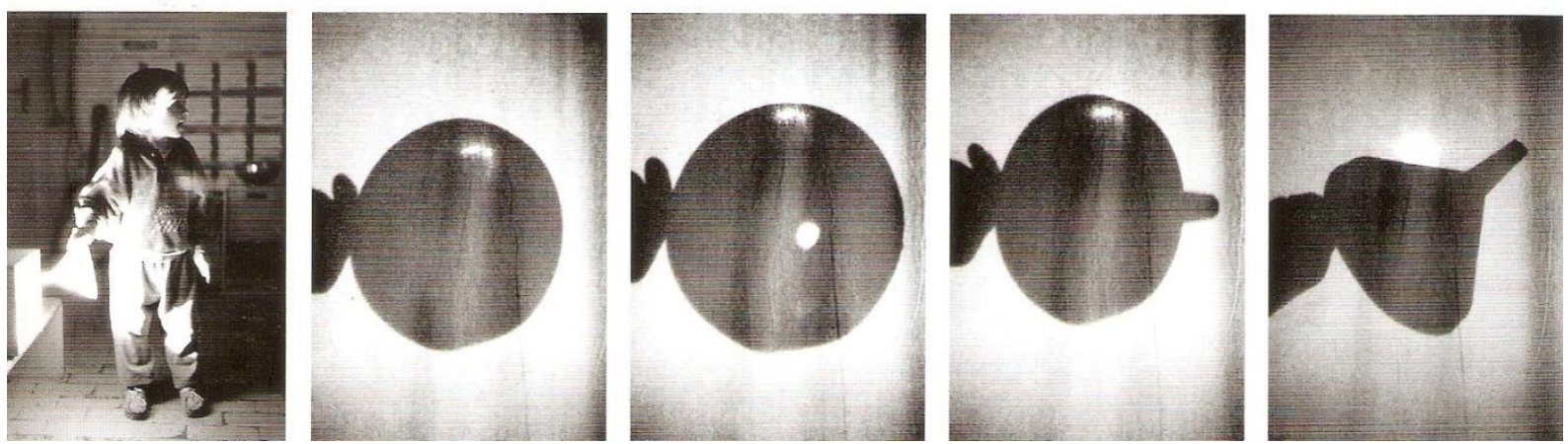


\section{A DOCUMENTAÇÃo PEDAGÓGICA COMO ESTRATÉGIA PARA COMUNICAR E CONSTRUIR MEMÓRIA}

Se, por um lado, os projetos documentados por Malaguzzi são importantes para compreendermos a didática que foi sendo construída, por outro lado, o modo como eles foram comunicados também revelam a natureza ideográfica do pedagogo em relação à imagem de criança, de adulto e de escola.

Comunicar os percursos das crianças significava, para Malaguzzi, tornar visível o modo como elas construíam o conhecimento, reconhecer como o adulto criava condições para as crianças e, logo, construir identidade e memória para uma verdadeira escola da infância. Ao mesmo tempo que desacreditava no modo como a academia vinha produzindo o conhecimento educacional, Malaguzzi percebia que as práticas pedagógicas, quando bem documentadas e bem comunicadas, se converteriam na melhor forma de colocar em relação a teoria e a prática.

Lá no início, no final dos anos sessenta e nos inícios dos anos setenta, Malaguzzi experimentou um modo de comunicar os projetos das crianças por meio das exposições dos desenhos que os meninos e meninas haviam feito nas escolas. Essa foi uma das primeiras tentativas que o pedagogo encontrou para chamar atenção da comunidade para que percebessem o valor da escola na formação das crianças. Mais ainda, era para ele uma oportunidade de mostrar o potencial das crianças e assim entender que a escola não poderia trair esse potencial, mas converter-se em espaço privilegiado para a aprendizagem, e essa era uma visão política de Malaguzzi. A relação entre a pedagogia e a política não era apenas uma adição de dois campos, mas uma afirmação de que pedagogia é política (BORGHI, 2017).

Depois das experiências com as mostras de desenhos, a recém-inaugurada Scuola Diana experimenta algumas propostas que se transformam em marco no que diz respeito à reflexão da Documentação Pedagógica na obra e no pensamento de Loris Malaguzzi. Lembremos que esta escola está situada em uma das praças centrais de Reggio Emilia, no Centro Histórico (Parco del Popolo), e que, por isso, havia um grande interesse por parte da administração pública para que ali se construísse um cinema, cujo nome seria Diana. Até o fim da construção da escola, foi preciso lutar para que se mantivesse a perspectiva da construção desse local.

Malaguzzi acompanhou a construção desta escola, não apenas para garantir que ali se fizesse mais uma escola, mas a partir de inúmeras sugestões, desejava que a arquitetura 
traduzisse os ideais educativos dos quais reivindicava, como pode ser percebida na carta enviada por Malaguzzi ao prefeito da cidade naquela ocasião:

\begin{abstract}
Na eminência do início da obra de construção da Scuola Materna Comunale, na área do ex Cinema Diana, considero oportuno sublinhar algumas considerações críticas em relação ao projeto. [...] d) o projeto não prevê uma sala-ateliê para o trabalho em grupos das crianças. Considerando que a sala-ateliê representa uma das realizações mais originais da nossa experiência, muita apreciada pelas crianças e pelas famílias, recomendo encarecidamente que se examine a possibilidade de instalar uma pequena construção no jardim (6x4 metros, construídas talvez com materiais recuperados da Scuola Materna de Pastrengo) que possa hospedar este tipo de atividade (MALAGUZZI, 1969b, p. 159).
\end{abstract}

Após muitos entraves, até que a abertura da escola pudesse ser concretizada, Malaguzzi propôs à Vea Vecchi, atelierista importante no cenário educativo de Reggio Emilia, para que organizasse uma exposição aberta à cidade para mostrar o trabalho que havia sido realizado no primeiro ano da instituição. Na ocasião, as professoras recém haviam descoberto a máquina fotográfica e, com isso, surgiu uma nova forma de narrar os percursos de aprendizagem das crianças. Assim nasceu a exposição Il Picione (Os Pombos).

O percurso narrado na exposição Il picione representa um novo estilo de trabalho daquela época, algo que foi se consolidando e se transformando até chegar ao que hoje conhecemos e que foi apresentado nos projetos anteriores. A comunicação desse projeto na exposição foi feita por meio de painéis, divididos em cinco partes, que tinham como intuito mostrar os diferentes sentidos da investigação que as crianças haviam realizado sobre a observação dos pombos: "o corpo do pombo (investigação geral), a parte do corpo do pombo (investigação analítica), o uso do corpo (investigação instrumental), relação e orientação espacial (investigação psicossociológica) e as hipóteses (investigação possível) ${ }^{62}$ " (HOYUELOS, 2004a, p. 72).

Vea, com sua visão artística, ofereceu um apuro estético ao modo como foi comunicada a investigação das crianças, aliando imagens que mostravam os meninos e meninas durante o processo e as investigações gráficas que haviam realizado. Mesmo para quem não tivesse acompanhado o percurso de investigação, era possível compreender o modo como as crianças haviam se movimentado no projeto. Aliás, essa era a ideia central da exposição, e a linguagem fotográfica era o recurso perfeito para comunicar esse propósito.

$62 \mathrm{Em}$ italiano, respectivamente: indagine generale, indagine analítica, indagine strumentale, indagine psicosociologica e indagine del possibile. 
Conforme Hoyuelos (2004a), essa foi uma experiência importante inclusive para as professoras que, graças à irrenunciável visão artística de Vea Vecchi, puderam renovar o modo como as professoras propunham as investigações às crianças.

Pode-se dizer que a exposição Il picione é a gênese do que posteriormente veio a ser a exposição L'occhio si salta il muro: narrativa del possibile (Quando os olhos saltam o muro: narrativas do possível) e que mais tarde é renomeada como I cento linguaggi dei bambini (As cem linguagens da criança). É importante lembrar que, depois dessa primeira exposição, Il picione, anualmente se produziam exposições abertas ao pública de tal modo que fosse possível narrar os projetos que as crianças haviam levado a cabo.

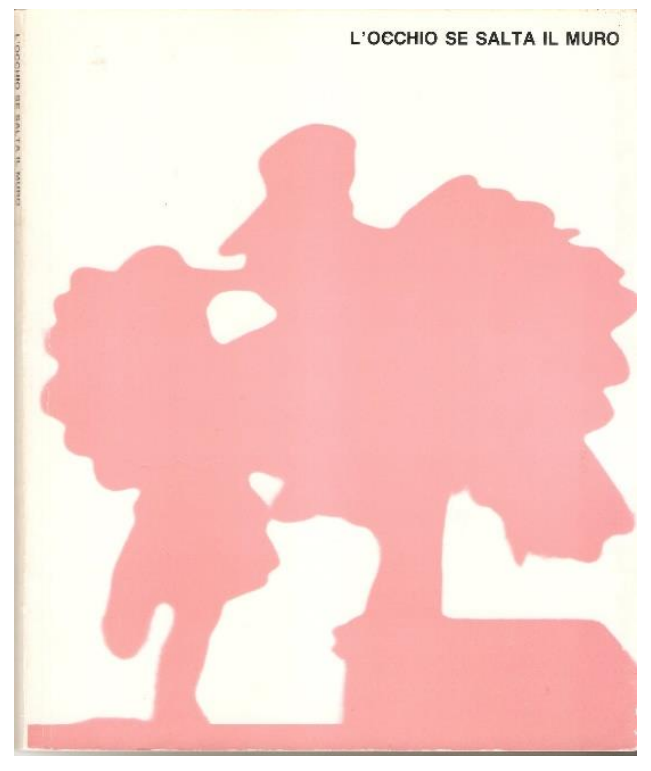

Seguindo esse raciocínio, a exposição L'occhio si salta il muro: narrativa del possibile é um outro símbolo da experiência educativa das escolas de Reggio Emilia e de Loris Malaguzzi. Em 1981, quando acontece pela primeira vez a exposição, várias escolas e creches municipais já haviam sido abertas e já haviam avançado significativamente no que diz respeito à compreensão de uma nova visão pedagógica para o trabalho com as crianças da Educação Infantil. Também já estava incorporado dentro das escolas o hábito de observar, registrar e interpretar os projetos educativos, o que havia produzido um montante de materiais riquíssimos ao longo dos últimos anos.

Como já dito anteriormente, nessa época, Malaguzzi havia se interessado muito pela Gestalt (MALAGUZZI, 1968; HOYUELOS, 2004a), e não apenas do ponto de vista da incorporação dos princípios na prática de trabalho com as crianças. Ele também se interessou em comunicar gestalticamente os projetos, característica notável na exposição L'occhio si salta il muro, que Malaguzzi coordenou em parceria com Mara Davoli ${ }^{63}$ e Vea Vecchi.

Em notas de leitura que Malaguzzi escreveu no catálogo de exposição, podemos encontrar diversas pistas de leitura e compreensão do trabalho pedagógico daquele momento. Talvez a mais significativa seja o próprio nome da exposição, que, nas palavras do próprio Malaguzi (1984, p. 20),

63 Agradeço imensamente todas as contribuições que Mara Davoli me deu a partir de entrevista e conversas pessoais que tivemos nos últimos dois anos. 
[...] carrega um título que é essencialmente um presságio. Que o olho, assim como ele representa, aqui se transforma em um chamado para ver e compreender as novas tarefas culturais na sociedade da visão e imagem e, aqui, ainda evocado como uma figura conceitual que resume os problemas de crescimento e promoção da criança e do homem, tem a força e a teimosia de pular o muro. O muro da incongruência, do banal, das velhas regras, das coisas rígidas e fechadas, das ações indescritíveis, automatizadas e retóricas que ainda se movem entorno da imagem de homem e do projeto educativo da criança. Como dissemos, um presságio. Uma tentativa.

A metáfora do olho que salta o muro é um emblema de mudança paradigmática sobre uma ideia de criança e de adulto na escola da Educação Infantil que, além de representar uma resposta aos problemas da época, ainda pode ser perfeitamente evocada como uma necessidade atual. Saltar o muro da banalidade foi, sem dúvida, o que Malaguzzi impulsionou ao longo de sua trajetória e de sua obra.

Também Malaguzzi (1984, p. 20) irá tratar "do prazer de aprender, de conhecer e de compreender como uma das primeiras sensações fundamentais que cada criança espera da experiência que afronta sozinha ou com os seus pares e os adultos”. Como inúmeras vezes é tratado em sua biografia pedagógica (HOYUELOS, 2004a), Malaguzzi insistia que a aprendizagem deveria ser uma experiência prazerosa, contrariando as suas memórias do tempo da escola.

Em diversos projetos, como já foi dito aqui, o pedagogo valorizava e reivindicava que fosse comunicado o prazer das crianças em conhecer e aprender, "uma sensação decisiva que é reforçada porque o prazer sobrevive mesmo quando a realidade diz que a aprendizagem, o conhecimento e a compreensão possam ser difíceis e cansativos" (MALAGUZZI, 1984, p. 20).

Além disso, ligado a esse prazer de conhecer está, por sua vez, o valor dos encontros e da amizade que se constrói quando se compartilham as jornadas de aprendizagem, "crianças e adultos que se aproximam do prazer de brincar, trabalhar, conversar, pensar e inventar juntos" (MALAGUZZI, 1984, p. 20). Essa ética do encontro (MOSS, 2016), do aprender melhor em companhia (OLIVEIRA-FORMOSINHO, 2004), é um dos fios da narrativa da exposição, que busca contar a convivência e o privilégio da construção do conhecimento compartilhado.

Também a exposição foi uma oportunidade encontrada por Malaguzzi em tornar visível o potencial das crianças, no sentido de como elas produzem suas teorias e sentido ao mundo. A respeito desse ponto, pode-se dizer que é uma marca identitária da obra de Malaguzzi, que não apenas torna visíveis os processos de como as crianças constroem conhecimento, como põe em evidência os sentidos particulares e coletivos que as crianças dão:

A tese de uma cultura e uma pedagogia que quebram, hierarquizam, autorizam ou negam - em uma babel geometrizada ou casual - os modos, qualidades e espaços de encontros e conexões das experiências das crianças com a natureza multiforme da 
realidade física e social, em virtude de prescrições distintas e opostas, é um dos temas polêmicos e opostos desta exposição (MALAGUZZI, 1984, p. 21).

Malaguzzi se referia ao modo artificial como a ciência da educação tem tratado a criança, compartimentando e negando seus processos subjetivos na elaboração dos seus saberes e da sua cultura. Em diversas ocasiões, o pedagogo já havia se manifestado a respeito desse perigo e de como uma nova escola da infância deveria responder a isso. Malaguzzi (1984) falava de como a criança desejava se sentir inteira e "sentir-se inteira é para a criança (e também para o homem) uma necessidade biológica e cultural: um estado vital de bem-estar" (MALAGUZZI, 1984, p. 21).

Disso decorre sua busca pela Gestalt como possibilidade de renúncia à escola da palavra, e do "reconhecimento que a espécie humana tem o privilégio de manifestar-se através de uma pluralidade de linguagens" (MALAGUZZI, 1984, p. 21). Esse tema das "cem linguagens" que Malaguzzi se dedicou tanto e que se transformou em símbolo do seu pensamento é algo que merece ser sublinhado.

Malaguzzi (1984) entendia que a exposição, uma vez que comunicava o projeto educativo das escolas municipais de Reggio Emilia, precisava deixar clara a importância da não hierarquização das linguagens e de como elas são parte vital da mente humana. Com isso, Malaguzzi (1984) ressalta sete pontos a respeito das linguagens da criança:

(i) o ser humano se expressa, por natureza, através de diferentes linguagens;

(ii) cada linguagem tem o direito de ser explorada e manifesta em sua totalidade e inteireza e, quanto mais se faz isso, mais se complexifica cada linguagem;

(iii) as diferentes linguagens nascem e se desenvolvem na reciprocidade entre elas e na experiência de cada criança;

(iv) a criança, enquanto sujeito histórico e cultural, é coautor e sujeito construtivo de cada linguagem;

(v) todas as linguagens têm o poder de ser generativa de outras linguagens, de outras ações, de outras lógicas, pois se situam na própria ação da criança;

(vi) todas as linguagens precisam ser valorizadas sem ser hierarquizadas, precisam estar em diálogo com a competência cultural do adulto e do contexto;

(vii) o reconhecimento dessa pluralidade de linguagens se coaduna com a ideia de criança que subjaz o trabalho desenvolvido.

Esse é o cenário de fundo não apenas da exposição, mas, sobretudo, daquilo que ela comunica enquanto uma representação de todo o pensamento que foi construído ao longo dos quase 30 anos anteriores. Malaguzzi (1984, p. 22) reforça esses aspecto, observando a 
necessidade de "pôr no centro da educação da criança uma experiência mais orgânica e variada do agir e do fazer. Em que o conhecimento se torna um sistema de exploração e de reflexão contextualizada às linguagens e à inteligência".

Por esse ângulo, Malaguzzi (1984) se refere também ao valor das diferentes sensações (olhos, ouvidos, tato, olfato, paladar) como um processo interligado, assim como cognição, emoção, imaginação, pensamento e linguagem. Reforça também que, mesmo nas linguagens da não palavra, existem os desejos, pensamentos e as palavras que se transformam em ato através das experiências das crianças. Assim, a organicidade no modo de propor e narrar as experiências de aprendizagem das crianças vão sendo trilhadas pela exposição.

Os projetos compartilhados na exposição se ocupavam de mostrar “[...] como as crianças investigavam através de percursos muito diferentes a evolução da forma conservação, trocas, transformação -, a possibilidade das metáforas verbais e gráficas, as variações do som e do brincar de faz de conta e a ambiguidade da imagem" (HOYUELOS, 2004a, p. 119). Assim, a exposição foi um ato testemunhal, e ao mesmo tempo formativo para a cidade, para os visitantes que puderam acompanhar, para os professores e para as escolas que viram seu trabalho restituído por meio de narrativas e metáforas visuais.

A exposição foi sediada, em 1981, na cidade de Reggio Emilia, e, no mesmo ano, em Stocolmo, na Suécia. Hoyuelos (2004a, p. 119) relata que "foi um desafio importante. Era a primeira vez que se propunham de realizar a experiência em outra cultura" e, com isso, o esforço de comunicar com todo o empenho a relação entre a didática do trabalho desenvolvido e o modo como estava sendo comunicado.

Malaguzzi, em diálogo com Vea Vecchi e Mara Davoli, discutiram intensamente sobre como construir as narrativas visuais de tal modo que se alcançasse com eficiência comunicativa aquilo que se desejava comunicar. E aqui está, como afirma Hoyuelos (2004a), um preciso momento histórico que marca a estética do trabalho desenvolvido nas escolas de Reggio Emilia: a elevada criatividade - praticamente comparável às grandes mostras de arte - com que são comunicados os percursos das crianças estão em perfeito diálogo com os diversos percursos perceptivos com que as crianças vão tecendo o seu conhecimento.

Depois da Suécia, a exposição ainda esteve em alguns outros países da Europa, como Espanha (Barcelona, Palma de Maiorca e Madri) e Alemanha (Berlim). 
No entanto, com a divulgação da exposição, aparecem dois problemas: o primeiro, relativo à preocupação de Malaguzzi de que as escolas municipais de Reggio Emilia fossem confundidas com escolas de arte. E, para ele, isso poderia ser um risco muito sério. Além de se tratar de algo absolutamente diferente, para Malaguzzi, confiar a potencialidade da criança apenas aos aspectos artísticos poderia cair no mesmo problema de confiar às crianças somente o ponto de vista da palavra. Perdia-se a inteireza da criança que Malaguzzi tanto defendia.

Logo, o pedagogo propõe que alguns novos projetos sejam incorporados na exposição de tal modo que mostrem outras linguagens e
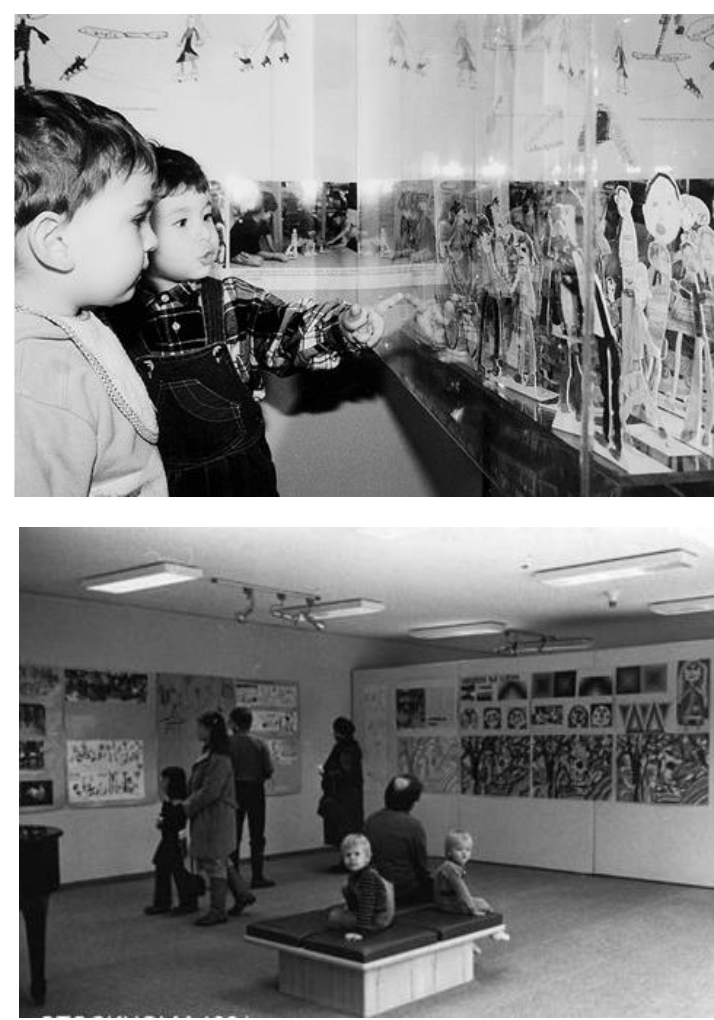
experiências em destaque. Ao mesmo tempo, para o catálogo da exposição, Malaguzzi propõe a Vea e Mara que buscassem personalidades italianas de diferentes campos do conhecimento para oferecerem seu olhar aos projetos compartilhados na exposição ${ }^{64}$. Mara Davoli (2017), em entrevista, conta o desafio que foi andar pela Itália com painéis da exposição debaixo dos braços, explicando para essas pessoas o trabalho que estava sendo feito. Não se conhecia muito sobre o trabalho desenvolvido no interior das escolas e tampouco se tinha familiaridade em fazer uma exposição cujo tema estivesse centrado nos percursos de aprendizagem das crianças.

Outro problema que apareceu foi em relação ao nome da exposição. Segundo Hoyuelos (2004a), Malaguzzi e sua equipe percebem que o nome L'occhio si salta il muro resultava difícil de ser traduzido e mantido o sentido em outras línguas. Além disso, Malaguzzi, ainda preocupado com a possibilidade de uma errônea compreensão sobre o trabalho desenvolvido em Reggio, acredita que o então nome da exposição, carregando a palavra "olho", daria muito acento à dimensão visual, e não sobre a ideia de inteireza da criança que eles reclamavam. Mais ainda, na ocasião do convite a Berlim, ter uma exposição, em 1986, cujo

\footnotetext{
64 Dentre as personalidades que aparecem no catálogo, destaco: Giulio Carlo Argan (estudioso da história da arte), Carlo Bernardini (estudioso da física e da matemática), Andrea Branzi (arquiteto e diretor da Domus Academy) Clotilde Pontecorvo e Egle Becchi (professoras universitárias de Pedagogia), Francesco Tonucci (pesquisador de Educação) entre outros.
} 
nome carregasse a palavra "muro", parecia ser totalmente inadequado desde o ponto de vista histórico, político e social.

Assim, Malaguzzi decide mudar o nome da exposição para I cento linguaggi dei bambini ${ }^{65}$, evidenciando, assim, a coerência conceitual advogada por ele.

Em 1987, a exposição viajava para o outro lado do oceano, aos Estados Unidos, e se realizava uma versão, em inglês, juntamente com um catálogo nas duas línguas (italiano e inglês). A respeito disso, pode-se notar que há uma clara evolução do modo como se narrava fotograficamente, no catálogo de 1984, e como foi se transformando na medida em que a mostra foi girando em outros países, outras culturas.
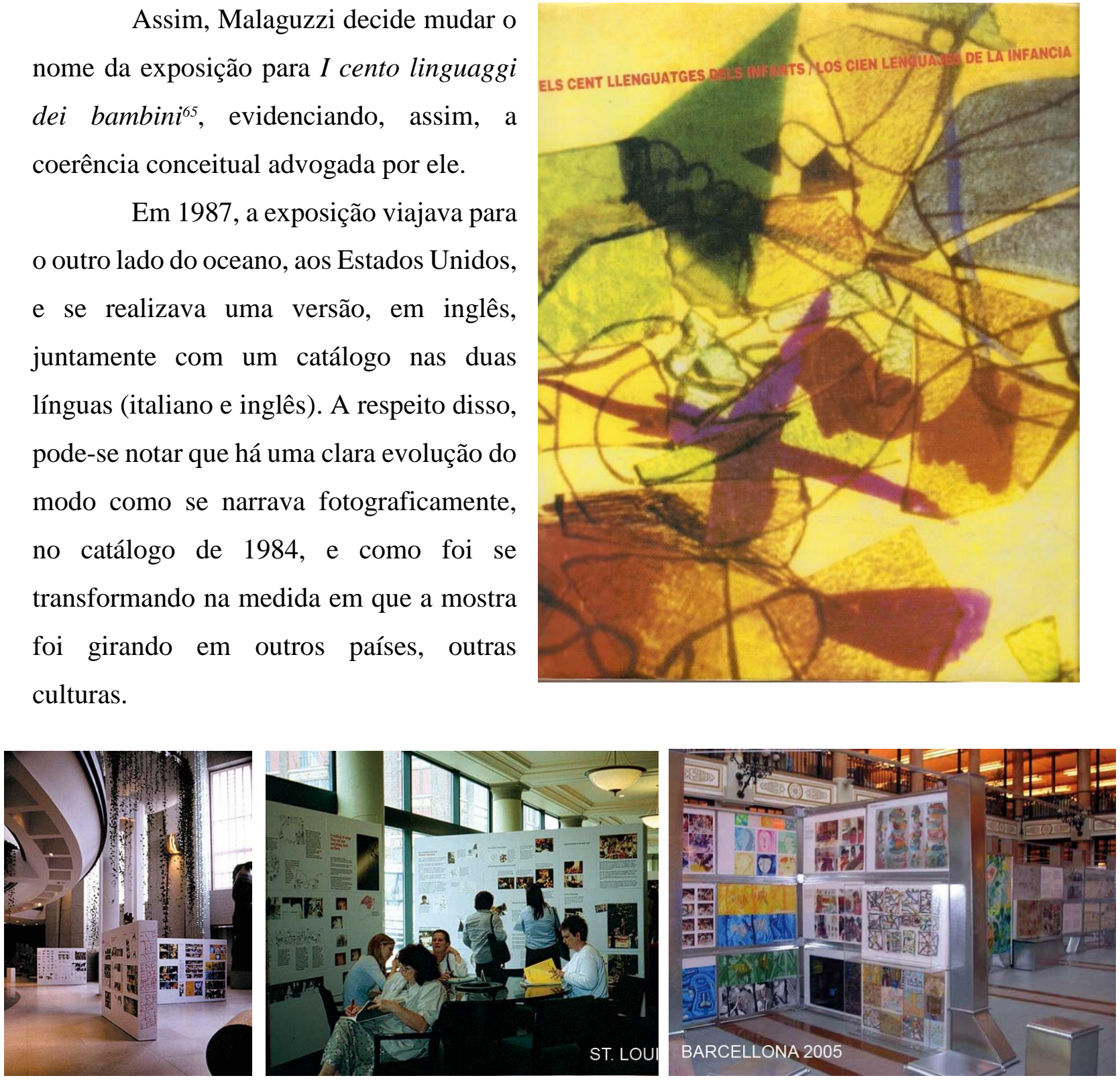

${ }^{65}$ A mostra percorreu diversos países, tais como: Edição Italiana - Itália (Reggio Emilia, Bolonha, Fano, Bari, Roma, Palermo, Torino, Varese, Ascoli Piceno, Napoli), Suécia (Estocolmo, Boras, Eskilstuna, Ümea, Kalmar, Göteborg), Dinamarca (Odense, Århus, Copenaghen, Aalborg), Noruega (Arendal, Hamar, Stavanger), Finlândia (Valkeaakoski), Alemanha (Berlim, Frankfurt, Hamburg, Brandeburg, Bremen, Stuttgart, Essen/Bielefeld, Kyritz, Düsseldorf), Islândia (Reykjavik), Reino Unido (Glasgow, Newcastle upon Tyne, London, Cardiff, Belfast, Exeter, Bristol, Bradford, Coventry), Austrália (Melbourne, Perth), Holanda (Amsterdam), Israel (Tel-Hai), França (Blois), Japão (Tokio), Hong Kong, Luxemburgo, Chile (La Serena, Santiago, Punta Arenas, Valparaiso); Edição Inglesa - USA (San Francisco, Fort Worth, Syracuse, Amherst, Holyoke, Boston, Cambridge, Newton, White Plains, Washington, Dayton, Detroit, St.Louis, Oklahoma City, Memphis, Salt Lake City, Lexington, Columbus, San Rafael, Portland, Des Moines, Chicago, New York, South Bend, Pittsburgh, Norwich, Austin, North Darmouth, Winston Salem, Santa Fe, Casper, Richmond, Fresno, Oakland, Atlanta), Canadá (Vancouver, British Columbia Calgary, Alberta). 
Houve mudanças, não apenas do ponto de vista da qualidade da narrativa visual, mas da incorporação de projetos - como já analisados e comentados anteriormente - que começaram a mostrar não somente o percurso das crianças, mas também o papel do adulto (por exemplo, Luna Park).

É importante dizer que, nessa mesma época, houve uma grande mudança reflexiva no pensamento pedagógico das escolas de Reggio Emilia, com a incorporação da ideia da proggetazione (como tratado anteriormente). E o catálogo, tal como a exposição, sublinham essas transformações didáticas.

Como exemplo disso, Hoyuelos (2004a, p. 124) destaca os processos do cavallini, ponti e sedie, "[...] com o objetivo de analisar as estratégias individuais do pensamento, para valorizar a subjetividade de cada menino e menina".
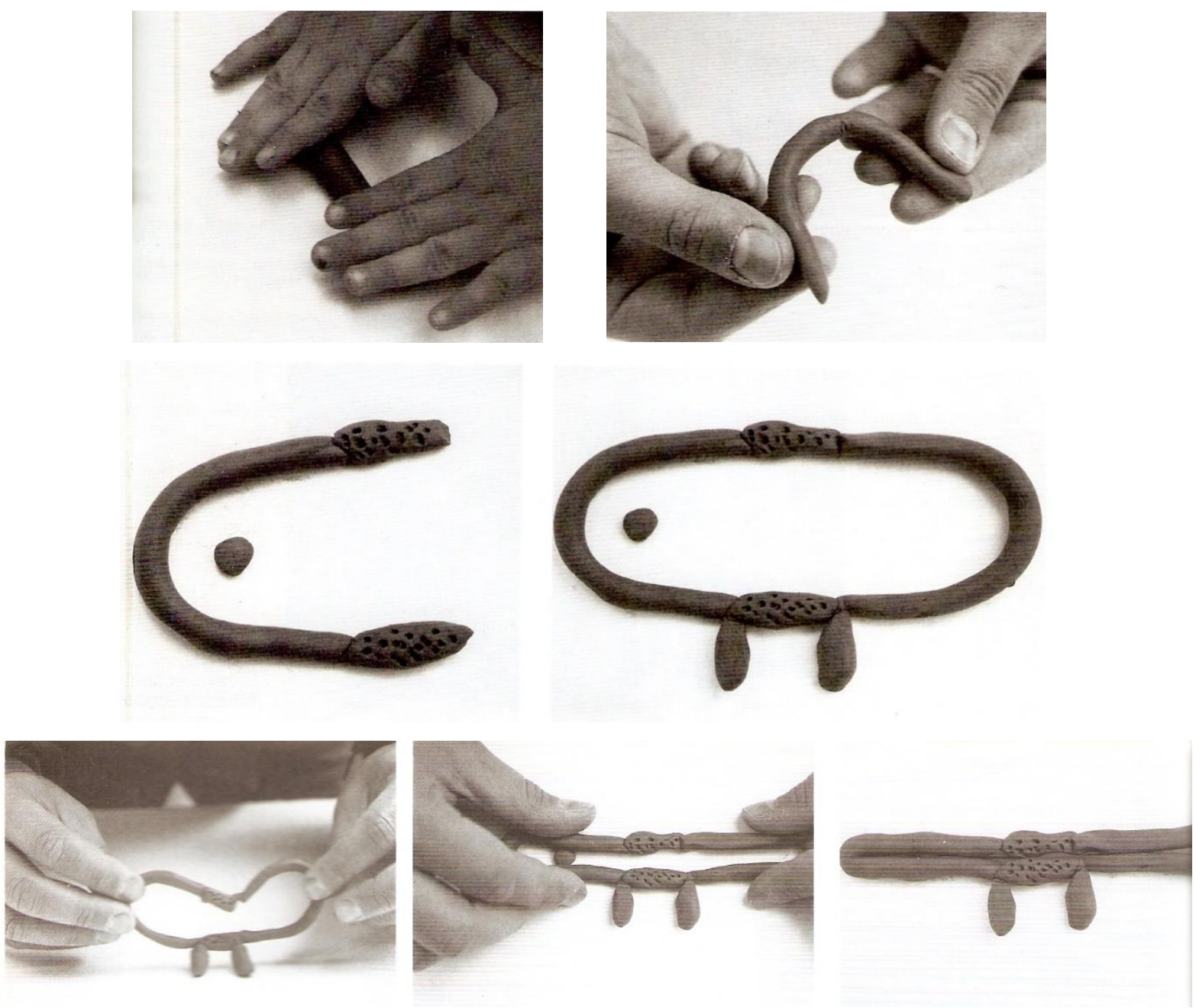

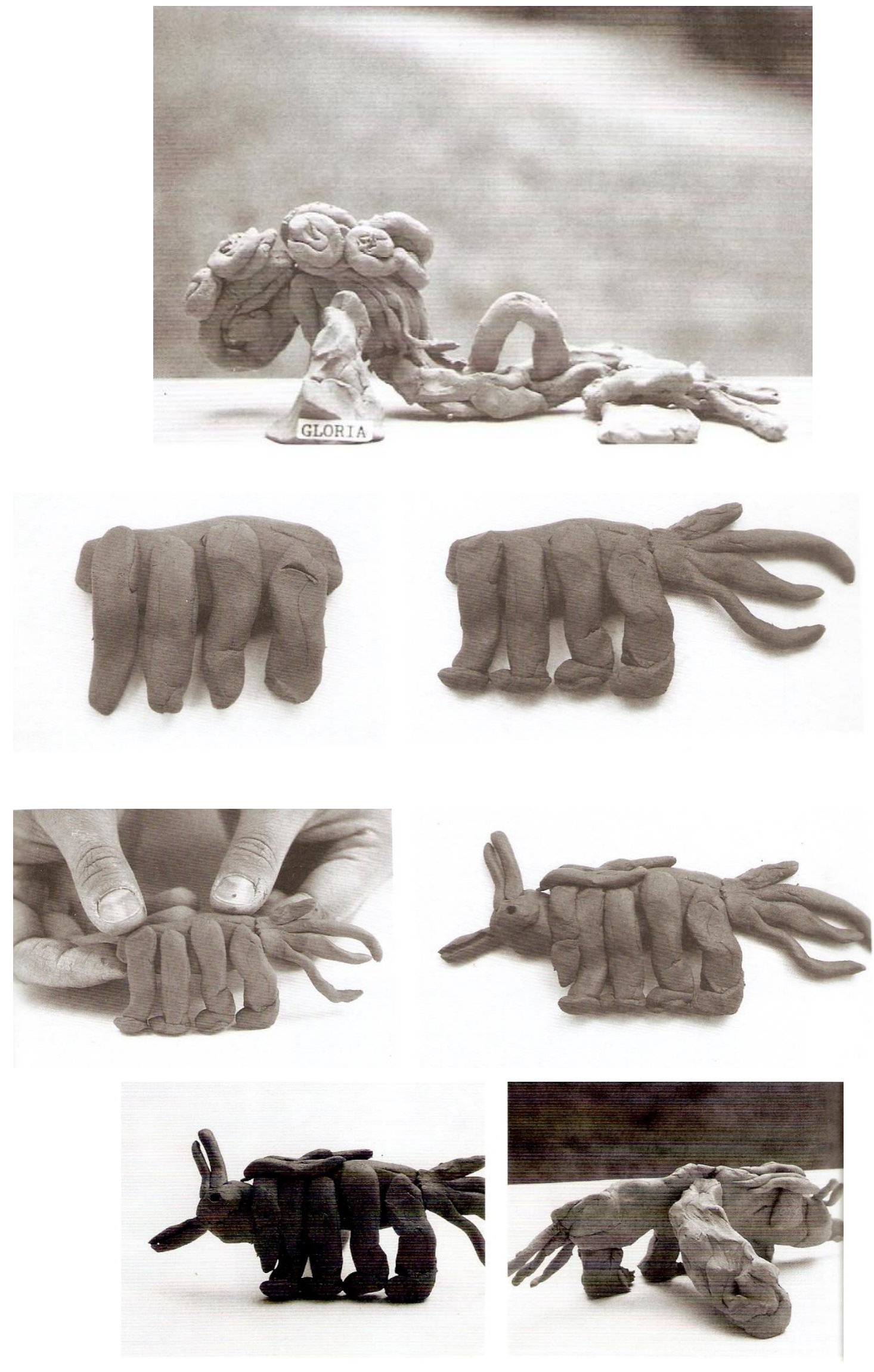
Como mostrado nas imagens anteriores, a professora tenta reproduzir o processo de construção utilizado pela criança para deixar em pé um cavalinho. Essa experiência foi a que deu origem para as mini-histórias como mote de comunicação. No entanto, essa modalidade em que o adulto reproduz o processo da criança não teve êxito, razão de encontrarmos apenas três publicações em formato de mini-história dessa natureza. Por outro lado, a possibilidade de comunicar em pequenos episódios se manteve como uma marca de Reggio Emilia. Um grande exemplar do uso das mini-histórias como estratégia de comunicação é a publicação The hundred languages in Ministories: told by teachers and children from Reggio Emilia.

Francesco and the Paper Tube

Protagunist: Francesco (1o months).
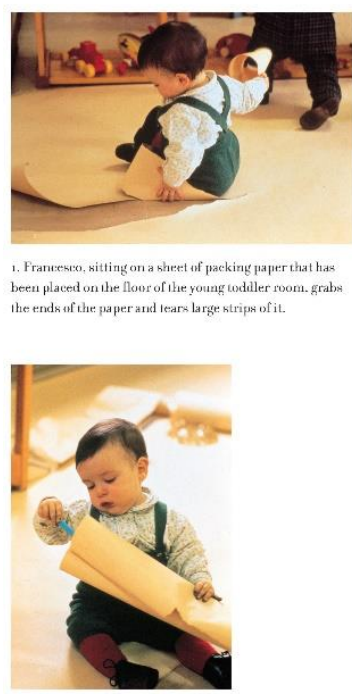

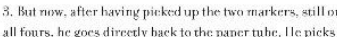
it up, titrs it, and inserts first the bluc marker.
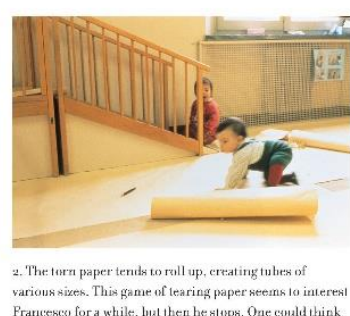
Franceseses for a while, hut then be stepse. One esulld think that the child might consider hat fame linished as he now
directs hir allention lo the markers. placed intentionally blue. Prancescos a approaches on all fours.,.

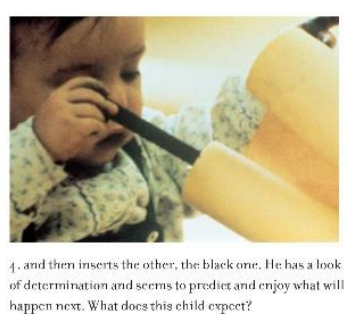

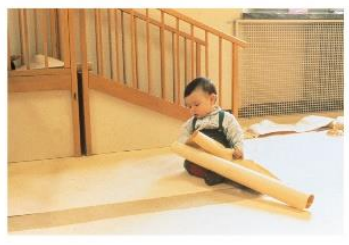
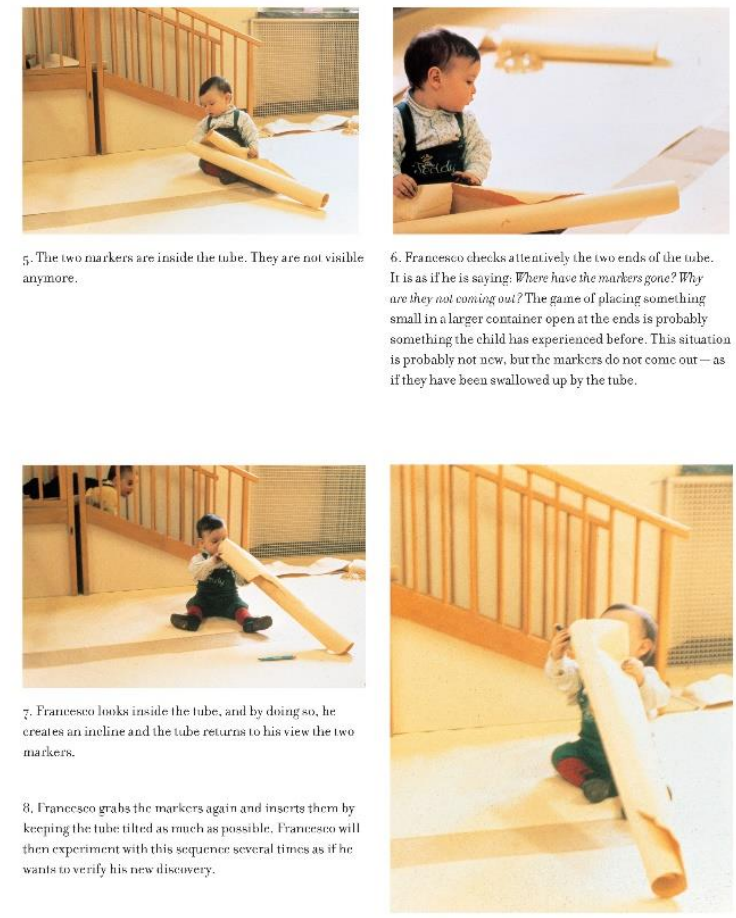

Voltando à exposição, Hoyuelos (2004a, p. 125) comenta as quatro razões que Malaguzzi acredita justificarem o sucesso desta:

A primeira é o desejo aventureiro de dar centralidade à temática da educação infantil com um projeto inovador em uma época de instabilidade política. O segundo tem a ver com a necessidade existente de ver criticamente a pedagogia e a didática tradicional para tentar novos conteúdos e novos modelos organizativos. O terceiro é a proposta estética e comunicativa que propõe uma mostra que defende a inteireza da criança e das cem linguagens. E a quarta é que se trata de um projeto educativo real, capaz de contar o possível que se confronta com uma realidade em contínua mudança.

A exposição foi se transformando tanto em nível de conteúdo quanto da forma, ou seja, não foi apenas o nome que mudou, mas o modo de como narrar, do que narrar e dos diálogos que se desejou criar a partir da exposição. Seu sucesso até hoje é uma demonstração do quanto 
a ideia de criança e de escola de Educação Infantil que encontramos na mostra inspira não uma pedagogia profética, mas a beleza de uma escola que articula fortemente uma herança teórica com o valor da escuta e respeito às crianças, uma escuta pedagógica que se revela através da polifonia de vozes presentes.

Tanto a exposição como os catálogos que derivaram dela são verdadeiros exemplares de qual concepção de criança, adulto e escola da experiência reggiana, além de colocar em relação indagações científicas e artísticas, algo que tanto fascinava Malaguzzi. 


\section{A DOCUMENTAÇÃO PEDAGÓGICA COMO ESTRATÉGIA PARA FORTALECER A IDENTIDADE}

Um outro ato criativo e de muita coragem de Malaguzzi foi a criação da revista Zerosei (1976 1984), junto a Ferruccio Cremaschi, Francesco Tonucci e Sergio Neri. Ocorre que a proposta de criar uma revista progressista sobre o tema da Educação Infantil partia de uma editora que era a própria representação do capitalismo industrial italiano (HOYUELOS, 2004a), algo que Malaguzzi desprezava.

No entanto, como narra Tonucci (1990 apud HOYUELOS, 2004a), Malaguzzi teve uma sabedoria política e criativa muito importante ao aceitar o convite, pois se tratava da oportunidade de difundir uma ideia e modelo pedagógico para além da cidade de Reggio Emilia, o que, na ocasião, significava oferecer uma outra ideia de escola que não aquela que na época se conhecia na Itália: escolas religiosas e privadas (HOYUELOS, 2004a). Nesse sentido,

Uma escolha nada óbvia, nada fácil,
que criou notável contraste e longa
incompreensão. Uma iniciativa que
trouxe a proposta de uma nova escola
da infância fora do círculo estreito das
cidades da Emilia Romanha, Toscana
e Umbría, dos leitores das nossas
revistas, que contribuiu notavelmente
a criar uma sensibilidade nova e
alargada (TONUCCI apud
HOYUELOS, 2004a, p.99).
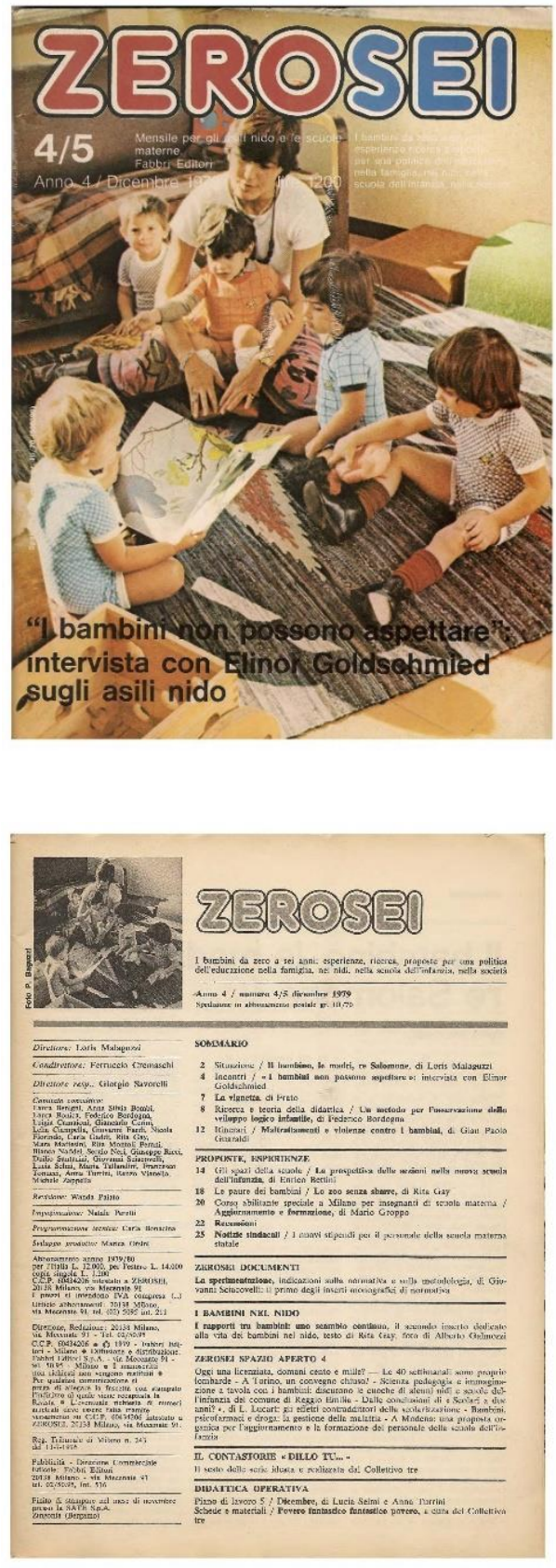

Em relação à revista, é importante destacar a respeito da característica dos textos e da periodicidade. Malaguzzi fazia uma grande crítica aos textos acadêmicos de Pedagogia que, por sua vez, esqueciam de colocar em relação os conceitos que discorriam com a prática das escolas. Malaguzzi sempre foi um defensor de que a Pedagogia fosse entendida na sua verdadeira relação entre teoria e prática. Sempre foi um crítico da prática esvaziada de reflexão e 
espontaneísta e, do mesmo modo, criticou inúmeras vezes o modo como a universidade distanciava as reflexões que fazia no seu interior da vida concreta das escolas.

Nesse sentido, o fato da revista ser mensal, dava a Malaguzzi a possibilidade de escrever textos com temas emergentes do contexto, ou seja, dava ao pedagogo a oportunidade de discutir os temas contemporâneos. Além disso, trouxe a característica de narrar situações cotidianas das escolas por meio de imagens, não apenas com textos. E isso, sem dúvida, transformou-se em uma das características da produção do conhecimento pedagógico de Loris Malaguzzi: mostrar as crianças através das imagens era também uma forma de dar voz a elas, em especial, de tornar visível uma imagem de criança inteira, em suas múltiplas linguagens.

Mas Malaguzzi também sabia que era estratégico convidar professores vinculados à universidade. Hoyuelos (2004a) destaca dois nomes: Susanna Mantovani e Egle Becchi, duas grandes e importantes pesquisadoras que foram fundamentais para a continuidade da revista posteriormente.

Hoyuelos (2004a) lembra ainda que até então havia duas grandes revistas de circulação no campo da Educação Infantil: Scuola Materna e Vita dela Infanzia - a primeira, de inspiração católica e oriunda das reflexões das Irmãs Agazzi, e a segunda para divulgação do pensamento montessoriano.

Em 1984, a revista Zerosei é encerrada por motivo de restruturação da editora e, no início de 1985, é continuado o projeto da revista Zerosei com um novo nome, Bambini, e uma nova editora, Edizioni Junior. A revista Bambini existe até hoje e teve Malaguzzi como diretor geral até 1993, levandoa assinatura de Malaguzzi em quase 100 artigos.

Cabe ainda destacar um último aspecto: Malaguzzi é muitas vezes acusado de não ter produzido uma grande obra como os grandes pensadores dos últimos séculos. Porém aqui reside um problema na compreensão do que significa uma

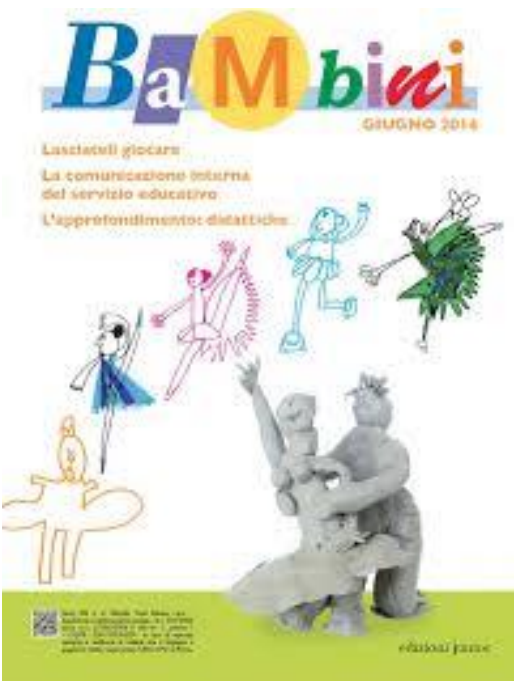
"grande obra".

A grande obra de Loris Malaguzzi foi um projeto educacional que existe até hoje, traduzido em um conjunto de escolas e creches municipais e que tem revolucionado o modo como se pensa, se faz e se fala sobre a Pedagogia, sobre as crianças e sobre o conhecimento pedagógico. 
A grande obra de Malaguzzi foi responder aos dilemas de sua época, em textos generosos e densos ao mesmo tempo. Malaguzzi era um grande e voraz leitor. Interessava-lhe, sobretudo, saber, como já se falou neste estudo. Seus breves textos endereçados às revistas Zerosei e Bambini mostram um outro modo de produzir conhecimento, diferentemente dos cânones oficias, mas que responderam e ainda respondem à complexidade de se fazer uma escola de qualidade e amável, como o próprio Malaguzzi reivindicava, para os meninos e as meninas.

A grande obra de Malaguzzi foi estruturada nos projetos documentados por ele e seus companheiros de trabalho que oferecem, por meio de imagens, excertos das falas das crianças e textos dos professores, identidade ao trabalho pedagógico, ao tex to pedagógico e à Pedagogia. Concretiza a imagem de criança inteira e capaz, que se traduz no respeitoso modo que lhe são oferecidas as situações de aprendizagem e pela forma que é narrada, ou seja, por ter sido tirada do anonimato.

O importante legado de Malaguzzi foi a construção de um conhecimento praxiológico que, como tal, se renovou e continua se renovando para responder às demandas de sua época. A obra de Malaguzzi segue como uma potente fonte de inspiração à Pedagogia contemporânea e nos ensina a respeitar e escutar as crianças em suas cem linguagens. É uma obra que reinvidica o fortalecimento das identidades plurais que existem dentro de cada escola nas vozes dos profissionais, das famílias e, especialmente, das crianças. Mas também, do reconhecimento da identidade que uma instituição dedicada aos bebês e crianças precisa defender para não cair nas amarras dos modelos transmissivos e escolarizantes que ainda persistem em existir.

Para o OBECI, especificamente, a obra de Malaguzzi serviu como referente para estruturar o modo como investigamos o cotidiano pedagógico e, por sua vez, o modo como temos construído o conhecimento praxiológico por meio da estratégia da Documentação Pedagógica, conforme será apresentado na Parte III. Seu legado é parte importante de nossa herança pedagógica, o que tem permitido construirmos uma prática situada, mas que é fecundada nas importantes contribuições que temos aprendido com esse importante pedagogo do século XXI. Criar um modo de ler e compreender a trajetória do Malaguzzi para devolve-la à comunicade profissional e acadêmica, é uma homenagem a esse grande intelectual que construiu um dos mais importantes projetos educativos que temos atualmente e que acreditava no valor das relações e da partilha como ideia central para a transformação da sociedade. 


\section{A OBRA NÃO SE FAZ SOZINHA}

Os desafios de um pátio podem ser vários. Subir uma escada, descer um escorregador, balançar bem alto, pendurar-se em argolas e aros, ou, equilibrar objetos. Ana

Laura é uma menina que gosta de desafios de todos os tipos. Depois de brincar com o grande grupo, encontrou nos cones de plástico uma nova brincadeira: fazer uma grande torre.

Ana Laura translada para suas brincadeiras do pátio as investigações que estão em curso com o grupo sobre os monumentos de Porto Alegre. Depois de um passeio pela cidade, o grande número de monumentos chamou a atenção das crianças, talvez pela beleza que contrasta com os prédios e ruas, quer pela indagação que evoca nos meninas e meninas sobre a tridimensionalidade.

Ana Laura começa sua construção e logo percebe a necessidade de um número grande do mesmo objeto. Sai pelo pátio em busca de mais cones para sua construção, os reúne em um espaço do pátio próximo a si e começa a construção.

Arthur e Betina, grandes companheiros de Ana Laura, percebendo a grande ideia, se prontificam buscar mais material para a torre em construção. E assim, em colaboração, a obra vai sendo construída e os desafios vão sendo partilhados com cumplicidade e grande amizade.

Crianças | Ana Laura, 5 anos, Betina; 5 anos; Arthur, 5 anos Professoras | Tatiana e Samantha Texto | Tatiana e Samantha Imagens | Samantha Escola Mimo de Gente
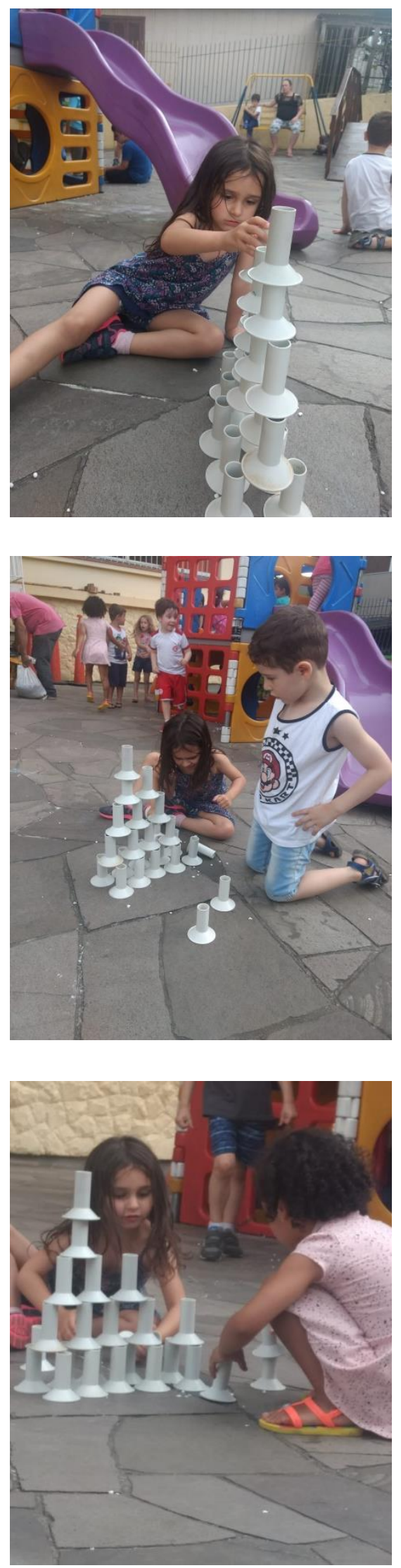


\section{PARTE III}

\section{O OBSERVATÓRIO DA CULTURA INFANTIL - OBECI: A DOCUMENTAÇÃO PEDAGÓGICA COMO ESTRATÉGIA PARA CONSTRUÇÃO E SUSTENTAÇÃO DO CONHECIMENTO PRAXIOLÓGICO}

O OBECI é uma comunidade de apoio ao desenvolvimento profissional que tem na centralidade do seu trabalho a investigação do cotidiano praxiológico. Compartilhamos da crença de que a investigação dos professores sobre sua própria prática é fonte para o desenvolvimento profissional (OLIVEIRA-FORMOSINHO, 2002a) e para a construção do conhecimento praxiológico (OLIVEIRA-FORMOSINHO, 2016a; COCHRAN-SMITH; LYTLE, 2002). Mais ainda, entendemos que a formação de uma comunidade, além de desencadear, apoiar e sustentar reflexões emergentes das investigações realizadas no interior de cada escola, envolve uma rede de profissionais em busca de um bem comum que gera significado à vida profissional e acumula esforços para transformar a realidade educativa.

Ainda que nossa centralidade notoriamente seja investigar, o OBECI não está vinculado a instituições universitárias, e essa é uma escolha. A lógica produtivista estabelecida nos programas de pós-graduação no Brasil pouco tem contribuído com a escola, além de ter se transformado em um processo endógeno de produção de conhecimento. Ou seja, o que se produz é tão somente endereçado aos próprios colegas investigadores e serve, apenas, como manutenção de credenciamento dos professores pesquisadores em seus programas de pósgraduação e da avaliação dos próprios programas. Não há valor acadêmico a transformação da realidade educativa, a menos que essa tenha se convertido em um artigo publicado em um periódico A1 ${ }^{66}$.

Malaguzzi (1988) disse que investigar é um comportamento vital. A vitalidade da nossa comunidade é sustentada por esse comportamento de quem busca observar a cotidianidade da Educação Infantil para construir um conhecimento situado que responda às perguntas de gestoras, coordenadoras pedagógicas, professoras e as minhas, como pesquisador. Perguntas que estão inscritas no campo pedagógico e que refletem a insatisfação e a busca curiosa, como dizia Paulo Freire (1979), de quem deseja migrar para outros lugares conceituais

\footnotetext{
${ }^{66}$ Esta tese não tem como foco o debate sobre o fenômeno que tem se nomeado como "produtivismo acadêmico". O destaque se faz como alerta e justificativa da não vinculação do OBECI aos modelos de grupo de pesquisa nas universidades. Para saber mais sobre o produtivismo acadêmico, é possível consultar Bianchetti; Valle (2011); Pimenta (2014); Vosgerau; Orlando; Meyer (2017); Patrus; Dantas; Shigaki (2015).
} 
e emocionais. Perguntas que não aceitam respostas rápidas e que acolhem a temporalidade das soluções, buscando com otimismo a transformação cotidiana de todos os processos educativos.

Para investigar, nossa estratégia tem se ancorado no legado de Loris Malaguzzi, em especial, sobre a reflexão a respeito da Documentação Pedagógica. Como já discutido na Parte II, o modo como o pedagogo constrói a ideia de Documentação Pedagógica está entrelaçado com uma dimensão didática e testemunhal da prática pedagógica, situada em um plano socioconstrutivista e complexo de aprendizagem e conhecimento.

Dahlberg (2016) sumarizou o pensamento de Malaguzzi sobre a Documentação Pedagógica como "o processo de tornar visível o trabalho pedagógico (ou outro) visível ao diálogo, interpretação, contestação e transformação" (DAHLBERG, 2016, p. 229). Trata-se de uma compreensão da escola como locus privilegiado para a prática democrática, "uma prática que abre um espaço público, um fórum na sociedade civil, onde discursos dominantes podem ser visualizados e negociados" (DAHLBERG, 2016, p. 229). Negociar a realidade sóciohistórico-cultural é um valor da Documentação Pedagógica que requer compreender a subjetividade de quem observa, registra, interpreta e comunica os processos educativos.

Nesse sentido, assumir um ponto de vista é também assumir uma dada ética, e, portanto, responsabiliza-nos como adultos e como sociedade, mostrando que "não é possível esconder-se atrás de alguma objetividade ou critério científico presumidamente oferecido por especialistas" (DAHLBERG, 2016, p. 229). Para isso, Malaguzzi (2001) destaca que a Documentação Pedagógica envolve o acompanhamento e a interpretação sistemática dos processos educativos por meio do uso da fotografia, de vídeos, das produções das crianças, das anotações dos professores para transformar a realidade e construir testemunho ético, político, pedagógico e cultural sobre as crianças, os adultos e o projeto educativo da escola. É por isso que Hoyuelos (2006) sintetiza o pensamento de Malaguzzi a respeito da Documentação Pedagógica enfatizando que se trata de uma estratégia extraordinária para o diálogo, para a mudança e para o compartilhamento.

Desde o começo do OBECI, apoiados pela Documentação Pedagógica, a pergunta chave que tem nos guiado é como organizar a vida cotidiana da instituição de Educação Infantil de modo que evidencie o papel da criança no processo educativo, convidando a reposicionar o papel do professor e a construir um contexto educativo de qualidade? Tal pergunta revela uma de nossas crenças importantes: de que as atividades da vida cotidiana são a espinha dorsal do trabalho pedagógico na Educação Infantil, pois nelas reside um verdadeiro 
laboratório de cidadania, de participação, de aprendizagem e de pertencimento a um dado contexto. Por isso, uma das ideias que nos guiam é o valor da vida cotidiana.

Também, nessa pergunta, expressa-se um dos principais desafios que temos enfrentado: reposicionar a criança e o adulto sem perder a nenhum dos dois na relação educativa. Temos percebido que há uma mescla entre as pedagogias diretivas (centradas no adulto e que perdem a criança) e as pedagogias não diretivas (centradas na criança e que perdem o adulto) como predomínio das práticas pedagógicas. Explicitar isso tem nos ajudado a buscar em qual tipo de pedagogia queremos nos situar, e, mesmo nas inúmeras contradições que significa fazer essa busca, tentar afirmar uma pedagogia relacional que reconheça a centralidade da criança mas que também saiba identificar a importância do papel do adulto no processo educativo. Como Malaguzzi $(1972 ; 1988)$ sempre afirmou, para conseguir reconhecer a competência da criança, é preciso ter adultos competentes também.

Assim, temos entendido que um contexto educativo de qualidade se constrói buscando uma escola amável, como nos ensinou Malaguzzi (apud HOYUELOS, 2013), ou seja, uma escola ativa, inventiva, habitável, testemunhada, um lugar de investigação, de aprendizagem, de reflexão em que se encontrem bem as crianças, os profissionais e as famílias. Recuperando o entendimento de Bondioli e Savio (2015, p. 24), compreendemos que "qualidade é uma construção de significados em torno da instituição e do serviço, uma reflexão compartilhada que enriquece os participantes, uma troca e uma transmissão de saberes."

Isso posto, nesta terceira parte da tese, explicito o modo como o OBECI está sendo construído e que escolhas estão sendo feitas desde sua criação. Assim, apresento os contextos que constituem esse Observatório, as ideias que guiam nossas ações e, dentre estas, a Documentação Pedagógica como estratégia central, nossos processos formativos e, por fim, nossos Organizadores da Ação Pedagógica.

\subsection{Construir um Observatório}

Para falar da constituição do OBECI, é preciso destacar três aspectos importantes: o forte interesse pela investigação, a escolha do nome e a natureza organizativa.

No Observatório, todos investigam: diretores e coordenadores pedagógicos investigam os processos formativos com os professores e a construção e concretização do projeto educativo da instituição; professores investigam o modo como as crianças aprendem e como criar as condições externas adequadas (tempo, espaço, materiais, organização de grupos), em especial, 
como reposicionar-se frente à relação educativa com os meninos e meninas. Professores, coordenadores pedagógicos e diretores investigam como comunicar a respeito do que investigam. As crianças investigam seu entorno para conhecer a si mesmas e o mundo físico e social, para dar significados e construir suas teorias provisórias. Também eu, como pesquisador, investigo a constituição desta comunidade de apoio ao desenvolvimento profissional e o modo pelo qual é construído o conhecimento praxiológico no seu interior. Estamos falando de uma interatividade entre os modos de investigar e de sustentar, por meio dessa investigação, a construção de um conhecimento situado.

Trata-se de um conhecimento dialógico entre o interno e o externo: interior de cada sala referência e o contexto da escola; interior de cada escola e o OBECI; do interior do OBECI e a retroalimentação do trabalho pedagógico das escolas. A ideia é, portanto, que o conhecimento se constrói entre o binômio interno e externo, “[...] como par justapostos, tentando centrar a questão sobre o professor e a professora como sujeitos cognoscentes e sobre a relação complexa e não linear entre ensino e conhecimento na medida em que o professorado se implica em contextos e relações" (COCHRAN-SMITH; LYTLE, 2002, p. 13).

Essa é uma mudança radical, sobretudo, se pensarmos na visão hierárquica que a universidade ocupa em relação às escolas em termos de pesquisa. Construir o conhecimento entre a visão interior das escolas e a visão exterior do pesquisador pode alimentar tanto o fazer e o pensar da própria instituição quanto da própria universidade. Mudar isso é modificar uma lógica da construção do conhecimento e das relações entre teoria e prática. Como afirma Rinaldi (2012, p. 184), "há uma ideia arrogante de uma separação contínua entre teoria e prática, cultura e técnica". Logo, a tônica nos práticos da escola se dá na perspectiva de ajudá-los a compreender e transformar a própria prática ao tempo que se reconhece e nomeia a própria epistemologia da prática, inalcançável nos domínios apenas de uma teoria isolada.

Nesse sentido, para construir esse conhecimento interno e externo, Erickson (2002, p. 9) observa que "investigar significa não apenas olhar de forma penetrante frente a algo que pretendemos falar, mas também, seguir os rastros, os vestígios das coisas. Investigar, então, é dar um segundo olhar; é conceder uma especial atenção a todas as possibilidades”. Lançar um segundo olhar para buscar compreender outras formas de constituir a escola de Educação Infantil, a formação dos professores e a própria pesquisa é o que tem caracterizado nosso modo de nos constituir como uma comunidade que investiga.

Tratando ainda sobre o tema da investigação, destaco a análise que Tonucci (1977) realiza sobre três modelos de escola para crianças. A primeira, a escola das liçõezinhas, ou seja, 
que tem sua centralidade em pequenas lições, coloca a criança como uma expectadora "[...] de um programa que só a ingenuidade ou ignorância de quem prepara as programações antecipadamente supõe que possa ser atrativo para os meninos e meninas" (TONUCCI, 1977, p. 22). Esse modelo de escola geralmente funciona pautado pelas datas comemorativas (geralmente, de cunho religioso, com acento no consumo, estereotipado), ou, ainda, pelas transições de estações do ano como mote para uma nova "atividade". Essa é uma escola que “[...] pede precocemente para a criança que renuncie a sua curiosidade, [...] uma escola que quer parecer o máximo possível ao modelo da escola fundamental” (TONUCCI, 1977, p. 22). Em outros termos, poderíamos dizer que essa escola pertence a um modelo pedagógico diretivo e de um modelo epistemológico empirista (BECKER, 1994).

$\mathrm{Na}$ segunda, a escola das atividades, ou, a escola da livre expressão, em contraposição ao modelo anterior de escola, a criança sempre escolhe o que fazer e, se por acaso pedir ao professor "o que fazer", possivelmente o adulto lhe dirá "faça o que quiser!". No entanto, essa resposta angustia a criança, abandonando-a sobre sua própria sorte. Como adverte Tonucci (1977, p. 24), “temos nessa forma de fazer escola uma forma de hiperestimulação da criança que produzirá muito, mas de maneira estéril”. Esse modelo de escola, muitas vezes, forja uma ideia de respeito às crianças, pressupondo que deixá-las fazer o que querem, isentando o papel do adulto, é oferecer aquilo de que as crianças precisam. Mas esse é um modelo de escola que abandona as crianças e justifica, inclusive, o retorno ao modelo anterior - o das liçõezinhas como resposta à aprendizagem das crianças. Falamos aqui de um modelo pedagógico não diretivo e de um modelo epistemológico apriorista (BECKER, 1994).

Por fim, a terceira é a escola da investigação. Uma escola que "nem confia ao sentido materno e nem à improvisação, mas tem necessidade de educadores preparados de uma forma nova e global: que une riqueza cultural crítica e científica" (TONUCCI, 1977, p. 26). Uma escola que não abandona a criança e tampouco centra-se em programas prescritos. Uma escola que tem na curiosidade da criança o motor para estabelecer uma relação entre os saberes e as experiências das crianças com o patrimônio que a humanidade sistematizou, ou seja, que compreende seu papel na organização de contextos que deem acesso ao patrimônio sóciohistórico-cultural. Essa é uma escola situada em um modelo pedagógico relacional e em um modelo epistemológico construtivista (BECKER, 1994).

Nosso trabalho, tanto no interior do OBECI, quanto nas escolas que o constituem, tem se localizado nesse terceiro modelo, de escolas que investigam e que desejam compreender os processos de construção do conhecimento tanto das crianças, como dos adultos. Entre todas as 
contradições e ambiguidades que significa se transformar, nosso intento tem sido o de promover o isomorfismo pedagógico entre a formação interna no OBECI, que fomenta a capacidade dos professores, coordenadores pedagógicos e diretores de investigar sobre sua prática, e, ao mesmo tempo, que incentiva esses profissionais a promoverem as investigações das crianças dentro das escolas:

\footnotetext{
O isomorfismo pedagógico é a estratégia metodológica que consiste em fazer experienciar, através de todo o processo de formação, o envolvimento e as atitudes; os métodos e os procedimentos; os recursos técnicos e os modos de organização que se pretende que venham a ser desempenhados nas práticas profissionais efetivas dos professores (NIZA, 2009, p. 352).
}

Além disso, compartilhamos do conceito de investigação apontado por Rinaldi (2012, p. 186), que, ao reivindicar a reconceitualização do termo, define-o como "a tensão cognitiva que se cria sempre que ocorrem processos autênticos de aprendizado e de construção de conhecimento". Nesse sentido, a autora provoca a pensar a produção do conhecimento próprio da escola - ou seja, o conhecimento da Pedagogia - como algo dinâmico, que se reinventa sempre que problematizado, refletido e compartilhado. A autora destaca que, na realidade cultural e social em que vivemos atualmente, de provisoriedade e hibridismos, uma nova noção de investigação, marcada por uma força vital, poderá responder às demandas da sociedade (RINALDI, 2012).

Portanto, para nós, investigar é aprender. Aprender a pensar sobre a prática e a reconhecer os caminhos que estamos trilhando. Aprender sobre os modos como as crianças aprendem e sobre os modos como nós vamos nos constituindo professores de crianças, formadores de professores, gestores de Educação Infantil, pesquisadores de processos de formação de professores de Educação Infantil. É uma aprendizagem negociada (FORMAN; FYFE, 2016), compartilhada (CRAFT; PAIGE-SMITH, 2010) e em companhia (OLIVEIRAFORMOSINHO, 2007).

Já a ideia de denominar esse grupo de Observatório da Cultura Infantil está diretamente vinculada a um dos pilares centrais da Documentação Pedagógica: a escuta. Para escutar, na perspectiva malaguzziana, é preciso aprender a observar os modos como a criança se relaciona com o mundo, como ela produz suas teorias (MALAGUZZI, 2001). Ou seja, é um modo ativo de pensar o trabalho educativo que envolve "um processo cooperativo que ajuda o professor a escutar e observar as crianças com que trabalha, possibilitando, assim, a construção de experiências significativas com elas" (GANDINI; GOLDHABER, 2002, p.150). Desse modo, a proposta do Observatório, como um lugar legítimo para o debate ampliado e de confronto a 
respeito das práticas educativas, é despertar no adulto a sua capacidade para ver criticamente a pedagogia latente nas escolas, reveladas por aquilo que está em curso na vida cotidiana da instituição. Além disso, compreender e interpretar as atuações das crianças para, então, saber planejar e projetar a continuidade do seu próprio fazer como professores, coordenadores pedagógicos e gestores.

Por isso a perspectiva assumida é a formação em contexto, pois "conceitualiza-se como forma de mediação pedagógica para o desenvolvimento profissional praxiológico" (OLIVEIRA-FORMOSINHO, 2016b, p. 93). Essa noção de desenvolvimento profissional na Educação Infantil foi exaustivamente tratada pelos estudos de Oliveira-Formosinho (2002a; 2009b; 2016b ${ }^{67}$. A ideia de desenvolvimento profissional é defendida como um "processo contínuo de melhorias das práticas docentes [...], incluindo momentos formais e não formais, com a preocupação de promover mudanças educativas em benefício dos alunos, das famílias e das comunidades" (OLIVEIRA-FORMOSINHO, 2009b, p. 226). A autora diferencia esse conceito da ideia de formação contínua. Para a autora, enquanto a formação contínua se centra no processo ensino/formação, a perspectiva de desenvolvimento profissional focaliza o processo de aprendizagem/crescimento.

Segundo Oliveira-Formosinho (2009b), o desenvolvimento profissional está intimamente ligado ao desenvolvimento organizacional, curricular e das aprendizagens. Para compreender melhor a respeito, tomo como exemplo o sistema anunciado pela autora ao explicitar o modelo de desenvolvimento profissional adotado pela Associação Criança.

Para Oliveira-Formosinho e Formosinho (2002, p. 6), nessa associação, “o desenvolvimento profissional é um processo vivencial não puramente individual, mas um processo em contexto". A partir dos argumentos da autora, podemos, então, pensar que a tônica está:

- nos processos - reconhecimento das necessidades e definição de estratégia de ação pelos participantes (professores, coordenadores pedagógicos e gestores);

- nos conteúdos concretos aprendidos - construção de um conjunto de conhecimentos fundamentais para a prática pedagógica (a herança teórica dos pedagogos do século XXI, por exemplo);

- nos contextos de aprendizagem - formação centrada na escola como lócus situado;

\footnotetext{
${ }^{67}$ Conforme Oliveira-Formosinho $\left(2002^{\mathrm{a}}, 2002 \mathrm{~b}\right)$ em outros contextos da educação, o tema do desenvolvimento
} profissional também já foi tratado por outros autores, tais como Fullan (1982) e Garmston; Lipton; Kaiser (2002). 
- na aprendizagem de processos - reconhecimento dos processos de aprendizagem das crianças e dos próprios adultos (metacognição);

- na relevância para as práticas - foco em responder aos problemas emergentes do cotidiano praxiológico;

- no impacto na aprendizagem das crianças - modo como o desenvolvimento profissional, organizacional, curricular e das aprendizagens afeta diretamente na criação de oportunidades de aprendizagem para as crianças.

Em tal perspectiva, acredita-se que a formação não prescinde do indivíduo, mas nasce dos saberes de sua experiência e, por isso, pode-se dizer que é na intersecção entre as diferentes dimensões do desenvolvimento que reconhecemos a participação dos profissionais. Do mesmo modo como não podemos olhar uma criança isolada, também não devemos fazer isso com os professores. A instituição (contexto) de que o professor participa impacta no desenvolvimento profissional, e sua formação e autoformação impactam no desenvolvimento do seu contexto. Esse é um jogo dialógico, como um jogo de espelhos que são colocados um frente ao outro e já não se sabe mais quando começa e quando termina o reflexo de um e de outro. Logo, aprender a se observar, observar as crianças e observar a própria instituição é, em analogia aos observatórios de astronomia, uma forma de compreender os fenômenos que estão entrelaçados pelas incertezas, provisoriedades, dinâmicas e inacabamentos que, neste caso, é fazer uma pedagogia da infância.

A partir dessa definição de formação, também encontramos a legitimidade dos "não saberes", tanto quanto daqueles saberes já existentes. Assim, conforme defende Pinazza (2014, p.56), "a tarefa do programa formativo é trazer à consciência das pessoas envolvidas a sua condição de inacabamento ou inconclusão". Assumimos, então, que enfrentar o desafio de fazer educação significa assumir que a aprendizagem profissional não está centrada em um período da vida (o de formação universitária, por exemplo), mas é um projeto de longo prazo, sem data para acabar, uma aprendizagem que se dá ao longo da vida (lifelong learning).

Em um relato de uma das participantes do OBECI no documento de reflexão que se faz a cada final de ano, aparece o quanto sua participação em uma comunidade de apoio ao desenvolvimento profissional tem transformado a si mesma e o cotidiano da escola:

Já se passam 26 anos de profissão, tinha a sensação de já saber tudo o que precisava saber. Estava enganada. Me tornei coordenadora no mesmo ano que começo a participar do OBECI. Aqui dentro [do OBECI] tenho aprendido mais que nos dois cursos de especialização que fiz. Em nossos encontros, tenho aprendido a colocar em suspensão 
minhas certezas para dar lugar à escuta das crianças. Saber que a cada 15 dias nos encontramos para falar da vida da escola, dos conteúdos de verdade, me dá ânimo. [...] Documentar o cotidiano tem nos ajudado a confrontar as certezas e a compartilhar com todos os envolvidos na escola para ampliar nossos debates. [...] Acolher as miudezas da vida, observar, acompanhar, interpretar, aprender a focar na criança, compartilhar os percursos, são possibilidades para se fazer uma escola que esteja atenta as especificidades das crianças, que acolha a cultura infantil. Luciane V., Coordenadora Pedagógica, EMEI João de Barro. Caderno de Reflexões, 2016, p. 6-7.

É interessante destacar que "a forma de ser dos professores é uma forma de comportamento cultural, não uma forma adquirida nos cursos de formação" (LARSON apud SACRISTÁN, 2012, p. 101). Assim tem sido no Observatório, uma oportunidade mobilizadora para criar um comportamento investigador, atento às crianças, e focado na formação contextualizada dos professores a partir dos pressupostos da Documentação Pedagógica. As gestoras, as coordenadoras pedagógicas e as professoras das instituições têm adotado determinadas características de comportamento que certamente têm sido construídas e suscitadas pelo próprio contexto. Cria-se um "jeito de ser" que está para além de uma teoria propriamente dita, mas da incidência nas próprias crenças e valores.

Se recuperarmos a etimologia da palavra comunidade, de origem latina, communitas, significa companheiro, compartilhado por muitos, que tem algo em comum, público. Ao tentar classificar a natureza organizativa do OBECI, fui compreendendo esse caráter de comunidade que se constituiu. Isso porque, desde o princípio, sabíamos que a razão de nos encontrarmos, periodicamente, estava atravessada por uma ideia comum: transformar as escolas a partir de uma mudança na ideia de criança, do papel do adulto e de conhecimento, o que implicava rever os processos formativos.

Também entendemos que, no Observatório, o diálogo, a cooperação, a negociação, o compartilhamento são palavras importantes que, ao mesmo tempo em que nos traduzem, são afirmados como postulados dentro e fora do grupo ${ }^{68}$.

Compreender que tipo de comunidade é o OBECI foi algo que se deu no decorrer do próprio desenvolvimento do Observatório. Pires (2013), ao discutir os projetos de formação em contexto da Associação Criança, do Movimento da Escola Moderna (MEM), da Fundação High Scope e do Centro Pen Green, refere-se a essas experiências como comunidades de apoio ao

68 Por isso que, desde 2014, temos organizado uma Jornada de Educação Infantil direcionada para outras instituições e profissionais como forma de compartilhamento dos temas que temos desenvolvido dentro do OBECI. O site e as publicações também têm esse mesmo sentido, que é o de construir um patrimônio pedagógico e partilhálo. 
desenvolvimento profissional de educadores de infância. Embora em sua tese não desenvolva nenhum tipo de conceito a respeito desse tipo de comunidade, ao observar os projetos que a autora classifica como comunidades de apoio ao desenvolvimento profissional, pude notar como características-chave a promoção da qualidade dos contextos, as aprendizagens das crianças e as aprendizagens dos profissionais ${ }^{69}$.

Percebo que, além dessas também serem características-chave do OBECI, esse Observatório pode ser entendido como uma comunidade de apoio ao desenvolvimento profissional porque:

a) é um espaço de formação e transformação que tem como pressuposto comum a estratégia da Documentação Pedagógica;

b) organiza-se com a finalidade de ser um espaço/tempo para o compartilhamento de dúvidas, de diálogo, de negociação, de cooperação em torno da aprendizagem profissional;

c) gera aprendizagem para e com seus participantes a partir de observáveis dos próprios contextos;

d) é um espaço de reflexão e retroalimentação sobre e para o cotidiano praxiológico;

e) produz, como uma estrutura social, produz conhecimento praxiológico situado;

f) tem o comprometimento de visibilizar os percursos das crianças e dos professores, a fim de criar uma memória pedagógica e cultural sobre a Educação Infantil, sobre a docência na Educação Infantil e sobre as crianças;

g) visa à construção da qualidade dos contextos de aprendizagem das crianças e dos profissionais;

h) propõe-se a promover as escolas participantes como comunidades de prática (NIZA, 2009; WENGER, 2010) para os profissionais e como comunidades embrionárias (DEWEY, 2002) para as crianças.

A respeito dos tópicos levantados anteriormente, é importante fazer algumas explicitações. O termo comunidade de prática é tratado por Niza (2009, p. 346) como sendo "o contexto social onde tem lugar a aprendizagem através das trocas que asseguram os progressos no trabalho". Já Wenger (2010) entende que uma comunidade de prática é sempre um sistema

${ }^{69}$ Identifico outras experiências que poderiam compor a lista de comunidades de apoio ao desenvolvimento profissional, embora elas mesmas não se auto denominam dessa forma: Reggio Emilia (Reggio Children), Parma Infanzia, Fundazione Crescere, na Itália; Rosa Sensat, na Espanha; Instituto Pikler-Loczy, na Hungria; Escuelas Pesta, no Equador. 
social de aprendizagem. Por crer nisso, o autor faz destaque para o fato de que as pessoas se agrupam pelo tipo de atividades que exercem. A partir disso, a prática compartilhada não apenas reúne as pessoas em torno de algo mas constrói saberes e modos de ser e estar. No meu entendimento, o OBECI é provocador de que as escolas se tornem comunidades de prática a partir do momento em que vai definindo modos de conceber e fazer um determinado tipo de pedagogia.

Construir uma comunidade é também tirar o professor do "isolamento docente" (COCHRAN-SMITH; LYTLE, 2002) e considerar que seu trabalho não se faz apenas na relação direta com as crianças, mas no diálogo e reflexão da sua própria prática com outros profissionais. Por isso, as estratégias estruturantes do Observatório ${ }^{71}$ ocorrem em horário de trabalho e exigem das escolas a dispensa dos professores, coordenadores e gestores para participar, salvo a Jornada de Educação Infantil anual e os Encontros das Escolas Observadoras, que ocorrem em sábados, pois implicam a participação de todos os profissionais das escolas. No entanto, o isolamento docente não é apenas uma questão de estruturação da jornada de trabalho, mas também uma forma que "[...] diminui a oportunidade do professor mostrar seus êxitos (e também) protege o direito a ocultar seus fracassos" (LITTLE, 1987, p. 60), mais ainda, o isolamento atua como um mecanismo que encerra o professor em si mesmo, desviando a perspectiva da docência como uma atividade colaborativa e social (COCHRAN-SMITH; LYTLE, 2002).

Já a ideia de comunidades embrionárias para as crianças, propostas por Dewey (2002, p. 26), reconhece, na escola, "a possibilidade de associar-se à vida, de tornar-se uma segunda morada da criança, onde ela aprende através da experiência direta, em vez de ser apenas um local onde decora lições". Assim, a escola é um verdadeiro laboratório de cidadania, de aprendizagem da cultura, de legitimidade da curiosidade das crianças e de promoção da cultura infantil e pedagógica.

$\mathrm{Na}$ sequência, além de compartilhar o modo como as escolas participantes foram convidadas e os movimentos de permanências, chegadas e partidas das instituições, construo cartas de identidade das escolas em diálogo com as profissionais das instituições.

\footnotetext{
${ }^{70}$ Segundo as autoras, "o isolamento docente ocorre em todas as etapas da carreira profissional e está muito bem documentado nos estudos de Goodlad (1984); Lieberman y Miller (1984); Lortie (1975)" (COCHRAN-SMITH; LYTLE, 2002, p. 135). No Brasil, o tema sobre o trabalho, o emprego e a carreira na Educação Infantil já foi tratado por Vieira e Souza (2010) e Gomes (2012).

${ }^{71} \mathrm{Na}$ sequência, irei tratar, com maior detalhamento, as estratégias do OBECI, mas, neste caso, estou referindome ao Grupo Gestor e aos Grupos de Investigação-Ação.
} 


\title{
1.2 As escolas que participam do OBECI
}

A participação das escolas ocorreu por meio de carta-convite. Naquela ocasião, foram convidadas cinco escolas, de cinco municípios diferentes. A razão central da escolha das escolas convidadas se deu por existir algum tipo de contato prévio, como, por exemplo, a gestora de uma delas havia sido minha aluna em um curso de extensão, a gestora de outra havia feito contato para uma formação interna em sua escola e a coordenadora de outra havia sido minha colega em curso de especialização. No entanto, o que nos unia era o fato de eu perceber o desejo dessas profissionais em compreender como transformar as escolas de que faziam parte. $\mathrm{Na}$ carta-convite, expressei essa questão:

\begin{abstract}
É com muito prazer que entro em contato para convidar sua escola de Educação Infantil para participar do Observatório da Cultura Infantil - OBECI. Esse projeto envolve um processo formativo às escolas participantes à luz da Abordagem da Documentação Pedagógica. Interessado em criar instrumentos que renovem as práticas pedagógicas, ao mesmo tempo, criar uma nova cultura sobre a escola, sobre as crianças e sobre a docência, o OBECI tem como objetivo fortalecer uma rede de escolas interessadas em promover um trabalho de qualidade e atento às crianças, sobretudo, que torne visível uma imagem de criança rica e capaz (MEMÓRIA DOS ENCONTROS DO OBECI. Carta Convite, 2013, p. 2).
\end{abstract}

Conforme se pode perceber no trecho compartilhado, já havia a clareza de que o objetivo da formação desse grupo centrava-se na transformação da cultura pedagógica instituída dentro das escolas, sustentadas pelos pressupostos da Documentação Pedagógica. A centralidade do trabalho que ainda hoje desenvolvemos no OBECI não se desviou em nada do que já se anunciava em 2013: pensar na formação da equipe da escola com vistas à promoção de um trabalho de qualidade traduzido pela atenção às crianças.

No dia 08 de março de 2013, foi enviada essa carta com a finalidade de agendar um primeiro encontro que aconteceu no dia 27 daquele mesmo mês, momento em que se apresentou a proposta de criação do Observatório. A partir daí, decidiu-se sobre as possibilidades de dar continuidade aos encontros. Nesse primeiro encontro, quatro escolas compareceram e uma delas optou por não continuar.

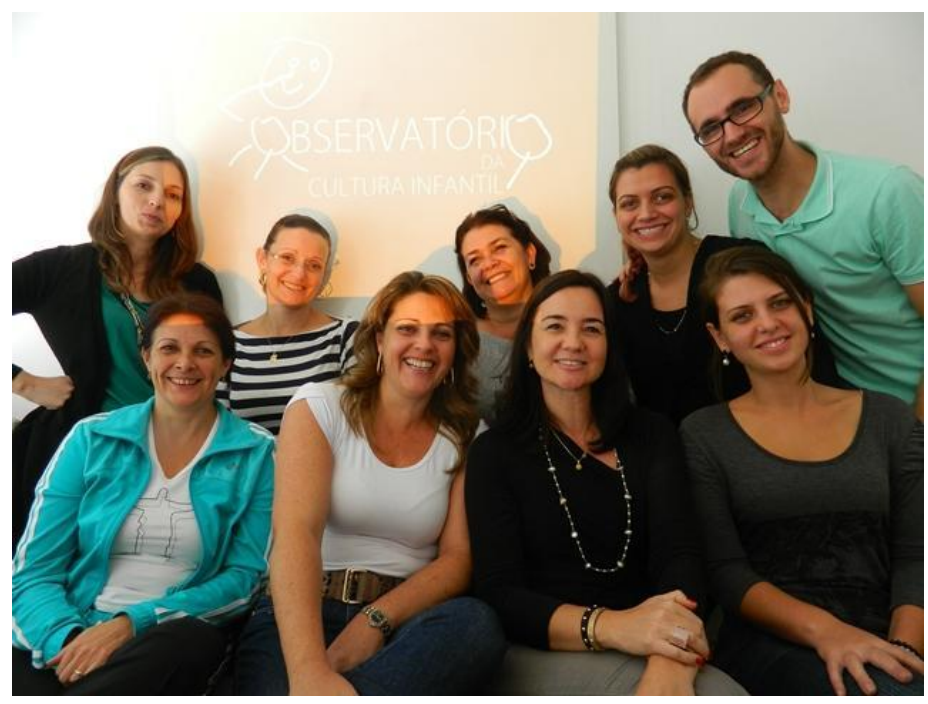


Atualmente, somos cinco escolas participantes e três representantes da Secretaria Municipal de Educação de Novo Hamburgo. O grupo foi se constituindo e se transformando, novos integrantes vieram compor e outros já não fazem mais parte. Nos encontros de cada final de ano em que refletimos e retomamos o percurso para decidir os horizontes pelos quais seguiremos, com frequência nos remetemos a esse primeiro dia e a essa primeira imagem com um certo entusiasmo pela comunidade que conseguimos constituir. Também percebo que, nesses documentos de reflexão, há diversas manifestações do valor de estar em grupo, de ter um espaço para dialogar e de retirar das abstrações os conteúdos e processos da transformação. Nos dois trechos a seguir, pode-se perceber a respeito:

[...] Trata-se de encontrar companheiros que ajudam a OLHAR. Olhar para os momentos especiais da vida cotidiana na escola. Luciane V., Coordenadora Pedagógica, EMEI João de Barro. 2016, p. 6

Não sei nem como, mas com ajuda do grupo algumas mudanças começaram a acontecer [...]. O grupo do Obeci então passou a ser companheiro, apoio, cobrança e balizador da caminhada que fazemos para transformar a escola em um lugar cada vez melhor. Gilneia, psicóloga, Espaço Girassol. 2016, p. 7

A permanência no Observatório envolve um desejo da equipe gestora acordado com suas respectivas equipes. Escolher manter-se é uma decisão fundamental, uma vez que o OBECI não é uma instituição oficial, ou seja, trata-se de um acordo de vontades, como afirmam Oliveira-Formosinho e Formosinho (2002). Por isso, anualmente, as escolas são convidadas a refletirem junto das suas equipes para que decidam sobre o seu desejo de permanência ou não no grupo.

O Observatório é constituído por escolas da rede pública e privada, e, com isso, há diferentes dinâmicas para a permanência dos diretores e da coordenação pedagógica nesse grupo. No caso da rede pública, a cada três anos, está-se sujeito à eleição de nova equipe gestora (diretor e coordenador pedagógico), ou, caso seja desejo de continuidade por parte da equipe e escolha da comunidade escolar, pode-se manter por seis anos (duas gestões) cada equipe. No caso da rede privada, a participação envolve as diferentes dinâmicas organizacionais de trabalho no que diz respeito à permanência de coordenadores. Já os diretores são também os proprietários das instituições. Logo, há uma variável de participação, que depende, por ora, das condições de vinculação de trabalho (permanência ou não), e, por outra, pelos movimentos que a própria instituição vai sofrendo a cada três anos. 
Como já dito, em 2013, éramos três instituições ${ }^{72}$ : EMEI Aldo Pohlmann (Novo Hamburgo), Espaço Girassol (Canoas) e Escola de Educação Infantil Mimo de Gente (Porto Alegre). No ano seguinte, houve a entrada da EMEI João de Barro (Novo Hamburgo) e de uma terceira escola municipal ${ }^{73}$, compondo um total de cinco escolas. Dadas essas alterações de gestão mencionadas anteriormente, uma das escolas que iniciou com o OBECI, a EMEI Aldo Pohlmann, a partir de 2015, deixou de compor o grupo e, agora, em 2018, retorna a fazer parte. Uma outra instituição, que entrou em 2014, permaneceu apenas naquele ano e decidiu não continuar em função de mudanças na gestão e problemas de saúde de uma das profissionais participantes. Em 2015, iniciou a EMEI Joaninha e uma outra escola municipal de Novo Hamburgo que, na ocasião, era dirigida pela anterior diretora da EMEI Aldo Pohlmann. Essa instituição permaneceu no OBECI até 2017 embora a antiga diretora estivesse nesse cargo apenas por um ano. A razão da saída dessa escola do OBECI se deu em função da impossibilidade da coordenadora em continuar frequentando os encontros devido ao tamanho da instituição (já que funcionavam turmas de pré-escola e turmas de ensino fundamental, totalizando cerca de 800 crianças e adolescentes).

Mesmo com esse movimento, desde 2014, o Observatório se mantém com cinco escolas, sendo sempre três públicas e duas privadas. Para fins desta pesquisa, irei trabalhar apenas com os dados das quatro escolas que iniciaram e permaneceram até o presente momento: EMEI João de Barro, EMEI Joaninha, Espaço Girassol e Escola de Educação Infantil Mimo de Gente $^{74}$.

Essas instituições são bastante diversas em termos da característica de atendimento, de estrutura e de número de crianças e profissionais. Estamos falando de duas tipologias de mantenedora, a pública e a privada; de arquiteturas que incluem os atuais prédios do Proinfância ${ }^{75}$ e de escolas que se constituem em casas adaptadas. Algumas das escolas atendem toda a etapa da Educação Infantil (0-6 anos), algumas apenas a etapa creche (0-3 anos) e outra

\footnotetext{
72 As escolas foram consultadas sobre o desejo do nome ser informado nesta tese ou não - no caso, poderia ser utilizado algum nome fictício. Todas as escolas optaram para que seus nomes fossem informados. Além disso, todas as participantes também optaram que fossem utilizados seus nomes verdadeiros ao longo da tese.

73 Não serão informados os nomes das duas instituições que não estão mais no OBECI, apenas será explicitado, para fins de compreensão, a respeito do trânsito e composição de escolas participantes no Observatório.

${ }^{74}$ A Escola Municipal de Educação Infantil Aldo Pohlmann participou no início do OBECI, em 2013 e 2014 . Na troca de gestão, a EMEI deixou de fazer parte e retornou em 2018. Para efeitos de pesquisa, dada a ausência da escola por longo período, essa instituição não compõe os dados utilizados nesta pesquisa.

75 Segundo Coelho (2015, p. 7), “O Proinfância é um programa do governo federal, criado em 2007, cujo objetivo principal é prestar assistência financeira, em caráter suplementar, ao Distrito Federal e aos municípios para a construção e aquisição de equipamentos e mobiliários para creches e pré-escolas públicas. A sua implementação abrange cinco dimensões: a disponibilização de projetos arquitetônicos padrão, o financiamento de obras, a aquisição de mobiliário e equipamentos, o assessoramento técnico-pedagógico e o custeio de novas matrículas".
} 
apenas algumas turmas da Educação Infantil. O número de crianças também é bastante variado, automaticamente, o quadro de profissionais também se modifica. As escolas atendem em turno parcial e integral e são de municípios com realidades sócio econômicas distintas.

Assim, o cenário que está configurado no atual momento é esse apresentado no Quadro 04:

Quadro 04 - Cenário de Instituições Participantes em 2018

\begin{tabular}{c|c|c|c|c}
\hline Instituição & Mantenedora & Município & $\begin{array}{c}\mathbf{N}^{\mathbf{0}} \text { de } \\
\text { crianças }\end{array}$ & Idade atendida \\
\hline EMEI Joaninha & Pública & Novo Hamburgo & 88 & 1 ano -4 anos \\
EMEI João de Barro & Pública & Novo Hamburgo & 105 & 4 meses -3 anos \\
EMEI Aldo Pohlmann & Pública & Novo Hamburgo & 80 & 2 anos -3 anos \\
Espaço Girassol & Privada & Canoas & 84 & 4 meses -5 anos $11 \mathrm{~m}$ \\
Mimo de Gente & Privada & Porto Alegre & 208 & 4 meses -5 anos $11 \mathrm{~m}$ \\
\hline
\end{tabular}

Fonte: elaborada pelo autor

Embora a perspectiva deste trabalho não seja fazer uma generalização das práticas desenvolvidas no OBECI, é fato que esse grupo de instituições representa parcialmente a complexidade das diferentes tipologias de organização e funcionamento da Educação Infantil no Brasil. Sem dúvidas, existem tantas outras formas, mas o desejo de refletir a formação em contextos de professores e a organização do cotidiano nessa etapa da educação parece estar bem contemplado devido às variáveis presentes no grupo.

Uma vez que o OBECI se constitui pelo encontro das escolas que o compõe, decidi fazer uma espécie de carta de identidade das instituições participantes. Além de compreender as dinâmicas de organização de cada instituição, como já explicitado anteriormente, construir essa carta implica entrar na história e no modo como essas escolas foram se constituindo. Para isso, mesmo tendo uma aproximação com as escolas e já sabendo de parte significativa de sua história, optei por escrever uma primeira versão dessas cartas me valendo dos Projetos Políticos-Pedagógicos e de documentos que fomos elaborando no interior do OBECI que apresentassem características de cada escola. Após essa escrita, compartilhei com as equipes das escolas pedindo que modificassem os textos de tal modo que a versão final representasse o melhor possível a instituição.

Também busquei imagens realizadas no interior da escola e que foram compartilhadas em nossos encontros ou em nossos grupos virtuais. Ademais, optei por utilizar os processos documentais $^{76}$ que as escolas construíram no segundo semestre de 2017 enquanto estive no meu estágio de doutoramento no exterior. Naquela ocasião, como os encontros passaram a acontecer

\footnotetext{
${ }^{76}$ Na Parte I deste trabalho, falou-se sumariamente sobre os processos documentais. Na sequência desta parte, serão abordados com maior profundidade.
} 
nas próprias escolas, optamos por fazer o que chamamos de "Escola amiga". Ou seja, uma das escolas que estava visitando a escola anfitriã, ao realizar um passeio pela instituição, fazia algumas fotos e anotações para a construção de um processo documental que era contrastado com um quadro analítico sobre organização de espaços e materiais que construímos a partir das indicações de Oliveira-Formosinho e Andrade (2011), Araújo (2011), Oliveira-Formosinho e Araújo (2013) e outros referentes que vínhamos estruturando dentro do OBECI ${ }^{77}$. A cada novo encontro, portanto em uma nova escola, essa proposta se repetia, e a escola que havia feito o processo documental da instituição anterior apresentava seu olhar destacando os pontos que considerava "fortalezas" do trabalho e outros pontos que sinalizava com a possibilidade de qualificar. Construímos isso como uma possibilidade de oferecer um olhar estrangeiro para cada escola, intuindo que esse olhar pudesse oferecer elementos para qualificar o trabalho.

A partir desse material é que também compus essa carta de identidade de cada escola para tentar expressar a sua dimensão social, cultural e pedagógica. Nela há uma pluralidade de vozes: a minha, como pesquisador, a das participantes das próprias escolas, a dos documentos da escola, a do olhar das outras escolas do OBECI e a das crianças a partir das imagens selecionadas. Esse material será apresentado a seguir.

\subsubsection{EMEI João de Barro $^{78}$}

A história dessa escola começa nos anos de 1962, com o nome de Creche Municipal Nossa Senhora das Graças, respondendo a uma demanda de atendimento das mães trabalhadoras do bairro Rondônia, no município de Novo Hamburgo. Foi a partir de uma portaria municipal, no ano de 1978, orientando para que as creches tivessem o nome de lendas e histórias da literatura infantil, que a escola passou a ser chamada de Creche Municipal João de Barro.
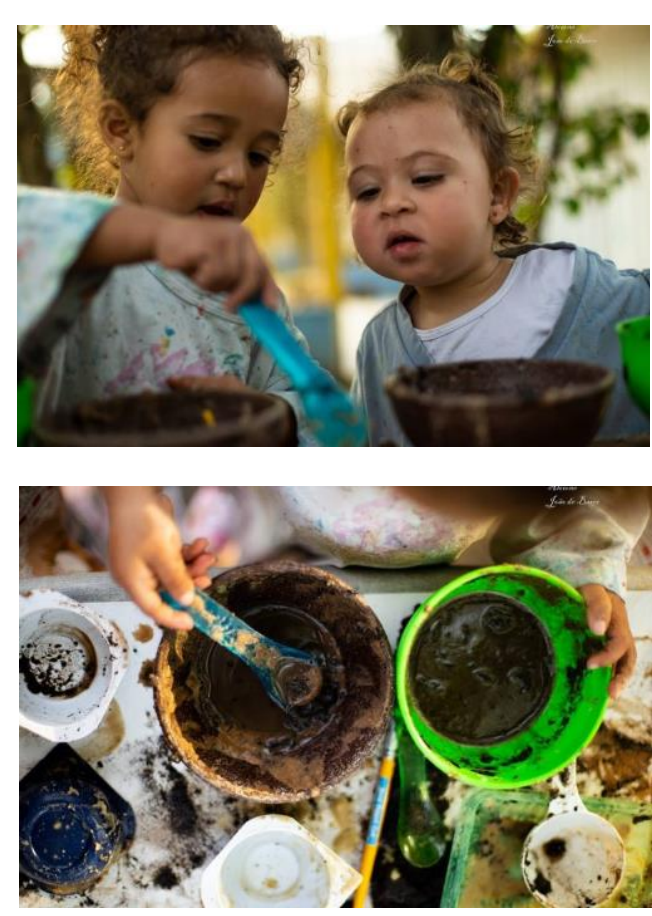

77 Posteriormente irei explicitar estes referentes construídos quando abordarei os Organizadores da Ação Pedagógica.

78 Agradeço a disponibilidade de Luciane L. e Alexandra no apoio necessário para a recolha de informações, bem como o material elaborado pela Espaço Girassol, em 2017, na ocasião das visitas das escolas amigas. 
A partir da LDB de 1996, que determina a Educação Infantil como primeira etapa da Educação Básica, as creches passam a ser de responsabilidade da Secretaria de Educação e Desporto municipal, o que implica a alteração do nome para Escola Municipal de Educação Infantil João de Barro.

Desde 2007, a EMEI se encontra em prédio próprio com amplo pátio externo. A João de Barro tem feito um grande investimento na organização dos espaços e na oferta de materiais que rendem grandes investigações pelas crianças. Tanto os espaços externos quanto os internos têm sido pensados para que as crianças habitem a escola. Para a João de Barro, organizar os espaços de forma acolhedora para as crianças é uma forma de traduzir a imagem de criança capaz e com direito a participar da vida cotidiana.

Em 2014, iniciou sua participação no OBECI, e, desde então, a equipe gestora e os professores têm feito grandes jornadas de aprendizagem e de transformação da escola. Dos conteúdos que temos desenvolvido no interior do Observatório, a João de Barro tem sido uma grande referência na elaboração de mini-histórias da vida cotidiana. Essa estratégia tem se efetivado em todas as turmas e está servindo como grande instrumento de comunicação e diálogo com as famílias.

Aliás, a participação das famílias é uma marca que faz parte da história dessa instituição. Em 1974, registra-se a primeira Associação de Pais, cujo objetivo era o de reunir-se mensalmente para discutir normas e diretrizes de funcionamento e planejar
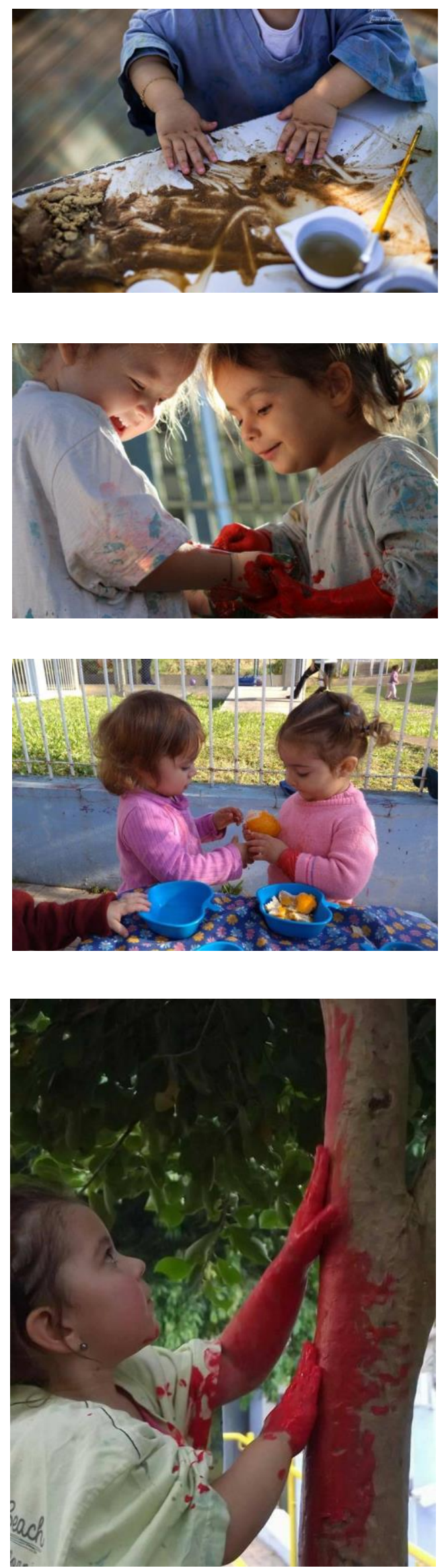
atividades para arrecadação de fundos e na promoção da conscientização dos pais em relação à educação dos filhos.

É uma característica dessa escola o investimento na formação dos professores em contexto, auxiliando-os a compreender seu cotidiano para poder transformá-lo. E, dessa natureza de formação realizada, são também estabelecidas relações com as famílias para o compartilhamento dos percursos das crianças individualmente, por meio de relatos que as professoras fazem com apoio de documentações construídas ao longo do percurso.

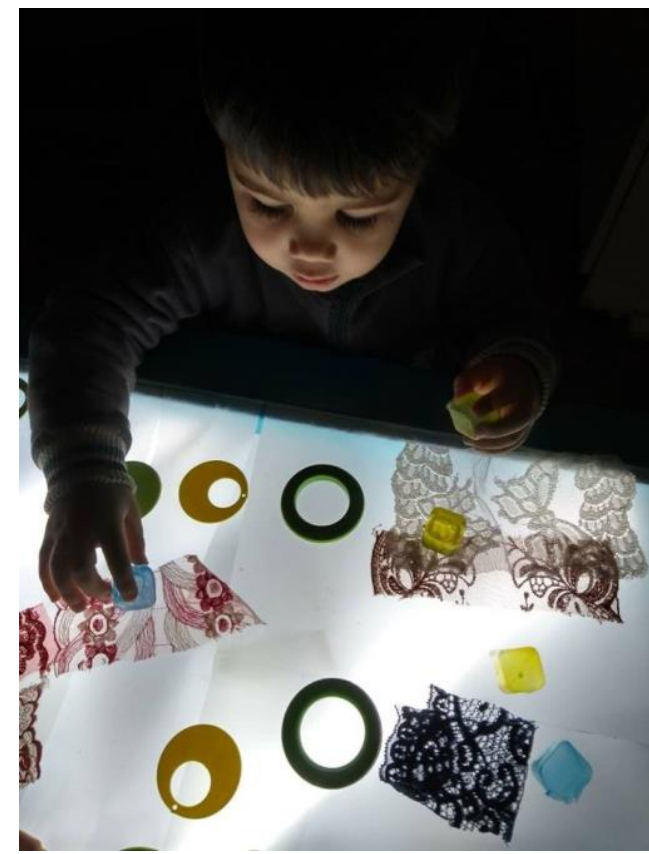

Anualmente é realizada a Mostra dos Observáveis, um momento para dar visibilidade aos percursos de investigação das crianças na escola. É uma oportunidade para as famílias participarem e experienciarem com as crianças um pouco das propostas desenvolvidas ao longo do ano.

Também, semestralmente, é feita a entrega de portfólios, um material que narra a trajetória (de quem?), oportunizando que as crianças e as famílias possam revisitar, refletir e compartilhar experiências vividas. Tal material possibilita às professoras dar visibilidade à escuta e observação feitas dos percursos e teorias pelos quais passam as crianças. Além disso, a escuta e a observação revelam suas preferências, a forma como se relacionam com as propostas, seus parceiros preferidos, suas narrativas: uma comunicação dos processos vividos na escola. Os pais também são constantemente convidados a participarem de situações da vida cotidiana da escola: para contar uma história, fazer uma receita, tocar um instrumento. Também são realizadas, mensalmente,
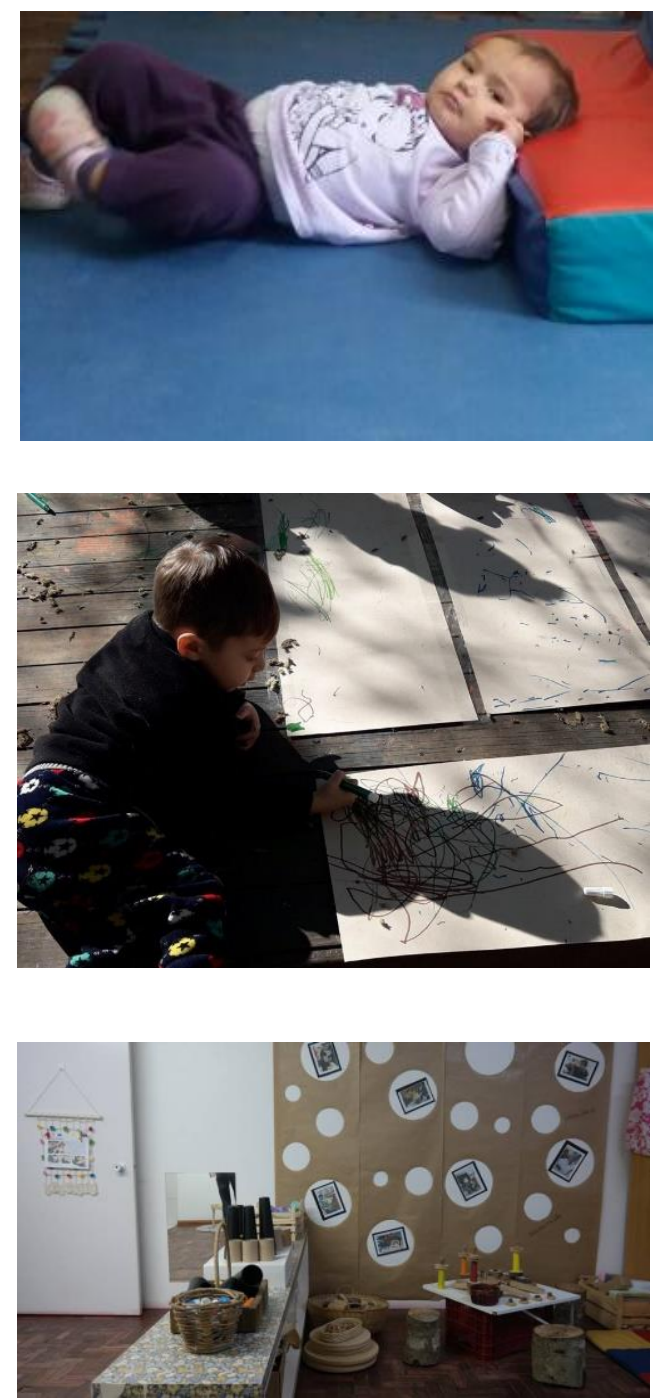
reuniões com a Associação de Pais com o objetivo de envolvê-los na organização de atividades para arrecadar fundos para a escola, fazer alguns reparos e discutir temas sobre seu funcionamento.

O trabalho com o Brincar Heurístico também se transformou em uma marca da prática pedagógica dessa escola. Desde a sua entrada no OBECI, a proposta com o brincar heurístico caracteriza-se, na escola, como estratégia escolhida para ajudar os professores a compreenderem melhor as dimensões do trabalho pedagógico na creche, valorando a competência e o protagonismo das crianças em descobrir o mundo por elas mesmas.

As práticas da vida cotidiana, como comer, deslocar-se pela escola, realizar a higiene e o descanso, são temas caros à João de Barro, o que, por sua vez, têm se transformado em um tema de muito investimento na qualificação desses momentos.

A EMEI, atualmente, atende cerca de 105 crianças com idade referente à creche (faixa etárias de 4 meses a 3 anos). A atual diretora é Luciane L. e a coordenadora pedagógica, Alexandra.
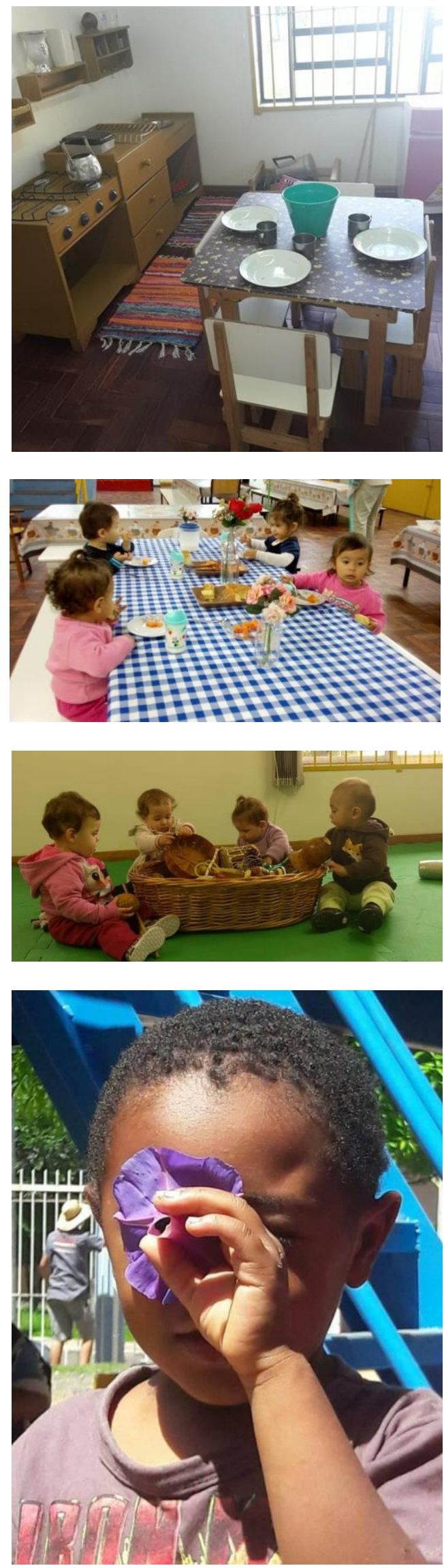


\subsubsection{EMEI Joaninha ${ }^{79}$}

A EMEI Joaninha também integra a rede pública de Novo Hamburgo e situa-se no maior bairro do município, Canudos, que ultrapassa o número de oitenta mil habitantes. Nesse bairro, há problemas relacionados ao saneamento básico, violência, invasões e ocupações de terrenos, depósito de lixos em locais inadequados, enchentes. Portanto, o tipo de serviço que essa escola oferece a essa comunidade é de grande valor cultural e pedagógico.

Foi inaugurada, em outubro de 2013, a partir do Programa Nacional de Reestruturação e Aquisição de Equipamentos para a Rede Escolar Pública de Educação Infantil (Proinfância), obra do Governo Federal em parceria com os municípios. O prédio da escola é uma construção do Proinfância, padrão tipo $\mathrm{C}$, portanto, com capacidade de atendimento para aproximadamente 88 crianças.

O nome da escola faz referência a um típico peixe encontrado na região, peixe Joaninha. A proposta de nomear as instituições de Educação Infantil com palavras referentes à fauna e flora local da Bacia dos Sinos é um projeto oriundo da Secretaria Municipal de Educação, com o intuito de sensibilizar e dar a conhecer a população local sobre todas as formas de vida e do ecossistema da região.

Há um amplo pátio externo e pequenos solários interligados às salas referência que tem sido explorado e enriquecido pelo trabalho das professoras e da escola: espaço de desafios, de descobertas, de
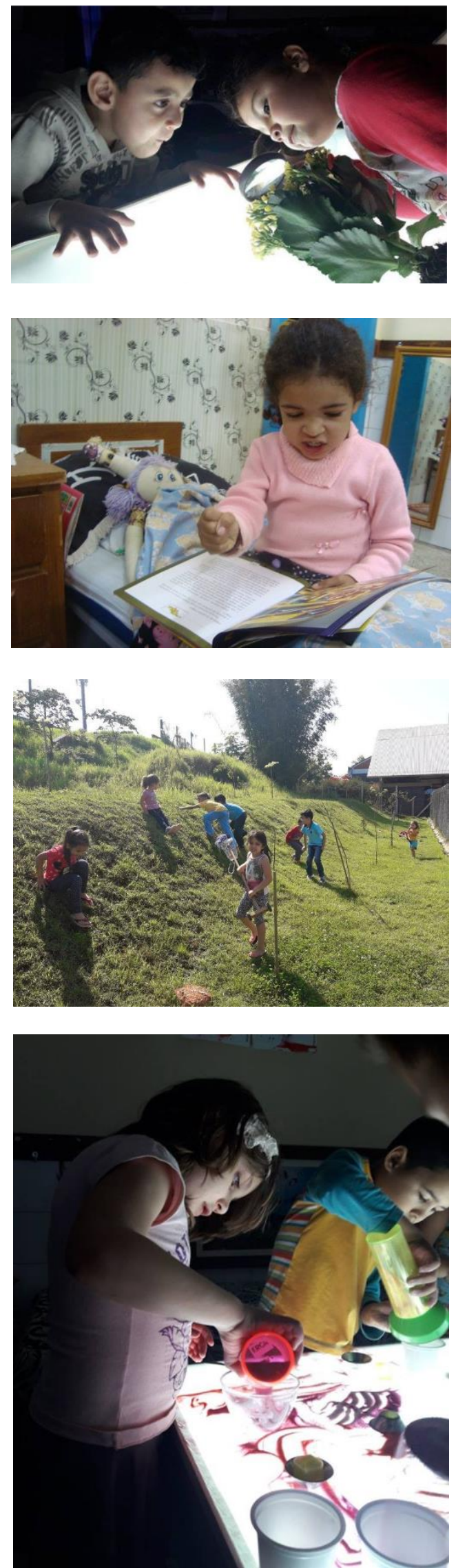

79 Agradeço a disponibilidade de Juliana e Liliane no apoio necessário para a recolha de informações, bem como o material elaborado pela Mimo de Gente, em 2017, na ocasião das visitas das escolas amigas. 
construir segredos e de compartilhar brincadeiras, algo que não se difere do interior de cada sala. As salas referências têm se estruturado para responder a aspectos importantes que temos desenvolvido dentro do OBECI: descentralizar do adulto a prática pedagógica por meio das opções diversas de espaços circunscritos para as brincadeiras das crianças e para a possibilidade de se agruparem em pequenos grupos conforme a característica de cada faixa etária.

Em consonância com o propósito da criação de unidades do Proinfância, a EMEI Joaninha é um local de grande investigação e reflexão sobre o trabalho pedagógico na Educação Infantil. A escola tem como objetivo permanente construir um cotidiano de qualidade para as crianças e adultos. Para isso, nas formações, pensamos e refletimos sobre as práticas cotidianas, sempre colocando a criança no centro do projeto educativo, fazendo escolhas pedagógicas pautadas em propostas significativas, assim como fazendo uma escuta sensível e respeitando a individualidade de cada uma.

Em 2015, quando entrou no OBECI, esse percurso ganha acento e direcionamentos importantes. Atualmente, a EMEI é uma grande referência para o trabalho com o Brincar Heurístico, transformando como um dos projetos estruturantes para o trabalho da escola. Logo, a EMEI Joaninha tem professor que atua especificamente com o trabalho do brincar heurístico, investigando e documentando os processos heurísticos dos meninos e meninas.
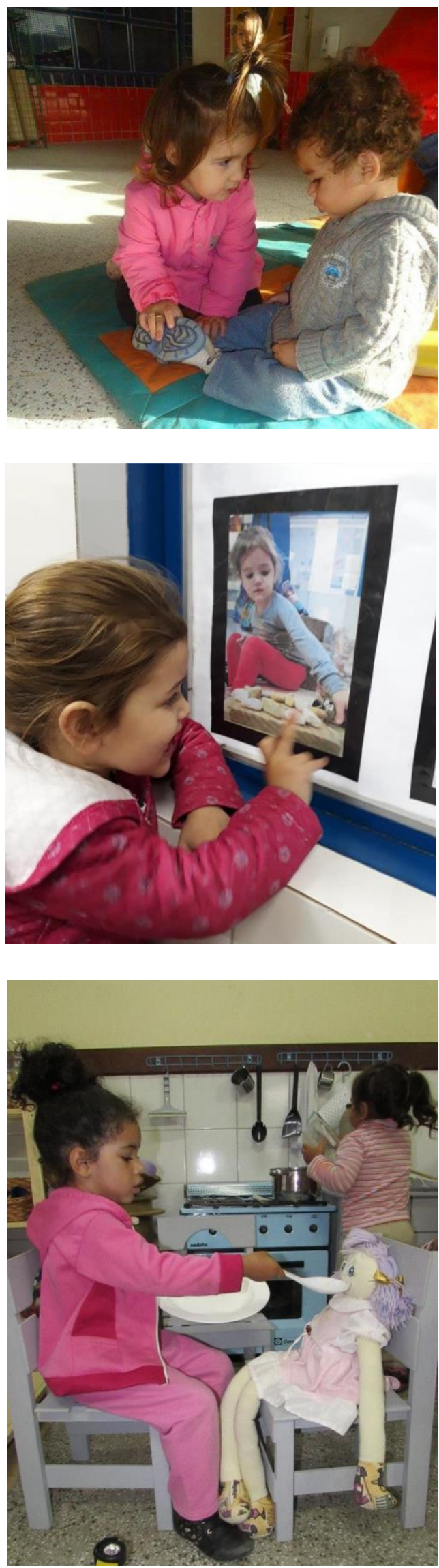
Outra característica da escola é o trabalho em pequenos grupos, tanto na jornada quanto nas sessões, o que qualifica a aprendizagem das crianças e contribui para um olhar mais individualizado sobre cada uma.

Também virou uma marca da escola o trabalho com as mini-histórias, servindo como estratégia de comunicação e diálogo com a comunidade educativa. Narrar imagética e textualmente as rapsódias da vida cotidiana tem ajudado as professoras dessa EMEI a compreender melhor as crianças e, com isso, construir pautas para o próprio trabalho. $\mathrm{O}$ trabalho dessa escola com as mini-história e com as investigações sobre o Brincar Heurístico é fortemente sustentado pelas condições de diálogo e partilha entre as professoras e a coordenação pedagógica.

Essa instituição atende crianças da faixa etária de 1 ano aos 4 anos; excetuando as turmas das crianças de 4 anos, as demais são em turno integral. Na escola, há uma Associação de Pais e Mestres, desde 2014, e, bianualmente, é realizada eleição para a composição dos representantes. A atual diretora é Juliana e a coordenadora, Liliane.
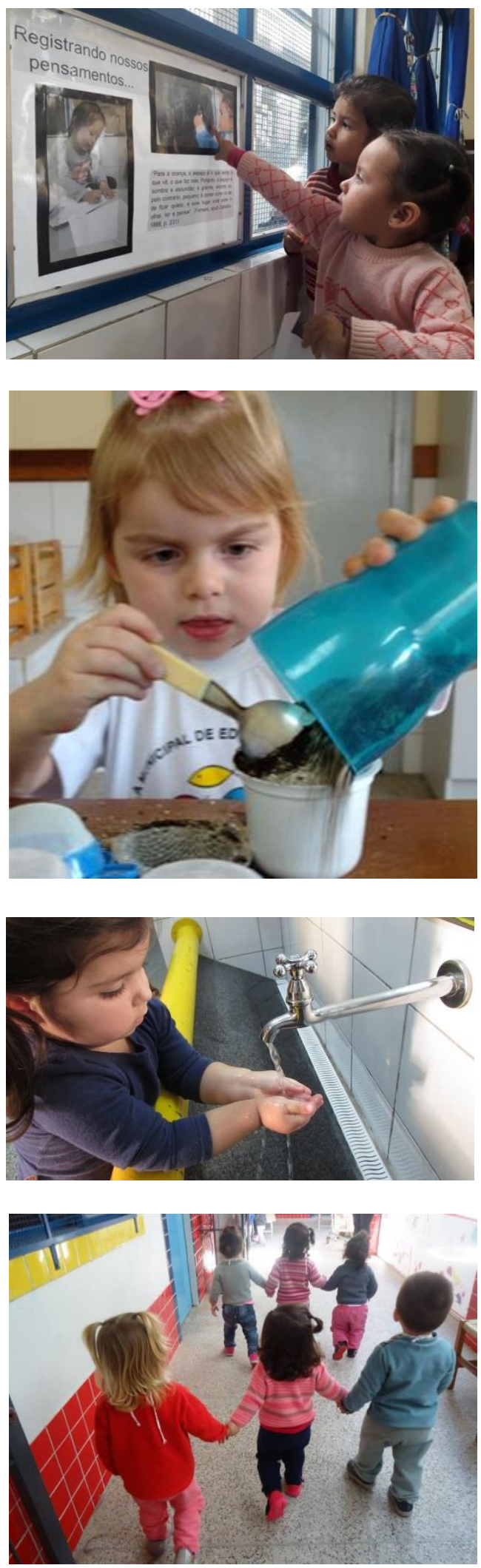


\subsubsection{Espaço Girassol ${ }^{80}$}

A Espaço Girassol é uma instituição privada, no município de Canoas, em uma rua tranquila que se pode escutar as sonoridades da infância. A escola foi fundada por Silvana, que também ocupa o papel de diretora pedagógica, e começou a ser projetada em 1999 com o propósito de construir uma escola diferenciada em termos filosóficos e pedagógicos. Algumas das fontes de inspiração para a construção da escola foram a Pedagogia Waldorf e o pensamento de Maria Montessori. A busca era construir um prédio que não se distanciasse tanto da ideia de uma casa para poder ser o mais amável possível no acolhimento das crianças.

Em 2002, a escola foi inaugurada com uma criança matriculada e outras cinco crianças, filhas de pessoas próximas à escola, situação que ofereceu à própria Espaço Girassol a possibilidade de ir compreendendo como ela poderia se constituir.

O nome, Espaço Girassol, revela a intenção da instituição, desde o princípio, em converter-se em um espaço de relação com a natureza. Esse valor é traduzido no amplo espaço externo, composto por hortas, fonte, mandala de temperos e ervas, árvores frutíferas, desníveis no solo, flores e animais que visitam o pátio.

A Espaço Girassol foi precursora na cidade, estabelecendo um marco divisor, por ser a primeira escola de Educação Infantil construída especialmente para atender a primeira infância, tornando concreto o
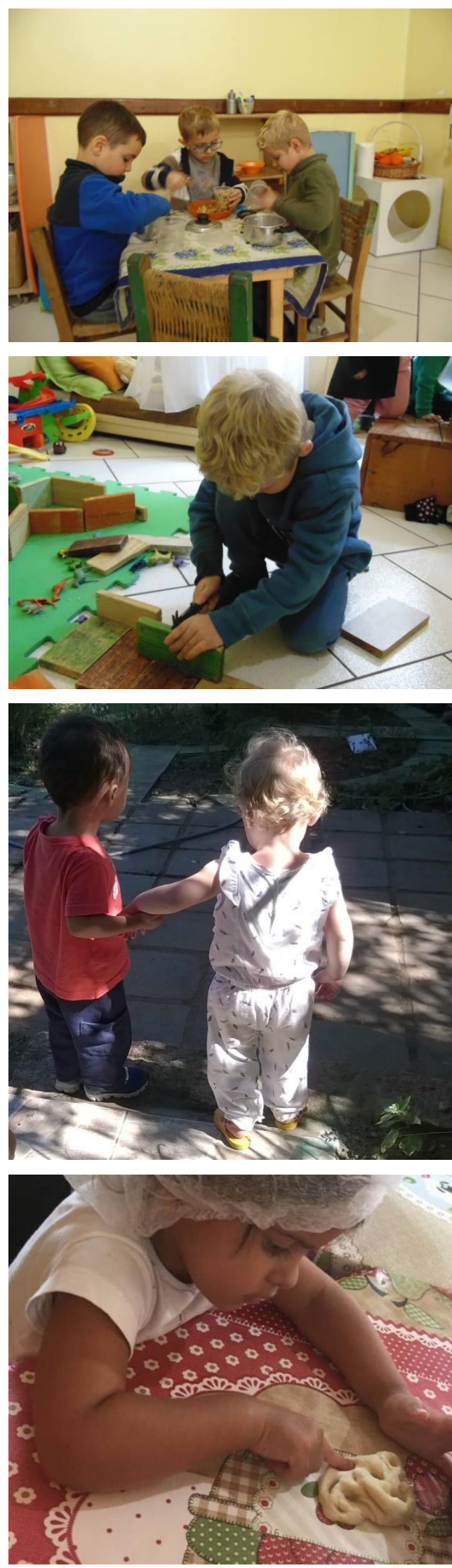

${ }^{80}$ Agradeço a disponibilidade de Silvana, Carolina e Gilneia no apoio necessário para a recolha de informações, bem como o material elaborado pela EMEI João de Barro, em 2017, na ocasião das visitas das escolas amigas. 
conceito de que o atendimento à criança deve ser pensado e organizado de modo específico e baseado em pressupostos teóricos. O espaço físico da escola por si só fala da importância que a Educação Infantil merece e que, na época de sua inauguração, não era comum na cidade. A organização dos espaços na escola e a forma como estruturou aspectos de seu funcionamento, como o livre acesso dos pais, a disposição das salas convergentes para uma área central, o não uso de uniformes, a forma personalizada de acolher as famílias no processo de adaptação e olhar a criança, a não adoção de materiais pedagógicos massificados, a proposta alimentar e o contato com a natureza, entre outros tantos que fizeram da Espaço Girassol uma escola diferenciada, concretizam concepções fundantes da pedagogia que a escola acredita.

A escola percorreu uma caminhada de onze anos antes de ingressar no OBECI, e, nesse período, foi se afirmando em suas propostas pedagógicas e, acima de tudo, promovendo a especialização de sua equipe de trabalho.

Em 2013, a Espaço Girassol iniciou no OBECI, desde então a escola participa do Observatório. O OBECI veio complementar o trabalho já existente e alavancou mudanças significativas, trazendo questionamentos e iniciando um ciclo de transformações na escola. Passa-se, então, a observar com olhar crítico para toda a organização pedagógica e a gestão a fim de garantir o protagonismo infantil e o respeito à infância, abandonando algumas práticas automatizadas. Mudanças começam a ocorrer a partir do exercício de pensar sob a perspectiva da criança, e
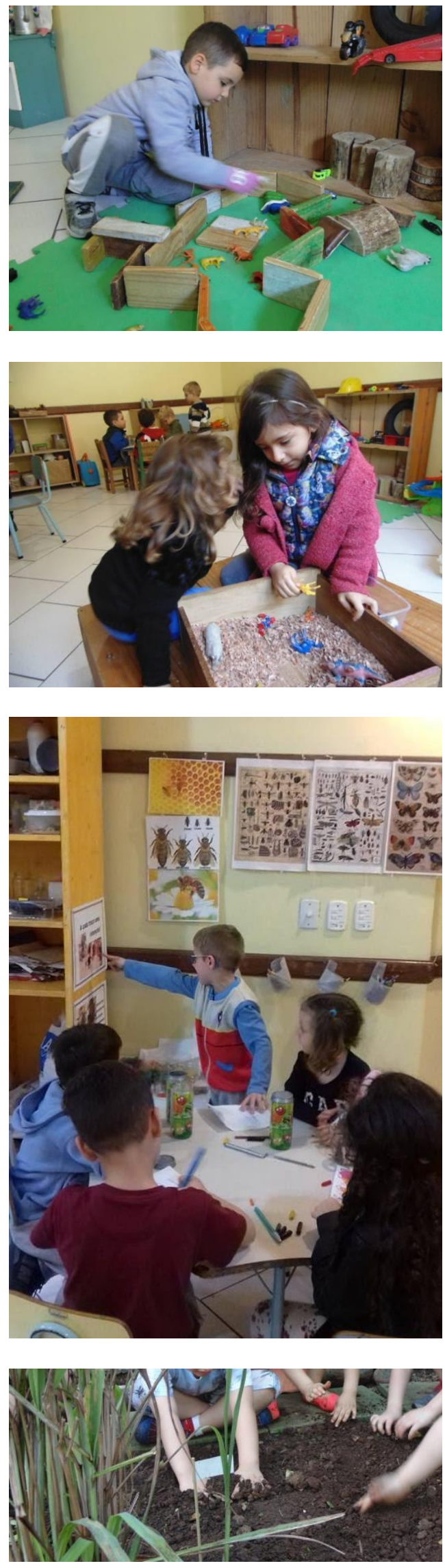
reconfiguram-se, na escola, o questionamento sobre as datas comemorativas, a organização dos espaços e do tempo, a estruturação de um espaço para o exercício da cidadania e da prática política, a reorganização dos momentos de alimentação, a forma de comunicar o processo de aprendizagem das crianças, o planejamento da jornada de trabalho, o acolhimento das famílias e, mais recentemente, de forma específica, a prática com o Brincar Heurístico e os Ciclos de Simbolização.

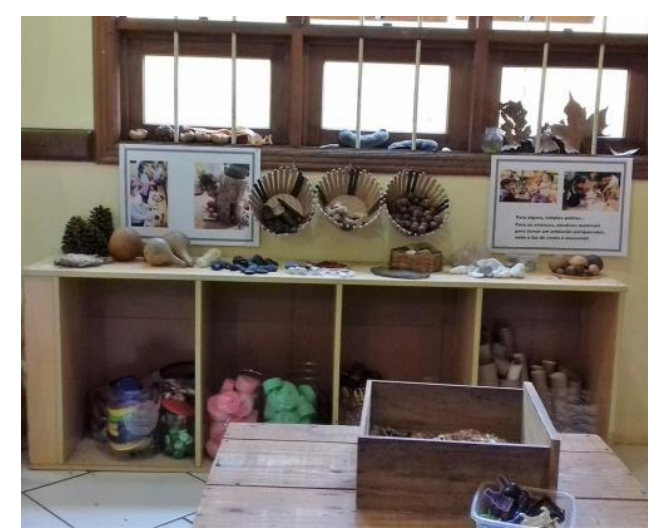

Nesse período, a escola/equipe sentiu a necessidade de fortalecer e evidenciar sua proposta e, provocada pelo OBECI, construiu os Referenciais da Espaço Girassol, que são cinco: Aprendizagem Protagonizada, Bem-estar, Educação ambiental, Relação escola-comunidade, Competências socioemocionais. É através deles que todas as ações e propostas são desenvolvidas dentro da escola.

As propostas oferecidas para cada faixa etária também foram repensadas, levando em consideração as necessidades e interesses das crianças. As investigações com os Ciclos de Simbolizações ocupam o lugar dos antigos projetos inflexíveis e descontextualizados, possibilitando uma aprendizagem mais participativa e real para as crianças. Assim como o Brincar Heurístico que, a cada sessão, possibilita descobertas tanto para as crianças, quanto para as educadoras, ao desconstruir uma prática centralizada no adulto, potencializando a observação, a escuta e a reflexão.

Ao pensar em momentos que respeitem as crianças, a sua cultura e a sua família, a escola foi estabelecendo outras formas de ser escola e relacionarse com toda a comunidade. Desta forma, foram
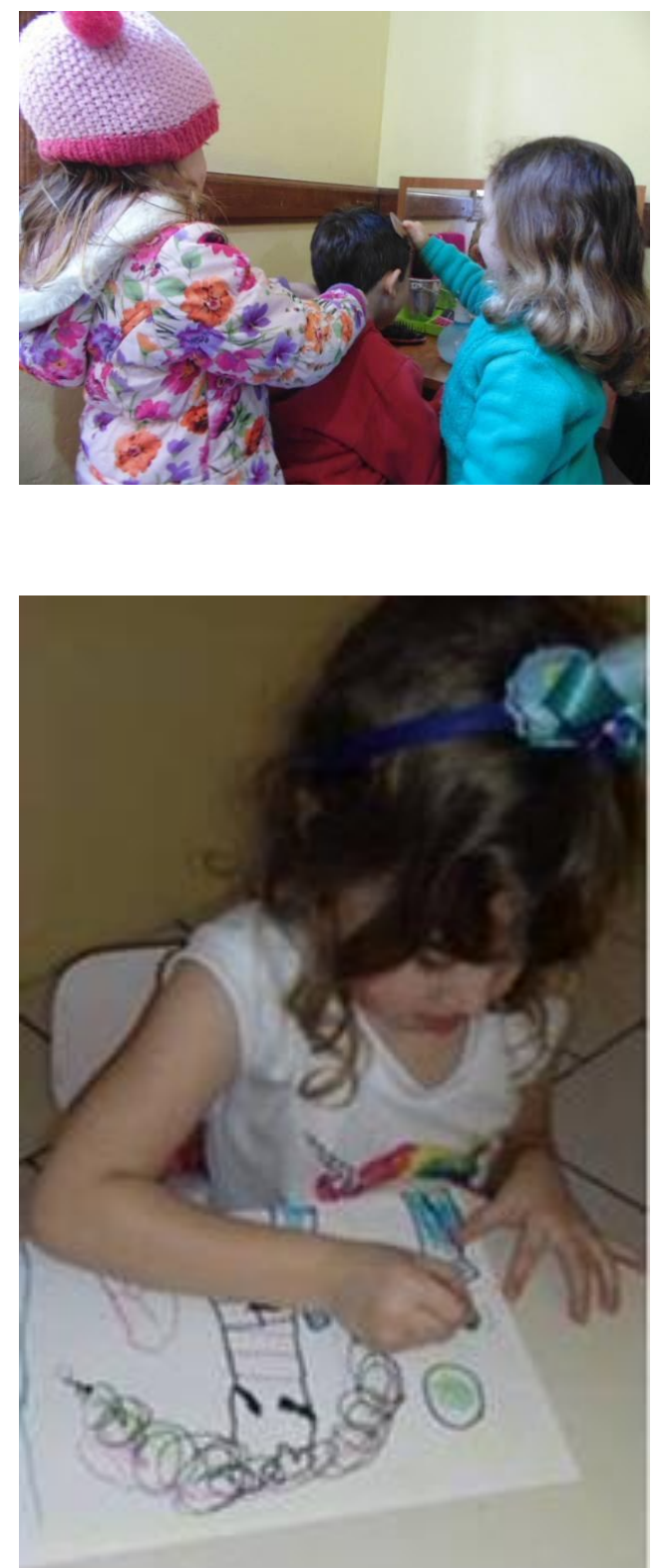
propostas atividades de integração e confraternização 
sem cunho religioso ou com viés de consumo, e, sim, privilegiando os encontros culturais verdadeiros e significativos para todos.

Atualmente a escola atende 84 crianças no horário das $7 \mathrm{~h}$ até as $19 \mathrm{~h}$, para todas as faixas etárias da Educação Infantil (4 meses a 5 anos e 11 meses). A diretora é Silvana, que conta com o apoio da coordenadora Carolina e da psicóloga Gilneia.

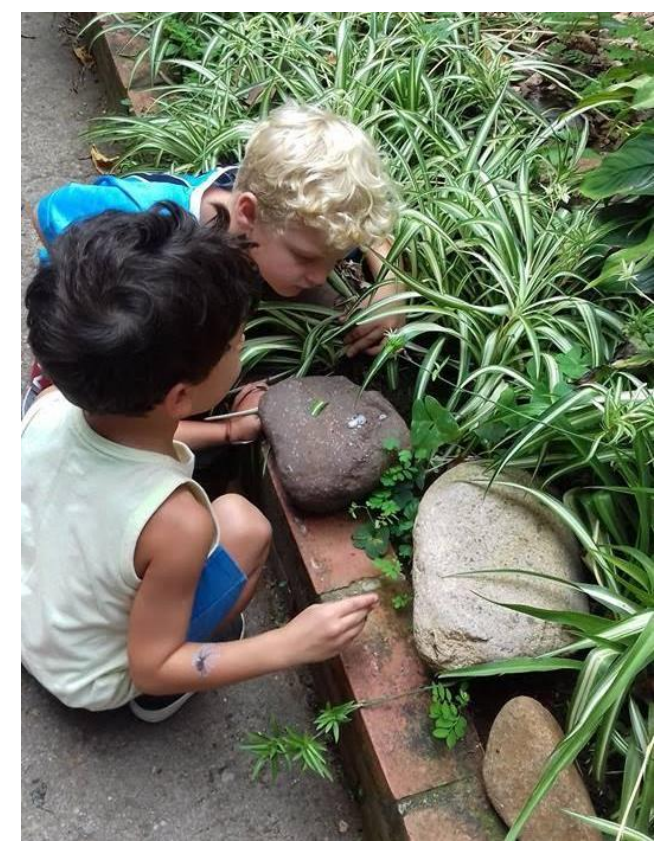




\subsubsection{Escola de Educação Infantil Mimo de Gente ${ }^{81}$}

A Escola de Educação Infantil Mimo de Gente começou sua história em 1990 com o nome de Creche e Hotelzinho Gente Miúda. Desde 2000, a escola foi comprada pela atual diretora, Ivana, e mudou não apenas o nome, como as concepções que a escola tem construído ao longo desses 28 anos.

A escola atende cerca de 200 crianças de toda a faixa etária da Educação Infantil (4 meses a 5 anos e 11 meses), e em horário bastante ampliado, já que há muitos anos tem um convênio de atendimento para funcionários de uma rede de hospitais, das 6h30min às 19h30min.

A instituição funciona em uma casa adaptada, de quatro andares. O pátio não é muito amplo, é irregular, com rampas e escadas. No entanto, é um espaço repleto de desafios que serve de palco para muitas brincadeiras inventadas pelas crianças ou provocadas pelas professoras.

Nas salas referência, a transformação dos espaços também foi um motor para a mudança de
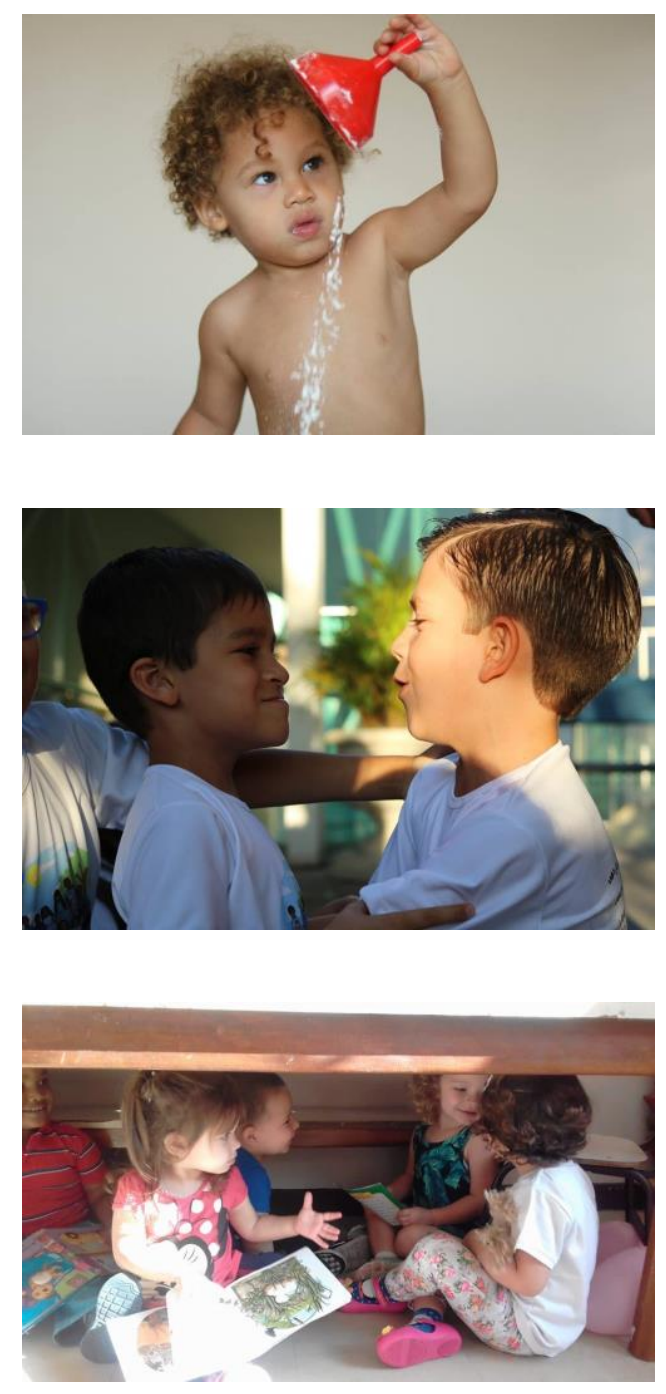
concepções e práticas. As salas se transformam ao longo do ano, de acordo com a proposta, necessidades, interesses e idade das crianças, partindo-se de observáveis que fazem olhar, refletir, pensar em possibilidades e agir. A construção de pequenos espaços nas salas convida a todos para longas brincadeiras e novas investigações.

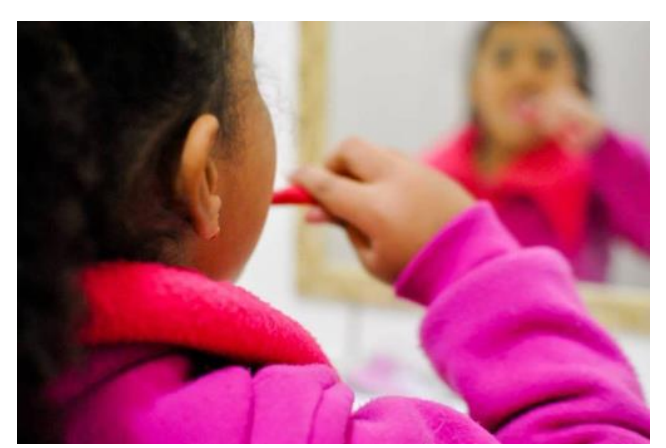

81 Agradeço a disponibilidade de Ivana e Vanessa no apoio necessário para a recolha de informações, bem como ao material elaborado pela SMED NH, em 2017, na ocasião das visitas das escolas amigas. 
É uma escola aberta para ouvir os pais e preocupada em atender cada criança nas suas necessidades; por isso, pensa e desenvolve possibilidades para incluir meninos e meninas em suas singularidades.

A Mimo tem uma biblioteca com uma vasta coleção de livros infantis. Essa biblioteca é conhecida como "Mimoteca". A mediação de leitura é pensada como um dos grandes valores da escola; por isso, buscam-se diversas alternativas para colocar as crianças em contato com a literatura. Essa é uma maneira de espalhar e provocar o hábito da leitura.

Desde 2013, a escola faz parte do OBECI e, atualmente, uma de suas fortalezas é o trabalho com o Brincar Heurístico, que se fortaleceu dentro da escola, transformando-se em uma prática cotidiana. A partir do Brincar Heurístico, as professoras têm descoberto o valor da documentação da prática como estratégia para auxiliar a desnaturalizar o óbvio e a transformar o modo como se relacionam com as crianças. Além disso, essa estratégia tem contribuído fortemente para repensar o papel do adulto, a seleção dos materiais e a organização dos espaços e do tempo.

Há um grande investimento na formação dos professores, iniciando o ano com a Jornada Pedagógica interna. Além disso, também são convidados profissionais a participarem de cursos externos à escola, e, mensalmente, acontecem reuniões de formações com a equipe a fim de discutir e alinhar questões referentes ao trabalho com as crianças.
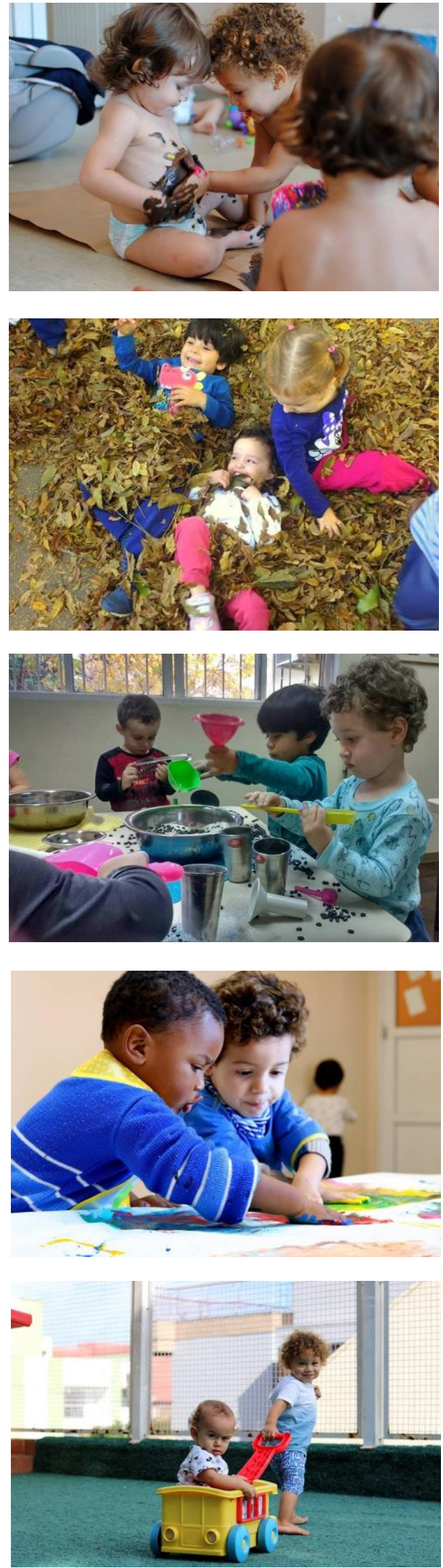
Outra fortaleza da Mimo de Gente são as fotografias. $\mathrm{O}$ modo como as profissionais da escola capturam a ação das crianças são reveladoras da transformação do olhar da própria instituição como um todo, que vem percebendo cada vez mais a complexidade e a força que existem em cada gesto e olhar dos meninos e meninas.

A partir do GIA dos Ciclos de Simbolização, a escola está apostando no investimento do desenho da criança e tem espalhado as marcas das crianças em toda escola, incluindo as sinalizações do interior da instituição. Esses desenhos também estampam as camisetas dos funcionários e das crianças, que, orgulhosas, vestem e mostram as belas imagens. Geralmente todo material gráfico produzido na escola provém dos desenhos infantis.

A escola também incentiva a autonomia dos meninos e meninas com pequenas ações, como servirse durante as refeições do que quer comer, escolher se irá dormir ou não, transitar pela escola para ir ao banheiro ou dar recados a outras turmas, trocar de ambientes sem fila. Estes e outros processos são observados e analisados para que mais possibilidades possam ser oferecidas às crianças.

A Escola Mimo de Gente é, na definição da própria instituição, um lugar onde a criança brinca, convive e aprende. A diretora é a Ivana e a coordenadora pedagógica, Vanessa.
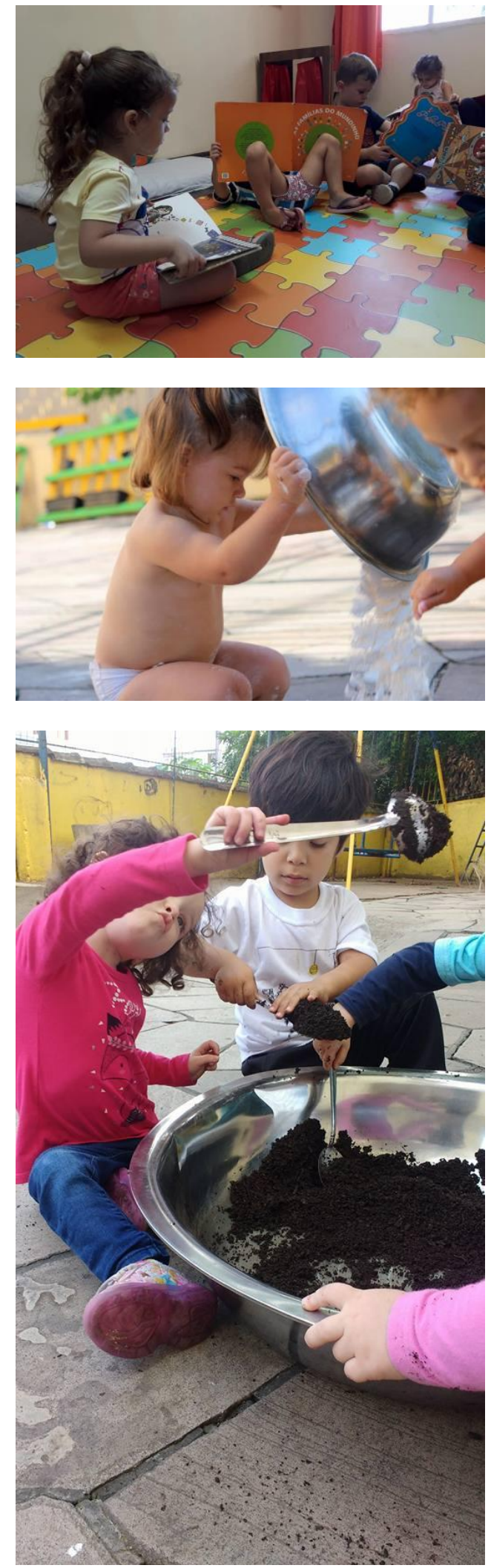


\subsection{As ideias assumidas como guias do trabalho}

Na natureza de organização do OBECI, partilhar algumas ideias para orientar a prática pedagógica é estruturante. Além de ser uma grande aprendizagem em nível de cooperação, negociação e respeito sobre o percurso de cada uma das instituições, é o que nos conecta e cria um espaço possível de diálogo e de confronto sobre os processos e conteúdos formativos que partilhamos. Por outro lado, isso não significa cancelar as diferenças das escolas porque, ao contrário, essa diversidade é o que torna o encontro dessas instituições uma oportunidade privilegiada para aprender, conhecer, refletir e qualificar a própria experiência.

O conhecimento que emerge do OBECI é resultado da relação pensante entre aquilo que as escolas estão fazendo, a herança pedagógica a qual escolhemos nos filiar e o modo como estamos refletindo e confrontando o contexto das escolas com as escolhas que fizemos. Por isso, é um conhecimento contextualizado, provisório e fundamentado em um quadro teórico.

Nesse sentido, mesmo na diferença de cada uma das instituições e dos profissionais que compõem o OBECI, também tivemos que encontrar alguns pontos de contato para efetivamente nos constituirmos como uma comunidade de apoio ao desenvolvimento profissional. Assim, desde o princípio, circunscrevemos algumas ideias em comum como guias do nosso trabalho. Essas ideias são o que Oliveira-Formosinho (2016b) chama de saliências partilháveis, ou seja, postulados para o trabalho pedagógico celebrado em cada instituição, que, dada a confluência com aqueles postulados pelas outras instituições e pelo próprio OBECI, criam um elo de partilhada e de possibilidade de desenvolvimento em conjunto.

Como desde o princípio o OBECI optou em trabalhar a partir dos pressupostos da Documentação Pedagógica, automaticamente já nos vinculamos a um determinado tipo de pedagogia, a família das pedagogias participativas (OLIVEIRA-FORMOSINHO, 2007). Logo, as escolas que passaram a compor o Observatório precisavam se sentir identificadas, ou interessadas a esse modo de fazer e pensar a pedagogia.

Para Oliveira-Formosinho (2007, p. 18), “a pedagogia da participação centra-se nos atores que constroem o conhecimento para que participem progressivamente, através do processo educativo, da(s) cultura(s) que os constituem como seres sócio-histórico-culturais". Neste modo de pensar e fazer pedagogia, as crianças e os adultos partilham e participam da construção de suas jornadas de aprendizagem. Reconhece-se, portanto, a agência dos diferentes sujeitos envolvidos no processo de construção de significados e, por isso, parte-se do 
pressuposto de que o conhecimento que a humanidade vem construindo está em contínuo desenvolvimento.

As pedagogias participativas acolhem diferentes modelos pedagógicos, são plurais, e, ao contrário da pedagogia transmissiva, é na explicitação do conhecimento em nível da teoria, dos princípios e da ética que é possível a transformação do cotidiano praxiológico. Como já afirmou João Formosinho (2013, p. 16), “para a renovação da prática pedagógica das escolas na direção de uma prática fundamentada, é essencial a sua transformação em práxis pedagógica, o que só se pode realizar utilizando pedagogias explícitas.”

No Observatório, nosso quadro referencial se estabelece a partir de modelos pedagógicos e pedagogos das famílias das pedagogias participativas, tais como Loris Malaguzzi e a experiência de Reggio Emilia (Reggio Approach), Elinor Goldschmied, Emmi Pikler e o Instituto Pikler-Loczy, a Pedagogia-em-participação, John Dewey, Gianfranco Staccioli, Penny Ritscher, Alfredo Hoyuelos, entre outros. Buscamos, nessa herança teórica, "a ruptura com a pedagogia transmissiva através da desocultação dessa naturalização que está por detrás da perpetuação da pedagogia transmissiva e através da proposição de uma práxis pedagógica alternativa fundamentada em teorias" (FORMOSINHO, 2013, p. 20).

Também temos dialogado com outros campos do conhecimento, tais como o design, a arte, as ciências naturais, a arquitetura, a filosofia, a psicologia, entre outras. No entanto, nossos diálogos não ocorrem por subordinação a esses outros campos, mas como possibilidade de ampliação e enriquecimento das possibilidades dos debates pedagógicos. Afirmamos a Pedagogia como a ciência que responde à complexidade da escola de Educação Infantil.

Com esse quadro referencial, vamos construindo uma constelação teórica própria que nos ajuda a fundamentar nossa prática e a apoiar nossos diálogos. A explicitação e a contextualização desse referencial é o que tem sustentado a transformação tanto em nível das práticas pedagógicas nas escolas, como na formação dos profissionais e na investigação. Formosinho (2013, p. 16) afirma que "a pedagogia baseia-se num saber práxico organizado em torno dos saberes que se constroem na ação situada, em articulação com as concepções teóricas e com as crenças e valores". Nesse sentido, a Pedagogia que comungamos não se faz por meio de aplicação ou aproximação de teorias, tampouco de uma prática que se fundamenta na ausência reflexiva dos práticos, que acabam se apoiando em um modus operandi assentado na tradição. Mas a Pedagogia se faz e se refaz na interatividade de uma práxis contextualizada e fundamentada em uma herança teórica explícita: 
Em síntese, a interatividade entre saberes, práticas e crenças, a centração nos atores como co-construtores da sua jornada de aprendizagem em um contexto de vida e de ação pedagógica determinado, através da escuta, do diálogo e da negociação, conduzem a um modo de fazer pedagógica caleidoscópico, centrado em mundos complexos de interações e interdependências, promovendo interfaces e interações. Esse modo de fazer pedagógico configura a ambiguidade, a emergência, o imprevisto como critério do fazer e do pensar, produzindo possibilidades múltiplas que definem uma pedagogia transformativa. Estas são características que fogem à possibilidade de uma definição prévia total do ato de ensinar e aprender, exigindo a sua contextualização cotidiana (OLIVEIRA-FORMOSINHO, 2007, p. 19).

Com esse grande pano de fundo das pedagogias participativas, reposicionamos as crianças e os adultos na relação educativa. Por isso, tem sido muito importante compreender quais são as ideias que temos tomado como postulados do Observatório para guiar as reflexões e problematizações que dele emergem. Compreender e significar tais ideias atravessa obrigatoriamente a reflexão sobre a própria prática, sobre o exercício político exercido no cotidiano das escolas. Considero político tal exercício, pois envolve aquilo que Pinazza (2014, p. 55) chama de “[...] uma ação engajada moralmente [...]", ou seja, trata-se de um posicionamento do sujeito, de um modo de estar implicado em um contexto. Assim,

\footnotetext{
Atuar na educação implica uma ação engajada moralmente e orientada para a compreensão ampliada dos processos educativos, visto pelos seus impactos sobre a vida dos indivíduos e da coletividade, em uma perspectiva temporal que extrapola o plano do imediato (PINAZZA, 2014, p. 55).
}

Para dizer de outro modo, compreender os impactos daquilo que diariamente estamos fazendo nas creches e pré-escolas demanda desnaturalizar matrizes fortemente constituídas em cada adulto que opera dentro das instituições. Assim, para produzir rupturas, o que buscamos é criar um espaço legítimo para as dúvidas e perguntas. Talvez, dessa forma, seja possível constituir uma "formação que mobilize os professores, a partir de suas aprendizagens experienciais, providenciando oportunidade de interpretá-las e reconstruí-las por meio do exercício reflexivo individual e coletivo" (PINAZZA 2014, p. 55).

Nesse mesmo sentido, também compreendemos que a construção de um quadro de ideias partilhadas se aproxima do que Oliveira-Formosinho e Formosinho (2002, p. 27) apontam sobre a tipologia de intervenção da Associação Criança, pois afirmam que, em tal associação, existe um processo de intervenção “[...] co-operada (operada conjuntamente), o que implica necessariamente co-laboração (laboração em conjunto)". Ademais, "essa característica de intervenção cooperada por colaboração exige um genuíno propósito de aceitar uma caminhada em comum. [...] A cooperação exige a progressiva partilha de um referencial educativo" (OLIVEIRA-FORMOSINHO; FORMOSINHO 2002, p. 27, grifo dos autores). Sobre esse referencial educativo partilhado, falarei brevemente a seguir. 


\title{
1.3.1 A criança e o currículo
}

Para ser coerente com as ideias antes postuladas a respeito de um modelo de escola que investiga e, por isso, se situa em modelos epistemológicos relacionais e nas pedagogias participativas, no OBECI, também temos nos interrogado sobre as noções de criança e currículo para compreender de que modo estabelecer a conexão entre esses dois campos (ou forças, nos termos de Dewey) que, muitas vezes, são colocados como opostos. Dewey (2002, p. 157), problematizando a respeito da criança e do currículo, afirmará que "o processo educativo é exatamente a interação destas forças. Esta visão, de uma em relação à outra, como facilitadora de uma interação mais completa e livre é a essência da teoria educativa". Para esse autor, quando transformamos a criança e o currículo como antagonistas e damos centralidade no que separa, inventamos um problema e não colocamos a devida energia no aspecto prático do conflito.

Assim, Dewey (2002) aponta que, se nos centrarmos no conflito, poderemos compreendê-lo sem perder a natureza relacional de cada um dos lados, enquanto que a nossa tradição insiste em colocar um em oposição ao outro e, com isso, anula a relação existente. Logo, é se mantendo no antagonismo entre criança e currículo que nascem as seitas, e, novamente, ou optam por abandonar a criança a sua própria sorte (pedagogias não diretivas), ou optam em artificializar a articulação dos saberes e da experiência da criança com a cultura (pedagogias diretivas). Assim,

\begin{abstract}
Em oposição fundamental entre a criança e o currículo, colocada por estas duas doutrinas, pode ser duplicada numa série de outros termos. A "disciplina" é a palavrachave daqueles que defendem o curso de estudos; o 'interesse' aquela dos que proclamam 'a criança' na sua bandeira. A posição dos primeiros é logica, a dos segundos psicológica. A primeira realça a necessidade de um treino e de uma erudição adequados da parte do professor; a segunda, a necessidade de simpatia para com a criança e o conhecimento dos seus instintos naturais. 'Orientação e controle' são o slogan de uma escola; 'liberdade e iniciativa', o da outra. A lei é afirmada ali, a espontaneidade proclamada aqui. $O$ antigo, a conservação do que foi conquistado com dor e trabalho ao longo dos séculos, é querido de uma; o novo, a mudança e o progresso, ganha a afeição da outra. A inércia e a rotina, o caos e a anarquia, são acusações arremessadas de parte a parte. A negligência da autoridade sagrada do dever é atacada por um dos lados, para se defrontar com o contra-ataque da supressão da individualidade por um despotismo tirânico (DEWEY, 2002, p. 162).
\end{abstract}

Em meio a esses binarismos, um lado precisa exterminar o outro, pois sacraliza ou a criança ou o currículo. Isso porque não se percebe a interatividade que há entre os interesses e ideias das crianças com os significados e valores sociais construídos pela sociedade. Logo, Dewey (2002, p. 163) advoga que "olhemos para a experiência como algo de fluente, 
embrionário e vital e compreendamos que a criança e o currículo são apenas dois limites que definem um só processo".

Compreendendo dessa forma, podemos nos centrar nas especificidades e limites entre as crianças e o currículo sem perder de vista a interação que há entre essas duas forças. Assim, Dewey (2002) segue afirmando que o mundo da criança tem como princípio a inteireza, e os significados e os sentidos são construídos a partir dos seus vínculos práticos e emocionais enquanto o currículo, em suas abstrações e necessidades de categorização, aproxima-se do mundo adulto e, por isso, deve servir como meio de interpretação do mundo da criança. Mais uma vez, o acento está na interação entre as condições internas das crianças (ímpeto por aprender) e as condições externas criadas pelo professor em nível de recursos e de interpretação. Para mostrar essa interação entre as crianças e o currículo, aqui entendido como mundo dos significados, tomo como exemplo essa mini-história, narrada pela professora Raquel, de um grupo de crianças de 5 anos a respeito de um grande debate sobre a diferenciação entre bicho e animal e do modo como negociam suas visões a respeito disso.
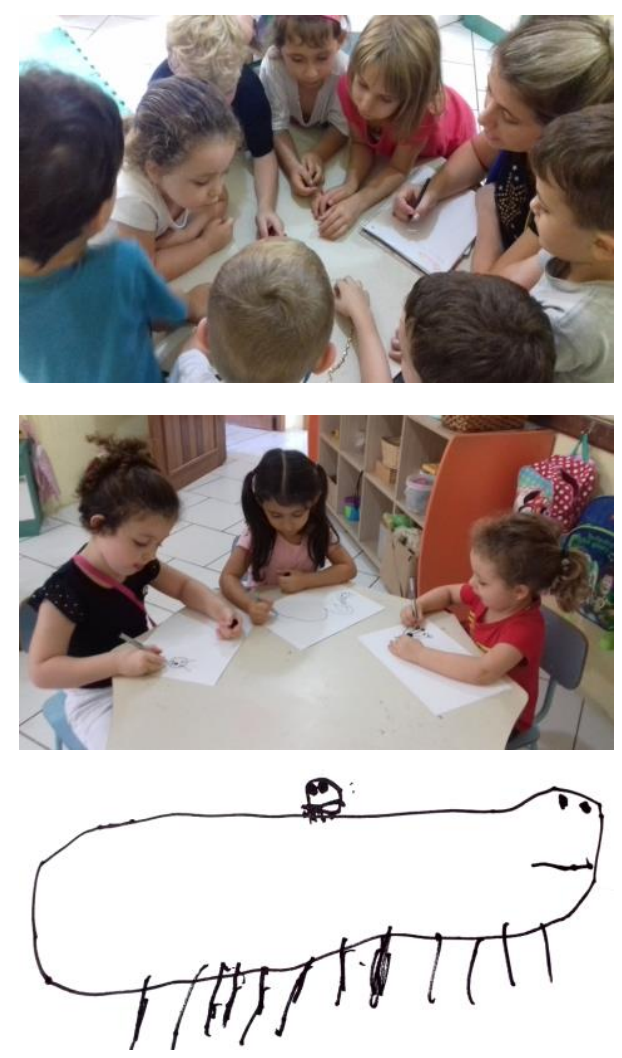

Sapo é um animal pequeno em cima do bicho pau. Marcos

\section{TEORIA BICHO ANIMAL}

Percebo uma discussão entre Valentina, Maria Clara e Francisco sobre a diferença entre bicho e animal. Valentina rapidamente afirma:

- Animais são grandes e bichos são muito pequenos. Os bichos já nascem adultos pequenos. E os animais nascem pequenos e crescem.

Francisco concorda com a amiga e cita exemplos:

- A girafa é um animal e a abelha é bicho.

Maria Clara afirma que os insetos que temos em nossa sala são bichos e não animais.

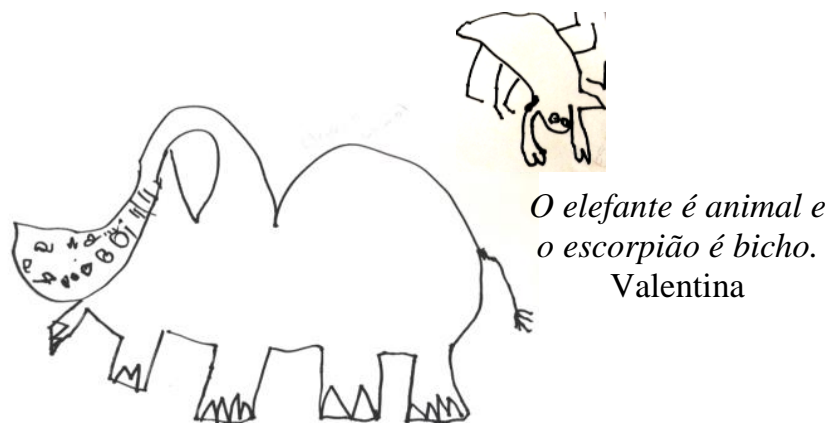


As crianças procuram construir teorias para explicar os acontecimentos que passam a perceber no seu entorno. Constroem teorias, como afirma Rinaldi (2012), ou seja, criam uma explicação plausível sobre algum fenômeno ao mesmo tempo que reconhecem sua provisoriedade e colocam sob negociação com seus pares e com os adultos. Por outro lado, como adultos, podemos traçar diversas conexões entre o modo como as crianças experimentam a explicação das diferenças entre o que é bicho e o que é animal com o modo como as ciências naturais, por exemplo, foram construindo categorizações sobre insetos, animais, etc. Nesse sentido, concordo com Rinaldi (2012, p. 205) que "os sentidos que as crianças produzem, as teorias explicativas que elas desenvolvem na tentativa de encontrar respostas são da máxima importância, pois revelam, de maneira vigorosa, como percebem, questionam e interpretam a realidade e seus relacionamentos com ela."

Assim, defendo que o grande propósito da Educação Infantil é criar condições para que as crianças se sintam encorajadas a construir explicações sobre o mundo, e não que sejam receptoras de um saber pronto e acabado. Para isso, o professor precisa aprender a ouvi-las e a restituir os modos como as crianças estruturam seus próprios mapas cognitivos, emocionais e sociais para não ficarem esquecidos ou apenas em nível de decoração.

Ao mesmo tempo, é preciso oferecer as condições externas para que as crianças possam tomar iniciativas e encontrar no contexto próximo delas os instrumentos para ajudá-las a nomear, explicar e significar os fenômenos. Logo, "o que importa não é dar valor a alguma coisa, mas, acima de tudo, entender o que há por trás dessas questões e teorias, e o que há por trás delas é algo verdadeiramente extraordinário” (RINALDI, 2012 p. 206).

É seguindo esse espírito que temos afirmado que nosso desafio tem sido o de reposicionar criança e adulto na relação educativa, e, para tal, uma das pistas tem sido compreender a relação entre a criança e o currículo.

Renunciamos ao discurso da criança vazia e passamos a acolher a dimensão histórica e cultural de cada menino e menina. Estamos abandonando a ideia de criança abstrata e começando a aprender a escutá-las em suas subjetividades. Estamos deixando de ver a criança de forma compartimentada e passando a percebê-la holisticamente. Temos um longo caminho para deixar de serem gerúndio as velhas visões e imagens de criança que marcam o modo como os adultos se relacionam com cada menino e menina e avançar para novas formas de se relacionar.

Esse deslocamento em que nos encontramos em relação à imagem da criança não é diferente se pensarmos na compreensão da identidade da Educação Infantil como a primeira 
etapa da Educação Básica. Já não nos serve a instituição assistencialista para as crianças, tampouco o que buscamos é a instituição que prepara para a etapa seguinte. A instituição de Educação Infantil é, segundo o Parecer 20/2009 que a orienta,

[...] espaço privilegiado de convivência, de construção de identidades coletivas e de ampliação de saberes e conhecimentos de diferentes naturezas por meio de práticas que atuam como recursos de promoção da equidade de oportunidades educacionais entre as crianças de diferentes classes sociais no que se refere ao acesso a bens culturais e às possibilidades de vivência da infância (BRASIL, Parecer 20/2009, p. 5).

E, como tal, a Educação Infantil, como espaço de convivência, de promoção da equidade e do acesso ao patrimônio que a humanidade já sistematizou, precisa também inventar um modelo de professor que ainda desconhecemos.

$\mathrm{Na}$ Educação Infantil, não cabe o professor que persegue metas predefinidas por meio de formas únicas que desconsidera os ritmos particulares das crianças. É preciso compreendermos cada vez mais a necessidade de reconhecer os ritmos próprios de cada criança e de respeitá-los ao pensar em como traduzi-los na relação educativa. A longa jornada de ir construindo junto à criança um sentido de grupo e de pertencimento a uma determinada cultura implica a instituição de Educação Infantil respeitar a história pessoal dos meninos e meninas e a herança histórica da qual fazem parte.

Por isso, o perfil do professor de Educação Infantil envolve saber criar contextos adequados para as crianças experimentarem diferentes possibilidades e construírem sentidos particulares e coletivos. Esse mesmo professor precisa responsabilizar-se em estar ao lado da criança, gerando confiança, observando e escutando as "cem linguagens", de que fala Loris Malaguzzi (2001), para poder interpretar e narrar os percursos de aprendizagem com a devida complexidade que lhes é merecida. Ainda, o professor precisa saber restituir os percursos das crianças, a própria ação pedagógica e o projeto educativo, possibilitando a criação de significados novos. Significados esses que estamos buscando no fortalecimento de uma identidade que acolha a complexidade das crianças e da Educação Infantil.

Por sorte, a visão de criança e de currículo proposta pelas Diretrizes Curriculares Nacionais para a Educação Infantil - DCNEIs nos ajuda a empreender tal desafio. Nesse documento legal, em consonância com tantos outros autores e modelos pedagógicos, a criança é definida como um

[...] sujeito histórico e de direitos que, nas interações, relações e práticas cotidianas que vivencia, constrói sua identidade pessoal e coletiva. Brinca, imagina, fantasia, deseja, aprende, observa, experimenta, narra, questiona e constrói sentidos sobre a natureza e a sociedade, produzindo cultura (BRASIL, 2010, p. 12). 
Essa ideia de criança não representa algo simples de ser incorporado nas práticas cotidianas. Ainda somos fortemente atravessados por crenças que minimizam as competências das crianças, que não autorizam a sua participação nas decisões cotidianas e, em muitas ocasiões, que as tratam como sujeitos vazios, sem nenhum tipo de experiência prévia, praticamente um sujeito sem história e sem identidade.

Assim, colocar-se diante da experiência concreta de cada uma das instituições e refletir sobre o lugar das crianças significa enfrentar as crenças sobre a imagem de criança que cada um de nós tem e que orientam nossas formas de atuar e de nos relacionar com os meninos e as meninas para poder ressignificá-los. Talvez esse seja o ponto de encontro mais coerente entre teoria e prática (HOYUELOS, 2004b).

Do ponto de vista da ação pedagógica, essa visão de criança precisa encontrar eco em uma ideia de currículo que supere a lógica do conhecimento acabado a ser transmitido. Logo, a dimensão de currículo que a DCNEI afirma nos ajuda a fazer isso, pois trata o currículo como um

[...] conjunto de práticas que buscam articular as experiências e os saberes das crianças com os conhecimentos que fazem parte do patrimônio cultural, artístico, ambiental, científico e tecnológico, de modo a promover o desenvolvimento integral de crianças de 0 a 5 anos de idade (BRASIL, 2010, p. 12).

Essa visão ampliada do que significa currículo na Educação Infantil aproxima o mundo da criança do mundo do adulto. Isso porque, ao compreender as práticas da vida cotidiana como uma das dimensões curriculares, além de orientar um certo modo de organizar os contextos educativos em direção ao bem-estar global das crianças, acolhe a experiência de cada menino e menina como modo de subjetivação e de produção de sentidos.

Além disso, dá o devido acento na perspectiva de que se articulem os saberes e as experiências das crianças com os patrimônios que a humanidade já sistematizou. Isso está em perfeita harmonia com o debate que Dewey (2002, p. 163) propõe como alternativa de superação do antagonismo entre a criança e o currículo, pois "os fatos e as verdades que entram na experiência presente da criança e aqueles contidos nos assuntos-matérias dos estudos são os termos inicial e final de uma mesma realidade".

A linha que conecta a criança ao currículo é exatamente a interatividade dessa dimensão que acolhe a vida cotidiana e que se movimenta no sentido de ampliar horizontes. É isso que responde à inteireza da criança que está expresso na visão de criança e currículo da DCNEI (2009) e também reclamada por Dewey (2002). 
Por fim, tanto a visão de criança como de currículo tem sido problematizada, comunicada e apoiada pela estratégia da Documentação Pedagógica. Dessa mesma maneira, ainda estamos caminhando no sentido de pensar como comunicar as experiências das crianças no interior das escolas, demonstrando os modos como elas operam e constroem suas experiências de aprendizagens, e de perceber como são "[...] capazes de criar mapas intencionais sobre seus percursos de aprendizagem, demonstrando que o desejo em descobrir o mundo estrutura esquemas de ações" (FOCHI, 2013, p. 160). Nosso exercício tem sido aproximar a vida cotidiana com as demais oportunidades que podemos oferecer para as crianças de modo que ampliem seus horizontes. Porém, estamos tentando fazer isso sem hierarquizar conhecimentos, pois partimos da ideia de que, desde a chegada das crianças na cena humana, ela está aprendendo.

\subsubsection{Focagem na Vida cotidiana}

Uma premissa importante para o OBECI e para as escolas que o compõem é a de que problematizar a vida cotidiana significa entrar no subsolo da Educação Infantil, ou seja, naquilo que sustenta a transformação e que esconde os maiores desafios. Sustenta a transformação, pois envolve a tomada de consciência sobre o dia a dia de uma creche e pré-escola e do valor que as atividades cotidianas ocupam na vida das crianças e dos adultos. Também porque no cotidiano está o conteúdo da vida, da cultura e das relações, e uma escola não pode se apartar disso para responder ao seu papel social, político e pedagógico. Esconde grandes desafios pelo enfrentamento aos dilemas que é necessário ser feito quando se pretende transformar o cotidiano pedagógico, mudar o que está instituído.

Para uma mudança na lógica da relação entre adultos e criança, por exemplo, é preciso modificar o espaço, e, para tal, se faz necessário construir uma nova compreensão sobre a gestão do tempo (todos os momentos não podem ser conduzidos pelo adulto, logo, o espaço precisa ser satisfatório ${ }^{82}$ ). Não adianta apenas organizar o espaço de forma diferente se não é problematizado o modo como as relações ali podem se estabelecer. A simples modificação do espaço e da gestão do tempo envolve não apenas os professores que atuam diretamente com as crianças, mas também os demais funcionários que precisam limpar a sala de referência e o

\footnotetext{
82 Ainda nesta Parte III, quando forem tratados os Organizadores da Ação Pedagógica, estes tópicos serão desenvolvidos. Aqui apenas estou citando a título de exemplo.
} 
coordenador pedagógico que deve fazer a gestão dos horários de atividades de planejamento de todos os professores da escola.

Por tudo isso, consideramos a vida cotidiana a espinha dorsal do nosso trabalho. Tanto do ponto de vista das crianças como dos adultos, em cada momento da vida cotidiana, existem extraordinárias possibilidades para aprender e para gerar um bem-estar global. As pequenas coisas, como deslocar-se de um lugar para o outro, compartilhar uma refeição, ser higienizado ou higienizar-se, disputar um brinquedo, comemorar um aniversário ou tirar um casaco porque está quente, são práticas sociais que vão inserindo os meninos e meninas em uma dada cultura e podem, quando dadas as condições adequadas para tal, representar um marco importante para o desenvolvimento e para o bem-estar das crianças. Logo, o debate sobre a vida cotidiana é algo do campo da gestão da escola e da gestão pedagógica do professor que precisam estar em perfeita sintonia para efetivar transformações que respondam às necessidades das crianças e dos adultos.

Cabanellas et al (2007, p. 35) afirma que é necessário "iluminar a complexidade natural das atuações infantis para que o olhar do adulto mude, para encontrar novas vias de abordagens didáticas, mais viáveis, mais respeitosas e mais ricas, para romper os limites que separam a cultura da infância da cultura do adulto". A afirmação da autora põe um desafio crucial, uma vez que nos faz entender que a diversidade de situações que temos tratado com banalidade ou como mera repetição, como as anteriormente citadas, são fruto também de uma compreensão limitada sobre as crianças e sobre sua relação com o contexto.

Do mesmo modo, Brougère e Ulmann (2012, p. 2) advertem que as aprendizagens da vida cotidiana, "se não completamente negadas como saberes, também não são verdadeiramente reconhecidas como tais". Para as crianças, esse não reconhecimento dessas aprendizagens que elas intensamente vão construindo pela sua natureza de recém-chegadas banaliza parte importante de sua trajetória educativa, mesmo que, no fundo, são essas as aprendizagens que estruturam e sustentam as condições internas para o desenvolvimento de outras aprendizagens ditas formais. Brougère e Ulmann (2012, p. 2) concordam que "relegadas ao segundo plano, as aprendizagens da vida cotidiana permanecem confinadas no invisível mesmo quando contribuem para desenvolver inúmeros conhecimentos naqueles lugares oficiais destinados a transmitir um saber válido e reconhecido".

Quando entendemos que as diferentes situações da vida cotidiana implicam uma ampla e complexa rede de atuações das crianças, conectadas com situações concretas e que respondem a necessidades diversas dos meninos e meninas, remodelar a lógica de compreensão do trabalho 
pedagógico é tirar da sombra os temas da vida cotidiana e reposicioná-los como parte de uma ecologia educativa complexa.

Vejamos um episódio da vida cotidiana, narrada a partir da mini-história das professoras Karin e Sissa, em uma turma de faixa etária 2 da EMEI Joaninha.
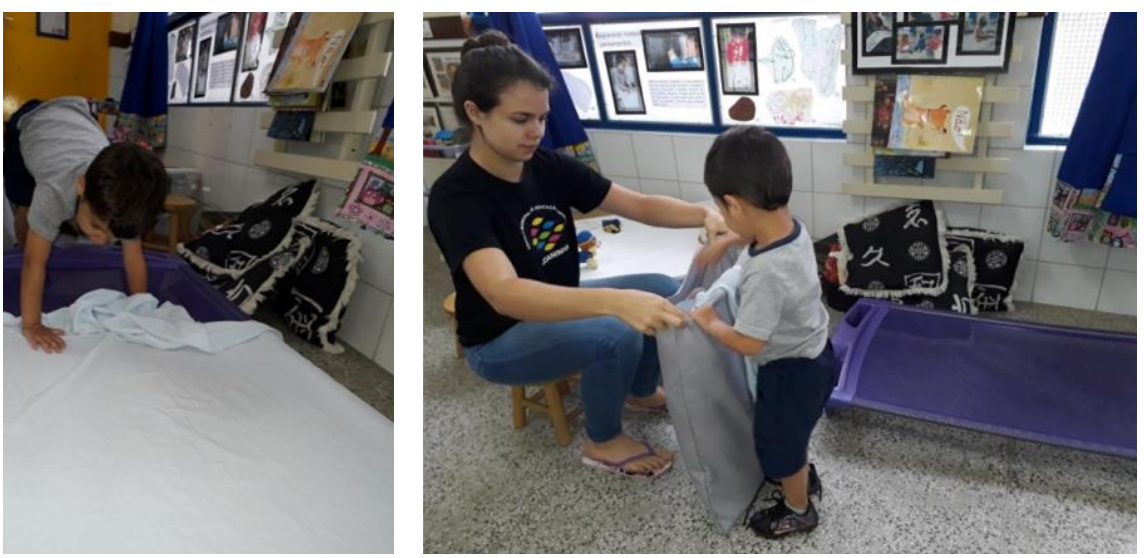

PARCERIA DE TODOS OS DIAS

Luís começou a frequentar a escola recentemente e já compreendeu que na jornada da turma existem algumas atividades que se repetem. Desde os primeiros dias, o menino se interessou em participar da organização do dormitório. Ao acordar, retira o lençol, a coberta e o travesseiro da sua cama e cuidadosamente os guarda na sacola com o auxílio da professora. Em uma troca de olhares cúmplices, Luís e a professora guardam também a cama. Espontaneamente, ele pega a sacolinha com as roupas de cama, leva até o armário e volta para sala na expectativa de que algum amigo desperte para poder continuar sua parceria na arrumação. Participar das atividades da vida cotidiana é também um modo de construir vínculos com um novo grupo, que aqui se expressa na parceria de todos os dias entre Luís e a professora.
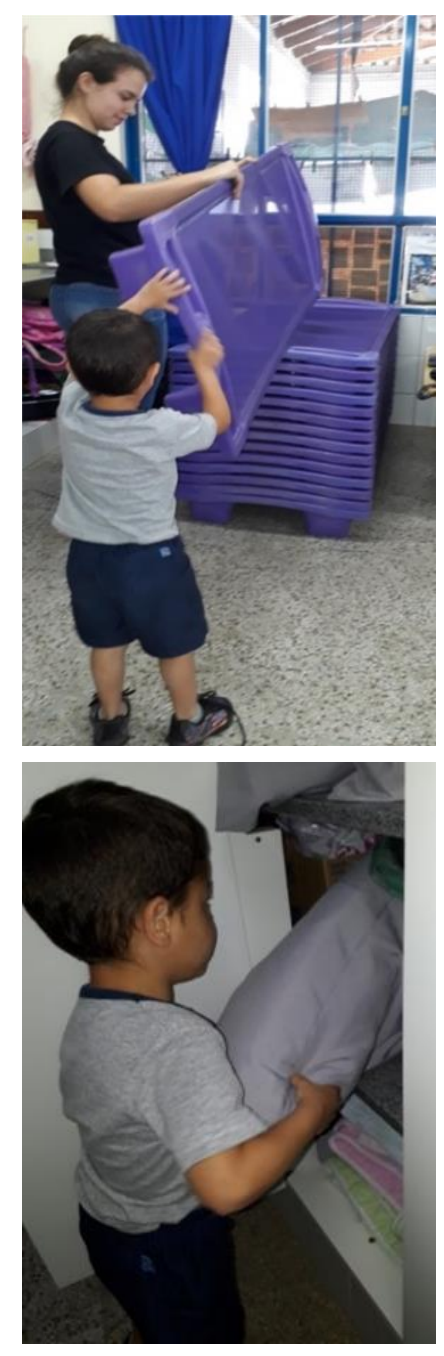

Esse breve episódio, mas não menos profundo, remete a uma máxima de Brougère (2012, p. 14) quando afirma que a "vida cotidiana não é genética; trata-se de uma construção humana particular", e, como tal, nos leva a saber agir em uma determinada cultura, a compreender as maneiras de fazer, de ser e de estar no e com o mundo de que se participa. Nesse sentido, "o cotidiano pode então ser aprendido como a base, o suporte ou mesmo o fundamento de qualquer prática social" (BROUGÈRE, 2012, p. 14).

Compartilhar uma tarefa pode ser um modo de estabelecer vínculos e ir construindo um lugar de participação e envolvimento de uma criança nova na turma, um gesto diário de construção de proximidade e afeto. Como lembra Galardini (2017, p. 23), "a grande ambição da escola deve ser criar em seu interior uma comunidade de interesses recíprocos, em que 
professores e crianças aprendem juntos e avançam juntos; uma comunidade em que as crianças são convidadas para serem membros competentes tal como os adultos". Além disso, Ritscher (2011, p. 116) reforça que participar da vida cotidiana “[...] é um gesto de cultura, significa assumir uma responsabilidade pessoal para o entorno coletivo. É um costume de cidadania ativa".

Há um outro elemento importante que se pode refletir a partir do episódio: o da continuidade. Para as crianças, a continuidade acaba "[...] estabelecendo hábitos, isto é, momentos reconhecíveis pela sua identidade e repetitividade" (BONDIOLI; MANTOVANI, 1998, p. 32), e, na vida cotidiana, a repetição é inerente ao próprio mundo cotidiano. Brougère (2012, p. 18) afirma que "criar o mundo cotidiano é aprender o mundo, entender como ele funciona para mergulhar nele. O mundo cotidiano é um mundo aprendido, na passagem da estranheza à familiaridade".

Por isso, ir compreendendo que algumas coisas se repetem oferece para os meninos e meninas a possibilidade de familiarizar-se com seu entrono e de decidir sobre sua participação, assegurando-lhes de que aquele momento não representa a totalidade da sua jornada educativa, mas parte dela. Além disso, ajuda na construção da noção da temporalidade que é tão difícil de ser assimilada pelas crianças dessa faixa etária. Mas é importante alertar: reconhecer alguns elementos de continuidade não é o mesmo que estabelecer uma rotina tal como conhecemos no campo da Educação Infantil ${ }^{83}$.

A chegada, o lanche da manhã, o almoço, o lanche da tarde e a despedida são marcas temporais inevitáveis das crianças em uma jornada educativa. Pensar a continuidade é suficientemente satisfatória levando em consideração esses momentos, mantendo-se aberto ao inesperado e à diversidade de outras situações que podem ir tramando o todo da jornada. É um justo equilíbrio entre a continuidade e a descontinuidade, tal como a vida.

Quando as crianças chegam a uma instituição, como a escola de Educação Infantil, entram numa outra vida cotidiana e, por isso, o que é evidente para os outros não é para quem está chegando (BROUGÈRE, 2012). Por isso, a aprendizagem torna-se intencional, explícita e vai, aos poucos, tramando-se uma tessitura de temporalidades, relações e sentidos que tornam aquele que antes chegava como parte daquele novo grupo social. Por isso é que Galardini (2017, p. 21) observa que "o cotidiano representa a realidade das crianças; é em sua vida diária, em

${ }^{83}$ A esse respeito, sugiro a leitura do livro Por amor e por força: as rotinas na educação infantil, de Maria Carmen Silveira Barbosa, Editora Penso, 2006. 
seus ritmos habituais e familiares, onde encontra os fundamentos das regras e dos significados compartilhados que conseguem que sintam responsáveis e tenham segurança”.

Vida cotidiana e aprendizagem formam um binômio que explicitam a natureza das jornadas de aprendizagem das crianças e dos adultos na Educação Infantil, pois, tal como anuncia Brougère (2012, p. 23), "a vida cotidiana é feita de múltiplas ocasiões de aprender. E, de modo simétrico, aprender é uma atividade da vida cotidiana, e não uma atividade que só poderia encontrar lugar rompendo com ela".

Também Strozzi (2016, p. 62) observa que a contínua atenção e reorganização do cotidiano nas escolas de Reggio Emilia são alternativas para manter próxima uma dada crença teórica do seu contexto prático, pois "quando separamos a teoria da organização do trabalho pedagógico, o risco é sempre muito alto. Isto é, o risco é de criar uma escola, como diz Bateson, 'que desinforme em vez de formar, porque tira o pulsar da vida"'. Logo, muitos mais importante do que compreender o que deve ocorrer cotidianamente, é preciso problematizar o como isso ocorre no dia a dia e o como é compreendido pelos adultos. Staccioli (2011, p. 22, grifo meu) lembra que "[...] colocar atenção no como significa respeito, significa ver a realidade pelo que é, significa reflexão, significa afeto pelas coisas que se faz (e pelas pessoas que estão conosco)". Discutir sobre como as atividades da vida cotidiana acontecem no dia a dia de uma escola significa compreender a composição de uma jornada educativa e decidir, portanto, as condições externas que precisam ser criadas para gerar um bem-estar global.

Comer, descansar, andar pela escola, encontrar os amigos, fazer amigos, brincar, ir para a caixa da areia, descobrir por onde passa a água em um conjunto de canos, podem ser atividades da vida cotidiana das crianças e merecem ser acolhidas no seu valor educativo. Carvalho e Fochi (2016, p. 158) destacam essa "unidade de inteireza da vida" que existe na vida cotidiana, pois nela se "[...] subvertem as perspectivas lineares, isto é, não se trata de conceber uma ideia de primeiro sentir, depois pensar, depois comunicar, mas, ao contrário, de modo interdependente e circular, se sente, se pensa e se comunica como um mesmo processo tramado por vários fios".

No OBECI, acreditamos que qualificar a vida cotidiana significa pôr atenção no modo como as crianças estão vivendo suas infâncias. Garantir que os meninos e as meninas tenham tempo para as diversas oportunidades educativas que acontecem em uma instituição, sem apressá-los, sem artificializar os modos que eles podem apreender o mundo, é um aspecto central na invenção da docência. $\mathrm{E}$ isso significa reposicionar o adulto "[...] para podermos transformar esse percurso em uma longa e bonita jornada a ser percorrida de mãos dadas, como 
alguém que acompanha, acolhe, cuida, compartilha e impulsiona a experiência de vida do outro" (FOCHI, 2014, p. 110).

Na sequência, para atender a essas ideias de criança, currículo e focagem na vida cotidiana, mostro como temos desenvolvido, em termos da formação, o trabalho dentro do OBECI.

\subsection{Os processos de formação no OBECI}

As reflexões que acontecem no OBECI perseguem os princípios das pedagogias participativas que, de acordo com Oliveira-Formosinho (2007, p.14), trata-se de uma "pedagogia transformativa, que credita a criança com direitos, compreende sua competência, escuta sua voz para transformar a ação pedagógica em uma atividade compartilhada”. Nessa perspectiva, não apenas a pedagogia para as crianças é outra, como a formação do adulto precisa romper com o modelo escolarizante de ensinar - modelo que define que aos professores cabe ensinar. Exige converter-se em uma formação que mobilize o professor a escutar as crianças, assentar-se em teorias de base (as pedagogias participativas) e contrastar o cotidiano para produzir o conhecimento praxiológico.

As pedagogias participativas “[...] produzem uma ruptura com uma pedagogia tradicional transmissiva para promover outra visão de ensino-aprendizagem e dos ofícios de criança e professor" (OLIVEIRA-FORMOSINHO; FORMOSINHO, 2011, p. 15). Sob essa ótica, Oliveira-Formosinho (2016b) fala da interatividade entre o direito dos profissionais à formação e o direito das crianças à aprendizagem, ambos os direitos pautados pela participação, pelo reconhecimento de sua agência e pela co-construção do conhecimento. Por isso, para essa autora, "estamos perante o isomorfismo pedagógico dos processos formativos em que a vivência de uma formação de educadoras baseada na ética do respeito se constitui em âncora para o desenvolvimento da qualidade pedagógica e educacional com as crianças" (OLIVEIRAFORMOSINHO, 2016b, p. 92).

Para atender a esse outro modo de fazer acontecer a formação dos profissionais, ao longo dos seis anos do OBECI, fomos construindo diferentes formas de estruturar os processos de formação dos coordenadores pedagógicos, gestores e professores para transformar os contextos educativos de acordo com as diferentes necessidades que percebemos. Atualmente acontece o Grupo Gestor (quinzenal), os Grupos de Investigação-Ação (mensal), os Encontros 
das Escolas Observadoras (semestral), a Jornada de Educação Infantil (anual) e a Mostra de Mini-histórias (anual).

Nos encontros do Grupo Gestor e dos Grupos de Investigação-Ação (GIA), é fundamental que o trabalho seja em um grupo não muito ampliado, dada a natureza de reflexões e o modo como acontecem as discussões e os encaminhamentos para o trabalho dentro das escolas. Já a proposta dos Encontros das Escolas Observadoras e da Jornada de Educação Infantil (e, dentro dela, a Mostra de Mini-histórias) reside em compartilhar alguns temas comuns que temos discutidos nos pequenos grupos para todos os demais profissionais das escolas e, no caso da Jornada, inclusive para profissionais de outras instituições.

Todos os processos de formação ${ }^{84}$ surgiram por um propósito e uma razão diferente; logo, cada um deles tem sua própria estrutura. Percebemos, por exemplo, que precisávamos discutir com um pequeno grupo de professores questões relativas à aprendizagem dos bebês e o papel do professor para essa faixa etária; por isso, criamos o GIA do Brincar Heurístico. Um outo exemplo, na medida em que o tema das mini-histórias começou a ser incorporado com mais força pelas escolas como estratégia de trabalho, diz da necessidade de reunir toda a equipe das escolas para discutir com mais profundidade sobre o tema, e assim, estruturamos os Encontros das Escolas Observadoras.

Cada processo de formação tem sua própria importância, mas é o seu conjunto que cria uma reciprocidade dinâmica para a transformação dos contextos educativos. O que conecta todos os processos de formação são:

a) os conteúdos emergentes das situações da vida cotidiana, que são para nós a espinha dorsal do trabalho, pois compreendem os conteúdos intelectuais necessários para a formação e para a transformação;

b) a figura do coordenador pedagógico, que participa de todos os momentos, pois representa uma ligação sistêmica entre a gestão da escola e gestão do trabalho pedagógico do professor;

c) a documentação pedagógica como estratégia para construir um conhecimento praxiológico partilhado, contextualizado, negociado, e para dar visibilidade sobre o modo como as crianças aprendem e como a ação pedagógica pode acontecer.

\footnotetext{
${ }^{84}$ No Apêndice B, sistematizei um quadro com os diferentes processos de formação, carga horária e público envolvido entre os anos de 2013 e 2018.
} 
Os conteúdos e processos de que temos tratado dentro do OBECI, graças à estratégia da Documentação Pedagógica, mantêm-se como um rico patrimônio pedagógico para cada uma das escolas e para as demais escolas participantes ${ }^{85}$. É esse patrimônio pedagógico que efetivamente vai se constituindo como o projeto educativo da instituição e, por sua vez, induzindo a uma certa prática tanto para os profissionais que já atuam, como para aqueles que chegam.

Ao longo dos seis anos, foram sendo explorados aspectos da vida cotidiana das escolas e compartilhadas reflexões entre as instituições que pudessem contribuir para a tomada de decisões em um alto nível de consciência. Destaco ainda que a produção do conhecimento que vem sendo realizada com os profissionais destas instituições e o compartilhamento do trabalho com a comunidade evocam aquilo que Dahlberg (2016, p. 230) destaca como a superação do "[...] pensamento que caracteriza o mercado de trabalho e os relacionamentos puramente contratuais", e esta mesma autora evidencia que "ao tornar o trabalho pedagógico visível e sujeito ao debate aberto e democrático, a documentação pedagógica oferece a possibilidade para que a educação infantil ganhe novo prestígio e legitimidade social”.

Na sequência, vou tratar cada um dos processos de formação que temos utilizado dentro do OBECI e explicitar o conteúdo e os processos desenvolvidos, as estratégias e os participantes.

\subsubsection{Grupo Gestor}

O Grupo Gestor é estruturante para o desenvolvimento do trabalho do OBECI, tanto para as escolas como para o próprio Observatório. Foi com esse grupo que se iniciou o trabalho desta comunidade de apoio ao desenvolvimento profissional, com a participação dos profissionais que atuam na gestão (coordenadores pedagógicos e diretores ${ }^{86}$ ) e, desde 2015, com as representantes da Secretaria Municipal de Educação ${ }^{87}$. A periodicidade dos encontros é quinzenal ${ }^{88}$ e neles desenvolvemos as investigações que geralmente se situam no âmbito da

85 Em seguida, tratarei de cada um dos processos formativos que, atualmente, temos utilizado e destacarei os conteúdos que já foram tematizados em nossas investigações.

${ }^{86}$ Em uma das instituições, a equipe gestora é formada pela diretora, coordenadora pedagógica e psicóloga. Neste caso, as três profissionais participam do Grupo Gestor.

87 Atualmente participam três assessoras da Secretaria Municipal de Educação, e o sentido dessa participação é apoiar as três escolas municipais que fazem parte do OBECI e poder se valer das reflexões que temos feito dentro do Observatório na rede municipal como um todo.

${ }^{88}$ Nos dois primeiros anos, os encontros eram mensais. Na medida em que começou a se sentir a necessidade de mais tempo, passamos a fazer encontros quinzenais. Desde 2015, os encontros permanecem quinzenalmente. 
constituição do projeto educativo (macros intervenções), e este é também o grupo em que se define o funcionamento desta comunidade de apoio ao desenvolvimento profissional.

É importante destacar que a razão do OBECI ter nascido com esse grupo gestor é o foco na construção de um sentido de gestão próxima, implicando estes profissionais com a vida cotidiana da escola que respeite os direitos das crianças e dos adultos. A ideia de uma gestão próxima é advinda das perspectivas pedagógicas de Loris Malaguzzi, que sempre perseguiu a descentralização de gestão, dizendo que considerava impossível um bom trabalho enquanto existisse muita distância entre a gestão e o cotidiano das crianças. Nas palavras de Tonucci (1998, p. 34), "Malaguzzi defendia a ideia que só com a sensibilidade e o cuidado que se pode dedicar às coisas próximas é que se pode fazer uma experiência de alto nível, assim como merecem as crianças".

A definição dos conteúdos de investigação é decorrente de um exercício reflexivo que se faz no início de cada ano nos primeiros encontros do Grupo Gestor, ou na análise do percurso vivido ao longo do ano projetando o próximo. Apoiando-nos na estratégia da Documentação Pedagógica, vamos construindo observáveis para olhar para a vida cotidiana das escolas e contrastar, dentro do OBECI, para poder projetar a transformação e realizá-la, como, por exemplo, no ano de 2016, em que cada coordenadora pedagógica acompanhou a jornada de uma das turmas de sua escola para compreender o modo como a organização do cotidiano privilegiava a participação das crianças ou não. Em outra oportunidade, em 2017, coordenadoras pedagógicas e diretoras elaboraram uma mini-história sobre uma cena do cotidiano e foram convidadas a buscar os conteúdos que poderiam ser refletidos a partir dela. Houve ainda o momento em que foi sendo percebida a temática que aprofundaríamos naquele ano, 2018, a partir das memórias escritas ao longo do ano anterior.

Um exemplo é a comunicação Alimentação na Mimo de Gente: construindo princípios para nutrir com afeto que a escola organizou e que eu apresento um excerto na sequência. $\mathrm{O}$ tema da alimentação é uma constante pauta de reflexão no OBECI. Desde 2013, esse assunto aparece como um dos aspectos da organização da jornada educativa que precisa ser problematizado e transformado. No caso da Escola Mimo de Gente, essa questão vem sendo olhada pela instituição de diferentes formas desde 2013.

Como síntese, os problemas giravam em torno da concepção dos professores de que comer era apenas uma tarefa diária; logo, entregavam os pratos já servidos, as frutas descascadas e picadas. As crianças eram apressadas e suas ações se resumiam, na maior parte das vezes, em escolher se iam ou não comer, a quantidade e o tipo de alimento. Atreladas a isso, 
as condições também dificultavam transformações: refeitório pequeno e número grande de turmas.

Desde então, a escola foi avançando em sua investigação para compreender a realidade, pensar estratégias de transformação e implementá-las. Reconhecido o terreno, a coordenadora pedagógica e a diretora foram escutando as versões das crianças e as versões das professoras sobre esse momento e, a partir dessa escuta, foram realizando formações dentro da escola.

Nessa comunicação do ano de 2016, a escola optou por retomar as narrativas do ano anterior que as crianças e as professoras fizeram sobre o momento das refeições. Como pode ser visto, a constatação do Lucas era de que havia muito barulho e pouco tempo, e da professora, a falta de tempo e a mecanização desse momento, incluindo a entrega das frutas cortadas para acelerar o processo. Como paralelo disso, a comunicação construída pela coordenadora e pela diretora mostra os princípios para alimentação que havia sido elaborado junto à equipe da escola ao longo dos três anos: ambiente organizado, paciência, respeito e autonomia. Essas palavraschave representavam aquilo que a instituição havia conseguido definir como as ideias irrevogáveis (postulados) para o momento da alimentação no contexto da instituição, ou seja, nos limites e possibilidades que lá existem. Por fim, as narrativas atuais das crianças e das professoras e algumas cenas atuais das refeições para expressar o que já havia avançado em direção aos princípios elaborados.
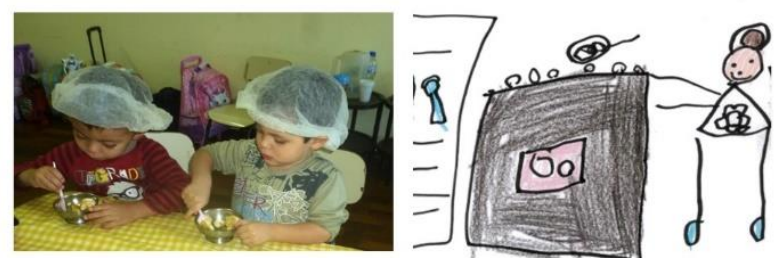

Alimentação na Mimo de Gente: Construindo princípios para nutrir com afeto

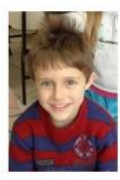

A gente ia pro refeitório e, às vezes, tinha outra turma... às vezes aumentava a gritaria porque tinha muita criança... às vezes baixava, às vezes aumentava...

Lucas, 5 anos

Cada turma tem sem horário para comer no refeitório. As professoras entregam os alimentos para as crianças e tem que comer tudo rápido por causa do horário. As frutas também são entregues cortadas e descascadas na mão das crianças. Vanessa, educadora 

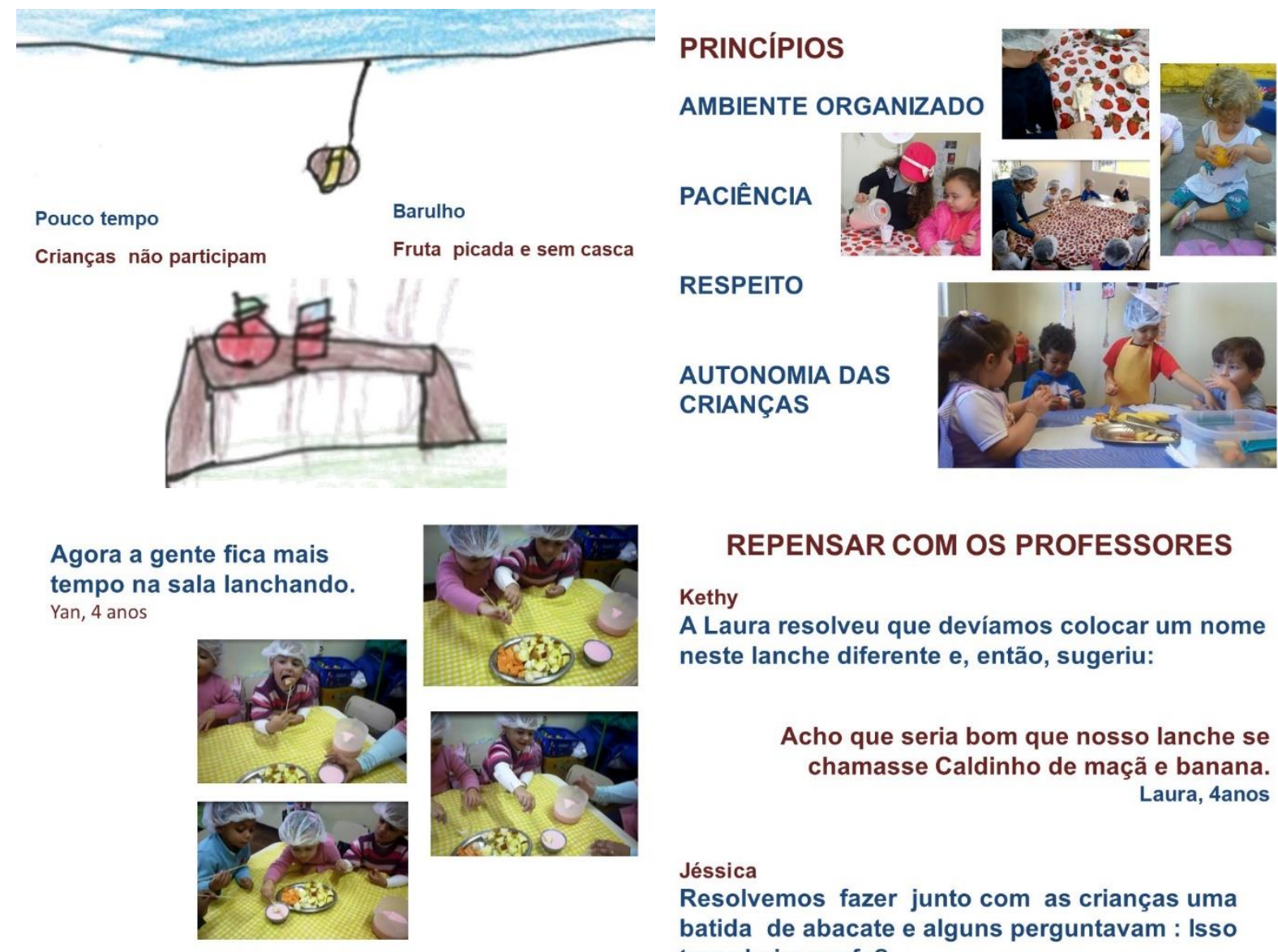

\section{REPENSAR COM OS PROFESSORES}

Kethy

A Laura resolveu que devíamos colocar um nome neste lanche diferente e, então, sugeriu:

\section{Acho que seria bom que nosso lanche se chamasse Caldinho de maçã e banana. Laura, 4anos}

Jéssica

Resolvemos fazer junto com as crianças uma batida de abacate e alguns perguntavam : Isso tem cheiro profe?

Independentemente do modo utilizado para circunscrever a temática a ser investigada, os conteúdos do Grupo Gestor são sempre vinculados à vida cotidiana, tais como o momento das refeições (almoço ou lanches), o momento do descanso, o ritmo da jornada educativa em cada turma, o momento da higiene (troca de fraldas), as chegadas e partidas dos bebês, o trabalho em pequenos grupos ${ }^{89}$, as microtransições. Cada vez mais, temos compreendido que esses temas são o verdadeiro conteúdo do projeto educativo e, por isso, os conteúdos formativos.

Envolver os coordenadores pedagógicos e gestores com os temas da vida cotidiana é responsabilizar a equipe pedagógica da instituição pelo funcionamento e pela concretização do projeto educativo, descentralizando, assim, o papel do professor como o único responsável pela dimensão pedagógica. A propósito: é dessa forma que temos afirmado a pedagogia dentro das instituições, como a ciência que sustenta as práticas pedagógicas e que conecta a todos em volta de um mesmo propósito.

\footnotetext{
${ }^{89}$ No Apêndice C, há um quadro com uma síntese de todos os conteúdos que as escolas têm tratado a cada ano no interior do OBECI.
} 
Aqui vale destacar um ponto importante. Na metade do primeiro ano do OBECI, em 2013, percebemos que, embora estivéssemos estudando a respeito da Documentação Pedagógica, não estávamos construindo a memória do trabalho desse Observatório. Por essa razão, decidimos que, em cada encontro, uma pessoa seria responsável por sistematizar de forma textual o que havia sido discutido. Chamamos esse documento de "Memória". No intervalo dos encontros, a memória é compartilhada em um grupo virtual para ser lida no começo do encontro posterior. Esta tem sido uma forma de produzir uma continuidade do trabalho que temos desenvolvido e de construir um material que sistematiza as vozes do desenvolvimento da nossa história. Escrever a respeito do que estamos discutindo e, especialmente, garantir que todos participantes possam escrever a partir de suas impressões foi um exercício muito importante para a construção da história formativa e metodológica desse grupo. Aliás, foi graças a isso que pude cartografar os conteúdos emergentes do OBECI.

Um outro aspecto que é de fundamental importância é a construção de um vínculo colaborativo entre os participantes do Grupo Gestor, porque, nesse grupo, estamos criando o que Hargreaves (1998) define como culturas profissionais docentes. Para o referido autor, a cultura é composta por forma (padrões de comportamento e relacionamento) e conteúdo (construído por aquilo que os outros pensam, fazem e dizem) dos membros de um determinado grupo. No tocante a respeito das culturas profissionais docentes, está se referindo, portanto, ao modo como os professores se relacionam e desenvolvem seu trabalho na escola e para a escola e ao modo como se traduzem em práticas as crenças, os valores e os padrões de comportamento com as próprias crianças, com os outros adultos e com a própria escola.

Hargreaves (1998) define cinco tipos comuns de culturas profissionais: individualismo fragmentado, balcanização, colegiado artificial, colaboração e mosaico fluído. Não é intenção aqui revisar cada uma dessas definições, mas sinalizar aquela que, em minha interpretação, representa o que constituímos no interior do OBECI, ou seja, a cultura profissional da colaboração.

As características de uma cultura profissional docente colaborativa, segundo Hargrevaes (1998), seria a da partilha, da confiança e do apoio, do trabalho em conjunto, do aperfeiçoamento contínuo. Essas são características que se notam fortemente no Grupo Gestor do OBECI. Não foram qualidades elencadas a priori como condição de participação. São, ao contrário, uma análise que só é possível de ser feita no distanciamento e na revisitação das memórias construídas no interior do Observatório e dos documentos reflexivos que os participantes produziram. 
Não sabíamos, mas para que um grupo de escolas distintas compartilhando suas fragilidades, escutando críticas e ponderações e assumindo determinados níveis de reflexão e de trabalho em conjunto pudesse dar certo, tais características seriam chave, quer seja para a continuidade do Observatório, quer seja para a própria transformação de cada escola.

Nos primeiros movimentos de compartilhar a respeito do que cada escola desejaria refletir, era notável que estavam preocupadas em mostrar um problema solucionado com sucesso antes de expor qualquer tipo de fragilidade da instituição. Hargreaves (1998, p. 189) descreve uma imagem representativa a respeito dessa tentativa de manter escondidas a dúvida e as fragilidades: "tal como a ostra que neutraliza um grão de areia irritante, cobrindo-o com camadas de pérola, os professores isolados parecem cobrir as suas dúvidas e inadequações irritantes com camadas reconfortantes de ilusão pessoal".

Foi preciso aprender a confiar no grupo e, talvez, a compreender que a tentativa de mascarar um problema jamais abriria as portas para uma possível transformação. Nesse sentido, entendo que as escolas conseguiram ir percebendo que a fragilidade de uma também era a fragilidade das demais, e que o grupo que ali estava se constituindo estava aberto ao diálogo e empenhado em colaborar mutuamente.

Além disso, na medida em que o grupo foi percebendo a possibilidade dos encontros do Observatório se configurarem como verdadeiros espaços legítimos de dúvidas e um tempo dedicado a olhar profundamente para as próprias escolas sem tentar mascarar os problemas, também se desvelou a problemática da formação que realizavam dentro das escolas: (i) não estava servindo para transformar a vida cotidiana; (ii) não eram abordados temas que pudessem transformar a prática dos professores em prol das crianças, (iii) não existia nenhuma metodologia de trabalho formativo dentro das escolas. Na verdade, concluiu-se o que Hargreaves (1998, p. 234) já havia anunciado: “os professores não se encontram quando deviam, encontram-se quando não há nada para discutir, e estão envolvidos em esquemas de treino com pares que não compreendem bem ou não conseguem fazer funcionar com os colegas adequados".

Assim, o trabalho do primeiro ano foi importante para a construção da forma de trabalho do OBECI - tanto em nível organizacional (a construção de uma cultura colaborativa), quanto em nível formativo (produzir observáveis do cotidiano das escolas e partilhar no OBECI com a finalidade de querer ver e compreender) - assim como para a circunscrição do conteúdo deste observatório: a vida cotidiana da escola, as aprendizagens das crianças, o modo de narrar e os processos formativos dos professores. 
Ao longo destes seis anos, o fortalecimento dessa cultura profissional docente colaborativa (HARGREAVES, 1998) também consolidou a ideia de comunidade comprometida com a transformação dos contextos que ali estamos construindo. A respeito disso, recupero o que Roldão (2006) discute ao tratar da ampliação da reflexão do trabalho colaborativo. Segundo a autora, para além de um grupo de pessoas estarem envolvidas em uma mesma tarefa, existem outras importantes características a considerar:

(i) o esforço conjunto e articulado para compreender e analisar o porquê de uma situação problemática (clínica ou de aprendizagem); (ii) a mobilização de tudo o que cada um sabe, e que é específico, para colocar em comum na discussão da situação global e na decisão da ação a adotar (clínica ou de ensino); (iii) o levantamento de novos e imprevistos problemas cuja solução é pesquisada de novo, e discutida por todos, dividindo tarefas, mas conjugando os resultados; (iv) o reconhecimento dos erros (por vezes da responsabilidade de um dos elementos) e o imediato esforço coletivo para os superar com uma nova alternativa de ação (clínica ou de ensino); (v) a responsabilidade de cada um e de todos nas falhas e nos sucessos, sem prejuízo dos contributos específicos de cada um; (vi) a centralidade da ação profissional no seu destinatário que é quem a ela tem direito (para os alunos o direito a aprender) (ROLDÃO, 2006, p. 22-23).

Senão exatamente essas seis características, pois a autora está se referindo à escola, mas seu sentido geral diz muito do que foi consolidado dentro do OBECI. Partilhar um tema tornou-se motivo para criar engajamento do grupo com o desejo de qualificar e de encontrar rumos a serem tomados. A investigação que uma escola está levando a cabo é um conteúdo partilhado com as demais e uma possibilidade de contrastes sobre diferentes pontos de vista que podem qualificar e auxiliar no trabalho. Celebramos aquilo que Oliveira-Formosinho (2009a) tão bem nos ensinou: que aprendemos melhor em companhia.

No grupo, as experiências de cada participante, seus saberes e a história de cada instituição enriquecem as possibilidades formativas de cada um exatamente porque não se pretende cancelar as diferenças, e, sim, celebrá-las. Sabemos que o trabalho em que estamos envolvidos tanto nas escolas como no próprio OBECI é um trabalho que se situa no campo da pluralidade, das teorias plurais, das visões plurais.

Graças à participação da coordenadora pedagógica, começamos a criar uma homologia dos processos do OBECI para dentro dos processos formativos das escolas. Ou seja, os modos como temos levado a cabo nossas investigações dentro do Observatório têm servido como formação ao coordenador pedagógico como formador de dentro da escola.

É no debate sobre essa relação entre as coordenadoras pedagógicas e as professoras dentro das escolas que surge o outro processo formativo que temos desenvolvido no OBECI: os Grupos de Investigação-Ação. 


\subsubsection{Grupos de Investigação-Ação}

Os Grupos de Investigação-Ação (GIA) surgem na medida em que fomos sentindo a necessidade de dialogar mais diretamente com os professores. Nos dois primeiros anos do OBECI, apenas o Grupo Gestor tinha encontros regulares, e os temas investigados, embora sempre estivessem vinculados à vida cotidiana das escolas, referiam-se muito a aspectos da gestão do trabalho educativo em uma dimensão macro. Porém, quanto mais avançávamos na compreensão sobre o funcionamento da escola, mais evidente ficava que precisávamos entrar nos meandros da ação pedagógica dos professores. Por um outro lado, desvelava-se a fragilidade das formações que já ocorriam dentro das escolas como pouco efetivas para o desenvolvimento profissional dos professores e, ligado a isso, o desconhecimento por parte dos coordenadores de como estruturar a formação dos professores.

No entanto, sempre esteve muito presente no Observatório que na gestão pedagógica reside a questão central daquilo que é necessário para a transformação: mudar o nexo saberpoder entre adultos e crianças, e entre adultos e adultos.

Como já tratado no item sobre a criança e o currículo, para construirmos uma coerência entre a ideia de conhecimento, de criança e de adulto que temos, precisamos problematizar nossas crenças internas para mudar o modo como nos relacionamos com as crianças. Mudar isso é mudar toda uma matriz didática e pedagógica que temos instituída sobre o papel do professor e da escola na sociedade.

Nos Grupos de Investigação-Ação, como o próprio nome sugere, e coerentemente com os propósitos do OBECI, o acento está em convidar o professor a investigar sua práxis para construir hipóteses e explicações, estabelecendo diálogos entre o cotidiano praxiológico e um quadro referencial. Neste grupo, a tônica tanto está na investigação quanto na ação para gerar intencionalidade e transformação da práxis.

A característica do GIA é a de mobilizar os professores das escolas que compõem o OBECI, acompanhados de seus coordenadores, em torno de uma temática partilhável para realizar determinadas investigações com seu grupo de crianças. No GIA, são compartilhados e contrastados os observáveis (fotos, vídeos, amostragem dos desenhos das crianças, anotações das falas das crianças) da sua prática para refletir e pensar em estratégias para retroalimentá-la.

Essa ideia coaduna com o pensamento de Stenhouse (1998) de que os professores devem adotar uma atitude de investigação para refletir sobre a sua própria prática de forma sistemática e criticamente. Para esse autor, o desenvolvimento curricular, a profissionalidade 
do professor e a investigação da prática são elementos fundamentais para a melhoria da educação (STENHOUSE, 1998). Na mesma linha, Cochram-Smith e Lytle (2002) abordam uma noção de professor que investiga intencional e sistematicamente. As autoras justificam que as matizes dadas ao termo professor investigador objetivam diferenciá-lo de uma investigação por acaso, espontânea, pressupondo que a intencionalidade também representa um grau de reflexão dos professores que sabem se fazer perguntas ou de perguntar sobre o seu entorno. E, a respeito da sistematicidade, não apenas responde a uma certa crença de investigação, mas de que no campo educacional o hábito em produzir dados para poder analisá-los e contrastá-los é, sem dúvida, uma estratégia para a construção do conhecimento pedagógico.

Malaguzzi (2001) também já tratou do tema, destacando que o conhecimento dos professores é um dos conhecimentos mais profundos sobre os problemas da educação, e que, por isso, "o papel da teoria consiste em ajudar aos professores a compreender de forma eficaz a natureza de seus problemas" (MALAGUZZI, 2001, p. 84). No entanto, isso não se faz por aproximação da teoria com a prática, mas da construção de uma prática situada e fundamentada em uma teoria de base (OLIVEIRA-FORMOSINHO, 2007).

O pedagogo também defende a natureza aprendente do professor como peça fundamental da prática pedagógica. Seguindo essas pistas de Malaguzzi (2001, p. 85), temos problematizado dentro dos GIA que "a atitude de aprender e re-aprender com as crianças é a linha do nosso trabalho. Trata-se de conseguir que as crianças não tomem a forma da experiência, mas sim, que sejam elas as que dão forma à experiência”.

Mas pensar na formação de um grupo que incida na investigação com os professores, pelos professores e na sua formação, também convoca refletir sobre os modelos de aprendizagem dos adultos. Considerando o percurso que temos desenvolvido dentro de cada GIA, os argumentos da aprendizagem experiencial postuladas por Kolb (1984) ajudam a clarificar os processos de aprendizagem dos professores e coordenadores. Para esse autor,

\footnotetext{
Aprendizagem experiência é o processo por onde o conhecimento é criado através da transformação da experiência. Esta definição enfatiza que o conhecimento é um processo de transformação, sendo continuamente criado e recriado... A aprendizagem transforma a experiência tanto no seu caráter objetivo como no subjetivo... Para compreendermos aprendizagem, é necessário compreendermos a natureza do desenvolvimento, e vice-versa (KOLB, 1984, p. 38).
}

Kolb (1984) aborda o processo de aprendizagem a partir de um ciclo de aprendizagem contínuo com quatro estágios: a experiência concreta (agir) está relacionada ao envolvimento das professoras à sua atividade profissional e de como se sentem nela; a observação e reflexão (refletir), como experiência concreta, permite que as professoras reflitam sobre e busquem mais 
informações a partir da observação e registro da sua prática que possa ajudá-las a compreender melhor a sua experiência; a conceituação abstrata (conceitualizar) é um momento crítico para contrastar com as teorias à disposição e estabelecer certas compreensões sobre a experiência concreta; a experimentação ativa (aplicar) faz referência ao momento quando retornam a sua atividade profissional com novos sentidos e significados a respeito da própria experiência com vistas a transformá-la. Assim como Kolb (1984) afirma, a aprendizagem não necessariamente começa no estágio da experiência concreta, embora o próprio autor defenda que a aprendizagem vista de uma forma mais abrangente envolva todos os estágios. Como todo nosso trabalho é ancorado pela Documentação Pedagógica e as professoras se encontram neste grupo para investigar e transformar algo de sua prática, as ideias desse autor nos servem como uma lente de compreensão do próprio processo que construímos dentro dos GIAs.

Isto posto, destaco alguns pontos gerais a respeito do funcionamento desses grupos:

a) Os encontros realizados ocorreram pela parte da manhã, paralelos aos encontros do Grupo Gestor, que ocorrem à tarde, ou seja, os dois grupos foram acontecendo contemporaneamente. Como já foi dito, os encontros ocorrem no horário de trabalho e têm gerado um efeito muito importante na compreensão sobre a amplitude do espectro do trabalho do professor, especialmente nas escolas privadas, que dificilmente garantem o tempo de planejamento (hora atividade) para os professores;

b) Cartazes e materiais de convite são feitos para os professores com o intuito de formalizar e dar visibilidade à participação da escola junto ao OBECI. O participante de cada escola precisa desejar, querer fazer parte do GIA. Do mesmo modo, as professoras e coordenadoras, quando se inscrevem nos GIAS, também assinam termos de autorização e consentimento sobre o uso de imagem e voz e dos materiais decorrentes daquele grupo.

c) A participação do coordenador junto com os professores foi exatamente para que o primeiro pudesse apoiar o segundo, e ambos difundissem aquilo que estava sendo discutido dentro do GIA com os demais professores da instituição.

d) A escolha de falar sobre esses temas centrais está diretamente ligada à perspectiva de que eles são o mote para entrarmos nos meandros da prática pedagógica. A partir desses debates e em diálogos com os que ocorriam no Grupo Gestor, surgiram os Organizadores da Ação Pedagógica, tópico que será discutido no capítulo seguinte. 
e) Como manutenção e espaço de partilha, para cada GIA, criamos um grupo virtual no facebook, como uma espécie de ambiente virtual de aprendizagem (AVA) para postagens dos observáveis das investigações das escolas e para reforçar a interação entre as escolas e postagens de textos, vídeos e outros tipos de materiais formativos.

f) Os GIA também são um espaço de formação de formadores. O modo como tratamos as discussões sobre o cotidiano pedagógico e e como vamos retroalimentando sua transformação oferecem aos coordenadores modelos e estratégias para construir seus próprios percursos formativos dentro das escolas.

g) A mobilização da criação do GIA era fazer com que as discussões que estávamos fazendo dentro do Grupo Gestor chegassem com mais força dentro de cada sala referência. Sempre estive consciente de que havia o risco do OBECI se transformar em uma ilha de discursos apartada do mar de realidade que é a escola se mantivéssemos nossas reflexões presas no próprio grupo.

Em 2015, criamos o primeiro Grupo de Investigação-Ação com ênfase nos Ciclos de Simbolização propostos por Malaguzzi (2001), convidando um professor de pré-escola e a coordenadora pedagógica de cada escola para encontros sistemáticos. Nos anos subsequentes, além de dar continuidade ao primeiro, organizamos outros três GIAs: o do Brincar heurístico, o dos Jogos de Luz e Sombra (que mais tarde se transformou em diálogos entre crianças e tecnologias) e o do Acompanhamento Projetual. Na sequência, comento brevemente cada um dos GIAs.

\subsubsection{GIA dos Ciclos de Simbolização}

Os Ciclos de Simbolização são uma proposta de Loris Malaguzzi, estruturada por George Formam (1999) sobre a investigação gráfica como plataforma para as crianças estruturarem suas teorias. No OBECI, a escolha em iniciarmos, em 2015, um GIA tratando desse tema se deu por um especial interesse no desenho uma vez que já vínhamos discutido desde anos anteriores a respeito. Havíamos percebido que as práticas com desenhos nas escolas pendulavam entre oferecer para as crianças desenhos prontos, estereotipados, ou, constantemente, uma folha em branco, sem nenhum tipo de intervenção. 
Fui entendendo junto ao Grupo Gestor que essas práticas em relação ao desenho dizem muito dos modos como os professores estão agindo na Educação Infantil. Em outras palavras, ou se permanece em uma pedagogia diretiva, centrada no adulto (desenho pronto), ou, então, nas pedagogias não diretivas, que abandonam as crianças, supondo que a simples relação destas com o material riscante e a folha branca fará com que descubram os mistérios e as alegrias de registrar no papel suas teorias a partir do desenho.

Nesse caso, e essa foi uma frase repetida pelo grupo do OBECI inúmeras vezes, percebemos que o desenho era o mote para o debate de tantos outros aspectos da relação educativa. Por isso, o que estava em jogo era descobrir como ser professor de crianças pequenas, mas também ampliar a compreensão sobre o desenho como uma das linguagens das crianças. O que permanecemos em busca, em termos de Pedagogia, são aquelas epistemologias relacionais, pois, conforme já tratei em outro texto,

[...] é possível colocar em relação tanto os saberes das crianças quanto os saberes dos adultos. Não se trata de uma pedagogia não diretiva, que supõe que o que as crianças precisam aprender já nasce com elas, que é inato a elas. Também não é o contrário, uma pedagogia diretiva, que percebe a criança como vazia, tabula rasa, cabendo ao adulto "preenchê-la" com os saberes já adquiridos por ele (FOCHI, 2016a, p. 5).

O Grupo de Investigação-Ação dos Ciclos de Simbolização foi dado continuidade até o ano de 2017, e fomos ampliando a participação dos professores com mais representantes de cada escola, além dos coordenadores e/ou diretores. Esse GIA é voltado para aqueles que trabalham com as turmas de pré-escola.

Vamos ver um fragmento de uma das investigações realizadas neste GIA.
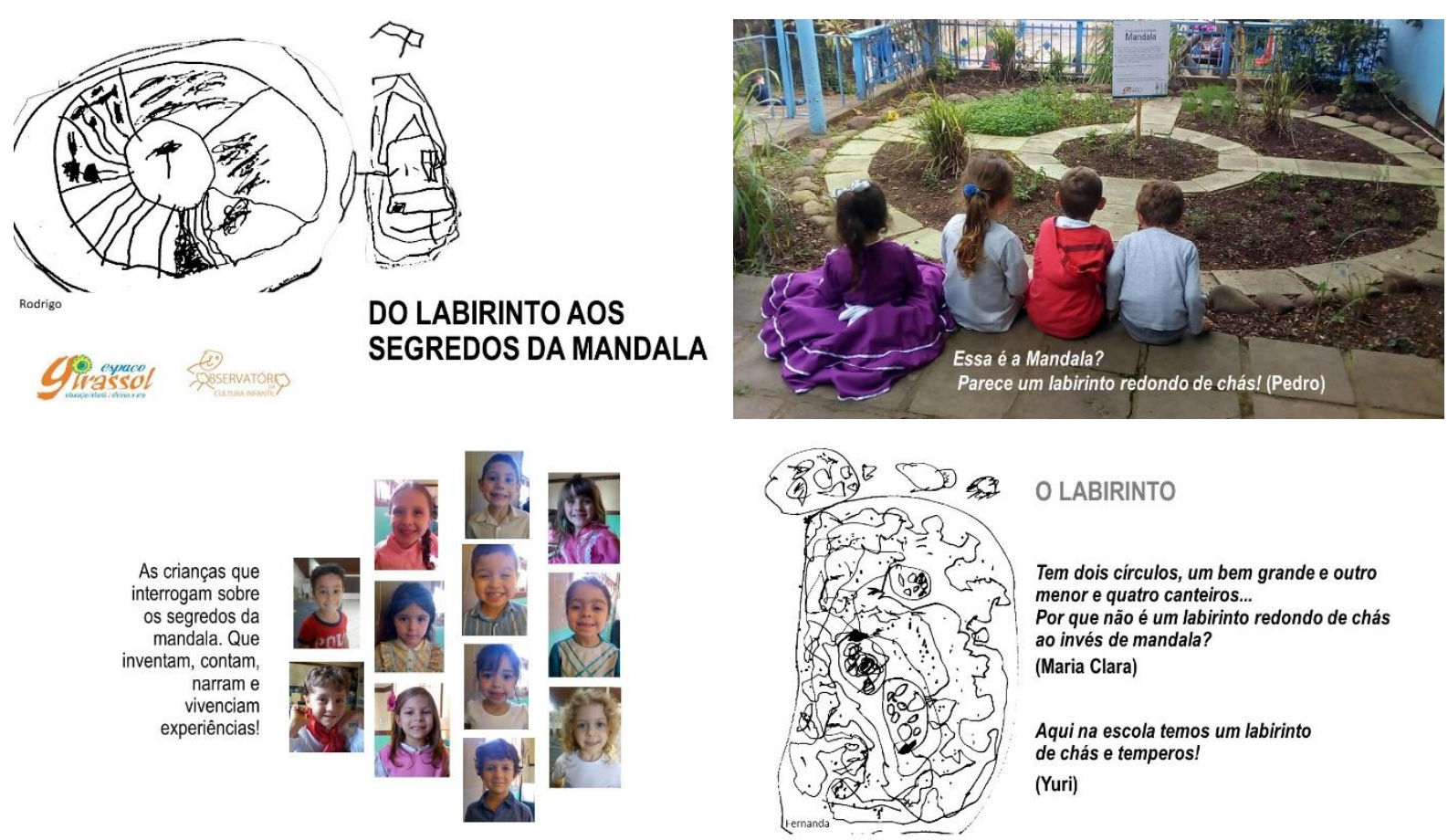


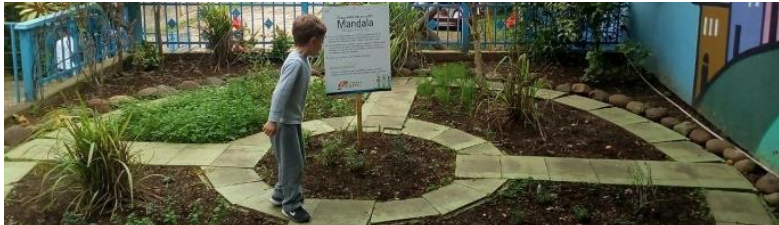

Antes de desvendar os segredos da Mandala, as crianças já tinham elaborado uma teoria sobre 0 que elas pensavam se tratar de um labirinto: Mandala significa pegadas para seguir, é um caminho... Mas que talvez possa se transformar em um vestido diferente! Entende? (Layla)

Realmente não é uma coisa fácil de se compreender, então a professora questionou: Como assim um caminho que se transforma em vestido? Assim, é uma coisa com muitos segredos! (Maria Clara)
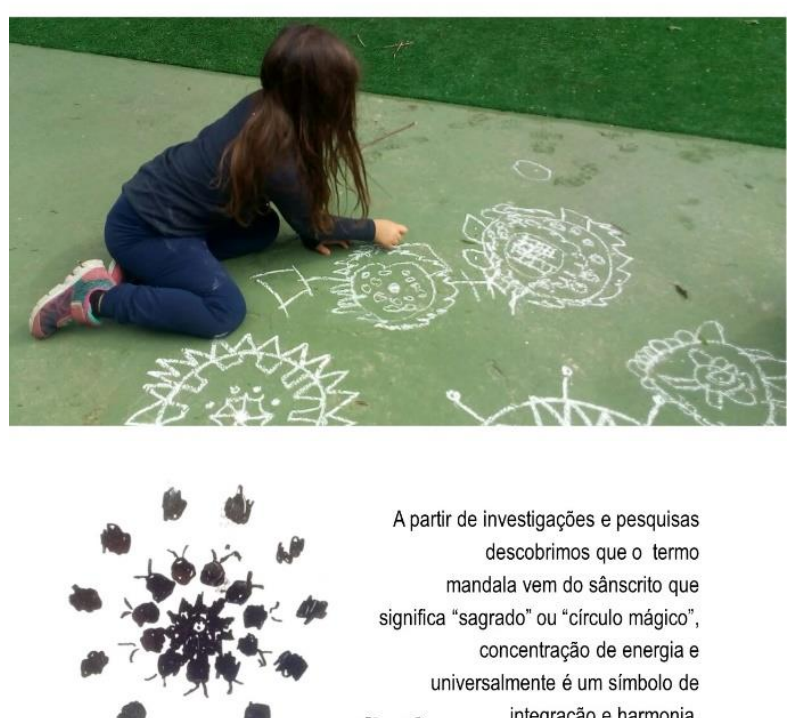

A partir de investigações e pesquisas

descobrimos que o termo

mandala vem do sânscrito que

significa "sagrado" ou "círculo mágico",

concentração de energia e

universalmente é um símbolo de
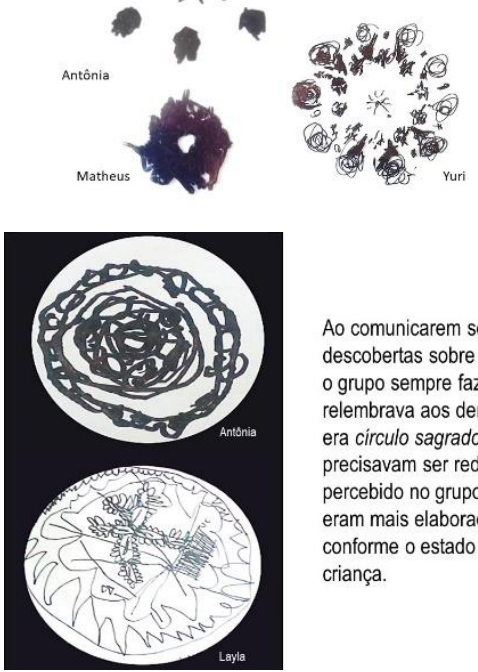

Ao comunicarem seus pensamentos e

descobertas sobre o conceito de Mandala, o grupo sempre fazia referência e relembrava aos demais que seu significado era circulo sagrado, além disso as obras precisavam ser redondas. Algo interessante percebido no grupo foi que as produções eram mais elaboradas e detalhadas conforme o estado espiritual de cada criança.

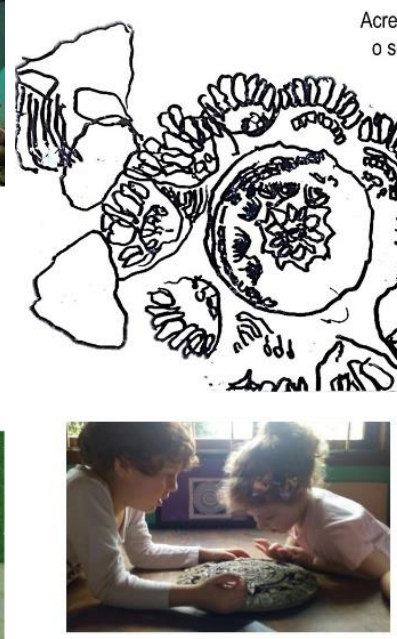

Acreditávamos que a teoria de Layla expressava seu mundo de faz de conta, onde seus lindo vestidos coloridos e rodados poderiam se transformar em belissimas mandalas, quando olhados de cima.
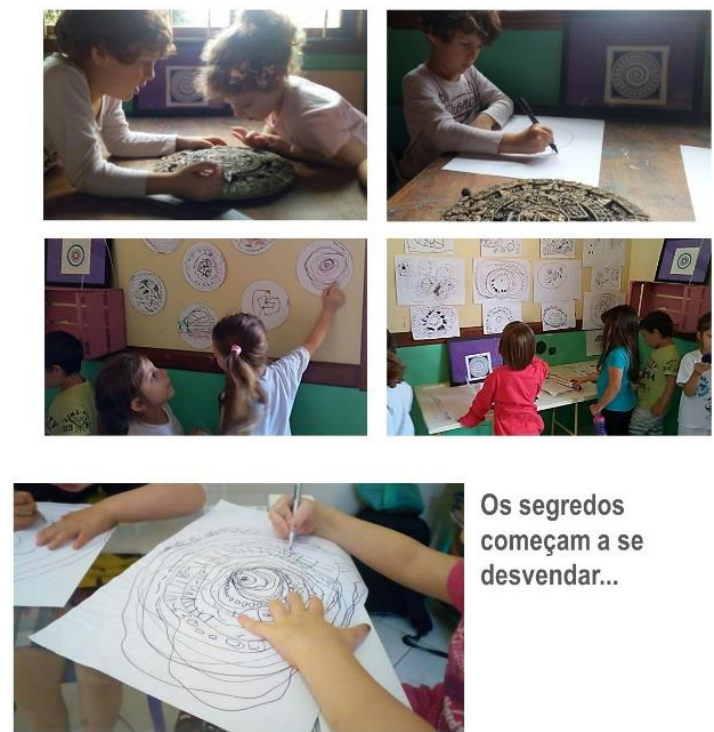

Os segredos começam a se desvendar..

Após a descoberta do significado de Mandala as crianças dizem:

Viu, tinha um segredo! E sabe como é que surgiu a Mandala? (Maria Clara) Acho que $\mathrm{o}$ asteroide soltou fogo, e explodiu! Então o fogo derreteu $\mathrm{o}$ asteroide, e assim profe... Destruiu o asteroide e se transformou em uma Mandala! (Matheus)

Ao longo das investigaçōes as crianças estavam convictas de que Mandala se tratava de segredos mágicos e a cada nova escolha de material para analisar ou representar graficamente, elas faziam referência a isso, tentando desvendar o seu segredo, como por exemplo, no objeto de origem Maia o qual elas analisaram e descreveram o que se passava no objeto.

Sabe o que acontece? Isso é um cidade com uma careta no meio. 0 raios levam energia para pétalas por fios. São energias melhores Esses pontos sao trabalhando e plantando o bem! Ah, e a careta do meio é a torre de controle. (Rodrigo)
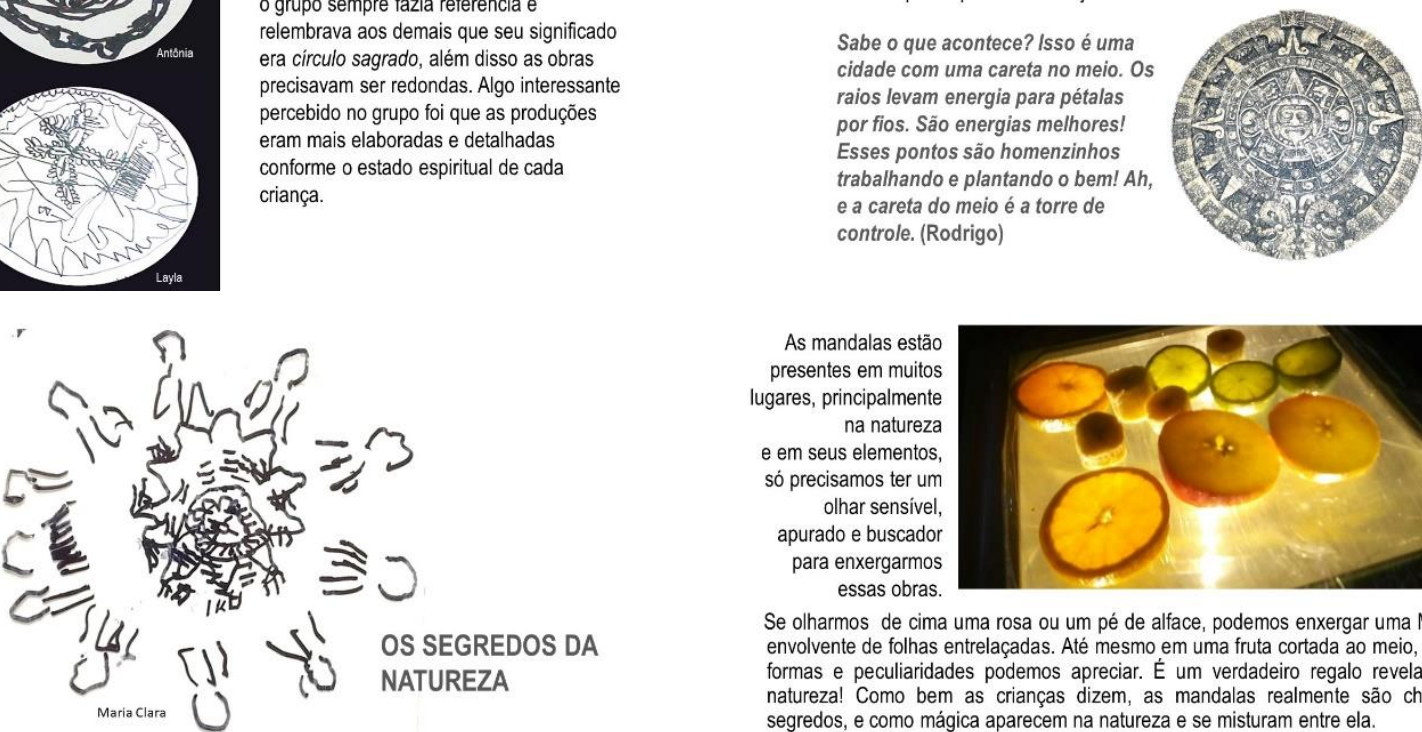

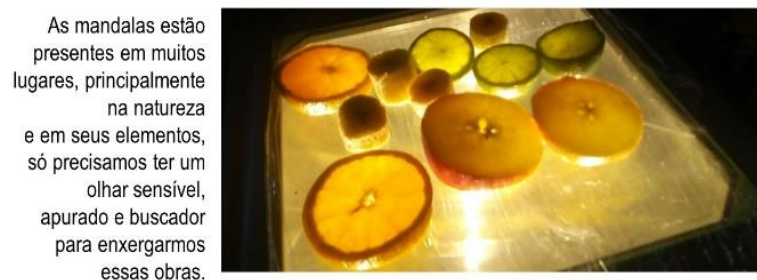
essas obras.

Se olharmos de cima uma rosa ou um pé de alface, podemos enxergar uma Mandala envolvente de folhas entrelaçadas. Até mesmo em uma fruta cortada ao meio, quantas formas e peculiaridades podemos apreciar. É um verdadeiro regalo revelado pela naturezal Como bem as crianças dizem, as mandalas realmente são cheias de segredos, e como mágica aparecem na natureza e se misturam entre ela. 


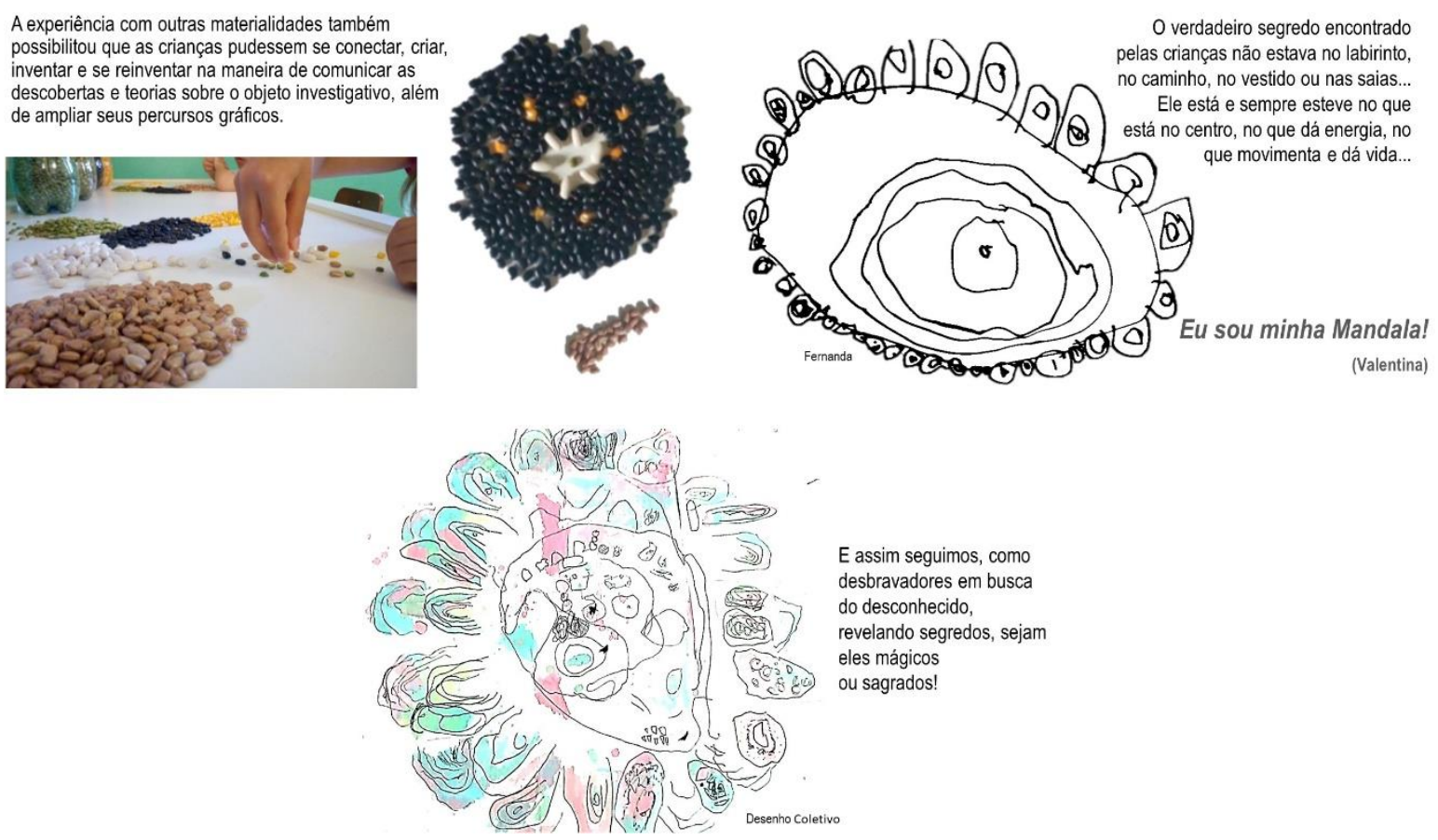

Na Espaço Girassol, há uma mandala de temperos e ervas, e, seguidamente, ela é alvo de diálogos entre as crianças. A professora Roberta decidiu embarcar nessa conversa e investigar com as crianças qual o significado de mandala.

Utilizando os Ciclos de Simbolização, a professora foi buscando compreender que narrativas as crianças tinham sobre a mandala da escola. "Essa Mandala parece um labirinto de chás”, falou Marcelo. Maria Clara concordou: "Tem dois círculos, um bem grande e outro menor e quatro canteiros... Por que não é um labirinto redondo de chás ao invés de Mandala?”. A investigação foi avançando e as narrativas das crianças também foram se transformando. "Mandala significa pegadas para seguir, é um caminho... Mas que talvez possa se transformar em um vestido diferente! Entende?”, disse Layla. “Assim, é uma coisa com muitos segredos”, retomou Maria Clara. Matheus resolveu explicar o surgimento da mandala: "Acho que o asteroide soltou fogo, e explodiu! Então o fogo derreteu o asteroide, e assim profe... Destruiu o asteroide e se transformou em uma Mandala!". Depois de muito segredos e mistérios partilhados, Valentina concluiu: "Eu sou minha Mandala!”.

Ao longo da investigação, é possível perceber que não apenas as narrativas orais se transformavam, como os desenhos iam ganhando detalhes e elementos a mais. O espaço da sala referência também foi ganhando elementos da cultura que pudesse servir de instrumentos para as crianças. A comunicação elaborada pela professora também mostra concepções. $O$ valor pelo traço das crianças, as imagens selecionadas, as palavras escolhidas para ir tecendo a narrativa de uma investigação tornam visíveis outras crenças sobre a infância, sobre a docência e sobre a Educação Infantil. 
A proposta de trabalho com os Ciclos de Simbolização de Loris Malaguzzi é para compreender "como as crianças aprendem a revisar verbalmente e a debater fatos, a agir ou a delinear seu entendimento atual, fazer representações gráficas de suas descobertas e invenções, e desenvolver notações e scripts para a comunicação desse conhecimento" (FORMAN, 1999, p. 180). Nesse sentido, a reflexão sobre os Ciclos de Simbolização vem para nos ajudar a responder a inúmeros questionamentos relativos à prática pedagógica, tais como O que é projeto na Educação Infantil? Como investigar com crianças de 3 a 6 anos? Qual a relação entre pensamento projetual e investigação com crianças pequenas? Como dar visibilidade para as teorias das crianças?

Ao longo dos três anos, as professoras passaram a experimentar esse tipo de investigação multissimbólica como uma das principais estratégias para compreender a construção das teorias das crianças em suas "cem linguagens". Fomos entendendo que o desenho, quando há um investimento e acompanhamento por parte do adulto, transforma-se em plataformas de grandes narrativas das crianças, em um canal de abertura para dar sentido ao mundo.

Com base no que foi vivenciado, compreendeu-se que é preciso saber criar bons contextos para a investigação, sabendo eleger materiais adequados para retroalimentar o percurso da investigação de tal modo que as diferentes linguagens fossem generativas uma das outras e também que a intervenção do adulto pudesse servir como ponte para as crianças irem ampliando e transformando seus desenhos.

\subsubsection{GIA do Brincar Heurístico}

No GIA sobre o Brincar Heurístico, participaram professores que atuam com turmas de 0-3 anos, cerca de 2 ou 3 representantes de cada escola, além das coordenadoras pedagógicas das instituições. Nesse grupo, levamos a cabo uma investigação sobre as diferentes modalidades do Brincar Heurístico com crianças pequenas: cesto de tesouros, jogo heurístico e bandejas de experimentação para problematizar algumas noções pedagógicas gerais.

A reflexão sobre o Brincar Heurístico é inspirada no trabalho desenvolvido por Elinor Goldschmied e trata-se de uma proposta para qualificar as oportunidades educativas na creche. Para essa autora, significa fomentar a concentração e a autoatividade das crianças bem pequenas. Segundo Majem e Òdena (2010), Goldschmied propõe algo muito mais amplo do que um método de organizar a brincadeira para as crianças, mostrando-nos como aproveitar a 
atividade espontânea de investigar, ou de "xeretar", que os meninos e meninas já carregam como oportunidades para criação de enredos lúdicos.

Tanto o cesto de tesouros, como o jogo heurístico e as bandejas de experimentação têm como denominador comum a exploração de materiais não estruturados e do que acontece com eles quando combinados os elementos entre si. Portanto, essas três modalidades compõem o que poderíamos nomear como Brincadeira Heurística.

A razão de escolher o Brincar Heurístico foi exatamente para problematizar o papel do professor e o modo como os bebês brincam na creche. As três modalidades do Brincar Heurístico colocam o adulto em uma situação privilegiada para apoiar os meninos e as meninas em suas descobertas, de modo a interferir o mínimo possível, mas criando as condições adequadas a partir da organização do espaço e dos materiais. Durante a brincadeira, o professor ocupa um papel importante para sustentar a atividade espontânea das crianças, e isso exige uma postura de disponibilidade, atenção e silêncio, permitindo que as crianças sigam seu ritmo e possam se concentrar em sua atividade de descoberta dos materiais não estruturados ofertados a elas.

Ao longo dos encontros, ao mesmo tempo em que refletíamos sobre como organizar a sessão, os melhores materiais para gerar investigações das crianças, o tempo necessário e o modo de organizar o espaço, reconhecemos como uma grande dificuldade o papel do adulto.

Tanto no que diz respeito à consigna que deveria ser dada para as crianças antes de iniciar a sessão (o que fazer e como agir durante a sessão), assim como a análise das atuações das crianças a partir do material documentado, foram os grandes tópicos desse GIA. Por isso, as professoras foram organizando dois tipos de filmagens e edição de vídeo. O primeiro foi referente ao modo de organizar uma sessão de cesto de tesouros, de jogo heurístico, de bandeja de experimentação, mostrando todas as etapas que envolvem propor isso na creche. Esse tipo de vídeo foi sendo construído na medida em que íamos assistindo pequenos episódios das escolas e íamos entendendo algumas ideias-chave para refletir a respeito; além disso, tinham como finalidade mostrar para outras professoras como ocorriam as sessões. O outro tipo de filmagem que foi organizado objetivava especificamente compreender de que modo as crianças exploram os materiais e que interpretações podemos fazer a partir disso. Nesse segundo tipo de vídeo, episódico, as professoras se detiveram em filmar passagens em que as crianças estavam realizando uma ação em que era possível perceber o início, o meio e o fim dos seus gestos. A partir desse segundo vídeo, foram se organizando algumas comunicações com a finalidade de narrar as aprendizagens das crianças. 
A mini-história que a professora Fabiana, da EMEI João de Barro, escreveu sobre um episódio da bebê Eduarda em uma sessão do Cesto de Tesouros revela a riqueza do olhar de uma professora que passa a compreender a complexidade dos gestos e dos olhares das crianças. Em vez de narrar com palavras generalizadoras, que minimizam as aprendizagem das crianças, Fabiana narra imprimindo a sutileza dos gestos da Eduarda explorando os objetos.

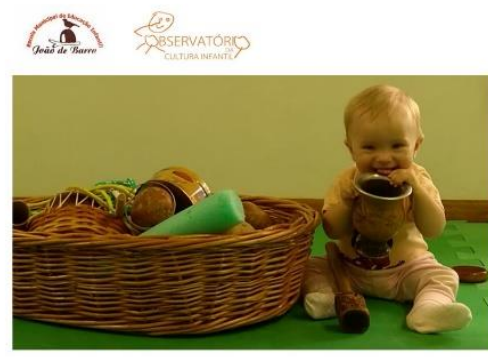

Professora Fabiana Martins | Criança: Eduarda, $8 \mathrm{~m}$

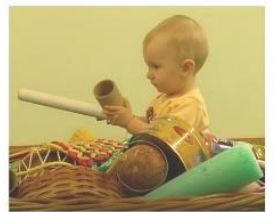

Eduarda seleciona dois rolos de papelão, segura um em cada mão. Demonstra um olhar de busca por um objeto especial, por algo que ainda não encontrou. Esse olhar que revista os tesouros do cesto, analisa, manipula os objetos e os sente através seu corpo.

Agora escolhe o mini porongo, segura-o com uma das mãos, sacode, faz barulho, troca o porongo de mão, pega o rolo novamente e então experimenta bater um no outro. Fixa seu olhar nos objetos, deixa o rolo cair de sua mão, permanece apenas com o mini porongo, apalpa com as duas mãos. Será que é duro?

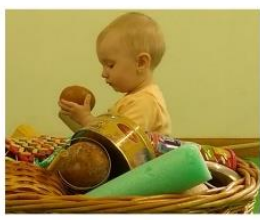

\section{BATENDO O OLHAR}

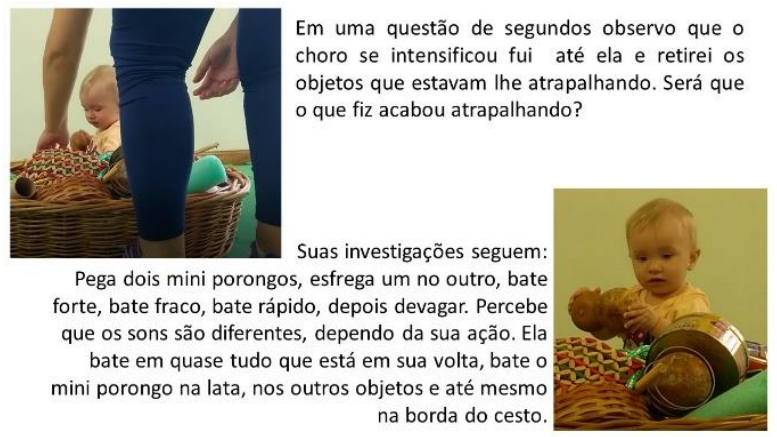

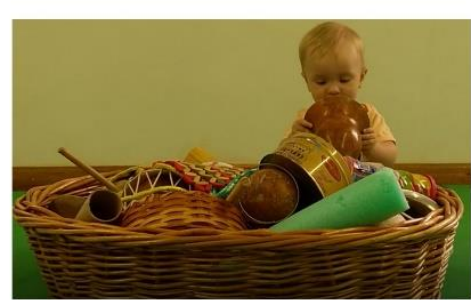

ogo ao iniciar a sessão Eduarda mergulha com os braços em direção ao Cesto de Tesouros, quase instantaneamente retira uma cuia de dentro do cesto, segurando fortemente com as duas mãos ela olha para dentro da mesma.

$\mathrm{O}$ que é isso? Me parece que Eduarda se faz essa pergunta.
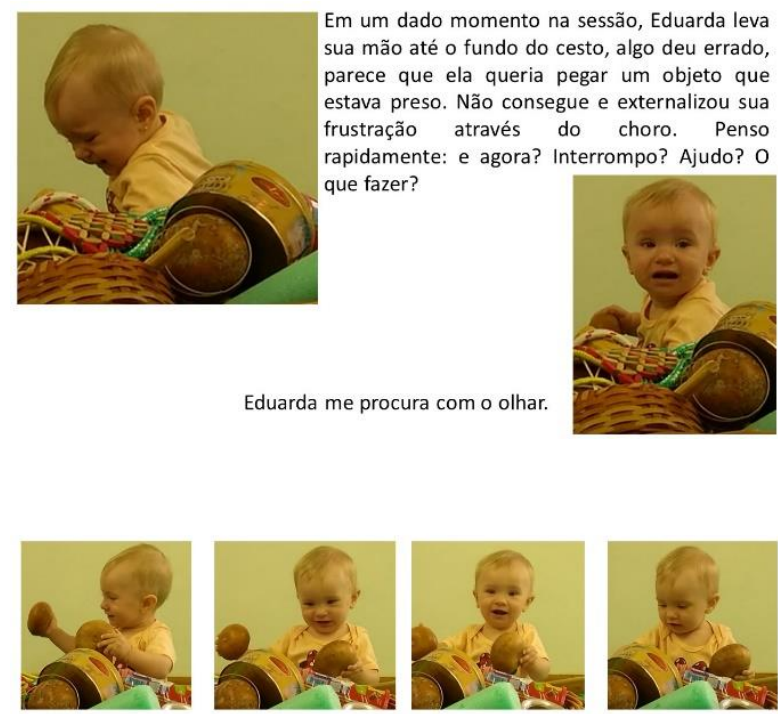

Eduarda, ao descobrir os barulhos, ou melhor, os diferentes barulhos que o mini porongo ressoa, sorri. Demonstra em seu olhar a satisfação por ter encontrado algo que parecia estar à procura.
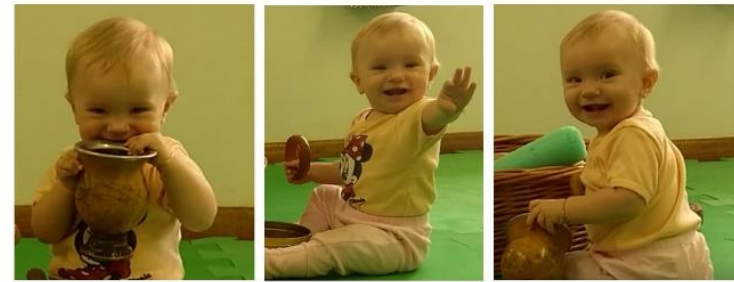

Logo, Eduarda acena, olha para a professora.

Não resisti, devolvi o sorriso, afinal ele era contagiante.

Esse GIA iniciou em 2016 e se estendeu até 2018. Decorrente dele, as professoras participantes e as coordenadoras escreveram um livro chamado "O Brincar Heurístico na creche: percursos pedagógicos no Observatório da Cultura Infantil - OBECI”, narrando suas 
experiências com cada uma dessas modalidades a fim de oferecer sua experiência para que outros professores possam pensar a prática com essa modalidade em suas (FOCHI, 2018)

\subsubsection{GIA do Acompanhamento Projetual}

Tanto no GIA do Ciclos de Simbolização como no do Brincar Heurístico, a ideia sempre foi que as temáticas escolhidas servissem como mote para pensar a ação pedagógica. No entanto, na medida em que avançamos com os GIA, um dos aspectos que ficou latente era a dificuldade dos professores em olhar para a globalidade da ação pedagógica. Na medida em que compreendiam os temas do GIAs anteriores, nem sempre conseguiam conectar com as outras dimensões da prática pedagógica. Assim surgiu esse GIA do Acompanhamento Projetual, para que uma turma de cada escola, acompanhada de sua coordenadora, participasse com a finalidade de refletir a globalidade da ação pedagógica.

Na verdade, o GIA do Acompanhamento Projetual é uma espécie de experimentação do que estávamos compreendendo nos anos anteriores do OBECI: de que precisávamos construir uma certa gramática pedagógica, como sugere Oliveira-Formosinho (2007). As gramáticas pedagógicas orientam um modo de pensar, de fazer e de refletir a práxis. Para essa

autora, a gramática pedagógica “[...] não é um conjunto de receitas e rituais. É uma gramática para o pensar, o fazer, o dizer e o avaliar do modo de viver a pedagogia em sala" (OLIVEIRAFORMOSINHO, 2016d, p. 139).

Nos primeiros cinco anos do OBECI, fomos investigando e transformando o cotidiano pedagógico tanto no nível da gestão como no nível da sala de referência e, com isso, percebemos a recorrência de alguns temas, por exemplo: a urgência de refletir sobre a organização do tempo, pois na medida em que avançávamos com as reflexões, mais notório ficava que o modo como a gestão do tempo acontecia nas escolas era problemática; o tipo de materiais que se oferecia para as crianças e as razões dessa oferta; o modo como organizar o espaço para superar uma simples ideia de decoração ou espaço recreativo e passar a compreender o espaço como relação; o trabalho com os pequenos grupos como alternativa para escutar as crianças e, talvez o principal tema, o reposicionamento do adulto e seu papel frente às crianças. Além desses que poderíamos dizer que compõem uma certa didática, o outro aspecto era como narrar as aprendizagens das crianças.

Nos outros GIAs, refletíamos e experimentávamos esses temas como pano de fundo, pois a centralidade permanecia nos Ciclos de Simbolização e no Brincar Heurístico. Em 2017, 
como uma primeira resposta a essas análises, realizamos uma série de encontros para tratar disso que já anunciávamos como Organizadores da Ação Pedagógica ${ }^{90}$.

Assim, este GIA do Acompanhamento Projetual foi um movimento a mais nessa construção de uma certa gramática pedagógica, embora nossa pretensão não seja exatamente fundar uma gramática pedagógica, mas explicitar o nosso modo de pensar, fazer, refletir a prática pedagógica. Oliveira-Formosinho (2016d, p. 139) destaca que "a gramática pedagógica progressivamente apropriada representa a saída da letargia da pedagogia implícita rotineira e costumeira ('sempre fiz assim...') para uma pedagogia explícita que sabe mostrar a ação imbuída de pensamento e fundada na ética".

Compartilho três fragmentos da investigação que as professoras Viviane e Julia, da EMEI João de Barro, construíram ao longo do GIA com as crianças da faixa etária 2 sobre a construção com materiais não estruturados. Essa temática surge da observação das professoras sobre o interesse das crianças em construir. O primeiro fragmento, os indícios iniciais:
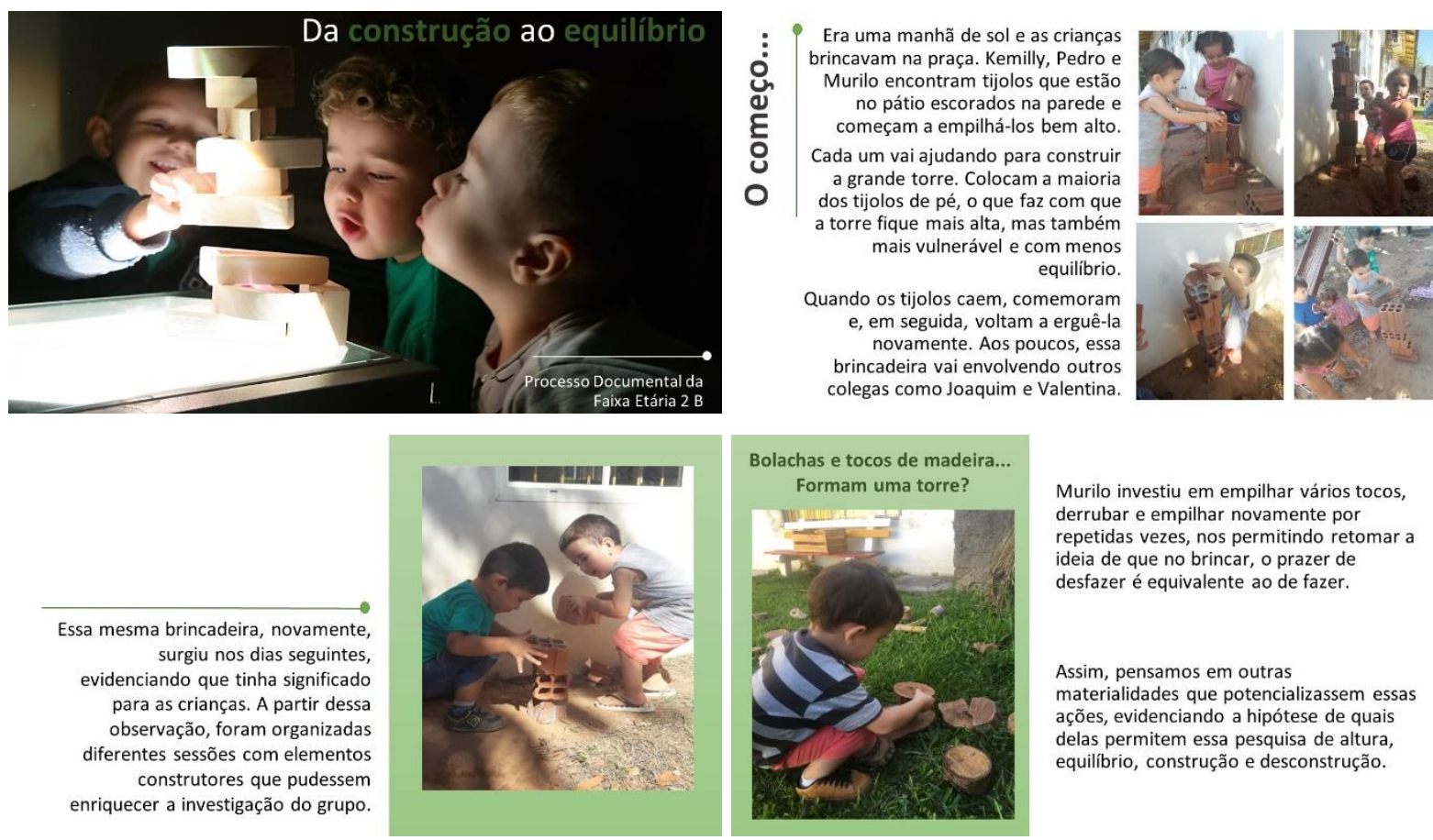

Murilo investiu em empilhar vários tocos, derrubar e empilhar novamente por repetidas vezes, nos permitindo retomar a ideia de que no brincar, o prazer de desfazer é equivalente ao de fazer.

Assim, pensamos em outras materialidades que potencializassem essas ações, evidenciando a hipótese de quais delas permitem essa pesquisa de altura, equilíbrio, construção e desconstrução.

${ }^{90}$ No próximo capítulo, irei tratar especificamente sobre os Organizadores. 


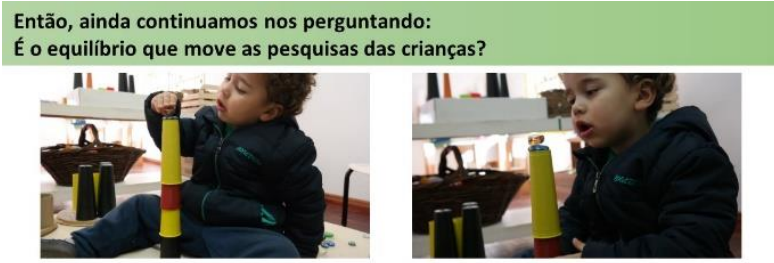

Nesta proposta, Lorenzo inicia sua investigação empilhando alguns cones e acima deles coloca uma pedra. Observa o que fez até então e decide colocar mais uma... Lorenzo percebe que colocar este segundo elemento depende de mais cuidado do que da primeira vez, assim, pega a pedra com a ponta dos dedos e, com olhar fixo em seu fazer, cumpre seu propósito: sua torre está subindo!
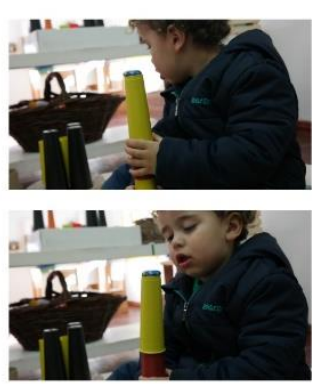

Subiu... e caiu!

A torre de Lorenzo com duas

pedras sobrepostas se manteve por

poucos segundos: uma pedra caiu!

Lorenzo atento ao que aconteceu, olha para sua construção querendo entender o que aconteceu:

-Aaah, caiu, que coisa!

Após lamentar o ocorrido, é hora de tentar novamente.

\section{E com outra pedra, a torre irá se equilibrar?}

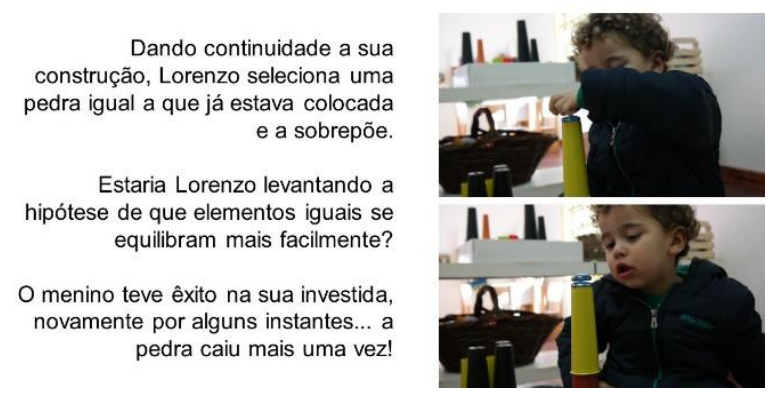

Depois de muito avançar com as construções em diferentes propostas, as professoras organizaram uma sessão inspiradas na Landart, com pedras e outros elementos da natureza. Eis que observam que as pedras viram grande atração das crianças para construir, pois a irregularidade da forma das pedras causa desequilíbrio e instabilidade; além disso, elas podem se transformar em muitas coisas, de astronautas a pizzas.

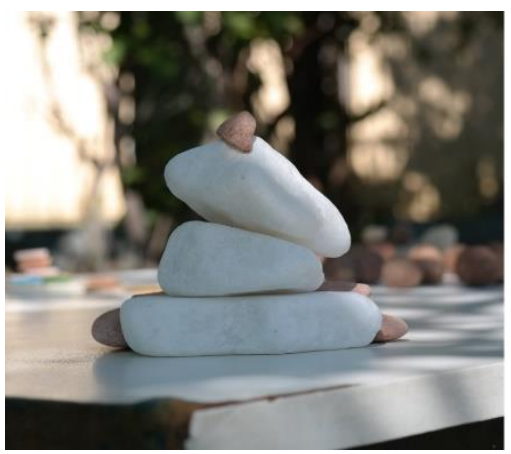

LAND ART: Possibilidades com pedras
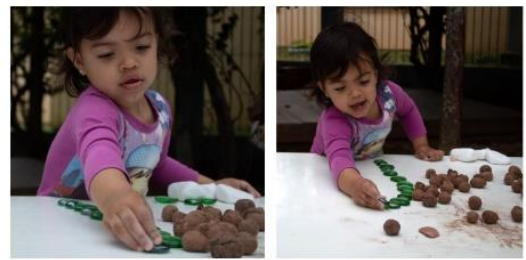

OLHAR,

TOCAR... SELECIONAR!

Entre as pedras que estavam na mesa, Alexia escolhe as verdes, jà conhecidas de outras sessões, e começa a organizá-las lado a lado. Forma uma longa fila... como se percorresse um caminho...

É a porta! A porta da minha casa.

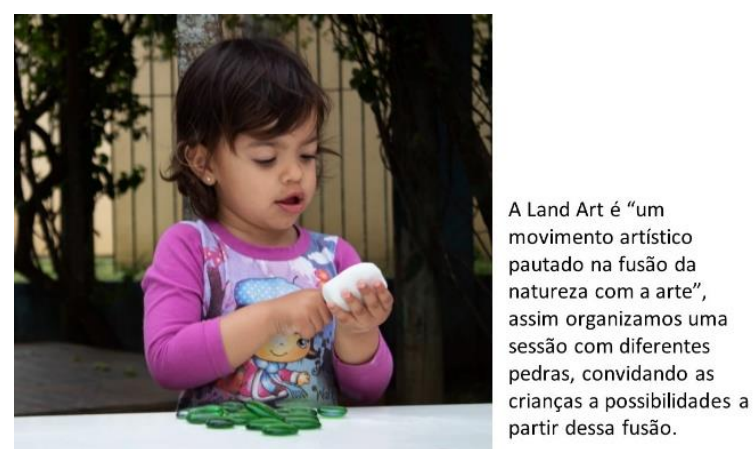

DEPOIS DA PORTA, O QUE VEM?

A casa!

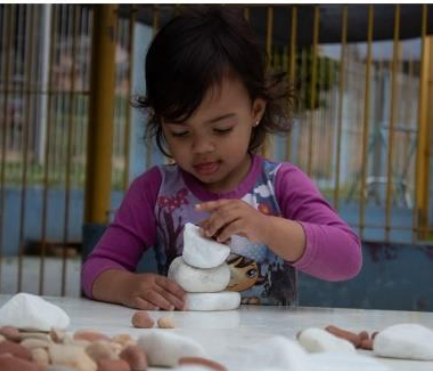




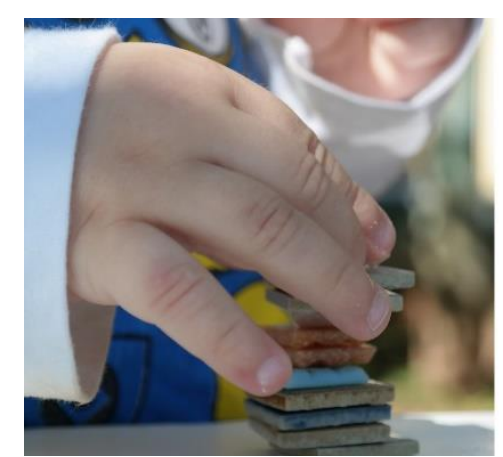

Na manhã seguinte, damos continuidade a sessão.

Desta vez acrescentamos um novo elemento junto às pedras: os azulejos em pastilhas.

E, então, observamos quais novas hipótese surgem e quais se repetem

Percebemos que as crianças ainda trazem em suas ações, fortemente, as torre e as casas. Com diferentes materialidades, pesquisam o equilibrio e o trazem às suas construções.
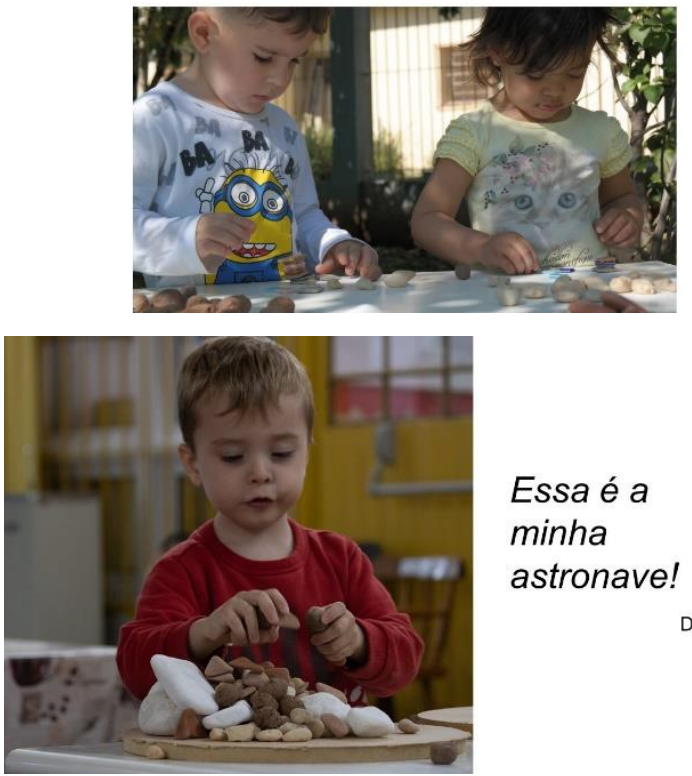

Essa é a minha astronave!

Dav

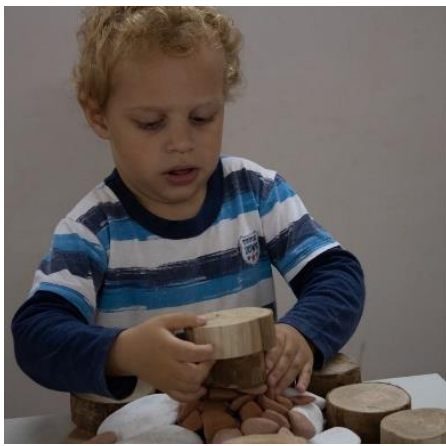

Tô fazendo a casa de tijolos dos porquinhos. Essa é a chaminé e o lobo está lá dentro!

Nícolas
Murilo investe em erguer uma torre com as pastilhas. Coloca uma sobre outra cuidadosamente, para que não caiam. Sua torre é alta, bem grande, como o próprio diz.

Em determinada altura, ele a derruba.
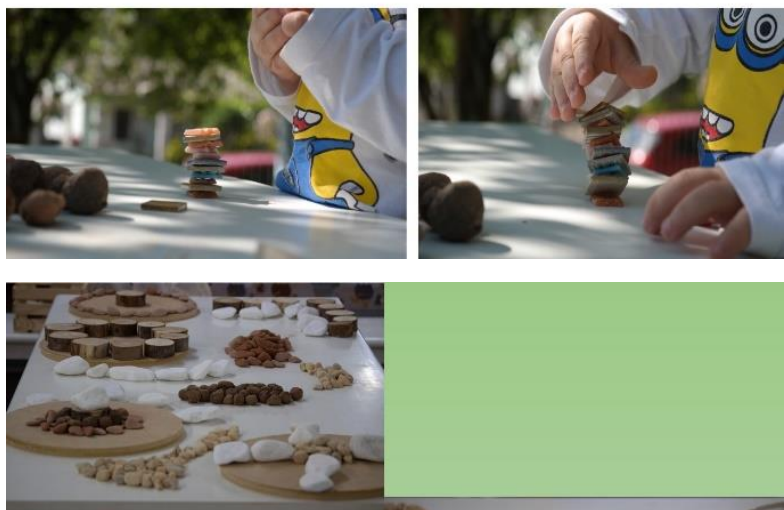

Pedras e tocos: outra possibilidade de Land Art
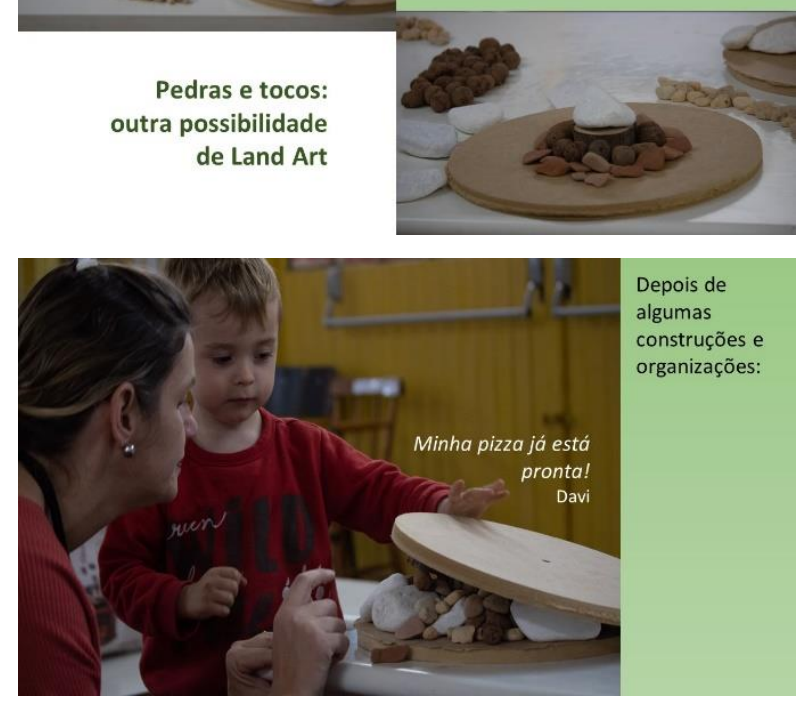

Olha meu bolo de chocolate, profe!

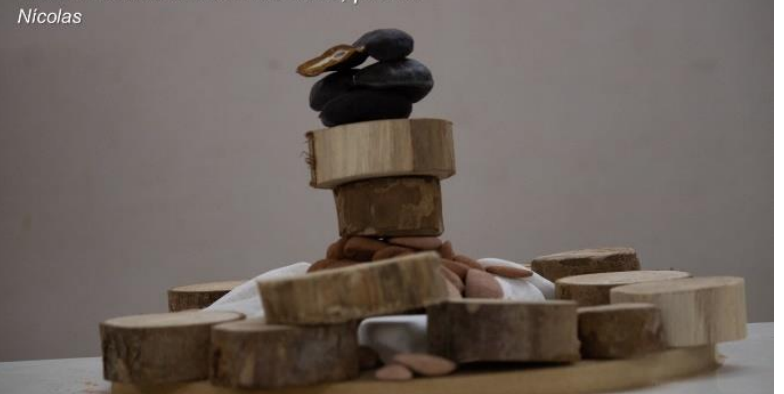

As pedras foram prolongando a investigação e, na combinação com outros materiais, novos rumos foram sendo pensados para dar continuidade nas investigações das crianças. Reflexo, pedras virtuais que apareciam no espelho: aprender a ir construindo as sessões a partir da reflexão que foi se construindo a respeito do próprio percurso e conseguir traduzir isso em narrativas que revelam a força das crianças e das professoras foi, sem dúvida, um dos principais avanços deste GIA. 

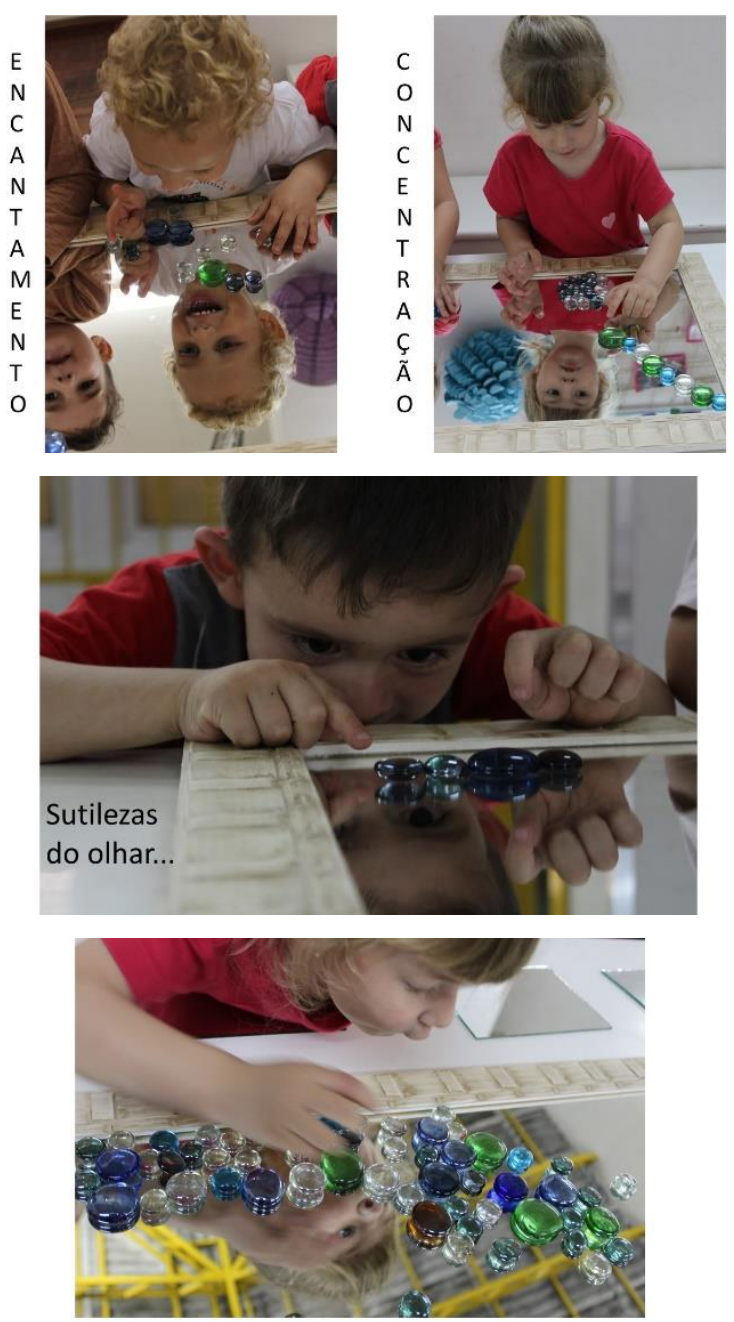

Helena constrói a casa e, em seguida, assopra para cair!
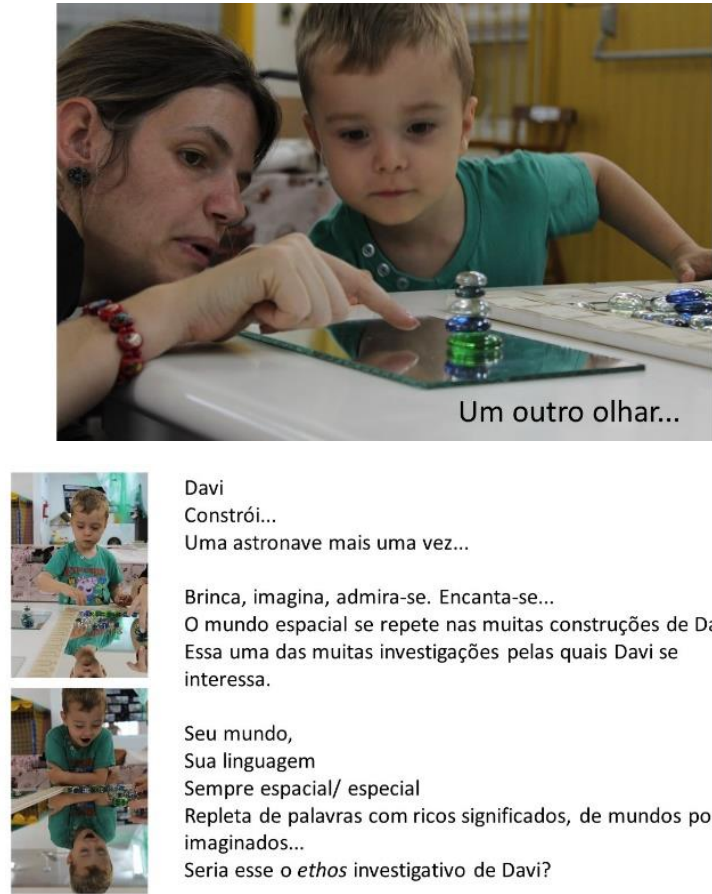

Davi
Constrói...

Uma astronave mais uma vez...

Brinca, imagina, admira-se. Encanta-se...

O mundo espacial se repete nas muitas construções de Davi. Essa uma das muitas investigações pelas quais Davi se interessa.

Seu mundo

Sua linguagem

Sempre espacial/ especial

Repleta de palavras com ricos significados, de mundos por ele imaginados..

Seria esse o ethos investigativo de Davi?

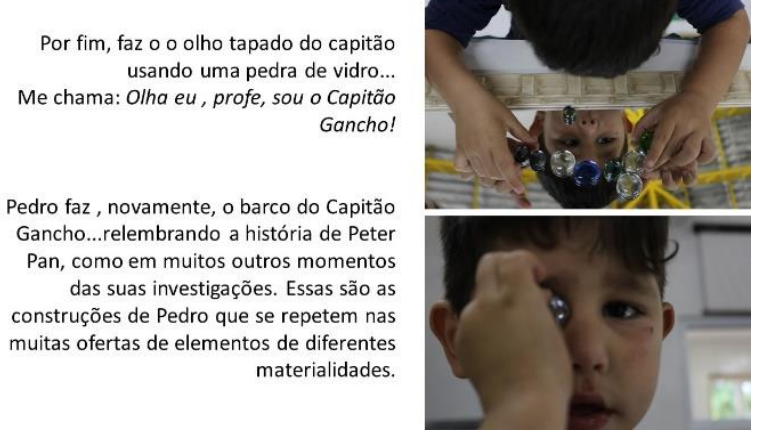

Resultados da experiência com esse grupo é que elegi as mini-histórias que abrem cada parte desta tese. Parte significativa dos dados que apresento no capítulo seguinte sobre os Organizadores da Ação Pedagógica também é oriunda desse trabalho, pois, em certa medida, ela representa o amadurecimento construído no OBECI ao longo dos seis anos de sua história.

\subsubsection{GIA do Jogos de luz e sombra}

O Grupo de Investigação-Ação dos Jogos de Luz e Sombra tem uma particularidade em relação ao seu funcionamento: tem ocorrido muito mais como ateliês do que exatamente como um processo contínuo de investigação e ação. Esse GIA surgiu, em 2017, pela demanda de uma das coordenadoras que destacou que, em sua escola, mesmo com um material bastante rico para investigar a luz e a sombra, não percebia o movimento dos professores. 
A luz “[...] é um dos grandes componentes da nossa percepção estética relacionados à emoção" (CEPPI; ZINI, 2013, p. 54). Brincar com a luz e com sombra é um laboratório estético, no sentido malaguzziano de que a estética é entrar em ressonância com o mundo (MALAGUZZI, 2001). Mais ainda, é aventurar-se em desvendar os mistérios entre a ciência e a arte, entre o real e o virtual, algo que fascina as crianças e os adultos.

Como um ateliê, a proposta desses encontros é sempre vivenciar os materiais disponibilizados e pensar nas possibilidades que eles podem se desdobrar na prática com as crianças. Por isso, criamos esse encontro para que os

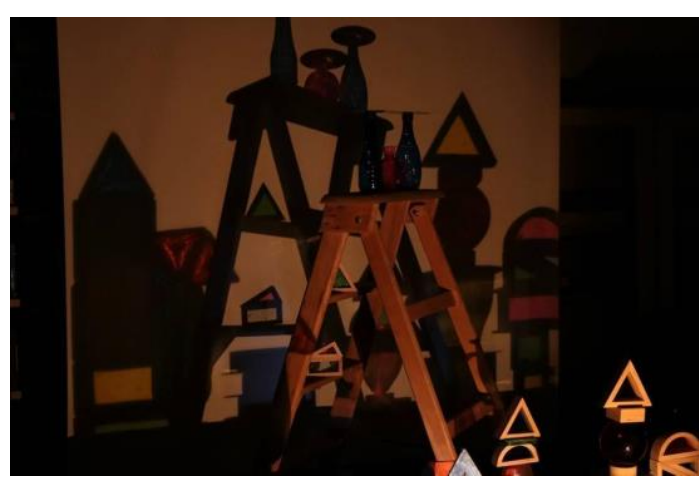
professores tivessem uma aprendizagem experiencial (LEAVERS, 2014), ou seja, com foco acentuado no processo, essa ideia de aprendizagem experiencial propõe ao adulto, professor de crianças, a experiência que se imagina propor a elas. Não demorou para as propostas começarem a aparecer nas escolas, como nestes dois casos narrados por meio das mini-histórias das professoras Samantha e Tatiane da Escola Mimo de Gente.
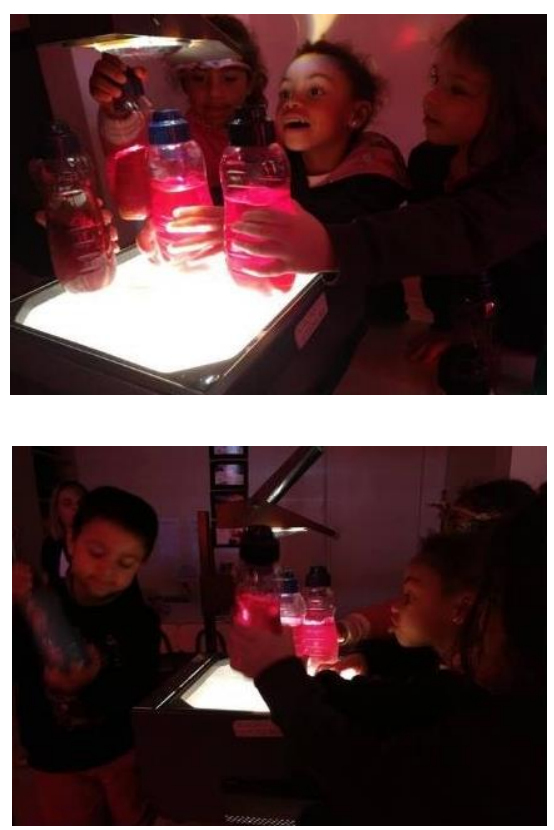

\section{LUZ E SOMBRA}

As crianças observavam com olhos atentos a luz que vinha de dentro do retroprojetor.

Que luz era aquela que iluminava a sala escura?

Manuela, Giovana, Lorenzo e Isabela aproximaram-se, curiosos, do retroprojetor.

Olharam atentos para a luz e, em seguida, para as garrafas com água colorida que estavam sobre a mesa. Logo começaram a colocar as garrafas sobre a superfície iluminada. Os olhares entre eles e suspiros demonstravam o deslumbre do que estavam vendo.

O meu é verde e ficou azul na luz, exclama Lorenzo. Ao contrário do que imaginávamos, as crianças sequer olharam para a parede para ver a projeção. Maravilharam-se com o brilho da água colorida nas garrafas atravessadas pela luz do retroprojetor. 


\section{NÃO É BRINCADEIRA, É TEATRO!}

Um pequeno grupo de crianças brinca durante uma sessão de

luz e sombra com lanternas e materiais de madeira.

Isadora encontra uma peça triangular, ergue-a e aponta a lanterna.

Parece uma montanha, exclama com expressão de entusiasmo.

Pega outra peça e percebe que sua sombra parece com a forma de um peixe. Movimenta a peça e inicia uma narrativa: um peixe nadando no mar.

Betina continua: encontra um peixinho bem pequeno, apontando para a sombra de um objeto circular que segurava

em suas mãos. Ela afasta o objeto da parede fazendo com que a sombra aumente de tamanho, e diz: E ele foi crescendo, crescendo... Após a sessão, perguntamos para as crianças sobre qual era a brincadeira. Betina alerta: não era brincadeira, era teatro!
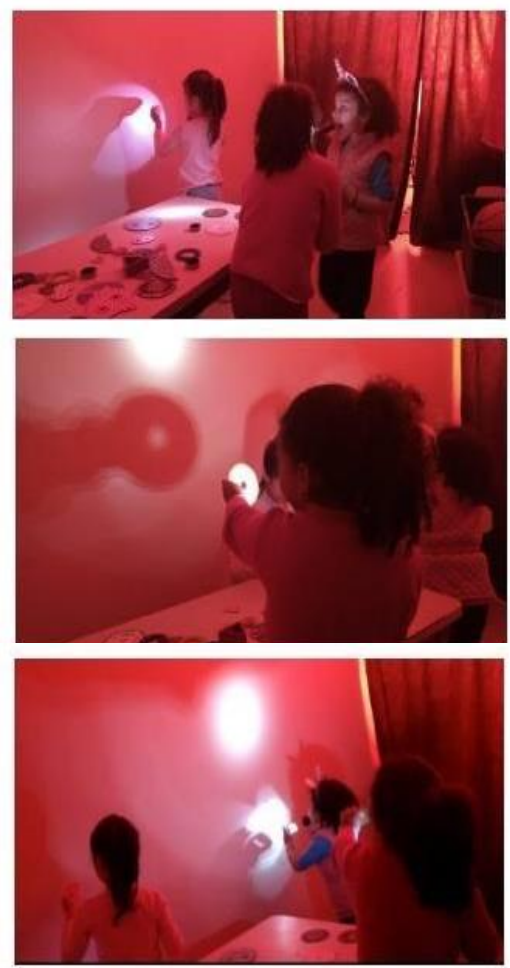

De uma prática inicial apenas com a luz e a sombra, passamos a incorporar outros instrumentos digitais, e esse GIA eventual acabou se transformando em um núcleo para refletir a relação entre a digitalidade e as crianças. Essa é uma certa resposta às crianças de hoje, superando a ideia de pensar sua relação com a linguagem tecnológica com softwares e jogos de computador ou o uso instrumental de novas tecnologias. A proposta, ao contrário, é buscar compreender o pensamento digital para ampliar os tipos de investigações que se faz com as crianças.

Entre 2017 e 2018, realizamos três encontros focalizando essa temática e em alguns são notórios os desdobramentos nas práticas das professoras.

\subsubsection{Encontro das Escolas Observadoras}

Além dos GIAs e do Grupo Gestor, com periodicidade semestral, passamos a organizar, desde 2017, encontros para o aprofundamento de grandes temas que estão em debate nas escolas. Os Encontros das Escolas Observadoras são voltados a todos os profissionais das instituições do OBECI e acabam sendo uma oportunidade de trocas e socialização entre as escolas. Diferentemente dos outros processos formativos que ocorrem durante a jornada de trabalho, esses encontros acontecem aos sábados, com duração de cinco horas. A característica 
desses encontros, em relação às demais propostas, é o fato de ser mais expositivo em virtude do número total de participantes, cerca de 100 profissionais.

Os conteúdos destes encontros foram escolhidos a partir da leitura que estávamos fazendo das necessidades das escolas, especialmente daqueles professores e demais profissionais que não estavam vinculados diretamente em algum dos processos de formação do OBECI. Assim, os temas dos Encontros das Escolas Observadoras foram Documentação Pedagógica, mini-histórias, transições educativas e Organizadores da Ação Pedagógica.

\subsubsection{Jornada de Educação Infantil}

Um dos grandes dilemas que aparece dentro do OBECI é como podemos compartilhar com outras instituições aquilo que estamos tratando no Observatório. Decorrente disso, anualmente, organizamos uma jornada aberta a outras instituições que não fazem parte do OBECI para o compartilhamento dos temas que estamos internamente aprofundando.

Este evento envolve um número expressivo de participantes, a última, em 2018, foi 800, e os temas abordados, nos últimos anos, foram Pedagogia da Comida (2014), Pedagogia do Cotidiano (2015), Documentação Pedagógica (2016) e Brincar Heurístico e Ciclos de Simbolização (2018). O formato das jornadas é sempre com a participação de palestrantes convidados para aprofundar os temas e a apresentação de comunicações das escolas do OBECI sobre as investigações que levam a cabo no Grupo Gestor ou nos diferentes Grupos de Investigação-Ação. Nas últimas duas jornadas, também realizamos a "Mostra de MiniHistórias: espalhando boas histórias da vida cotidiana" com exemplares selecionadas no interior de cada escola do OBECI.

Uma vez apresentados nossos processos de formação, discuto, na sequência, a estratégia que é transversal a todos esses processos e que tem nos ajudado a compreender como reposicionar crianças e adultos na relação educativa. Além disso, diferentemente da parte II, em que restituo o pensamento de Loris Malaguzzi sobre a Documentação Pedagógica, aqui mostro o modo como temos compreendido e desenvolvido o tema da documentação dentro do OBECI a partir da inspiração desse pedagogo. 


\subsection{A Documentação Pedagógica no Observatório da Cultura Infantil}

Conforme já tratado na Parte II desta tese, a obra de Malaguzzi é a que inspira o OBECI a pensar a Documentação Pedagógica com uma importante estratégia para a construção do conhecimento praxiológico e para dar testemunho ético, cultural e pedagógico das nossas crenças a respeito das crianças, dos profissionais e da identidade da Educação Infantil.

Em uma entrevista, Malaguzzi (2001, p. 61) conta que "o trabalho com a documentação pedagógica declarou o nosso modo de agir com as crianças. Forçou, de maneira agradável, a refinar os métodos de observação e registro de tal maneira que os processos de aprendizagem das crianças tornaram-se a base dos diálogos com os pais”. A construção de um modo de estar com as crianças, de compreender e dar visibilidade aos processos de aprendizagem e de se relacionar com a comunidade são os aspectos centrais que reconheço na Documentação Pedagógica.

Além disso, a forte aderência do OBECI em situar-se em um modelo de escola e comunidade com acento na investigação redefine os limites da teoria e da prática dentro das escolas e nos impulsiona a fazer uso de estratégias que nos ajudam a construir uma certa coerência entre nossos marcos conceituais e nossos marcos de ação.

No plano do marco conceitual, partilhamos de uma visão democrática de mundo, da noção do conhecimento como construção de significados, da abertura à pluralidade de visões e da perspectiva de que as crianças e os adultos partilham jornadas de aprendizagem a partir de seus processos de participação na construção de sentidos. Por isso, entendo que a Documentação Pedagógica não cabe em uma pedagogia qualquer (PINAZZA; FOCHI, 2018), ela se situa na família das pedagogias participativas (OLIVEIRA-FORMOSINHO, 2016c; PINAZZA; FOCHI, 2018), pois acolhe o sentido contextual, reflexivo e autoral que tais pedagogias comungam.

A Documentação Pedagógica é uma forma a mais nesta busca por constituir uma Pedagogia que se estabelece a partir do debate, da negociação, do trabalho em equipe e da curiosidade e para a curiosidade. Uma pedagogia que acolhe a dúvida e os inacabamentos como potencialidades para se recriar nas relações e nas incertezas; por isso, uma Pedagogia que não se filia às abstrações conceituais e aos reducionismos e explicações simplistas. Uma Pedagogia que confia na competência das crianças e dos adultos para construir jornadas de aprendizagens em parceria, de forma participativa e emancipatória. 
Também aprendemos com Malaguzzi (2001, p. 84) que "a prática se converte em um interlocutor necessário e decisivo para o êxito da teoria", o que implica ajudar os professores, coordenadores pedagógicos e gestores a problematizar e construir um grau de reflexividade sobre seus contextos.

Assim, do ponto de vista do marco da ação, temos entendido que, dentro do OBECI, a estratégia da Documentação Pedagógica, simultaneamente, ajuda-nos a (i) qualificar nossa capacidade de escutar as crianças, (ii) refletir a organização das propostas e da própria vida cotidiana, harmonizando as demandas e necessidades dos meninos e das meninas com as da instituição e dos adultos, (iii) criar abertura para transformar os contextos em que estão inseridos, (iv) vivenciar percursos de formação contextualizado e com alto grau de reflexividade para os profissionais, (v) construir um conhecimento situado e fecundado em teorias e (vi) narrar as aprendizagens das crianças, dos adultos e da identidade da escola.

Dessa forma, no Observatório, a Documentação Pedagógica é entendida como uma estratégia de formação, de investigação e de sustentação de um dado conhecimento praxiológico. Como Bonás (2011, p. 54) destaca, “a documentação interpreta, escreve teoria sobre uma prática que, ao mesmo tempo, se legitima”. Conecta, portanto, a contemporaneidade que há entre o mundo da prática e o mundo da construção de significados, sem se abster da forte exigência interpretativa que é construída a partir de marcos referenciais. Também Bonás (2011, p. 54) reforça que a Documentação Pedagógica “[...] não deixa de estar intimamente ligada à ética, não deixa de ser uma escolha, um posicionamento, uma tomada de decisão. Não deixa de ser também uma formulação de como nós somos como professores e professoras, que escola somos e para onde direcionamos nosso olhar".

É por isso que para nós, no interior do OBECI, além de ser uma possibilidade de declarar nossas concepções, a Documentação Pedagógica é uma estratégia central para nos ajudar a investigar, compreender e explicitar internamente a Pedagogia como um sistema complexo de crenças, valores, teoria e prática. E, exatamente pela sua explicitação, ascendemos a outros níveis de compreensão e de realização de uma prática pedagógica fundamentada e situada. Daí que a Documentação Pedagógica é uma estratégia importante para a construção e sustentação do conhecimento praxiológico e para o testemunho de nossa imagem de criança, de adulto e de escola.

Desde o surgimento do $\mathrm{OBECI}^{91}$, estamos permanentemente atentos às necessidades formativas que podem responder à complexidade da ação pedagógica; por sua vez, o que

91 Como já mencionado em detalhes no item 1.4 sobre os Processos de formação do OBECI. 
conecta os diferentes processos formativos é a estratégia da documentação pedagógica. Assim, desenhamos o funcionamento do Grupo Gestor com os coordenadores pedagógicos e diretores para investigar a formação e gestão do trabalho pedagógico das instituições, também com os Grupos de Investigação-Ação em que convidamos professores e coordenadores pedagógicos para olharem para seu trabalho com as crianças com vista a transformá-lo, e, não diferente, nas Jornadas e nos Encontros das Escolas Observadoras, compartilhamos os percursos de aprendizagens que estamos construindo dentro das escolas e do Observatório.

Assim, ancorados pelos conceitos já explicitados anteriormente e fortemente inspirados pelo percurso de Loris Malaguzzi, dentro do OBECI, desenhamos um caminho que tem nos ajudado a problematizar a Documentação Pedagógica como estratégia para construir o conhecimento praxiológico e para tornar visíveis os percursos de aprendizagem. Como nos alerta Oliveira-Formosinho (2016c, p. 114, grifo do autor), “a documentação, enquanto meio para revelar a aprendizagem das crianças e dos profissionais, necessita de clarificação teórica e conceitual, bem como de clarificação ao nível da techne, isto é, de como fazê-la".

Portanto, a proposta desta seção é compartilhar o modo como temos compreendido e realizado a Documentação Pedagógica tanto em nível da construção dos processos formativos e investigativos (que chamamos de processo documental), estruturando uma certa "didática" do trabalho do professor diretamente com as crianças, como no nível de comunicação das aprendizagens, tornando visível nossa imagem de criança, de adulto e de escola.

Frequentemente se vê a Documentação Pedagógica sendo tratada apenas como um documento em si, ou um produto concreto (PINAZZA; FOCHI, 2018). No entanto, a Documentação Pedagógica não é apenas produto, mas uma estratégia de investigação que resulta em um produto com ênfase no processo (FOCHI, 2013). Cientes desse desafio, no OBECI, nós criamos um ciclo de investigação que pressupõe a interatividade entre dois níveis focais. Um deles auxilia na elaboração de processos reflexivos e no planejamento da prática pedagógica aberto ao mundo das crianças. O outro nível não é uma etapa posterior ou anterior, mas uma outra camada que simultaneamente vai gerando informes que dão sentido e restituem a prática pedagógica e as aprendizagens das crianças e dos adultos. No esquema a seguir, presente na Figura 02, esboço a síntese do modo como tenho compreendido a Documentação Pedagógica e da maneira como tenho desenvolvido essa compreensão junto às escolas participantes do OBECI. 
Figura 02 - Níveis da Documentação Pedagógica

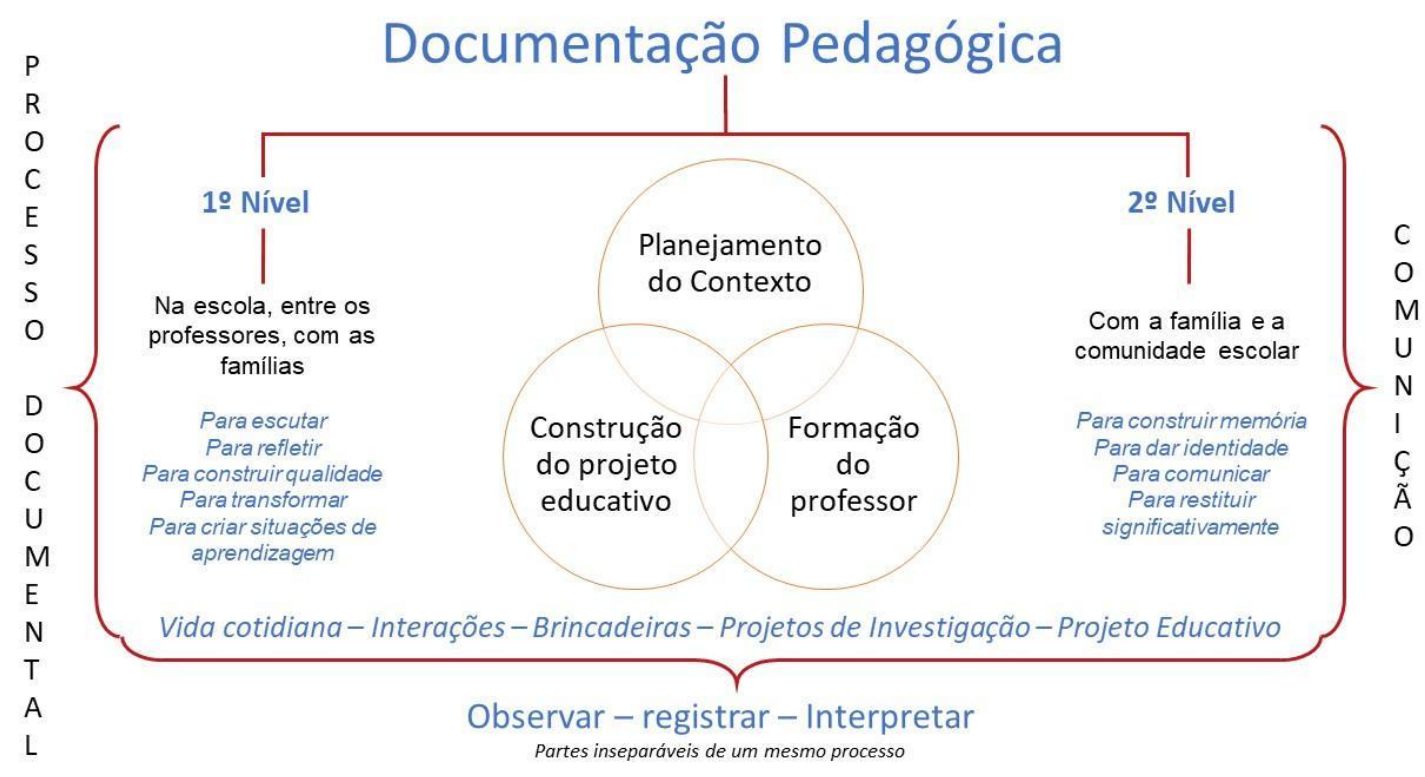

Fonte: Fochi, 2016b

Como já tratei em outros textos ${ }^{92}$, acredito que há dois níveis focais do trabalho na Documentação Pedagógica: o primeiro, interno, em que são gerados os processos documentais da construção de uma prática observada, registrada e interpretada para a sua retroalimentação e para a identificação das zonas de construção de conhecimento das crianças, dos profissionais e da instituição. O segundo nível, externo, trata da comunicação das crenças e dos valores que a instituição construiu, da comunicação dos percursos de aprendizagem das crianças e do modo como elas interpretam e elaboram sentidos para si mesmas, para os outros e para o mundo, ou seja, é um nível de compartilhamento e diálogo democrático com a comunidade.

Quando nos valemos da Documentação Pedagógica como estratégia para investigar algo, propositadamente estamos optando por observar e registrar os acontecimentos em nosso contexto a fim de refletir e tornar visíveis as descobertas do cotidiano das crianças e dos adultos em suas jornadas de aprendizagens.

As reflexões desses dois níveis focais são sustentadas por aquilo que tenho chamado de Pilares da Documentação Pedagógica: observar, registrar e interpretar. Esses pilares dão a tônica metodológica que subjaz a Documentação Pedagógica como uma estratégia para a

\footnotetext{
92 Em um texto publicado em um período acadêmico (FOCHI, 2016b), havia esboçado uma primeira formulação a respeito desses níveis focais da Documentação Pedagógica. Desenvolvi e ampliei essa formulação no texto de qualificação desta tese (FOCHI, 2017) e, mais recentemente, em uma pesquisa que conduzi para o Ministério da Educação e Unesco (FOCHI, 2019). Por isso, embora indique a referência da primeira formulação, é importante destacar que tenho continuamente refletido sobre esse tema e realizado pequenas alterações no esquema que apresento neste texto, muito embora a ideia central permaneça a mesma já indicada desde a primeira publicação.
} 
reflexão e a transformação dos contextos ao mesmo tempo que comunica as crenças e valores de uma dada instituição ou grupo de profissionais. Além disso, a ideia de identificá-los por meio de verbos é exatamente para acentuar sua qualidade de ação, de movimento e de interconectividade que há entre esses três pilares que são entendidos como partes inseparáveis de um mesmo processo.

Observar é compreendido como uma "tentativa de enxergar e entender o que está acontecendo no trabalho pedagógico e o que a criança é capaz de fazer sem qualquer estrutura predeterminada de expectativas e normas" (DAHLBERG; MOSS; PENCE, 2003, p. 192). Isso significa saber colocar em suspensão nossas ideias pré-fixadas a respeito das crianças para querer conhecê-las, compreender seus processos de aprendizagem e criar a temporalidade necessária para refletir sobre a própria relação com os meninos e meninas.

Registrar é uma forma de garantir modos concretos de nos enxergar e enxergar as crianças na vida cotidiana das escolas. Como afirma Malaguzzi (1988), é um modo de tirar as crianças do anonimato para iluminar a complexidade de suas ações. Os registros servem simultaneamente para ir construindo os observáveis que retroalimentam o trabalho pedagógico e servem como material para a elaboração das comunicações.

Interpretar tem um caráter ativo, ou seja, de interpretação para projetar algo. O termo em italiano é progettazzione, que não tem tradução para o português. No OBECI, tenho tratado o termo com o sentido de interpretar para projetar, como um meio para refletir sobre o trabalho pedagógico de maneira rigorosa, metódica e democrática, perspectivando a proposição de organizar, planejar e realizar a transformação do cotidiano pedagógico.

Além disso, os interesses dos dois níveis focais da Documentação Pedagógica são bem ampliados e envolvem os diferentes âmbitos que compõem uma instituição educativa. Tanto no primeiro nível, que se centra na "didática" do cotidiano, ou seja, nos modos de pensar, fazer e narrar a cotidianidade pedagógica, como no segundo nível, em que se comunica a respeito dos percursos de aprendizagem, o interesse atravessa questões relativas ao âmbito do professor, das crianças, do projeto educativo da escola e da relação entre eles.

Nesse sentido, destaco que a documentação pedagógica tem como interesse investigar e tornar visíveis:

a) os distintos aspectos da vida cotidiana, como o momento da alimentação, os deslocamentos entre os diferentes espaços, o momento da troca; 
b) as diversas camadas das interações entre as crianças ou das crianças com os adultos, da constituição das amizades entre elas, do como se tornam grupo no cotidiano das instituições e de como interagem com o seu entorno;

c) das brincadeiras como valor para a promoção da cultura infantil;

d) dos projetos de investigação levados a cabo com as crianças em pequenos ou grandes grupos e do modo como aprendem e constroem sus teorias;

e) do projeto educativo da instituição como reflexão e tradução dos valores e princípios da escola.

Por esse espectro ampliado de interesses, é que a Documentação Pedagógica acaba incidindo na constituição de uma prática altamente reflexiva, resultando em uma postura de investigação e de transformação do contexto. Quando declaradas as concepções que emergem desse processo, interrompe-se o círculo vicioso de fazer abstrações genéricas nos documentos que a escola comunica e de criar abismos entre o dito e o feito. Testemunhar a prática pedagógica e as aprendizagens das crianças envolve "uma certa dose coragem, a coragem de tornar pública essa decisão" (BONÁS, 2011, p. 54), ou seja, como nos relacionamos e nomeamos a infância, a docência e a Educação Infantil.

Tanto no primeiro como no segundo nível, a incidência está na promoção da cultura da infância e a promoção de uma cultura pedagógica. Nesse sentido, reafirma-se a crença de que a escola é espaço privilegiado para a garantia dos direitos das crianças e reconhece na pedagogia a possibilidade de inovar e estabelecer-se como ciência que efetivamente contribua com os modos de fazer, pensar e comunicar a complexidade do que se faz em uma instituição de Educação Infantil.

Por isso, na interatividade entre os dois níveis da Documentação Pedagógica, acredito que sejam mobilizadas três dimensões importantes:

a) o planejamento do contexto educativo, em que se organizam os tempos, os espaços, as materialidades e os diferentes arranjos de grupos com maior consciência e assertividade em termos de resposta das necessidades das crianças, graças ao nível de reflexividade dos adultos;

b) a construção e concretização de um projeto educativo, que não se limita a um documento escrito, mas que se mantém vivo, comunicado e constantemente revisitado pelos diferentes atores da escola, traduzido no cotidiano da instituição;

c) um modo contextualizado e permanente de formação dos professores. 
O exercício de construir a ação pedagógica implicada na observação, no registro e na reflexividade do cotidiano educativo mobiliza o professor a aprender tomar consciência sobre o seu próprio fazer. Assim, comunicar, posteriormente, também o responsabiliza e lhe confere a devida importância e valor no processo educativo de uma criança.

O desdobramento desses níveis focais constituiu a construção de um ciclo de investigação. Tal ciclo é resultado dos seis anos que temos experienciado no OBECI a respeito do tema em busca de compreender algumas pistas para orientar o trabalho dos professores, coordenadores pedagógicos e gestores. Essas pistas, em suas ambiguidades e contradições, tentam expressar a nossa tônica na investigação e a crença de que o modelo pedagógico ao qual nos filiamos é aquele relacional e participativo, ou seja, que nem abandona a criança a sua própria sorte e nem é demasiado intervencionista. Também expressa o modo como temos tentado acolher a dimensão da vida cotidiana como uma das forças para o bem-estar e para a construção de percursos de aprendizagens das crianças.

Figura 03 - Ciclo de Investigação Processo Documental - Comunicação

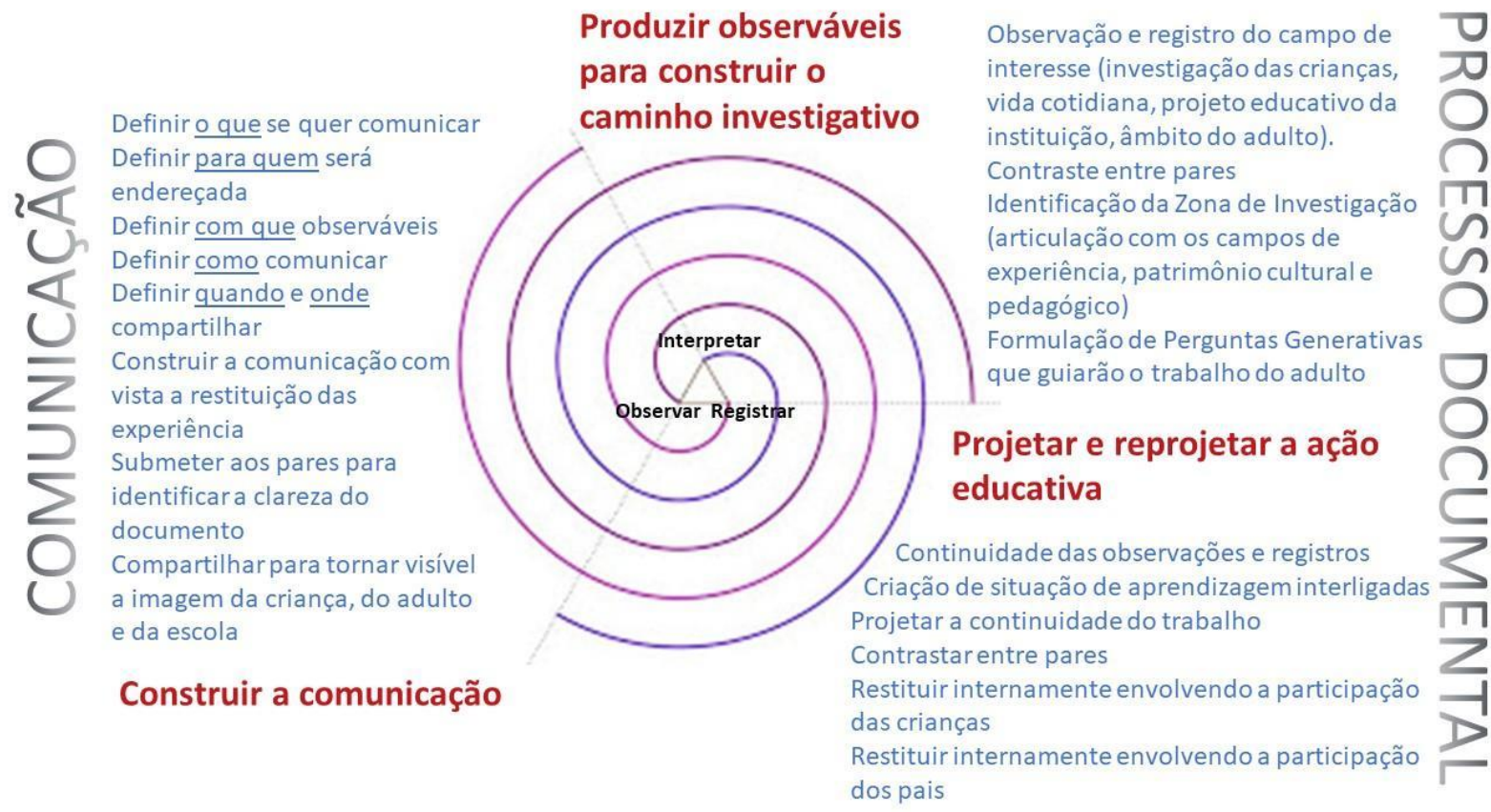

Fonte: FOCHI, 2019

Nesse ciclo, partimos dos pilares da Documentação Pedagógica, como já foi explicitado na Figura 03: observar, registrar e interpretar. A partir desses, desdobram-se os dois níveis da Documentação Pedagógica: o interno, vinculado à construção do processo documental, e o externo, em que se desdobram as comunicações. Para criar a circularidade entre esses dois níveis, elaboramos um caminho aberto para nos ajudar nas investigações que os 
professores realizam com as crianças e com a equipe gestora, que realiza os processos formativos e a consolidação do projeto educativo.

$\mathrm{Na}$ sequência, para apresentar detalhadamente os diferentes momentos do ciclo de investigação que temos desenvolvido no OBECI, tratarei de cada tópico estabelecendo articulação com excertos das investigações que temos desenvolvido no Observatório.

\subsubsection{A construção dos processos documentais no interior da instituição de Educação} Infantil: o primeiro nível

Um dos aspectos centrais da Documentação Pedagógica é a escuta. Para Malaguzzi (2001), a escuta é uma metáfora que convida o adulto a acolher o universo das crianças, é uma postura que nos ensina a levar os meninos e meninas a sério. A escuta é entendida como verbo ativo, como premissa da relação de aprendizagem, como curiosidade, como tempo de silêncio e pausas interiores, como suspensão, como sensibilidade para aquilo que nos conecta aos outros e a nós mesmos (RINALDI, 2012). Escutar as crianças é dar um passo atrás, é uma "metáfora de disponibilidade" (RINALDI, 2014, p. 82). A escuta não é um exercício de fazer perguntas para dar respostas, mas de conseguir traduzir no cotidiano pedagógico as necessidades e exigências das crianças. Por isso, é um antídoto contra a traição do potencial das crianças e, assim, um modo de diminuir os abismos entre o que dizemos em relação às crianças e como nos relacionamos com elas.

Em vista disso, pode-se dizer que o primeiro nível é estruturante para refletir a respeito do agir do adulto e do modo como as crianças constroem sentido sobre si, sobre o outro e sobre o mundo. A função desse primeiro nível é compreender e acolher o sentido que emerge da experiência educativa para saber criar situações de aprendizagem e projetar a continuidade da ação educativa, pois o passado é propulsor do futuro, já afirmou Dewey (2010, p.28), “assim como nenhum homem vive e morre para si mesmo, nenhuma experiência vive e morre para si mesma".

A oportunidade de restituir a ação educativa a partir de um conjunto de registros, frutos de observações (que preferimos chamar de observáveis), ajuda a propor situações de aprendizagem que não pareçam um acúmulo de situações distintas e desconexas. Ao contrário, devem ter continuidade e conectividade, proporcionando às crianças contextos em que possam aprofundar e investigar potencialmente. Não podemos apenas falar de uma criança competente, é preciso saber criar ambientes que acolham sua potência. 
Recolher, organizar e analisar os observáveis, reelaborando os momentos significativos em um documento contínuo e em processo para refletir o passado e o presente e projetar o futuro, é o que temos chamado de processo documental. O processo documental ${ }^{93}$ é um documento construído a partir da coleção de observáveis e que serve de bússolas para auxiliar o professor a se movimentar dentro das investigações que realiza com seu grupo de crianças ou mesmo de investigações que um grupo de professores ou a própria instituição está colocando em curso.

O processo documental é a construção de uma certa organização dos observáveis gerados no cotidiano pedagógico que, ao serem revisitados, servem para o professor notar, anotar e refletir sobre o caminho que está trilhando. Além disso, conforme o processo documental vai sendo elaborado, além do professor poder conhecer melhor como as crianças aprendem, o processo documental ajuda a decidir como dar continuidade às propostas e aos processos de investigação das crianças, pois esses documentos se constituem a partir de observações e registros que vão sendo contrastados, refletidos e interpretados para projetar entre pares (professor e professor; professor e coordenador pedagógico).

Entendo que a construção de uma práxis refletida e densamente documentada é peçachave para a construção de contextos de qualidade, pois construir qualidade significa "[...] deixar vestígios da memória, produzir continuidade, refletir, projetar, comunicar, transferir conhecimento" (TOMASELLI, ZOCCHI, 2009, p. 27).

Há uma ruptura importante no que diz respeito à noção da temporalidade da aprendizagem dos meninos e meninas, pois o processo documental acaba mostrando que a aprendizagem das crianças não é tão desorganizada e desconexa como se pensa. Uma vez que a construção desse documento é realizada continuamente, pode-se perceber as transformações e conexões das teorias das crianças, ou mesmo os modos como exploram e experimentam certas materialidades e conceitos. Também é possível compreender o valor contextual e social da aprendizagem, pois torna visíveis as relações que as crianças vão estabelecendo entre si para negociar significados.

Assim, o processo documental representa o passado, o presente e o futuro. Ou seja, é um elo de recuperação e memória da história da criança, da aprendizagem da criança e do grupo, das decisões tomadas pelo professor ou mesmo da história que a própria instituição trilhou. Também é motor para a tomada de decisão do aqui e agora, auxiliando o adulto a eleger qual o

93 No OBECI, geralmente temos utilizado o software Microsoft Power Point ${ }^{\circledR}$ para construir o Processo Documental. Na sequência deste texto, irei utilizar um processo documental construído no interior de um GIA por duas professoras a respeito de uma investigação com crianças de 2 anos. 
caminho que pretende percorrer dentro de uma investigação - quer seja no âmbito das crianças, quer seja da escola e dos professores. Ao mesmo tempo, é a construção de um sentido de continuidade para o futuro, pois cria uma conexão entre as situações de aprendizagem que se transformam em oportunidades de aprofundamento nas investigações das crianças.

Nos processos documentais que temos estruturado dentro do OBECI, vamos organizando episódios que mostrem os interesses das crianças e, a partir disso, vamos identificando perguntas generativas e zonas de investigação para o professor ou a equipe pedagógica irem construindo o caminho que pretende trilhar junto das crianças. Ao longo desse material, incorporam-se os instrumentos de planejamento e as reflexões sazonais que os professores realizam. Sempre que identificamos um rumo para a investigação, para ampliar e complexificar os diferentes conteúdos que podem estar relacionados à zona circunscrita para investigar, os professores criam uma constelação de possibilidades. Essas constelações servem apenas aos adultos e não têm outro propósito senão o de criar uma abertura no horizonte de possibilidades. Assim, o professor ensaia pequenas narrativas visuais e textuais em formato de episódios elaboradas a partir do conjunto dos observáveis do cotidiano educativo.

O que vai sendo produzido ao longo do primeiro nível se configura como um planejamento refletido, que nasce da escuta ativa do adulto em relação às crianças; portanto, que se traduz no modo como se organiza o cotidiano pedagógico e que é capaz de narrar seus percursos de aprendizagem. Assim, os processos documentais vão construindo um rico patrimônio do conhecimento praxiológico elaborado pelas professoras no exercício reflexivo sobre a práxis pedagógica. Esse material já se configura como um grande testemunho ético, cultural e pedagógico sobre o trabalho desenvolvido, assim como é a partir dele que se retroalimenta a continuidade da prática e se decide sobre as comunicações que serão feitas durante ou ao final da investigação.

Finalmente, pode-se dizer que esse primeiro nível é aquele que se ocupa com a transformação. O cotidiano de cada instituição precisa ser visto como algo que dê o que pensar. Por sua vez, quando observado, registrado e refletido, o cotidiano autoriza e encaminha as tomadas de decisões sobre a criação de um contexto educativo que acolhe o universo das crianças.

Dentro desse primeiro nível, há duas camadas: produzir observáveis para construir o caminho da investigação e projetar e reprojetar a ação educativa. Passo a discutir cada uma delas. 


\subsubsection{Produzir observáveis para construir o caminho da investigação}

Já mencionei, anteriormente, que a investigação pode ser de diferentes âmbitos: da instituição, do professor e da criança. Por isso, para gerar a circularidade investigativa que desejamos, começamos a construir o processo documental a partir da reunião de observações e registros que nos ajudam a direcionar um ou mais caminhos. A esse conjunto de observações e registros chamamos de observáveis.

O termo observáveis é nomeado no interior do OBECI para os indícios gerados no cotidiano pedagógico, frutos da observação e do registro, que permitem ao adulto compreender a complexidade da ação das crianças, confrontar suas escolhas e problematizá-las para as desnaturalizar. Trata-se de anotações do professor, fotografias, vídeos, exemplares de produções das crianças, gravações em áudio, ou seja, registros que podem ser colocados sob análise e reflexão desde outros pontos de vistas (outros professores, coordenador pedagógico, outras escolas do OBECI) e que, em um intercâmbio ativo, ajudam a compreender as distintas explicações, visões e possibilidades que cada observável oferece.

Bruner (2001, p. 140) afirma que "ouvir dois relatos contrastantes, mas igualmente razoáveis do 'mesmo' acontecimento [...] nos leva a examinar como dois observadores poderiam 'enxergar' as mesmas coisas acontecendo e sair com histórias tão diferentes do que aconteceu. Isto nos desperta”. Tomando emprestado de Bruner (2001) o conceito de contrastes, fazer esse exercício é contrastar pontos de vista, que, além de afirmar a dialogicidade que há na Documentação Pedagógica, são um antídoto para não reduzirmos a complexidade que há nas coisas e nos acontecimentos a uma única visão. Mesmo quando não há um parceiro para contrastar os observáveis, ou quando já se tem um alto grau de consciência sobre a prática pedagógica, é possível fazer o que Rinaldi (2012, p. 65) define como "escuta interna, escuta de nós mesmos". Contrastar, consigo mesmo ou com os pares, é sempre uma oportunidade singular de "uma pausa, uma suspensão, um elemento que engendra ouvir os outros, mas que também é gerado pelo escutar o que os outros têm de nós" (RINALDI, 2012, p. 65).

Além disso, a possibilidade de voltar a ver o cotidiano pedagógico a partir dos observáveis gera aquilo que Schön (2000) chama de reflexão sobre a ação, ou seja, de pensar depois do fato para descobrir, em uma reconstrução mental retrospectiva da ação, como nosso ato de conhecer-na-ação pode ser interpretado e reanalisado desde outras vias de compreensão.

Valendo-me do alerta de Malvasi e Zoccatelli (2013, p. 32), sublinho que aquilo que capturamos a partir de um conjunto de observáveis "não é uma descrição objetiva da realidade, 
mas sim o resultado de escolhas que, enquanto tal, pressupõe uma assunção de responsabilidade no que diz respeito aos significados da ação educativa". Por isso, selecionar e contrastar os observáveis que irão compor os processos documentais é um importante exercício para construir uma "experiência conscientizadora" (GANDINI, GOLDHABER, 2002) e para poder chegar à zona de investigação e às perguntas generativas da investigação.

Vejamos um trecho inicial do processo documental construído pelas professoras Karin e Sissa, da EMEI Joaninha, no Grupo de Investigação-Ação do Acompanhamento Projetual (2018), que mostra fragmentos do percurso de investigação das crianças de faixa etária 2 anos em torno do tema da comida.
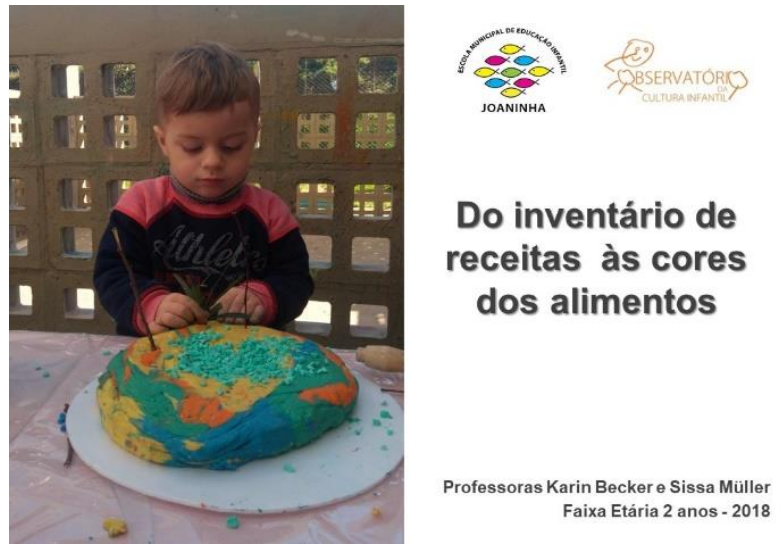

Nas primeiras sessões organizamos uma cozinha no solário com materiais que as crianças demonstravam interesse em manusear: pratos, talheres e panelas. Oferecemos, também, elementos para que pudessem fazer suas comidinhas. Porém, percebemos que os materiais oferecidos não foram suficientes para enriquecer o repertório e aprofundar as pesquisas.
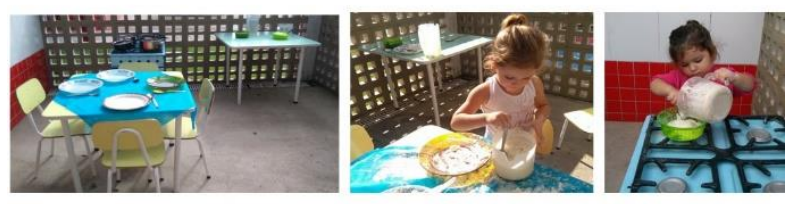

E agora, qual o melhor caminho a seguir?

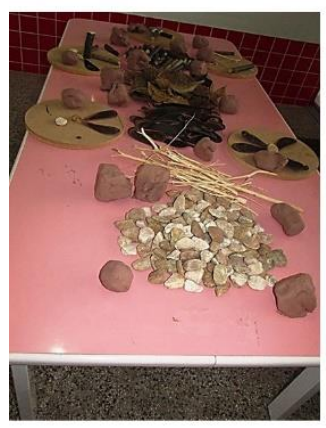

A partir das conversas no $\mathrm{OBECl}$, começamos a fazer alguns estudos sobre Loose Parts, o que nos sugeriu um novo direcionamento. Desta forma, procuramos dar um olhar especial para que os materiais selecionados se combinassem em um contexto criativo. Na sessão seguinte organizamos uma mesa grande com pedaços de madeira, círculos de MDF, argila, folhas, pedras e galhos secos.

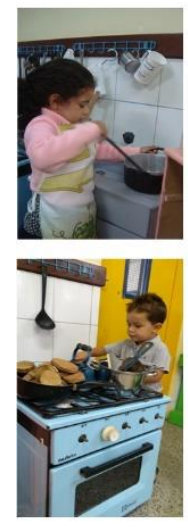

\section{Acolhendo as pistas}

Logo no início do ano, as crianças nos mostraram um forte interesse em brincar de preparar alimentos. Atentas, fomos apresentando diferentes possibilidades, tanto na organização da sala referência como nas sessões. A partir disso, as crianças nos deram indícios de caminhos a serem pensados.

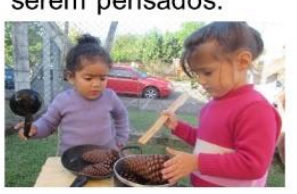
A Educação do olhar é um exercício, uma construçãon qual a percepção e a sensibilidade estão imbricadas na produção do conhecimento Tornar visivel o que se olha é uma concepção do sensivel. (LEITE, OSTETTO, 2005,p.85)
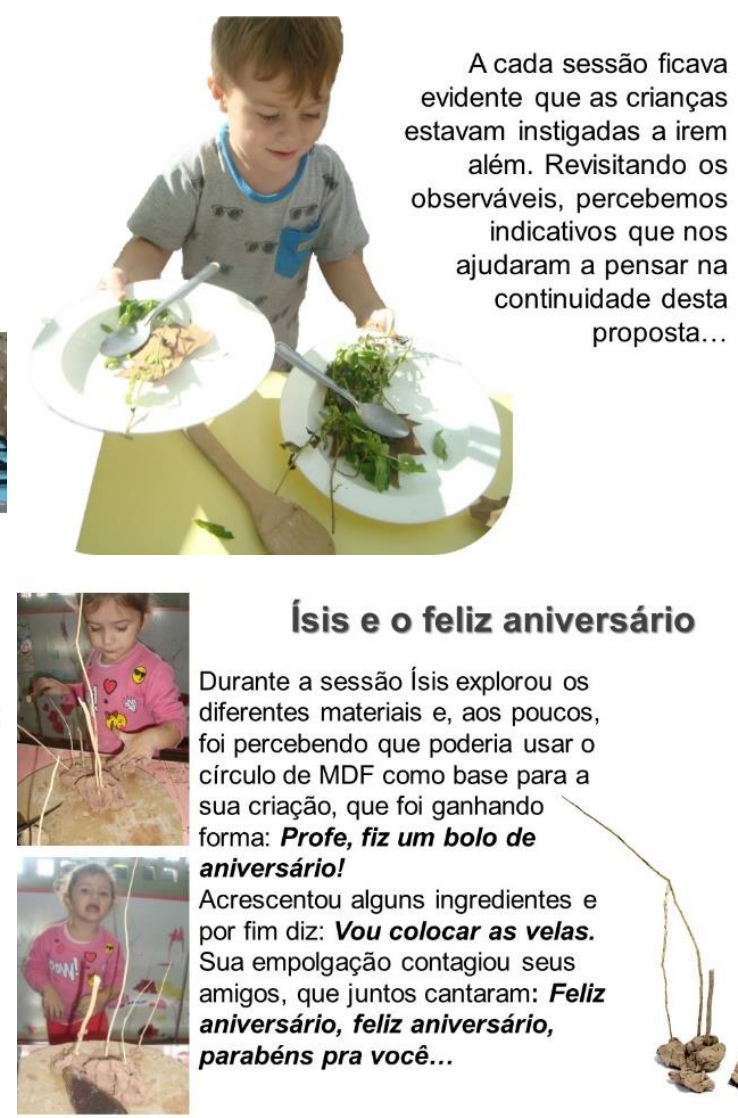

Ísis e o feliz aniversário

Durante a sessão Ísis explorou os diferentes materiais e, aos poucos, foi percebendo que poderia usar o circulo de MDF como base para a sua criação, que foi ganhando forma: Profe, fiz um bolo de aniversário!

Acrescentou alguns ingredientes por fim diz: Vou colocar as velas. Sua empolgação contagiou seus amigos, que juntos cantaram: Feliz aniversário, feliz aniversário, parabéns pra você... 

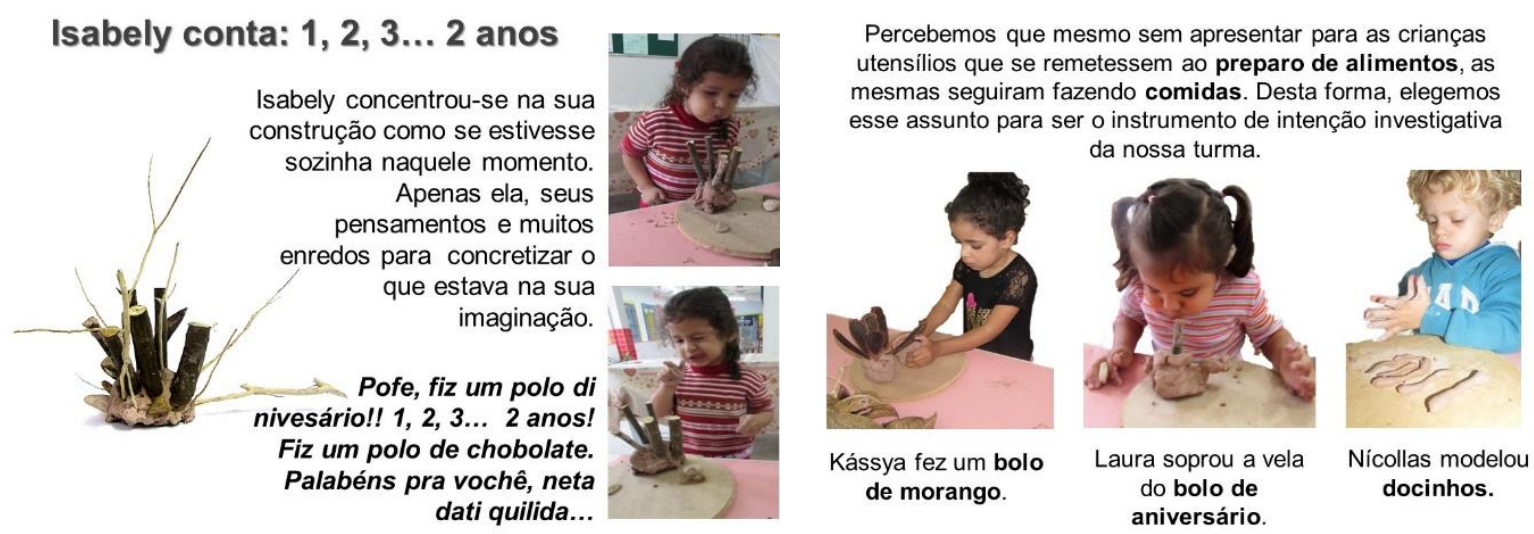

A observação das professoras dos interesses das crianças em brincar de comidinha mobilizou-as a criar contextos de aprendizagens que gerassem mais possibilidades a essa brincadeira simbólica. Tudo se transformava em enredos para cozinhar, fazer bolos, fazer churrasco. Ao compartilharem esses primeiros observáveis no GIA do Acompanhamento Projetual no OBECI, apresentei a elas o conceito de Loose Parts (teoria das partes soltas), do arquiteto britânico Simon Nicholson $(1972)^{94}$, propondo dar continuidade à investigação sobre a temática da comida em diálogo com essa teoria da arquitetura.

Definido o rumo da investigação, as professoras construíram uma pequena narrativa que explicita o Contexto Observado e Refletido (fato e reflexão) para, então, identificar a Zona de Investigação (âmbito conceitual) que está articulada com os campos de experiência, patrimônio cultural e pedagógico e a formulação das Perguntas Generativas (âmbito operativo) que guiarão o trabalho do adulto. Esses três campos constituem um instrumento de intenção investigativa, que foi elaborado no interior do OBECI para criar a articulação entre o planejamento das sessões e a estratégia da Documentação Pedagógica.

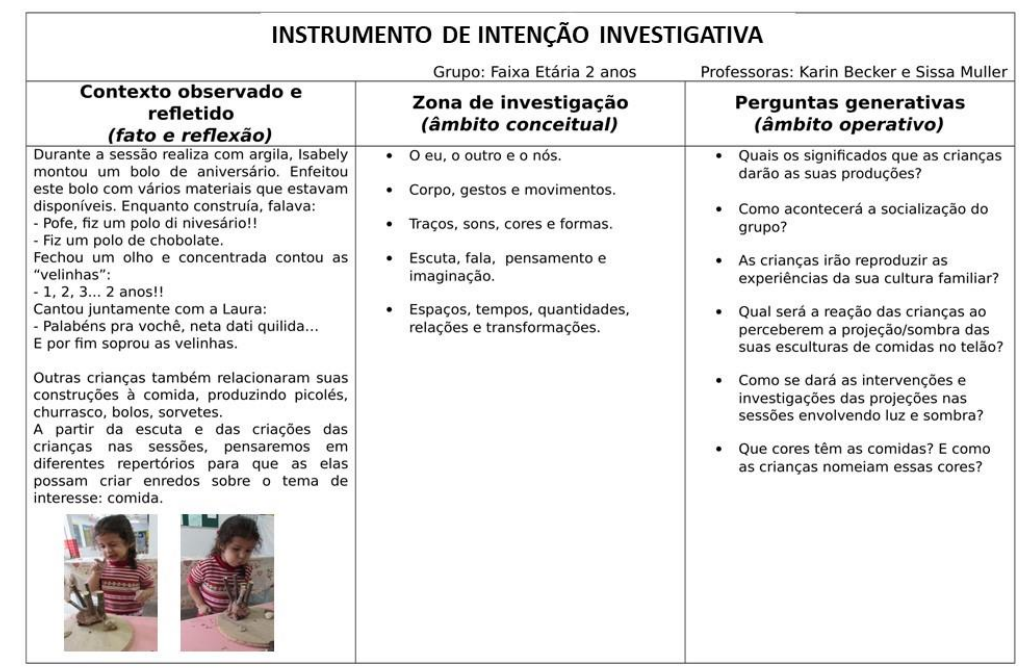

${ }^{94}$ A respeito do conceito de Loose parts, ou teoria das partes soltas, desenvolvo nos Organizadores da Ação Pedagógica no item dos Materiais. 
Também exercitamos, no GIA, a construção de uma constelação de possibilidades com o intuito de ampliar a compreensão sobre o objeto estudado e tornar visíveis as diversas possibilidades que se podem explorar a partir de um mesmo aspecto. Essa constelação

Constelação que nos guia a pensar em possibilidades

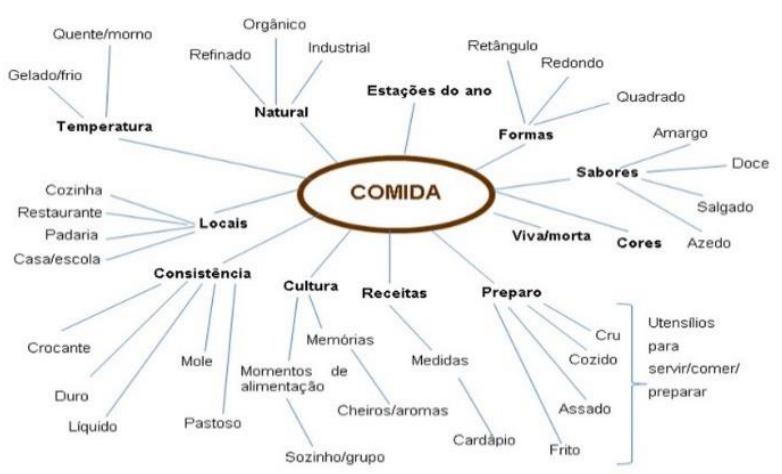
serve essencialmente aos adultos e não tem finalidade de ser uma lista de assuntos a serem investigados com as crianças, é apenas uma constelação de possibilidades para o professor prefigurar possibilidades de se movimentar com as crianças. A ideia de fazer essas constelações surgiu da observação de que muitas vezes as professoras acabavam ficando na obviedade do tema. Costumo chamar essa prática de investigação "globo repórter: como nascem, como se reproduzem, onde vivem...”. Para descontruir essa tendência, construímos as constelações para ampliar e diversificar o máximo possível os olhares sobre o que se pretende investigar.

A partir daí, as professoras decidem dar continuidade ao ato de investigar esse tema e vão estruturando sessões e as retroalimentando a partir da continuidade das próprias sessões. Aqui entramos na segunda camada do primeiro nível.

\subsubsection{Projetar e reprojetar a ação educativa}

Nessa segunda camada, é dada a continuidade na investigação. A partir da definição da zona de investigação e das perguntas generativas, tanto a organização do contexto de um modo geral pode ir se transformando como o desenho das sessões que serão propostas podem ir estabelecendo uma certa noção de continuidade educativa.

Retomando o exemplo do processo documental das professoras Karin e Sissa, uma das intervenções que elas fizeram foi disponibilizar, no espaço da sala, que estava circunscrito com livros e uma área de tranquilidade, a colocação de livros de receitas (livros informativos) e encartes de mercado. Esse diálogo que se estabelece entre o que está sendo investigado e a vida cotidiana gera a possibilidade das crianças irem experimentando práticas sociais ao mesmo 
tempo que criam uma certa atmosfera cultural para fomentar a elaboração de hipóteses, negociação de ideias e construção de sentidos entre as crianças.

A ideia de sessão que temos desenvolvido dentro do OBECI se difere da perspectiva de atividades. Trata-se de um conjunto aberto de

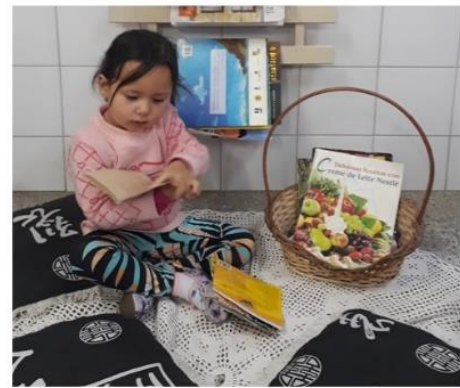

Livros informativos de receitas foram disponibilizados na sala para instigar a curiosidade das crianças e enriquecer as nossas pesquisas.

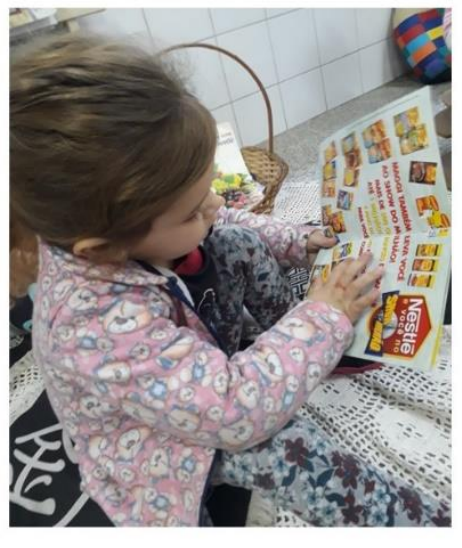
possibilidades proposto pelo adulto a partir da organização de contextos de aprendizagem, o que significa pensar com clareza a organização do espaço, a seleção de materiais, a organização de pequenos grupos e a garantia de tempo para as crianças viverem suas experiências (FOCHI, 2015b). As sessões são sempre um recorte espaço-temporal que um pequeno grupo de crianças participa para levar a cabo as suas investigações. Ao longo da jornada, não necessariamente todas as crianças participam da mesma sessão, pois, em um período de turno integral, por exemplo, o que temos conseguido realizar é no máximo uma sessão por turno ${ }^{95}$.

Para planejar as sessões, também elaboramos um instrumento de planejamento, conforme pode ser visto no excerto do processo documental a seguir. Esse instrumento é desdobramento do instrumento anterior (instrumento de intenção investigativa) e convida o professor a tomar consciência sobre os Organizadores da Ação Pedagógica que orientam a estruturação das sessões: organização do grupo e tempo; organização do espaço e dos materiais; o planejamento do que será observado e como será observada a sessão. É válido ressaltar que, nesse terceiro aspecto, o guia de orientação são as perguntas generativas do instrumento anterior.

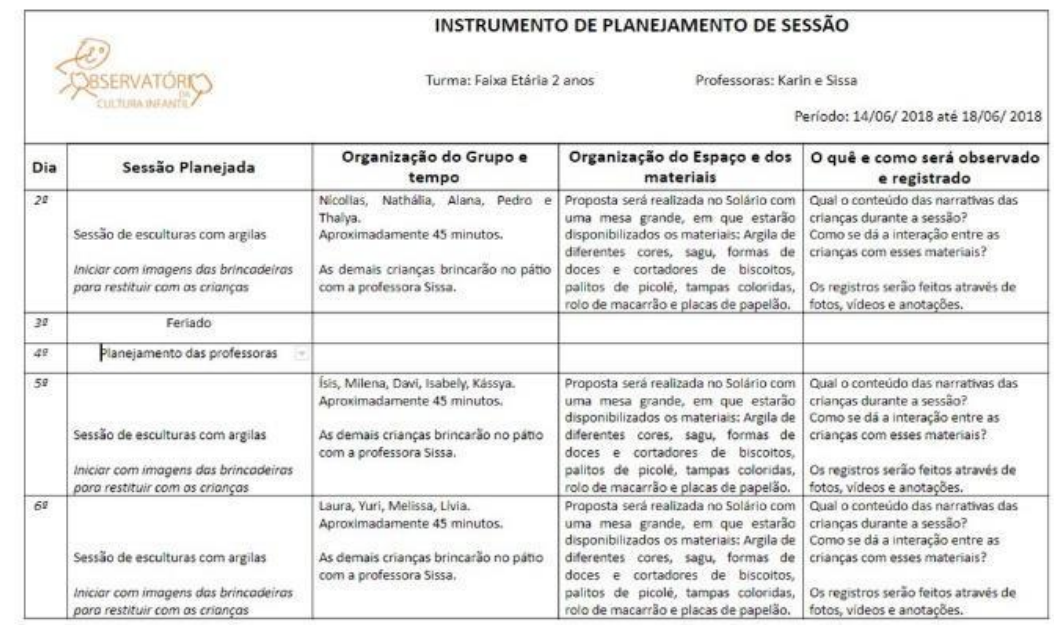

95 A esse respeito, irei tratar com mais detalhes no item Organizadores da Ação Pedagógica. Lá diferencio o planejamento de sessão e o planejamento de contexto. 

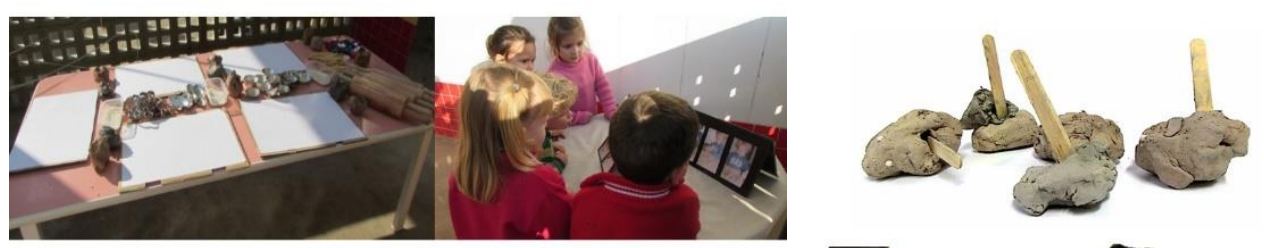

Muitos sorvetes

Na sessão seguinte disponibilizamos elementos que se remetessem a outras receitas, tais como argila, palitos de picolé, cortadores de biscoitos, formas de diversos tamanhos, sagu, tampinhas coloridas, rolos de macarrão e placas de papelão. Utilizando fotos, realizamos uma conversa nos pequenos grupos para restituir o processo já vivenciado.
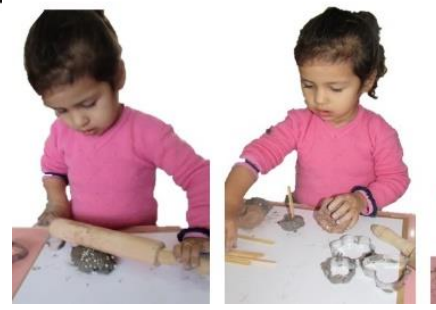

Fiz sovete marrom.

Dois sovetes! Olha pofe, meu sovete.

Analisando nossos registros, percebemos que as crianças prepararam diferentes tipos de comidas, mas o bolo sempre estava presente no contexto das sessões.
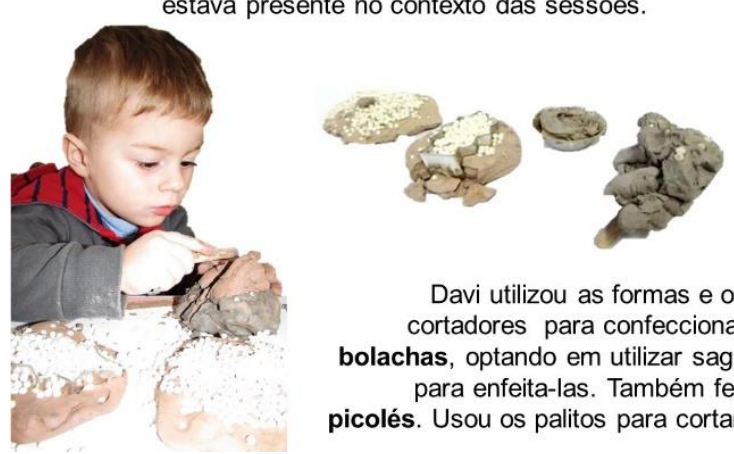

Davi utilizou as formas e os cortadores para confeccionar bolachas, optando em utilizar sagu para enfeita-las. Também fez picolés. Usou os palitos para cortar.

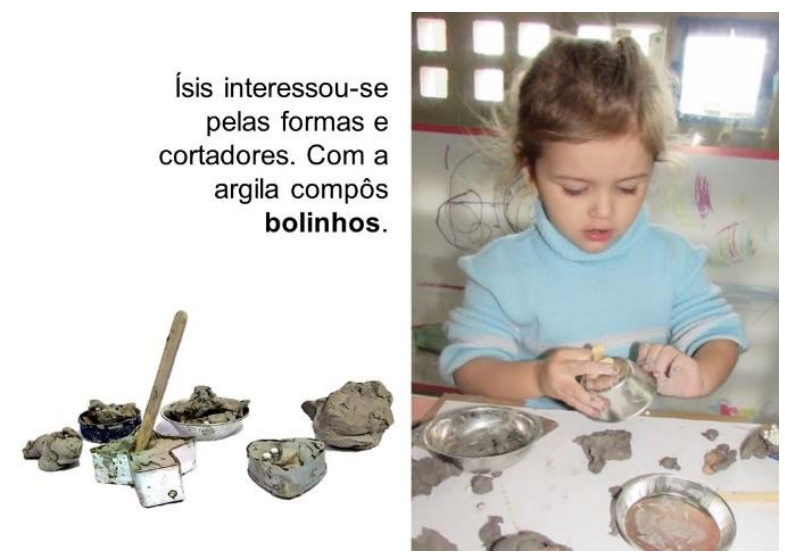

Na sequência do processo documental destacado, além de exemplificar uma sessão com materiais não estruturados, também mostra o momento em que as professoras se valem de imagens de outros momentos das crianças brincando de fazer comida para restituir a elas o percurso de investigação. Como Davoli (2011, p. 19) destaca, "devemos permitir aos meninos e meninas, e a nós mesmos, tempo para refletir sobre o que se faz e como se faz. São os processos de metalinguagem e metaconhecimento que nos permitem construir conhecimento". Restituir, assim, ajuda às crianças a reconhecerem como aprendem, não apenas o que aprendem.

Um outro aspecto importante de ser sublinhado nesta segunda camada do primeiro nível diz respeito ao projetar e reprojetar como possibilidades de construção da continuidade. As sessões ou um conjunto de sessões se transformam em situações de aprendizagem que podem se converter em importantes momentos para as crianças construírem sentido para o conhecimento gerado. Quando um professor elabora suas estratégias a partir da escuta ativa dos percursos das crianças, consegue construir jornadas de aprendizagem que permitem aos meninos e meninas irem elaborando, aprofundando e ganhando intimidade com os saberes e os objetos de investigação. A desconexão das propostas oferecidas às crianças são reveladoras do como não compreendemos sua competência para atribuir significado a sua própria aprendizagem. Malaguzzi (2001) falava da capacidade das crianças em criarem seus próprios 
mapas cognitivos, emocionais e sociais, o que significa considerar que "as experiências de aprendizagem das crianças envolvem tempo. [...] Como a realidade da criança é ainda bastante fragmentada, marcada pelo 'aqui e agora', a possibilidade de continuidade garante o crescimento e qualidade das experiências dos meninos e meninas" (FOCHI, 2015a, p. 225-226).
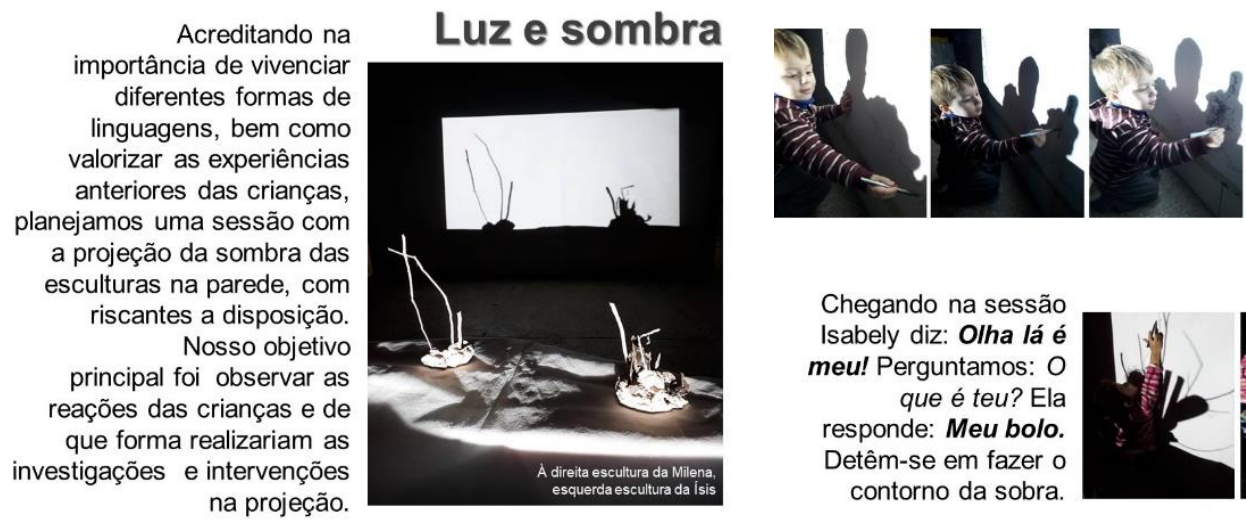

Davi identificou que a sombra na parede era

do seu bolo e seu churrasco. Optou por pintar a sombra, mantendo-se envolvido desde o início da sessão.

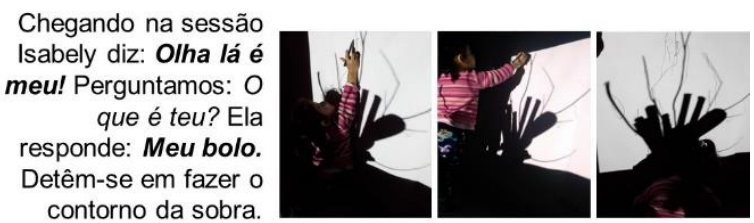

\section{Esculturas e desenhos da sombra}

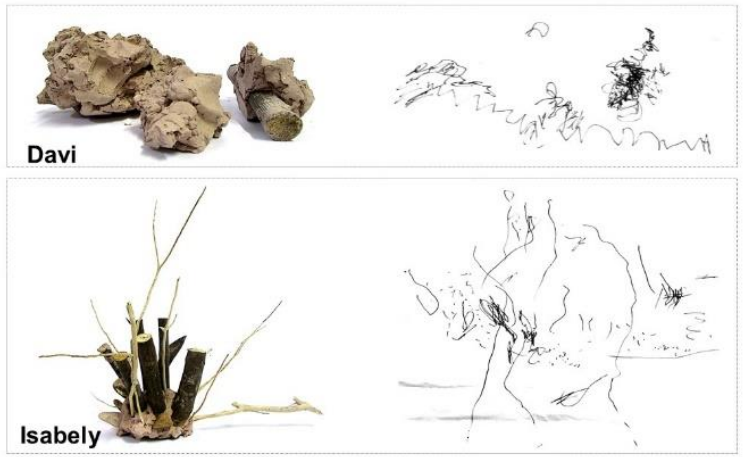

\section{Pintando com as tintas produzidas}
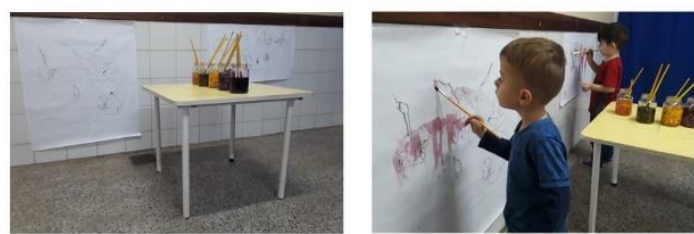

A natureza oferece matéria prima abundante para colorir nossa vida sem danificá-la. Essa matéria prima são os pigmentos naturais, que ao invés de serem feitos de produtos químicos, são extraídos de elementos da natureza. Eles podem ser feitos a partir de cascas, raizes, folhas, frutas, pétalas, plantas, legumes, verduras, terra, entre outros, dependendo da época do ano. (Jhon Bermond)
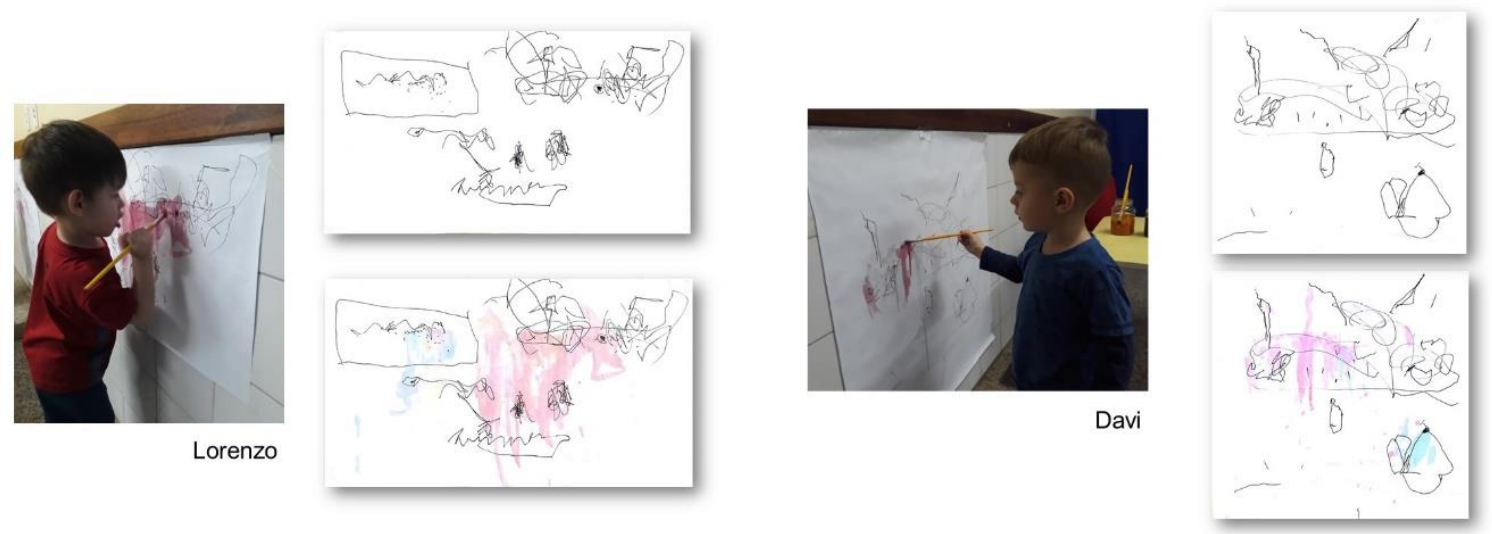

No excerto do processo documental acima, vemos várias sessões distintas, mas interligadas. Na primeira imagem, as esculturas utilizadas para brincar com a luz e a sombra são fruto das primeiras sessões em que as crianças foram convidadas a pensar a tridimensionalidade. Nessa sessão, primeira e segunda imagem, a proposta gira em torno de convidar os meninos e as meninas para perceber a forma das suas esculturas a partir de sua 
silhueta. Na terceira imagem, pode-se perceber o modo como as professoras restituem para as crianças as experimentações gráficas com as esculturas. A quarta, quinta e sexta imagem envolvem a pintura dos desenhos que as crianças fizeram a partir da sombra das esculturas com tintas extraídas de alimentos em outras sessões.

Como é possível perceber nas narrativas que as professoras fazem no processo documental, as crianças reconhecem suas produções e vão ampliando os sentidos a respeito delas a partir das novas sessões. Por isso, pensar em sessões e em linhas de continuidades envolve ter a clareza da investigação que está em curso e a construção objetiva de um contexto favorável. A elaboração do processo documental, seguindo esse raciocínio de recolher os observáveis e uni-los ao planejamento e a reflexão após a experiência, pode ser utilizado para envolver as crianças e escutar as narrativas que elas próprias constroem a partir dos seus percursos. Com isso, auxilia-se tanto a restituir internamente, envolvendo a participação das crianças, como a oferecer oportunidades de reuniões com as famílias, sendo possível restituir internamente a partir da participação dos pais. Ao longo dos processos documentais, também são utilizadas as mini-histórias semanais ${ }^{96}$.

Por fim, é importante relembrar que os momentos de contrastes, dos quais falei na primeira camada do primeiro nível, também são realizados ao longo de todo a investigação. Dialogar e submeter a outros pontos de vista são sempre oportunidades singulares e de grande crescimento profissional.

O segundo nível - centrado na construção da comunicação dos percursos de aprendizagem -, que é decorrente das investigações fortemente refletidas, é parte estruturante da estratégia da Documentação Pedagógica. Tratarei desse tópico na sequência.

\subsubsection{Comunicar os percursos de aprendizagem: o segundo nível}

A partir dos processos documentais, decide-se o que, para quem, com quem, como, quando e onde ${ }^{97}$ serão compartilhadas as comunicações que tornam visíveis os processos de aprendizagens das crianças, a intencionalidade do adulto e o projeto educativo da instituição.

\footnotetext{
${ }^{96}$ A esse respeito, ampliarei na sequência desse mesmo capítulo.

${ }^{97}$ Estas cinco perguntas são conhecidas no universo jornalístico como os $5 \mathrm{~W}$ de ouro: Who (quem), What (o que), When (quando), Where (onde) e Why (por que). Na literatura específica sobre Documentação Pedagógica, encontramos implícita ou explicitamente um novo elemento, With (com que), conforme pode ser visto em Malvasi e Zocccatelli (2013) e Edward et al. (2007).
} 
A comunicação é o produto ou documento elaborado a partir dos observáveis que expressam a tomada de decisão de que um ou mais elementos do percurso, que está sendo investigado, já pode ser compartilhado, ou seja, que foi suficientemente refletido no interior da instituição. Como Malaguzzi (2005b, p. 10) sempre afirmou, “o que não se vê não existe”. Este nível é de grande importância para a Documentação Pedagógica, pois é quando se transforma uma trajetória em que respeitam as crianças e os adultos e que foi altamente refletida em um documento aberto a contestações, diálogos e memória.

A comunicação pode ser a partir de um painel, de um livreto, de um portfólio temático, de uma mini-história, de uma exposição, de um vídeo ou de outros suportes que cumprem muitos papéis, dentre estes, criar uma memória pedagógica e cultural da instituição, das crianças e do professor. Cada um desses suportes que aqui exemplifico não tem o valor em si mesmo. Ou seja, não se trata apenas de fazer portfólio e com isso nomear como Documentação Pedagógica. A comunicação a que aqui estou me referindo tem valor porque está situada em uma práxis altamente refletida e que objetiva tornar visíveis as aprendizagens das crianças.

Um exemplo de comunicação é o folheto "Olho de criança: ideias e teorias", fruto de uma investigação que as professoras participantes do Grupo de Investigação-Ação dos Ciclos de Simbolização (2016) realizaram.

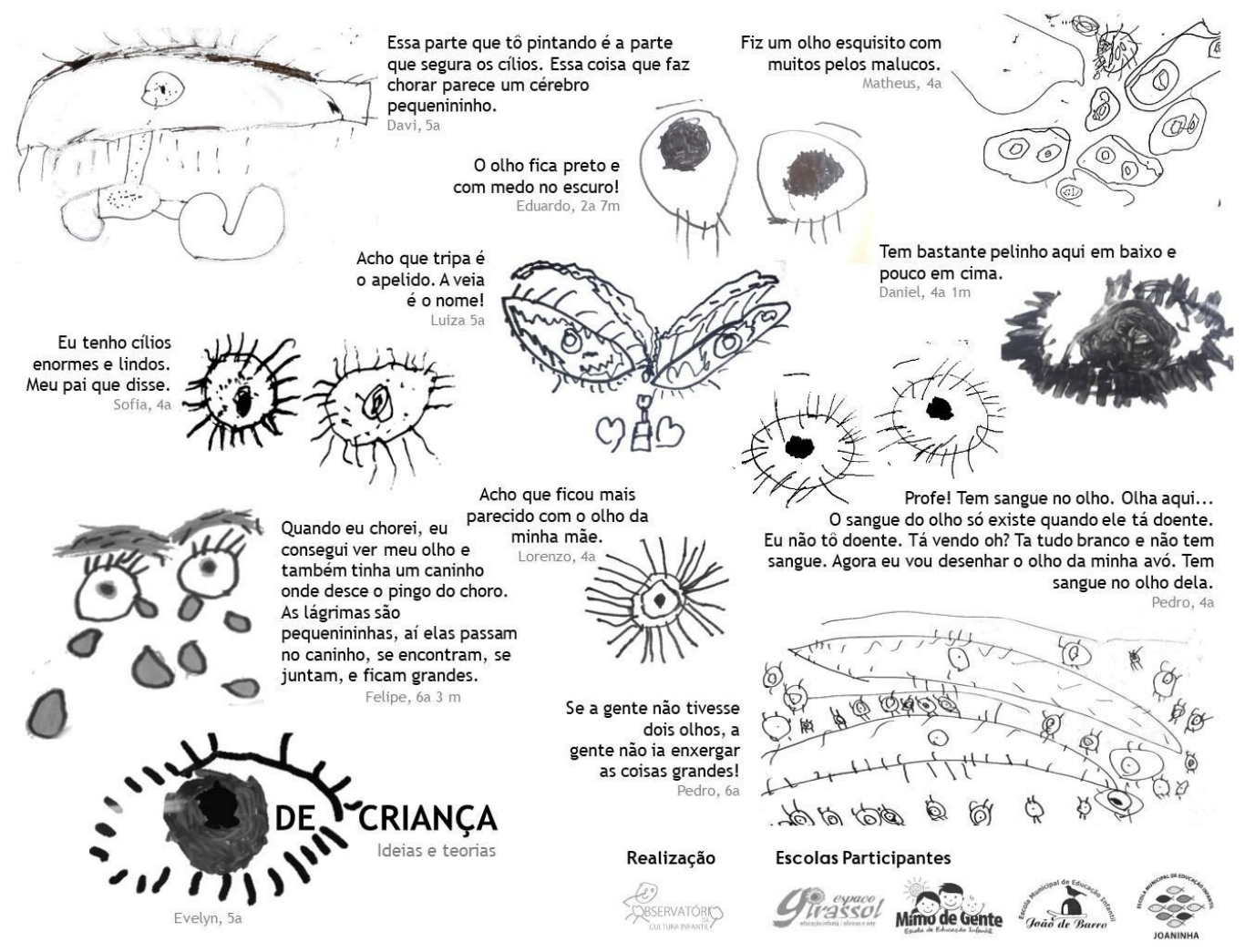


Nesse folheto, por exemplo, no tempo em que investigávamos a partir dos ciclos de simbolização de Loris Malaguzzi (2001) o modo como as crianças compreendiam sobre o funcionamento do olho e do olhar, percebemos que os meninos e meninas construíam algumas teorias a respeito do tema. Logo, decidimos criar esse folheto para tornar visível, desde o ponto de vista gráfico, como das vozes das crianças, a pluralidade e complexidade de suas ideias. É importante destacar que, apesar da escolha desta comunicação se tratar das "teorias das crianças", outras comunicações a respeito dessa mesma investigação poderiam ser feitas com outras chaves de leitura.

Ademais, vale destacar que, em algumas situações, o que é comunicado está diretamente vinculado com as perguntas generativas que foram elaboradas inicialmente, em outros casos, o que é comunicado é emergente do processo, ou seja, nasce da interpretação e reflexão do professor a respeito de um tópico que não havia sido vislumbrado inicialmente. $\mathrm{Ou}$ seja, existe uma ampla temporalidade das comunicações, pois estas não são resultado de um processo de compilação de registros, mas da intencionalidade de contar algo que está em processo, in itinere.

A decisão de compartilhar não é apenas para evidenciar nosso respeito e amorosidade em relação às crianças (BONÁS, 2011), compartilhamos para nutrir nas famílias novas formas de reconhecerem seus filhos e para ganhar notoriedade, no trabalho do professor, tal como a complexidade da aprendizagem das crianças. Também comunicamos para olhares externos à escola, e isso acaba tornando o documento compartilhado um lugar de encontro para crescer juntos, além de constituir um rico patrimônio pedagógico. Deixar memória pedagógica sobre o que é feito nas escolas pode ser uma afirmação a respeito de um momento particular da vida das crianças em espaços institucionais. E construir a memória das crianças é também construir a memória da instituição. Tendo em vista que a Educação Infantil é uma instituição ainda recente em nossa realidade, o valor da comunicação como memória é também uma defesa e afirmação do valor político que é para as crianças esta instituição.

A esse respeito, Dahlberg, Moss e Pense (2005) destacam que a estratégia da Documentação Pedagógica pode se converter em uma verdadeira ética do encontro, pois a abertura para as experiências das crianças é a tradução da coragem para a construção ética da relação com o outro e o mundo. No modo como comunicamos as aprendizagens dos meninos e meninas, criamos pontos de encontro que conectam o mundo dos adultos e o mundo das crianças. Como Malaguzzi (2001) sempre afirmou, tornando visíveis as experiências educativas, podemos criar e afirmar uma identidade a respeito da instituição de Educação 
Infantil, da docência com crianças pequenas e de uma nova imagem de criança, rica, competente, feita de "cem linguagens". Aliado a isso, temos investido em construir um outro tipo de competência, que poderíamos chamar da elaboração de uma certa proficiência técnica para “[...] desenvolver rotas de comunicação" (FILIPPINI, 1999; FILIPPINI et al, 2016).

Como nosso trabalho se assenta na Documentação Pedagógica, foi preciso aprender a comunicar. No ano de 2015, sentimos a necessidade de compreender melhor a forma, além do conteúdo da comunicação. Comunicar envolve uma linguagem específica, que, para além do que comunicamos, é preciso compreender como comunicar de forma assertiva as jornadas de aprendizagem das crianças e dos adultos. Um dos campos que tem nos ajudado a compreender melhor a comunicação é o design da informação.

Campos (2016, p. 49, grifos do autor), retomando os conceitos de Niemeyer (2010), afirma que "o design participa de um processo de comunicação amplo, que parte de um gerador, é mediado por um produto ${ }^{98}$ portador de uma mensagem direcionada a um interpretador". Ao tratar o design da informação dessa forma, Campos (2016) propõe uma mudança no entendimento da comunicação como uma simples representação ou apresentação de dados, mas “[...] como articulação dos processos compreendidos na comunicação entre os polos de geração e interpretação" (CAMPOS, 2016, p. 49). O profissional que está construindo a comunicação dos processos na Documentação Pedagógica (o produto em si) pode atuar de maneira mais próxima tanto do gerador quanto do interpretador das mensagens, "mas sempre está envolvido com os processos de semiose, ou seja, de construção dos significados inerentes ao produto para a geração de sentidos, através da configuração de mensagens a serem interpretadas" (CAMPOS, 2016, p. 49).

No interior do campo do design da informação, há alguns princípios que têm nos auxiliado na reflexão sobre como elaborar, do ponto de vista técnico, cognitivo e estético, as comunicações das nossas investigações. Campos (2016) e Fronza, Blum e Lima (2014), indicando os estudos de Petterson (2013), destacam três princípios estruturantes para auxiliar o design da informação quando se pretende sistematizar uma comunicação de maneira satisfatória:

a) Princípios funcionais - Elementos que precisam ser levados em conta durante a fase inicial da preparação da comunicação.

\footnotetext{
${ }^{98}$ A autora observa que produto é empregado “[...] na acepção abrangente de resultado de um projeto de design" (CAMPOS, 2016, p. 49).
} 
- Definição do problema - etapa em que se analisa gerador e interpretador, mensagem pretendida, meio e forma adequada para a representação;

- Criação da estrutura - construção de uma lógica hierárquica das informações a partir de um design gráfico. A estrutura de uma comunicação está diretamente ligada à ênfase que se estabelece entre as informações;

- Definição da clareza visual - legibilidade do material, ou seja, relação entre cor do plano de fundo e a fonte (tipografia), tipo de fonte, tamanho da fonte;

- Simplicidade - simplicidade de um material facilita a interpretação da mensagem. Quanto menos esforço a audiência precisa fazer para compreender a lógica que estrutura as informações, melhor acontece a comunicação.

- Saber dar ênfase - para melhorar a atenção da audiência sobre o que se pretende comunicar, pode-se elencar elementos para oferecer ênfase (texto maior ou em destaque, imagem maior ou em destaque);

- Construção da unidade -coerência e harmonia entre as partes que formam o todo da comunicação.

b) Princípios cognitivos - elementos que estruturam a compreensão e o significado na mensagem transmitida.

- Mediar a atenção - o material informativo precisa manter a atenção da audiência em si próprio. Por isso, é importante evitar excessos de informação e é preciso definir com clareza a mensagem que se pretende comunicar;

- Mediar a percepção - quando se constrói um material informativo, despertam-se emoções e sentimentos no interpretador. É preciso ter clara a experiência que se quer transmitir.

- Mediar o processamento mental - a informação precisa evitar ambiguidades sem ser fechada em uma única explicação. É possível construir uma mensagem clara com abertura para o interpretador criar suas próprias narrativas. 
- Evocar a memória - o interpretador sempre parte de um elemento conhecido para dar significado ao que está vendo e, ao mesmo tempo, o que está vendo passa a compor o seu repertório pessoal.

c) Princípios estéticos - o que é referente à estética geral do material informativo (comunicação).

○ Criação de harmonia - relativo à harmonia entre todos os elementos gráficos do material.

- Proporção estética - no sentido de compreender aquilo que está dentro do repertório estético do interpretador do material.

A partir desses princípios, é que podemos tentar harmonizar o complexo jogo existente entre linguagem verbal e linguagem não verbal, e, conforme Campos (2016), pela linguagem sincrética, que é uma das mais utilizadas no design, já que este se utiliza de códigos distintos para compor o material informativo. Segundo a autora, "os diferentes modos das linguagens gráficas combinam-se para gerar significados, que são interpretados pelos usuários, dando origem aos sentidos das mensagens no processo de comunicação do produto" (CAMPOS, 2016, p. 52).

Construir uma comunicação na Documentação Pedagógica "significa deixar uma marca estética e narrativa de forma visual, audiovisual e escrita de um processo educativo que estamos observando e refletindo" (HOYUELOS, 2012, p. 4). Portanto, compreender a linguagem comunicativa envolve percorrer temas que dificilmente temos tratado na formação pedagógica. Narrar visual ou textualmente e saber harmonizar tais linguagens, conseguindo informar algo ao mesmo tempo que não se reduza isso que se quer informar a uma descrição simplificada do processo educativo, é um grande exercício que temos tentado empreender dentro do OBECI.

Sabemos que, no nosso caso, forma é conteúdo e vice e versa. Ou seja, o modo como comunicamos os percursos das crianças também constrói uma dada estética da infância e da Educação Infantil que, inclusive, pode subverter a lógica estereotipada de atividades, do universo colorido e já conhecido dos personagens da televisão que com frequência temos visto conectados a tudo que se refere às crianças ${ }^{99}$. Hoyuelos (2007) e Oliveira-Formosinho (2016b) também já discutiram o que se esconde por trás de uma "folhinha de atividade": há uma

\footnotetext{
99 Carlos Laredo (2003) tem chamado isso de "curral da infância", referindo-se aos padrões das produções na arte e na cultura que têm se desenvolvido para crianças.
} 
pedagogia implícita carregada de concepções sobre aprendizagem, sobre a docência e sobre a própria criança.

Ainda sobre a forma e o conteúdo narrativo (textual e imagético) em comunicações na Documentação Pedagógica, Hoyuelos (2015) elenca cinco princípios que podemos levar em conta a partir da obra de Ítalo Calvino no livro “As cidades invisíveis” (1993):

\begin{abstract}
1) leveza, saber escolher o essencial e retirar o que pesa e é desnecessário; 2) rapidez, como economia expressiva; 3) exatidão, que digamos o que queiramos dizer, mesmo que queiramos mostrar as ambiguidades cotidianas da realidade; para isso, é imprescindível conhecer a linguagem cinematográfica e ter muito claro o que queremos dizer, para saber como dizê-lo, com que planos, com que duração, com que efeitos, com que cortes, mediante imagens nítidas, incisivas e memoráveis; 4) visibilidade, que o relato tenha sido previamente, de alguma maneira, visualizado imaginariamente por nós, a fim de antecipá-lo; e 5) multiplicidade, que dê conta da diversidade da realidade, que seja como seu holograma, onde o tempo narrativo seja representante de todo o tempo discursivo real, que o que mostremos seja variado, sem ser disperso para ser atrativo (HOYUELOS, 2015, p. 20-21, grifos do autor).
\end{abstract}

Esses princípios foram tema de grandes debates nos encontros do OBECI, retomados em diversos momentos, tendo em vista sua complexidade. Construir uma forma de comunicar é também um processo formativo intenso e extenso. Envolve, inclusive, as noções estéticas que cada professor, coordenador pedagógico e gestor têm e como podem romper com esses padrões e construir novos. A aposta que tenho feito dentro do Observatório é a de ampliar a "coleção de exemplos $^{100 "}$ dos profissionais e, junto a isso, sempre que discutimos sobre o conteúdo do que está sendo comunicado, também abordo as questões da forma, inclusive nos seus aspectos técnicos.

Concordo com Hoyuelos (2012, p. 4) ao afirmar que quando comunicamos algo também construímos sua existência: "a documentação não se limita de fazer visível as coisas que já existe, mas sim, faz existir as coisas sobretudo porque torna visível e, portanto, possível. Essa é uma forma de entender a educação das crianças como incerteza, enigma e mistério".

Em se tratando dos diversos formatos que se pode comunicar, no OBECI, temos utilizado a mini-história com a finalidade de tornar visíveis situações episódicas do cotidiano.

\footnotetext{
100 A expressão "coleções de exemplos" é tratada pelo artista e crítico contemporâneo Thierry De Duve, e eu a escutei pela primeira vez em uma banca de doutorado pelo professor Marcos Vilella Pereira quando este se referiu à diferença entre repertório e coleção. De Duve $(2009$, p. 51$)$ dirá que "a arte não é um conceito, é uma coleção de exemplos" e difere, com isso, da ideia de repertório, pois, em uma coleção, não temos fim, e sempre será diferente para cada um. Essa ideia de De Duve (2009) coaduna com a de Eco (2010) quando trata do quanto o homem gosta de listar e de como esse modo primitivo de listar, na medida em que as pessoas se aproximaram da compreensão da dimensão do infinito, tornou-se a forma como elas se mobilizam para dar sentido a sua própria vida. Isso significa que essas listas também se modificaram, devido à busca da ideia da permanência da magia, ou daquilo que escapa das listas sem limites, mantendo-se, assim, um espaço para o sem-fim. ECO (2009, p.) diz: “A lista é a origem da cultura [...] o que a cultura quer? Tornar a infinitude compreensível".
} 
Como já mencionei anteriormente, a mini-história é um tema que me interessou durante a dissertação e que, desde então, tenho me aprofundado a respeito. A ideia da mini-história está ligada à revisitação dos observáveis produzidos pelos professores no cotidiano pedagógico. A partir de uma breve narrativa imagética e textual, o adulto interpreta esses observáveis de modo a tornar visíveis as rapsódias da vida cotidiana. Essas rapsódias são fragmentos poéticos, portanto sempre episódicos, que, quando escolhidos para serem interpretados e compartilhados, ganham valor educativo, tornam-se especiais pelo olhar do adulto que acolhe, interpreta e dá valor para a construção de uma memória pedagógica.

Esse exercício de olhar para um material que já existe, buscando extrair sentidos, é uma experiência ímpar de autoformação para o professor, pois implica fazer uma escolha dentre tantas. Uma escolha de que, de alguma forma, o próprio professor faz parte. E fazer isso implica deixar algo de fora, não escolher. Como Malvasi e Zoccatelli (2013, p. 32) observam, "não se trata de pensar em dar novo significado a tudo o que acontece no cotidiano, mas de o evidenciar, procurando chegar ao âmago das pequenas ou grandes histórias que, em cada dia, ganham vida nas creches e nos jardins de infância, colocando no centro o sentido e verdadeiro valor daquela experiência".

Ainda a respeito da mini-história, as escolas têm feito o exercício de construir uma mini-história por semana para que os pais possam ir acompanhando o valor dessas rapsódias da vida cotidiana. A ideia de partilhar uma única mini-história por semana é também um convite para os pais aprenderem a olhar as outras crianças, compreendendo que elas estão em um contexto social. O compartilhamento dessa mini-história semanal é via rede social da escola e murais na instituição. No final do ano, o conjunto dessas mini-histórias são compiladas e contam a história pedagógica do grupo que temos chamado de "Dia após Dia na turma " $x$ ".

Seguindo essa linha para compreender a linguagem da comunicação e me fazendo valer da regra de ouro do jornalismo, os 6W, mostro, na Figura 04, como adaptei para a Documentação Pedagógica essa estrutura e compartilho cada um dos 6 pontos a fim de mostrar a construção de uma mini-história feita ao longo da investigação das professoras Karin e Sissa, com as crianças da faixa etária 2 da EMEI Joaninha, sobre a comida, fruto do processo documental apresentado no primeiro nível. 
Figura 04 - Perguntas para pensar a comunicação

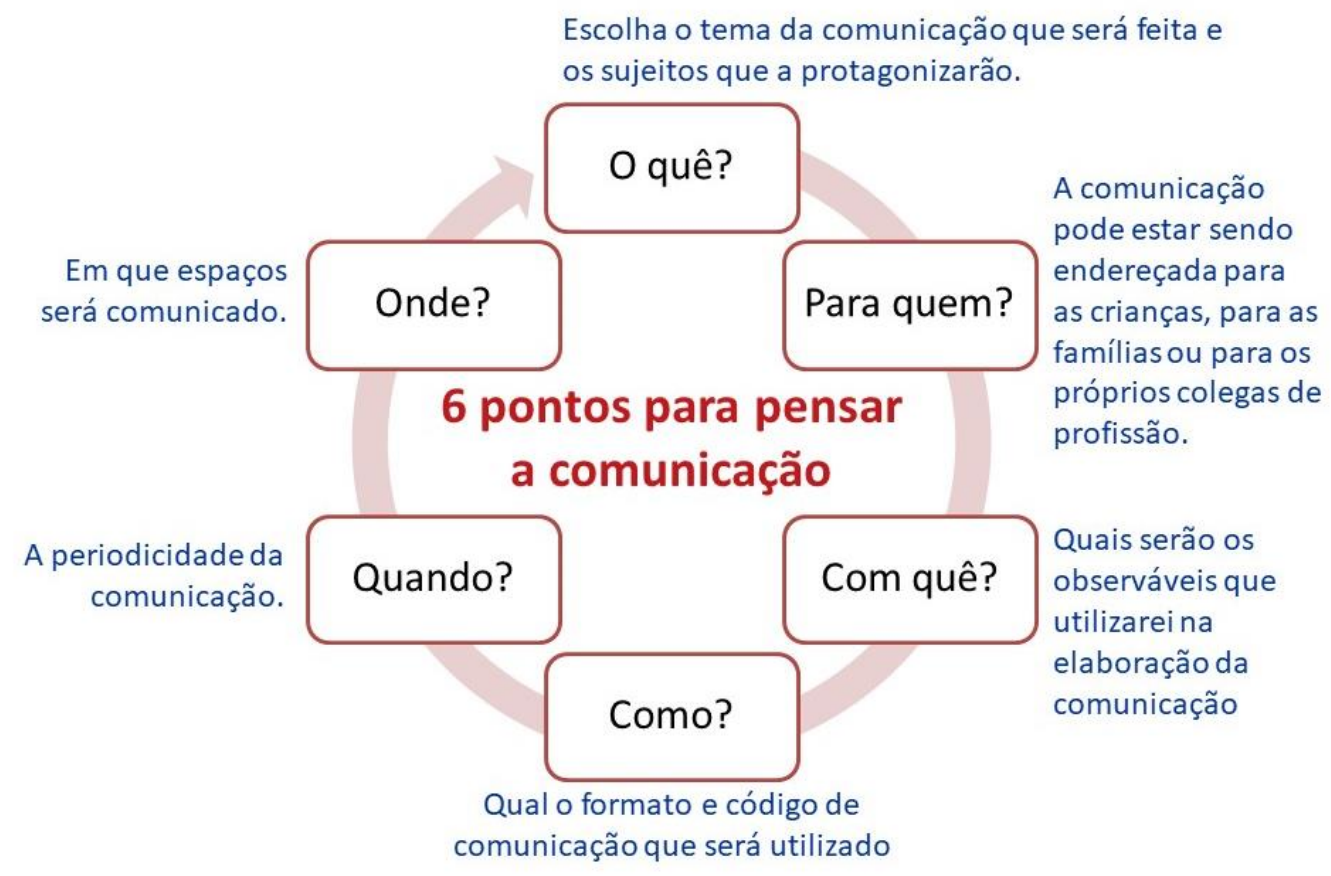

Fonte: Fochi, 2019

A definição do que contar e de qual sujeitos protagonizarão, O quê?, é essencial para começar a estruturar a comunicação. Dalhlberg, Moss e Pence (2003, p. 195) destacam que, quando decidimos que algo deve ser compartilhado, é preciso ter em mente que sempre "representa uma escolha, uma escolha entre tantas outras, uma escolha na qual participam os próprios educadores. Da mesma forma, aquilo que não escolhemos constitui uma escolha".

Definir o que se quer comunicar é definir uma chave de leitura para os observáveis que serão utilizados na comunicação. No OBECI, temos tratado o conceito de chave de leitura como o exercício analítico de conseguir fazer emergir o que é implícito do trabalho educativo, procurando exatamente tornar explícitos os significados frequentemente implícitos ou dados como adquiridos. A chave de leitura deve se tornar compreensível para quem não participou do que foi documentado e deve induzir uma escrita que avance a simples descrição, para dar lugar a uma escrita tridimensional (MALAVASI, ZOCATELLI, 2013), ou seja, capazes de transmitir não tanto a objetividade do acontecimento, mas sim o esforço de dar o significado.

No caso da mini-história que irei utilizar como exemplo, as professoras haviam percebido o enorme interesse das crianças em brincar de fazer comidinhas. Em especial, uma das crianças, a Milena, repetidamente construía bolos, não qualquer bolo, mas bolo de 
aniversário. Assim, as professoras definiram que a protagonista dessa mini-história seria Milena, de 2 anos, e o que seria contado os bolos de aniversário de Milena.

A comunicação, Para quem?, poderá ser endereçada às crianças, às famílias ou aos colegas de profissão. Para cada um deles, há particularidades a serem observadas no estilo de linguagem utilizada, nos observáveis escolhidos,

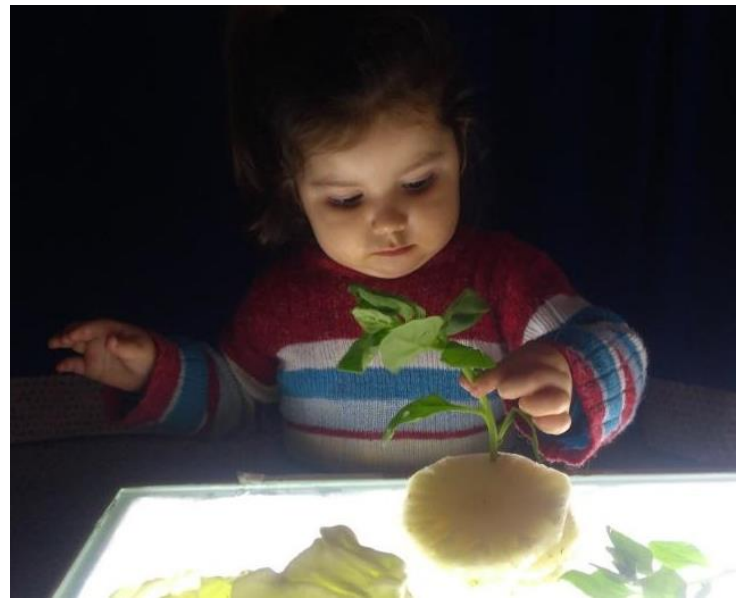
no local em que será afixado (por exemplo, sendo para as crianças um painel, este deve estar na altura delas) e na mensagem que se pretende contar. É certo que uma mesma comunicação pode ser lida por todos, mas a intenção de quem produz a comunicação é fundamental no direcionamento de ideias que se pretendem partilhar:

a) Para as crianças - $\mathrm{O}$ primeiro aspecto a ser considerado sobre as comunicações endereçadas às crianças é o fato de que mostramos a elas que existe um adulto interessado no que ela tem a dizer. E esta mensagem implícita é fundamental para a criança confiar e ter uma imagem positiva de si (ALTIMIR, 2011). O outro ponto é a observação de Malvasi e Zoccatelli (2013, p. 35) de que "encorajar a formação da identidade de cada criança significa valorizar a sua história pessoal”, e, no caso do seu tempo em uma instituição, o valor da história de cada criança também se dá a partir "da construção das relações com outras crianças e adultos, dos percursos de exploração e das emoções ligadas à criação e à descoberta" (MALVASI; ZOCCATELLI, 2013, p. 35). Quando comunicamos endereçando às crianças, oferecemos a elas a oportunidade de ver outra vez seu percurso, abrimos um espaço para que possam compreender o modo como apreendem, o modo como fazem e como constroem significado. Isso significa restituir às próprias crianças a sua aprendizagem. Quando fazemos isso, estamos, com as crianças, colecionando exemplos particulares sobre nós mesmos, mergulhando fundo em um processo de autoconhecimento e de aprendizagem.

b) Para as famílias - As comunicações direcionadas às famílias desempenham diferentes papéis. Um deles é de criar pontes para diálogos entre escola e família. Subverter a lógica passiva de receber informes semestrais para uma 
cultura de diálogo, transforma a participação dos pais no processo educativo das crianças. Assim, quando comunicamos para as famílias, não apenas lhes mostramos o valor de um serviço educativo, mas também lhes oferecemos a oportunidade de conhecer e (re)conhecer seus filhos a partir de outros olhares. Sentindo-se seguros ao conhecer melhor as jornadas educativas das escolas, os pais podem descobrir diferentes formas de apoiar o trabalho que ali é feito. Em resumo, comunicar para as famílias "[...] representa refletir juntos sobre os significados das experiências que as crianças estão vivendo, representa investir na construção partilhada da história de crescimento de cada criança" (MALVASI; ZOCCATELLI, 2013, p. 36).

c) Para outros profissionais - É fato que a comunicação possui em si um grande valor formativo, pois, além de servir ao profissional que a elaborou, cria um testemunho pedagógico que pode migrar para outros contextos como fonte de reflexão e inspiração. Por isso, sempre que uma comunicação é direcionada aos pares, é possível confrontar conceitos, dar valor à profissão e construir instrumentos de trabalho que não são meras incorporações abstratas. Nesse sentido, uma boa comunicação para os pares profissionais é, também, uma boa oportunidade de fazer novas perguntas e inventar novos modos de trabalhar com as crianças. É uma chance de desafiar os discursos dominantes (DAHLBERG; MOSS; PENCE, 2003). É um modo de traduzir as escolhas e de "[...] exprimir a vontade de ser visível [...]” (MALVASI, ZOCCATELLI, 2013, p.34) e de declarar “[...] quem são os protagonistas da experiência [...]" (DOLCI, 2011, p.29).

No caso da mini-história que as professoras Karin e Sissa construíram, o endereçamento delas são os pais. Portanto, os recursos de linguagem utilizados em termos de imagem e texto buscam evocar as famílias para que conheçam os enredos lúdicos que as crianças criam na vida cotidiana e o modo como as professoras acolhem o universo das crianças.

Já definidos os protagonistas, o assunto e o endereçamento, a próxima etapa é selecionar os observáveis, Com quê?, que serão utilizados na elaboração da comunicação. Selecionar um ou mais observáveis para comunicar a respeito de algo e de alguém exige que, além de estar atento ao endereçamento, se reflita sobre o equilíbrio, a legibilidade e a expressividade do material utilizado. Em geral, há uma forte tendência pelo uso de imagem preterindo a escrita, no entanto, é bom relembrar a advertência de Malaguzzi (2001, p. 45): “é 
mais fácil um caracol deixar rastros de onde passou que um professor deixar marcas do seu trabalho". Escrever implica assumir um alto grau de responsabilidade sobre como nomeamos e definimos o que interpretamos. Juan Mata (2012) adverte que, para as crianças, devemos utilizar a nossa melhor linguagem, não a mais simplificada. Isso não é simples e talvez, por isso, preterimos tanto a escrita.

As diferentes linguagens (escrita, fotográfica, videográfica, gráfica...), quando bem combinadas, amplificam a expressividade dos documentos e abrem possibilidades de leituras mais ampliadas e abertas. Juntas, estas linguagens "[...] possuem um fortíssimo valor comunicativo e representativo, por terem a capacidade de evocar e falar com cada um de nós, respeitando a sensibilidade individual e possibilitando a transmissão de conexões e cruzamento com outras imagens, outras passagens, outras linguagens" (MALVASI; ZOCCATELLI, 2013, p. 42).

No caso da mini-história sobre a Milena, as professoras optaram em recolher imagens da menina, em diferentes situações do cotidiano pedagógico, que mostrassem essa repetição em fazer bolos de aniversário, independentemente do material utilizado. Lembrando que, neste caso específico, as imagens servem como motor para a construção da narrativa da mini-história.
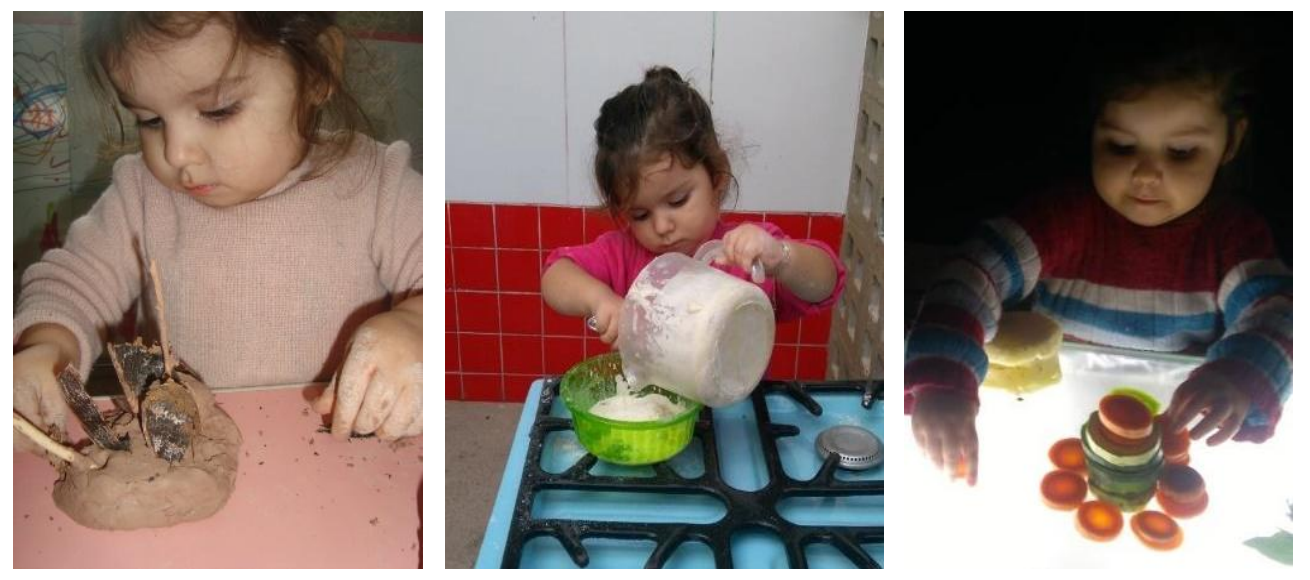

São vários os formatos de comunicação, Como?, que podem ser utilizados: painéis, vídeos, exposição, mini-história, portfólios, livretos, projeções. No entanto, nem todos os formatos respondem às demandas de cada situação que se pretende comunicar. No caso da Milena, foi escolhida a mini-história pelo seu caráter episódico e pela intenção das professoras em realizar uma comunicação mais breve.

No quadro a seguir, exemplifico alguns formatados e suas possíveis utilizações. 
Quadro 05 - Formatos de comunicação

\begin{tabular}{ll}
\hline Formato & \multicolumn{1}{c}{ Como pode ser utilizado } \\
& É um formato interessante para comunicar o projeto educativo da instituição. Cria uma "segunda \\
& pele".
\end{tabular}

Painel Pode ser mais permanente e dar a identidade de determinadas áreas.

Pode comunicar a respeito de projetos de aprendizagem ou, também, de uma zona de investigação específica.

São narrativas breves que narram episódios da vida cotidiana. Podem ser realizadas semanalmente e

Mini-histórias afixadas em local visível para as famílias.

Podem ser uma estratégia para ir contando a respeito do grupo ao longo de um ano de trabalho.

Podem converter-se em um poderoso material para ir sendo construído e contando a jornada

Portfólios educativa das crianças ao longo do seu percurso na instituição.

temáticos

Também podem ser utilizados para narrar a respeito de um ou mais argumentos, utilizando-se de imagens, textos, produções das crianças, falas das crianças a respeito de um projeto de aprendizagem.

Muitas vezes, um projeto de aprendizagem pode converter-se em um montante de processos documentais que, ao serem profundamente interpretados e refletidos, possibilitam encontrar ou criar

Exposição chaves de leituras para narrá-los integralmente. Neste caso, uma exposição que reúna painéis, portfólios, exemplares das produções das crianças, vídeos, áudios podem transformar-se em uma bela exposição.

Nem sempre os formatos que se utilizam de uma linguagem estática respondem à necessidade que se

Vídeos pretende comunicar. Às vezes é fundamental escutar as crianças, vê-las em movimento. Neste caso, a edição e a decuopage de vídeos podem transformar-se em ricos materiais comunicativos.

Projeções

Uma parede, na recepção da escola, um computador e um projetor podem servir muito quando se pretende comunicar algo mais episódico.

Todos os formatos anteriores podem ser utilizados em uma reunião de pais como disparadores para

Reuniões de dialogar, conhecer e aprender mais sobre as crianças. Uma compilação provisória de cenas do pais cotidiano em um Power Point também pode servir para comunicar a respeito de algo que se pretende dialogar com as famílias.

Fonte: FOCHI, 2017

A periodicidade da comunicação, Quando?, pode determinar muitos aspectos em relação à comunicação. No caso da mini-história da Milena, é utilizada uma mini-história por semana e a natureza do seu formato é de ser uma breve narrativa imagética e textual. Essa 
escolha se deu observando a própria estrutura de funcionamento da escola (disponibilidade de tempo das professoras, necessidade de dialogar com as famílias, escolhas pedagógicas).

Além da mini-história, é possível colocar em marcha outros tipos de comunicação, por exemplo, semanalmente é compartilhada uma mini-história; o conjunto dessas mini-histórias compõe um Diário de Grupo anual; duas ou três vezes por ano são realizadas reuniões com as famílias para compartilhar e refletir com elas episódios dos próprios processos documentais; anualmente, é realizada uma mostra que conta, a partir de uma chave de leitura, o percurso das crianças naquele ano; no final de cada investigação, é organizado um portfólio temático. O que na verdade é preciso transformar é a lógica de duas vezes ao ano submeter algo para as famílias e estar satisfeito com isso. Além desse ser um modelo que afasta as famílias da escola, não permite que elas se percebam responsáveis pelo processo educativo dos seus filhos.

Por fim, estruturado o documento que será comunicado, é preciso estabelecer em que contextos será comunicado, Onde?. Essa definição está em perfeito diálogo com o endereçamento da comunicação: se for endereçado às crianças, é preciso estar à altura delas e com qualidade e resistência para o seu manejo; se for aos pais, a localização precisa ser de acesso e circulação das famílias, e os formatos podem articular imagens, textos, por exemplo; se for aos profissionais, podem ser provocações na sala dos professores ou mesmo na biblioteca para consultas e usos formativos.

Voltando ao caso da mini-história de Milena, a escola tem o hábito de postar as minihistórias semanalmente nas redes sociais além de deixar uma versão impressa na porta da sala de referência das crianças.

Como nota final, antes de mostrar a mini-história da Milena, destaco que comunicar, nessa perspectiva da Documentação Pedagógica, abre um espaço público para que as crianças e suas aprendizagens possam ser vistas e escutadas novamente, para sair do anonimato e serem narradas em sua complexidade. Por isso, é preciso estar atento à vida cotidiana para "manifestar o sentido da experiência das crianças, sem aprisionar tal experiência em sentenças escritas num piscar de olhos, mas restituindo-as à sua plenitude" (FORTUNATI, 2012, p. 5). 

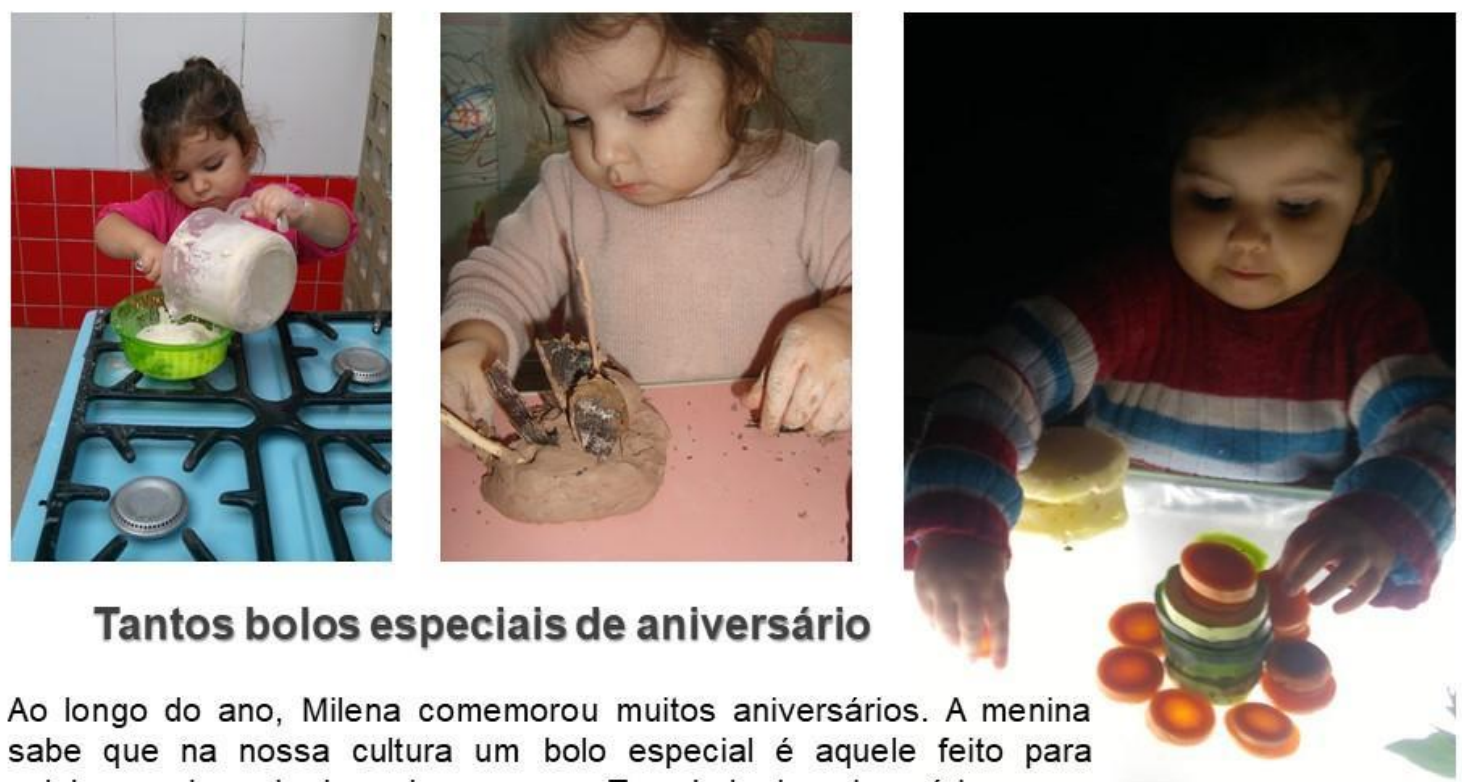

Tantos bolos especiais de aniversário

Ao longo do ano, Milena comemorou muitos aniversários. A menina sabe que na nossa cultura um bolo especial é aquele feito para celebrar a chegada de cada novo ano. Teve bolo de aniversário para a mãe, algumas vezes para a própria Milena e até para sua personagem preferida: a Frozen.

Seu olhar atencioso e concentrado em cada detalhe, nos mostra o saberes que Milena têm para lidar com os ingredientes, com os instrumentos, com os sabores e aromas. A menina sabe que o que torna especial cada bolo, depende dos sutis detalhes com que prepara cada um deles.

No capítulo seguinte, desenvolvo a respeito dos Organizadores da Ação Pedagógica. Esse tema, como será amplamente discutido a seguir, é um ponto central desta tese, pois evidencia o conhecimento praxiológico desenvolvido por essa comunidade de apoio ao desenvolvimento profissional sustentada pela estratégia da Documentação Pedagógica. 


\section{ORGANIZADORES DA AÇÃo PEDAGÓGICA}

No decorrer do trabalho desenvolvido ao longo dos seis anos no interior do OBECI, avançamos significativamente em relação à compreensão do tema da Documentação Pedagógica como estratégia central para investigar, refletir e comunicar o cotidiano praxiológico e as aprendizagens das crianças e dos adultos. Na medida em que conseguíamos nos apropriar dessa estratégia como meio para observar, registrar e interpretar o cotidiano pedagógico, bem como narrar para argumentar sobre nossa imagem de criança, adulto e escola, fomos construindo algumas pistas relativas à organização pedagógica.

A ideia de planejamento é uma delas. O planejamento emergente do OBECI envolve duas modalidades coincidentes: o planejamento de contexto e o planejamento de sessão (FOCHI, 2015b) ${ }^{101}$. Ocorre que a ideia de planejamento que temos desenvolvido “[...] não está direcionada a um conjunto de aulas ou atividades e, tampouco, a propostas relacionadas às datas comemorativas" (FOCHI, 2015b, p. 5) Também não é a construção do "semanário", que não auxilia em nada na reflexão da prática pedagógica e nem torna visível a intenção educativa, apenas cumpre com uma burocracia. Ao contrário, "planejar é fazer um esboço mais amplo sobre a gestão do tempo, sobre a organização dos espaços, sobre a oferta de materiais e sobre os arranjos dos grupos" (FOCHI, 2015b, p. 5). Além disso, planejar é criar situações significativas de aprendizagem que contribuam para as crianças atribuírem significado para as suas experiências no mundo.

Assim, temos entendido que, antes de mais nada, é preciso que o professor elabore o planejamento do contexto com uma visão macro para criar uma certa atmosfera de bem-estar global, que represente uma escolha em construir um certo ritmo para a vida cotidiana em que são respeitadas as distintas necessidades das crianças em diálogo com as necessidades dos adultos e da instituição e que traduza as crenças educativas no modo como as diferentes situações da jornada acontecem. Planejar o contexto é desnaturalizar o óbvio, o "sempre foi assim" para desconstruir a lógica de que uma jornada educativa é uma corrida de obstáculos.

Quando antes expus que uma das ideias que guiam as ações no OBECI é a focagem na vida cotidiana, vincula-se diretamente a essa perspectiva de planejar o contexto como uma tomada de consciência para decidir sobre o modo como organizamos o contexto educativo em

101 Me remeto a texto já publicado em que comento especificamente ao modo como temos encaminhado o planejamento dentro do OBECI. Obviamente, essa perspectiva de planejar está alinhada às ideias dos autores que tem nos inspirado no Observatório. 
suas dimensões espaço-temporais e, consequentemente, na promoção de relações e interações. Estou de acordo com o que destaca Branzi (2013, p. 129): “as revoluções mais bem-sucedidas geralmente são aquelas que começam exatamente pelo pequeno, pelo diário, pelo indispensável”.

A vida cotidiana tem um valor muito grande tanto no que diz respeito às aprendizagens que dela decorrem, como do clima que ela pode gerar. Nesse sentido, uma das finalidades do planejamento de contexto é a descrição e a reflexão da vida educativa a partir de observáveis da vida cotidiana com vista a organizá-la para melhor responder às necessidades dos sujeitos nela envolvidos.

Isso posto, as dimensões do planejamento de contexto envolvem a organização do espaço da sala de referência, os tipos de materiais disponibilizados, o modo como é gestado o tempo e as possibilidades dadas às crianças para se auto organizarem ou para o adulto propor organizações diferentes para os arranjos de grupos (grande grupo, pequenos grupos, trios, duplas). Além dos aspectos relativos ao espaço, aos materiais, aos tempos e aos arranjos de grupo, é preciso lembrar que temos de ir reconstruindo outras dinâmicas da relação entre adultos e crianças, como poderá ser visto a seguir, pois isso está diretamente atrelado aos aspectos anteriores, é simultaneamente condição e resultado.

Também o planejamento de contexto requer problematizar o modo como as microtransições ocorrem. Para nós, pensar a respeito dessas transições da vida cotidiana (que internamente no OBECI passamos a chamar de microtransições) significa ser coerente com a imagem de criança que pensa, que sente, que deseja e, assim, que precisa ser respeitada desde a sua condição humana. Mas não só isso, também significa reconhecer que os contextos em que as crianças estão inseridas e o como elas os vivem impactam direta e profundamente os seus modos de compreender a natureza relacional (criança-criança; adulto-criança; adulto-adulto). Portanto, problematizar as microtransições envolve contrapor práticas automatizadas e pôr acento nas interações e relações para estruturar a jornada educativa.

Por fim, o planejamento de contextos também engloba a reflexão e a tomada de decisão sobre as atividades de atenção pessoal. David e Appel (2010), valendo-se da abordagem de Emmi Pikler, referem-se aos momentos da alimentação, da higiene e do descanso como atividades de atenção pessoal. Em geral, esses momentos estão longe de serem refletidos dentro das escolas e mais parecem uma corrida de obstáculos em que o único objetivo é finalizar o momento da forma mais rápida possível. Quando se compreende que essas também são situações importantes e, por isso, devem ser planejadas, podemos dar um outro ritmo ao 
funcionamento da jornada educativa que seja mais respeitoso e que acolha as temporalidades das crianças e que promova o envolvimento e a participação dos meninos e das meninas na aventura e na desventura que implica cada uma dessas atividades de atenção pessoal. Como destaca Òdena (1995, p. 24), "não podemos esquecer que a criança evolui e aprende graças a sua própria atividade"; logo, o seu papel não pode ser passivo, como se o comer, o descansar e o higienizar-se fosse apenas uma necessidade fisiológica, quando não é. É fisiológica, mas também é cultural, representa marcos de autonomia e, portanto, é também moral. Quando bem pensadas, as atividades de atenção pessoal são laboratórios embrionários para a participação ativa, para o comprometimento com o seu entorno, para o convívio e para o autoconhecimento.

Uma vez que o contexto esteja planejado, a outra modalidade é o planejamento de sessão, ou seja, propor a pequenos ou grandes grupos situações significativas de aprendizagem que articulem os seus saberes com aqueles já sistematizados pela humanidade (FOCHI, 2015b).

Como já tratado no capítulo sobre a Documentação Pedagógica no $\mathrm{OBECI}^{102}$, sessão não é sinônimo de atividade. Planejar a sessão corresponde ao desenho de um percurso praticável com bases em algumas Figura 5 - Planejamento

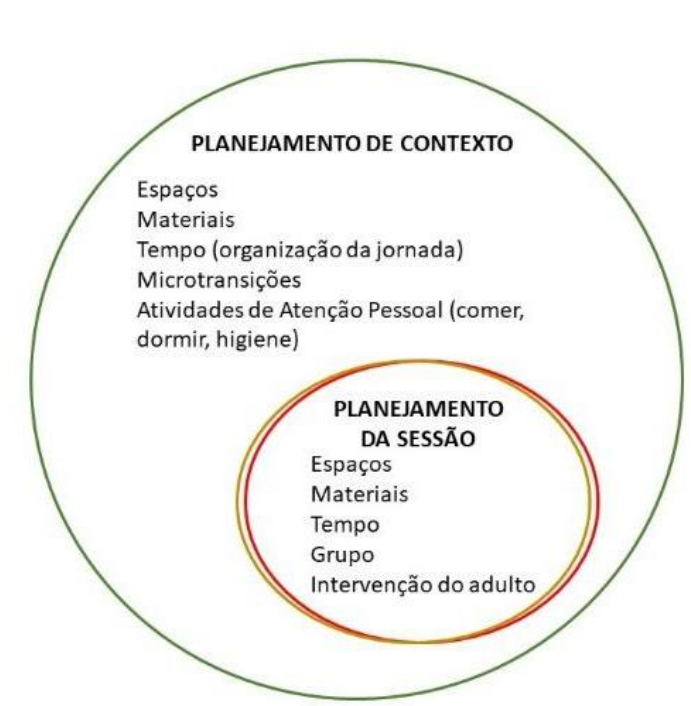

Fonte: Elaborada pelo autor premissas epistemológicas que, no caso do Observatório, já anunciei anteriormente: a tônica na investigação, a visão de criança competente e da dimensão do currículo como um mundo de significados, a aprendizagem negociada, a crença nas pedagogias participativas e os modelos pedagógicos relacionais.

As sessões ou um conjunto de sessões se transformam em situações de aprendizagem que podem se converter em importantes momentos para as crianças construírem sentido para o conhecimento gerado. Quando um professor elabora suas estratégias a partir da escuta ativa dos percursos das crianças, ele consegue construir jornadas de aprendizagem que permitem aos meninos e meninas irem elaborando, aprofundando e ganhando intimidade com os saberes e os objetos de investigação. A desconexão das propostas oferecidas às crianças são reveladoras de

102 No capítulo sobre documentação, são explicitados os instrumentos de planejamento de sessão. 
como não compreendemos sua competência para atribuir significado a sua própria aprendizagem (FOCHI, 2019).

Também no planejamento de sessão, refletimos sobre a organização do espaço, os materiais ofertados, a organização do tempo e do grupo e o tipo de intervenção necessária do adulto. Compreender essas dimensões do planejamento tem nos ajudado a reposicionar as crianças e os adultos na relação educativa.

Ambos os planejamentos, de contexto e de sessão, coincidem na crença de que criar modelos alternativos para o funcionamento das escolas significa estranhar o familiar para estabelecer novos modos de estar com as crianças e de promover jornadas de aprendizagens. Assim, como pode ser visto, o tema relativo aos espaços, materiais, tempos, grupos e papel do adulto estruturam as reflexões a respeito do planejamento e constituem, para o OBECI, o que nomeamos como Organizadores da Ação Pedagógica.

É curioso observar que esses temas muitas vezes são entendidos como decorativos ou como dados no contexto escolar. Ou seja, o modo como o contexto está organizado e como promove as interações, nessa visão decorativa do contexto, não implica desenvolvimento do sujeito. A ausência de perguntas sobre esses elementos parece mostrar uma certa ideia de desenvolvimento humano que não considera o valor do contexto para a aprendizagem das crianças. Assim, é facilmente justificado que a criança seja vista isoladamente, sem considerar a relação que se estabelece entre o contexto educativo ofertado e sua aprendizagem.

No entanto, a perspectiva de que a criança é um sujeito biologicamente cultural (ROGOFF, 2005) implica considerar a trama de representações, símbolos e interações a que ela está sujeita. Os contextos de que ela participa, e, dentre esses, a escola, converte-se em um privilegiado espaço para o seu desenvolvimento global, por isso, é preciso prestar "atenção à ecologia em que a criança se encontra, impregnada por complexas circunstâncias do ambiente, assim como de ideias, representações, expectativas dos adultos que colocam em marcha estratégias para sua socialização" (COMELLES, 2011, p. 13). Nesse sentido, em consonância com os estudos realizados no campo de orientação construtivista, o modo como os contextos são organizados favorecem, dificultam ou consolidam as experiências de aprendizagem das crianças.

Revisando a literatura pedagógica da área, aquilo que no OBECI nomeamos como Organizadores, também coincide, em certo ponto, com o que Bondioli (2011, p. 27) tem chamado de organização pedagógica, citando o espaço, o tempo e o grupo como elementos que "[...] contribuem a desenhar a fisionomia educativa da vida cotidiana na escola" (BONDIOLI, 
2011, p. 27). Bondioli (2011) trata desses três temas articulando com um sistema de avaliação do contexto educativo de modo que "analisa a interação dinâmica que se estabelece entre a organização do contexto, o modelo pedagógico e as práticas educativas da instituição, destacando sua indissociabilidade" (COMELLES, 2011, p. 14). Para Bondioli (2011), quando a instituição passa a problematizar e refletir sobre essa organização pedagógica, explicita a pedagogia latente e a qualidade do contexto educativo.

Barbosa (2006) também já anunciou categorias similares em seu estudo de doutoramento a respeito das rotinas. A organização do ambiente, o uso do tempo, a seleção e a oferta de materiais e a seleção e as propostas de atividades são, para a autora, os elementos constitutivos das rotinas: "o momento da categorização e de classificação é necessário para que se possa compreender melhor a função pedagógica e social da rotina, verificar seus modos de operar e, quem sabe, poder redimensioná-las” (BARBOSA, 2006, p. 117). Barbosa (2006), em uma vasta análise em diferentes organizações de instituições no Brasil e no exterior, busca evidenciar a pedagogia que se esconde na organização das rotinas e mostra a relação que se estabelece desta com os demais elementos indicados.

Em meu estudo de mestrado (FOCHI, 2013), também elenquei esses elementos, nomeando-os como categorias pedagógicas para a prática reflexiva do professor de Educação Infantil: o espaço, os materiais, o tempo, a organização de grupo e o tipo de intervenção do adulto. O foco, no entanto, é mostrar que essas categorias são uma alternativa para "[...] gerar a condução da prática pedagógica por meio de outras vias, ou seja, parece que o interesse do adulto não é tanto planejar atividades para as crianças realizarem, mas criar as condições adequadas, ou satisfatórias, para que elas atuem" (FOCHI, 2013, p. 151). Por isso, destaco que as categorias servem como pontos de atenção que se deve dar para a realização da prática pedagógica, sustentadas em um certo quadro teórico e que constituem marco para a construção de uma epistemologia relacional (FOCHI, 2013).

Nos modelos pedagógicos emergentes do último século, também há forte relação entre os temas que encontramos no OBECI e aqueles encontrados em alguns modelos. OliveiraFormosinho (2016d) nomeia-os de dimensões curriculares integradas da Pedagogia-emParticipação: o espaço e os materiais, o tempo, a interação, a observação, o planejamento e avaliação das crianças, os projetos e atividades e a organização de grupos. Nesse sentido, "a interconectividade destas dimensões tem como objetivo o desenvolvimento de identidades plurais e relações cooperativas, pertenças participativas, explorações comunicativas, significados narrativos" (OLIVEIRA-FORMOSINHO; FORMOSINHO, 2013, p. 18). 
No High Scope, chama-se roda da aprendizagem ativa e têm-se como ideias fundamentais para orientar o trabalho pedagógico a observação da criança, a interação adultocriança, o ambiente físico e os horários e rotinas (POST; HOHMANN, 2003). Nesse modelo, essa roda da aprendizagem ativa é uma forma do adulto tomar consciência da sua prática para apoiar as iniciativas das crianças e sustentá-las (HOHMANN; WEIKART, 2011).

$\mathrm{Na}$ experiência de Reggio Emilia, não há uma sistematização clara sobre essas categorias, mas dada a minha vasta leitura a respeito dessa experiência, posso inferir que a ideia do espaço como um terceiro educador, a cultura do ateliê ${ }^{103}$ (destacando o valor dos materiais e da projetualidade), a dupla pedagógica, a organização em pequenos grupos e a Documentação Pedagógica compõem as ideias que guiam o trabalho pedagógico nas escolas municipais dessa cidade. A dimensão do tempo e de pequeno grupo, por exemplo, é percebida no modo como a jornada das crianças é organizada, ou seja, entre situações em pequenos e grandes grupos ${ }^{104}$, envolvimento nos projetos e em outras situações do cotidiano.

O Movimento da Escola Moderna (MEM) chama de organização do cotidiano de vida e aborda a organização do grupo, a organização dos espaços e materiais e a organização temporal do cotidiano (FOLQUE; BETTENCOURT, 2018). Estes compõem os pressupostos do processo educativo e é onde se fundamenta a dinâmica social da atividade educativa (NIZA, 2013).

Quando falamos de modelos ligados à creche, Elinor Goldschmied também apresenta alguns itens relativos à organização do trabalho pedagógico: a organização do espaço para viver, aprender e brincar (nomeado como espaço satisfatório), o educador referência (pessoachave) e o valor da atividade lúdica, com a proposta do cesto de tesouros e jogo heurístico que se pode perceber a preocupação com os materiais (GOLDSCHMIED; JACKSON, 2006). Na concepção de Goldschmied (1981), acolher as crianças em um ambiente institucional deve harmonizar o cuidar e o educar; logo, é dever dos adultos atentarem para todos esses itens necessários para estruturar as condições de bem-estar global dos meninos e meninas.

\footnotetext{
103 Cultura de ateliê é um termo que vem sendo discutido muito em Reggio Emilia. Na medida em que as escolas foram incorporando o trabalho com o espaço do ateliê e os mini ateliês dentro das escolas, compreenderam que a prática que se estabelecia dentro desses espaços era um modo de ser e estar com as crianças em todas as investigações independentemente do espaço em si. Por isso, passou-se a utilizar a expressão cultura do ateliê para dar ênfase à ideia da ação das crianças, da investigação das materialidades, do pensamento projetual para concretizar algo, do tipo de material que se oferece para as crianças, da sedução estética do ambiente.

${ }^{104}$ Recordo, por exemplo, em uma das oportunidades em que estive em Reggio Emilia, na Scuola de Infanzia do Centro Internacional Loris Malaguzzi, que, em um grupo de 22 crianças de 3 e 4 anos, havia 9 situações simultâneas acontecendo.
} 
Na experiência de Pikler-Loczy, também conseguimos localizar alguns elementos fundamentais para o professor se movimentar no trabalho pedagógico. O espaço e os materiais são denominados de entorno positivo ou entorno ótimo (GODAL, 2016), termo que significa a criação de um espaço seguro, que responda às necessidades das crianças para o seu movimento livre e da oferta de materiais que promovam a brincadeira. A relação adulto e criança também é um elemento fundamental para o bem-estar das crianças e caracteriza-se pela forma e pelo conteúdo que são estabelecidos nessa relação. Um adulto de referência ocupa um papel importante para cada pequeno grupo de crianças nas atividades de atenção pessoal, ao passo que os demais adultos se envolvem com essas mesmas crianças em outras situações do cotidiano. O tempo é uma chave de leitura importante para a experiência húngara, em especial, o respeito ao tempo das crianças em suas situações cotidianas.

De modo geral, pode-se observar que essas dimensões/categorias/organizações compõem uma zona de reflexão para o professor se movimentar e refletir sobre o cotidiano praxiológico. Mais ainda, são parte importante dos modelos pedagógicos, pois, como já afirmou Oliveira-Formosinho (2007, p. 31, grifos da autora), "uma ideia, uma teoria, uma pedagogia não existe, no âmbito educativo, por si, qual essência platônica. Existe na práxis, pois a práxis é a casa da pedagogia".

Para nós, do Observatório, a necessidade de ir reconhecendo, nomeando e estruturando isso que chamamos de "Organizadores da Ação Pedagógica" surgiu na medida em que íamos percebendo as lacunas do trabalho que se realizava dentro das instituições, a falta de coerência entre a prática dos professores de uma mesma escola e o grau de compreensão que fomos construindo sobre o papel do contexto para as aprendizagem das crianças. Notávamos que os projetos pedagógicos não expressavam e nem induziam um determinado tipo de prática. Aliada a isso, a ausência do debate pedagógico nos cursos de formação também deixava lacunas para práticas sem sentidos para as crianças, transformando-se em um conjunto de tarefas a serem cumpridas.

Os Organizadores da Ação Pedagógica são uma forma de concretizar as concepções de cuidado e de educação e sintetizar e ou efetivar o projeto pedagógico. Estruturam as concepções e a proposta da ação educativa dos profissionais tanto no campo da práxis como no da formação e podem - quando ativamente discutidos, elaborados e criados por todos os interlocutores envolvidos na sua execução - facilitar a construção de ricas aprendizagens.

Esses Organizadores retomam uma ideia interessante de que uma certa ideia de didática pode ser pensada desde as crianças. Como a centralidade do trabalho pedagógico na 
Educação Infantil deve estar nos meninos e nas meninas, pensar uma didática desde as crianças significa colocar um adulto em relação, auxiliando a desenvolver a sua competência de observação e interpretação necessária para compreender o mundo da criança e ser seu parceiro na construção de significados no e para o mundo. Esse é um grande antídoto para os materiais e sistemas prontos - que mais do que nunca, estão batendo na porta das escolas - ou para as ideias espontaneístas que atribuem na livre expressão o seu credo pedagógico.

Seguindo a sugestão de Hawkins (2016, p. 93), a melhor forma de respeitar uma criança é saber traduzir esse respeito na organização do contexto e do ambiente educativo de modo que "potencialize seus interesses e talentos e que aprofundem seu envolvimento na prática e no pensamento". Reconhecer os Organizadores da Ação Pedagógica ajuda o professor a se movimentar através de elementos que criam conectividade entre o que se diz e o que se faz, transformando-se em uma estratégia para não criar um vácuo educacional, mas atento para a riqueza e promessa de novidades que os meninos e meninas carregam consigo (HAWKINS, 2016).

Como o modo que temos reconhecido, refletido e transformado a vida cotidiana tem se apoiado a partir da estratégia da Documentação Pedagógica, é dessa forma que passamos a reconhecer os conteúdos e processos emergentes. Assim, os Organizadores surgem das "saliências partilháveis" (OLIVEIRA-FORMOSINHO, 2016b, p.) entre as escolas, ou seja, tanto em nível das possibilidades como dos limites, abordar os Organizadores é mergulhar nas entranhas da pedagogia latente para torná-la explícita, com nome (FORMOSINHO, 2018). Nesse sentido, antes de discutir cada um dos Organizadores, apresento o modo como eles foram desenvolvidos em termos de formação e pesquisa dentro do OBECI.

\subsection{O processo de análise e de formação para chegar aos Organizadores da Ação Pedagógica no/do OBECI}

O modo como se chegou aos Organizadores da Ação Pedagógica, que serão apresentados na sequência, é importante de ser explicitado, quer seja pelo seu valor formativo, quer pelo seu valor investigativo. Esses dois âmbitos, da formação e da investigação, caminham juntos no processo desta tese, pois, em uma investigação de natureza praxiológica, o papel do investigador é uma das fontes de dados. Assim, o compromisso ético em não mitigar as vozes, os feitos e as identidades é crucial tanto para a formação como para a investigação (OLIVEIRAFORMOSINHO; FORMOSINHO, 2012). Especialmente neste tópico, que decorre de um 
processo integrado, precisam ser explicitados os movimentos feitos para se chegar ao que será apresentado na sequência.

Para o projeto de qualificação desta tese (FOCHI, 2017), havia sido realizada uma análise flutuante das Memórias do OBECI dos anos de 2013 a 2016. A partir dessa primeira análise, imediatamente após a qualificação, foi novamente realizada a análise de conteúdo do conjunto de Memórias com o apoio do software MAXQDA para poder compreender a narrativa do processo dessa comunidade de apoio ao desenvolvimento profissional. A partir dessa análise, ficou evidente que havia uma necessidade de entrar em temas que auxiliassem o professor e a equipe pedagógica das instituições a estruturarem questões relativas à organização pedagógica, tendo em vista as várias situações em que se discutiu a respeito de temas como o espaço, os materiais, o tempo, os grupos e o papel do adulto. Mais do que apenas constatar essa necessidade, a análise de conteúdo permitiu que se verificasse que já havia algumas pistas que indicavam uma certa compreensão do OBECI em relação a esses temas, mesmo que ainda não estivessem explicitadas ao grupo.

Isso posto, organizamos dois Encontros das Escolas Observadoras, em 2017, dedicados a discutir esses tópicos, que passei a chamar de Organizadores da Ação Pedagógica. No primeiro Encontro, foram apresentados os Organizadores e alguns conceitos-chave encontrados na literatura que tratam desses temas. Na ocasião, fui delineando, junto aos professores e a equipe pedagógica das escolas, alguns pontos de atenção para cada um dos Organizadores, estabelecendo relação entre o percurso do OBECI ao longo dos anos anteriores, as cenas do cotidiano que tínhamos produzido e a literatura da área.

Depois desse encontro, que ocorreu no primeiro semestre, até o encontro seguinte, no segundo semestre, cada instituição foi refletindo a respeito dos Organizadores em diálogo com o próprio cotidiano. A partir disso, no segundo Encontro das Escolas Observadoras ${ }^{105}$, as próprias escolas retomaram os elementos já levantados anteriormente para pensar quais seriam efetivamente os pontos de atenção para cada um dos Organizadores anunciados em cada agrupamento etário. Essa ideia de olhar a partir da organização administrativa (por faixa etária) das turmas foi uma estratégia para poder construir a reflexão, em pequenos grupos, que não fosse organizada por escolas, mas que pusesse as professoras e equipe pedagógica das escolas em diálogo a partir de um ponto em comum. Assim, os professores das escolas se organizaram em grupos e, a partir dos observáveis que foram produzidos no próprio cotidiano, elencaram os

\footnotetext{
105 Como, nesse período, eu estava fora do país para o doutorado sanduíche, elaborei a organização do encontro junto das coordenadoras pedagógicas e diretoras, e foram elas que conduziram o encontro.
} 
pontos de atenção para o espaço, materiais, tempo, organização de grupo e papel do professor e, ao final desse encontro, compartilharam para o grande grupo com o objetivo de verificar as saliências partilháveis (OLIVEIRA-FORMOSINHO, 2016b).

Desde então, com vista a esses pontos, temos aprofundado o tema e buscado compreender esses Organizadores nas diferentes investigações que temos levado a cabo dentro do OBECI. Em 2018, no Grupo Gestor, a centralidade de nossa investigação foram as microtransições e, no GIA de Acompanhamento Projetual, a globalidade do trabalho das professoras. Em ambos os grupos, os Organizadores da Ação Pedagógica foram sendo experimentados e aprofundados. Mesmo em 2016, com os GIA do Brincar Heurístico e os Ciclos de Simbolização, os Organizadores já estavam lá, ainda que não fossem anunciados e reconhecidos por nós. Prova disso é que o livro sobre o Brincar Heurístico ${ }^{106}$, que foi lançado em 2018, explicita claramente esse avanço e as narrativas das professoras se organizam exatamente a partir dos organizadores. Para nós, esses organizadores constituem a elaboração de um conhecimento praxiológico.

Neste caso, é interessante destacar que esta tese tem um papel importante na restituição das reflexões acerca desses Organizadores desenvolvidos internamente no OBECI. Devolvêlos ao OBECI, elaborados, refletidos e contrastados com o que produzimos, é dar a essa comunidade um retorno significativo da investigação que se realizou. Ademais, a proposta é também tornar visível o conhecimento praxiológico construído tanto em nível dos práticos (professoras, coordenadoras pedagógicas, diretoras) como em nível do investigador e formador. Esses dois níveis, além de serem complementares e estarem em interatividade, servem ao mesmo tempo para mostrar como tem se respondido às exigências dos próprios contextos participantes do OBECI, assim como devem servir para migrar para outros contextos e inspirar outras realidades.

Assim, com a finalidade de mostrar o conhecimento praxiológico construído pelos práticos e evidenciar a relação existente entre os Organizadores, optei por apresentar uma comunicação de uma das escolas que exemplifica como esses estão a serviço da reflexão da prática pedagógica. Entendi que compartilhar uma comunicação inteira, tal como foi produzida pela escola, daria a noção da totalidade da reflexão e possibilitaria a compreensão dos organizadores em ação a partir dos próprios usuários.

${ }^{106}$ FOCHI, Paulo (org). O Brincar Heurístico na creche: percursos pedagógicos no Observatório da Cultura Infantil - OBECI. Porto Alegre: Paulo Fochi Estudos Pedagógicos, 2018. 
O contexto desta comunicação é parte de uma investigação sobre as microtransições que foi levada a cabo no ano de 2018 pelo Grupo Gestor. A escolha dessa comunicação devese à investigação realizada pela coordenadora Liliane e pela diretora Juliana que se deu na sala de referência da faixa etária 2 das professoras Sissa e Karin, que participam do Grupo de Investigação-Ação do Acompanhamento Projetual no OBECI. Nessa comunicação, vê-se o resultado de uma proposta em que a direção e as professoras partilham conscientemente de um mesmo referencial, e, embora a investigação que as professoras estavam levando a cabo fosse outra $^{107}$, os Organizadores eram sua forma de estruturar a prática pedagógica.

Além disso, foi uma opção minha apresentar essa comunicação tanto em termos de conteúdo quanto de forma da comunicação, tal como a equipe diretiva elaborou, para também compartilhar essa competência comunicativa que foi sendo desenvolvida ao longo desses seis anos do OBECI.

Na sequência da comunicação apresentada, discuto cada um dos Organizadores para aprofundar a respeito e estruturar um referencial que possa ser partilhado não apenas entre as escolas do OBECI, mas também entre outros contextos, possibilitando sua migração. Até então, não tínhamos estruturado sobre o tema dos Organizadores a esse nível dentro do OBECI, por isso o conhecimento praxiológico que restituo, a partir da experiência que temos desenvolvido, mostra uma dada compreensão situada sobre os temas do espaço, materiais, tempo, grupo e a relação adulto e criança, mas que está em diálogo com a literatura que compõe nosso quadro referencial. Além disso, com o intuito de mostrar o modo como, nas outras escolas e em outras situações, os Organizadores da Ação Pedagógica são utilizados, para cada uma das categorias, apresento alguns recortes menores em forma de imagens utilizadas no âmbito das nossas reflexões, mini-histórias, trechos de processos documentais ou comunicações para sublinhar algumas ideias-chave.

\footnotetext{
${ }^{107}$ No capítulo sobre a Documentação Pedagógica, serão apresentados trechos da investigação das professoras com as crianças.
} 


\section{Microtransições}

\section{Experiências, relações e construção de conhecimento em pequenos grupos}
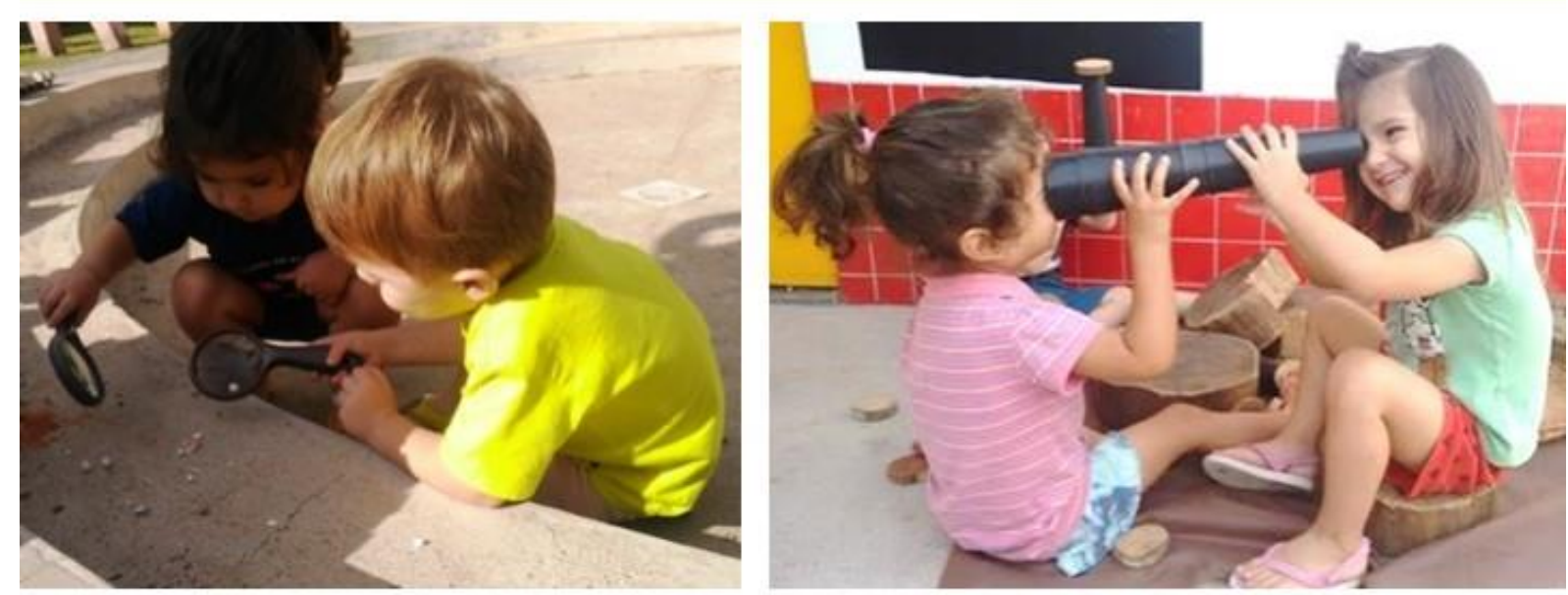

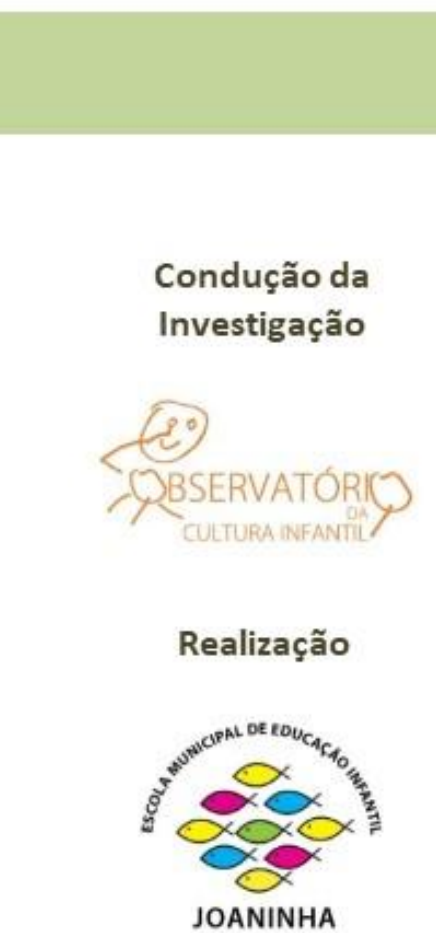

NOVEMBRO / 2018
Coordenação da Investigação

Paulo Fochi Luciane Varisco Focesi

Fotos e Vídeos Juliana Gallina Karin Becker Liliane Ceron Sissa Muller

Organização do Processo Documental e Comunicação Liliane Ceron Juliana Gallina

Turma faixa etária 2 Alana, Anthony, Bárbara, Davi, Isabelly, Ísis, Kássia, Laura, Lívia, Lorenzo, Milena, Nathália, Nícollas, Pedro, Thalya, Yuri

Professoras da turma Karin Becker Sissa Muller 
A aprendizagem é o surgir daquilo que antes não havia, é uma pesquisa do único, do Outro, dos Outros que se encontram em volta de um assunto (RINALDI, 2014 p. 46).

Todos os momentos da vida cotidiana na escola, se intencionalmente pensados e planejados, desenvolvem importantes processos de aprendizagem. Compreender esses processos é um campo que desperta o nosso interesse, tornando-se foco de investigação permanente na escola. Por isso, temos aprofundado a observação e a documentação das propostas em pequenos grupos para acompanhar os processos de aprendizagem das crianças.

Entendemos que, nos grupos de aprendizagem, as crianças compartilham suas experiências, criam estratégias, negociam, experimentam novas perspectivas e maneiras de pensar que as permitem aprender com os outros. Os conhecimentos construídos por meio de relações de grupos qualificam a aprendizagem, especialmente, das crianças, mas também dos professores.

A definição de grupo de aprendizagem é descrita por Krechevsky e Mardell (2014, p. 292) como "um conjunto de pessoas que estão envolvidas emocional, intelectual e esteticamente na solução de problemas, na elaboração de produtos e na construção de significados - um grupo em que juntos, cada pessoa aprende autonomamente e por estilos de aprendizagens dos outros".

As propostas para as crianças são planejadas de modo que aconteçam situações de aprendizagem em grupo e individualmente, sendo que a organização destas é competência dos professores que elaboram estratégias e condições para que o trabalho seja enriquecedor e permita o desenvolvimento de diversos aspectos da inteligência e construção de conhecimento.

A jornada das crianças, na escola, igualmente é pensada e estruturada a fim de que promova condições para que os meninos e meninas usufruam da companhia de seus pares e para que haja flexibilidade e conforto nas microtransições da vida cotidiana na creche.

As crianças passam de uma atividade a outra, e isso ocorre diversas vezes durante a jornada diária. Planejar esses momentos de maneira que possibilitem construção de sentido para as crianças e que aconteçam de forma tranquila é um dos desafios a que nos propomos pensar e repensar frequentemente. E essa reflexão está diretamente ligada aos professores a partir da organização de contexto, da escuta e das mudanças de estratégias que favoreçam o bem-estar e as aprendizagens das crianças. 

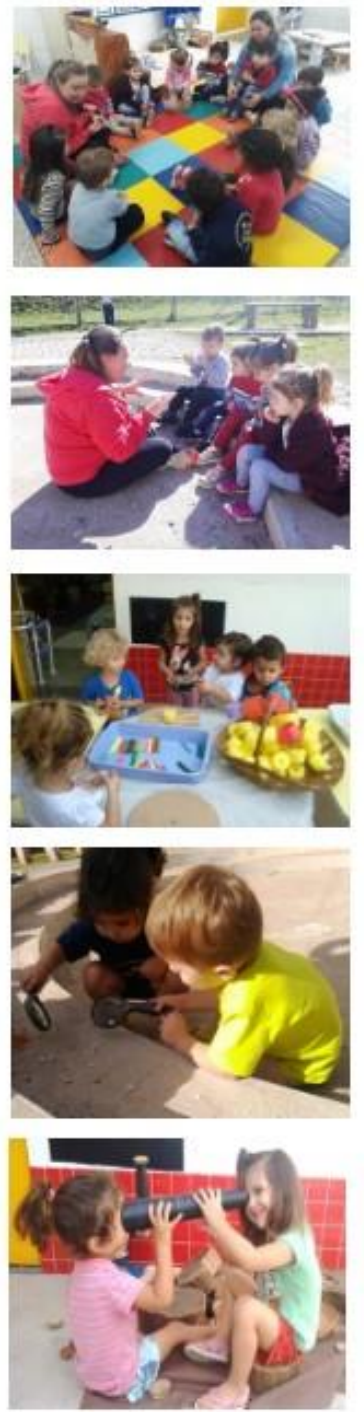
ajudar a problematizar as microtransições a fim de pensar e qualificar a prática pedagógica e construir certos horizontes para nortear as ações das professoras nas microtransições do grande grupo para o pequeno grupo no cotidiano na creche.

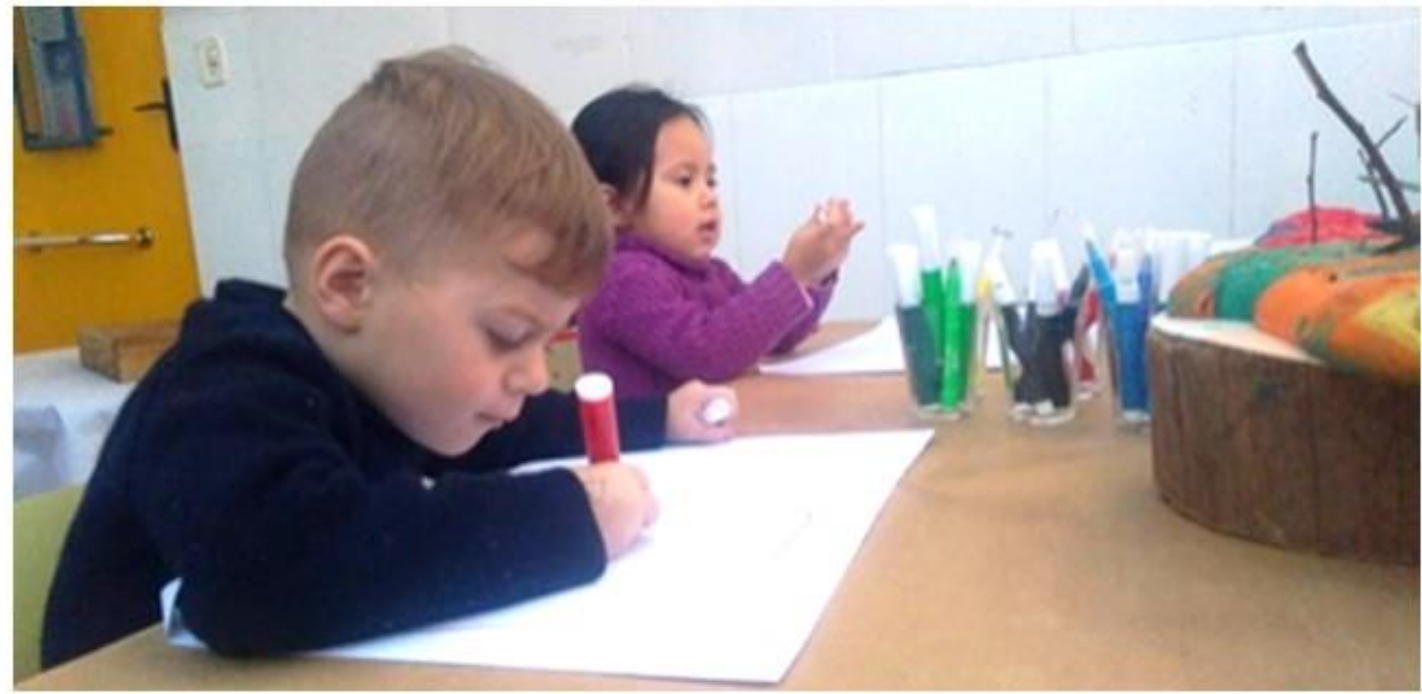




\section{UM CONVITE ESPECIAL}

Durante a jornada das crianças na creche, elas passam por inúmeras microtransições: trocam de ambientes, de propostas, de grupos, de professores, de situações de cuidado, de higiene, entre outras tantas que, muitas vezes, passam despercebidas.

Documentar as microtransições nos ajuda a repensar esses momentos e encontrar estratégias que deem conta de realizá-las com intencionalidade e que sejam significativas e respeitosas para quem está envolvido.

Essa mini-história testemunha como uma professora convidou um pequeno grupo de crianças a participarem de uma sessão sem que todo o grupo fosse mobilizado para esse momento.

Durante a roda de conversa, que acontece no início do turno, as professoras combinaram com as crianças quem iria participar da sessão naquele dia. Depois do lanche, as crianças foram para a área coberta da escola onde brincam. No momento planejado para a realização da sessão, a professora se dirigiu até as crianças que participariam da proposta. Com sutileza na fala e nos gestos, convidou-as para irem concluindo suas brincadeiras e se encaminharem até a sala.

Davi preferiu permanecer mais alguns instantes na brincadeira que criara com os amigos. A professora atentou a isso, deu o tempo necessário para que ele concluísse sua ação. Após alguns minutos, retomou o convite a Davi. O menino, então, decidiu acompanhar a professora até o espaço onde seria realizada a consigna da sessão.
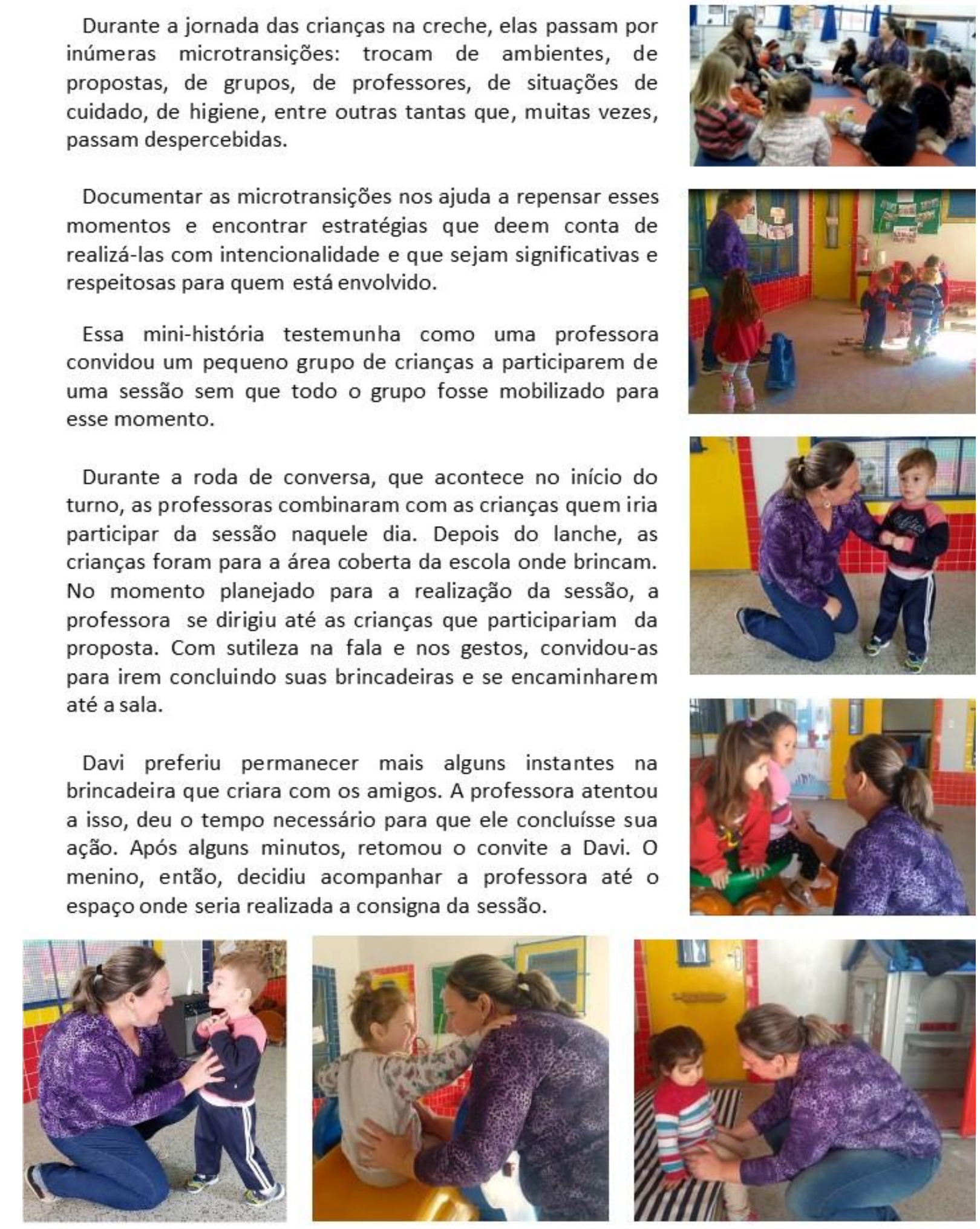


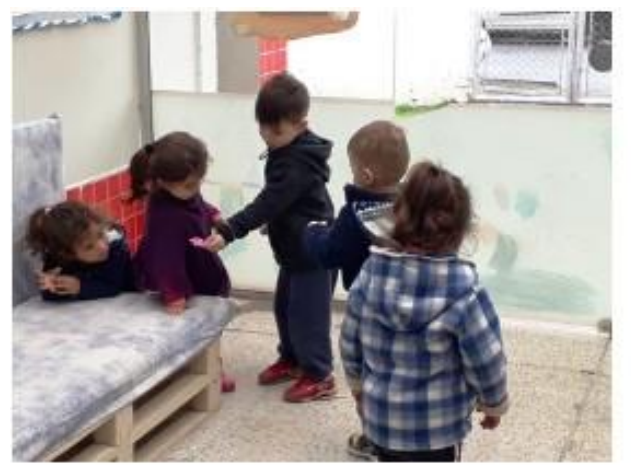

Enquanto o grupo que participaria da sessão se direcionava para a sala, o restante das crianças continuou com uma professora fazendo outra proposta, nesse caso, brincando no pátio.

Davi, Isabelle, Milena, Alana e Ísis estavam atentos à consigna que a professora Karin tinha feito para a sessão. Na consigna, a professora fez uma breve conversa sobre o espaço que tinha sido organizado para a sessão, afirmando que poderiam brincar com

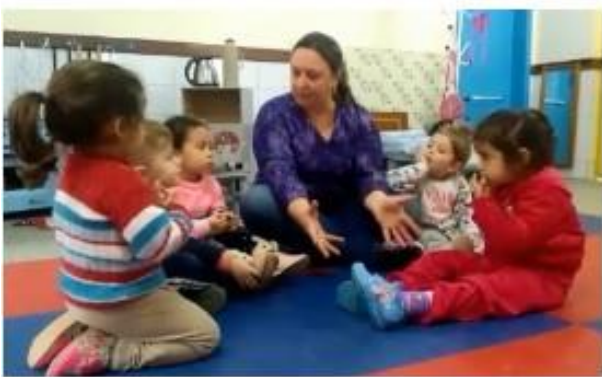
todo material disponível, relembrando alguns combinados. As crianças concordaram com os combinados e ficaram na expectativa do que estaria por vir.

Feitos os combinados, as crianças se dirigiram até o espaço do solário que tinha sido organizado previamente pela professora para a sessão proposta naquele dia.

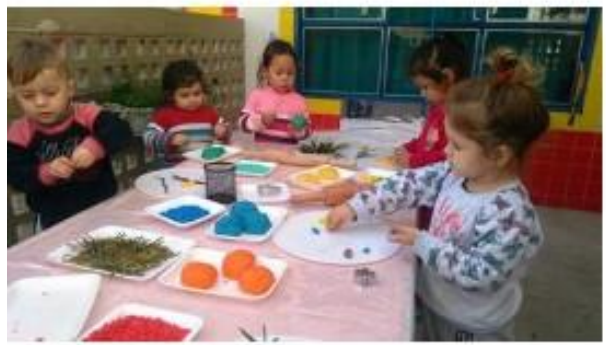

As crianças estavam investigando comidas e a sessão foi especialmente preparada para que as crianças pudessem levar a cabo suas investigações. Na medida em que a professora percebia que a sessão estava acabando, propôs que as crianças finalizassem e retornassem ao grande grupo.

E assim vai seguindo e fluindo a jornada educativa da faixa etária $2 \ldots$

\section{PROBLEMATIZAR AS MICROTRANSIÇÕES}

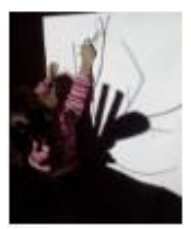

\section{ESPAÇOS E MATERIAIS}

Circunscrição dos espaços para o grande grupo

Espaços e materiais para pequenos

grupos: a sessão

Senso de pertencimento

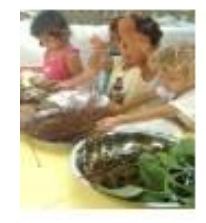

GRUPOS DE APRENDIZAGEM

Importância dos pequenos grupos

A regularidade e permanência dos

grupos

Critérios para formação dos

pequenos grupos

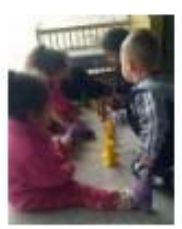

A GESTÃOD O TEMPO

O tempo de estar nos pequenos grupos

O tempo de estar no grande grupo

Tempos de transição

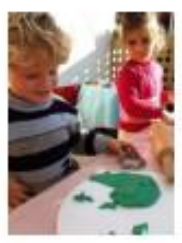

PAPEL DO PROFESSOR

Observação, escuta e fala

Planejamento e organização de

contexto

Observação, registro, interpretação e

comunicação 


\section{ESPAÇOS E MATERIAIS}

\section{Circunscrição dos espaços para o grande grupo}

Os ambientes coletivos são organizados para que as crianças se autogerenciam nas formações de grupos conforme seus interesses. A organização dos espaços e dos materiais favorecem a atuação das crianças e criam cenários de possibilidade, sugestões e provocações que promovem a autoatividade, as interações entre elas com o espaço e os

materiais.
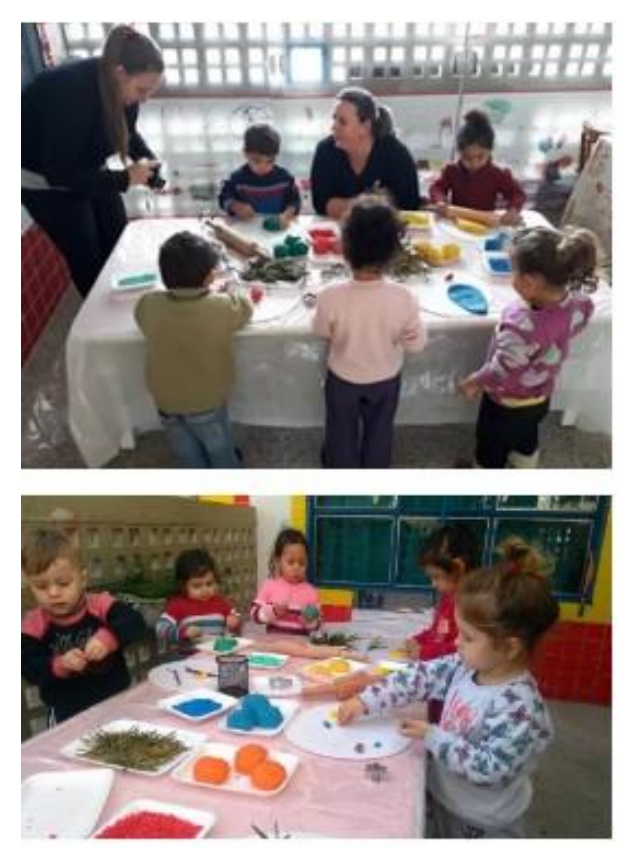

Espaços e materiais para pequenos

\section{grupos: a sessão}

As sessões são realizadas em um ambiente previamente preparado por um adulto, que organiza um conjunto de materiais para as crianças fazerem suas investigações. Esse contexto é pensado a partir dos observáveis de sessões anteriores, garantindo a continuidade das propostas.

Um espaço satisfatório (GOLDSCHMIED, 2006) proporciona às crianças a possibilidade de pesquisas em que elas se tornam protagonistas de sua própria aprendizagem.

\section{Senso de pertencimento}

A organização, o cuidado e o respeito ao ambiente mostram o quanto as crianças nutrem um senso de pertencimento a esse espaço. Nas paredes da sala, as comunicações convidam as crianças a sentirem-se parte desse ambiente, além de restituir as experiências e valorizar o que é vivido nos espaços. Segundo Hoyuelos (2006), uma escola amável envolve uma arquitetura na qual as paredes falam; falam por meio de uma documentação estética que forma uma segunda pele: uma documentação estética da cultura, das pessoas que ali habitam.

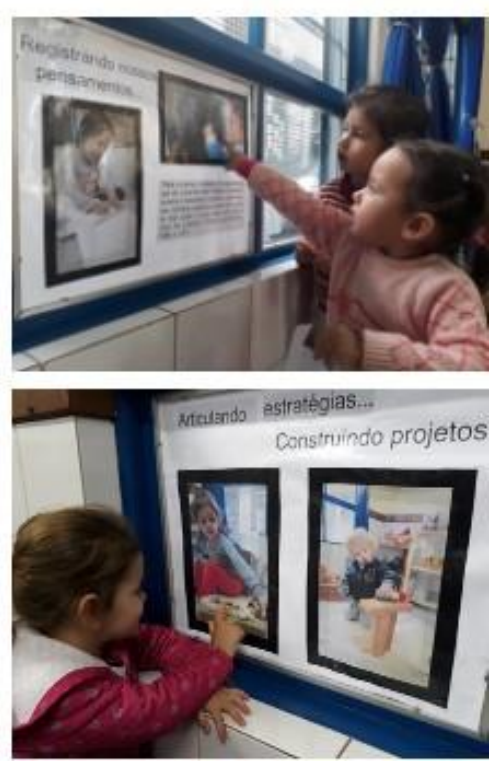




\section{A JORNADA DE ÍSIS E MILENA}

Milena e Ísis têm uma proximidade muito grande que iniciou no ano anterior, quando as duas começaram sua jornada na escola, criando um vínculo de amizade e companheirismo.

Ao longo da jornada, uma busca a companhia da outra, como no espaço dos materiais não estruturados, onde permanecem bons momentos escolhendo pedras e palavras para brincar.

Milena percebendo a presença da professora, logo a convida para participar da brincadeira. A professora Karin se delicia com as receitas das duas amigas.

Como tem tempo na escola para as tantas brincadeiras das crianças, quando se esgotam as possibilidades em um dos espaços, não é problema, pois existem outros. Agora elas decidiram que é hora de desenhar. Nesse espaço, registram e deixam suas marcas e reconhecem nos painéis os seus traços e dos amigos que também já deixaram.

Mesmo nessa amizade tão intensa, também abrem um lugarzinho para outros amigos, como Pedro e Yuri, que se juntam a elas e um novo grupo se forma a partir dos interesses comuns: mais histórias, agora com novas vozes e sons de riscantes no papel.

Como boas amigas, depois de tantos afazeres, as meninas decidem brincar de "tomar chimarrão". Esse hábito tão comum na nossa cultura foi representado por elas evidenciando não apenas os gestos característicos, mas a ocasião em que um chimarrão não pode faltar.

Na roda de chimarrão, de mão em mão, não passa só a cuia, mas a certeza de que é assim que os elos se fortalecem, cativando novas amizades e perpetuando nossa cultura.
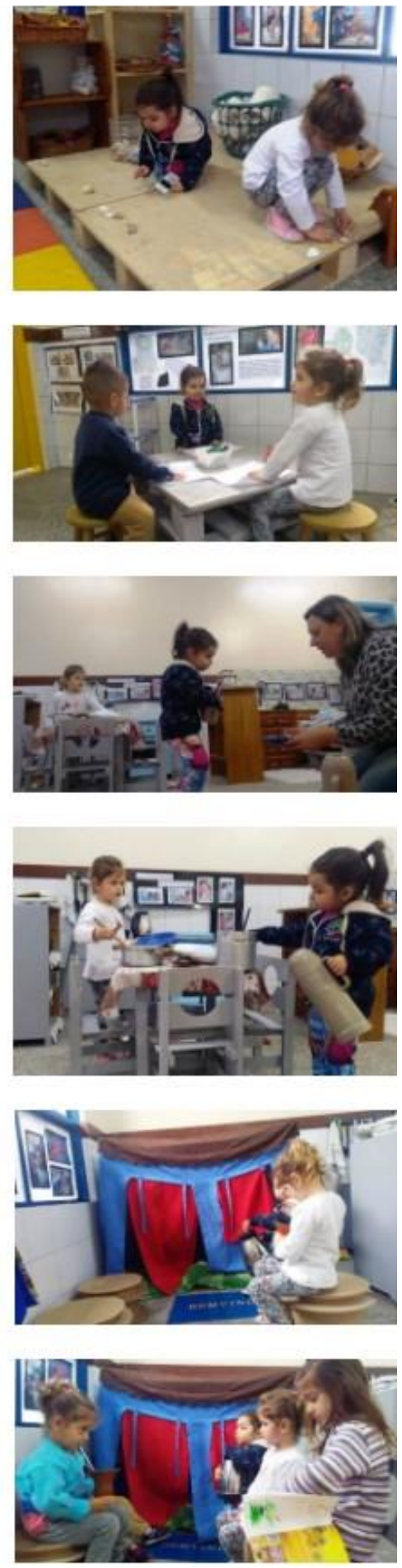


\section{A GESTÃO DO TEMPO}

\section{O tempo de estar nos pequenos grupos}

O tempo em pequenos grupos proporciona às crianças experiências que talvez de outra maneira não pudessem vivenciar. $\mathrm{O}$ ambiente tranquilo proporcionado nos pequenos grupos favorece as trocas entre as crianças, a observação, a negociação de ideias, a partilha.
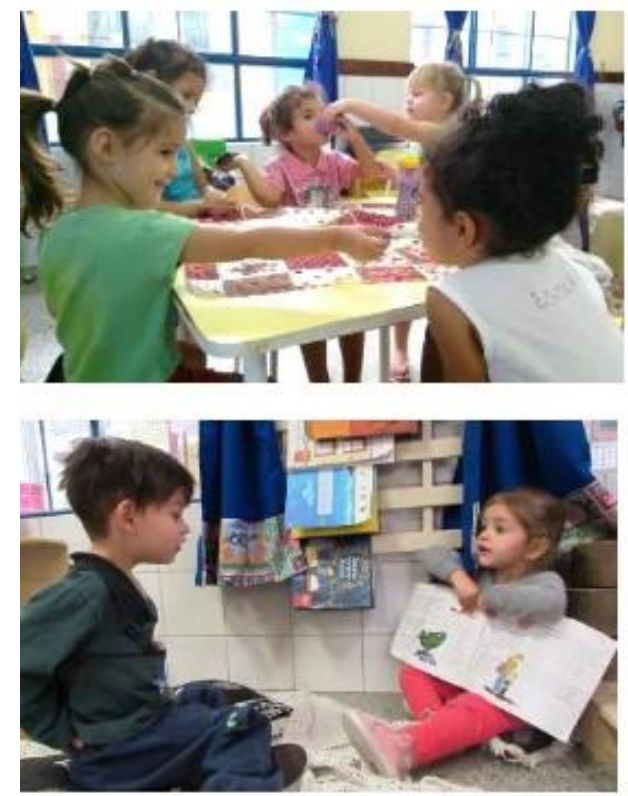

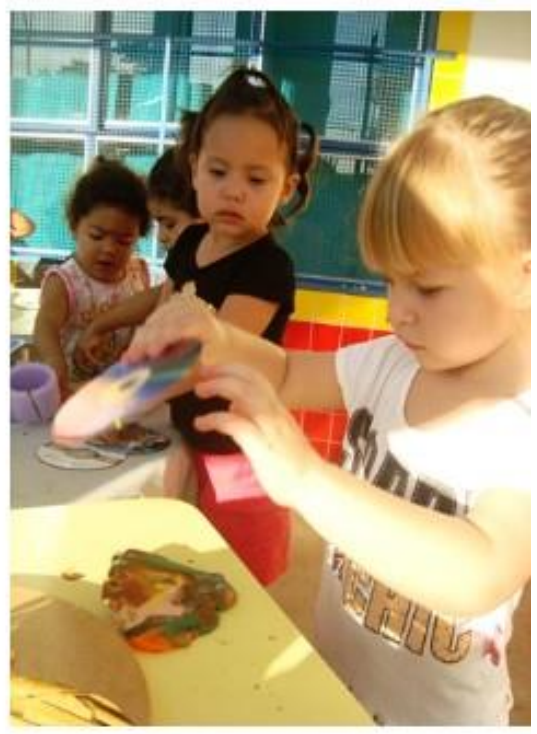

O tempo de estar no grande grupo

No grande grupo, as crianças se auto-organizam de acordo com seus interesses; os grupos não estão estabelecidos: podem brincar sozinhas, com um amigo, em grupos ou com adulto. É um movimento contínuo, em que as crianças têm autonomia para mudarem seus interesses, suas companhias e relações.

Os momentos em grande grupo também são momentos de trocas e conversas entre adultos e crianças.

\section{Tempos de transição}

Dar o tempo necessário para que a crianças possam concluir sua brincadeira antes de propor outra atividade, avisá-las com antecedência quando irão mudar de proposta ou ambiente são exemplos de microtransições que devem ser planejadas pelos professores. Refletir sobre esses momentos, respeitando o tempo das crianças, é fundamental para que as microtransições se realizem com intencionalidade e promovam situações de aprendizagem aos adultos e crianças.

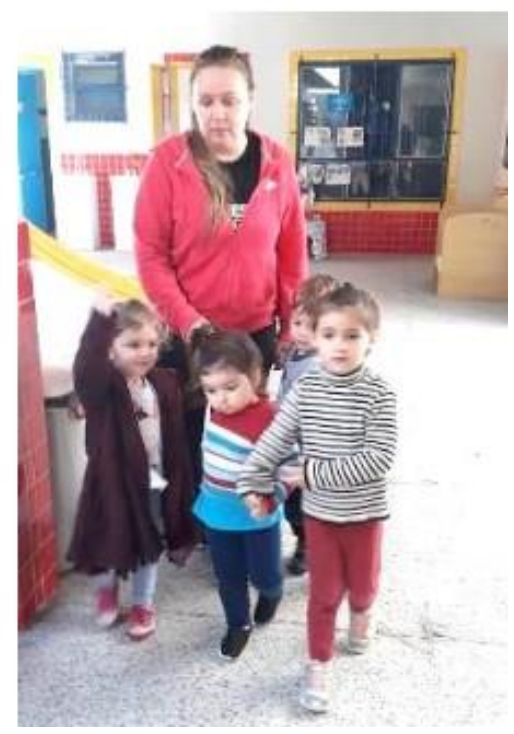




\section{É TEMPO DE DAR TEMPO}

O lanche da tarde é um dos momentos da jornada em que todas as crianças da turma vão juntas ao refeitório da escola. Ali elas se alimentam, conversam, trocam olhares, fazem escolhas...

Assim que as primeiras crianças terminam seus lanches, elas retornam à sala acompanhadas de uma das professoras. Algumas crianças voluntariamente vão se dirigindo até o banheiro para realizarem a escovação dos dentes sobre o olhar atento do adulto.

As outras crianças que ficaram na sala e as que estão chegando têm a possibilidade para escolherem com quem e com o que querem brincar nos diversos espaços disponíveis. Mais algumas crianças entram na sala e vão se integrando ao grupo que já está envolvido em diversas brincadeiras.

Ainda no refeitório, permanece um grupo de meninas que estão lanchando calmamente. Elas desfrutam desse momento, se servem sozinhas, saboreiam seus alimentos com tranquilidade. Ao terminarem, as meninas retornam à sala acompanhadas pela professora que estava junto delas no refeitório.

Porém Bárbara ainda permaneceu lanchando, pois queria tomar seu leite vagarosamente. Assim que terminou, se levanta da cadeira e retorna até a sala de referência.

Ela entra e observa atentamente o grande grupo em suas brincadeiras. Após alguns instantes, elege um espaço para brincar com seus amigos.

Ter tempo, dar tempo, planejar o tempo é fundamental para que, na jornada educativa, as crianças possam fazer escolhas, ter seu tempo individual em harmonia com o tempo coletivo.
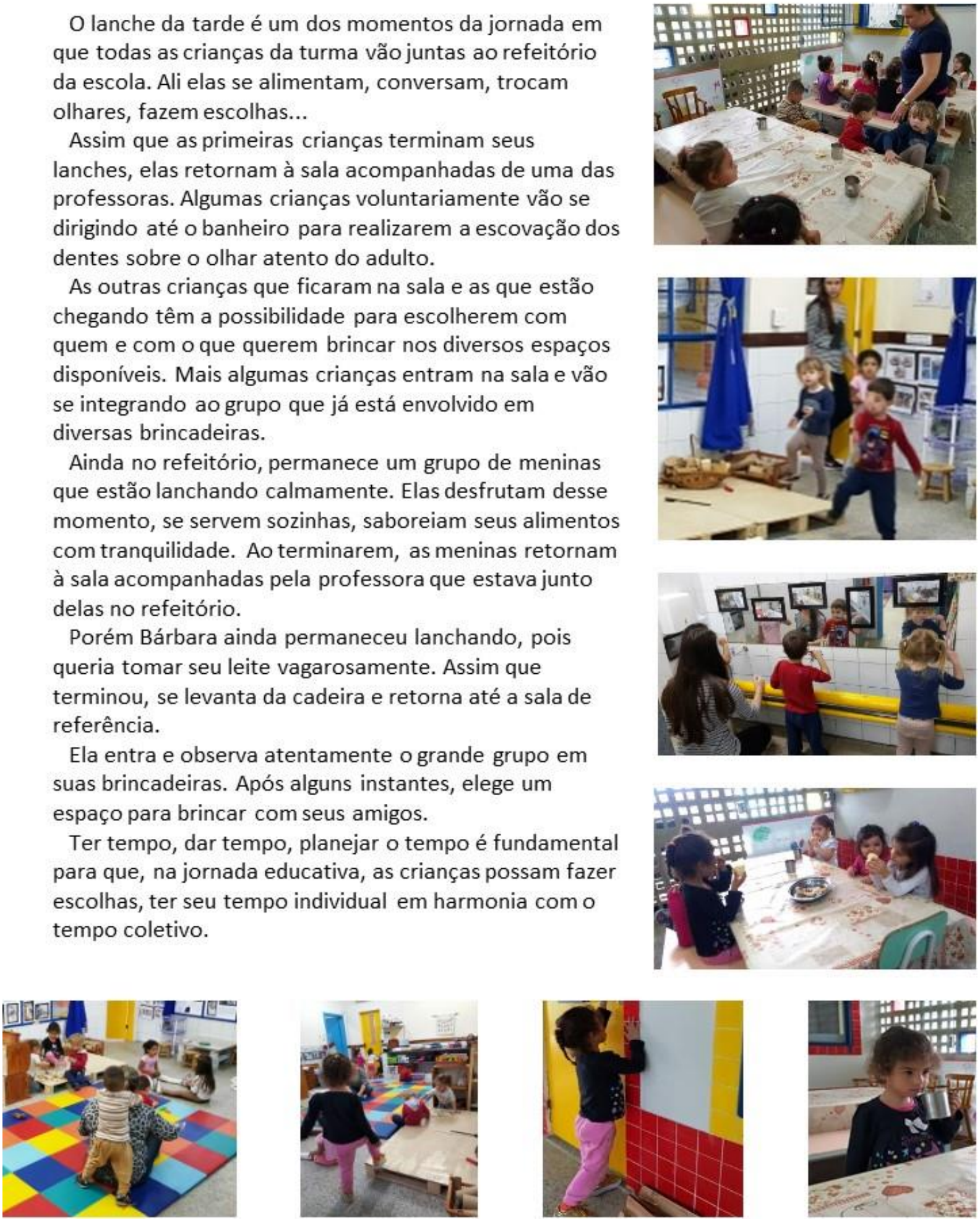


\section{GRUPOS DE APRENDIZAGEM}

\section{Importância dos pequenos grupos}

As crianças aprendem umas com as outras e se ajudam mutuamente. Nos pequenos grupos, elas têm oportunidades de experimentar suas ideias e compartilhar das ideias dos outros num ambiente

tranquilo e com um adulto atento por perto.

Também os pequenos grupos permitem maior visibilidade para as pesquisas individuais que acontecem em um espaço coletivo.

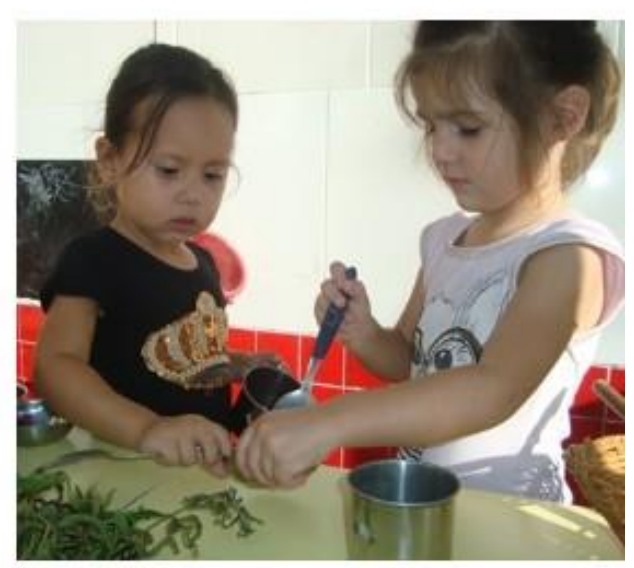

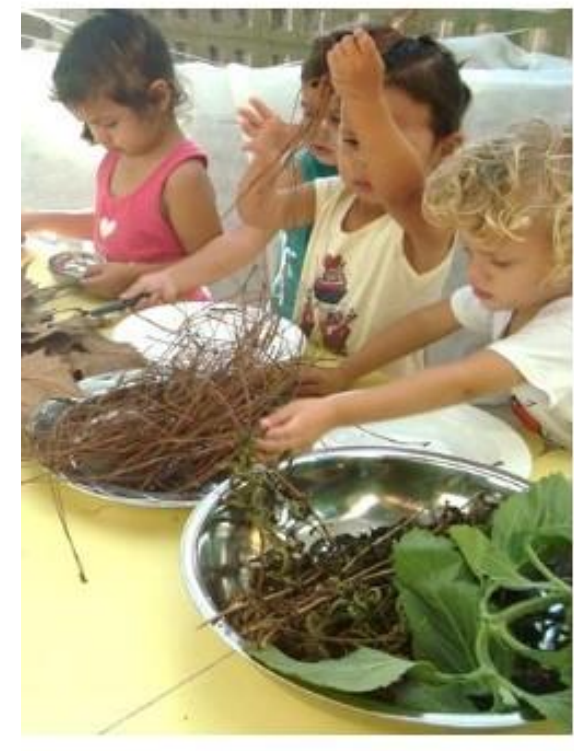

\section{Critérios para formação de pequenos grupos}

A formação de um grupo é muito importante quando pensamos nas dinâmicas de aprendizagem. Muitos critérios podem ser levados em conta, desde que qualifiquem as interações entre as crianças. Dependendo da proposta organizada pelo professor, a composição dos grupos é pensada a partir da idade, dos interesses, das amizades, das preferências, da familiaridade das crianças entre si e com os materiais propostos.

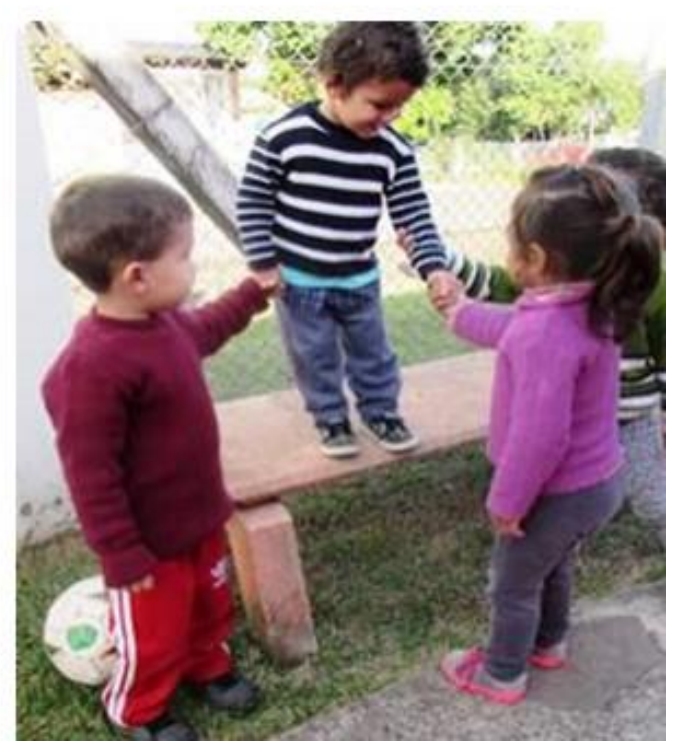




\section{PARTILHAR EXPERIÊNCIAS E CONSTRUIR RELAÇÕES}
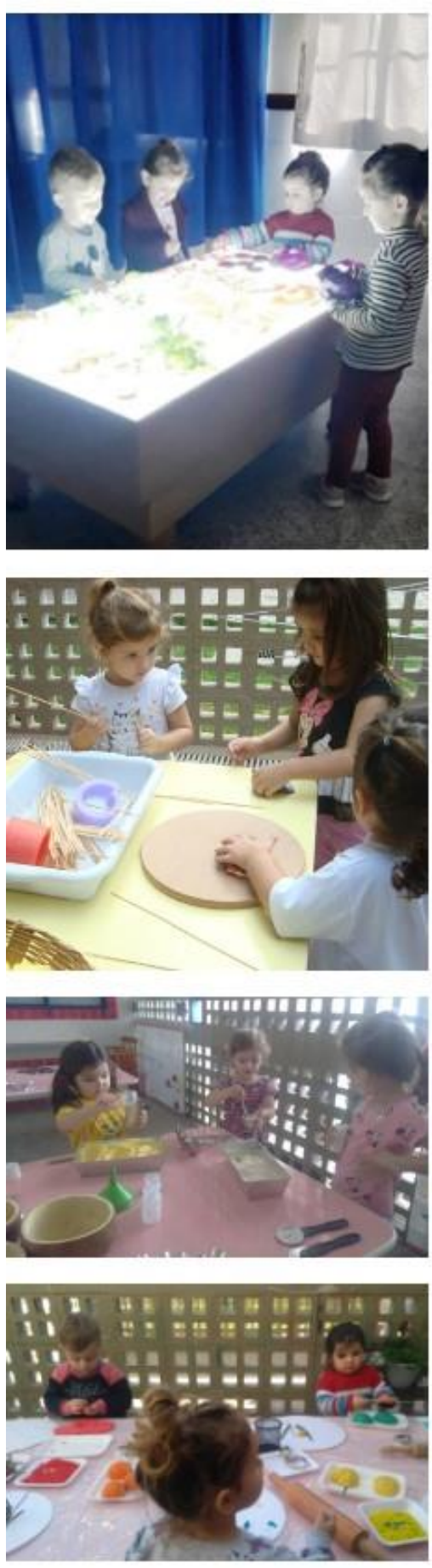

Estar em uma proposta em pequenos grupos é uma oportunidade para as crianças criarem intimidade e aprenderem umas com as outras.

Quando o pequeno grupo se mantém regular, vai se construindo um ambiente de proximidade e de vínculo entre os participantes, como no caso de Davi, Ísis, Nathália e Milena.

Em diversas sessões, o grupo permaneceu com a mesma composição, o que estreitou relações, qualificando a aprendizagem coletiva $\mathrm{e}$ individual. Graças à intimidade que já construíram, as trocas e interações foram sempre tranquilas e com espaço e tempo para conversar, negociar e decidir juntos, visto que já estabeleceram um grau de afinidade e confiança entre eles.

Partilhar descobertas, comunicar suas percepções, socializar, ter autonomia para realizar explorações e serem solidários com os colegas são exemplos de situações que visualizamos cotidianamente nos pequenos grupos.

Pensar em estratégia de manutenção e permanência de grupo é também pensar numa "segurança afetiva, num mundo repleto de incertezas" (GODALL, 2002, p. 20).

Além disso, para o professor, é uma oportunidade de conhecer melhor cada criança e compreender os modos como aprende. É só na proximidade com as crianças que podemos verdadeiramente saber responder às suas necessidades.

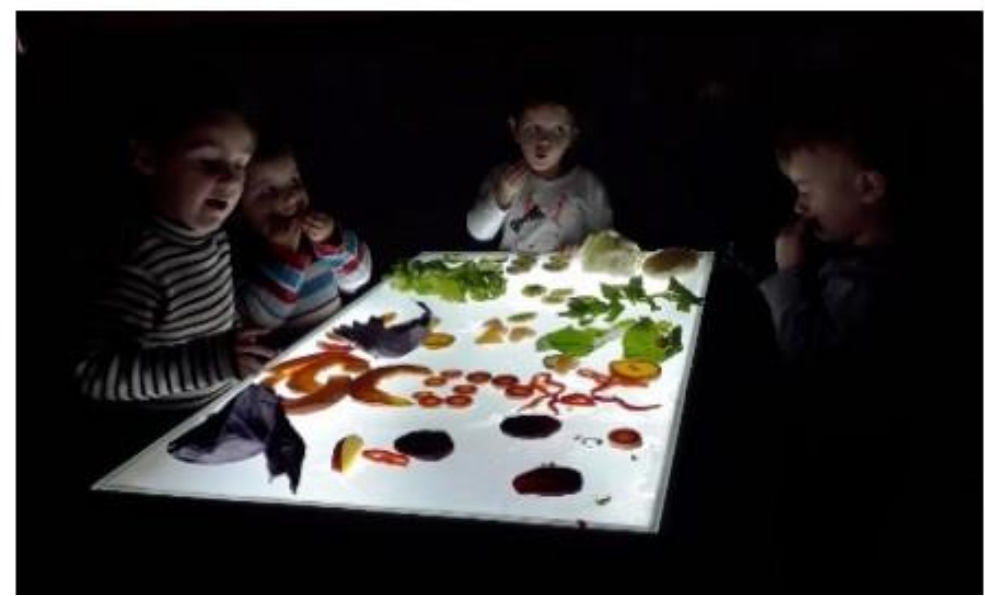




\section{PAPEL DO PROFESSOR}

\section{Observação, escuta e fala}

Nos pequenos grupos, é mais fácil respeitar, acompanhar o ritmo e observar as características

individuais de cada criança e de como elas se relacionam com o grupo. A escuta torna-se uma importante estratégia para relançar as ideias que surgem nas sessões. De igual importância também é o modo como o professor conversa com as crianças, dirigindo-se a elas com respeito e interesse em
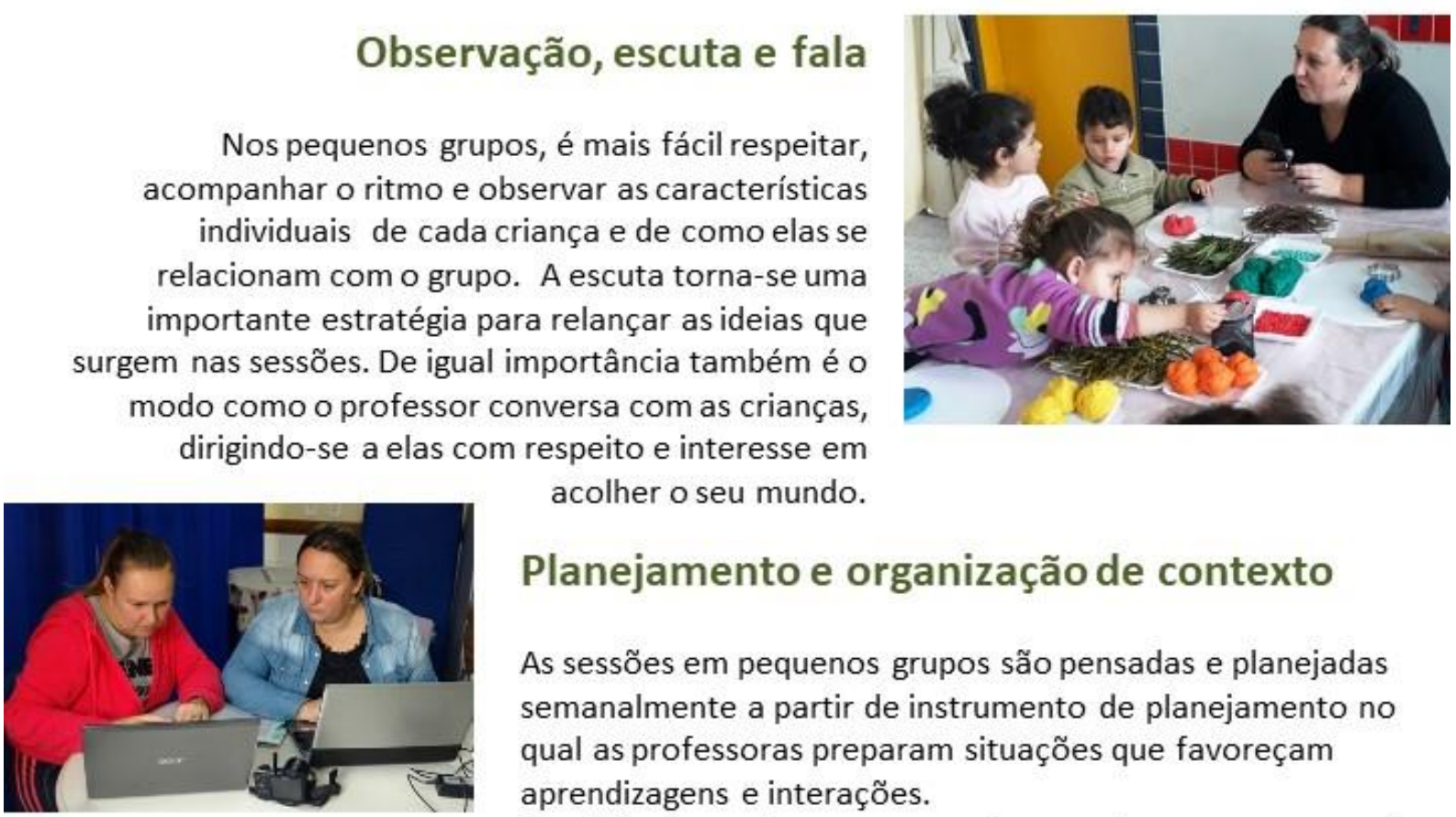
acolher o seu mundo.

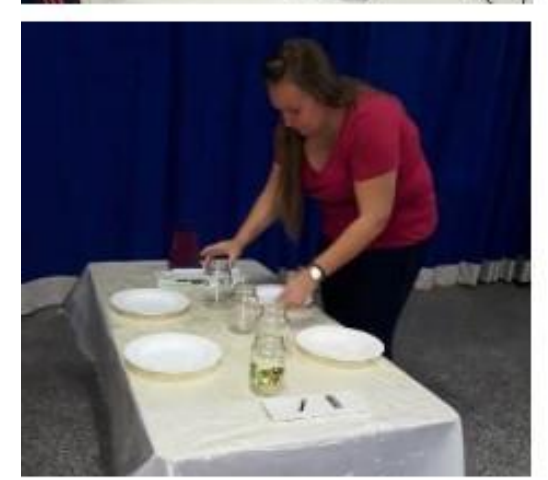

\section{Observar, registrar, interpretar e} comunicar

A partir da observação e registro, os professores coletam informações para projetar e retroalimentar as propostas para as crianças.

Tornam visíveis as aprendizagens a partir de comunicações produzidas. Nas paredes da sala e da escola, são compartilhadas as comunicações em que os processos e experiências vivenciadas pelos meninos e meninas são restituídos a eles e às famílias.
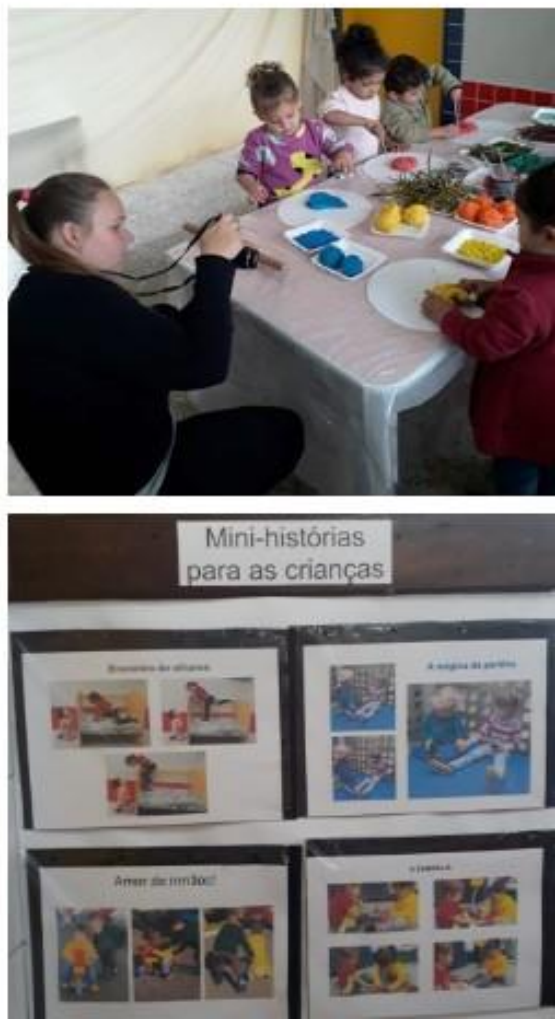


\section{PROFESSORAS POTENTES}
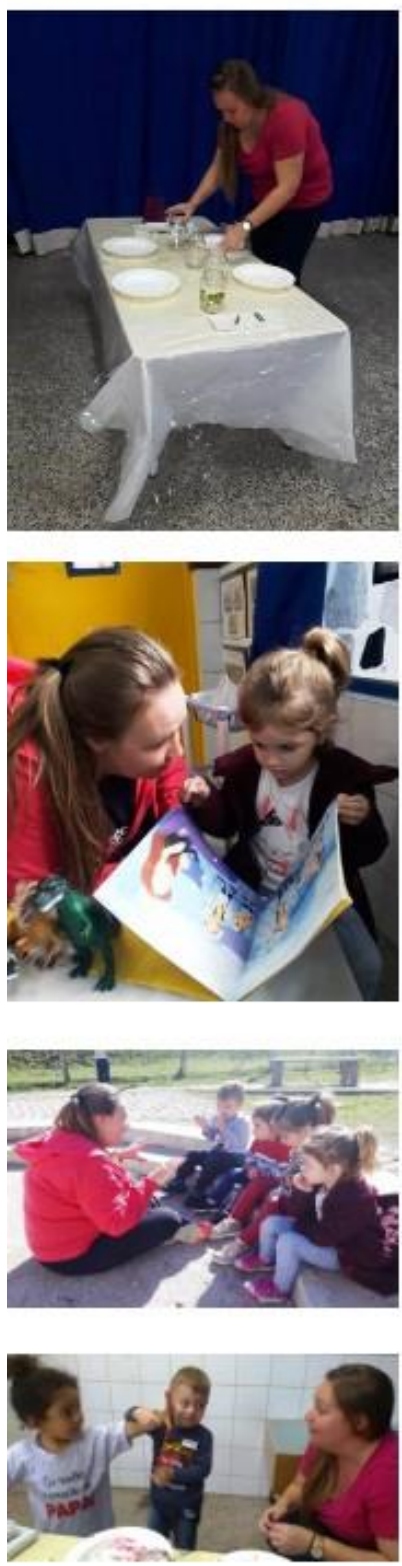

Referências
Quando pensamos na organização de propostas para os meninos e as meninas, pressupomos uma imagem de criança competente, ativa, sujeito de direitos. No entanto, para isso ser possível, é também preciso reconhecer professores potentes, que saibam reconhecer sua importância e responsabilidade diante das crianças.

O professor referência ocupa um papel fundamental na organização e construção dos contextos significativos de aprendizagem, que possibilitem a exploração, investigação e formulação de hipóteses das crianças.

A escuta por parte do professor sobre os interesses das crianças é importante para traduzir contextos ricos em possibilidades.

Escutar, acompanhar, retroalimentar são ações desse adulto que possibilitam a continuidade de um trabalho que é contextualizado e que busca responder às necessidades das crianças.

Convidar as crianças para participar de uma sessão, acompanhar e sustentá-las durante as propostas, observar, registrar e interpretar os observáveis são parte das atribuições do professor.

Nós entendemos que professores potentes são aqueles que não perdem a capacidade de se admirar, encantar, pesquisar e dar sentido ao que fazem.

Pensar e refletir sobre o saber fazer das crianças é o modo mais eficiente que temos encontrado para construir boas jornadas de aprendizagem tanto para os adultos, como para os meninos e as meninas.

GODALL, T. Del contacto con y sin tacto. Revista Aula infantil. n. 6, mai, 2012, p. 15-19.

GOLDSCHMIED, E. ; JACKSON, S. Educação de 0 a 3 anos: o atendimento em creche. Porto Alegre: Artmed, 2006. HOYUELOS, A. La estética en el pensamiento y obra de Loris Malaguzzi. Barcelona: Octaedro, 2006.

MARDELL, B. KRECHEVKY, M. Quatro características dos grupos de aprendizagens. In: Zero, Project. Tomando visível a aprendizagem: criançasque aprendem individualmente em grupo. São Paulo: Phorte, 2014.

RINALDI, C. Creche e escolas da infância como lugares de cultura. In: Zero, Project. Tomando visivel a aprendizagem: criançasque aprendem individualmente em grupo. São Paulo:Phorte, 2014. 


\subsection{A organização do Espaço Educativo}

Quaisquer que sejam as limitações de um prédio, sempre há algo que pode ser feito para torná-lo mais confortável e atrativo para os adultos e as crianças que nele passam longas horas do dia (GOLDSCHMIED; JACKSON, 2006, p. 33).

Muitos autores concordam que há uma pedagogia implícita no modo como organizamse os espaços ${ }^{108}$. Caggio (1998, p. 33, grifo do autor) afirma que "o espaço fala da pedagogia elegida, mais ou menos explicitamente, e das contradições que existem entre o declarado, o possível e o praticado [...]". Por ser o elemento que favorece ou impossibilita as relações, por impulsionar a ação das crianças e dos adultos, por comunicar a partir dos materiais e do modo como está organizado, o espaço ganha uma força maior que o projeto educativo em si, pois "o estilo de um professor e de uma escola não se define tanto pelo que se afirma na programação escrita, mas sim pelo que se faz na cotidianidade concreta" (CAGGIO, 1998, p. 33).

Da mesma forma, há um certo consenso que o modo como os espaços estão organizados favorece menos ou mais a aprendizagem das crianças, isso porque gera um clima menor ou maior de cooperação, diálogo e interação das crianças entre elas, delas com os adultos e delas com o entorno. Como destaca o arquiteto Andrea Branzi (2013), criar um espaço relacional é entrar nas questões essenciais das funções do espaço (para que serve) e das relações que dele decorrem. A pergunta "para que servem" os espaços é importante para auxiliar na reflexão sobre como organizar e responder às necessidades das crianças e dos adultos. Uma sala de referência, por exemplo, é um espaço que precisa responder a múltiplas funções: precisa ao mesmo tempo ser um lugar para o grupo mas também ser o lugar para cada criança, ou seja, deve fortalecer a identidade grupal e as identidades de cada um; é um espaço para aprendizagens plurais e que igualmente precisa acolher a pluralidade de temporalidades (de cada criança, do grupo de criança, dos adultos, da instituição); é um espaço que serve ainda a distintas funções (também são realizadas as refeições, o descanso). O modo como o espaço está organizado pode representar o acesso aos instrumentos da cultura (OLIVEIRA-FORMOSINHO; ANDRADE, 2011) e pode ser fonte inesgotável para gerar um clima de pertencimento e de fortalecimento das relações.

Seguindo nesse mesmo sentido, Rinaldi (2013, p. 122) observa que os espaços “[...] podem ser experienciados não como tempo e espaço para reproduzir e transmitir conhecimentos já estabelecidos, mas como um lugar para a verdadeira criatividade". O que a autora propõe

108 Citando alguns: Caggio (1998), Malaguzzi (2001), Horn (2004, 2017), Cabanellas e Eslava (2005); OliveiraFormosinho e Andrade (2011), Gariboldi (2011), Ceppi e Zini (2013). 
significa uma ruptura nas matrizes pedagógicas transmissivas e um convite para a criação de um ambiente estético, que compreende a capacidade do homem em religar-se ao mundo para a criar significados, para a inventividade, para fluir as relações. Nos meandros do pensamento de Loris Malaguzzi, conhecer está relacionado com a dimensão estética. Para o pedagogo, a estética é uma condição de estarmos em ressonância com o mundo. Conhecer é esta vibração estética da criança com o mundo a sua volta, "[...] é a vibração estética que nos empurra a dar nomes, nomes às figuras e cores, e às figuras e cores que parecem não existir" (MALAGUZZI, 2005, p. 83).

Também tem se reconhecido que o espaço possui uma linguagem, uma dimensão comunicativa que "[...] tende a influir e regular os comportamentos dos indivíduos, e especialmente dos sujeitos em processo de desenvolvimento" (GARIBOLDI, 2011, p. 99). Para Hoyuelos (2005, p. 172), pensar no espaço, desde seu âmbito comunicativo, é diminuir as distâncias entre as identidades dos sujeitos com o espaço, em que "o direito à identidade de cada pessoa possa encontrar acolhimento, intercâmbio e enriquecimento mútuo”.

O espaço é, em suas características físicas, expressivas e simbólicas, recurso pedagógico e aspecto fundamental para a qualidade da organização do contexto educativo, sobretudo para aquelas instituições que acolhem o universo da brincadeira dos meninos e meninas como eixo central da prática pedagógica na Educação Infantil e que assumem que a escola pode ser um espaço privilegiado para a aprendizagem.

Embora a tônica da discussão esteja na sala referência, a compreensão do espaço como uma categoria pedagógica precisa ser ampliada para todos os demais ambientes de uma escola, desde a área da entrada, em que se pode declarar a metáfora da identidade pedagógica (VECCHI, 2013), como os banheiros, o refeitório, os corredores, os espaços externos ${ }^{109}$.

Como já tratado anteriormente, a organização dos espaços nos diferentes modelos curriculares das pedagogias participativas é um ponto de muita atenção, tendo em vista que, a partir disso, se mobiliza uma outra forma de ser e estar com as crianças.

Dentro do OBECI, de uma maneira geral, temos entendido que a organização do espaço deve permitir à criança:

a) brincar e articular seus saberes e experiências com o patrimônio que a humanidade já sistematizou;

${ }^{109}$ Em recente estudo, Horn (2017) realiza diversas proposições a respeito da organização dos espaços e dos materiais nos diferentes ambientes de um prédio escolar (especialmente aqueles prédios do Proinfância), tanto do ponto de vista interno quanto do ponto de vista externo. 
b) expressar sua potencialidade, sua curiosidade, suas explorações e investigações sozinhas, com outras crianças e adultos;

c) escolher onde e como brincar, realizar seus projetos pessoais e participar de projetos coletivos;

d) encontrar lugares para descansar e contemplar;

e) sentir-se parte e partícipe da construção da identidade cultural do grupo que faz parte a partir da natureza ideográfica construída no espaço;

f) reconhecer-se no modo como o espaço comunica a respeito de sua identidade pessoal e coletiva;

g) sentir-se acolhida pela natureza estética (padrão harmônico, iluminação, sonoridade, temperatura);

h) participar dos cuidados e da organização.

Considerando tais aspectos, no Observatório, temos considerado três grandes dimensões para a organização dos espaços: a descentralização do adulto, a circunscrição dos espaços de modo que as crianças possam se auto-organizar e a identidade do espaço.

\subsubsection{A descentralização do adulto}

Aprendemos com Loris Malaguzzi (2001) que o espaço precisa ocupar o lugar de um terceiro educador. No entanto, na realidade brasileira, em que nem sempre dispomos de uma dupla pedagógica (professor e professor), como falava Malaguzzi, mas de um professor e outros adultos (auxiliares, monitores, estagiários), essa ideia de um terceiro educador precisa ser contextualizada e refletida. Horn $(2004$, p.) chamou de "solidária parceria entre espaço e educador" e, com isso, sugere que as dinâmicas da vida no interior da escola também sejam marcadas por uma rede de relações da cultura e da vida familiar das crianças. Portanto, entre o espaço e o educador, há uma cultura que se forma e é formada pela participação das crianças, pelo modo como se organiza e arranja o espaço, pelos materiais ofertados, pelo papel que os adultos ocupam, por aquilo que se comunica interna e externamente.

Marina Ballo (1991) realizou um estudo sobre a relação entre a organização do espaço educativo e o papel do educador, categorizando-os em três tipos. O primeiro é aquele bastante conhecido por todos nós: um conjunto de mesas para as crianças, a mesa do professor em posição principal e um armário com materiais armazenados. O professor organiza sua jornada de modo que sua centralidade vá controlando o ritmo e as atividades das crianças, de tal sorte 
que todas as crianças façam, todas juntas, a mesma atividade, ao mesmo tempo e da mesma forma ${ }^{110}$. Como destaca Ballo (1991, p. 43), "nesta realidade, esse estar na escola para a criança não coincide com estar com outros, mas sim, apenas fazer ao lado dos outros”. Nesse tipo de organização, há uma desvalorização das relações entre as crianças, a não ser nos poucos minutos de recreio ou atividades livres no pátio. Aliás, momento em que geralmente o professor desaparece totalmente de cena e não se interessa pelo que pode emergir do encontro entre os meninos e meninas. Também nesse tipo de organização o professor é quem determina tudo o que as crianças desejam e necessitam: "o resultado é a anulação dos desejos das crianças como ser individual” (BALLO, 1991, p. 43). A imagem de criança que está por trás desse tipo de organização é de um sujeito passivo, vazio e que não sente, não deseja, não é.

Esse é um exemplo de organização do espaço que não tem outra função a não ser regular e conter as crianças em um ambiente fechado. A iniciativa da criança é praticamente anulada e a centralidade do adulto acaba por cegá-lo e deslocá-lo da relação com as crianças.

O segundo tipo de organização é aquele em que se definem pequenos espaços, ainda que não estejam bem estruturados. Mantém uma zona central destinada às mesas para a realização das “atividades pedagógicas" e, assim como o espaço está organizado, a centralidade permanece nas atividades em que o professor figura a pessoa chave e os usos dos espaços circunscritos se restringem apenas aos momentos de transição, de espera ou recreativos. Esse tipo de espaço mantém a mesma organização do tempo, em que o professor conduz todos os momentos da jornada com todo o grupo fazendo a mesma coisa, ou melhor, "a ideologia ainda é priorizar o momento do trabalho, isto é, da atividade do programa. A tarefa é fazer a turma trabalhar" (BALLO, 1991, p. 46).

Como no primeiro tipo, as atividades que as crianças podem gestar de maneira autônoma não têm valor pedagógico. O brincar permanece como preenchimento do tempo. Uma vez que a tentativa de organizar os cantos não é satisfatória - quer seja pela ausência de materiais, quer pela falta de circunscrição adequada -, estes não exercem nenhuma função a não ser a de acomodar alguns poucos materiais que ficam à disposição das crianças.

O terceiro e último tipo de organização do espaço apresentado por Ballo (1991) é radicalmente diferente dos anteriores. Um dos fatores que explica isso é que o modo como se organiza esse espaço descentraliza a figura do adulto e muda a hierarquia dos diferentes momentos da jornada educativa. Nesse tipo, não há uma área com mesas para as atividades formais. Os cantos estão bem circunscritos e estruturados de tal modo que criem zonas menores

110 Como Formosinho $(1987$, p.) já chamou, “currículo uniforme pronto a vestir em tamanho único”. 
em que as crianças possam se auto-organizar em pequenos grupos, favorecendo os processos colaborativos. Os materiais que compõem cada canto se encontram nas áreas por razões claras e bem definidas e são em quantidade suficiente. Como destaca Ballo (1991, p. 52), "se pode dizer, portanto, que o espaço/área contém o poder que antes se colocava ao educador e serve de espaço de transição entre a autonomia e a individualização.”

Aqui, o espaço se converte em um verdadeiro dispositivo pedagógico, que não apenas muda o cenário pedagógico como mobiliza outra forma de organizar o tempo e as relações (adulto-criança; criança-criança).

Seguindo essa perspectiva, é importante lembrar que Froebel já abordou em sua obra um conceito importante para pensar a organização do espaço: a autoatividade da criança, ou seja, "pela ação, [a criança] expressa intenções em contato com o mundo externo" (KISHIMOTO, PINAZZA, 2007, p. 44). Na verdade, o que o pedagogo alemão propunha era de que a "auto-atividade [...] implica[sse] não meramente que o aprendiz faça tudo por si, mas que ele poderá ser beneficiado somente pelo que faz" (FROEBEL, 1896 apud KISHIMOTO, PINAZZA, 2007, p. 45). Em uma mini-história da Escola Mimo de Gente, as professoras Samantha e Tatiane narram uma cena da vida cotidiana da turma em que Lorenzo, um menino de 5 anos, percebendo seu cansaço e sabendo que na sua sala de referência havia um espaço para descanso, organizou-se para poder atender sua necessidade. Esse fato exemplifica a força que há em um espaço que está organizado de modo que descentralize do adulto e favoreça que a criança tome a iniciativa em atender suas necessidades. Entendo que pensar a auto-atividade não pode estar apenas voltado às situações de brincadeira ou de alguma outra atividade considerada mais estruturada, mas a todas as situações da vida cotidiana que são fontes inesgotáveis de aprendizagem dos meninos e meninas.

\section{QUANDO O CANSAÇO CHEGA}

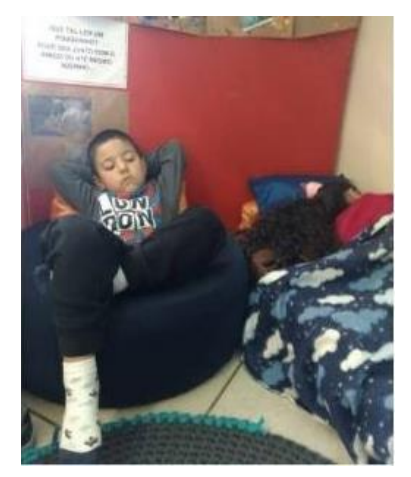

Lorenzo brincava na sala com alguns amigos, enquanto outros estavam deitados descansando.

Lorenzo percebendo seu cansaço, guarda seu brinquedo e senta-se em um almofadão no cantinho do descanso ao lado da amiga Vitória.

Ali, aninha-se e se coloca em posição que se sente confortável. Suspira e fecha os olhos, iniciando seu momento de descanso. 
Esse conceito pode ser interessante para levarmos em conta a relação existente entre a organização dos espaços e a descentralização do adulto, visto que, se satisfatório, a criança pode criar sua própria atividade de acordo com as condições externas ofertadas. Estamos falando aqui de uma negociação entre condições internas (iniciativa, interesse, autonomia das crianças e sua capacidade de agir) e condições externas (qualidade do espaço organizado para as atividades das crianças). Nesse sentido,

\begin{abstract}
A atividade e a ação são os primeiros fenômenos da vida da criança. Essa atividade e essa ação são, na verdade, a expressão central do interno (...) que aparece em harmonia com sentimentos e percepção, indicando a apreensão e compreensão de si pela criança assim como uma germinação da capacidade individual. (FROEBEL, 1912, p. 23 apud KISHIMOTO; PINAZZA, 2007, p. 45).
\end{abstract}

Quando é realizada a organização dos espaços em profundidade, implica uma redefinição considerável do papel do adulto, da gestão dos tempos cotidianos e, por sua vez, das prioridades educativas. Como afirma Gariboldi (2011, p. 104), "pode também significar a valorização de distintas maneiras de aprendizagem e põe relevo em outras formas de atividades que antes se consideravam marginais".

Ballo (1991) alerta para que o professor não transfira tudo para o espaço e subtraia o seu papel, minimizando seu papel na relação educativa: "aqui também está o risco que a educadora não utilize as áreas como elementos de transição, mas como elementos estáticos, espaços que se delega também a relação com ela através dos brinquedos e materiais" (BALLO, 1991, p. 52). Esse alerta me parece importante para diferenciar o que é descentralizar do adulto de transferir ao espaço o papel do adulto.

Valendo-se dos estudos de Ballo (1991), que se deram por mais de vinte anos, e da elaboração dos três tipos de organização, podemos considerar que, se por um lado, os dois primeiros centralizam no adulto toda a relação educativa, o terceiro é uma alternativa para descentralizar, o que não significa substituir o papel do adulto. O modo como esse terceiro tipo de espaço está organizado permite que o professor, conseguindo gestar o tempo e ter no espaço o apoio para que as crianças criem suas próprias atividades, ocupe um papel menos diretivo, mas que continua presente para sustentar e apoiar as jornadas de aprendizagem das crianças. Transita, assim, entre situações mais próximas e outras mais distantes, mas com o mesmo grau de importância e atenção.

Gariboldi (2011, p. 107) observa que, nesse terceiro tipo, “a contraposição brincartrabalho, atividade informal e formal perde significado, e a atividade associativa e cooperativa das crianças se interpreta em seu potencial de construção social e de transmissão horizontal das 
aprendizagens". Ou seja, essa mudança na organização do espaço cria uma dinâmica menos verticalizada entre adultos e crianças e mais aberta aos processos de co-construção do conhecimento. Assim,

Ao estruturar o espaço em áreas diferenciadas por finalidades se toma consciência de que o espaço escolar se converte em uma variável de formação e de que tal variável deve considerar parte do projeto elevando-a a nível pedagógico, explicitando as relações sistêmicas entre o modelo organizativo e a programação educativa. (GARIBOLDI, 2011, p. 107)

Nesse sentido, retomando o que anteriormente havia sinalizado, o espaço torna-se um outro educador exatamente no ponto em que se transforma em mediador da aprendizagem (HORN, 2017) e mobiliza novas relações de poder entre os adultos e as crianças. Ou seja, o modelo organizativo do espaço pode, em termos éticos, promover a participação das crianças no cotidiano pedagógico, entendendo que participar é dividir o poder.

Por fim, cabe ainda lembrar que o aspecto vinculado à segurança dos espaços é fundamental para que o adulto ocupe um outro papel. Se o modo como um espaço está organizado demanda do adulto a sua participação para evitar acidentes ou atenção para que os objetos e móveis não caiam ou quebrem, isso não permite o trânsito das crianças e a livre exploração dos espaços. Da mesma forma, a higiene dos espaços é fundamental para garantir às crianças seu bem-estar. Estar atento à higiene e à segurança são aspectos-chave para a construção de um ambiente que favoreça a atuação das crianças e o deslocamento do adulto para ocupar outros papéis.

\subsubsection{Espaços circunscritos}

Como foi tratado no tópico anterior, a circunscrição dos espaços em áreas distintas favorece uma outra dinâmica entre as crianças, das crianças com os adultos e de cada criança consigo mesma, redefinindo o papel do professor.

Um dos elementos-chave para pensar a circunscrição dos espaços é apoiar diferentes brincadeiras e atividades das crianças. Por isso, observar as necessidades e características de cada faixa etária, assim como o modo de auto-organização das crianças são fatores fundamentais para a definição de quais e de quantas áreas serão necessárias para ser organizadas, por exemplo, em um grupo de crianças de 2 anos, o modo como elas se autoorganizam é absolutamente distinto do modo que as de 4 anos fazem. Enquanto as mais velhas já brincam em grupos de 3 a 5 crianças, as menores brincam individualmente ou em duplas, ou 
seja, ainda não constituem a noção de grupo. Do mesmo modo, as crianças de 2 anos têm um fascínio por subir e descer desníveis, além de possuírem um grande prazer em se esconder em pequenos espaços. Enquanto que as crianças de 4 anos gostam de construir cenários e enredos mais complexos para suas brincadeiras, experimentar papéis sociais a partir de jogos simbólicos e a desenhar, recortar, colar e brincar com papéis (deixar marcas).

Esses são alguns exemplos que, longe de tentar definir características gerais e abstratas para cada faixa etária, são, na verdade, algumas características que temos observado no interior das escolas do OBECI para conseguir estruturar a organização dos espaços de acordo com cada grupo etário. O fato é que a estruturação das áreas circunscritas precisa ser organizada tendo em vista a dinâmica do grupo de crianças que habita aquele espaço e, longe de ser apenas espaço recreativo, precisa se converter em um contexto que acolhe as subjetividades das crianças e cria um sentido de pertencimento.

$\mathrm{O}$ arquiteto coreano Yi-Fu Tuan, em sua obra Topofilia: um estudo da percepção, atitudes e valores do meio ambiente ${ }^{111}$, define o conceito de topofilia como sendo "todos os laços afetivos dos seres humanos com o meio ambiente material” (TUAN, 1980, p. 107). Com isso, o arquiteto dá um nome para uma amplitude de sentimentos e emoções que os ambientes produzem. Tuan (1980) associa ainda o valor emocional e o prazer que o meio ambiente desperta, conferindo um novo status, o de lugar. Mais tarde, o mesmo autor tem publicado no Brasil a obra Espaço e lugar: a perspectiva da experiência em que aprofunda essa diferenciação entre esses dois conceitos, mostrando que, embora possa parecer se tratar da mesma coisa, o significado do lugar está diretamente vinculado à emoção a que nos relacionamos com um determinado espaço, encontrando e ou transformando-o em um lugar (TUAN, 1983).

Nos estudos desse arquiteto, sua análise direciona para o valor perceptivo que há entre a relação dos sujeitos com o meio ambiente e mostra que, apesar de todos dispormos dos mesmos sentidos, a experiência e a noção de mundo que cada indivíduo tem é diferente em virtude da cultura em que está inserido. Nesse sentido, o arquiteto mostra a estreita relação existente entre os aspectos biológicos e os culturais para perceber e se relacionar com os espaços.

Tomando emprestados os conceitos de Tuan, entende-se que, ao circunscrever o espaço da sala referência em áreas, é preciso considerar a dimensão topofílica, ou seja, é preciso

\footnotetext{
111 A obra Topofilia: um estudo da percepção, atitudes e valores do meio ambiente foi originalmente publicada em inglês no ano de 1974. No Brasil, teve a primeira edição publicada com a revisão técnica e tradução da professora Lívia de Oliveira (UNESP). Em 1983, a obra Espaço e Lugar: a perspectiva da experiência também foi publicada no Brasil e, mais recentemente, Paisagens do medo (2006).
} 
se perguntar de que forma as crianças estabelecem elos afetivos com os espaços que ocupam e que elementos no espaço contribuem para que este se torne lugar.

Quando a criança começa a falar, sente a necessidade de nomear e ordenar o que está a sua volta. Interessar-se pelo meio ambiente físico e conhecê-lo faz parte de sua tarefa de organizar suas vivências. Assim, conforme vai crescendo, começa a estabelecer laços com objetos e lugares (TUAN, 1983). Um exemplo de organização do espaço é a sala das professoras Karin e Sissa da faixa etária de $2 \operatorname{anos}^{112}$. No mapa elaborado pela coordenadora pedagógica, são sinalizados quantos espaços e quais espaços as professoras organizaram. Na comunicação que foi apresentada no início desta seção, podem ser percebidos os diferentes usos das crianças em relação às áreas e como elas vão transformando os espaços em lugares habitados pela infância.

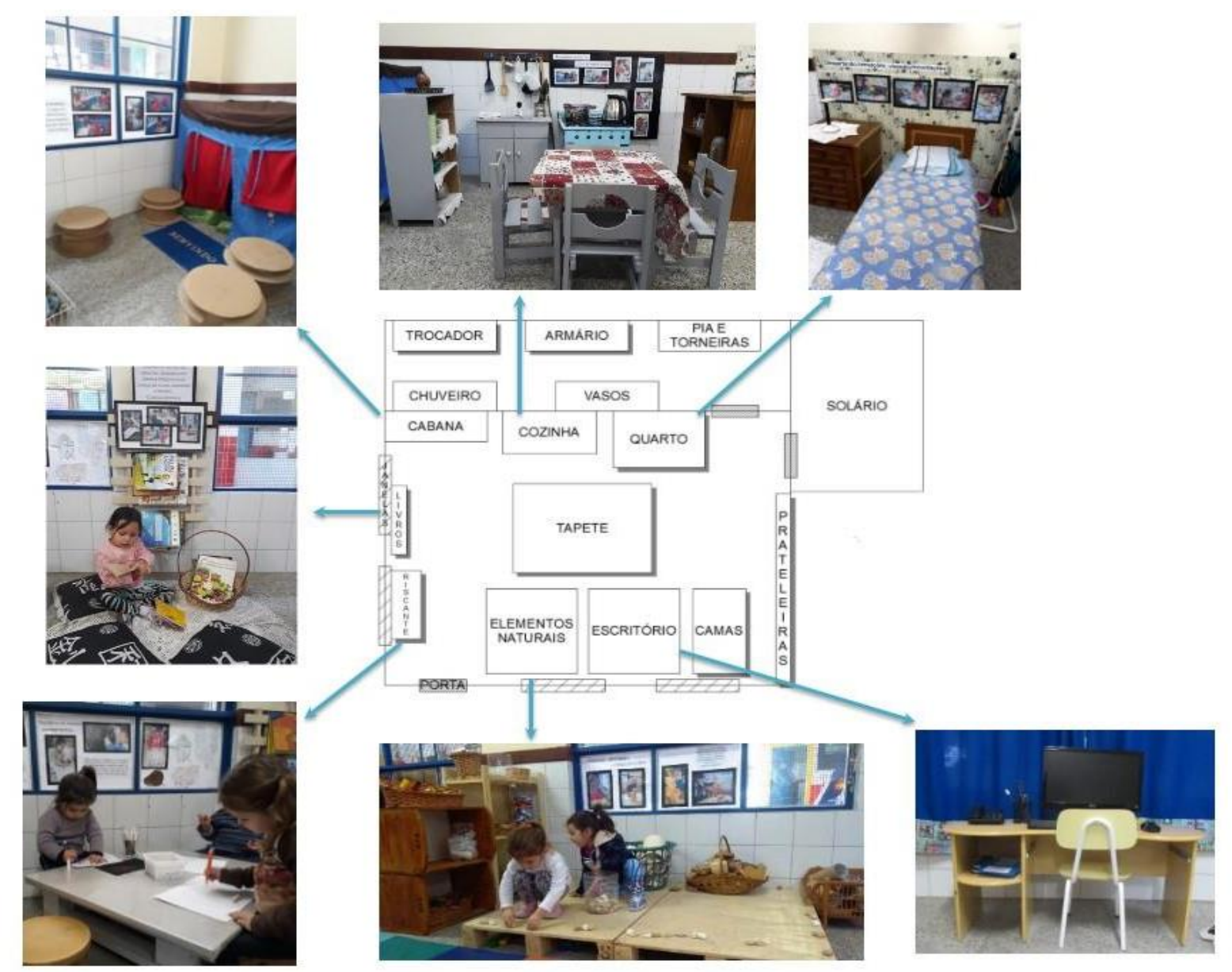

${ }^{112}$ A sala das professoras é reorganizada diariamente para o horário do sono, isso explica porque a área central é mais livre. 
Observar, portanto, as crianças para construir as áreas circunscritas é elemento-chave. Não se trata apenas de dividir o espaço em pequenos ambientes, deslocando armários da parede, mas de responder às necessidades e interessas das crianças de tal modo que se criem opções diversas para as crianças brincarem e investigarem seu entorno.

Um outro elemento importante para pensar a circunscrição do espaço é o conceito de ambiente psicológico que Gariboldi (2011) toma emprestado de Kurt Lewin. Segundo Gariboldi (2011, p. 100), “o comportamento humano está em função, tanto das características do indivíduo como do ambiente. [...] a influência do ambiente é decisiva não apenas por suas características objetivas, mas também pelo como se representa na mente da pessoa". Seguindo esse raciocínio, a circunscrição do espaço em pequenas áreas também deve considerar a dimensão daquilo que é gerenciável pelas crianças, o que oferece a elas um “[...] espaço de vida do sujeito" (LEWIN, 1951 apud GARIBOLDI, 2011, p. 100). Uma grande sala sem limites compatíveis com o tamanho das crianças é absolutamente perturbador, pois não oferece a possibilidade das crianças definirem e estruturarem os modos como o seu entorno mais próximo pode e deve funcionar. Por outro lado, quando há limites claros, a criança consegue estabelecer normas de funcionamento, decidir sobre quem pode fazer parte e quais os códigos autorizados dentro daquele lugar.

Quando aprendemos a observar as crianças, notamos que sempre que elas se encontram em uma sala que não tem circunscrições, é dada a oportunidade delas inferirem no espaço, muito possivelmente elas criem - por meio de almofadas ou cadeiras - limites para sua área de brincadeira, ou escolham um lugar pequeno - como embaixo da mesa do professor para brincar. Isso não é um simples detalhe, mas uma necessidade auto reguladora da criança. Ou seja, o espaço de vida do sujeito se estrutura a partir dos fatores físicos e sociais em que "as iniciativas lúdicas, as condutas sociais e o grau de atenção da criança influenciam em seus processos de aprendizagem" (GARIBOLDI, 2011, p. 101). Um exemplar do que estou me referindo aqui é a mini-história com a jornada de Isis e Milena na comunicação apresentada inicialmente, pois mostra o valor das áreas circunscritas e o modo como as meninas vão gerenciando a participação de outras crianças, como transitam entre as áreas e a forma como criam enredos lúdicos.

A circunscrição do espaço também precisa ser analisada a partir da ideia de continuidade. Na medida em que as crianças reconhecem as possibilidades que os espaços circunscritos oferecem, podem antecipar as atividades que querem desenvolver em cada espaço e desfrutar do prazer do já sabido. Por isso, ter os materiais adequados (blocos de madeira na 
área de construção; canetas hidrocor, tintas, pincéis, argila e papéis na área do ateliê, por exemplo) disponíveis para as crianças em cada área circunscrita, é também permitir que elas possam tomar iniciativas sobre o que, como, quanto e quando desejam fazer algo, concentrandose no seu processo e nas interações que dali emergem. Quando o espaço não é uma constante transformação e responde a uma certa continuidade, associada a sua satisfatória organização, 'fala-se menos de ordem e antes se propicia um cotidiano ordenado em que a criança possa ser autônoma e cooperativa" (OLIVEIRA-FORMOSINHO, ANDRADE, 2011, p. 12).

No entanto, não pode ser confundido continuidade com paralisia. A organização dos espaços precisa ser flexível o suficiente para responder às necessidades das crianças que, por sua vez, possivelmente se transformem ao longo do ano, ou seja, "segue o metabolismo das transformações em relação ao uso e à função das coisas” (BRANZI, 2013, p. 134). Em uma turma de berçário, por exemplo, os bebês começam o ano sem engatinhar e muitos terminam caminhando. Automaticamente, o modo como o espaço deve estar organizado precisa responder a essas transformações das crianças. Do mesmo modo, em períodos mais quentes, áreas com água são mais adequadas do que nos períodos mais frios, ou, ao contrário, nos períodos mais frios, ter pequenos ninhos com almofadas que aquecem são mais interessantes que no verão.

Quando é organizado o espaço em áreas circunscritas, além de gerar mais espaços (ou lugares) dentro de um único espaço, também é uma forma de criar "um espaço para cada coisa e um espaço para todos" (ÒDENA, 1995, p. 34). Como o tamanho dos espaços cria um microclima propício para as relações das crianças, a circunscrição dos espaços acaba se transformando em "um sistema difuso de incubadoras no qual novos vínculos podem ser ativados e criados dentro das redes de relações” (MALAGUZZI, 2001, p. 59).

\subsubsection{A identidade do espaço comunicada}

Um outro aspecto que podemos aprender da experiência de Loris Malaguzzi com as escolas de Reggio Emilia é a reivindicação de uma escola que comunica, que narra a sua história e a história das crianças.

Os espaços da escola precisam narrar e dar visibilidade aos processos de investigação das crianças para tornar visível o modo como elas aprendem. Bruner (1997a) refere-se a esse tipo de narrativa, chamando atenção para dois cenários: o primeiro, que trata da gramática do acontecimento, e o segundo, que fala das emoções do acontecimento. A gramática do acontecimento seria os elementos presentes na ação propriamente dita: a intenção ou objetivo, 
a situação, a disponibilidade. O outro cenário, as emoções dos acontecimentos, diz respeito ao que emergem das experiências documentadas. Trata-se da possibilidade de dar visibilidade àquilo que é invisível: é o dito e o não dito, o que se sabe e o que não se sabe, o que se pensa e o que não se pensa sobre os acontecimentos.

Nós precisamos que alguém nos narre a vida. Somos constituídos por essas narrativas que nos são feitas ao longo de nossa existência. Barcena e Mèlich (2000, p. 113) irão dizer que, "ao narrar para o outro, a história de vida de um pode adquirir sentido para a existência tanto do narrador como do personagem da narração". Ao narrar para a criança no espaço que ela habita, cria-se uma identidade emocional em relação ao ambiente, além dela ir aprendendo como aprende, ou seja, de ver restituídos seus processos como uma possibilidade de metacognição sobre sua própria aprendizagem, como pode ser visto na comunicação que foi apresentada inicialmente quando essa se refere ao senso de pertencimento ou quando mostra o papel do professor em observar, registrar e comunicar os processos das crianças.

Quando os espaços comunicam, narrando as aprendizagens das crianças, eles "revelam a presença das crianças mesmo quando elas estão ausentes" (CEPPI, ZINI, 2013, p. 33). Dão identidade e valor pedagógico aos vestígios da infância, geram uma espécie de "pele psíquica, uma segunda pele provedora de energia constituída de textos, imagens, objetos e cores" (CEPPI, ZINI, 2013, p. 33).

Comunicar a identidade do espaço também pode servir para recuperar as memórias dos acontecimentos de cada área circunscrita, ou mesmo das identidades de determinados lugares, como refeitório, banheiros e entradas das escolas. Compor esses espaços com imagens ou outros elementos da cultura reforça um microclima e dá importância para aprendizagens banalizadas. As imagens a seguir, por exemplo, foram captadas pela diretora Ivana e pela coordenadora Vanessa ao longo da investigação que o grupo gestor fez sobre as microtransições para que o banheiro da escola fosse ambientado com as marcas identitárias daquele lugar.
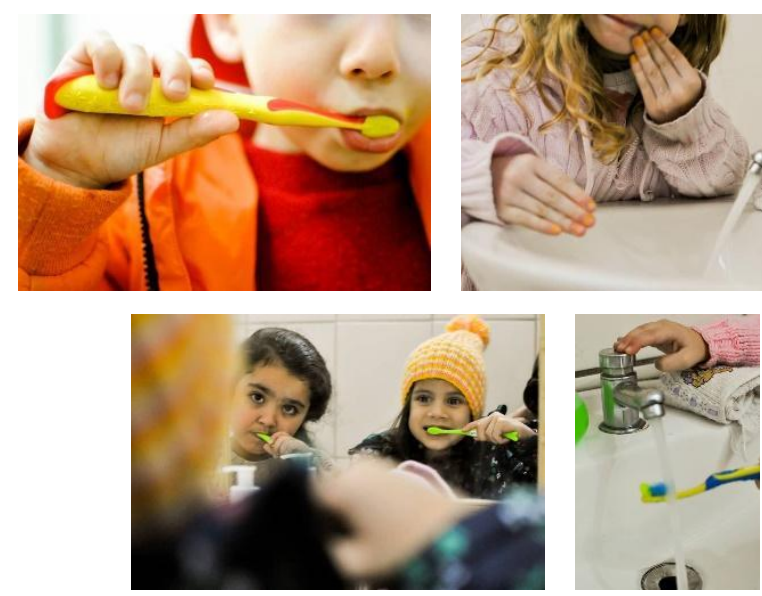

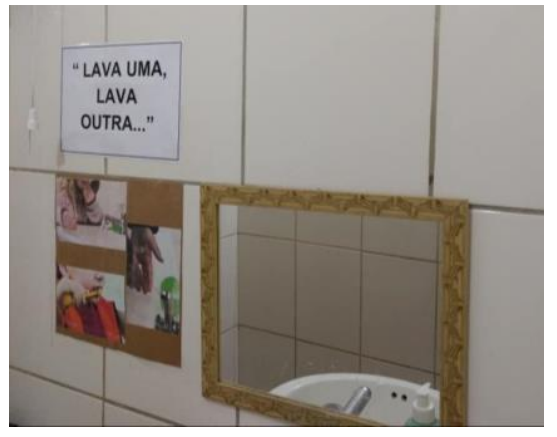


Também o espaço pode comunicar o patrimônio cultural, artístico, científico, ambiental que a nossa sociedade vem construindo ao longo dos anos, criando laços de conexão entre a criança e o mundo de que ela faz parte, como nesta imagem da sala da professora Raquel que organizou a sala com imagens dos insetos, tema de investigação das crianças. Essa é uma característica da comunicação do espaço, mas também da habitabilidade e da significatividade. Isso significa uma ruptura aos desenhos estereotipados e à ideia de "decoração" com personagens de desenhos animados. Ao contrário, assume-se que as escolhas que são feitas para compor a identidade do espaço são expressões das nossas crenças sobre as crianças, sobre

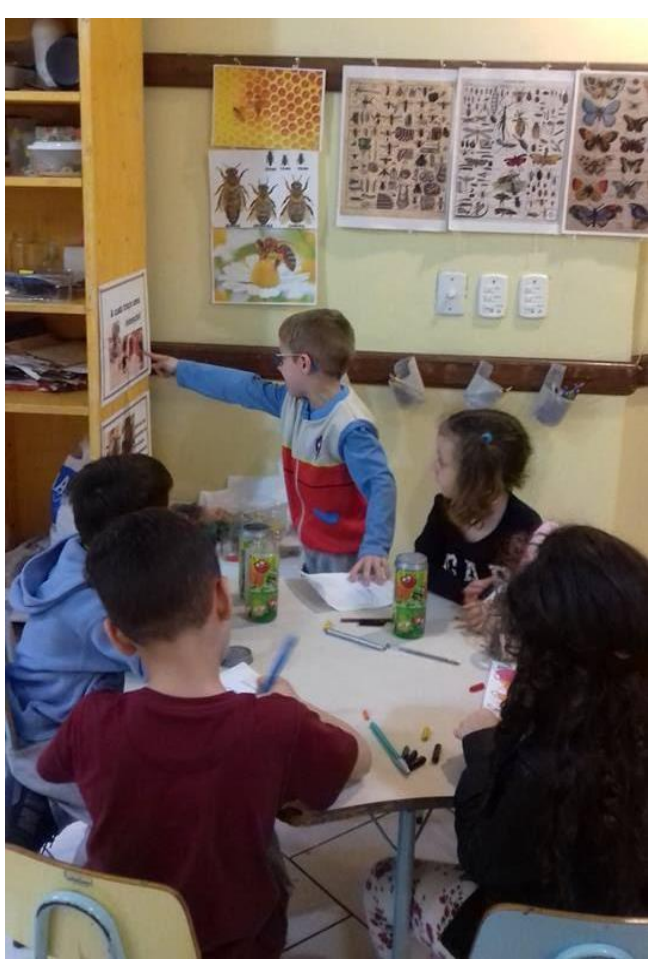
a docência e sobre a Educação Infantil.

\subsection{Os materiais}

O pensamento aristotélico questionava se seria primazia do tato o único sentido a perceber as coisas ou se seria a soma dos outros sentidos (CEPPI; ZINI, 2013; PALASMAA, 2012). Atualmente, campos como os da Antropologia, da Medicina, da Psicologia e da Arquitetura conferem ao toque um papel importante para o desenvolvimento humano, e, com isso, "sabemos que a pele age como um mediador entre nós e o mundo, de modo que o sentido do tato não pode ser visto como um artifício específico, mas como algo difuso e conectado fortemente com as experiências do indivíduo" (CEPPI; ZINI, 2013, p. 80).

O toque é um gesto cultural para conhecer a cultura, é arte e parte da história da humanidade. As mãos, como já indicado na introdução desta tese, tem um "papel embrionário na evolução da inteligência, da linguagem e do pensamento simbólico humano" (PALASMAA, 2012, p. 34). Pelo toque, as crianças conhecem o mundo como exploradores que escovam ossos e descobrem a cultura pela forma, temperatura, textura, durabilidade dos materiais. Nessa relação das mãos e do corpo inteiro com as coisas, as crianças corporeificam os conceitos e experenciam antes de nomeá-los. Percebem, anteriormente à linguagem oral, as nuances dos materiais e reconhecem o modo de interagir com eles, ou seja, se precisam ser delicadas, 
cuidadosas, vorazes ao tocarem algo. Já se sabe, a partir dos estudos da neurobiologia e da neurociência, o "coprotagonismo dos sentidos na construção do conhecimento e da memória individual e coletiva" (CEPPI, ZINI, 2013, p. 24).

Nesse sentido é que destaco o conceito de multissensorialidade (CEPPI; ZINI, 2013), ou seja, a abertura do corpo em sua inteireza para a experiência sensorial no e com o mundo evoca à sinestesia o seu papel na cognição, na criação e até mesmo na formação dos processos identitários. Segundo Ceppi e Zini (2013, p. 24), “o estado sinestésico é a condição de vida típica da plasticidade sensorial das crianças pequenas".

No entanto, como comentam Ceppi e Zini (2013), com a transformação do panorama tátil devido à industrialização no pós-guerra, a sensibilidade do tato muda radicalmente devido ao empobrecimento dos contrastes entre os materiais: a madeira é alisada e passa por um longo processo de industrialização até chegar ao receptor, a ascensão do plástico domina a paisagem tátil das pessoas. Empobrece a variedade de materiais e empobrece a nossa capacidade de percebê-los.

Quando se pensa no binômio material e escola, também pode remeter a uma paisagem sensorial bem empobrecida, basta considerar as listas de materiais enviadas às famílias e ver as filas de pais comprando os "materiais escolares" nas papelarias no início de cada ano. Em função disso, a reflexão sobre os materiais é um tema importante para pensarmos como uma das categorias dos Organizadores da Ação Pedagógica. Mudar a compreensão sobre qual tipo de material deve compor a paisagem de materialidades de uma escola significa interpelar a compreensão que temos da construção do conhecimento pelas crianças e qual o papel que o contexto tem nisso.

Por isso é que, conectado ao conceito de multissensorialidade, deve estar o de polimaterialidade, ou seja, é preciso que as crianças tenham acesso a uma amplitude de materialidades para amplificar e complexificar suas percepções e compreensões do seu entorno. No entanto, a polimaterialidade não pode ser entendida como a construção de um tapete ou painel dos sentidos para que as crianças caminhem artificialmente
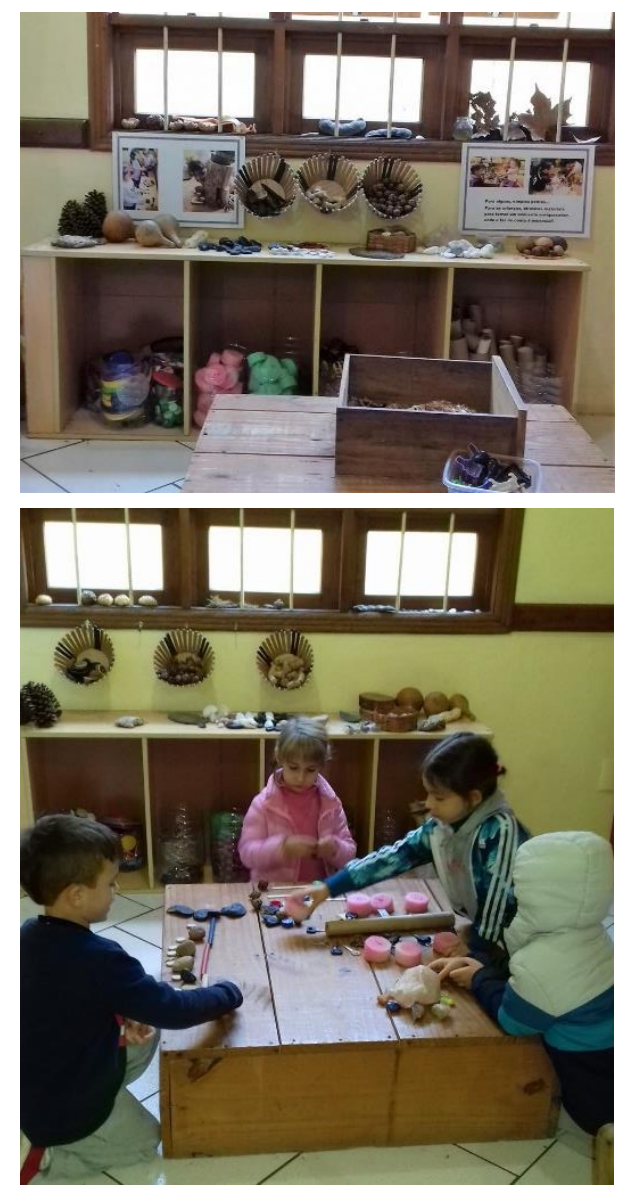
em um dado momento do dia dedicado a isso; ao contrário, a polimaterialidade deve estar presente no entorno dos meninos e das meninas, na vida cotidiana, como nas imagens da sala da professora Raquel, na Escola Espaço Girassol, em que se percebe que a ampla variedade de materiais são fontes de exploração e de inventividade das crianças, que nesta cena testam suas hipóteses sobre as casas dos insetos. Nesse sentido, há um forte convite para que seja revista a paisagem visual de cada sala referência e de cada escola e que transformem aquele cenário de cores primárias e predominantemente plástico por uma outra estética, que dá abertura a uma paleta de cores, de texturas, de odores e de formas muito mais ampliada e diversificada.

Tonucci113 (2008, p. 11) define “o termo 'materiais' no sentido mais estrito e elementar possível, indicando só aquele que em si não é nada, que não tem absolutamente nem forma e nem significado próprio e por isso espera que quem o utilize dê forma e significado". A questão é que esse autor associa os materiais com a possibilidade de expressão e comunicação da criança com o mundo, tentando diferenciar assim da ideia de materiais como "[...] passatempos estúpidos [...]" (TONUCCI, 2008, p. 14). Ou seja, os materiais são pontes entre o eu interno da criança e o eu externo, são possibilidades de materializar (forma e estrutura) conceitos, de interpelar a cultura. Não querendo estabelecer paralelos entre as crianças e os artistas, mas, tal como uma obra que se concretiza pela experiência
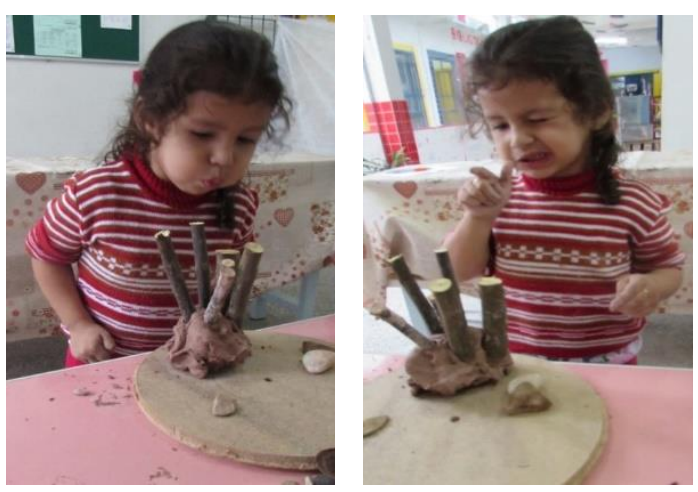
do artista com os materiais, as crianças também necessitam de uma ampla e rica materialidade que permita, mesmo em um sentido inicialmente exploratório e mais tarde projetual, concretizar suas ideias. Gosto dessa cena da EMEI Joaninha em que Isabely decide fazer um bolo de aniversário com material não estruturado, tema que estão investigando profundamente com o grande grupo.

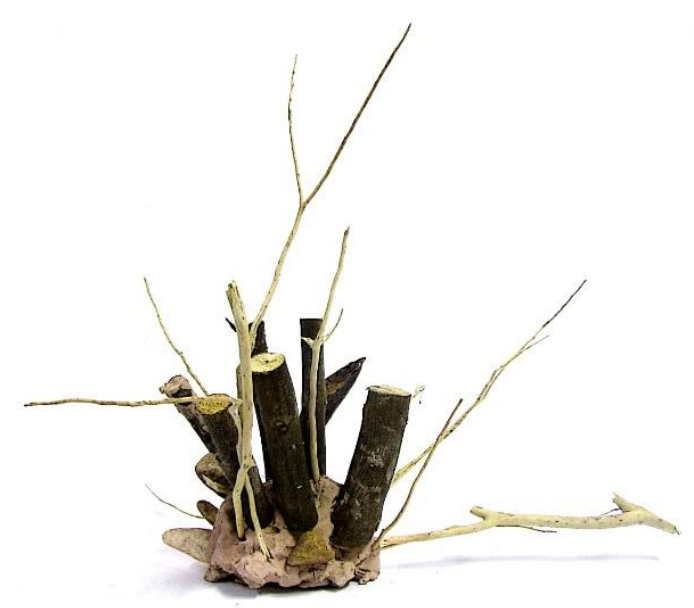

113 Tonucci se interessou por escrever sobre os materiais, tema não muito usual em suas obras, devido ao seu encantamento pessoal com as materialidades que lhe remetiam a sua própria infância e ao sentido expressivo que eles ocuparam na sua vida. Esse autor é um dos poucos da pedagogia que encontrei tratando sobre o tema. Os demais autores com os quais trabalho, neste capítulo, são oriundos dos campos da arquitetura e das artes visuais. 
Nesse sentido, acredito que o tema dos materiais, desde a perspectiva que Tonucci apresenta, é de grande relevância no atual cenário em que muitas crianças vivem. $\mathrm{O}$ forte apelo da virtualidade cada vez mais precoce distancia a criança da concretude do material, ou seja, daquilo que faz com que ela descubra as propriedades da materialidade e, consequentemente, corporeifique os conceitos decorrentes da sua experiência. Também essa virtualidade não abre espaço para as crianças saírem de si mesmas, ou seja, não se presta tal qual os materiais, a ser uma ponte entre o interior e o exterior dos meninos e das meninas. É por isso que muitos estudos hoje têm apontado ressalvas na relação coexistente entre o desenvolvimento da linguagem e o tempo de exposição a computadores, tablet, celular.

Vila e Cardo (2005, p. 47) igualmente observam que "o que habitualmente se entende por brinquedo, que oferecem uma grande gama de cores e outras qualidades, nos parecem que provocam ações limitadas; são atrativos à primeira vista, mas pobres em brincadeira e em criatividade para as crianças". Não se trata de demonizar os brinquedos, mas de reclamar a atenção que se deve dar a outros tipos de materiais, que usualmente não se concebem como um material escolar, e, assim, transformar as paisagens sensoriais das escolas.

\subsubsection{Os tipos de materiais}

Para começar a tratar sobre os tipos de materiais que podem compor o cenário educativo, retomo a definição dada por Tonucci (2008, p. 11):

\footnotetext{
Se por materiais queremos indicar tudo aquilo com o que se faz algo, que serve para produzir, para inventar, para construir, deveríamos falar de tudo o que nos rodeia, desde a água à terra, das pedras aos animais, do corpo às palavras... inclusive das plantas e a nuvens [...]. Também as roupas, brinquedos e livros... Porque tudo isso pode ser material para construir nas mãos de uma criança que vive em um ambiente onde inventar é lícito e desejável.
}

A ideia central do que estou tratando como material está diretamente ligada à ação da criança com ele. Não é apenas o material em si que me interessa, mas a possibilidade de negociação entre a ação da criança e o material que dá o valor do ponto de vista educativo. $\mathrm{Na}$ exploração das crianças em relação ao seu entorno físico e social, elas tocam, experimentam, colocam, tiram, apertam, jogam, deixam cair, esfregam, batem, empilham, montam, desmontam, equilibram, desequilibram, repetem, reagem ao que sentem, expressam... e tantas outras ações que poderiam ir ampliando a lista de tudo aquilo que fazem para ir compreendendo os fenômenos a sua volta. E assim, "esse descobrimento dos diferentes fatores que compõem 
nosso entorno faz do gesto dos meninos ou das meninas uma atividade de espírito científico, no qual, através da curiosidade, conhecem nosso mundo" (VILA, CARDO, 2005, p. 17).

Nesse sentido, quanto mais ampliada for nossa compreensão sobre as propriedades dos materiais, mais podemos oferecer para as crianças em termos de possibilidades e acesso. Goldschmied e Jackson (2006) sugerem uma lista ampliada de materiais que podem ser utilizados para o cesto de tesouros e que servem de grande inspiração, tais como materiais naturais (castanhas, nozes, conchas, pedras etc), objetos feitos de materiais naturais (alças de sacolas, bolas de lã, cestos etc), objetos de madeira (colher, cubos, castanholas etc), objetos de metal (chaves, correntes, forminhas etc), objetos de couro, têxteis, borracha e pele (bola de borracha, bolsa de couro etc) e papel e papelão (caixas, cilindros etc).

Ceppi e Zini (2013, p. 82-83) se referem a mapas polares, destacando os adjetivos que ajudam a perceber as percepções sinestésicas dos materiais. A partir desse mapa, também se consegue visualizar uma lista infindável de possibilidades de materiais a partir das propriedades destes.

Figura 6 - Mapas polares

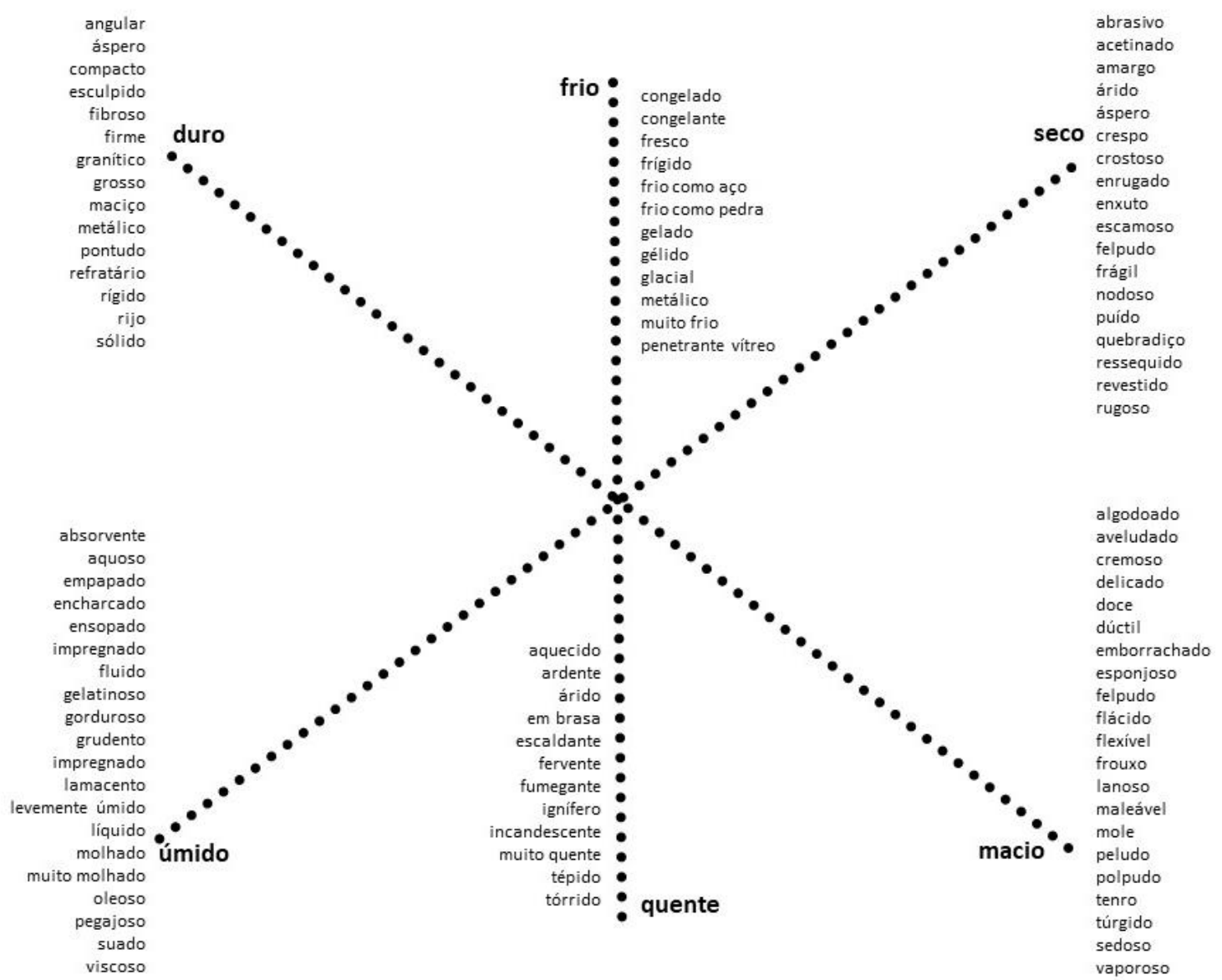

Fonte: CEPPI, ZINI, 2013 
No OBECI, nós temos trabalhado com a ideia dos quadrantes de materialidades, que tratam da intersecção entre material natural e material artificial com os materiais estruturados (brinquedos com certa estrutura narrativa, tais como bonecas, carrinhos, ursos de pelúcia etc) e materiais não estruturados (materiais que usualmente não são considerados como objetos para as crianças brincarem e que não tenham uma estrutura narrativa, tais como rolos, blocos de madeira, cones, tampas etc). Por exemplo, há possibilidades de materiais não estruturados naturais (pedras, conchas, tocos de madeira, sementes etc) e artificiais (mangueiras, correntes, chaves, tampas de plástico, rolos de cabelo etc).

Figura 7: Quadrante de materiais

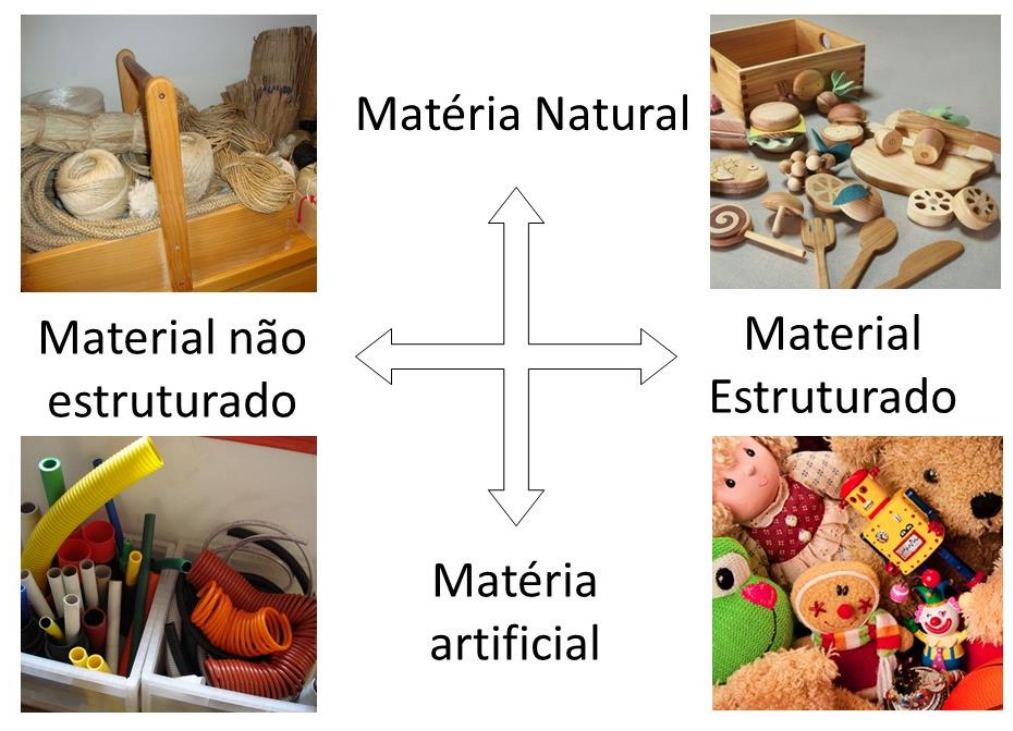

Fonte: Elaborada pelo autor

Aqui cabe destacar que a ideia do que é material natural e material artificial não tem limites tão bem definidos. Como lembram Ceppi e Zini (2013, p. 84), o debate sobre o quão natural é um material está diretamente ligado com as noções do pensamento moderno e pósmoderno, "a opinião moderna considerou por muito tempo que a redução fosse um fenômeno positivo, enquanto a cultura pós-moderna de hoje valoriza mais [...] a coexistência de diferentes materiais com lógicas contrastantes, em sistemas descontínuos”.

Para Ceppi e Zini (2013, p. 84), “o conceito de 'natural' está sujeito à verificação, e a atenção mudou o foco para o grau de manipulação de um material, o quanto ele foi processado e se fornece alguma informação sobre suas características 'genéticas' ou se elas foram transformadas". Para esses autores, a definição do que é natural parece estar localizada no 
quanto se consegue perceber e acessar a materialidade em sua unidade original, ou seja, a centralidade é a matéria em si.

Já para Palasmaa (2011, p. 30, grifo do autor), “os materiais naturais expressam sua idade e história, além de nos contar suas origens e seu histórico de uso pelos humanos. Toda a matéria existe em um continuиm temporal". Diferentemente da visão anterior, a qualidade dada ao material como natural está na sua temporalidade, ou seja, na sua história. O arquiteto finlandês se refere a esse aspecto justamente contrapondo ao material industrializado, que não permite aos nossos olhos perceber sua idade, e alerta: "esse temor dos traços do desgaste e da idade se relaciona com nosso medo da morte" (PALASMAA, 2011, p. 32).

Meu interesse não é tanto em colocar limites tão definidos sobre o que é natural ou artificial (industrializado), mas de compreender que a escolha dos materiais entra em sintonia com fatores:

- Ambientais - temos que nos sensibilizar a produzir menos lixo e saber aproveitar os recursos que temos em abundância no nosso entorno (terra, areia, pedras) sem devastá-los. Essa conexão das crianças com os materiais do seu entorno religa (resgatando a etimologia da palavra religião) os meninos e as meninas ao mundo natural, creditando a eles "a responsabilidade de estabelecer novos modos de estar e relacionar-se com o nosso entorno" (FOCHI, 2015d, p. 6);

- Culturais - há uma história em cada material. Na cultura gaúcha, por exemplo, uma cuia de chimarrão tem um enredo cultural, tal como pode ser visto na comunicação apresentada quando Isis e Milena sentam para uma roda de chimarrão. Tonucci (2008, p. 15) comenta que alguns materiais “[...] estão unidos à milenar história artística e artesanal do homem, desde as grandes obras de arte de todas as épocas até as pequenas e preciosas obras artesanais daqueles ateliês que hoje estão desaparecendo". Os materiais criam enredos narrativos e simbólicos para as crianças; além disso, a relação estabelecida por elas com os materiais, dominando seus usos, é um modo de participar e pertencer a uma determinada cultura;

- Econômicos - é preciso encontrar alternativas viáveis para garantir que os contextos educativos tenham uma variedade e riqueza de materiais e que não seja custoso ou insustentável do ponto de vista financeiro. Dialogar com empresas locais que tenham determinados tipos de materiais de descarte, ou convidar as 
famílias para prestarem atenção aos materiais que descartam em suas casas (potes, caixas, chaves, correntes, mangueiras etc) pode ser uma alternativa razoável.

- Potencial criativo - a definição de quais materiais devem ser ofertados às crianças deve ser balizada pelo seu potencial criativo. O arquiteto Simon Nicholson (1972, p. 5), fundador do conceito da teoria das partes soltas (loose parts), acredita que "a criatividade é jogar com os componentes e variáveis do mundo para experimentar e descobrir coisas novas e formar novos conceitos”. Para ele, quanto maior as possibilidades de interação das crianças com uma variedade de materiais, maior capacidade de experimentar e criar novas respostas aos problemas do seu entorno ela terá.

Por isso, a escolha que temos feito é de ampliar os tipos de materiais a partir de sua qualidade (tecido, madeira, plástico, vidro), durabilidade (resistente, delicado, efêmero) e fisicalidade (textura, temperatura, cor, cheiro, sabor).

\subsubsection{Alguns critérios para escolher os materiais}

A escolha dos materiais está diretamente associada às nossas crenças sobre o tipo de escola, à imagem de criança e à função do professor. Tonucci (2008) estabelece uma relação entre os materiais escolhidos e os três tipos de escola ${ }^{14}$ : das liçõezinhas, da livre expressão e da que investiga (TONUCCI, 1977). Segundo o autor, na escola das liçõezinhas, "os materiais são os instrumentos para comentar a lição da professora com desenhos e trabalhinhos. E do mesmo modo que a liçãozinha é autoritária, o uso dos materiais é passivo" (TONUCCI, 2008, p. 13). A passividade dos materiais se assemelha à compreensão que nessa escola se tem da criança e do seu processo de conhecimento.

$\mathrm{Na}$ escola da livre expressão, os materiais deixam de ser passivos e ganham a centralidade. O objetivo é o próprio material, no entanto, como adverte Tonucci (2008, p. 14), "a atividade por si mesma, a criança que pinta por pintar, modela por modelar, provoca a repetição de estereótipos". Como não há nenhuma ponte que conecte o desejo da criança com o material, após ela esgotar as possibilidades encontradas por ela própria, parte para um outro material.

\footnotetext{
114 Já tratei a respeito das três escolas que Tonucci nomeia no capítulo sobre o OBECI - sugiro colocar o número do capítulo.
} 
Já na escola que investiga, "os materiais não são nem passatempo estúpidos, nem objetivos de atividades, mas sim [...] os meios para expressar-se e comunicar-se" (TONUCCI, 2008, p. 14). Nesse modelo de escola, os materiais servem à criança para inventar, criar, experimentar, investigar e concretizar suas ideias, são instrumentos para elaborar e responder aos problemas que a criança, um grupo de criança ou o próprio adulto reconhecem. Quando as crianças começam a se fazer perguntas sobre a sombra, por exemplo, a professora oferece materiais que ajudam as crianças a compreender melhor e mais profundamente sobre suas perguntas de investigação, como nas imagens das professoras Samantha e Tatiana da escola Mimo de Gente.

A partir dessas ideias, no OBECI, temos feito o exercício de problematizar a respeito dos materiais considerando que a criança possa:

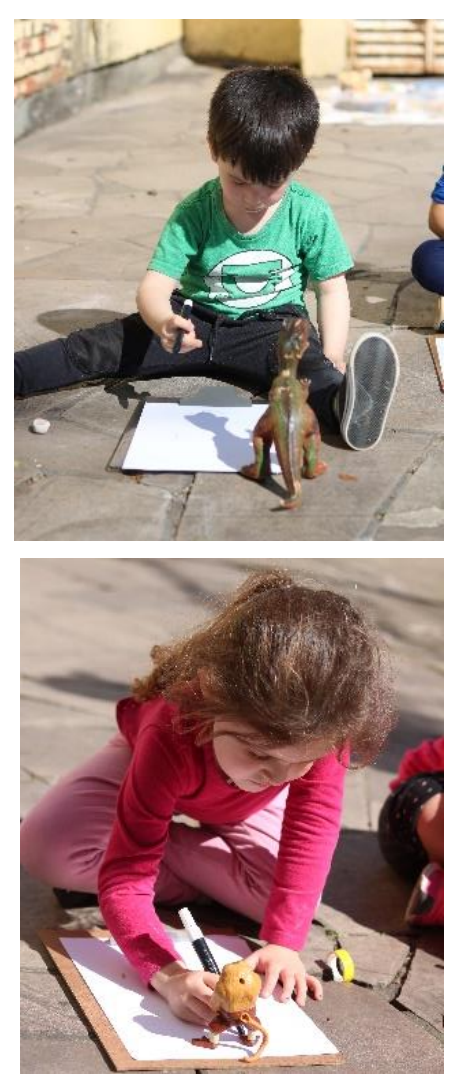

a) Escolher os materiais que lhe interessem;

b) Agir sem muita intervenção adulta; portanto, deve ser seguro o suficiente para que a criança utilize;

c) Explorar por conta própria;

d) Criar enredos narrativos e visuais;

e) Combinar diferentes materiais para ampliar e complexificar suas brincadeiras;

f) Ter tempo para brincar com os materiais;

g) Acessar os materiais sem depender do adulto;

h) Ter acesso à diversidade de tipos;

i) Ter acesso à quantidade satisfatória;

j) Ser apoiada na exploração dos materiais quando estes exigem o conhecimento de determinadas técnicas;

k) Descobrir a resposta natural dos materiais (se deixar cair um vidro, por exemplo, quebrará);

1) Criar suas próprias coleções de materiais.

Em troca, para atender a isso, é preciso que o professor fique atento para alguns fatores essenciais: 
- Segurança - é uma premissa básica, o professor precisa estar suficientemente seguro na escolha dos materiais ofertados. Para as crianças bem pequenas, por exemplo, materiais como sementes ou com pontas precisam ser avaliados - ou evitados. Além disso, certos tipos de materiais podem ser utilizados, mas terão uma durabilidade menor, implicando sua substituição ou retirada. A higiene dos materiais também é um fator de segurança, por isso vale dizer que determinados materiais podem ter uma demanda diferente de higienização do que outros, de qualquer forma, é preciso prever a higienização com uma certa regularidade. $\mathrm{O}$ essencial é estar suficientemente tranquilo em relação aos materiais para possibilitar que o adulto não fique mediando a interação das crianças;

- Diversidade - é importante compreender que a qualidade, fisicalidade e durabilidade dos materiais são fontes de informações para as crianças; por isso, na medida em que se amplia a paisagem cromática, textual, de odores, de sabores, de peso, de temperatura, um universo de possibilidade, de linguagens, de conceitos, de símbolos, de sensações se amplia para as crianças. Quanto mais rica for a diversidade de materiais ofertados para as crianças, mais possibilidades de investigação elas terão.

- Quantidade - é fundamental oferecer muito do mesmo, especialmente quando se fala de materiais não estruturados. As crianças são colecionadoras e uma quantidade satisfatória amplia as possibilidades de "fabricação" pelas crianças, ou seja, da combinação dos materiais as crianças fabricam novas estruturas a partir da união, separação, experimentação (SINCLAIR; STAMBAK 2012). Além disso, uma quantidade satisfatória de materiais diminui os conflitos, já que as crianças não ficam ansiosas por tomar posse do material já que este é escasso.

- Negociabilidade - é um elemento importante saber eleger materiais que entre eles geram novas combinações e possibilidades. Ao contrário das práticas correntes, os materiais individualizados não são oferecidos com a premissa de esgotar as suas possibilidades (um dia caixas, outro dia tecidos, outro dia cordas). Quando o professor reflete sobre as qualidades dos materiais e oferece às crianças certas combinações de materiais, permite que os meninos e meninas negociem a relação entre os materiais e os explorem potencialmente, assim, oferecendo em um mesmo dia cordas, caixas, tecidos, prendedores de roupas, muitas coisas podem 
surgir. As professoras Viviane e Julia, fomentando o interesse das crianças da faixa etária de 2 anos da EMEI João de Barro sobre as construções, ofereceram blocos translúcidos com um foco de luz, que ao mesmo tempo que possibilitavam a construção real com os materiais, virtualmente se formava a sombra da construção com diferentes texturas para sombra produzida, já que o material era feito de madeira e acrílico colorido. Essa é uma bela amostra do que pode gerar a negociabilidade dos materiais.

- Acesso - é fundamental pensar no acesso, quando se fala em materiais. Isso significa problematizar a capacidade do adulto em selecionar quais materiais, em qual quantidade e de que forma eles podem ser disponibilizados para as
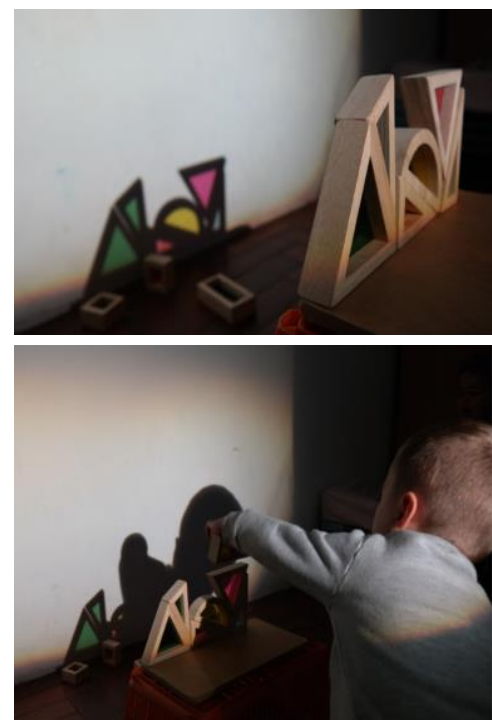
crianças. É importante que, na organização do espaço, como já discutido anteriormente, cada área tenha disponíveis os materiais que a correspondem, por exemplo, blocos, caixas, cones, cds, entre outros materiais, na área de construção; tintas, pincéis, folhas, argila, tripés na área do ateliê. Novamente, a função dos materiais é que a criança possa saber escolher qual responde melhor a sua intenção, ao seu desejo em fazer algo.

- Organização - é feita uma ruptura na necessidade do adulto ordenar quando se organiza um ambiente, como destacam Oliveira-Formosinho e Andrade (2011). O modo como os materiais são armazenados, disponibilizados e a manutenção disso é fator decisivo para que ele mesmo regule o uso por parte das crianças.

Finalmente, vale lembrar que todos os espaços da escola podem se valer dessas reflexões a respeito dos materiais. A relação da criança com seu entorno, em sua inteireza de sentidos e percepções, não tem hora e nem espaço, é da própria estrutura vital da criança conhecer e se relacionar com o mundo. 


\subsection{A organização do tempo}

Se é verdade que existe uma pedagogia no espaço e nas materialidades, também é que existe no tempo educativo. A reflexão sobre a organização do tempo que aqui faço parte do pressuposto de que há uma via dupla que precisa ser conciliada dentro da escola: (i) o tempo institucional, ou seja, o fluir e o ritmo das diversas situações cotidianas que envolve desde os horários de entrada, saída, momentos das refeições até os períodos de trabalho dos funcionários e usos dos espaços, e (ii) o tempo das crianças, que, embora elas já participem de um espaço social fora do ambiente familiar desde muito cedo - portanto, já sendo expostas à coletividade e a todas as estruturas que em cada espaço social existe -, ainda se encontram em processo de elaboração da construção do sentido do tempo que emerge a partir das próprias vivências que compartilham nos diferentes espaços que frequentam. Nigito $(2004 ; 2011)$ observa que, nas ciências sociais, essas duas vias é o que se reconhece pelo conjunto de significados culturais e sociais e a subjetividade individual do tempo.

Nesse sentido, pensar a gestão do tempo dentro das escolas não é uma questão apenas de estruturação objetiva, mas de "[...] um dispositivo de socialização e de aprendizagem [...]" (NIGITO, 2004, p. 45). Isso porque a especificidade das crianças que frequentam a Educação Infantil envolve, ao mesmo tempo, construir sua própria noção interna de tempo e compreender e internalizar a noção social do tempo.

Daí o interesse em compreender a organização do tempo nas escolas, uma vez que se reconhece que a experiência educativa que os meninos e as meninas vivem dentro das instituições influencia o modo pelo qual constroem sua própria identidade e o modo como poderão, não apenas participar dos tempos sociais, mas também interrogá-los ${ }^{115}$. Nessa mesma linha, Nigito (2004, p. 44) destaca que "a aquisição de um sentido de tempo compartilhado por parte da criança pequena e a própria possibilidade de conceituar o tempo são fortemente influenciadas pelo modo como ele é gerido [...] pelos adultos que têm responsabilidade educativa".

Dentro do OBECI, considerando o papel que os adultos e a instituição ocupam na construção da noção do tempo pelas crianças e o modo como a estruturação desse tempo repercute diretamente no respeito e no bem-estar dos meninos e das meninas, temos apostado

\footnotetext{
115 Barbosa $(2006 ; 2013)$ vem discutindo a necessidade de interrogarmos a noção de tempo que as crianças estão vivenciando dentro das creches e pré-escolas, chamando atenção, especialmente, para o fato de que as instituições estão inseridas as crianças precocemente ao tempo do capital. Outros autores, como Staccioli e Ritscher (2005), Ritscher (2011) e Francesch (2009), também reivindicam a lentidão do tempo nas escolas como uma noção de respeito e de contradiscurso a essa sociedade que valoriza demasiadamente a produtividade.
} 
na perspectiva de compreender a organização do tempo partindo da ideia de jornada educativa. São várias as razões que nos ajudam a sustentar essa ideia, começo pela questão etimológica da palavra.

A palavra jornada, etimologicamente falando ${ }^{116}$, está conectada à palavra dia (dies, em Latim). No Latim vulgar, a palavra dia se transformou em diurnus, referindo ao que acontece diariamente, todos os dias. Dessa base, surgiu diurnata, o que se faz em um dia e, logo, no Italiano, giornata e, no Francês, journée, o trabalho ou o trajeto feito num dia. Com o passar dos anos (por volta do século XVI), a palavra jornada, que carregava consigo o sentido de tempo e espaço, perde seu acento no sentido temporal e passa a ser relacionada quase que exclusivamente a distância, ao trajeto.

Curiosamente, a palavra jornaleiro - que originalmente significa "aquele que é pago por dia de trabalho" e atualmente se utiliza apenas para "vendedor de jornais" - se conecta, do ponto de vista etimológico, com a palavra jornada. Em Francês, papier journal significava "escrito diário, texto renovado a cada dia" que, com o tempo, acabou ficando apenas a palavra journal, que, no português, utiliza-se jornal. Daí que nossa metáfora para pensar o tempo é a jornada, pois, além de falar do transcorrer de um dia, envolve também aquilo que é renovado a cada dia, mesmo na estrutura prévia e conhecida que se repete. Todos os dias da semana as crianças vão para escola, tem uma mesma sala de referência com um mesmo grupo de colegas e um mesmo professor (ou mais). Chegam, lancham, brincam, almoçam, descansam, fazem outro lanche, brincam novamente e se despedem para, no próximo dia, repetir todas essas situações novamente. Essa é a linha de continuidade da jornada, que em uma certa medida, faz com que as crianças possam ir reconhecendo a estrutura do seu dia, o que as tranquiliza. No entanto, a renovação dessa repetição também gera uma abertura para que a novidade apareça. O prazer do já sabido possibilita se aventurar em novas descobertas que produzem a descontinuidade, outra linha que trama a jornada educativa. As relações que são travadas entre as crianças, delas com os adultos e com seu entorno, é o elemento primordial para a renovação, no sentido de abertura ao novo. Nigito (2004, p. 44), tratando sobre os elementos da continuidade e descontinuidade do tempo, sugere que este é em um jogo de oscilações que "se traduzem em uma vivência que se articula entre o pólo do familiar, do habitual e do previsível, e o pólo do inédito, do inesperado e do estimulante".

\footnotetext{
${ }^{116}$ Essas informações foram organizadas a partir do site Origem da Palavra, www.origemdapalavra.com, que se ocupa em tratar exclusivamente da discussão sobre a etimologias das palavras.
} 
A predominância de qualquer um dos extremos - só o familiar ou só a novidade parece não ser interessante para as crianças (e também para os adultos). Se todos os dias a jornada educativa é um caos, as crianças não conseguem se dedicar aos processos do que estão vivendo porque precisam compreender o tempo todo a estrutura. Por um outro lado, se é sempre igual, rotineiro, não acolhe a novidade que as crianças carregam consigo ${ }^{117}$.

Um outro fator que nos mobiliza a pensar a gestão do tempo como jornada educativa é a ideia de colocar o acento no giorno (dia) da criança. Muitas vezes, crianças que permanecem em turno integral nas instituições e têm dois professores distintos (e as vezes, com o mesmo professor) vivenciam dois turnos totalmente desconexos, apenas conectados pelo horário do almoço, tendo em vista o modo como o tempo é pensado e organizado ${ }^{118}$. Assim, ao invés de pensar na rotina como elemento decisório para organizar o tempo, a reflexão se direciona em sentido à jornada da criança na escola, ou seja, como uma tentativa de acolher o seu tempo subjetivo em meio às outras temporalidades: das outras crianças, dos adultos, da instituição.

Nesse mesmo sentido, dentro da jornada educativa, estão contemplados os distintos momentos que a compõe: de brincar, de pátio, de refeições, de higiene, de descanso, de estar com o grande grupo escutando uma história, de estar em pequenos grupos envolvidos em uma investigação, de chegar, de partir etc. Todos esses momentos, de igual valor pedagógico, precisam ser refletidos desde o momento em que a criança chega à escola até o momento de ir embora. E, como lembra Ritscher (2011), o que está em jogo é como as crianças o vivem, e não, simplesmente, passar por eles (novamente, como uma corrida de obstáculos).

Na medida em que é compreendido que o acento deve estar na jornada da criança, é legítimo que, em uma turma de berçário (bebês menores de 2 anos), por exemplo, desconstruase a lógica de que todas os bebês devem comer, descansar e ser higienizados ao mesmo tempo em nome da rotina institucional. Para os bebês, esses momentos precisam ser o mais individualizado possível, porque, antes de ser uma oportunidade social (que será mais tarde), é um momento de saciar suas necessidades físicas e uma aprendizagem individual: aprender a comer, aprender a utilizar os apetrechos do momento da comida (talheres, prato, copo). Um bebê não consegue "esperar mais cinco minutos" para almoçar e depois dormir, pois sua

\footnotetext{
${ }^{117}$ Malaguzzi (2001) já falava sobre a criança ser portadora do inédito. Arendt (2007) também se refere aos novos em seus começos, referindo-se à natalidade.

${ }^{118}$ Godoi (2015) em seu estudo de mestrado, orientado pela professora Mônica Appezzato Pinazza, trata a respeito das duplas jornadas das crianças que frequentam turno integral.
} 
necessidade é imediata ${ }^{119}$. Um exemplo diferente, que acolhe as temporalidades e que mostra a consciência que se tem do valor das diferentes experiências da jornada educativa das crianças, é a situação compartilhada na comunicação sobre as microtransições a respeito do horário do almoço das crianças da faixa etária 2. Para essas crianças, participar de uma mesma situação de refeição junto com seus amigos e colegas é uma experiência social, por isso faz todo o sentido que iniciem em um mesmo período; no entanto, como também se trata de uma aprendizagem em processo, é importante observar que, conforme as crianças foram terminando, eram convidadas a se dirigir para fazer a higiene e para a sala referência, permitindo que quem come mais lentamente, possa assim fazer sem nenhum tipo de pressão e sem que os demais precisem esperar.

Um último elemento é que, na palavra jornada, como já exposto anteriormente, também são contempladas outras dimensões, como a do espaço e das relações. Refletir sobre a organização do tempo educativo envolve pensar em outras configurações do espaço que geram múltiplas dinâmicas das relações entre as crianças e das crianças com os adultos. Organizar os espaços para descentralizar do adulto, por exemplo, é também transformar uma lógica institucional sobre adultos e crianças.

Passo agora e explicitar algumas ideias que desenvolvemos nos últimos seis anos no OBECI para refletir as possibilidades de organizar a jornada educativa.

\subsubsection{Possibilidades para organizar a jornada}

Nigito (2011) propõe que se estranhe a arquitetura temporal das escolas, partindo do pressuposto de que o modo como a organizamos não seja um fato incontestável, muito pelo contrário, seja compreendido como escolha e esta deve estar sujeita a ser contestada, revisada, transformada. Para essa autora, a arquitetura temporal engendra as dimensões afetiva, psicológica, social e objetiva (física) do tempo, que, juntas, constroem um sentido que não é apenas da ordem do tempo objetivo e subjetivo, mas da própria existência dos sujeitos (NIGITO, 2011).

Entendo que interrogar essa arquitetura temporal envolve ampliar a compreensão sobre a organização do tempo na escola para além de sua dimensão institucional, mas vê-la como estratégia para gerar bem-estar para as crianças e os adultos, para criar a oportunidade do

119 Quando definitivamente compreendermos isso, não veremos mais bebês pegando no sono enquanto almoçam porque os professores o fizeram esperar. E, mais triste ainda, ver professores filmando e achando engraçada uma cena de tamanho desrespeito e descuidado. Isso era o que Pikler chamava de doces maldades. 
encontro e da partilha, para construir um ritmo em que os meninos e as meninas possam encontrar tempo para construir sentidos pessoais e coletivos, ou seja, elaborar sua experiência.

Barbosa (2006) critica que o modo como o tempo na Educação Infantil está organizado pendula entre o tempo mecânico e a inserção ao tempo do capital. Para a autora,

\begin{abstract}
Os tempos de grande parte das instituições educacionais continuam, em sua maioria, sendo o tempo do início da modernidade, o tempo rígido, mecânico, absoluto. [...] Algumas instituições tentam aderir a um novo tipo de marcação do tempo e de inserção do tempo do capital na vida das crianças, [...] com a antecipação, com a aceleração que incentiva as crianças pequenas a iniciar determinadas atividades cada vez mais cedo, antes de e, se possível, cada vez mais rápido, para que adquiram um maior número de habilidades para competir no mercado (BARBOSA, 2006, p. 141).
\end{abstract}

Nesse sentido, não se trata nem do tempo mecânico e nem do tempo da produção, o que desejamos é que a jornada educativa seja refletida como um tempo em que as necessidades das crianças sejam contempladas e que sirvam de horizonte para pensar as temporalidades da instituição.

Alguns postulados importantes que nos orientam é o de que a criança possa:

a) Brincar diariamente, quer seja no pátio, quer seja na sala referência;

b) Ter tempo para se alimentar, descansar e viver as situações de higiene sem pressa;

c) Ter tempo para levar a cabo suas investigações pessoais;

d) Compartilhar de propostas em pequenos ou grandes grupos sem ser apressada;

e) Desfrutar do prazer de descobrir e de fazer algo, para que não se transforme em tarefas a serem cumpridas;

f) Ter tempo para viver as microtransições entre os diferentes momentos da vida cotidiana;

g) Ter tempo para explorar livros, fantasias, jogos simbólicos e canções em que experimente papéis e enredos lúdicos;

h) Ter tempo para estar com os amigos;

i) Ter tempo com situações de deleite e prazer;

j) Ter tempo para narrar e compartilhar suas teorias, ideias e histórias;

k) Ter tempo de chegar e de se despedir.

Como pode ser visto, nesses postulados, a dimensão de tempo que se reivindica nos ambientes educativos se traduz basicamente pelo tipo de atividade das crianças e pelo modo como o adulto a propõe. 
Por isso, para dar conta desse desafio, a estrutura que tenho proposto é partir da lógica de que todas as crianças vivem situações de alimentação, descanso ou repouso, de higiene ou de se higienizar e de se vestir ou se desvestir. Para esse grupo de atividades, tomo emprestado o conceito de Emmi Pikler, no Instituto Lóczy, e as nomeio de atividades de atenção pessoal. Não sendo essas atividades, há outro conjunto amplo que envolve todas as demais: brincar, investir em algo, ouvir uma história, cantar uma canção, pintar, esculpir, entre outras, e que, embora reconheça que possam ser individuais, em duplas, trios, pequenos grupos ou grande grupo, tenho chamado de atividades coletivas, ou seja, mesmo sendo singular, designa-se ao que acontece na coletividade ${ }^{120}$.

Por um outro lado, o adulto pode propor as diferentes situações (atitividades de atenção pessoal ou coletivas), conduzindo-as a partir de um arranjo que dê a possibilidades das crianças optarem. Dentre estas situações, por exemplo, podemos ter o descansar após o almoço para as crianças de 4 anos que se caracteriza como uma atividade de atenção pessoal e poderia ser um momento optativo, ou seja, as crianças que desejam descansar podem ir para o local apropriado para isso e as que não queiram terão outras opções do que fazer (jogos de mesa, ver livros etc).

O desenho para mostrar esse encontro entre a atividade da criança - que é sempre a base - e o modo como o adulto a propõe podem ser visualizados no esquema a seguir. São quatro quadrantes que expressam isso: atividade de atenção pessoal em momentos conduzidos; atividade de atenção pessoal em momentos optativos; atividade coletiva em momentos conduzidos; atividade coletiva em momentos optativos.

Figura 8 - Quadrantes do tempo

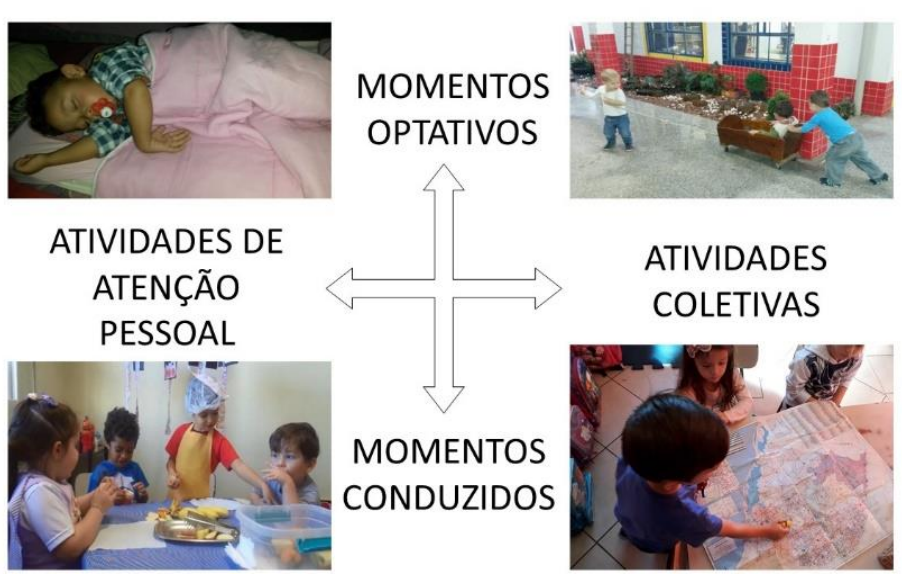

Fonte: Elaborada pelo autor

120 Òdena (1995) comenta que é difícil tentar catalogar as distintas atividades das crianças em uma instituição; no entanto, como a própria autora observa, é importante tentar fazer certas circunscrições para tomar consciência e para auxiliar o adulto a organizar sua prática pedagógica. 
A ideia não é delimitar exatamente como cada situação cotidiana pode ser classificada, mas criar um cenário reflexivo que possa auxiliar o professor a problematizar o modo como organiza a jornada educativa, escapando da armadilha de justificar que o tempo institucional é o que determina, ou que as crianças podem fazer o que querem. A escola, sendo uma instituição, tem uma estrutura que precisa estar em harmonia com as necessidades das crianças, dos pais e dos profissionais. A grande questão é não continuar colocando as necessidades das crianças em segundo plano, ou responder a uma ideia de organização da jornada educativa pautada na expectativa da produtividade.

Vale destacar sobre o tempo das microtransições, tão importante e tão apagado das reflexões dos adultos. Entre um momento e outro, é fundamental que se reflita de que modo o professor intervém e propõe a mudança da situação. Na comunicação que foi partilhada no início deste capítulo, a professora passou a convidar as crianças que estavam brincando no pátio individualmente para ir para a sessão que ela havia programado para um pequeno grupo. Essa mudança aconteceu após a coordenadora convidar as professoras a refletirem de que modo poderiam transitar entre o grande grupo para o pequeno grupo de um modo generativo, ou seja, que “[...] pode constituirse uma ocasião de crescimento e aprendizagem" (OLIVEIRAFORMOSINHO; PASSOS; MACHADO, 2016, p. 36). Pensar as microtransições como parte da jornada educativa significa mobilizar outras estratégias para construir o fluir da jornada de modo que respeite as crianças. Outro fragmento de nossas investigações que acredito demostrar o valor do tempo das transições é essa cena em que a professora Jéssica da EMEI João de Barro, observando que uma das crianças poderia necessitar ser trocada, dirige-se até a menina e conversa com a ela a respeito e depois pergunta se pode verificar sua fralda. Esse trecho, parte da investigação sobre as microtransições, demonstra um salto de compreensão sobre o tempo das microtransições, mas também sobre o tempo das relações, do
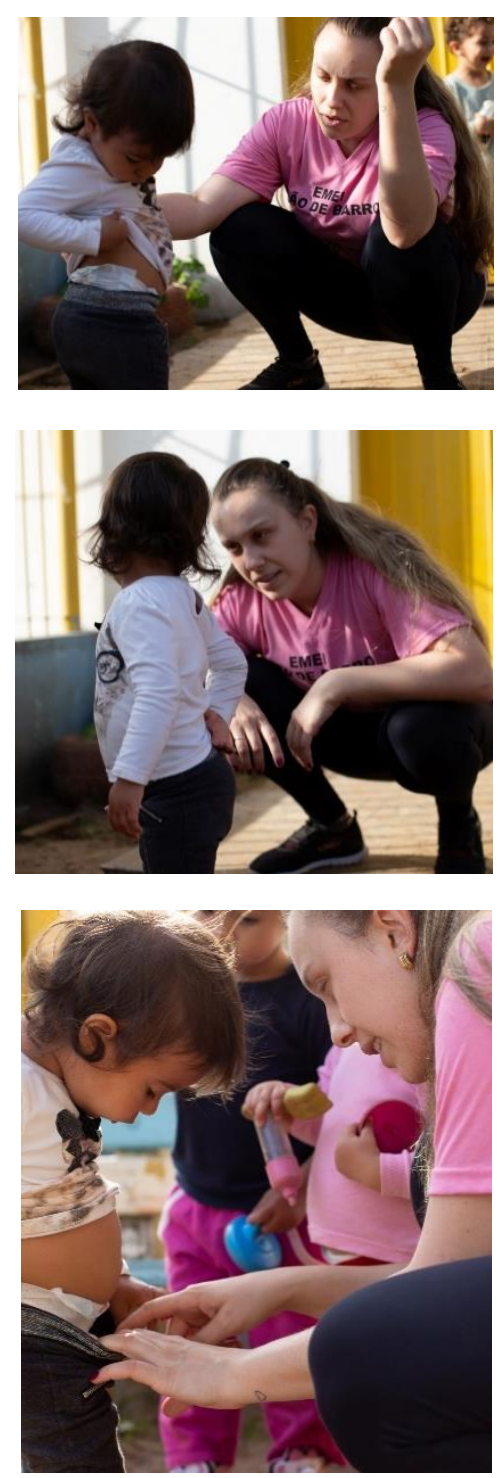
respeito e da importância do papel do adulto. 
Um outro aspecto que gostaria de destacar é que, em nossas observações, percebemos que uma sequência de momentos conduzidos deixa as crianças exauridas. Mais ainda, quando começamos a fazer uma análise do como estavam organizadas as jornadas educativas das escolas participantes do OBECI ${ }^{121}$, percebemos que há uma forte tendência de que isso ocorra sem que se perceba o quanto é enfadonho para as crianças. Um exemplo clássico é o período do final da manhã para o início da tarde. Em geral, as crianças têm uma proposta conduzida no final da manhã, depois almoçam, são todas colocadas para dormir, acordam e são convidadas para uma roda de conversa que antecipará o lanche da tarde e, na sequência, uma nova proposta. Em termos do tempo- relógio, estamos falando do intervalo de aproximadamente 5 horas, entre as 10 horas da manhã até as 15 horas da tarde. Em todo esse tempo, as crianças passaram por momentos conduzidos pelo professor. Quando se observa isso com algum guia de reflexão, pode-se reorganizar a jornada educativa criando intervalo com momentos optativos. Seguindo o exemplo dado, antes do almoço, é melhor que as crianças estejam em um momento optativo (por exemplo, brincando nos espaços da sala ou no pátio), depois que acordam, poderão novamente brincar nos espaços da sala ou no pátio. Quebrando a sequência de, no máximo, 3 situações consecutivas de momentos conduzidos com um momento optativo, muda-se radicalmente a relação das crianças com os adultos, porque muda a relação delas com o tempo, os espaços e as relações.

Seguramente, esse é um tema que pode ser estudado de forma ampliada, buscando compreender os padrões de comportamento das crianças e alternativas distintas para conseguir conciliar o tempo de cada menino e menina com o tempo da instituição.

\subsection{O trabalho nos pequenos e no grande grupo}

Para abordar o valor do trabalho em pequeno e grande grupo, um primeiro aspecto a ser discutido é a noção de conhecimento de que partilhamos. Como já anunciado anteriormente, no OBECI, nos aproximamos das visões sócio construtivistas e coconstrutivistas, que foram redefinidas por Forman e Fyfe (2016) como aprendizagem negociada.

A premissa básica da aprendizagem negociada parte do que Vygotsky (1998) já havia anunciado, reiterado posteriormente por autores como Jerome Bruner (2008) e Bárbara Rogoff (1993), de que aprendizagem e o desenvolvimento, assim como a formação da mente humana, ocorrem na relação do indivíduo com o seu ambiente, sua comunidade e sua cultura. À vista

${ }^{121}$ E eu tenho feito isso em diferentes situações (tais como consultorias, estágios etc) e o resultado é o mesmo. 
disso, o desenvolvimento humano é inseparável dos processos sociais, porque é resultado da participação do sujeito na cultura e na sociedade.

Essa crença pressupõe a natureza social do conhecimento, e, portanto, acredita-se que isso ocorre a partir de uma construção que nasce do sentido da ação humana, daquilo que Bruner (2006) chama de qualidade nata do ser humano, que é a curiosidade em aprender para fazer uso dos instrumentos culturais da nossa sociedade (BRUNER, 2008; ROGOFF, 1993). Logo, essa visão se opõe a ideia de que o conhecimento é acabado, pronto e fechado, e que, por isso, ocorre por vias de aquisição.

Por esse ângulo, o papel da educação na aprendizagem negociada está em ajudar a criança a criar sentido sobre sua própria experiência, a negociar significados com outras crianças e adultos, em um contexto de diálogo, simbolização e prazer pelo reconhecimento do próprio processo de aprender (metacognição).

Segundo Forman e Fyfe (2016), o papel dos professores na aprendizagem negociada é o de compreender as hipóteses e teorias das crianças sobre seu entorno e conseguir traduzir, em um contexto que as oportunize, possibilidades de experimentarem e de se sentirem encorajadas a compartilhar suas explicações sobre distintos fenômenos (sociais, culturais, naturais etc). Mesmo para os bebês e para as crianças bem pequenas, que não se utilizam da palavra para narrar sua própria experiência, é possível “[...] explorar novos objetos ou materiais de modo que o professor (observando suas estratégias) possa inferir quais são as suas teorias" (FORMAN; FYFE, 2016, p. 250). Além disso, a aprendizagem negociada está diretamente ligada à Documentação Pedagógica. Isso quer dizer que também é papel do professor saber narrar para argumentar sobre as jornadas de aprendizagens dos meninos e das meninas, não apenas para torná-las visíveis, mas para restituir à própria criança os seus percursos de aprendizagem.

Como pode ser visto, negociar, compartilhar, dialogar, são palavras estruturantes para essa perspectiva de aprendizagem. Logo, a pergunta que pode ser feita nesse momento é se conseguimos imaginar um grupo de 20 crianças negociando e dialogando ativamente sobre algum problema ou produto em comum ao mesmo tempo. Possivelmente a resposta seja negativa. O que se pode encontrar na literatura sobre esse tema é que a construção de um contexto que favorece as relações é fundamental para o processo de socialização das crianças (ISAACS, 1973; EDWARDS; GANDINI; NIMMO 1994; MALAGUZZI, 2001; JOHNSON; JOHNSON, 2001; TOGNETTI, RUBINO, ZINGONI, 2003; KRECHEVSKY, MARDELL, 2009; SAVIO, 2011). 
Com isso, já se anunciam dois pontos importantes: o primeiro, a socialização é uma aprendizagem complexa, ou seja, se desenvolve por uma conjugação de múltiplos fatores que estão relacionados às categorias geracionais, aos grupos sociais de que as crianças participam, ao suporte que adultos ou crianças mais experientes oferecem aos meninos e meninas. Barbosa (2017, p. 7) lembra que o conceito de socialização tem se modificado nos últimos anos, especialmente na assunção da ideia do "ser humano como sujeitos plurais, em constante construção e atualização, em um processo de socialização que também não é único, mas com muitas e diferentes influências e interpretação dessas influências". Também Savio (2011, p. 132) ressalta que sustentar as atividades sociais em um grupo "necessita capacidades de elaboração refinadas para compreender e conectar a variedade e quantidade de informações, pontos de vista e demandas, a princípio contraditórias, que caracteriza a participação em um grupo".

Daí o segundo ponto, as condições do ambiente que as crianças estão inseridas são estruturantes para a promoção de contextos relacionais. Nesse sentido, a competência do adulto em criar configurações de diferentes arranjos de grupo para responder melhor às necessidades das crianças é fundamental, além do apoio que pode oferecer para as crianças construírem os recursos internos necessários para estar em um grupo com outras crianças.

Um parâmetro empírico significativo, para nós do OBECI, é observar o modo como as crianças se arranjam em suas brincadeiras. O bebê começa a brincar sozinho e, aos poucos, compartilha sua atenção com outro bebê. Um pouco mais tarde, as crianças começam a brincar em duplas e, conforme o tempo vai passando, começam a agregar uma ou duas crianças a mais em suas brincadeiras (formam, aos poucos, trios). Até o final dos seis anos, idade da Educação Infantil, possivelmente o máximo de crianças reunidas ativamente em uma mesma situação não passe de seis crianças.

Seguindo nesse raciocínio, é fácil compreender as razões do porquê se dá valor para os pequenos grupos de aprendizagem. No Observatório, temos afirmado, desde o princípio, que a prática pedagógica precisa se organizar a partir de estratégias que auxiliem a criança a construir seus conhecimentos na interação com outras crianças e adultos, em que o que está em jogo não é apenas o conteúdo intelectual da situação, mas os conteúdos e processos emocionais, afetivos e sociais. É em meio a essas situações que, além da criança aprender a construir explicações sobre seu entorno, ela também aprende a estar com os outros de uma maneira respeitosa e a se sentir respeitada. 
Ou seja, estamos tratando - assim como já abordado no organizador do tempo - do fato de que a socialização da criança também precisa ser interpretada desde um ponto de vista pedagógico. Nesse sentido, Savio (2011, p. 137) observa que é preciso compreender profundamente a respeito dos processos de socialização das crianças para ir mais além do simples agrupamento por razões administrativas, já que "a socialização natural não pode ser considerada garantia de desenvolvimento e aprendizagem".

Isaacs (1973) ressalta três condições para socialização das crianças: a primeira, a estabilidade do grupo, que oferece para as crianças a possibilidades de ir se conhecendo melhor e conhecendo seus pares para compartilhar experiências, apoiar e sentir-se apoiada pelo grau de intimidade e confiança construído. A segunda, a qualidade do ambiente, especialmente no que diz respeito à natureza lúdica, está diretamente relacionada com os organizadores do espaço e dos materiais, pois, como já foi mencionado anteriormente, a possibilidades das crianças atuarem com liberdade no espaço e de se autogestionarem está relacionada ao tipo de material e ao modo como o espaço está organizado. Por fim, a terceira condição é a presença do adulto, que deve ajudar o grupo a regular-se e auxiliar nos momentos em que é necessária a compreensão de novos recursos relacionais que as crianças desconhecem (por exemplo, como ela pode dizer ao colega que naquele momento ela precisa de um material que se encontra de posse dele).

Portanto, se é certo que a socialização faz parte de um processo de aprendizagem, também é que a gestão pedagógica pode ser de grande valia para a construção do sentido de grupo a partir do modo como se organiza a jornada educativa, já que estar juntos não é suficiente para estar em um grupo de aprendizagem.

\subsubsection{Diversos arranjos para os diversos momentos da jornada educativa}

É natural que uma jornada de 4 a 12 horas diárias exija diferentes arranjos em um grupo de criança. Querer que as crianças permaneçam toda a sua jornada educativa fazendo a mesma coisa, ao mesmo tempo, do mesmo modo, além de ser uma total desconexão com a vida, é sintoma de que não se conhecem as necessidades das crianças ou não se respeitem os meninos e as meninas.

Por isso, observar a dinâmica da jornada educativa e compreender as exigências que se faz para atender as características das crianças podem ser o primeiro passo para eleger os diferentes critérios para criar arranjos distintos de grupos. Bondioli (2012, p. 41) sublinha que 
é preciso ter presente que não apenas em situações "conduzida[s] em primeira pessoa pelo adulto que as atitudes sociais das crianças se desenvolvem, mas é em espaços íntimos e em situações de duplas, e progressivamente em pequenos grupos, que as crianças realizam as primeiras experiências sociais entre pares". Assim, tanto do ponto de vista da dinâmica da jornada quanto das diferentes necessidades das crianças, promover arranjos distintos de grupo representa a qualidade profissional de uma equipe em pensar a ecologia pedagógica em seu amplo aspecto, que é educar e cuidar crianças em uma escola.

Construir um horizonte reflexivo para a organização dos grupos é uma forma de evitar que a única oportunidade das crianças estarem em pequenos grupos aconteça apenas quando o professor realiza o que comumente se define como "pátio livre, atividade livre". Ou melhor, ter a consciência da importância da aprendizagem social é compreender que "a interação entre as crianças tem um valor fundamental na experiência dos primeiros anos de vida. Trata-se de uma demanda, de um desejo, de uma necessidade que toda criança tem e que quer satisfazer em situações adequadas que favoreçam essas interações" (MALAGUZI, 2001, p. 58).

Por esse ângulo, no OBECI, nossa reflexão caminha em sentido a garantir que a criança possa:

a) Viver em um ambiente que favoreça a construção das relações;

b) Construir amizades e estar próxima dos amigos;

c) Viver situações estáveis com pequenos grupos para fortalecer relações;

d) Compartilhar de investigações com seus pares com tempo suficiente e materiais adequados;

e) Estar sozinha quando assim desejar;

f) Ser ouvida quando desejar se manifestar no grande grupo;

g) Ser respeitada no seu desejo de ficar em silêncio;

h) Ser apoiada na busca de recursos para expressar seus desejos, suas emoções e sentimentos;

i) Viver conflitos tendo no adulto o suporte para compreendê-los.

Um aspecto importante de ser destacado é o longo processo que exige para construir um clima de cooperação e de envolvimento entre as crianças em um grupo. Isso requer estratégias conscientes por parte dos adultos e a abertura para ir modulando a prática pedagógica com vistas a esse horizonte.

Krechevsky e Mardell (2009, p. 286) definem grupo de aprendizagem como "um conjunto de pessoas que estão envolvidas emocional, intelectual e esteticamente na solução de 
problemas, na elaboração de produtos e na construção de significados". Para chegar a esse grau de envolvimento, que caracteriza efetivamente um grupo de aprendizagem, é preciso criar um ambiente que favoreça a qualidade social dos pequenos grupos (SAVIO, 2011), isto é, gerar um clima de confiança e intimidade ligado a um percurso de aprendizagem social das crianças que se dá pelo quão habituadas estão em construir jornadas de aprendizagens em pequenos grupos.

Nesse sentido, passo agora a explorar algumas ideias particulares dos diferentes arranjos de grupo ao longo da jornada educativa.

\section{Organização dos pequenos grupos pelo professor}

A situação de organização de pequenos grupos criadas pelo professor ocorre durante as sessões de investigação e experimentação. São situações que acontecem uma vez por turno de trabalho (portanto, uma de manhã e uma de tarde), em um período de tempo reservado de aproximadamente uma hora, em pequenos grupos (quanto menor as crianças, menores os grupos). Assim, ao longo de uma semana, é possível que cada pequeno grupo vivencie entre uma ou duas sessões de investigação, dependendo do número de crianças total do grande grupo.

Em geral, procura-se manter grupos estáveis de crianças por alguns meses, intencionando colaborar com a criação de vínculo e de relações significativa entre elas, como pode ser visto na comunicação sobre as microtransições na mini-história Partilhando experiências e construindo relações, que mostra exatamente o percurso de um mesmo pequeno grupo em diferentes sessões e o grau de proximidade e colaboração construído. Por outro lado, em outras oportunidades da jornada educativa, as crianças são incentivadas a estarem com outros grupos, ampliando assim seu círculo social.

Nas sessões, é investido significativamente a criação de um ambiente convidativo e esteticamente interessante para envolver as crianças em propostas que, ao mesmo tempo que são intencionalmente preparadas pelo professor (ou seja, decorrem de perguntas e zonas de investigação previamente refletidas), também são suficientemente abertas para as crianças levarem a cabo suas próprias teorias e hipóteses.

A principal função dos pequenos grupos, durante as sessões, é criar um clima de aprendizagem e apoio mútuo entre as crianças e das crianças com os adultos e, ao mesmo tempo, ser um espaço privilegiado para o adulto observar e registrar as aprendizagens das crianças e dar sustentação para as investidas de cada menino e menina. Isso é o que Malaguzzi (2001) e Savio (2011) chamam de intercâmbios positivos entre pares e com o adulto. 
Para Malaguzzi (2001, p. 58), “as interações das crianças em pequenos grupos permitem negociações e dinâmicas mais frequentes, interessantes, produtivas e diversas, e não menos importantes que as que se dão entre crianças e adultos". Isso decorre exatamente pelo clima amistoso que ocorre, ou seja, há menos variáveis por parte das crianças para gerenciarem (menos crianças, menos variáveis). Para o pedagogo italiano,

as interações entre as crianças põem em jogo condutas sociais, emocionais,
comunicativas e cognitivas. As variáveis de conteúdo e forma da interação serão as
que desenharão a qualidade e a quantidade dos diversos pontos de vistas que terão que
ser coordenados. Essa riqueza não se dá quando as crianças estão sozinhas
(MALAGUZZI, 2001, p. 58).

Do ponto de vista de situações de conflitos que podem surgir, tanto as crianças têm mais condições de gerenciá-las como os professores podem intervir de forma que auxiliem as crianças a compreender a situação em si.

Também interessa sublinhar que, em um grupo de bebês, dando como exemplo uma sessão de cesto dos tesouros, organiza-se um trio ou um quarteto de bebês para configurar uma sessão que contribua com o ambiente tranquilo que essa modalidade do brincar exige. No entanto, é muito comum que, durante as sessões, os bebês permaneçam parte significativa do tempo explorando os objetos sozinhos. Porém, é importante destacar que, nesse caso, o olhar interessado de um bebê para o modo como o outro bebê explora um objeto faz parte dos primórdios dos jogos de interação entre os bebês (STAMBAK et al, 2011; GOLDSCHMIED, JACKSON, 2006). Assim, a organização do pequeno grupo está para criar o ambiente adequado para as necessidades das crianças e favorecer que esse prelúdio do jogo social aconteça.

\section{Auto-organização em pequenos grupos}

Não é apenas nas situações de sessões que as crianças podem estar em pequenos grupos. Vinculado aos três organizadores anteriores, ou seja, (i) ao modo como o espaço está circunscrito por áreas, que, por sua vez, em um mesmo espaço, cria outros espaços (lugares) descentralizadores do adulto, (ii) à qualidade da diversidade e quantidade dos materiais que estão disponíveis para as crianças e (iii) à forma como o tempo está organizado, que prevê momentos optativos, as próprias crianças podem se auto-organizar em duplas, trios ou pequenos grupos para brincarem.

Além desse ser um momento muito propício para o professor observar os arranjos dos grupos, as proximidades entre as crianças e os papéis que cada uma ocupa nas dinâmicas existentes entre os grupos, também serve como um "laboratório transformativo" 
(MALAGUZZI, 2016, p. 83), em que as crianças elaboram suas próprias regras, administram os modos como podem funcionar, experimentam papéis, vivenciam conflitos, resolvem os conflitos etc. Na comunicação apresentada no início deste capítulo, há diversos episódios que exemplificam isso: no momento em que a professora convida as crianças que participarão da sessão, as demais estão no pátio brincando; no trecho em que é abordado o tempo do grande grupo, também se evidencia o modo como as crianças se arranjam nos espaços e, com mais força ainda, na mini-história sobre a Jornada de Ísis e Milena, mostra a jornada das duas meninas nos diferentes espaços e os diferentes enredos lúdicos criados por elas.

Cabe ressaltar que essa é, na verdade, uma situação em que as crianças estão no grande grupo, mas o modo como o ambiente está organizado (em termos de tempo, espaço e materiais) promove que elas se auto-organizem em pequenos grupos. Por isso, diferentemente dos pequenos grupos nas sessões, aqui ocorre um fenômeno distinto, em que algumas crianças serão mais flutuantes, ou seja, não permanecerão muito tempo em nenhum agrupamento de crianças mas também não levarão a cabo uma brincadeira sozinha; outras crianças poderão permanecer longos períodos brincando sozinhas; já outras poderão estabelecer duplas, trios ou pequenos grupos e darão continuidade em um longo período nessa configuração.

Já em grupos de bebês e crianças bem pequenas, os processos de interação geralmente acontecem por aquilo que Stambak e Barrière (2011) chamam de "pré-colaborações" de uma atividade compartilhada: um começa a guardar objetos em um receptáculo e outro inclui-se na brincadeira. Um outro exemplo é a organização de pequenos lugares para os bebês se esconderem, ou mesmo, a oferta de objetos como tecido, caixas e potes. Essa brincadeira do aparecer e do desaparecer cria, entre os bebês e dos bebês com os adultos, enredos lúdicos que favorecem a ampliação dos jogos sociais. Embora a temporalidade dessas relações seja distinta das crianças maiores, é fundamental que o adulto compreenda que há "um equilíbrio entre os dois polos, cognitivos e afetivos" (STAMBAK; BARRIÈRE, 2011, p. 48), logo são os primórdios do jogo social entre as crianças.

$\mathrm{Na}$ investigação sobre as microtransições, por exemplo, a diretora Silvana, da Escola Espaço Girassol, acompanhou as chegadas e despedidas no berçário, e um dos desdobramentos da organização do espaço e da oferta de materiais não estruturado nesses momentos foram as brincadeiras que os bebês começaram a criar entre eles. Esse recorte de uma das cenas em que Laís se aventura em entrar na caixa enquanto Manuela observa o desafio é uma situação 
interessante para observar a relação entre os bebês em situações que eles próprios se organizam. Uma vez que as condições do entorno oferecem essas possibilidades, os desafios são partilhados e sustentados pelo olhar cúmplice de uma amiga que apoia a jornada de aprendizagem da outra e celebram a conquista.

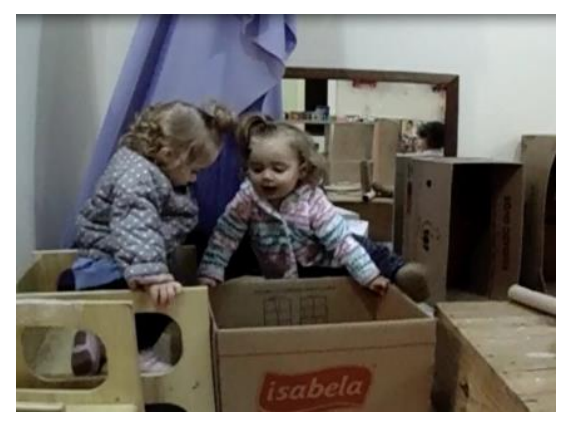

\section{Os momentos de grande grupo}

Uma outra modalidade para organização do grupo são as situações em que se reúnem todas as crianças, que aqui chamo de grande grupo. Essas são situações geralmente breves em que o papel principal é compartilhar algumas informações, planejar a jornada educativa, comunicar aos demais sobre suas investigações, ouvir uma história, cantar alguma canção.

O sentido do grande grupo não pode ser para controle ou para colocar as crianças em situações de espera (espera para ir lanchar, espera para os pais chegarem, espera
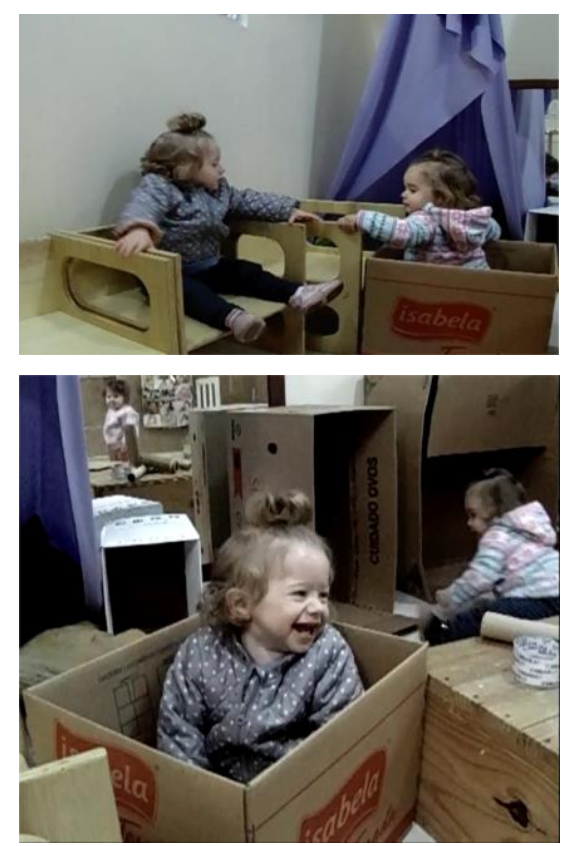
para a próxima situação acontecer). Ao contrário, devem ser úteis para construir um sentimento de pertencimento, de compartilhar experiências comuns e de construir planejamentos e organizações com a participação ativa das crianças, como nesta cena em que a professora Raquel reúne a turma para uma assembleia a respeito das investigações que as crianças estão fazendo sobre os insetos.

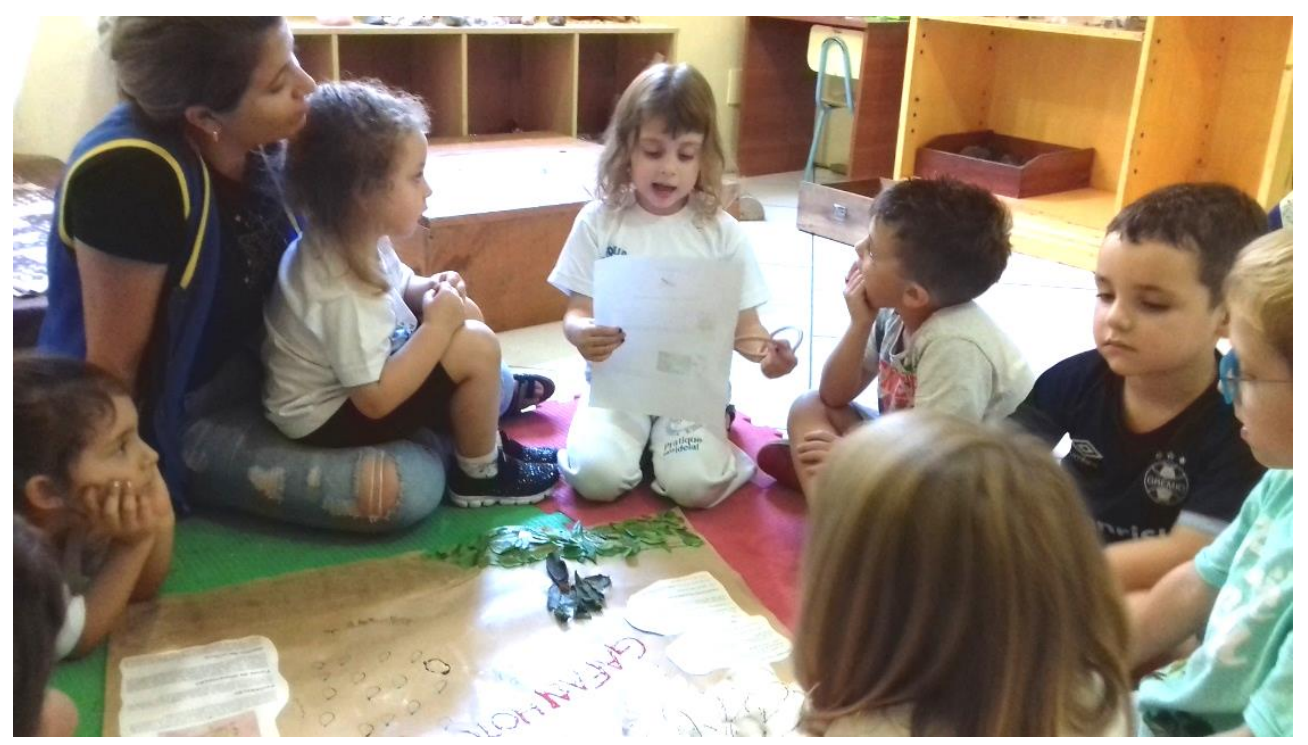


No caso dos bebês, não recomendo que seja proposto que todos estejam em uma situação de grande grupo. Mesmo em momentos como contar uma história ou compartilhar uma canção, é mais adequado seguir a própria configuração dos bebês do que os colocar em roda. Se aproximar de um ou dois bebês e interagir com ele(s) a partir de um livro ou de uma canção, responde melhor às suas necessidades.

Cabe destacar que temos discutido significativamente sobre a prática de contar histórias na Educação Infantil dentro do OBECI. Entendo que contar uma história é uma das formas de mediar a leitura, mas não a única. Em geral, destaco que a mediação de leitura pode ser feita por meio (i) do acesso a livros pela própria organização da sala; (ii) da participação do adulto como leitor, ou seja, se disponibilizando a ler livros dessa área da sala com livros; (iii) do uso de livros informativos como recurso de pesquisa com as crianças, inclusive, disponibilizando a elas e (iv) do compartilhamento de histórias pelo puro deleite. Nesse último caso, por exemplo, é o que envolveria o grande grupo, mas compartilhar uma história precisa ser com o único interesse de dividir com as crianças um produto da cultura. É momento de compartilhamento e não de trampolim para projetos. Particularmente, não considero adequado utilizar livros de literatura infantil para serem utilizados como porta para projetos. Um livro de literatura precisa se bastar nele mesmo, é a experiência literária e humana que está em jogo.

Como pode ser visto, há diferentes possibilidades para criar arranjos do grupo, o que não apenas responde a uma necessidade vital das crianças, como cria possibilidades de transformar a própria experiência de estar com as outras crianças em uma privilegiada oportunidade de aprendizagem social.

\subsection{A relação entre adultos e crianças}

Em todos os demais organizadores, ao mesmo tempo em que abordei sobre o conteúdo central do organizador - espaço, materiais, tempo, grupos -, também fui sublinhando o papel do professor no cotidiano pedagógico. Há uma clara intencionalidade nesta tese em problematizar o papel do professor na Educação Infantil e, mais do que isso, oferecer a ele alguns elementos que ajudem na construção da sua práxis pedagógica a partir da experiência que temos levado a cabo dentro do OBECI. No entanto, embora tangenciava a dimensão relacional enquanto mostrava o papel do professor, optei por dedicar um único tópico sobre a relação adulto e criança na Educação Infantil para poder entrar em alguns aspectos que considero importantes. 
Malaguzzi (2001), Hoyuelos (2006), Rinaldi (2012) e Oliveira-Formosinho (2016) afirmam que, a partir da imagem que temos de criança, construímos nossos sistemas de relação com elas, ou seja, se partimos de uma criança que ainda não é, anteciparemos a ela tudo o que precisa para tão logo "ser”, mas, se nossa imagem de criança está centrada no que ela já é, buscaremos uma posição nessa relação que acolha seu mundo interno e a encoraje para construir significados no mundo que acaba de chegar. Também a partir do nosso imaginário, de nossas crenças, das nossas experiências como aluno, da nossa formação e da nossa cultura, temos uma ou mais imagens sobre o que é ser professor. Cabem muitas imagens na intersecção entre criança e professor no ambiente da Educação Infantil.

Muitas vezes, as crianças, na Educação Infantil, estão sujeitas a uma dupla relação assimétrica de poder: primeira, do adulto frente à criança na sociedade, que considera agressão quando dois adultos brigam, maus tratos quando se machuca um animal, mas considera educação dar palmadas nas crianças. Essa mesma sociedade considera engraçados e divertidos vídeos e postagens em redes sociais de crianças em situação vexatória, inclusive publicadas por aqueles que são responsáveis por elas. Segunda, a relação naturalizada dentro do ambiente escolar entre professor e aluno, que pressupõe que o professor é quem define tudo, até mesmo o que a criança deve sentir, pensar, comer e fazer em longas jornadas diárias. Ademais, considera adequado as crianças andarem em fila segurando a camiseta uma das outras, que ri de um bebê pegando no sono durante o almoço, que grita, que ameaça. Enquanto essas relações não forem interrogadas, nós continuaremos a reproduzir as mazelas e as desigualdades da sociedade no modo de estar com os meninos e as meninas.

Não se pode atribuir única e simplesmente à proporção adulto-criança o modo como se dão as relações na Educação Infantil. É também isso, mas muito mais. É uma imagem de criança que não sente, que não pensa, que não é, que não ascendeu à categoria do humano, e, por isso, autoriza-se esse tipo de relação ${ }^{122}$.

Como um modelo alternativo de estar com as crianças, que admiro e desejo que todas possam ter, remeto-me ao "convite especial" que as professoras Karin e Sissa fazem para cada criança antes de começar a sessão, aproximando-se delas e convidando-as ${ }^{123}$, como narrado na comunicação que abre os Organizadores. É sútil, por vezes, quase imperceptível, mas radicalmente diferente do que dar três palmas e soltar um grito em meio ao pátio anunciando

\footnotetext{
122 Por um outro lado, não me espanto, em um país que ovaciona um presidenciável que exalta torturador e que chama "esse povo dos direitos humanos" como um grupo querendo privilégios, é, no mínimo, compreensível, porque gera tanto espanto tratar com dignidade as crianças.

${ }^{123} \mathrm{E}$ lembrando que antes de irem ao pátio, as crianças e as professoras, em grande grupo, já haviam combinado a organização da jornada.
} 
que a criança A, B, C e D devem se aproximar da professora para ir para "a atividade" ou, pior, chamar o grupo todo para colocar 20 crianças a fazer algo ao mesmo tempo. É preciso estar muito consciente do nosso papel com as crianças para que cada instante seja permeado por "essa cultura da hospitalidade na forma de se aproximar do outro também como acolhida, enigma, incógnita ou mistério" (HOYUELOS, 2017, p. 12).

Hoyuelos (2017), em um artigo brilhante sobre a relação adulto e criança, compartilha algumas cenas de professoras que ele admira pela forma como se relacionam com cada menino e menina. Para esse autor, a questão que as une é que cada uma "tem muito claro que o encontro com o outro é de respeito e não de domínio" (HOYUELOS, 2017, p. 12). Escolher o respeito como via da relação com as crianças, além de ser ético, é um ato revolucionário em tempos de tamanha austeridade frente ao outro.

Ser professor de Educação Infantil implica um gesto de grande responsabilidade, que requer, além do domínio pedagógico, metodológico e cultural, uma abertura e disponibilidade para se relacionar com as crianças (CATARSI, 2013). A respeito do professor da primeira infância, Mantovani e Perani (1999) advertem que essa é uma profissão a ser inventada, e, embora se refiram especificamente à creche, creio que o apelo não seja diferente para a Educação Infantil como um todo, como já sublinhado por Rocha e Batista (2015), quando demonstram que ainda a visão médico-higienista e assistencialista é predominante nas práticas das professoras.

É importante lembrar que o debate em torno da relação do professor com as crianças tem efeito no relacionamento com as famílias, abrindo vias de diálogo e de superação de uma postura binária na educação das crianças. Como destaca Catarsi (2013, p. 10),

\footnotetext{
a consciência do caráter "ecológico" e global do desenvolvimento infantil, ao contrário, deve tornar cada vez mais clara a necessidade de uma relação orgânica e continuada, inclusive com as famílias, às quais é preciso dirigir-se com uma postura que inspire segurança e empatia.
}

Essa visão ampliada e global da criança inclui não apenas a esfera imediata de sua participação, como é o caso da escola, mas os outros contextos dos quais ela faz parte. Assim, desde o ponto de vista que educar as crianças é um processo de co-responsabilização entre família e escola, abrir-se ao diálogo e informar e dar a possibilidade das famílias pensarem sobre o modo como os professores se relacionam com as crianças pode ser o motor propulsor para construir novas imagens de criança na sociedade.

Seguindo esse caminho, no âmbito das relações, no OBECI, acreditamos que a criança precisa: 
a) Ser respeitada em sua singularidade;

b) Participar dos diferentes momentos da vida cotidiana;

c) Iniciar suas atividades e ser respeitada pelo que está fazendo;

d) Ser acolhida em seus temores, esperanças, incertezas, sonhos e motivações;

e) Ter suas ideias e voz consideradas como elementos de investigação, de proposição do trabalho pedagógico.

Nesse sentido, pensando em contribuir com a (re)invenção dessa profissão, mas dando um especial acento ao tópico das relações, já que acredito que o pedagógico, o metodológico e o cultural já foram em certa medida tratados ${ }^{124}$, destaco os pontos a seguir: o acolhimento do universo das crianças, o desafio de não criar dependência e não criar abandono; além disso, as interações como o coração da Pedagogia.

\subsubsection{Acolher o universo das crianças}

Staccioli (2013, p. 25) define muito bem o sentido de acolhimento quando comenta que esse não pode ser um sentimento restrito a um determinado momento do dia ou do ano, mas "um método de trabalho complexo, um modo de ser do adulto, uma ideia-chave no processo educativo". Quando o acolhimento se transforma em uma postura do adulto para estar com as crianças, a lacuna que há entre os dois mundos diminui, mudando com isso a hierarquia das relações e dos diferentes momentos da jornada educativa.

Por esse ângulo, organizar o ambiente em termos de espaço, materiais e tempo é a tradução concreta do que significa acolher, já que é preciso efetivar, na vida cotidiana, um modo distinto de estar com as crianças. Da mesma forma, propor situações em pequenos grupos porque se compreende a natureza organizativa dos meninos e meninas é acolher as suas necessidades. Não manter centralizado no adulto o pulsar da vida da escola e estabelecer um ritmo que considera as temporalidades das crianças é sintoma de uma transformação que compreende que as relações dos adultos com as crianças podem se dar por outras vias.

${ }^{124}$ Em hipótese alguma, estou querendo separar a dimensão relacional das dimensões pedagógicas, culturais e metodológicas. Apenas para seguir a indicação de Catarse (2013) e respondendo ao objetivo desta seção, darei ênfase à dimensão relacional, inclusive evidenciando sua interface metodológica, pedagógica e cultural. 

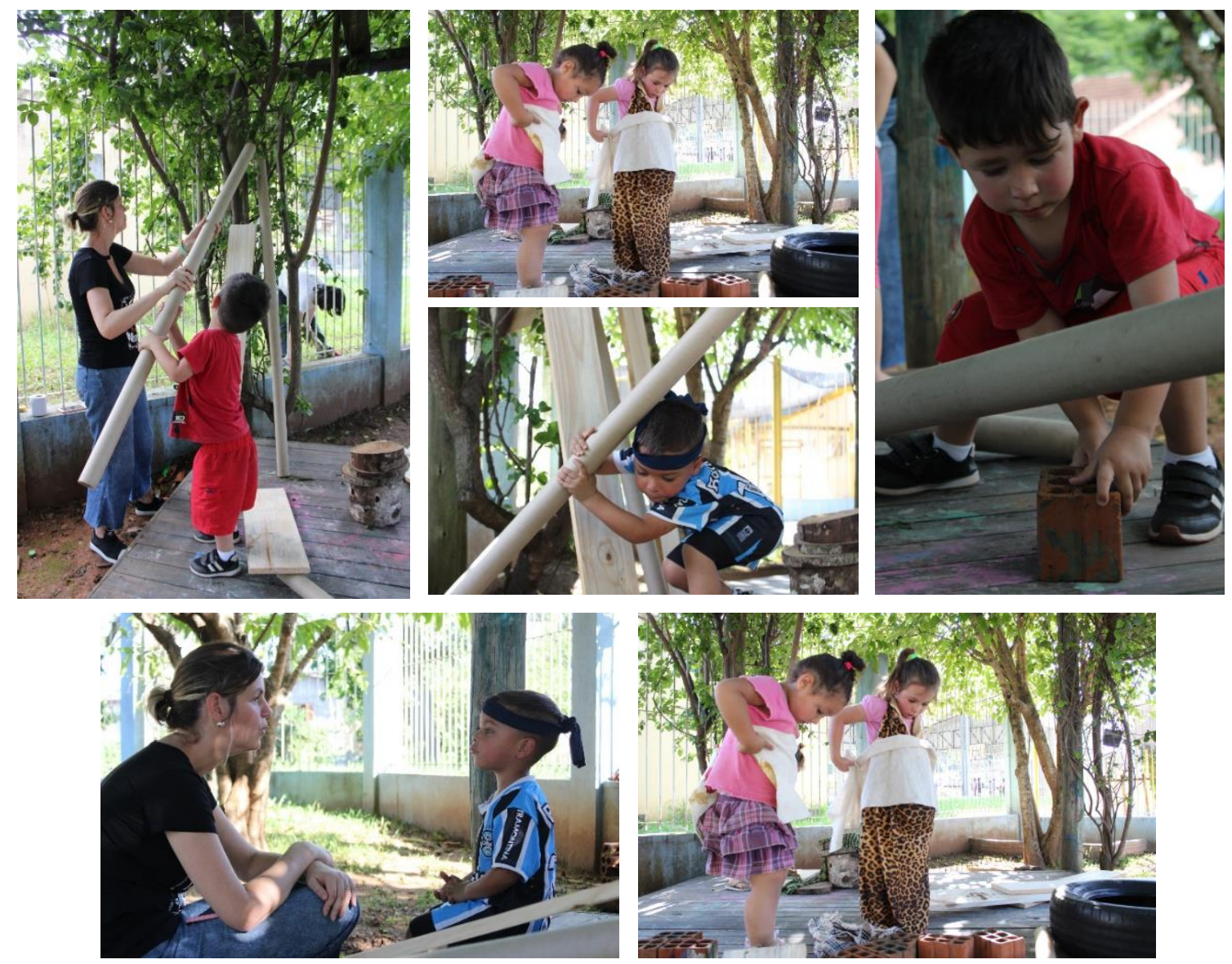

Durante uma investigação das crianças da faixa etária 2 da EMEI João de Barro, o interesse pelas construções foi se ampliando ao longo do ano, de pequenas construções com blocos e peças menores, passou a grandes construções, como fazer a casa do lobo no pátio. A professora Viviane, além de já ter acolhido os interesses das crianças por construir, equilibrar, subir torres, aceitou o convite de um pequeno grupo de crianças que resolveu construir uma grande casa do lobo cheia de histórias e enredos. Assim, acolher tornou-se um gesto sútil de disponibilidade e capacidade de saber recuar para não invadir com as próprias expectativas os interesses das crianças.

Staccioli (2013, p. 28) reforça que "acolher uma criança é, também, acolher o seu mundo interno, as suas expectativas, os seus planos, as suas hipóteses e as suas ilusões". Por isso é que a postura do professor deve criar margens para as crianças levarem a cabo suas ideias e visões sobre o seu entorno e a si mesmas, em se solidarizar e se comprometer com as dificuldades das crianças em expressarem seus sentimentos, auxiliando-as a perceber o que está acontecendo e como podem expressá-las. 


\subsubsection{Não criar dependência e não criar o abandono}

Muitas vezes, na busca por um equilíbrio em estar com as crianças, acaba-se caindo em polarizações. Em um dos polos, está a dependência. Do ponto de vista objetivo, ela ocorre pelo modo pelo qual está centralizada a relação educativa no adulto para que a criança possa realizar qualquer tipo de atividade na escola: depender do adulto que pegue um material que não está acessível, esperar a permissão do adulto para poder brincar depois de uma série de propostas conduzidas, aguardar na mesa do almoço até que todos os colegas acabem de comer para poder ir ao banheiro. Do ponto de vista subjetivo, isso ocorre na relação de interdependência que se cria com a criança nos excessos de elogios e aprovações que o adulto cria para satisfazer a criança. Isso gera uma dependência emocional que faz com que a criança só se sinta satisfeita quando o adulto consentiu com a aprovação, não percebendo o seu próprio sentimento frente à situação (TARDOS, 2008).

No outro polo, está o abandono. Nesse ponto, há um adulto indiferente, que se perde entre uma visão romantizada da criança e que supõe que ela pode dar conta de tudo ou de que ela ainda é muito nova para participar, expressar ou compreender algo. Além disso, esse adulto não cria as condições adequadas para as crianças realizarem suas próprias atividades, abandonando a criança a sua própria sorte sem fazer nenhum tipo de investimento, sem criar horizontes para ela. Essa é uma visão que não percebe que a criança se desenvolve pela sua participação nos contextos em que está inserida, e, portanto, esses contextos pressupõem interações, acesso aos instrumentos da cultura, diálogos, construção da confiança para realizar suas próprias atividades etc.

Uma alternativa a esses dois modelos pode ser encontrada nos pressupostos de Emmi Pikler e de suas companheiras de trabalho no Instituto Lóczy. Para Tardos (2008), uma das condições fundamentais para a construção da autonomia da criança está na relação adulto e criança: "a criança, para sentir desejo de atuar, para ser capaz desta aprendizagem baseada na atividade autônoma, tem a necessidade de uma relação profunda, que lhe proporcione o sentimento de segurança, condição necessária para um estado afetivo conveniente" (TARDOS, 2008, p. 51).

Assim, Tardos (2008) destaca dois níveis de impacto que a relação adulto e criança pode gerar na atividade autônoma. O primeiro nível diz respeito aos "aspectos imediatos do comportamento do adulto" (TARDOS, 2008, p. 53), ou seja, significa o adulto perceber a distinção entre os seus desejos e projeções frente aos desejos e necessidades das crianças. A 
autora toma como exemplo um bebê explorando um objeto e atento à atividade que ele mesmo iniciou, quando o adulto, pela sua necessidade em ter o bebê no colo, desvia a atenção dele chamando-o ou já o pegando em seus braços. Nesse exemplo, é importante perceber que a necessidade em ter o bebê no colo é do adulto, não da criança. É óbvio que uma das necessidades das crianças é corporal e está relacionada ao contato físico, mas não é a única. Daí que entra o segundo nível, que envolve a forma como a criança é considerada ou identificada frente ao adulto (TARDOS, 2008). Assim como já mencionei anteriormente que a imagem de criança que temos é um aspecto-chave para o modo como nos relacionamos com ela, para Tardos (2008, p. 55), aqui reside toda a estrutura que estabelecerá os códigos da relação: “a criança é nossa companheira na relação, nossa interlocutora em um diálogo. A criança não é simplesmente o objeto de nossas atenções e afetos".

Relacionar-se com a criança como nos relacionamos com outro ser humano pressupõe que ela sente, tem seus desejos e dará sinais das suas necessidades. Nosso papel, portanto, é garantir que ela se sinta capaz e sinta prazer em sua própria atividade, que tenha as condições externas adequada e que possa reconhecer no adulto um parceiro que lhe oferece segurança e tranquilidade. Esse é o desafio que faz parte da aventura em construir essa trama de relações respeitosa entre adulto e criança.

\subsubsection{As interações são o coração da Pedagogia}

Oliveira-Formosinho e Formosinho (2018) comentam que as interações são o coração da Pedagogia e o coração da Educação Infantil. Para os autores, "a visão do mundo informa toda a pedagogia da formação das crianças e dos adultos. [...] O alfa e o ômega dos processos formativos é a pessoa [...].” (OLIVEIRA-FORMOSINHO; FORMOSINHO, 2018, p. 20). Estou de acordo com os autores em sublinhar a pessoa humana como a centralidade dos processos educativos, em especial, porque isso acentua as interações como dimensão importante na construção do conhecimento, das identidades, do suporte às relações e daquilo que determina o pulsar da Pedagogia que acredita na participação e nas relações como a chave para a transformação social.

A qualidade das interações é um aspecto-chave que diferencia os modos de fazer pedagogia. Conforme Oliveira-Formosinho (2007, p. 17), a pedagogia transmissiva “[...] resolve a complexidade através da escolha unidirecional dos saberes a serem transmitidos e da delimitação do modo e dos tempos para essa transmissão, tornando neutras as dimensões que contextualizam esse ato de transmitir". Nesse modo de fazer Pedagogia, nem a compreensão 
do que representa o conhecimento e tampouco a valorização da interação entre os sujeitos e deles com o seu entorno têm lugar de relevância, isso porque a visão de mundo - que é o ponto de partida - é simplista, homogênea e previsível. Já para as pedagogias participativas,

a interatividade entre saberes, práticas e crenças, a centração nos atores como coconstrutores da sua jornada de aprendizagem em um contexto de vida e de ação pedagógica determinado, através da escuta, do diálogo e da negociação, conduzem a um modo de fazer pedagógico caleidoscópico, centrado em mundos complexos de interações e interdependências, promovendo interfaces e interações (OLIVEIRAFORMOSINHO, 2007, p. 19).

Pensar na relação do adulto com as crianças, compreendendo a interação como a centralidade da ação pedagógica, não apenas reposiciona os papéis das crianças e dos adultos, como já discutidos nos pontos anteriores, mas muda uma dada visão de mundo e de conhecimento que se coloca mais aberta e receptiva às imprevisibilidades, à negociação e à participação.

Pensar na relação entre adulto e criança é pensar em uma dimensão micro, das sutilezas do cotidiano que têm impactos profundos na formação dos meninos e meninas e, também, em uma dimensão macro, que envolve desde uma dada visão de conhecimento e de aprendizagem até uma compreensão ética (que estabelece o modo como as relações acontecem), política (no direito a participar ativamente da vida cotidiana) e estética (pela curiosidade e acolhimento ao mundo das crianças). 


\section{O ENIGMA DA VIDA}
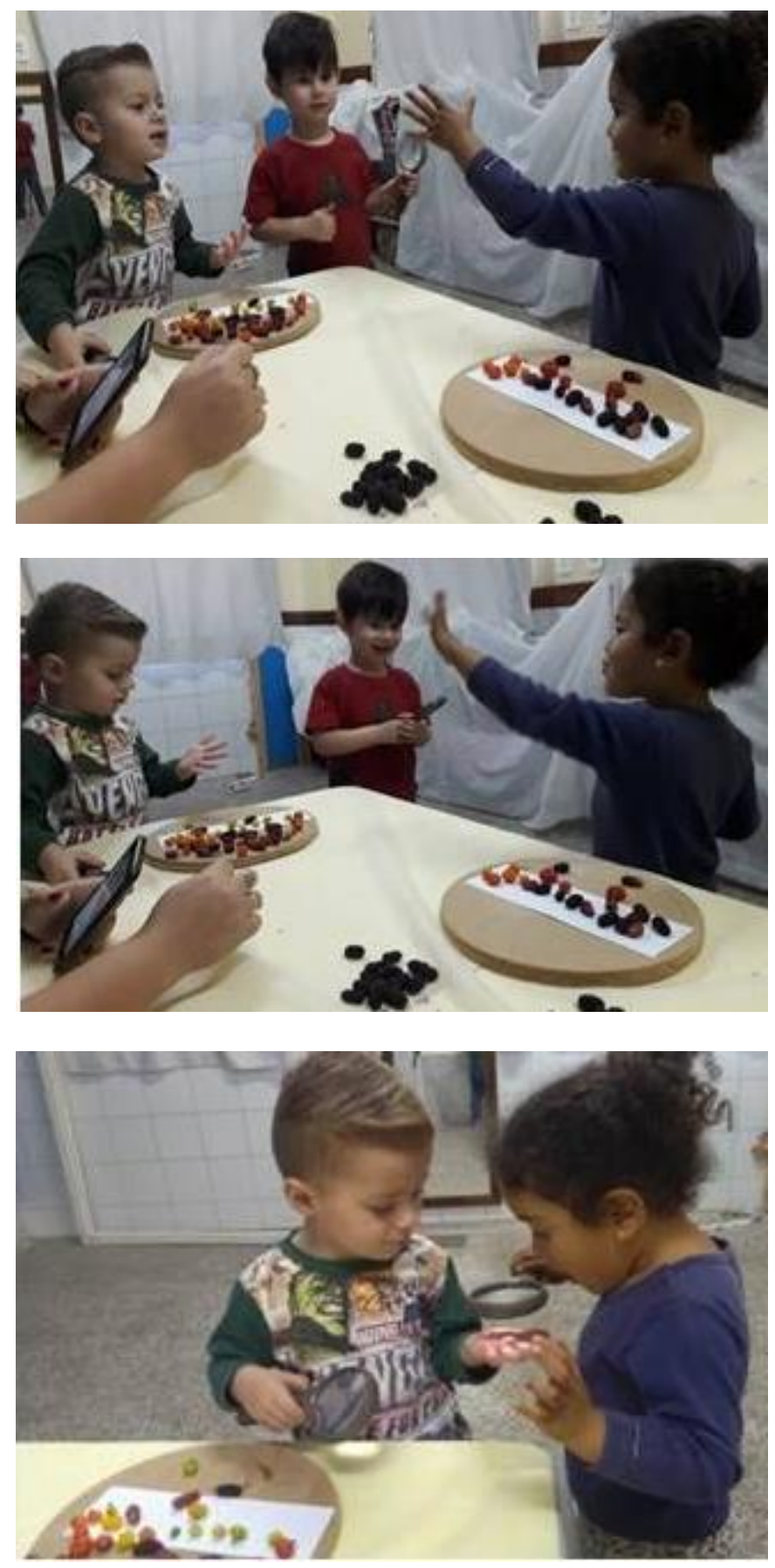

Crianças | Livia, 2 anos; Davi, 2 anos Professoras | Karin, Sissa Texto | Karin, Sissa Imagens | Karin, Sissa EMEI Joaninha
Durante a sessão, uma descoberta de Lívia contagiou o grupo. Enquanto explorava as frutas, percebeu algo diferente em sua mão. Com expressão de encantamento, voltou-se para os colegas e, em tom eufórico, disse: "Olha!" Imediatamente os olhares curiosos se fixaram naquela mão, na expectativa de saber o que havia acontecido. Lívia disse: “Pintou!".

Davi também foi checar se havia acontecido algo com sua mão. Com a lupa, Lívia vai ao encontro do amigo para ajudá-lo a desvendar o enigma. Ao descobrir que a mão do amigo também estava pintada, sua reação foi de assombro, própria de uma criança curiosa e interessada em desvendar o mundo. 


\section{CONSIDERAÇÕES FINAIS}

Olha! Exclama Lívia, surpresa por descobrir que as frutas que manipulava acabaram pintando suas mãos. Essa também poderia ser a minha exclamação na altura em que me ocupo a escrever as considerações finais desta tese, não apenas pela surpresa - e alívio - em chegar ao fim, mas pela emoção que é regressar ao trabalho escrito e perceber a jornada de aprendizagem construída.

Nas minhas incursões na obra de Malaguzzi, fui compreendendo que conhecer e aprender, além de ser uma atitude cotidiana, é uma manifestação da nossa relação com o entorno e que, por isso, conectado à aprendizagem, está o valor da surpresa e do espanto frente ao mundo. Para Malaguzzi (1988), estética é a capacidade de entrarmos em ressonância com o mundo, daí que o pedagogo costuma relacioná-la à aprendizagem, nomeando-a como uma estética do conhecer. Fazer uma tese envolve uma dada estética do conhecer, ou seja, pressupõe fazer escolhas, estabelecer relações entre as diferentes partes, conjugar vozes, dar mais força para alguns elementos que para outros, e, especialmente, dar forma (o objeto tese) ao conhecimento construído ao longo de pelo menos quatro anos.

É justamente por isso que escolhi a mini-história $O$ enigma da vida como abertura para as considerações finais, pois, inspirado pela surpresa de Livia e Davi, também quero terminar esta tese expressando o meu testemunho de uma jornada intensa de aprendizagem, quer seja como formador, quer como investigador. Dentre tantos aspectos que poderia abordar aqui, escolhi aqueles que são transversais na tese e que poderiam passar desapercebidos, a saber: o tom narrativo, as vozes da tese, a proximidade como elemento central da investigação praxiológica e a triangulação da Pedagogia.

Se aventurar em produzir uma tese distante dos domínios que conhecemos - Bruner (1997b) chama esse percurso de paradigmático ou lógico-científico - foi, sem dúvida, uma experiência necessária na afirmação do campo de conhecimento ao qual me vinculo: a Pedagogia. A escolha pela narrativa como forma de construção da realidade (BRUNER, 2001) está diretamente ligada ao compromisso subjetivo que assumo frente à investigação realizada. Cada modo de pesquisar nos obriga a fazer escolhas sobre como estruturar a textualidade que resultará da pesquisa, entendo, nesse sentido, tomando emprestado de Italo Calvino (2015, p. 75), que "escrevemos para que o mundo não escrito possa exprimir-se por meio de nós". Assim, escrever sobre a Pedagogia da formação (ou do adulto), a Pedagogia da criança e a Pedagogia da investigação desta tese me posiciona na narratividade pelo modo como se criam círculos de 
compreensão em torno do objeto de estudo e pela "preocupação com a condição humana" (BRUNER, 1997b, p. 15), que é própria da narrativa.

A investigação que dá origem à tese e ao objeto tese são testemunhos de um percurso em que se buscou compreender de que modo uma comunidade de apoio ao desenvolvimento profissional, ancorada pela estratégia da Documentação Pedagógica, pode sustentar e gerar um certo conhecimento praxiológico a partir dos processos de transformações que a própria comunidade foi provocando. Por isso, especialmente na parte III, narro a criação do OBECI para tramar a Pedagogia que o sustenta e o conhecimento praxiológico que emerge nesse Observatório. Também narro as escolhas, os conteúdos, a arquitetura de diálogos (OLIVEIRAFORMOSINHO, 2012) que fomos construindo para sustentar nossos processos de formação e a práxis das professoras nas escolas. Nesse sentido, estou de acordo com a afirmação de Bruner (1997b, p. 17), quando afirma que "a narrativa trata das vicissitudes das intenções humanas" e, com isso, ressalta que a narratividade é a melhor estratégia para acolher a atividade mental humana e sua relação com os instrumentos da cultura.

Também destaco a parte II da tese, quando reconstituo o percurso de Malaguzzi para elaborar o conceito da Documentação Pedagógica, o tom narrativo abriu espaço para que a análise dos projetos não perdesse o valor da experiência pedagógica que havia neles. Quando Bruner (1997b) sublinha as vicissitudes da intenção, recupera qualquer coisa de original da ação humana, que é agir e reagir ao mundo. A experiência das escolas municipais de Reggio Emilia, iniciadas pelo brilhante trabalho de Malaguzzi, é um marco em nossa história recente da Pedagogia exatamente porque mostra como uma comunidade se mobiliza para transformar seu entorno social depois da devastação de uma guerra. Com isso, não tenho dúvida de que jamais se "fará Reggio fora de Reggio", mas também estou certo de que é preciso honrar com o legado pedagógico que Malaguzzi deixou. A mim e ao OBECI, Malaguzzi é fonte de grande inspiração. É uma das vozes que nos ajuda a construir nossa jornada de aprendizagem e que nos impulsiona a usar de determinadas lentes teóricas para responder ao nosso entorno social. Fazer esse caminho de compreensão sobre sua obra é um modo que encontrei para contribuir com o campo da Educação Infantil e de explicitar nesta tese a construção de um dos conceitos-chave de Malaguzzi, e de que, no OBECI, nos valemos para investigar e formar, que é a Documentação Pedagógica.

Oliveira-Formosinho e Formosinho (2012) destacam que a narratividade também acolhe as diferentes vozes, os diferentes feitos e as diversas identidades, e, por isso, representa uma eleição ética de olhar os participantes da pesquisa e de preservar suas identidades. Isto 
posto, a minha escrita se situa nos domínios da narratividade, pois ao passo que constrói uma narrativa praxiológica da Pedagogia sobre os processos de transformação, abre as portas para a compreensão e o diálogo entre as diferentes vozes.

A esse respeito, destaco que um dos desafios que encontrei na escrita desta tese foi o de conciliar as vozes da tese. Pela abordagem metodológica que escolhi, a investigação praxiológica, inevitavelmente assumo diferentes vozes dentro do texto, mostrando os diferentes papéis que ocupei ao longo da pesquisa (como formador, como investigador). Também acolho, em primeira pessoa (o eu do outro), as vozes das professoras, das coordenadoras pedagógicas, das diretoras e das crianças, criando uma outra camada no texto, o que confere a ele a polifonia própria de um texto narrativo.

No entanto, o eu da tese (o meu eu, o eu das profissionais e das crianças das escolas), muitas vezes, não dava conta e, por isso, foi preciso criar o nós, que não apenas expressa a minha voz e a voz das profissionais e das crianças das escolas, mas uma nova voz. Ou seja, isso que parecia ser um problema para a gramática tradicional, constitui-se uma marca ética. Pendular entre o eu - referindo-me a minha trajetória, investida como formador e investigador e o eu das profissionais e das crianças - e o nós - referindo-me ao percurso desenvolvido no diálogo com as professoras, coordenadoras pedagógicas e diretoras das escolas dentro do OBECI - foi o modo natural que as diferentes vozes desta tese pedagógica dialogaram na construção do conhecimento praxiológico aqui apresentado.

Nesse sentido, a tese acaba por se transformar em uma terceira voz, que Pascal (apud OLIVEIRA-FORMOSINHO, 2016) refere-se como we-ness, ou seja, na soma entre a minha voz com a voz das profissionais das escolas, não apenas se conciliam as vozes, mas se cria uma nova voz que é resultado desse diálogo polifônico. Essa terceira voz, o we-ness, resulta de um processo em que a força das vozes das profissionais com a força da voz do investigador e formador criam não apenas vozes em conjunto, mas uma terceira realidade, que é a relação entre as duas vozes que agora compartilhamos e alimentamos em conjunto. O we-ness é a voz do OBECI, uma voz que se constitui pela minha voz e pela voz de cada profissional que faz parte dessa comunidade.

Tanto o tom narrativo quanto a polifonia de vozes desta tese pedagógica me parecem ser uma exigência própria da investigação praxiológica. Aliás, a esse respeito, gostaria de reforçar o papel que o pesquisador ocupa nessa forma de investigar, já que aqui reside o rigor e a ética da pesquisa. 
Como já discutido na parte I da tese, o investigador é o principal instrumento da pesquisa (FORMOSINHO, 2016) e sua proximidade com o campo é o que torna possível promover as transformações e compreender a complexa trama em que elas se dão. O duplo papel de formador e investigador, e o modo como olhei para o cotidiano que não é meu (o das escolas), mas do qual também faço parte a partir dos processos de formação que desenvolvo dentro do OBECI e que se desdobram no interior das escola, me exigiu compreender uma outra temporalidade das transformações.

Isso está melhor expresso na parte III da tese, quando não apenas anuncio o papel do pesquisador em uma investigação praxiológica (tal como na parte I), mas narro o percurso do OBECI e, ao narrá-lo, narro o percurso das escolas que o compõem. Essa evidência de um processo vivido integrado só pôde ser narrada por causa da proximidade, o que me fez crescer em compreensão sobre os processos formativos, sobre a Pedagogia e sobre a investigação, mas também me possibilitou traduzir o nosso percurso em um texto pedagógico.

É importante destacar que muitos desafios foram os que vivenciei ao longo dos seis anos da pesquisa: a dinâmica das escolas, que envolve mudança constante nos quadros funcionais, a própria movimentação de entrada, saída e permanência das instituições no OBECI, as expectativas de cada um e suas possibilidades de gerar mudança dentro das escolas em que atuam, os processos de resistência dos professores, o tempo de compreensão sobre alguns temas complexos e tantos outros desafios próprios de uma comunidade que envolve diferentes instituições. Poder acompanhar as demandas que foram aparecendo e respondê-las de alguma forma me exigiu ter uma certa intimidade suficientemente distante. Esforço que me mobilizou estar próximo, para acompanhar ${ }^{125}$ e sustentar os processos de transformação, mas, com distância, poder oferecer um olhar que ajudasse a desnaturalizar as práticas pedagógicas e o funcionamento das instituições.

Retomar essa jornada de aprendizagem desenvolvida ao longo da tese também me remeteu à triangulação da Associação Criança, que institui um modelo de investigação (a investigação praxiológica), um modelo de formação (a formação em contexto) e um modelo pedagógico (a Pedagogia-em-Participação) (OLIVEIRA-FORMOSINHO, FORMOSINHO, 2017). Essa triangulação aborda os diferentes âmbitos para o pensar, o fazer e o dizer do cotidiano pedagógico, pois trata da interatividade entre uma pedagogia do adulto, uma

125 Isso me remete ao que Hoyuelos me disse em uma conversa durante meu estágio doutoral no exterior: "só critique o que puderes acompanhar". A proximidade nos ensina a fazer uma crítica que ajuda a migrar para outros lugares cognitivos, como costuma lembrar Júlia Oliveira-Formosinho. 
pedagogia da criança e um modo de produzir o conhecimento praxiológico (que se sustenta nas crenças, valores, teorias e práticas) (OLIVEIRA-FORMOSINHO; FORMOSINHO, 2017).

Também no OBECI temos pensado a respeito disso. Ao longo da tese, explicitei (especialmente na parte III) a fundamental importância entre a aprendizagem do adulto (em seus processos de formação) e a aprendizagem da criança (na pedagogia praticada no cotidiano pedagógico por esse adulto), o que se traduz na partilha de uma visão de mundo, de homem, de aprendizagem. Quando narro os processos de formação e mostro a interatividade deles com o cotidiano pedagógico das escolas, não estou tratando de mundos opostos, mas da consequência de um dado tipo de formação (que, neste caso, é fortemente inspirado na formação em contexto) com os resultados que ele almeja: qualificar o cotidiano pedagógico das crianças e dos adultos. Logo, investigar uma práxis situada e contextualizada também requer um modelo que acolha esses processos de transformação em sua complexidade e dinamicidade, e acolha as subjetividades das crianças e dos adultos. Daí que, nesta tese pedagógica, escolho a investigação praxiológica como modelo de investigação.

Por fim, destaco que se perguntar sobre como é fazer uma tese pedagógica implicou abrir mão dos modelos de tese que faziam parte do meu repertório e apostar numa jornada intensa de aprendizagem. A construção desta tese foi um exercício de idas e regressos, de desenhos em mapas mentais, de insistência e abandono, de diálogos, de suspensão, de coragem. Mas isso me fez perceber o que significa a aventura e a desventura do aprender, e me mostrou, como sujeito aprendente e curioso que sou, a travessia que significa formar e investigar situado na Pedagogia, ou seja, de estar engajado eticamente com a vida em processo das crianças, das professoras, das coordenadoras pedagógicas e das diretoras.

O OBECI foi uma oportunidade singular na minha vida, que, além de ter se transformado em uma comunidade que apoia processos de desenvolvimento profissional e organizacional, se transformou em um lugar de luta e resistência frente às desigualdades sociais e frente aos discursos massivos que vêm ganhado espaço na educação. O OBECI é nosso espaço de voz - das crianças e dos adultos -, que recupera o passado (por meio da nossa herança teórica), que cria um presente (por meio do cotidiano pedagógico dos contextos envolvidos) e que gera um futuro (por meio do conhecimento praxiológico que temos produzido). 


\section{REFERÊNCIAS BIBLIOGRÁFICAS}

ALARCÃO, Isabel. Novas Tendências nos paradigmas em Educação. In. ALARCÃO, Isabel (org). Escola reflexiva e nova racionalidade. Porto Alegre: Artmed, 2001, p. 135 - 144.

ALTIMIR, David. Como escuchar a la infancia. Barcelona: Octaedro, 2010.

ALTIMIR, David. Escuchar para documentar. In. RED TERRITORIAL DE EDUCACIÓN INFANTIL DE CATALUÑA. Documentar la vida de los niños y las niñas en la escuela. Barcelona: Octaedro, 2011, p. 37 - 52.

AMADO, João. Manual de investigação qualitativa em educação. Coimbra: Universidade de Coimbra, 2013.

AMADO, João; FREIRE, Isabel. Estudo de caso na investigação em educação. In. AMADO, João. Manual de investigação qualitativa em educação. Coimbra: Universidade de Coimbra, 2013, p. 123-146.

ARAUJO, Sara Barros. Pedagogia em creche: da avaliação da qualidade à transformação praxiológica. Tese (Doutorado em Estudos da Criança), Instituto de Educação, Universidade do Minho. Braga, 2011.

ARCOBALENO, Escuela Maternal. En la escuela maternal: primer año, primer día, primeras anotaciones. In. REGGIO EMILIA, Escuelas Infantiles. La inteligencia se construye usándola. Madrid: Morata, 1995, p. 21-26.

ARENDT, Hanna. A condição humana. Rio de Janeiro: Forense Universitária, 2007.

BALLO, Marina. L'uso dello spazio e la relazione educatrice-bambini nella scuola materna: alcune ipotesi in rapporto al problema separazione-individuazione. In. VARIN, Dario. Ecologia psicologica e organizzazione dell'ambiente nella scuola materna. Milão: Cortina, 1991, p. 41-53.

BARBOSA, Maria Carmen Silveira. Por amor e por força: as rotinas na Educação Infantil. Porto Alegre: Artmed, 2006.

BARBOSA, Maria Carmen Silveira. Reconfiguración de las relaciones entre niños y adultos. Revista In-fan-cia, Barcelona: Rosa Sensat, n. 165, p. 5 - 8, Set / Out, 2017.

BARBOSA, Maria Carmen Silveira. Tempo e cotidiano: tempo para viver a infância. Leitura: teoria e prática, Campinas, v. 31, n. 61, p. 213 - 222, nov, 2013.

BARBOSA, Maria Carmen Silveira. Três notas sobre formação inicial e docência na Educação Infantil. In. CANCIAN, Viviane Ache; GALLINA, Simone Freitas da Silva; WESCHNFELDER, Noeli (org). Pedagogias das infâncias, crianças e docências na educação infantil. Santa Maria: Ipê amarelo, 2016, p. 131 - 139.

BARCENA, Fernando; MÈLICH, Juan. La educación como acontecimiente ético: natalidade, narración y hospitalidad. Barcelona: Paidós, 2000. 
BECKER, Fernando. Modelos Pedagógicos e Modelos Epistemológicos. Revista Educação e Realidade. 19 (1): 89-96, jan. jun. Porto Alegre: UFRGS, 1994.

BIANCHETTI, Lucídio; VALLE, Ione Ribeiro. Produtivismo acadêmico e decorrências às condições de vida/trabalho de pesquisadores brasileiros e europeus. Anais da Reunião Naiconal da ANPAE. São Paulo, 2011. Acesso disponível em $<$ http://www.anpae.org.br/simposio2011/cdrom2011/PDFs/trabalhosCompletos/comunicacoe sRelatos/0301.pdf $>$.

BOGDAN, Robert C.; BILKEN, Sari Knopp. Investigação qualitativa em educação. Porto: Porto Editora, 1994.

BONAS, Meritxell. El arte de pintos de paisajes. Algunas reflexiones en torno a la documentación. In. RTEIC. Documentar la vida de los niños y las niñas en la escuela. Barcelona: Octaedro, 2011, p. 53 - 57.

BONDIOLI, Anna. Os modos de educar. In: BECHI, Egle (Org.). Ideias orientadoras para a creche: a qualidade negociada. Campinas: Autores Associados, 2012, p. 36-43.

BONDIOLI, Anna. Prólogo. In. BONDIOLI, Anna; NIGITO, Gabriella (coords.). Tiempos, espacios y grupos: el análisis y la evaluación de la organización en la escuela infantil: DAVOPSI. Barcelona: Graó, 2011, p. 17 - 18.

BONDIOLI, Anna; MANTOVANI, Susanna. Introdução. In: BONDIOLI, Anna; MANTOVANI, Susanna (Org.). Manual de educação infantil: de 0 a 3 anos. Porto Alegre: Artmed, 1998.

BONDIOLI, Anna; SAVIO, Donatella. Elaborar indicadores de qualidade educativa das instituições de Educação Infantil: uma pesquisa compartilhada entre Itália e Brasil. In. SOUZA, Gisele de; MORO, Catarina; COUTINHO, Angela S. Formação da rede em Educação Infantil: avaliação de contexto. Curitiba: Appris, 2015. p. 21 - 49.

BONILAURI, Simona; DESTEFANI, María Pia. Ojos vivos sobre la ciudad. In. REGGIO EMILIA, Escuelas Infantiles. La inteligencia se construye usándola. Madrid: Morata, 1995, p. 68-85.

BORGHI, Battista Quinto. Diana: la scuola dellinfanzia più bella del mondo. In. FRABBONI, Franco; BORGHI, Battista Quinto. Loris Malaguzzi e la scuola a nuovo indirizzo. San Paola d'Argon: Zeroseiup, 2017, p. 41-63.

BORGHI, Battista Quinto. Loris Malaguzzi e la documentazione: il diario di sezione nei primi anni delle scuole dell'infanzia di Modena. In. MANTOVANI, Susanna. Nolstalgia del futuro: liberare speranze per una nueva cultura dell'infanzia. Reggio Emilia: Edizioni Junior, 1998, p. 185-196.

BRANZI, Andrea. Educação e espaço relacional. In. CEPPI, Giulio; ZINI, Michele (org). Crianças, espaços, relações: como projetar ambientes para a educação infantil. Porto Alegre: Penso, 2013, p. 129 - 135.

BRASIL. Conselho Nacional de Educação (CNE). Câmara de Educação Básica (CEB). Parecer CNE/CEB $n^{\circ}$ 20, de 11 de novembro de 2009. Revisão das Diretrizes 
Curriculares Nacionais para a Educação Infantil. Diário Oficial da União, Brasília, 9 dez. 2009a. Seção 1, p. 14.

BRASIL. Ministério da Educação. Diretrizes Curriculares Nacionais para educação infantil. Brasília: MEC, 2010.

BROUGÈRE, Gilles. Vida cotidiana e aprendizagens. In. BROUGÈRE, Gilles; ULMANN, Anne-Lise. Aprender pela vida cotidiana. Campinas: Autores Associadas, 2012, p. $11-24$.

BROUGÈRE, Gilles; ULMANN, Anne-Lise. Sair das sombras: as aprendizagens cotidianas. In. BROUGÈRE, Gilles; ULMANN, Anne-Lise. Aprender pela vida cotidiana. Campinas: Autores Associadas, 2012, p. $01-10$.

BRUNER, Jerome. A cultura da Educação. Porto Alegre: Artmed, 2001.

BRUNER, Jerome. La educación, puerta de la cultura. Madrid: Aprendizaje Visor, 1997a.

BRUNER, Jerome. Realidade Mental, mundos possíveis. Porto Alegre: Artes Médicas, 1997b.

BRUNER, Jerome. Sobre a teoria da instrução. São Paulo: Phorte, 2006.

BRUNER, Jerome. Sobre o conhecimento: ensaios da mão esquerda. São Paulo: Phorte, 2008.

CABANELLAS, Isabel et al; Ritmos infantiles: tejidos de un paisaje interior. Barcelona: Octaedro, 2007.

CABANELLAS, Isabel; ESLAVA, Clara (org). Territórios de la infancia: diálogos entre arquitectura y pedagogia. Barcelona: Graó, 2005.

CAGGIO, Francesco. La scuola come luogo dei bambini. Bambini, n. 8, p. 28-34, Reggio Emilia: Edizioni Junior, 1998.

CAGLIARI, Paola et al. Loris Malaguzzi y las escuelas de Reggio Emilia. Madrid: Morata, 2017.

CALVINO, Italo. Mundo escrito e mundo não escrito: escritos, esboços e conferências. São Paulo: Companhia das Letras, 2015.

CAMPOS, Ana Paula. Inventório - processos de design na divulgação científica para crianças: estudo de caso de livro informativo. Dissertação (Mestrado em Arquitetura e Urbanismo) Faculdade de Arquitetura e Urbanismo da Universidade de São Paulo, São Paulo, 2016.

CARVALHO, Rodrigo Saballa de; FOCHI, Paulo Sérgio O muro serve para separar os grandes dos pequenos: narrativas para pensar uma pedagogia do cotidiano na Educação Infantil. Textura, Canoas, v.18, n.36, p.153-170, Jan / Abr, 2016. 
CASTAGNETTI, Marina et al. La aventura de aprender. In. REGGIO CHILDREN. El zapato y el metro: los niños y la medida, primera aproximación al descubrimiento, a la función y al uso de la medida. Barcelona: Octaedro, 2005, p. 66 - 70.

CATARSI, Enzo. As competências relacionais do professor na escola do acolhimento. In. STACCIOLI, Gianfranco. Diário do acolhimento na escola da infância. Campinas: Autores Associados, 2013, p. 7-12.

CEPPI, Giulio; ZINI, Michele. Crianças, espaços, relações: como projetar ambientes para a educação infantil. Porto Alegre: Penso, 2013.

CIARI, Bruno. As novas técnicas didácticas. Lisboa: Editora Estampa, 1978.

COCHRAN-SMITH, Marilyn; LYTLE, Susan L. Dentro/Fuera: enseñantes que investigam. Madrid: Akal, 2002.

COELHO, Rita de Cassia de Freitas. Prefácio. In.: FLORES, Maria Luiza Rodrigues; ALBUQUERQUE, Simone Santos de. Implementação do Proinfância no Rio Grande do Sul: perspectivas políticas e pedagógicas. Porto Alegre: EDIPUCRS, 2015, p. 7 - 8.

COMELLES, Teresa Huguet. Prólogo a la edición española. In. BONDIOLI, Anna; NIGITO, Gabriella (coords.). Tiempos, espacios y grupos: el análisis y la evaluación de la organización en la escuela infantil: DAVOPSI. Barcelona: Graó, 2011, p. 13-16.

CONTRERAS, José Domingo. Pedagogías de la experiencia y la experiencia de la pedagogía. In. CONTRERAS, José Domingo; FERRÉ, Nuria Perez de Lara (org). Investigar la experiência educativa. Madrid: Morata, 2010, p. $241-271$.

CRAFT, Anna; PAIGE-SMITH, Alice. O que é refletir sobre a prática. In. CRAFT, Anna; PAIGE-SMITH, Alice (org). O desenvolvimento da prática reflexiva na educação infantil. Porto Alegre: Artmed, 2010, p. 33 - 46.

DAHLBERG, Gunila; MOSS, Peter; PENSE, Alan. Qualidade na educação da primeira infância: perspectivas pós-modernas. Porto Alegre: Artmed, 2003.

DAHLBERG, Gunilla. Documentação pedagógica: uma prática para a negociação e a democracia. In. EDWARDS, Carolyn; GANDINI, Lella; FORMAN, George. As cem linguagens da criança: A experiência de Reggio Emilia em transformação. v. 2. Porto Alegre: Penso, 2016, p. $229-234$.

DAL-RI, Marcelly. Intervenções no espaço da educação infantil: um olhar sobre o papel do adulto. Trabalho de Conclusão de Curso (Licenciatura em Pedagogia, Universidade do Vale do Rio dos Sinos - Unisinos), 88f., São Leopoldo, 2016.

DAVID, Mirian; APPEL, Geneviéve. Lóczy, una insólita atención personal. Barcelona: Ocatedro, 2010.

DAVOLI, Mara. Documentar processos, recoger señales. In. RED TERRITORIAL DE EDUCACIÓN INFANTIL DE CATALUÑA. Documentar la vida de los niños y las niñas en la escuela. Barcelona: Octaedro, 2011, p. 15 - 26. 
DAVOLI, Mara. Entrevista sobre documentação pedagógica [nov. 2017], gravação digital. Entrevista concedida a Paulo Fochi, Reggio Emilia, 2017.

DE DUVE, Therry. Cinco reflexões sobre o julgamento estético. Revista Porto Arte, Porto Alegre, v.16, n. 27, p. 43-65, 2009.

DELEUZE, Gilles. Conversações. Rio de Janeiro: Ed 34, 1992.

DEWEY, John. A escola e a sociedade e a criança e o currículo. Lisboa: Relógio D’água, 2002.

DEWEY, John. Experiência e Educação. Petrópolis, Rio de Janeiro: Vozes, 2010.

DOLCI, Mariano. Afinando la vista para captar los momentos. In. RED TERRITORIAL DE EDUCACIÓN INFANTIL DE CATALUÑA. Documentar la vida de los niños y las niñas en la escuela. Barcelona: Octaedro, 2011, p. 27 - 36.

ECO, Umberto. Como se faz uma tese. São Paulo: Perspectiva, 2008.

ECO, Umberto. O google é uma tragédia para os jovens. 2009. Disponível em <http://www.vermelho.org.br/noticia.php?id_noticia=119398\&id_secao=11> Acesso em $10 \mathrm{de}$ novembro de 2018.

ECO. Umberto. A vertigem das listas. Rio de Janeiro: Record, 2010.

EDWARD, Carolynn et al. Students learn about education throughout their teacher education program. Early Childhood Research and Practice, v.9, n. 2, 2007, p. 1 - 27.

EDWARDS, Carolyn; GANDINI, Lella; FORMAN, George. As cem linguagens da criança. Porto Alegre: Artes Médica, 1999.

EDWARDS, Carolyn; GANDINI, Lella; NIMMO, John. Promoting Collaborative Learning in the Early Childhood Classroom: Reggio Emilia, Italy, and Amherst, Massachusetts. IN In KATZ, Lilian; CESARONE, Bernard (eds). Reflections on the Reggio Emilia Approach. Perspectives from ERIC/EECE: A Monograph Series, n. 6. Pennsylvania: Urbana ERIC Clearinghouse, 1994, p. 81-104.

EDWARDS, Carolyn; RINALDI, Carla. The diary of Laura: perspectives on a Reggio Emilia Diary. St. Paul: Redleaf Press, 2009.

ERICKSON, Frederic. Prefácio. In. COCHRAN-SMITH, Marilyn; LYTLE, Susan L. Dentro/Fuera: enseñantes que investigam. Madrid: Akal, 2002, p. 9 - 12.

FILIPPINI, Tiziana et al. A equipe de coordenação pedagógica e o desenvolvimento profissional. In. EDWARDS, Carolyn; GANDINI, Lella; FORMAN, George. As cem linguagens da criança: A experiência de Reggio Emilia em transformação. v. 2. Porto Alegre: Penso, 2016, p. 143 - 152.

FILIPPINI, Tiziana. O papel do Pedagogista. EDWARDS, Carolyn; GANDINI, Lella; FORMAN, George. As cem linguagens da criança. Porto Alegre: Artes Médica, 1999, p. 123127. 
FOCHI, Paulo (org). O Brincar Heurístico na creche: percursos pedagógicos no Observatório da Cultura Infantil - OBECI. Porto Alegre: Paulo Fochi Estudos Pedagógicos, 2018.

FOCHI, Paulo Sergio. "Mas os bebês fazem o quê no berçário, heim?": documentando ações de comunicação, autonomia e saber-fazer de crianças de 6 a 14 meses em um contexto de vida coletiva. Dissertação (Mestrado em Educação), Programa de PósGraduação em Educação, Universidade Federal do Rio Grande do Sul, Porto Alegre, 2013.

FOCHI, Paulo Sergio. A didática dos campos de experiência. Revista Pátio Educação Infantil, Porto Alegre, n. 49, p. 4-7, Out / Dez, 2016 a.

FOCHI, Paulo Sergio. Abordagem da documentação pedagógica na investigação praxiológica de contextos de Educação Infantil. Qualificação de tese (Doutorado em Educação), Faculdade de Educação, Universidade de São Paulo, São Paulo, 2017.

FOCHI, Paulo Sergio. Afinal, o que os bebês fazem no berçário? Comunicação, autonomia e saber-fazer de bebês em um contexto de vida coletiva. Porto Alegre: Penso, 2015a.

FOCHI, Paulo Sergio. Observatório da Cultura Infantil: a documentação pedagógica como mote de formação de professores. Revista Sensos - INED, Porto, v.I, n.1, p. 83-108, $2016 b$.

FOCHI, Paulo Sergio. Planejar para tornar visível a intenção educativa. Revista Pátio Educação Infantil, Porto Alegre, n. 45, p. 4 - 7, Out / Dez, 2015 b.

FOCHI, Paulo Sergio. Será que um dia os arco-íris terão cores? In: GAI, Daniele Noal; FERRAZ, Wagner. Parafernálias II: currículo, cadê a poesia. Porto Alegre: Indpein, 2014. p. 98-111.

FOCHI, Paulo. Documentação Pedagógica: uma possibilidade metodológica caderno 2. Brasília: MEC / UNESCO, 2019.

FOCHI, Paulo. Sobre os mundos possíveis. In. HOLM, Anna Marie. Eco-Arte com crianças. São Paulo: Ateliê Carambola, 2015d, p. 6 - 7.

FOLQUE, Maria Assunção; BETTENCOURT, Marta. O modelo Pedagógico do Movimento da Escola Moderna em creche. In. OLIVEIRA-FORMOSINHO, Júlia; ARAÚJO, Sara Barros. Modelos pedagógicos para a Educação em Creche. Porto: Porto Editora, 2018, p. 113-138.

FORMAN, George. Helping children ask good questions. In. NEUGENBAUER, BONIE. The wonder of it: exploring how the word works. Redmond: Exchange Press, 1989, p. 21-25.

FORMAN, George. Múltipla simbolização no projeto do Salto em distância. In. EDWARDS, Carolyn; GANDINI, Lella; FORMAN, George. As cem linguagens da criança. Porto Alegre: Artes Médica, 1999, p. 176-193.

FORMAN, George; GANDINI, Lella; WINNER, Ellen; PUFALL, Peter. La inteligencia se despierta usándola: El Salto de longitud: una experiencia de investigacion de 
niños y adultos cuidadosamente registrada y documentada. In. REGGIO EMILIA, Escuelas Infantiles. La inteligencia se construye usándola. Madrid: Morata, 1995, p. 141-161.

FORMAN, George; LEE, Moonja; WRISLEY, Linda; LANGLEY, Joan. A cidade na neve - aplicação da abordagem multissimbólica em Massachusetts. In. EDWARDS, Carolyn; GANDINI, Lella; FORMAN, George. As cem linguagens da criança. Porto Alegre: Artes Médica, 1999, p. 235-252.

FORMAN, Geroge; FYFE, Brenda. Aprendizagem negociada pelo design, pela documentação e pelo discurso. In. In. EDWARDS, Carolyn; GANDINI, Lella; FORMAN, George. As cem linguagens da criança: A experiência de Reggio Emilia em transformação. v. 2. Porto Alegre: Penso, 2016, p. 249 - 272.

FORMOSINHO, João. A formação prática de professores: da prática docente na instituição de formação à prática pedagógica nas escolas. In: CAMPOS, Bartolo. (Org.). Formação profissional de professores no ensino superior. Porto: Porto Editora, 2001. p. 4664.

FORMOSINHO, João. Estudando a praxis educativa: o contributo da investigação praxeológica. Revista Sensos. v. I, n.1, p. 15-38, Porto: INED, 2016.

FORMOSINHO, João. O Currículo Uniforme Pronto a Vestir de Tamanho Único. In. Cadernos de Análise Social da Educação: O Insucesso Escolar em Questão. p. 41-50. Braga: Universidade do Minho, 1987.

FORMOSINHO, João. Prefácio. A educação em Creche: o desafio das pedagogias com nome. In. OLIVEIRA-FORMOSINHO, Julia; ARAÚJO, Sara (org). Modelos pedagógicos para a Educação em Creche. Porto: Porto Editora, 2018, p.7 - 28.

FORMOSINHO, João. Prefácio. OLIVEIRA-FORMOSINHO, Julia (org). Modelos pedagógicos para a Educação de Infância: construindo uma práxis de participação. Porto: Porto Editora, 2013, p.9- 24.

FORMOSINHO, João; MACHADO, Joaquim. A pedagogia burocrática como pedagogia oficial do sistema escola. ProfMat - Atas, 20 anos de encontros. Evora, p. 1 - 12, 2005.

FORMOSINHO, João; OLIVEIRA-FORMOSINHO, Julia; MONGE, Graciete. Introdução. In. FORMOSINHO, João; OLIVEIRA-FORMOSINHO, Julia; MONGE, Graciete (org). Transições entre ciclos educativos: uma investigação praxeológica. Porto: Porto Editora, 2016, p.09- 15.

FORTUNATI, Aldo. A observação como instrumento para conhecer, contar e refletir. Revista Pátio Educação Infantil, Porto Alegre, ano X, p. 4-7, Jan / Mar, 2012.

FRABBONI, Franco; BORGHI, Battista Quinto. Loris Malaguzzi e la scuola a nuovo indirizzo. San Paola d'Argon: Zeroseiup, 2017.

FRANCESCH, Joan Domènech. Elogio de la educación lenta. Barcelona: Graó, 2009. 
FREIRE, Paulo. Educação e mudança. 2a ed. Rio de Janeiro: Paz e Terra, 1979.

FRONZA, André Luiz; BLUM, Ariana; LIMA, Mary Vonni Meüer. Recomendações sobre design informacional aplicado em motion graphics. Revista brasileira de design da informação. São Paulo, v. 11, n. 1, p. 50 - 63, 2014.

GALARDINI, Ana Lia. Participación. Barcelona: Octaedro, 2017.

GAMBETTI, Amelia. O professor observador: a observação como uma ferramenta recíproca do desenvolvimento profissional. Entrevista concedida a Lella Gandini. In. EDWARDS, Carolyn; GANDINI, Lella; FORMAN, George. As cem linguagens da criança: A experiência de Reggio Emilia em transformação. v. 2. Porto Alegre: Penso, 2015, p. 175 186.

GANDINI, Lella, The amusement Park for Birds: emergence and process of a Project. In. GANDINI, Lella; HILL, Lynn; CADWELL, Louise; SCHWALL, Charles. In the Spirit of the Studio: learning from the Atelier of Reggio Emilia. New York: teachers College, 2015, p, $23-41$.

GANDINI, Lella; GOLDHABER, Jeanne. Duas reflexões sobre a documentação. In: EDWARDS, Carolyn; GANDINI, Lella. Bambini: a abordagem italiana à educação infantil. Porto Alegre: Artmed, 2002, p. $150-169$.

GARIBOLDI, Antonio. El espacio y su organizacion. In. BONDIOLI, Anna; NIGITO, Gabriella (coords.). Tiempos, espacios y grupos: el análisis y la evaluación de la organización en la escuela infantil: DAVOPSI. Barcelona: Graó, 2011, p. 99 - 120.

GODAL, Teresa. Movimiento libre y entorno óptimos. Reflexiones a partir de un estudio con bebés. Revista Latinoamericana de Educación Infantil, Santiago de Compostela, v. 5, n. 3, p. 87-97, septiembre, 2016.

GODOI, Lidia. Práticas educativas entre pares: estudo do trabalho diário de professoras em um centro de educação infantil paulistano. Dissertação (Mestrado em Educação) Faculdade de Educação, Universidade de São Paulo, São Paulo, 2015

GOLDSCHMIED, Elinor. I rapporti tra famiglia e nido. Zerosei, Reggio Emilia, n. 11, p. 4-6, giugno, 1981.

GOLDSCHMIED, Elinor; JAKSON, Sonia. Educação de 0 a 3 anos: o atendimento em creche. Porto Alegre: Artmed, 2006.

GOMES, Marta Quintanilha. Trilhas profissionais na educação infantil: os sentidos atribuídos ao lugar de atuação pelas professoras da rede municipal de ensino de Porto Alegre. Tese (Doutorado em Educação), Programa de Pós-Graduação em Educação, Universidade Federal do Rio Grande do Sul, Porto Alegre, 2012.

GOODSON, Ivor. Currículo, narrativa e futuro social. Revista Brasileira de Educação. v. 12, n. 35, p. 241 - 257, mai/ago. 2007 b.

GOODSON, Ivor. Políticas do conhecimento: vida e trabalho docente entre saberes e instituições. Goiania: Cegraf, 2007a. 
HARGREAVES, Andy. Os professores em tempos de mudança: $O$ trabalho e a cultura dos professores na idade Pós-moderna. Lisboa: MacGraw \&Hill, 1998.

HAWKINS, David. A história de Malaguzzi, outras histórias e o respeito pelas crianças. In. EDWARDS, Carolyn; GANDINI, Lella; FORMAN, George. As cem linguagens da criança: A experiência de Reggio Emilia em transformação. v. 2. Porto Alegre: Penso, 2015, p. $88-94$.

HOHMANN, Mary; WEIKART, David. Educar a criança. Lisboa: Fundação Calouste Gulbenkiam, 2011.

HORN, Maria da Graça Souza. Brincar e interagir nos espaços da escola infantil. Porto Alegre: Penso, 2017.

HORN, Maria da Graça Souza. Sabores, cores, sons, aromas: a organização dos espaços na educação infantil. Porto Alegre: Artmed, 2004. 2004.

HOUSSAYE, Michel et al. Manifesto a favor dos pedagogos. Porto Alegre: Artmed,

HOYUELOS, Alfredo. Cada uno cresce solo se es soñado. In. VECCHI, Vea. Arte y creatividad en Reggio Emilia: el papel de los talleres y sus possibilidades en educación infantil. Madrid: Morata, 2013, p. 11 - 32.

HOYUELOS, Alfredo. Documentación como narración y argumentación. Revista Aula de Infantil. n. 39, 2007. p. 1-4, Barcelona: Graó, 2007.

HOYUELOS, Alfredo. Entre ciencia y arte: la relación dialógica professional con los niños y las niñas. Revista In-fan-cia, Barcelona: Rosa Sensat, n. 164, P. 9 - 18, jul/ ago, 2017.

HOYUELOS, Alfredo. La complejidad en el pensamiento y obra de Loris Malaguzzi. Mexico: Multimedios, 2003

HOYUELOS, Alfredo. La escuela, ámbito estética educativo. In. CABANELLAS, Isabel; ESLAVA, Clara (org). Territórios de la infancia: diálogos entre arquitectura y pedagogia. Barcelona: Graó, 2005, p. 168 - 175.

HOYUELOS, Alfredo. La estética en el pensamiento y obra de Loris Malaguzzi. Barcelona: Octaedro, 2006.

HOYUELOS, Alfredo. La ética en el pensamiento y obra de Loris Malaguzzi. Barcelona: Octaedro, 2004b.

HOYUELOS, Alfredo. Las imágenes fotograficas como documentacion narrativa. Revista In-fan-cia, Barcelona: Rosa Sensat, n. 133, mai / jun, p. 4-11, 2012.

HOYUELOS, Alfredo. Loris Malaguzzi: biografia pedagogica. Azzano Sao Paolo: Edizioni Junior, 2004a.

HOYUELOS, Alfredo. Prefácio: Tempo de Silêncio. In. FOCHI, Paulo. Afinal, o que os bebês fazem no berçário? Comunicação, autonomia e saber-fazer de bebês em um contexto de vida coletiva. Porto Alegre: Penso, 2015, p. 15 - 22. 
ISAACS, Susan. Lo sviluppo sociale del bambini. Firenze: Nuova Itália, 1973.

JOHNSON, David W.; JOHNSON, Roger T. Learning together an alone: cooperative, competitive and individualistic learning. Asia Pacific Journal of Education. Boston, v. 22, n.1. p. 95-105, 2002.

KISHIMOTO, Tizuko Morchida, PINAZZA, Mônica Appezzato. Froebel: uma pedagogia do brincar para infância. In: OLIVEIRA-FORMOSINHO, Julia; KISHIMOTO, Tizuko Morchida; PINAZZA, Mônica Appezzato (org). Pedagogia(s) da infância: dialogando com o passado: construindo o futuro. Porto Alegre: Artmed, 2007, p. 13 - 36.

KISHIMOTO, Tizuko Morchida. Um estudo de Caso no Colégio D. Pedro V. In. OLVEIRA-FORMOSINHO, Julia; KISHIMOTO, Tizuko Morchida Formação em contexto: uma estratégia de integração. São Paulo: Pioneira Thomson Learning, 2002, p. 153 - 202.

KNÖPKER, Mônica. Fazendo o neoliberalismo funcionar 'dentro de nós': um estudo sobre a atuação de organizações da sociedade civil sem fins lucrativos na forma(ta)ção docente. Tese (Doutorado em Educação), Programa de Pós-Graduação em Educação, Universidade Federal do Rio Grande do Sul, Porto Alegre, 2018.

KOLB, Donald. Experiential learning. Englewood Cliffs, New Jersey: Prentice Hall, 1984.

KRECHEVSKY, Mara; MARDEL, Ben. Quattro Caratteristiche dei grupppi di apprendimento. In. REGGIO CHILDREN; PROJECT ZERO. Rendere visibile l'apprendimento: bambini che apprendono individualmente e in grupo. Reggio Emilia: Reggio Children, 2009.

LAEVERS, Ferre. Fundamentos da educação experiencial: bem estar e envolvimento na educação infantil. Estudos em Avaliação Educacional, São Paulo, v. 25, n. 58, p. 152-185, maio/ago. 2014.

LAREDO, Carlos. La mirada exilada de los niños. Las puertas del drama. Associación de Autores de Teatro, Madrid, n. 14, p. 16-25, set / dez, 2003.

LITTLE, Judith. Teachers as colleagues. In. RICHARDSON-KOEHLER, Virginia (ed). Educators' handbook. New York: Longman, 1987, p. 491 - 518.

LORENZONI, Ombretta; BORGHI, Ettore; CANOVI, Antoni. Una storia presente: l'esperienza della scuole comunali dell'infanzia a Reggio Emilia. Reggio Emilia: RSLibri, 2001.

MAJEM, Tere; ODENA, Pepa. Descobrir brincando. Campinas: Autores Associados, 2010.

MALAGUZZI, Loris. L'ombra e il pallottoliere dei bambini. In. REGGIO CHILDREN. Tutto ha un ombra meno le formiche. Reggio Emilia: Reggio Children, 1999, p. $24-29$. 
MALAGUZZI, Loris. Borrador para un discurso sobre la sonda de investigación-ación (1988). In. CAGLIARI, Paola et al. Loris Malaguzzi y las escuelas de Reggio Emilia. Madrid: Morata, 2017, p. 365 - 380.

MALAGUZZI, Loris. Carta al alcalde, al assessore de las escuelas y al ingeniero jefe de la municipalidad (1969b). In. CAGLIARI, Paola et al. Loris Malaguzzi y las escuelas de Reggio Emilia. Madrid: Morata, 2017, p. 159.

MALAGUZZI, Loris. Commentari: per un codice di lettura della mostra. In. COMUNE DI REGGIO EMILIA. L'occhio se salta il muro: narrativa del possibile. Proposte di bambini delle scuole comunali dell'infanzia di Reggio Emilia. Reggio Emilia: COMUNE DI REGGIO EMILIA, 1984, p. 20 - 25.

MALAGUZZI, Loris. El "qué podemos hacer" de los adultos. In. REGGIO CHILDREN. Las fuentes: a partir de un proyecto de construcción de un parque de atracciones para pajáros. Barcelona: Octaedro, 2006c, p. 13 - 15.

MALAGUZZI, Loris. El cuento de los peces con los niños del cine mudo. In. REGGIO CHILDREN. Los pequeños del cine mudo: juegos en la escula infantil entre niños y peces. Barcelona: Octaedro, 2004a, p. $9-11$.

MALAGUZZI, Loris. El juego de "qué podemos hacer". In. REGGIO CHILDREN. Las fuentes: a partir de un proyecto de construcción de un parque de atracciones para pajáros. Barcelona: Octaedro, 2006b, p. $11-12$.

MALAGUZZI, Loris. El zapato y el metro. In. REGGIO CHILDREN. El zapato y el metro: los niños y la medida, primera aproximación al descubrimiento, a la función y al uso de la medida. Barcelona: Octaedro, 2005b, p. $10-11$.

MALAGUZZI, Loris. Experiencias educativas con niños de 4 y 5 años (1969a). In. CAGLIARI, Paola et al. Loris Malaguzzi y las escuelas de Reggio Emilia. Madrid: Morata, 2017, p. $150-158$.

MALAGUZZI, Loris. Experiencias en las Scuole dellInfanzia. Consejos esculaciudad. Documento 1 - Modena (1969c). In. CAGLIARI, Paola et al. Loris Malaguzzi y las escuelas de Reggio Emilia. Madrid: Morata, 2017, p. 159 - 164.

MALAGUZZI, Loris. História, ideias e princípios básicos: uma entrevista com Loris Malaguzzi. Entrevista concedida a Lella Gandini. In. EDWARDS, Carolyn; GANDINI, Lella; FORMAN, George. As cem linguagens da criança: a experiência de Reggio Emilia em transformação. v.2, Porto Alegre: Penso, 2016, p. 23 - 44.

MALAGUZZI, Loris. Juegos con la sombra. In. REGGIO CHILDREN. Los cien linguajes de la infáncia. Barcelona: Rosa Sensat, 2005c, p. 118 - 119.

MALAGUZZI, Loris. Juegos con la sombra. In. REGGIO CHILDREN. Los cien linguajes de la infáncia. Barcelona: Rosa Sensat, 2005c, p. 118 - 119.

MALAGUZZI, Loris. La ciudad y la lluvia: los niños, la ciudad y la lluvia. In. REGGIO CHILDREN. Los cien linguajes de la infáncia. Barcelona: Rosa Sensat, 2005a, p. $78-87$. 
MALAGUZZI, Loris. La educación del niño desde los 3 a los 6 anõs (1967). In. CAGLIARI, Paola et al. Loris Malaguzzi y las escuelas de Reggio Emilia. Madrid: Morata, 2017, p. $138-146$.

MALAGUZZI, Loris. La educacion infantil en Reggio Emilia. Barcelona: Octaedro, 2001

MALAGUZZI, Loris. La idea del parque de atracciones para pájaros y de las fuentes. In. REGGIO CHILDREN. Las fuentes: a partir de un proyecto de construcción de un parque de atracciones para pajáros. Barcelona: Octaedro, 2006a, p. 9 - 10.

MALAGUZZI, Loris. La inteligencia se despierta usándola: "El salto de longitud" una experiencia de investigación de niños y adultos cuidadosamente registrada y documentada. In. REGGIO EMILIA, Escuelas Infantiles. La inteligencia se construye usándola. Madrid: Morata, 1995, p. 141-143.

MALAGUZZI, Loris. Lo visible y lo invisible en la interacción entre los niños. In. REGGIO CHILDREN. Los pequeños del cine mudo: juegos en la escula infantil entre niños y peces. Barcelona: Octaedro, 2004b, p. $12-14$.

MALAGUZZI, Loris. No hay nada qué hacer. Los cien está aquí (s/d). In. CAGLIARI, Paola et al. Loris Malaguzzi y las escuelas de Reggio Emilia. Madrid: Morata, 2017, p. 292 293.

MALAGUZZI, Loris. Procedimiento para pasar de un león a otro león. In. REGGIO CHILDREN. Los cien linguajes de la infáncia. Barcelona: Rosa Sensat, 2005d, p. 54 - 57.

MALAGUZZI, Loris. Resumem de la conferencia realizada por Malaguzzi en la reunión de profesores de las escuelas municipales (1972). In. CAGLIARI, Paola et al. Loris Malaguzzi y las escuelas de Reggio Emilia. Madrid: Morata, 2017, p. 207 - 2014.

MALAGUZZI, Loris. Scuole Materne Comunali: una pedagoía a la par con lons niños de nuestro tiempo (1968). In. CAGLIARI, Paola et al. Loris Malaguzzi y las escuelas de Reggio Emilia. Madrid: Morata, 2017, p. 147 - 149.

MALVASI, Laura; ZOCCATELLI, Barbara. Documentar os projetos nos serviços educativos. Lisboa: APEI, 2013.

MANTOVANI, Susanna; PERANI, Rita. Uma Profissão a ser Inventada: o educador da primeira infância. Pro-Posições, Campinas, v. 10, n. 1, p. 75-98, 1999.

MARQUES, Franciele de Menighi. Currículo narrativo: uma possibilidade para olhar a creche como contexto de vida coletiva. Trabalho de Conclusão de Curso (Licenciatura em Pedagogia, Universidade do Vale do Rio dos Sinos - Unisinos), 65f., São Leopoldo, 2016. Paulo, 2012.

MATA Juan. Conferência: a narratividade e as linguagens, gravação digital. São

MEIRIEU, Phillipe. Recuperar la pedagogía: de lugares comunes a conceptos claves. Buenos Aires: Paidós, 2016. 
MORIN, Edgar. A cabeça bem feita: repensar a reforma, reformar o pensamento. Rio de Janeiro: Bertrand Brasil, 2017.

MORIN, Edgar; ROGER, Emilio C.; DOMINGO, Raul. Educar em la era planetária. El pensamento complejo como método de aprendizaje em el error y la incertitumbre humana. Salamanca: Unesco, 2002.

MORSCHEL, Rosangela. Crianças que contam histórias: possibilidades para pensar a ação pedagógica na educação infantil. Trabalho de Conclusão de Curso (Licenciatura em Pedagogia, Universidade do Vale do Rio dos Sinos - Unisinos), 89f., São Leopoldo, 2016.

MOSS, Peter. Microprojeto e macropolitica: aprendizagem por meio de relações. In. EDWARDS, Carolyn; GANDINI, Lella; FORMAN, George. As cem linguagens da criança: a experiência de Reggio Emilia em transformação. v.2, Porto Alegre: Penso, 2016, p. 113 124.

NICHOLSON, Simon. The teory of Loose parts: an important principle for design methodology. Studies In Design Education Craft \& Technology. v.4, n.2, p. 5 - 14. Open University, 1972.

NIGITO, Gabriella. Por una pedagogía de la temporalidad. In. BONDIOI, Anna; NIGITO, gabriela (coords). Tiempos, espacios y grupos: El análisis y la evaluación de la organización en la escuela infantil: DDAVOPSI. Barcelona: Graó, 2011, p. 73 - 98.

NIGITO, Gabriella. Tempos institucionais, tempos de crescimento: a gestão do cotidiano dos pequenos, dos médios e dos grandes na creche. In. BONDIOI, Anna (org). $\mathbf{O}$ tempo no cotidiano infantil: perspectivas de pesquisa e estudos de caso. São Paulo: Cortez, 2004, p. 43 - 95.

NIZA, Sergio. Contextos Cooperativos e Aprendizagem Profissional: A Formação no Movimento da Escola Moderna. In. FORMOSINHO, João (org). Formação de Professores: Aprendizagem profissional e ação docente. Porto: Porto Editora, 2009, p. 345-362.

NIZA, Sergio. O Modelo Curricular de Educação Pré-escolar da Escola Moderna Portuguesa. In. OLIVEIRA-FORMOSINHO, Julia (org). Modelos pedagógicos para a Educação de Infância: construindo uma práxis de participação. Porto: Porto Editora, 2013, p. 141-160.

NODARI, Felipe; SOARES, Mauren C.; WIEDENHOFT, Guilherme C.; OLIVEIRA, Mírian. Contribuição do Maxqda e do NVivo para a Realização da Análise de Conteúdo, Rio de Janeiro, ANais do XXXVIII Anpad, p. 1 - 16, 2014.

ÒDENA, Pepa. Infancia y escuela de 0 a 3 años. Barcelona: Rosa Sensat, 1995.

OLIVEIRA, Júli Caroline de. Os segredos do Pátio: crianças, natureza e o lugar para habitar as infâncias. Trabalho de Conclusão de Curso (Licenciatura em Pedagogia, Universidade do Vale do Rio dos Sinos - Unisinos), 96f., São Leopoldo, 2016.

OLIVEIRA-FORMOSINHO, J. Da formação dos supervisores cooperantes à formação dos futuros professores de crianças: o ciclo da homologia formativa. In: 
GUIMARÃES, Celia Maria. (Org.). Perspectivas para educação infantil. Araraquara: Junqueira \& Marin Editores, 2005, p. 3 - 31.

OLIVEIRA-FORMOSINHO, Julia. A formação em contexto: a mediação do desenvolvimento profissional praxiológico. In. CANCIAN, Viviane Ache; GALLINA, Simone Freitas da Silva; WESCHNFELDER, Noeli (org). Pedagogias das infâncias, crianças e docências na educação infantil. Santa Maria: Ipê amarelo, 2016b, p. 87 - 111.

OLIVEIRA-FORMOSINHO, Julia. A investigação praxeológica: um caminho para estudar as transições na Pedagogia-em-Participação. In. FORMOSINHO, João; OLIVEIRAFORMOSINHO, Julia; MONGE, Graciete (org). Transições entre ciclos educativos: uma investigação praxeológica. Porto: Porto Editora, 2016a, p.17 - 34.

OLIVEIRA-FORMOSINHO, Júlia. Aprender em companhia: uma pedagogia participativa. In. OLIVEIRA-FORMOSINHO, Júlia (org). Podiam chamar-se lenços do Amor. Lisboa: Ministério da Educação, 2009a, p. 5-13.

OLIVEIRA-FORMOSINHO, Júlia. As gramáticas pedagógicas participativas e a construção da identidade da criança. Revista Textura (ULBRA), Canoas, v. 18, n. 38, p. 132 $-152,2016 \mathrm{~d}$.

OLIVEIRA-FORMOSINHO, Julia. Desenvolvimento Profissional dos professores. In: FORMOSINHO, João (coord). Formação de professores: Aprendizagem profissional e acção docente. Porto: Porto Editora, 2009b, p. 221 - 284.

OLIVEIRA-FORMOSINHO, Júlia. Entrevista sobre pedagogia [ago. 2017], gravação digital. Entrevista concedida a Paulo Fochi, Porto, 2017.

OLIVEIRA-FORMOSINHO, Julia. O desenvolvimento profissional das educadoras de infância: entre os saberes e os afetos, entra a sala e o mundo. In: OLVEIRA-FORMOSINHO, Julia; KISHIMOTO, Tizuko Morchida Formação em contexto: uma estratégia de integração. São Paulo: Pioneira Thomson Learning, 2002a, p. 31 - 88.

OLIVEIRA-FORMOSINHO, Julia. Pedagogia(s) da infância: reconstruindo uma práxis de participação. In: OLIVEIRA-FORMOSINHO, Julia; KISHIMOTO, Tizuko Morchida; PINAZZA, Mônica Appezzato (org). Pedagogia(s) da infância: dialogando com o passado: construindo o futuro. Porto Alegre: Artmed, 2007, p. 13 - 36.

OLIVEIRA-FORMOSINHO, Júlia. Pedagogic documentation: uncovering solidary learning. In. OLIVEIRA-FORMOSINHO, Júlia; PASCAL, Christine. Assessment and evaluation for transformation in Early Childhood. Londres: Routledge, 2016c, p. 107 - 128.

OLIVEIRA-FORMOSINHO, Júlia. Um capítulo metodológico: os estudos de caso. In: OLVEIRA-FORMOSINHO, Julia; KISHIMOTO, Tizuko Morchida Formação em contexto: uma estratégia de integração. São Paulo: Pioneira Thomson Learning, 2002b, p. 89 108.

OLIVEIRA-FORMOSINHO, Júlia; ANDRADE, Filipa F.. O espaço na Pedagogiaem-Participação. In. OLIVEIRA-FORMOSINHO, Julia (org). O espaço e o tempo na Pedagogia-em-Participação. Porto: Porto Editora, 2011, p.9 - 69. 
OLIVEIRA-FORMOSINHO, Júlia; ARAÚJO, Sara. Educação em creche: participação e diversidade. Porto: Porto Editora, 2013.

OLIVEIRA-FORMOSINHO, Julia; FORMOSINHO, João. A formação como Pedagogia da Relação. Revista FAEEBA Educação e Contemporaneidade. Salvador, v. 27, n. 51, p. 19-28, jan./abr. 2018.

OLIVEIRA-FORMOSINHO, Julia; FORMOSINHO, João. A formação em contexto: a perspectiva da Associação Criança. In: OLVEIRA-FORMOSINHO, Julia; KISHIMOTO, Tizuko Morchida Formação em contexto: uma estratégia de integração. São Paulo: Pioneira Thomson Learning, 2002, p. 2 - 40.

OLIVEIRA-FORMOSINHO, Julia; FORMOSINHO, João. A perspectiva da Associação Criança: A pedagogia-em-Participação. OLIVEIRA-FORMOSINHO, Julia (org). Modelos pedagógicos para a Educação de Infância: construindo uma práxis de participação. Porto: Porto Editora, 2013, p.25 - 60.

OLIVEIRA-FORMOSINHO, Júlia; FORMOSINHO, João. A perspectiva pedagógica da Associação Criança: A Pedagogia-em-Participação. In. OLIVEIRA-FORMOSINHO, Júlia; GAMBÔA, Rosário (org). O trabalho de projetos na Pedagogia-em-Participação. Porto: Porto Editora, 2011, p.12 - 45.

OLIVEIRA-FORMOSINHO, Júlia; FORMOSINHO, João. Pedagogia-emParticipação: a documentação pedagógica no âmago da instituição dos direitos das crianças no cotidiano. Revista Em Aberto, Brasília, v. 30, n. 100, p. 115-130, set./dez. 2017.

OLIVEIRA-FORMOSINHO, Júlia; FORMOSINHO, João. Towards a social Science of the social: the contribuition of praxeological research. European Early Childhood Education Research journal, 20(4), p. 591 - 606. 2012.

OLIVEIRA-FORMOSINHO, Julia; KISHIMOTO, Tizuko Morchida; PINAZZA, Mônica Appezzato (org). Pedagogia(s) da infância: dialogando com o passado: construindo o futuro. Porto Alegre: Artmed, 2007.

OLIVEIRA-FORMOSINHO, Júlia; PASSOS, Filipa; MACHADO, Inês. O bem-estar das crianças, das famílias e equipas educativas: as transições sucedidas. In. FORMOSINHO, João; OLIVEIRA-FORMOSINHO, Julia; MONGE, Graciete (org). Transições entre ciclos educativos: uma investigação praxeológica. Porto: Porto Editora, 2016, p.35 - 53.

PALLASMAA, Juhani. La mano que piensa: sabiduria existencial y corporal en la arquitetura. Barcelona: Gustavo Gili, 2012.

PALLASMAA, Juhani. Os olhos da pele: a arquitetura e os sentidos. Porto Alegre: Bookman, 2011.

PATRUS, Roberto; DANTAS, Douglas Cabral; SHIGAKI, Helena Belintani. O produtivismo acadêmico e seus impactos na pósgraduação stricto sensu: uma ameaça à solidariedade entre pares? Cadernos EBAPE.BR, Rio de Janeiro, v. 13, n. 1, p. 1-18, jan./mar, 2015. 
PIMENTA, Alessandra Giuliani. (Des)caminhos da pós-graduação brasileira: o produtivismo acadêmico e seus efeitos nos professores pesquisadores. Dissertação (Mestrado em Educação), Faculdade de Educação, Universidade Federal da Paraíba, João Pessoa, 2014.

PINAZZA, Mônica Appezzato, FOCHI, Paulo Sergio. Documentação Pedagógica: observar, registrar e (re)criar significados. Revista Linhas. Florianópolis, v. 19, n. 40, p. 184199, maio/ago. 2018.

PINAZZA, Monica Appezzato. Formação de profissionais da educação infantil em contextos integrados: informes de uma investigação-ação. Tese (Livre Docência em Educação Infantil), Faculdade de Educação, Universidade de São Paulo, São Paulo, 2014.

PIRES, Cristina Maria Mesquita Gomes. A voz da criança sobre a inovação pedagógica. Tese (Doutorado em Estudos da Criança), Instituto de Educação, Universidade do Minho. Braga, 2013.

POST, Jacalyn; HOHMANN, Mary. Educação de bebés em infantários: cuidados e primeiras aprendizagens. Lisboa: Fundação Calouste Gulbenkiam, 2003.

REGGIO CHILDREN. Los cien linguajes de la infáncia. Barcelona: Rosa Sensat, 2005.

RINALDI, Carla. Diálogos com Reggio Emilia: escutar, investigar e aprender. São Paulo: Paz e terra, 2012.

RINALDI, Carla. Documentação e avaliação: qual a relação? In: ZERO, Project. Tornando visível a aprendizagem: crianças que aprendem individual e em grupo. São Paulo: Phorte, 2014, p. 80 - 91.

RINALDI, Carla. O ambiente da infância. In. CEPPI, Giulio; ZINI, Michele (org). Crianças, espaços, relações: como projetar ambientes para a educação infantil. Porto Alegre: Penso, 2013, p. 122 - 128.

RINALDI, Carla. Reinventing Laura: An educational Diary in a Reggio Emilia Nido. In. EDWARDS, Carolyn; RINALDI, Carla. The diary of Laura: perspectives on a Reggio Emilia Diary. St. Paul: Redleaf Press, 2009, p. 9 - 15.

RINALDI, Carla. Una medida para la amistad. In. REGGIO CHILDREN. Zapato y metro: los niños y la medida. Barcelona: Octaedro, 2005, p. 71 - 73.

RITSCHER, Penny. Slow School: Pedagogia del quotidiana. Firenze: Giunti, 2011.

ROCHA, Eloisa A. C. A pedagogia e a educação infantil. Revista Brasileira de Educação, n. 16, p. 27-34, 2001.

ROCHA, Eloisa Candal; BATISTA, Rosa. A Constituição Histórica da Docência na Educação Infantil: um estudo a partir do contexto catarinense do início do século XX. In: REUNIÃO ANPED GT7, 37., 2015, Florianópolis, Anais, Florianópolis: 2015.

ROGOFF, Barbara. A natureza cultural do desenvolvimento humano. Porto Alegre: Artmed, 2005. 
ROGOFF, Barbara. Aprendices del pensamiento: el desarrollo cognitivo en el contexto social. Buenos Aires: Paidós, 1993.

ROLDÃO, Maria do Céu. A mudança anunciada da Escola ou um Paradigma de Escola em ruptura?. In. ALARCÃO, Isabel (org). Escola reflexiva e nova racionalidade. Porto Alegre: Artmed, 2001, p. 115 - 134.

ROLDÃO, Maria do Céu. Trabalho colaborativo. O que fazemos e o que não fazemos nas escolas? Revista Noesis, 66, 2006, p. 22-23.

RTEIC, Red Territorial de Educación Infantil de Cataluña. Documentar, una mirada nueva. Barcelona: Octaedro, 2012.

SACRISTÁN, José Gimeno. Tendências investigativas na formação de professores. In. PIMENTA, Selma Garrido; GHEDIN, Evandro (org). Professor reflexivo no Brasil: gênese e crítica de um conceito. São Paulo, Cortez: 2012, p. 94 - 102.

SAVIO, Donatela. Los grupos como recurso educativo. In. Tiempos, espacios y grupos: El análisis y la evaluación de la organización en la escuela infantil: DDAVOPSI. Barcelona: Graó, 2011, p. 121 - 144.

SCHÖN, Donald A. Educando o Profissional Reflexivo: um novo design para o ensino e a aprendizagem. Porto Alegre: Artmed, 2000.

SINCLAIR, Hermine; STAMBACK, Mira. Os bebês e a física. In. SINCLAIR, Hermine et al. Os bebês e as coisas. Campinas: Autores Associados, 2012, p. 62 - 125.

SOËTARD, Michel. Ciência(s) da educação ou sentida da educação? A saída pedagógica. In. HOUSSAYE, Michel et al. Manifesto a favor dos pedagogos. Porto Alegre: Artmed, 2004.

SOUSA, J. Formação em contexto: um estudo de caso praxiológico. 2016. $111 \mathrm{f}$. Dissertação (Mestrado em Educação de Infância) - Universidade Católica Portuguesa, Lisboa, 2016.

SOUSA, Joana; FOCHI, Paulo. Participatory pedagogies with children: making real children's right. Keynote co-presented at the 27th EECERA Conference, Bologna, Italia.

SPAGGIARI, Sergio. Per stupirci coi bambini. In. REGGIO CHILDREN. Tutto ha un ombra meno le formiche. Reggio Emilia: Reggio Children, 1999, p. 8 - 9.

STACCIOLI, Gianfranco. Diário do acolhimento na escola da infância. Campinas: Autores Associados, 2013, p. 7-12.

STACCIOLI, Gianfranco. Rifflessione Introduttiva. In. RITSCHER, Penny. Slow School: Pedagogia del quotidiana. Firenze: Giunti, 2011.

STACCIOLI, Gianfranco; RITSCHER, Penny. Vivere a scuola: programmare per situazioni. Roma: Carocci Faber, 2005.

STAKE, Robert E..Investigación con estudio de casos. Madrid: Morata, 2007. 
STAMBAK, Mira et. al. Os bebês entre eles: descobrir, brincar, inventar juntos. Campinas: Autores Associados, 2011.

STAMBAK, Mira; BARBIÉRE, Michéle. Troca em uma situação de brincadeiras motoras. In. STAMBAK, Mira et. al. Os bebês entre eles: descobrir, brincar, inventar juntos. Campinas: Autores Associados, 2011, p. 9-50.

STENHOUSE, Lawrence. La investigación como base de la enseñanza. Madrid: Ediciones Morata, 1998.

STROZZI, Paola. Um dia na escola, um cotidiano extraordinário. In: ZERO, Project. Tornando visível a aprendizagem: crianças que aprendem individual e em grupo. São Paulo: Phorte, 2014, p. 60 - 79.

TARDOS, Anna. Autonomía y/o dependencia. In. FALK, Judit (org). Lóczy: educacion infantil. Barcelona: Ocatedro, 2008, p. 47-58.

TOGNETTI, Gloria; RUBINO, Maria; ZINGONI, Sara. La documentazione delle esperienze di piccolo grupo. TOGNETTI, Gloria (org). Creare esperienze insime ai bambini: la documentazione dele esperiene dei bambini nel nido. Azzano Sao Paolo: Edizioni Junior, 2003, p. $101-147$.

TOMASELLI, Anna; ZOCCHI, Alessandra. Perché documentare. In: COMUNE DI FERENZE. Linea guida: per i servisi educativi ala prima infanzia. Azzano São Paolo: Junior, 2009 , p. $24-76$.

TONUCCI, Francesco. A los tres años se investiga. Editorial Avance: Barcelona, 1977.

TONUCCI, Francesco. Loris: la creatività istituzionale. In: Nostalgia del futuro: liberare esperanze per uma nuova cultura dell'infanzia. Bergamo: Junior, 1998, p. 31 - 44.

TONUCCI, Francesco. Los materiales. Buenos Aires: Losada, 2008.

TUAN, Yi-Fu. Espaço e lugar. a perspectiva da experiência. São Paulo: Difel, 1983.

TUAN, Yi-Fu. Topofilia: um estudo da percepção, atitudes e valores do meio ambiente. São Paulo: Difel, 1980.

VECCHI, Vea. Arte y creatividad en Reggio Emilia: el papel de los talleres y sus possibilidades en educación infantil. Madrid: Morata, 2013.

VIEIRA, Lívia M. F.; SOUZA, Gisele de. Trabalho e emprego na educação infantil no Brasil: segmentações e desigualdades. Educar em Revista (Impresso), v. 1, p. 119-139, 2010.

VILA, Berta; CARDO, Cristina. Materiales sensoriales (0-3 años): manipulación y experimentación. Barcelona: Graó, 2005.

VOSGERAU, Dilmeire Sant'Anna Ramos; ORLANDO, Evelyn de Almeida; MEYER, Patricia. Produtivismo acadêmico e suas repercussões no desenvolvimento profissional de professores universitários. Educação e Sociedade, Campinas, v. 38, nº 138 , p.231-247, Jan / Mar, 2017. 
VYGOTSKY, Lev S. Pensamento e linguagem. São Paulo: Martins Fontes, 1998.

WENGER, Etienne. Communities of practice and social learning systems: the career of a concept. In. BLACKMORE, Chris. Social leaning systems and communities of pratice. Dusseldorf: Springer, 2010, p. $179-198$.

ZAMBONI, Chiara. Intermedio: inventar, agradecer: pensar. In. DIOTIMA. El perfume de la maestra: en los laboratorios de la vida cotidiana. Barcelona: Icaria, 2002, p. 22 -28 . 


\section{REFERÊNCIA DAS IMAGENS}

p. 68 - REGGIO CHILDREN. Non in un posto qualquasi: Reggio Emilia - un'esperienza educativa raccontada dai protagonista. Reggio Emilia: Reggio Children, 2002. DVD (72 minutos), son, col.

p. 70 - REGGIO CHILDREN. Non in un posto qualquasi: Reggio Emilia - un'esperienza educativa raccontada dai protagonista. Reggio Emilia: Reggio Children, 2002. DVD (72 minutos), son, col.

p. 73 - Elaborada pelo autor

p. 78 - REGGIO CHILDREN. Non in un posto qualquasi: Reggio Emilia - un'esperienza educativa raccontada dai protagonista. Reggio Emilia: Reggio Children, 2002. DVD (72 minutos), son, col.

p. 84 - EDWARDS, Carolyn; RINALDI, Carla. The diary of Laura: perspectives on a Reggio Emilia Diary. St. Paul: Redleaf Press, 2009.

p. 85 - EDWARDS, Carolyn; RINALDI, Carla. The diary of Laura: perspectives on a Reggio Emilia Diary. St. Paul: Redleaf Press, 2009.

p. 87 - REGGIO CHILDREN. Los cien linguajes de la infáncia. Barcelona: Rosa Sensat, 2005 .

p. 88 - REGGIO CHILDREN. Los cien linguajes de la infáncia. Barcelona: Rosa Sensat, 2005 .

p. 89 - REGGIO CHILDREN. Los cien linguajes de la infáncia. Barcelona: Rosa Sensat, 2005 .

p. 90 - COMUNE DI REGGIO EMILIA. L'occhio se salta il muro: narrativa del possibile. Proposte di bambini delle scuole comunali dell'infanzia di Reggio Emilia. Reggio Emilia: COMUNE DI REGGIO EMILIA, 1984.

p. 91 - REGGIO CHILDREN. Los cien linguajes de la infáncia. Barcelona: Rosa Sensat, 2005.

COMUNE DI REGGIO EMILIA. L'occhio se salta il muro: narrativa del possibile. Proposte di bambini delle scuole comunali dell'infanzia di Reggio Emilia. Reggio Emilia: COMUNE DI REGGIO EMILIA, 1984.

LORENZONI, Ombretta; BORGHI, Ettore; CANOVI, Antoni. Una storia presente: l'esperienza della scuole comunali dell'infanzia a Reggio Emilia. Reggio Emilia: RSLibri, 2001.

p. 91 - REGGIO CHILDREN. Las fuentes: a partir de un proyecto de construcción de un parque de atracciones para pajáros. Barcelona: Octaedro, 2006.

p. 92 - REGGIO CHILDREN. Las fuentes: a partir de un proyecto de construcción de un parque de atracciones para pajáros. Barcelona: Octaedro, 2006. 
GANDINI, Lella, The amusement Park for Birds: emergence and process of a Project. In. GANDINI, Lella; HILL, Lynn; CADWELL, Louise; SCHWALL, Charles. In the Spirit of the Studio: learning from the Atelier of Reggio Emilia. New York: teachers College, 2015

p. 93 - GANDINI, Lella; HILL, Lynn; CADWELL, Louise; SCHWALL, Charles. In the Spirit of the Studio: learning from the Atelier of Reggio Emilia. New York: teachers College, 2015

p. 94 - GANDINI, Lella; HILL, Lynn; CADWELL, Louise; SCHWALL, Charles. In the Spirit of the Studio: learning from the Atelier of Reggio Emilia. New York: teachers College, 2015

p. 95 - GANDINI, Lella; HILL, Lynn; CADWELL, Louise; SCHWALL, Charles. In the Spirit of the Studio: learning from the Atelier of Reggio Emilia. New York: teachers College, 2015

p. 96 - GANDINI, Lella; HILL, Lynn; CADWELL, Louise; SCHWALL, Charles. In the Spirit of the Studio: learning from the Atelier of Reggio Emilia. New York: teachers College, 2015

p. 99 - REGGIO CHILDREN. Los cien linguajes de la infáncia. Barcelona: Rosa Sensat, 2005 .

p. 100 - REGGIO CHILDREN. Los cien linguajes de la infáncia. Barcelona: Rosa Sensat, 2005.

p. 101 - FORMAN, George. Helping children ask good questions. In. NEUGENBAUER, BONIE. NEUGENBAUER, BONIE. The wonder of it: exploring how the word works. Redmond: Exchange Press, 1989.

p. 102 - REGGIO CHILDREN. Los cien linguajes de la infáncia. Barcelona: Rosa Sensat, 2005 .

p. 103 - REGGIO CHILDREN. Los cien linguajes de la infáncia. Barcelona: Rosa Sensat, 2005 .

p. 105 - REGGIO CHILDREN. Los pequeños del cine mudo: juegos en la escula infantil entre niños y peces. Barcelona: Octaedro, 2004.

p. 106 - REGGIO CHILDREN. Los pequeños del cine mudo: juegos en la escula infantil entre niños y peces. Barcelona: Octaedro, 2004.

p. 107 - REGGIO CHILDREN. Los pequeños del cine mudo: juegos en la escula infantil entre niños y peces. Barcelona: Octaedro, 2004.

p. 111 - REGGIO EMILIA, Escuelas Infantiles. La inteligencia se construye usándola. Madrid: Morata, 1995.

p. 113 - EDWARDS, Carolyn; GANDINI, Lella; FORMAN, George. As cem linguagens da criança. Porto Alegre: Artes Médica, 1999.

p. 114 - REGGIO CHILDREN. El zapato y el metro: los niños y la medida, primera aproximación al descubrimiento, a la función y al uso de la medida. Barcelona: Octaedro, 2005.

p. 115 - REGGIO CHILDREN. El zapato y el metro: los niños y la medida, primera aproximación al descubrimiento, a la función y al uso de la medida. Barcelona: Octaedro, 2005. 
p. 116 - REGGIO CHILDREN. El zapato y el metro: los niños y la medida, primera aproximación al descubrimiento, a la función y al uso de la medida. Barcelona: Octaedro, 2005.

p. 117 - REGGIO CHILDREN. El zapato y el metro: los niños y la medida, primera aproximación al descubrimiento, a la función y al uso de la medida. Barcelona: Octaedro, 2005.

p. 118 - REGGIO CHILDREN. El zapato y el metro: los niños y la medida, primera aproximación al descubrimiento, a la función y al uso de la medida. Barcelona: Octaedro, 2005.

p. 119 - REGGIO CHILDREN. Tutto ha un ombra meno le formiche. Reggio Emilia: Reggio Children, 1999.

p. 120 - REGGIO CHILDREN. Tutto ha un ombra meno le formiche. Reggio Emilia: Reggio Children, 1999.

p. 121 - REGGIO CHILDREN. Tutto ha un ombra meno le formiche. Reggio Emilia: Reggio Children, 1999.

p. 124 - COMUNE DI REGGIO EMILIA. L'occhio se salta il muro: narrativa del possibile. Proposte di bambini delle scuole comunali dell'infanzia di Reggio Emilia. Reggio Emilia: COMUNE DI REGGIO EMILIA, 1984

p. 128 - www.reggiochildren.it

p. 129 - REGGIO CHILDREN. Los cien linguajes de la infáncia. Barcelona: Rosa Sensat, 2005 .

p. 129 - $\underline{\text { www.reggiochildren.it }}$

p. 130 - REGGIO CHILDREN. The hundred languages in Ministories: told by teachers and children from Reggio Emilia. Worcester: Davis, 2016

p. 131 - REGGIO CHILDREN. The hundred languages in Ministories: told by teachers and children from Reggio Emilia. Worcester: Davis, 2016

p. 133 - Reviste Zerosei

p. 134 - Reviste Bambini

p. 130 - REGGIO CHILDREN. The hundred languages in Ministories: told by teachers and children from Reggio Emilia. Worcester: Davis, 2016

p. 148 - Memória, OBECI, 2013.

p. 152 - 165 - Processo Documental, Grupo Gestor, João de Barro; Joaninha; Espaço Girassol; Mimo de Gente, OBECI, 2017

p. 170 - Mini-história, GIA Acompanhamento Projetual, Espaço Girassol, OBECI, 2018.

p. 176 - Mini-história, GIA Acompanhamento Projetual, Joaninha, OBECI, 2018.

p. 183 - 1984 - Processo Documental, Grupo Gestor, Mimo de Gente, OBECI, 2015. 
p. 192 - p. 194 - Comunicação, GIA Ciclo de Simbolização, Espaço Girassol, OBECI, 2017.

p. 197 - Mini-história, GIA Brincar Heurístico, João de Barro, OBECI, 2018.

p. 199 - p. 202 - Processo Documental, GIA Acompanhamento Projetual, João de Barro, OBECI, 2018.

p. 203 - Memória, OBECI, 2018.

p. 204 - p. 205 - Mini-história, GIA Acompanhamento Projetual, Mimo de Gente, OBECI, 2018.

p. 217 - p. 222 - Processo Documental, GIA Acompanhamento Projetual, Joaninha, OBECI, 2018.

p. 224 - Folheto, GIA Ciclo de Simbolização, João de Barro; Joaninha; Espaço Girassol; Mimo de Gente, OBECI, 2017.

p. 199 - p. 200 - Processo Documental, GIA Acompanhamento Projetual, João de Barro, OBECI, 2018.

p. 232 - p. 237 - Mini-história, GIA Acompanhamento Projetual, Joaninha, OBECI, 2018.

p. 249 - p. 261 - Comunicação, Grupo Gestor, Joaninha, OBECI, 2018.

p. 266 - Mini-história, GIA Acompanhamento Projetual, Mimo de Gente, OBECI, 2018.

p. 270 - Comunicação, Grupo Gestor, Joaninha, OBECI, 2018.

p. 273 - Processo Documental, GIA Acompanhamento Projetual, Mimo de Gente, OBECI, 2018 .

p. 274 - p. 275 - Processo Documental, GIA Acompanhamento Projetual, Espaço Girassol, OBECI, 2018.

p. 276 - Processo Documentaç, GIA Acompanhamento Projetual, Joaninha, OBECI, 2018.

p. 282 - Processo Documental, GIA Acompanhamento Projetual, Mimo de Gente, OBECI, 2018.

p. 284 - Processo Documental, GIA Acompanhamento Projetual, João de Barro, OBECI, 2018.

p. 291 - Comunicação, Grupo Gestor, João de Barro, OBECI, 2018.

p. 300 - Comunicação, Grupo Gestor, Girassol, OBECI, 2018.

p. 300 - Processo Documental, GIA Acompanhamento Projetual, Girassol, OBECI, 2018.

p. 305 - Processo Documental, GIA Acompanhamento Projetual, João de Barro, OBECI, 2018. 


\section{APENDICE A - MODELOS DE TERMOS DE CONSENTIMENTO E AUTORIZAÇÃO}

-FEOSP

Faculdade de Educąădo

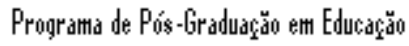

\section{TERMO DE CESSÃO PARA USO DE VOZ E IMAGEM}

$\mathrm{Eu}$,

inscrito(a)

no CPF sob o $\mathrm{n}^{\mathrm{o}}$ e portador(a) do $\mathrm{RG} \mathrm{n}^{\circ}$. residente e domiciliado na cidade de $\_$RS, na Rua/Av. , na qualidade de responsável

legal do/a meu/minha filho/a, , que frequenta

a

instituição

gratuita, total e definitivamente a Paulo Sergio Fochi, doutorando em Educação na Universidade de São Paulo - USP, que desenvolve a pesquisa intitulada: A construção do conhecimento praxiológico no Observatório da Cultura Infantil - OBECI, na linha de pesquisa Didática, Teorias de Ensino e Práticas Escolares e orientado pela professora Dra Monica Appezzato Pinazza (FE USP).

No âmbito desta pesquisa que acontece desde 2013, as instituições participantes são convidadas a i) registrar o cotidiano para refleti-lo; ii) criar estratégias de intervenção na instituição de modo a qualificar a ação pedagógica dos profissionais envolvidos (professores, direção, coordenadores); iii) comunicar as aprendizagens das crianças e os processos de ação dos professores. Os registros utilizados são realizados pelos profissionais da instituição e ocorrem através de foto, vídeo, gravações de voz e uso dos exemplares das produções das crianças.

$\mathrm{O}$ pesquisador compromete-se a esclarecer qualquer dúvida ou questionamento que eventualmente os participantes venham a ter durante a pesquisa.

Os responsáveis que aqui assinam, autorizam o uso da imagem e voz para divulgação dos dados gerados ao longo da pesquisa para fins exclusivos de divulgação acadêmico-científica em eventos, revistas científicas, livros, capítulos de livros e demais publicações voltadas a área, em números indeterminado de vezes, haja vista o caráter educacional e pedagógico da pesquisa.

Contato do Pesquisador:

Paulo Sergio Fochi

51999688214

paulo.fochi@hotmail.com

Assinatura de ciência

Data: 
- FEUS P P

Faculdade de Educą̧ẵo

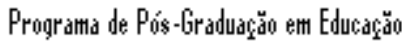

\section{TERMO DE CONSENTIMENTO LIVRE E ESCLARECIDO}

Na condição de Professor(a) da Escola Municipal de Educação Infantil João de Barro, pertencente à Secretaria Municipal de Educação de Novo Hamburgo, declaro, formalmente, minha participação na pesquisa intitulada A construção do conhecimento praxiológico no Observatório da Cultura Infantil - OBECI, coordenada pelo professor Paulo Sergio Fochi, aluno do doutorado em Educação da Universidade de São Paulo - USP, na linha de pesquisa Didática, Teorias de Ensino e Práticas Escolares e orientado pela professora Dra Monica Appezzato Pinazza.

No âmbito desta pesquisa, as instituições são convidadas i) registrar o cotidiano para refleti-lo; ii) criar estratégias de intervenção na instituição de modo a qualificar a ação pedagógica dos profissionais envolvidos (professores, direção, coordenadores); iii) comunicar as aprendizagens das crianças e os processos de ação dos professores.

$\mathrm{O}$ pesquisador compromete-se a esclarecer qualquer dúvida ou questionamento que eventualmente os participantes venham a ter durante a pesquisa.

Ciente das realizações conjuntas entre o OBECI e as Escolas participantes no âmbito da pesquisa, autorizo o uso e divulgação dos dados gerados ao longo da pesquisa para fins exclusivos de divulgação acadêmico-científica em eventos, revistas científicas, livros, capítulos de livros e demais publicações voltadas a área. Autorizo também o uso de imagem, relatos escritos e orais, por mim emitidos para fins de pesquisa, em números indeterminado de vezes, haja vista o caráter educacional e pedagógico da pesquisa.

Contato do Pesquisador:

Paulo Sergio Fochi

51999688214

paulo.fochi@hotmail.com

Assinatura de ciência

Data:

$\mathrm{CPF}$

Nome Completo: 


\section{- FE $\mathbb{E} \mathbb{S}$ \\ Faculdade de Educaçăo \\ Prognatitla de Pós-Graduaçăo em Educaçăo}

\section{TERMO DE CONSENTIMENTO LIVRE E ESCLARECIDO}

Na condição de Coordenadora Pedagógica da Escola Municipal de Educação Infantil João de Barro, pertencente à Secretaria Municipal de Educação de Novo Hamburgo, declaro, formalmente, minha participação na pesquisa intitulada A construção do conhecimento praxiológico no Observatório da Cultura Infantil - OBECI, coordenada pelo professor Paulo Sergio Fochi, aluno do doutorado em Educação da Universidade de São Paulo - USP, na linha de pesquisa Didática, Teorias de Ensino e Práticas Escolares e orientado pela professora Dra Monica Appezzato Pinazza.

No âmbito desta pesquisa, as instituições são convidadas i) registrar o cotidiano para refleti-lo; ii) criar estratégias de intervenção na instituição de modo a qualificar a ação pedagógica dos profissionais envolvidos (professores, direção, coordenadores); iii) comunicar as aprendizagens das crianças e os processos de ação dos professores.

$\mathrm{O}$ pesquisador compromete-se a esclarecer qualquer dúvida ou questionamento que eventualmente os participantes venham a ter durante a pesquisa.

Ciente das realizações conjuntas entre o OBECI e as Escolas participantes no âmbito da pesquisa, autorizo o uso e divulgação dos dados gerados ao longo da pesquisa para fins exclusivos de divulgação acadêmico-científica em eventos, revistas científicas, livros, capítulos de livros e demais publicações voltadas a área. Autorizo também o uso de imagem, relatos escritos e orais, por mim emitidos para fins de pesquisa, em números indeterminado de vezes, haja vista o caráter educacional e pedagógico da pesquisa.

Contato do Pesquisador:

Paulo Sergio Fochi

51999688214

paulo.fochi@hotmail.com

Assinatura de ciência

Data:

Nome Completo:

$\mathrm{CPF}$ : 


\section{-FEOSP \\ Faculdade de Educaçăa \\ Prọgrama de Pó́s-Graduaçăo em Educaçăo}

\section{TERMO DE CONSENTIMENTO LIVRE E ESCLARECIDO}

Na condição de Diretora da Escola Municipal de Educação Infantil João de Barro, pertencente à Secretaria Municipal de Educação de Novo Hamburgo, declaro, formalmente, minha participação na pesquisa intitulada A construção do conhecimento praxiológico no Observatório da Cultura Infantil - OBECI, coordenada pelo professor Paulo Sergio Fochi, aluno do doutorado em Educação da Universidade de São Paulo - USP, na linha de pesquisa Didática, Teorias de Ensino e Práticas Escolares e orientado pela professora Dra Monica Appezzato Pinazza.

No âmbito desta pesquisa, as instituições são convidadas i) registrar o cotidiano para refleti-lo; ii) criar estratégias de intervenção na instituição de modo a qualificar a ação pedagógica dos profissionais envolvidos (professores, direção, coordenadores); iii) comunicar as aprendizagens das crianças e os processos de ação dos professores.

$\mathrm{O}$ pesquisador compromete-se a esclarecer qualquer dúvida ou questionamento que eventualmente os participantes venham a ter durante a pesquisa.

Ciente das realizações conjuntas entre o OBECI e as Escolas participantes no âmbito da pesquisa, autorizo o uso e divulgação dos dados gerados ao longo da pesquisa para fins exclusivos de divulgação acadêmico-científica em eventos, revistas científicas, livros, capítulos de livros e demais publicações voltadas a área. Autorizo também o uso de imagem, relatos escritos e orais, por mim emitidos para fins de pesquisa, em números indeterminado de vezes, haja vista o caráter educacional e pedagógico da pesquisa.

Contato do Pesquisador:

Paulo Sergio Fochi

51999688214

paulo.fochi@hotmail.com

Assinatura de ciência

Data:

$\mathrm{CPF}$ :

Nome Completo: 
· FEUSP

Faculdade de Educą̧⿸尸𠃋

Programa de Pós-Graduadăo em Educąăăo

\section{TERMO DE CONSENTIMENTO LIVRE E ESCLARECIDO}

Na condição de Assessora da Educação Infantil, pertencente à Secretaria Municipal de Educação de Novo Hamburgo, declaro, formalmente, minha participação na pesquisa intitulada A construção do conhecimento praxiológico no Observatório da Cultura Infantil - OBECI, coordenada pelo professor Paulo Sergio Fochi, aluno do doutorado em Educação da Universidade de São Paulo - USP, na linha de pesquisa Didática, Teorias de Ensino e Práticas Escolares e orientado pela professora Dra Monica Appezzato Pinazza.

No âmbito desta pesquisa, as instituições são convidadas i) registrar o cotidiano para refleti-lo; ii) criar estratégias de intervenção na instituição de modo a qualificar a ação pedagógica dos profissionais envolvidos (professores, direção, coordenadores); iii) comunicar as aprendizagens das crianças e os processos de ação dos professores.

$\mathrm{O}$ pesquisador compromete-se a esclarecer qualquer dúvida ou questionamento que eventualmente os participantes venham a ter durante a pesquisa.

Ciente das realizações conjuntas entre o OBECI e as Escolas participantes no âmbito da pesquisa, autorizo o uso e divulgação dos dados gerados ao longo da pesquisa para fins exclusivos de divulgação acadêmico-científica em eventos, revistas científicas, livros, capítulos de livros e demais publicações voltadas a área. Autorizo também o uso de imagem, relatos escritos e orais, por mim emitidos para fins de pesquisa, em números indeterminado de vezes, haja vista o caráter educacional e pedagógico da pesquisa.

Contato do Pesquisador: Paulo Sergio Fochi 51999688214 paulo.fochi@hotmail.com

Assinatura de ciência

Data:

$\mathrm{CPF}$ :

Nome Completo: 


\section{· FEUSP \\ Faculdade de Educą̧ădo

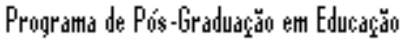

\section{TERMO DE CONSENTIMENTO LIVRE E ESCLARECIDO}

Na condição de Diretora e Proprietária da Escola Mimo de Gente, declaro, formalmente, minha participação na pesquisa intitulada A construção do conhecimento praxiológico no Observatório da Cultura Infantil - OBECI, coordenada pelo professor Paulo Sergio Fochi, aluno do doutorado em Educação da Universidade de São Paulo - USP, na linha de pesquisa Didática, Teorias de Ensino e Práticas Escolares e orientado pela professora Dra Monica Appezzato Pinazza.

No âmbito desta pesquisa, as instituições são convidadas i) registrar o cotidiano para refleti-lo; ii) criar estratégias de intervenção na instituição de modo a qualificar a ação pedagógica dos profissionais envolvidos (professores, direção, coordenadores); iii) comunicar as aprendizagens das crianças e os processos de ação dos professores.

$\mathrm{O}$ pesquisador compromete-se a esclarecer qualquer dúvida ou questionamento que eventualmente os participantes venham a ter durante a pesquisa.

Ciente das realizações conjuntas entre o OBECI e as Escolas participantes no âmbito da pesquisa, autorizo o uso e divulgação dos dados gerados ao longo da pesquisa para fins exclusivos de divulgação acadêmico-científica em eventos, revistas científicas, livros, capítulos de livros e demais publicações voltadas a área. Autorizo também o uso de imagem, relatos escritos e orais, por mim emitidos para fins de pesquisa, em números indeterminado de vezes, haja vista o caráter educacional e pedagógico da pesquisa.

Contato do Pesquisador:

Paulo Sergio Fochi

51999688214

paulo.fochi@hotmail.com

Assinatura de ciência

Data:

$\mathrm{CPF}$ :

Nome Completo: 


\section{- FE巴S \\ Faculdade de Educaçắo \\ Programa de Pós-Graduaçắo em Educaçăo}

\section{TERMO DE CONSENTIMENTO LIVRE E ESCLARECIDO}

$\mathrm{Na}$ condição de integrantes da Equipe Gestora da Escola Espaço Girassol, declaramos, formalmente, a participação desta instituição na pesquisa intitulada A construção do conhecimento praxiológico no Observatório da Cultura Infantil - OBECI, coordenada pelo professor Paulo Sergio Fochi, aluno do doutorado em Educação da Universidade de São Paulo - USP, na linha de pesquisa Didática, Teorias de Ensino e Práticas Escolares e orientado pela professora Dra Monica Appezzato Pinazza.

No âmbito desta pesquisa, as instituições são convidadas i) registrar o cotidiano para refleti-lo; ii) criar estratégias de intervenção na instituição de modo a qualificar a ação pedagógica dos profissionais envolvidos (professores, direção, coordenadores); iii) comunicar as aprendizagens das crianças e os processos de ação dos professores.

Esclarecemos que toda a equipe da instituição antes nominada, está ciente deste acordo e motivada em partilhar das ações de formação, pesquisa e intervenção nas práticas educativas, passando a constar no Projeto Político-Pedagógico a parceria deste Observatório com a instituição. Também os pais são cientes do envolvimento da instituição com o trabalho desenvolvido.

$\mathrm{O}$ pesquisador compromete-se a esclarecer qualquer dúvida ou questionamento que eventualmente os participantes venham a ter durante a pesquisa.

Ciente das realizações conjuntas entre o OBECI e as Escolas participantes no âmbito da pesquisa, autorizo o uso e divulgação dos dados gerados ao longo da pesquisa para fins exclusivos de divulgação acadêmico-científica em eventos, revistas científicas, livros, capítulos de livros e demais publicações voltadas a área. Autorizo também o uso de imagem, relatos escritos e orais, por mim emitidos para fins de pesquisa, em números indeterminado de vezes, haja vista o caráter educacional e pedagógico da pesquisa.

Contato do Pesquisador:

Paulo Sergio Fochi

51999688214

paulo.fochi@hotmail.com

Assinatura de ciência da Diretora

CPF da Diretora:

Nome Completo Diretora:

Assinatura de ciência da Coordenadora Pedagógica CPF da Coordenadora Pedagógica:

Nome Completo Coordenadora

Pedagógica:

Data:

I 


\section{APENDICE B - SISTEMATIZAÇÃO DE CARGA HORÁRIA E ATIVIDADE DOS PROCESSOS FORMATIVOS DO OBECI}

\begin{tabular}{lccc}
\hline \multicolumn{1}{c}{ Procesos Formativos } & Ano & Participantes & Carga Horária \\
\hline & 2013 & 8 & $36 \mathrm{~h}$ \\
Grupo Gestor & 2014 & 10 & $24 \mathrm{~h}$ \\
& 2015 & 11 & $33 \mathrm{~h}$ \\
& 2016 & 10 & $45 \mathrm{~h}$ \\
& 2017 & 10 & $45 \mathrm{~h}$ \\
GIA Ciclos de Simbolização & 2018 & 15 & $45 \mathrm{~h}$ \\
\hline GIA Acompanhamento Projetual & 2015 & 9 & $12 \mathrm{~h}$ \\
& 2016 & 15 & $18 \mathrm{~h}$ \\
GIA Brincar Heurístico & 2017 & 16 & $18 \mathrm{~h}$ \\
\hline & 2018 & 19 & $40 \mathrm{~h}$ \\
\hline GIA Jogos de Luz e Sombra & 2016 & 18 & $21 \mathrm{~h}$ \\
& 2017 & 18 & $18 \mathrm{~h}$ \\
& 2018 & 18 & $18 \mathrm{~h}$ \\
\hline Encontro de Escolas Observadoras & 2016 & 32 & $3 \mathrm{~h}$ \\
& 2018 & 32 & $3 \mathrm{~h}$ \\
\hline Jornada de Educação Infantil & $2016 / 1$ & 83 & $5 \mathrm{~h}$ \\
& $2016 / 2$ & 108 & $5 \mathrm{~h}$ \\
& $2017 / 1$ & 112 & $5 \mathrm{~h}$ \\
\hline Roteiros Pedagógicos * & $2017 / 2$ & 112 & $5 \mathrm{~h}$ \\
\hline Assessoria direta na escola ** & $2017 / 2$ & 107 & $5 \mathrm{~h}$ \\
\hline & $2013 / 1$ & 7 & $8 \mathrm{~h}$ \\
\hline & $2013 / 2$ & 14 & $8 \mathrm{~h}$ \\
\hline
\end{tabular}

* Atividades de visitas em algumas instituições de educação infantil com a finalidade de conhecer práticas pedagógicas.

** Atividade de formação direta na escola apenas para os professores da instituição. Isso ocorreu no primeiro ano para fins de elucidação de alguns conceitos iniciais estruturantes. 


\section{APENDICE C - SISTEMATIZAÇÃO DOS CONTEÚdOS DOS PROCESSOS FORMATIVOS DO OBECI}

\begin{tabular}{|c|c|c|c|c|c|}
\hline \multicolumn{2}{|c|}{$\begin{array}{l}\text { Processo } \\
\text { Formativo }\end{array}$} & Mimo de Gente & \multicolumn{3}{|c|}{ EMEI João de } \\
\hline \multirow{6}{*}{ 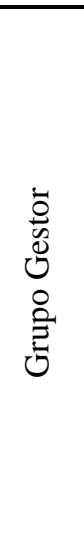 } & 2013 & $\begin{array}{l}\text { Organização da } \\
\text { Biblioteca }\end{array}$ & Soninho & - & - \\
\hline & 2014 & Alimentação & Alimentação & Alimentação & - \\
\hline & 2015 & Uma tarde no Jardim & Uma tarde no Jardim & Uma tarde na FE1 & Uma tarde na FE0 \\
\hline & 2016 & Pensamento Projetual & $\begin{array}{l}\text { Atividades comum / } \\
\text { turno da manhã }\end{array}$ & Postura do adulto & $\begin{array}{l}\text { Microtransição: ir ao } \\
\text { banheiro }\end{array}$ \\
\hline & 2017 & $\begin{array}{l}\text { Microtransição: } \\
\text { descanso }\end{array}$ & Transição: adaptação & $\begin{array}{l}\text { Microtransição: } \\
\text { consignas do adulto }\end{array}$ & $\begin{array}{l}\text { Microtransição: grande } \\
\text { grupo - pequeno grupo }\end{array}$ \\
\hline & 2018 & $\begin{array}{l}\text { Microtransição: } \\
\text { almoço }\end{array}$ & $\begin{array}{l}\text { Microtransição: } \\
\text { chegadas e partidas }\end{array}$ & Microtransição: Troca & $\begin{array}{l}\text { Microtransição: grande } \\
\text { grupo - pequeno grupo }\end{array}$ \\
\hline \multirow{3}{*}{ 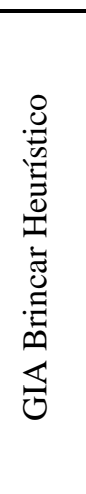 } & 2016 & $\begin{array}{l}\text { Cesto de tesouros, Jogo } \\
\text { Heurístico, Bandeja de } \\
\text { Experimentação }\end{array}$ & $\begin{array}{l}\text { Cesto de tesouros, Jogo } \\
\text { Heurístico }\end{array}$ & $\begin{array}{l}\text { Cesto de tesouros, Jogo } \\
\text { Heurístico, Bandeja de } \\
\text { Experimentação }\end{array}$ & $\begin{array}{l}\text { Jogo Heurístico, } \\
\text { Bandeja de } \\
\text { Experimentação }\end{array}$ \\
\hline & 2017 & $\begin{array}{l}\text { Cesto de tesouros, Jogo } \\
\text { Heurístico, Bandeja de } \\
\text { Experimentação }\end{array}$ & Jogo Heurístico & $\begin{array}{l}\text { Cesto de tesouros, Jogo } \\
\text { Heurístico, Bandeja de } \\
\text { Experimentação }\end{array}$ & $\begin{array}{l}\text { Jogo Heurístico, } \\
\text { Bandeja de } \\
\text { Experimentação }\end{array}$ \\
\hline & 2018 & $\begin{array}{l}\text { Cesto de tesouros, Jogo } \\
\text { Heurístico, Bandeja de } \\
\text { Experimentação }\end{array}$ & $\begin{array}{l}\text { Cesto de tesouros, Jogo } \\
\text { Heurístico, Bandeja de } \\
\text { Experimentação }\end{array}$ & $\begin{array}{l}\text { Cesto de tesouros, Jogo } \\
\text { Heurístico, Bandeja de } \\
\text { Experimentação }\end{array}$ & $\begin{array}{l}\text { Jogo Heurístico, } \\
\text { Bandeja de } \\
\text { Experimentação }\end{array}$ \\
\hline \multirow{3}{*}{ 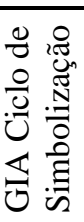 } & 2015 & Dente de leão & Dente de leão & Dente de leão & Dente de leão \\
\hline & 2016 & Com olhos de criança & Com olhos de criança & Com olhos de criança & Com olhos de criança \\
\hline & 2017 & Folhas & Mandala & Os voos de Pedro & $\begin{array}{l}\text { Para que serve o } \\
\text { umbigo? }\end{array}$ \\
\hline 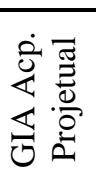 & 2018 & $\begin{array}{l}\text { Porto Alegre vista } \\
\text { pelas crianças }\end{array}$ & Arquitetura de insetos & Construções & Inventário de Receitas \\
\hline \multirow{3}{*}{ 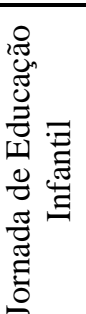 } & 2015 & Alimentação & $\begin{array}{l}\text { Organização dos } \\
\text { Espaços para acolher }\end{array}$ & Jogo Heurístico & Uma tarde na creche \\
\hline & 2016 & Ciclos de Simbolização & $\begin{array}{l}\text { Bem comum na } \\
\text { Educação Infantil }\end{array}$ & Mini-histórias & Brincar Heurístico \\
\hline & 2018 & Cesto de Tesouros & $\begin{array}{l}\text { As Mandalas e Jogo } \\
\text { Heurístico }\end{array}$ & $\begin{array}{l}\text { Os voos de Pedro e } \\
\text { Brincar Heurístico }\end{array}$ & Brincar Heurístico \\
\hline
\end{tabular}

FE - Faixa etária

GIA - Grupode Investigação-Ação 